UNIVERSIDADE DE SÃO PAULO - USP

MUSEU DE ARQUEOLOGIA E ETNOLOGIA - MAE

PROGRAMA DE PÓS-GRADUAÇÃO EM ARQUEOLOGIA

\title{
SOCIEDADE SAMBAQUIEIRA, COMUNIDADES MARÍTIMAS
}

Flávio Rizzi Calippo

Tese apresentada ao Programa de PósGraduação em Arqueologia, do Museu de Arqueologia e Etnologia da Universidade de São Paulo, como parte dos requisitos obrigatórios para a obtenção do título de Doutor em Arqueologia

Orientador:

Profa. Dra. Maria Cristina Mineiro Scatamacchia

Linha de Pesquisa:

Processos de formação do registro arqueológico

São Paulo, março de 2010 
UNIVERSIDADE DE SÃO PAULO - USP

MUSEU DE ARQUEOLOGIA E ETNOLOGIA - MAE

PROGRAMA DE PÓS-GRADUAÇÃO EM ARQUEOLOGIA

\section{SOCIEDADE SAMBAQUIEIRA, COMUNIDADES MARÍTIMAS}

\section{Flávio Rizzi Calippo}

Tese apresentada ao Programa de Pós-Graduação em Arqueologia, do Museu de Arqueologia e Etnologia da Universidade de São Paulo, como parte dos requisitos obrigatórios para a obtenção do título de Doutor em Arqueologia

Orientador:

Profa. Dra. Maria Cristina Mineiro Scatamacchia

Linha de Pesquisa:

Processos de formação do registro arqueológico 
O velho barco toda vez que vê o mar

Fica confuso, com vontade de zarpar Ever o mar às vezes bem que é preciso,

Pra ter certeza de ainda estar-se vivo

Mesmo que o casco esteja velho e corroído

Olhos Profundos

(Renato Teixeira) 
Para Glória,

por ter transformado

estes últimos e difíceis anos

em os mais felizes da minha vida

Para meus pais,

Rosa e Francisco,

por estarem, sempre

e incondicionalmente,

ao meu lado 


\section{AGRADECIMENTOS}

Uma Tese não se faz sozinho. Ainda que esse esforço, por vezes, seja solitário, em cada parte do texto reconheço influências, conselhos, árduas discussões, recomendações de leitura e oportunidades propiciadas por professores, amigos e colegas. Ao relê-la, uma última vez, sentime grato e honrado por terem compartilhado comigo seus conhecimentos e amizade, ajudandome a concluir esta tarefa. Por isso, gostaria de manifestar meus mais profundos agradecimentos:

À Profa. Dra. Maria Cristina Mineiro Scatamacchia, pela orientação, confiança, liberdade e apoio fundamentais para a construção de minha própria compreensão dos povos sambaquieiros. A ela agradeço também a oportunidade de pesquisar os sambaquis do baixo vale do Ribeira.

Ao Conselho Nacional de Desenvolvimento Científico e Tecnológico (CNPq), pela concessão da bolsa de estudo e da reserva técnica; e à Fundação de Amparo à Pesquisa do Estado de São Paulo (FAPESP), pelo financiamento, no âmbito do Programa Arqueológico do Baixo Vale do Ribeira, da maior parte das etapas de campo.

Ao Museu de Arqueologia e Etnologia (MAE/USP) pela oportunidade de fazer o Doutorado e por ter-me cedido as amostras para a realização das análises de estrôncio. Em especial à professora Marisa Afonso e aos técnicos Paulo Jacob, Dária Barreto e à arqueóloga Silvia Piedade, que me orientaram tanto na seleção das amostras como na obtenção da autorização de saída do material.

Ao Programa de Pós-Graduação em Arqueologia do MAE/USP por ter me indicado como bolsista CNPq e pelo apoio ao longo de todo o Doutorado. Em especial, aos professores Levy Figuti, Marisa Afonso, Paulo De Blasis, Eduardo Neves, Fabíola Silva, Maria Isabel Fleming, Walter Bissa, Astolfo Araújo, Verônica Wesolowski e Sabine Eggers pelas inúmeras conversas e conselhos. Ao Eduardo agradeço ainda a possibilidade ter ministrado aulas em suas disciplinas, à Fabíola e à Marisa por terem me aceito como aluno ouvinte e à Mabel pela elaboração do abstract e pelas oportunidades de colaborar com a Revista do MAE. À Marisa agradeço também o convite para participar do simpósio sobre shellmounds, organizado por ela e por Geoff Bailey (Universidade de York), no Congresso da IUSPP (Lisboa, 2006), onde pude apresentar e discutir parte dos resultados desta Tese.

Aos professores Felipe Toledo e Karen Costa, do Instituto Oceanográfico (IO/USP), cujo apoio e generosidade foram fundamentais para a realização desta Tese. Além de sugerirem a utilização dos métodos isotópicos e guiarem-me na realização das análises, nunca mediram esforços para que os melhores resultados fossem atingidos. A eles agradeço também o convite de integrar a equipe do Laboratório de Paleoceanografia do Atlântico Sul (LaPAS/IO/USP), a oportunidade de ministrar aulas em suas disciplinas e a amizade, a ética, a gentileza e o respeito dedicados a mim e a todo estudante.

Aos professores Pedro Paulo Funari (UNICAMP), Gilson Rambelli (UFSE) e Leila Ferreira da Costa (UNICAMP), pela oportunidade de ter cursado disciplinas que me permitiram compreender de forma mais aprofundada a Arqueologia marítima, a Sociologia Ambiental e a própria ciência Arqueologia. Agradeço, ainda, a todos os outros membros do NEPAM e do NEE e, em particular, à Ziara, ao Wagner e à Fátima. 
Aos professores Farid Chemale (Laboratório de Geológica Isotopia - LGI/UFRGS) e Koji Kawashita (IGC/USP) pelo financiamento e realização das análises de estrôncio. A eles e a Márcia Machado, técnica da UFRGS, agradeço, ainda, o empenho e os esforços para que as análises fossem realizadas a tempo da conclusão desta Tese.

Aos professores Águeda e Denis Vialou, do Museu Nacional de História Natural de Paris, por me recepcionarem em Paris e propiciarem todas as condições para o levantamento bibliográfico a respeito das evidências pré-históricas européias de pesca e navegação. A eles agradeço ainda os ensinamentos e a atenção dedicada desde os tempos do abrigo Santa Elina.

Ao professor Francisco Alves por ter-me orientado no levantamento bibliográfico a respeito das técnicas de construção naval e pela gentileza de permitir meu acesso à sua biblioteca pessoal e a do Departamento de Arqueologia Náutica e Subaquática (DANS/IPA/Ministério da Cultura de Portugal).

À professora Maria Helena Hollanda (Laboratório de Isótopos Estáveis - LIE/IGC/USP) pela realização das análises dos isótopos estáveis e ao técnico do LIE, Luis Mancini, pela gentileza e paciência para me explicar todos os procedimentos analíticos.

Aos professores Moysés Tessler, Valdenir Furtado, Michel Mahiques, Rubens de Mesquita e Luis Américo Conti, e aos técnicos Clodoaldo Vieira, Edilson Faria, Marcelo Rodrigues, do IO/USP, pelas conversas, contribuições, indicações de leituras e auxílio na realização das amostragens.

Aos amigos e colegas do MAE, Paulo Bava de Camargo, Leandro Duran, Gilson Rambelli, Lucas Bueno, Juliana Machado, Paulo Zanettini, Cristina Demartini, Sandra Lacerda (viva Malinoivisky), José Filippini, Manoel Gonzalez, Danilo Assunção, Tânia Ferraz, Fabiana Belém, André Penin, Cláudia Plens, Paula Nishida, Daniela Klökler, Rafael Cortelleti, Rafael Milheira, Camila Moraes e Luciana Alves, pelos divertidos momentos, pelas acaloradas discussões e indicações de leitura, os quais me ajudaram tanto a avançar com a Tese como a manter a sanidade nos momentos mais difíceis. Agradeço ainda à Luciana pelo auxílio na preparação das amostras de estrôncio, ao Leandro pela criteriosa revisão da Tese, à Paula a oportunidade de conhecer e escavar os sambaquis de Santa Catarina, ao Paulo pela possibilidade de visitar os sítios líticos do médio Ribeira e as bacias de polimento do litoral norte e à Cristina Tenório a oportunidade de pesquisar os sambaquis de Arraial do Cabo.

À todos os membros das comunidades da llha do Cardoso e monitores e funcionários do PEIC, com quem aprendi muito sobre a vida no mar e a respeito dos sambaquis. Em especial ao Jorge, ao Zico, ao Nanuca, ao Marcos Campolim, ao seu Ivo e ao Serginho, cujo apoio e saberes foram fundamentais para a localização dos sítios e realização dos trabalhos.

Ao capitão da reserva Carlos Rios, por se dispor a me levar ao Seridó, enfrentando mais de cinco horas de carro sertão a dentro, para apreciarmos e registrarmos uma das mais antigas representações de embarcações pré-históricas.

Aos funcionários do MAE, em especial à Dária, ao Paulinho, à Vanusa, ao Geraldo, à Regina, à Eleusa, ao Hélio, ao Alberto, à Neliana, à Conceição, ao Marinho, ao Nicássio, ao Omildo, ao Messias, ao Renato, à Nice e à Sandra, pelo apoio, conselhos, por ouvirem meus desabafos e pelo bom humor. 
A todos os integrantes do antigo CNANS e atual DANS, em particular, aos amigos Miguel Aleluia, José Bettencourt, Patrícia Carvalho, Inês, João Alves e Vanessa Loureiro, por terem me dado abrigo e tornado minha estadia em Portugal tão agradável e proveitosa.

Aos colegas do LaPAS/IO, em especial, à Louise Oliveira (pela preparação de amostras e elaboração de lâminas), à Maria Pivel (pela revisão da versão em inglês do artigo para os Anais do Congresso da IUSPP e pelo transporte das amostras para a UFRGS) e à Darién Mizuta, por ter preparado todo o caminho para a realização das análises de carbono e oxigênio.

Aos colegas do Programa Arqueológico do Baixo Vale do Ribeira, em especial ao Leandrinho, ao Bava, ao Gilsão, ao Guimarães e à Cristininha pela amizade, pelo companheirismo, pelos mergulhos, por compartilharem comigo seus conhecimentos e pelos inesquecíveis dias em Cananéia.

Aos amigos e professores Catharina Torrano Ribeiro e Pedro Augusto Mentz Ribeiro (UFURG) (em memória) pelo incentivo, ensinamentos, conselhos, preocupação, exemplos, carinho e boas risadas. Agradecimento que estendo também a Manuel Haimovici, professor da UFURG, com quem espero ter a oportunidade de trabalhar novamente.

Aos meus amigos e familiares Paulão, Dunza, Leandro, Lorena, Gilsão, Karina, Anna, Zaneta, Ana, Bernardo, Lorenzo, Pedro Paulo, João (que tem um coração maior do que esta Tese), Mariângela, Ana Lígia, Renato, Débora, Ivana, Otton, Luci, Bianca, Paulinho, Guta, Laura (minha meque), Helena, Paulo, Valéria, Leo, Dunirinho, Dirce (DD), Márcia, Zé (agora eu vou para Botucatu!), Felipe, Karen, Dani, Fúlvio, Mônica, Ana Maria, Geraldo, José Manoel, Zenilde, Elza, Helinho, Moniquinha, Andréia, Junior, Etelvina, Hélio, Eucenir, Celso, Jô, Ximena, Gilmar, Milla, Freddo, Mel, Igor, Zig e Frida agradeço a compreensão, por ouvirem meus desabafos, pela franca amizade, por terem me ensinado tanto e, principalmente, por estarem sempre ao meu lado.

A Dirce e Adoniro Tega pela confiança, pelo apoio, pela franqueza, pela sabedoria, pelos ensinamentos e pelo carinho. Espero um dia realmente ter a oportunidade de retribuir à altura.

À meus pais pela sensibilidade do silêncio e da fala nos momentos exatos. Aos sorrisos francos, aos puxões de orelha e aos abraços apertados que foram e serão sempre meu porto seguro. Amo e admiro vocês. A minha mãe, Rosa, agradeço ainda o auxílio na elaboração da bibliografia e da lista de figuras, e a meu pai, Francisco, a colaboração na impressão e encadernação.

À Glória, minha esposa, não tenho como agradecer. Ela participou desta Tese desde o préprojeto até a última conclusão, dando sugestões, sofrendo com minhas preocupações, vibrando com as conquistas, ouvindo meus monólogos arqueológicos, revisando todos os textos (alguns, mais de uma vez) e até colaborando na impressão. Sempre com tanta boa vontade, cuidado, carinho, paixão e amor, que não me resta outra opção: oferecer-lhe co-autoria. Para esta Tese e para a nova vida que se inicia com sua conclusão. 


\section{RESUMO}

Tendo como referencial teórico abordagens focadas na Arqueologia Marítima (MUCKELROY, 1978; ADAMS, 1998, 2002), na Antropologia Marítima (MALINOWSKI, 1986 [1922]; DIEGUES, 1998) e em estudos de Percepção Ambiental (INGOLD, 2000), buscou-se desenvolver e testar a hipótese de que, embora houvesse uma unidade cultural que permitisse o estabelecimento de uma ampla sociedade sambaquieira, os povos dos sambaquis estariam organizados em comunidades costeiras regionais, as quais teriam se desenvolvido e se organizado em diferentes comunidades marítimas, costeiras e fluviais, em conseqüência dos diferentes modos com que eles se relacionariam (dialeticamente) com o ambiente,

Para sustentar tal hipótese foi elaborado um modelo de predição de sítios submersos e realizadas análises da composição isotópica do estrôncio (HÖLZL, 1997; PRICE et al., 2000; BENTLEY et al, 2003; HODELL, 2004), do carbono e do oxigênio (KEITH, 1964; COSTA, 2000; MIZUTA, 2007) presentes (em amostras de conchas e ossos humanos) em sambaquis localizados ao longo do médio e baixo Vale do Ribeira, bem como em sítios do litoral central (Baixada Santista e Bertioga) e norte do estado de São Paulo (Ubatuba). Essas evidências foram correlacionadas à abordagem teórica através de uma proposta elaborada a partir do estudo dos processos de formação do registro arqueológico desenvolvidos por Schiffer (1972).

Com base nessas análises, além de diferenciar os povos do médio Ribeira dos sambaquieiros do litoral, foi possível, entre outras, propor uma fronteira cultural entre os conjuntos de sítios do litoral sul/centro do estado de São Paulo e os sambaquis do litoral norte de São Paulo/sul do Rio de Janeiro. Especificamente em relação aos sambaquis de Cananéia, a análise isotópica das conchas evidenciou, ainda, que os locais e os propósitos da coleta estariam mais relacionados a aspectos culturais do que à simples exploração dos recursos mais abundantes.

\section{PALAVRAS-CHAVE}

Sambaquis; Arqueologia Marítima; Composição Isotópica; Sambaquis Submersos; Processos Formativos; Modelo Preditivo 
ABSTRACT

Using as theoretical reference approaches focused on the Maritime Archaeology (MUCKELROY, 1978; ADAMS, 1998, 2002), on the Maritime Anthropology (MALINOWSKI, 1986 [1922]; DIEGUES, 1998) and on studies of Environmental Perception (INGOLD, 2000), we tried to develop and test the hypothesis that, notwithstanding the evidence of a cultural unity that allowed for the establishment of an ample shellmound society, people of the shellmounds were organized in regional coastal communities. These would have developed and organized in different maritime communities, both coastal and fluvial, in consequence of the different ways in which they (dialectically) related with the environment.

To support such hypothesis a model was elaborated predicting underwater sites, an analyses was realized of the isotopic composition of strontium (HÖLZL, 1997; PRICE et al., 2000; BENTLEY et al, 2003; HODELL, 2004), of carbon and of oxygen (KEITH, 1964; COSTA, 2000; MIZUTA, 2007) present (in samples of shells and human bones) in shellmounds located along the medium and low Vale do Ribeira, as well as in sites at the central coast (Baixada Santista and Bertioga) and north (Ubatuba) of the state of São Paulo. The evidences were correlated to the theoretical approach through a proposal elaborated from the study of the formation processes of the archaeological record developed by Schiffer (1972).

Based on these analyses, beyond differentiating the people from the medium Ribeira from the coastal shellmound people, it became possible, among other things, to propose a cultural borderline between the ensembles of sites of the south/center coast of São Paulo and the shellmounds of northern São Paulo and southern Rio de Janeiro. Specifically with regard to the shellmounds of Cananéia, the isotopic analysis of shells evinced, yet, that the locals and goals of collecting were more related to cultural aspects than to the simple exploration of the more abundant resources.

KEYWORDS

Shellmounds; Maritime Archaeology; Isotopic Composition; Underwater Shellmounds; Formative Processes; Predictive Model 


\section{ÍNDICE}

$\begin{array}{ll}\text { INTRODUÇÃO } & 01\end{array}$

$\begin{array}{ll}\text { OBJETIVOS } & 07\end{array}$

$\begin{array}{ll}\text { PARTE I - ENCAMINHAMENTO DA PESQUISA } & 10\end{array}$

1. PRESSUPOSTOS TÉORICOS 11

1.1. OS SAMBAQUIS SOB O PONTO DE VISTA DA ARQUEOLOGIA MARÍTIMA

1.2. O UNIVERSO MARÍTIMO DOS POVOS DOS SAMBAQUIS 16

1.3. SOCIEDADE SAMBAQUIEIRA, COMUNIDADES MARÍTIMAS

1.4. POVOS SAMBAQUIERIOS, POVOS NAVEGADORES 31

1.4.1. Evidências bioarqueológicas 32

1.4.2. As mais antigas evidências de navegação na América do Sul 37

1.5. A PERCEPÇÃO DO AMBIENTE

1.5.1. A construção de uma percepção ambiental sambaquieira 51

1.5.2. Reinterpretando os processos de formação do registro arqueológico 58

2. AS ESTRATÉGIAS DE PESQUISA

2.1. O RECORTE AMOSTRAL 71

2.1.1. Os sambaquis do Baixo Vale do Ribeira 72

2.1.1.1. A formação do baixo Vale do Ribeira e o estabelecimento dos sambaquis $\quad 73$

2.1.1.2. Hipóteses para a ocupação do baixo Vale do Ribeira 82

2.1.1.3. Os sambaquis pesquisados no baixo Vale do Ribeira 91

2.1.1.3.1. O sambaqui Cambriu Grande $\quad 94$

$\begin{array}{ll}\text { 2.1.1.3.2. O sambaqui Cachoeira Mirim } & 104\end{array}$

$\begin{array}{ll}\text { 2.1.1.3.3. O sambaqui Branco } & 113\end{array}$

2.1.1.3.4. O sambaqui llha do Cambriu $\quad 125$

2.1.2. Os sambaquis do estado de São Paulo 126

2.2. A PROPOSTA ANALÍTICA 129

2.2.1. Coleta e seleção de amostras 130

2.2.2. Datações radiocarbônicas 132

2.2.3. Modelo de predição 134

2.2.4. Análises isotópicas 140

$\begin{array}{ll}\text { 2.2.4.1. Isótopos radiogênicos: estrôncio } & 141\end{array}$

$\begin{array}{ll}\text { 2.2.4.2. Isótopos estáveis: carbono e oxigênio } & 148\end{array}$

2.2.4.2.1. Composição isotópica dos elementos carbono e oxigênio 150

$\begin{array}{ll}\text { 2.2.4.2.2. O processo analítico } & 153\end{array}$

$\begin{array}{lll}\text { 2.2.4.2.3. Conjunto amostral } & 155\end{array}$ 
3. INTERVENÇÕES ARQUEOLÓGICAS 162

3.1. O SAMBAQUI CAMBRIU GRANDE 162

3.2. O SAMBAQUI CACHOEIRA MIRIM 165

4. ISÓTOPOS RADIOGÊNICOS 167

4.1. AS RAZÕES ISOTÓPICAS DE SÃO PAULO 172

4.1.1. As razões isotópicas do litoral de São Paulo 172

4.1.2. As razões isotópicas a partir de uma perspectiva temporal 174

4.1.3. A dispersão das razões isotópicas de cada conjunto 177

4.2. AS RAZÕES DO LITORAL DE SÃO PAULO VERSUS SANTA CATARINA

4.3. ANÁLISE COMPARATIVA ENTRE OS TIPOS DE VESTÍGIOS ANALISADOS 186

$\begin{array}{lll}\text { 5. ISÓTOPOS ESTÁVEIS } & 194\end{array}$

5.1. A DISTRIBUIÇÃO TEMPORAL DAS RAZÕES ISOTÓPICAS DE CARBONO E 197 OXIGÊNIO

5.2. O SIGNIFICADO DA VARIAÇÃO DAS RAZÕES ISOTÓPICAS 204

6. MODELO DE PREDIÇÃO $\mathbf{2 1 6}$

6.1. UM MODELO GERAL PARA A COSTA BRASILEIRA 216

6.1.1. A chegada ao litoral através de uma região atualmente submersa 226

6.1.2. A chegada através do interior 231

6.2. UM MODELO ESPECÍFICO PARA A COSTA DO ESTADO DE SÃO PAULO 240

6.2.1. A ocupação do litoral do estado de São Paulo 244

6.2.2. As conexões com os sítios do médio curso do Ribeira 254

$\begin{array}{ll}\text { CONSIDERAÇÕES FINAIS } & 260\end{array}$

$\begin{array}{ll}\text { CONCLUSÃO } & 267\end{array}$

REFERÊNCIAS BIBLIOGRÁFICAS

$\begin{array}{lr}\text { ANEXOS } & 290\end{array}$ 


\section{LISTA DE FIGURAS}

Figura 0.01 - Mapa de localização do baixo Vale do Ribeira

Figura 0.02 - Mapa do estado de São Paulo com a localização aproximada dos sambaquis analisados através da análise das razões isotópicas do estrôncio.

Figura 1.01 - Representação de um pescador do Rio Kaveri (sul da Índia) usando um flutuador de natação

Figura 1.02 - Miniatura de balsa de junco encontrada, no norte do Chile

Figura 1.03 - Painel Casa Santa, Carnaúba dos Dantas, RN (Borges, 2008)

Figura 1.04 a 1.07 - Prováveis representações de pirogas (classificadas como da tradição nordeste) em abrigos sob rocha da região do Seridó, Rio Grande do Norte

Figura 1.08 - Representações de pirogas encontradas no sítio Pedra do Alexandre, em Carnaúba dos Dantas

Figura 1.09 - Mapa hidrográfico do Rio Grande do Norte

Figura 2.01 - Estágios evolutivos da planície costeira de Cananéia-Iguape

Figura 2.02 - Datações dos sambaquis da costa brasileira por classes de idade

Figura 2.03 - Curva de Variação do Nível Relativo do Mar para a costa brasileira

Figura 2.04 - Curvas de Variação do Nível Relativo do Mar para a região de Cananéia, SP

Figura 1.05 - Correlação da distribuição temporal dos sambaquis com a curva de variação do nível relativo do mar elaborado

Figura 2.06 - Hipóteses para a ocupação da porção sul do baixo vale do Ribeira

Figura 2.07 - Hipóteses para a ocupação de todo o baixo vale do Ribeira

Figura 2.08 - Hipótese para a chegada dos sambaquieiros à atual área do Baixo vale do Ribeira

Figura 2.09 - Sítio conchífero Espírito Santo e abrigo Maximiniano

Figura 2.10 - Implantação e vistas do sambaqui Moraes, Miracatu, SP

Figura 2.11 - Imagens de um dos perfis e área de escavação do sambaqui Capelinha

Figura 2.12 - Mapa de localização dos sambaquis analisados em Cananéia

Figura 2.13 - Samba Cambriu Grande

Figura 2.14 - Vista da face sul do sambaqui Cambriu Pequeno

Figura 2.15 - Mapa geomorfológico da região do Cambriu com a posição dos sambaquis

Figura 2.16 - Hipótese da ocorrência dos sambaquis Cambriu Pequeno e Grande

Figura 2.17 - Testemunho realizado no sambaqui Cambriu Grande

Figura 2.18 - Vista a partir da Ponta do Cambriu

Figura 2.19 - Perfil esquemático do sambaqui Cambriu Grande

Figura 2.20 - Obtenção de testemunho junto à base do perfil oeste do sambaqui Cambriu Grande

Figura 2.21 - Obtenção de testemunho junto ao perfil leste do sambaqui Cambriu Grande

Figura 2.22 - Porção do sambaqui Cambriu Grande impacta por queda da árvore 
Figura 2.23 - Evidenciação do perfil e detalhe da seqüência estratigráfica evidenciada do sambaqui Cambriu Grande

Figura 2.24 - Vista superior das duas metades do testemunho retirado da base do perfil evidenciado na face leste do sambaqui Cambriu Grande

Figura 2.25 - Detalhe da localização do sambaqui Cachoeira Mirim, que se encontrada recoberto pela vegetação

Figura 2.26 - Detalhe do mangue que recobre a feição arenosa e parte dos vestígios erodidos

Figura 2.27 - Croquis do sambaqui Cachoeira Mirim, com a posição dos testemunhos subaquáticos

Figura 2.28 - Testemunhos subaquáticos realizados no sambaqui Cachoeira Mirim

Figura 2.29 - Perfil inferido do sambaqui Cachoeira Mirim com a posição dos testemunhos

Figura 2.30 - Testemunhos retirados junto à base do sambaqui Cachoeira Mirim

Figura 2.31 - Imagem vértice do perfil nordeste do poço teste de coleta

Figura 2.32 - Perfil do poço teste

Figura 2.33 - Testemunho retirado da base da sondagem

Figura 2.33 - Testemunho retirado da base da sondagem

Figura 2.34 - Vista da porção sudoeste do sambaqui Branco

Figura 2.35 - Vista do perfil exposto do sambaqui Branco a partir do Canal do Ararapira

Figura 2.36 - Área de mangue que margeia o sambaqui Branco

Figura 2.37 - Vista da feição arenosa sobre a qual o sambaqui Branco foi construído

Figura 2.38 - Croquis do sambaqui Branco com a posição dos testemunhos

Figura 2.39 - Testemunhos a percussão realizados no sambaqui Branco

Figura 2.40 - Perfil inferido do sambaqui Branco

Figura 2.41 - Uma das metades do testemunho C01

Figura 2.42 - Sambaqui Pereirinha III

Figura 2.43 - Ilha do Cambriu, com o local do sambaqui

Figura 2.44 - Mapa com a localização aproximada dos sambaquis analisados ao longo do litoral do estado de São Paulo e Vale do Ribeira

Figura 2.45 e 2.46 - Amostragem com a utilização de amostrador tipo vibracorer

Figura 2.47 - Croquis da posição da amostra coletada no sambaqui Cachoeira Mirim

Figura 2.48 - Croquis da localização das amostras coletadas, no sambaqui Cambriu Grande

Figura 2.49 - A costa do Golfo e posição aproximada das paleolinhas de costa

Figura 2.50 - Distribuição dos paleovales e paleoníveis marinhos ao longo da plataforma continental submersa adjacente ao litoral do estado de São Paulo

Figura 2.51 - Mapa Batimétrico da Margem Sul da Plataforma Continental Brasileira

Figura 2.52-Mapa Fisiográfico da Região Oceânica Sul da Plataforma Continental Brasileira

Figura 2.53 - Processo de limpeza através de ultra-som

Figura 2.54 - Utilização de broca odontológica para a preparação das amostras (dentes e ossos)

Figura 2.55 - Dentes e ossos antes e depois do processo de preparação das amostras 
Figura 2.56 - Conchas antes e depois do processo de lavagem com água deionizada e ultra-som

Figura 3.01 - Localização e posicionamento dos testemunhos coletados no sambaqui Cambriu Grande

Figura 3.02 - Detalhes da seqüência de camadas arqueológicas identificadas no sambaqui Cambriu Grande

Figura 4.01 - Dispersão das razões isotópicas do estrôncio presentes nos sambaquis do litoral e do médio vale do Ribeira

Figura 4.02 - Dispersão das razões isotópicas do estrôncio presentes nos sambaquis do litoral (dois conjuntos à esquerda) e do médio vale do Ribeira (direita)

Figura 4.03 - Mapa da porção sul/sudeste do estado de São Paulo, com a correlação dos conjuntos de sambaquis e os compartimentos geológicos do litoral e do Vale do Ribeira

Figura 4.04 - Dispersão das razões isotópicas do estrôncio presentes nos sambaquis do litoral sul

Figura 4.05 - Distribuição temporal das razões isotópicas de estrôncio

Figura 4.06 - Distribuição temporal das razões isotópicas de estrôncio

Figura 4.07 - Dispersão das razões isotópicas do estrôncio presentes nos sambaquis do litoral norte e centro-sul

Figura 4.08 - Amplitude dos valores das razões isotópicas do estrôncio presente nos sítios do litoral sul e centro do estado de São Paulo

Figura 4.09 - Dispersão da razão isotópica do estrôncio presentes nos sambaquis do estado de São Paulo e do litoral de Santa Catarina

Figura 4.10 - Boxplot das razões isotópicas dos indivíduos sepultados nos níveis cerâmicos e précerâmicos do sítio Forte Marechal Luz

Figura 4.11 - Dispersão das razões isotópicas do estrôncio presentes nos sambaquis do litoral do estado de São Paulo

Figura 4.12 - Razões isotópicas do estrôncio relativo aos diferentes tipos de ossos e dentes analisados (sítios do litoral e médio ribeira)

Figura 4.13 - Razões isotópicas do estrôncio relativo aos diferentes tipos de ossos e dentes analisados (sítios do baixo Ribeira, Baixada Santista e litoral norte)

Figura 4.14 - Razões isotópicas do estrôncio relativo aos diferentes tipos de ossos e dentes analisados (sítios do baixo Ribeira e Baixada Santista)

Figura 5.01 - Razão isotópica do carbono presente nas conchas dos quatro sítios analisados

Figura 5.02 - Razão isotópica do oxigênio presente nas conchas dos quatro sítios analisados

Figura 5.03 - Correlação das razões isotópicas do Carbono e do Oxigênio presentes nas conchas dos sambaquis Branco, Ilha do Cambriu, Cachoeira Mirim e Cambriu Grande

Figura 5.04 - Relações idealizadas entre o ambiente e a composição isotópica das conchas

Figura 5.05 - Razões isotópicas do Carbono e do Oxigênio presente nas conchas dos três sítios contemporâneos ao último grande máximo transgressivo holocênico

Figura 5.06 - Perfil esquemático do sambaqui branco. 
Figura 5.07 - Razões isotópicas do carbono e do oxigênio presente nas conchas do sambaqui Branco

Figura 5.08 - Razões isotópicas do carbono e do oxigênio presente nas conchas dos sambaquis Cachoeira Mirim e Ilha do Cambriu

Figura 5.09 - Razões isotópicas do carbono e do oxigênio presente nas conchas do sambaqui Cambriu Grande

Figura 5.10 - Correlação das curvas de variação do nível relativo do mar com a distribuição temporal das razões isotópicas do carbono presente nas conchas dos quatro sítios analisados

Figura 5.11 - Correlação das curvas de variação do nível relativo do mar com a distribuição temporal das razões isotópicas presente nas conchas dos quatro sítios analisados

Figura 6.01 - Modelo de predição de sambaquis submersos ao longo da plataforma continental brasileira

Figura 6.02 - Detalhe do modelo de predição de sambaquis submersos para a costa sudeste

Figura 6.03 - Rota costeira de dispersão de populações paleoindígenas (DIXON, 1999; 2001)

Figura 6.04 - Rota costeira de dispersão de populações paleoindígenas (NEVES et al, 2003)

Figura 6.05 - Mapeamento dos antigos e atuais limites da costa brasileira, com as prováveis rotas de migração ao longo do litoral e das bacias hidrográficas.

Figura 6.06 - Ponta de projétil (tradição Umbu) encontrada em uma praia atlântica da região do Albardão, entre os municípios de Chuí e Rio Grande (RS)

Figura 6.07 - Mapa de localização do rio Aucilla e imagem dos anzóis em osso

Figura 6.08 - Pontas de projétil e artefato em marfim encontrados em sítios do rio Aucilla, Flórida

Figura 6.09 - Conjuntos de paleovales entre Santos e Vitória

Figura 6.10 - Modelo de predição com as principais rotas de chegada ao litoral via interior e posterior dispersão ao longo do litoral

Figura 6.11 - Ponta de projétil serrilhada encontrada no abrigo RS- TQ:58

Figura 6.12 - Dentes de Tubarão e conchas costeiras encontrada no abrigo RS- TQ:58

Figura 6.13 - Pesos de rede, utilizados por populações indígenas norte americanas

Figura 6.14 - Diferentes tipos de peso de rede (períodos pré-histórico, galo romano e atual) provenientes da França

Figura 6.15 - Artefatos em osso (polido) que poderiam ser utilizadas como anzóis (sambaquis do litoral centro e sul do Rio Grande do Sul)

Figura 6.16 - Esquema para utilização em anzol; gravura (sobre galhada de rena) que representa um peixe engolindo um anzol (magdaleniense francês; anzol em madeira atualmente utilizado no sudoeste da França; e esquema para a preparação de anzóis em osso

Figura 6.17 - Pingentes peças de uso desconhecido (litoral centro e sul do Rio Grande do Sul) que poderiam ser pesos de rede, pesos para anzóis e enxós

Figura 6.18 - Distribuição dos paleovales submersos (ao longo da porção sumersa da plataforma continental do estado de São Paulo) em relação à posição do atual litoral brasileiro e às antigas linhas de costa 
Figura 6.19 - Modelo de predição de sambaquis submersos ao longo da plataforma continental do estado de São Paulo

Figura 6.20 - Perfis estratigráficos dos sambaquis Jabuticabeira II e Cachoeira Mirim

Figura 6.21 - Vista da superfície e das intervenções realizadas nos sambaquis llha do Mar Virado e Ilha da Boa Vista I

Figura 6.22 - Duas vistas de um enxó e um esquema de sua utilização

Figura 6.23 - Esquema dos ângulos de incidência de um enxó sobre a madeira

Figura 6.24 - Desenho esquemático e detalhe da borda de um machado

Figura 6.25 - Desenho esquemático e detalhe da borda de um enxó

Figura 6.26 - Modelo esquemático da ocupação do Vale do Ribeira

Figura 6.27 -. Diagrama de percentagens de polens arbóreos encontrados ao longo da cratera Colônia, localizada na periferia da cidade de são Paulo 


\section{LISTA DE TABELAS}

Tabela 2.01 - Idade dos sambaquis do baixo Vale do Ribeira analisados

Tabela 2.02 - Idade e localização dos sambaquis ao longo do litoral do estado de São Paulo e Vale do Ribeira

Tabela 2.03 - Idade e profundidade dos paleoníveis marinhos utilizados como referência

Tabela 2.04 - Amostras de ossos e dentes humanos utilizadas para a realização das análises isotópicas de estrôncio

Tabela 2.05 - Conjunto amostral das análises isotópicas de carbono e oxigênio

Tabela 3.01 - Datações radiocarbônicas realizadas nos sambaqui Cambriu Grande

Tabela 3.02 - Datações radiocarbônicas realizada no sambaqui Cachoeira Mirim

Tabela 4.01 - Composição isotópica do estrôncio presente em ossos e dentes humanos provenientes de sambaquis do litoral de São Paulo e vale do Ribeira

Tabela 5.01 - Caracterização das amostras e apresentação dos resultados das análises isotópicas de carbono e oxigênio 


\section{INTRODUÇÃO}

Nas últimas décadas as pesquisas em sambaquis vêm atravessando um período de intensas inovações teóricas e metodológicas que revolucionaram a maneira como os sítios e os povos que os construíram vinham sendo compreendidos. De simples acúmulos de restos de comida, os sambaquis passaram a ser entendidos também como estruturas verdadeiramente construídas, imbuídas de intencionalidade, de monumentalidade e de um forte significado simbólico, cujos construtores organizavam-se em sociedades que, segundo De Blasis et al. (2007), encontravam-se em um processo de complexificação social.

Procurando contribuir com a consolidação dessa nova maneira de conceber os sambaquis e o sistema sócio-cultural de seus construtores, foi desenvolvida no âmbito desta Tese uma proposta que procura compreender os povos dos sambaquis como organizados em comunidade marítimas, para as quais os ambientes aquáticos deixariam de ser somente um local de captação de recursos e vias de circulação para se tornarem parte de um espaço percebido e incorporado às suas práticas sociais econômicas e simbólicas. Espaço em meio ao qual os povos dos sambaquis teriam aprendido, produzido, acumulado e transmitido conhecimentos desenvolvidos com base na transformação de seu meio e em sua própria modificação a partir de uma relação dialética com a natureza.

A fim de sustentar tal hipótese, foi desenvolvida uma abordagem teóricometodológica que considera os elementos materiais presentes nos sambaquis do baixo Vale do Ribeira (figura 1.01) como indicadores da percepção do ambiente marítimo, de sua apropriação cultural e da maritimidade dos povos dos sambaquis. Abordagem essa fundamentada, principalmente, em propostas provenientes da Arqueologia marítima (DELGADO, 1997; ADAMS, 2002;), da Antropologia marítima (DIEGUES, 1998, 2000; MALINOWSKI, 1986 [1922] ${ }^{1}$ ), da Sociologia Ambiental (HERRERA, 2002; MAYORGA, 2006), de análises de Percepção Ambiental

\footnotetext{
${ }^{1}$ Ainda que Malinowski não seja considerado um Antropólogo marítimo, ele é aqui compreendido nesse contexto (junto com os autores que adotam tal perspectiva) em conseqüência do detalhado registro antropológico e etnográfico que desenvolveu a respeito das sociedades marítimas tobriandesas, os quais são de suma importância para a fundamentação da abordagem marítima proposta nesta Tese.
} 
(INGOLD, 2000) e do estudo dos processos de formação do registro arqueológico (SCHIFFER, 1972; STEIN, 2000).

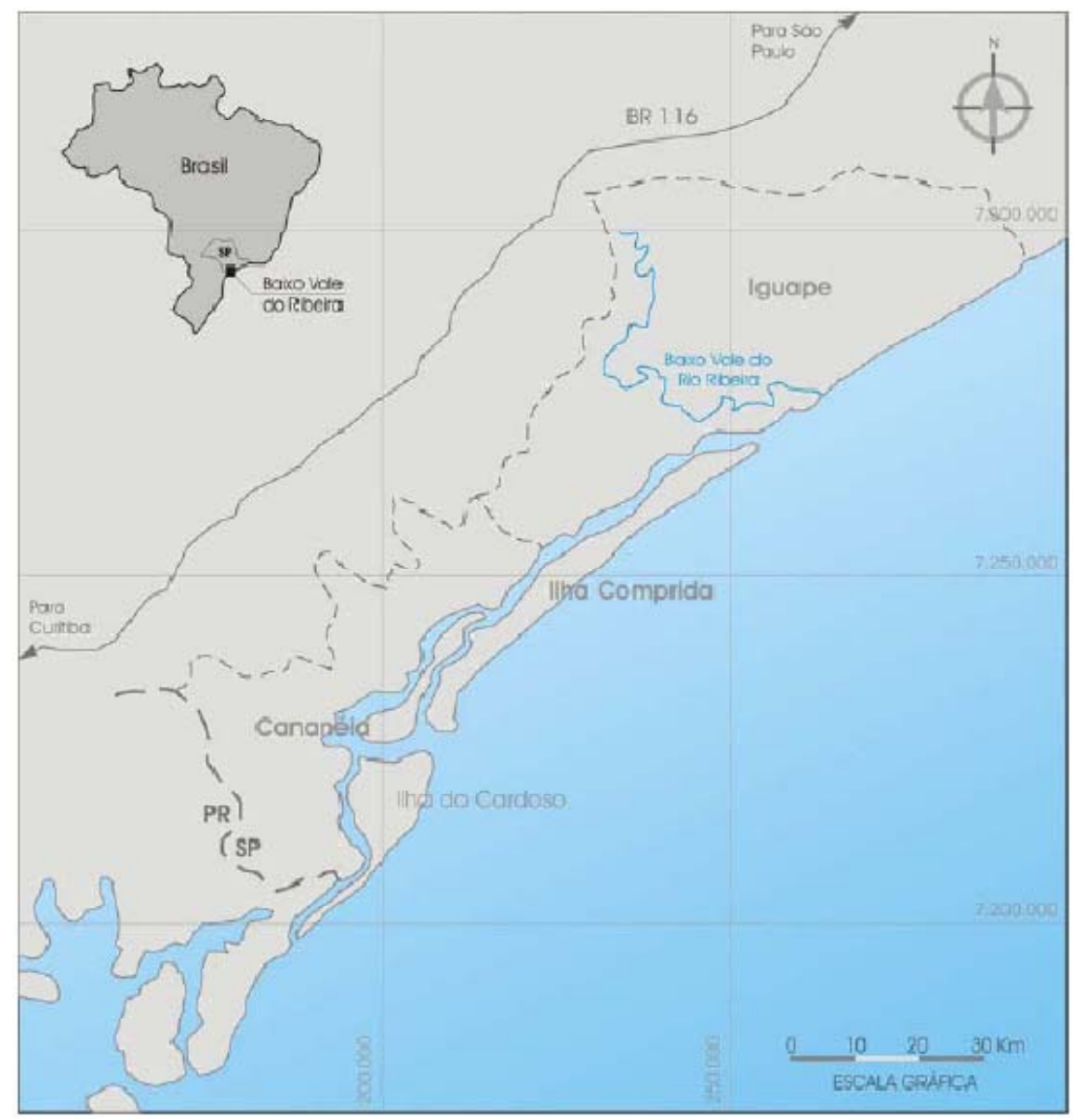

Figura 0.01 - Mapa de localização do baixo Vale do Ribeira

Além de contribuir com novas discussões a respeito do estabelecimento de territórios, da sedentarização, da mobilidade e da adoção ou desenvolvimento de técnicas e tecnologias náuticas, tal abordagem objetiva ainda a proposição de um olhar marítimo em relação à organização social dos povos dos sambaquis, através do qual o sistema sócio-cultural dos povos dos sambaquis possa ser compreendido de uma forma mais integrada ao ambiente marinho.

Do ponto de vista do estudo dos processos de formação do registro arqueológico, a proposta desta Tese também é uma continuidade das pesquisas desenvolvidas ao longo da dissertação de mestrado intitulada Os Sambaquis 
Submersos de Cananéia, SP: um Estudo de Caso de Arqueologia Subaquática² (CALIPPO, 2004), na qual, através do estudo do processo de formação de alguns sambaquis de Cananéia, foi possível obter uma compreensão inicial da ocupação sambaquieira da região do baixo Vale do Ribeira. Neste trabalho foram formuladas hipóteses a respeito da chegada dos povos dos sambaquis a essa região e das conseqüências das intensas modificações ambientais holocênicas para a formação e a preservação dos sambaquis.

A presente tese, também realizada de forma integrada ao Projeto Arqueológico do Baixo Vale do Ribeira ${ }^{3}$, mais do que considerar os fatores ambientais que modificaram o meio no qual os sambaquieiros se inseriam, buscou compreender como e em que medida as modificações ambientais e os próprios ambientes eram percebidos e incorporados às práticas sociais dos sambaquieiros.

Assim, uma vez estabelecidas as principais características paleoambientais e os impactos gerados sobre o registro arqueológico dos sambaquis, foram agora pesquisados os modos pelos quais os indivíduos se relacionavam com a natureza e as conseqüências dessa interação na organização sócio-cultural sambaquieira.

Para substanciar tal pesquisa, foi desenvolvida uma proposta analítica fundamentada, principalmente, na utilização da composição isotópica do carbono, oxigênio (estáveis) e estrôncio (radiogênico), presentes em conchas e em ossos humanos provenientes de sambaquis, como indicadores dos ambientes de coleta dos sambaquieiros de Cananéia e da sedentarização e mobilidade entre os conjuntos de sambaquis do baixo Vale do Ribeira, do médio curso do rio Ribeira de Iguape, da Baixada Santista e do litoral norte do estado de São Paulo (figura 0.02).

Como tais relações desenrolaram-se em meio a um espaço que se encontrava em constante transformação, em um segundo momento foi estabelecida uma seqüência temporal que também contextualizasse o entendimento desses processos em meio às profundas mudanças ambientais holocênicas. Em conseqüência de na região do Vale do Ribeira estarem localizados alguns dos sambaquis (costeiros e

\footnotetext{
${ }^{2}$ Dissertação de Mestrado realizada no âmbito do Programa Arqueológico do Baixo Vale do Ribeira, sob a orientação da Profa. Dra. Maria Cristina Mineiro Scatamacchia (MAE/USP).

3 Projeto coordenado pela Profa. Dra. Maria Cristina Mineiro Scatamacchia e financiado pela Fundação de Amparo à Pesquisa do Estado de São Paulo (FAPESP).
} 
fluviais) mais antigos conhecidos, a elaboração dessa cronologia teve início a partir da importância da antiguidade (entre 8.000 e 10.000 anos AP) da ocupação dessa região para a discussão das origens de uma sociedade sambaquieira que dominou grande parte do atual litoral brasileiro.

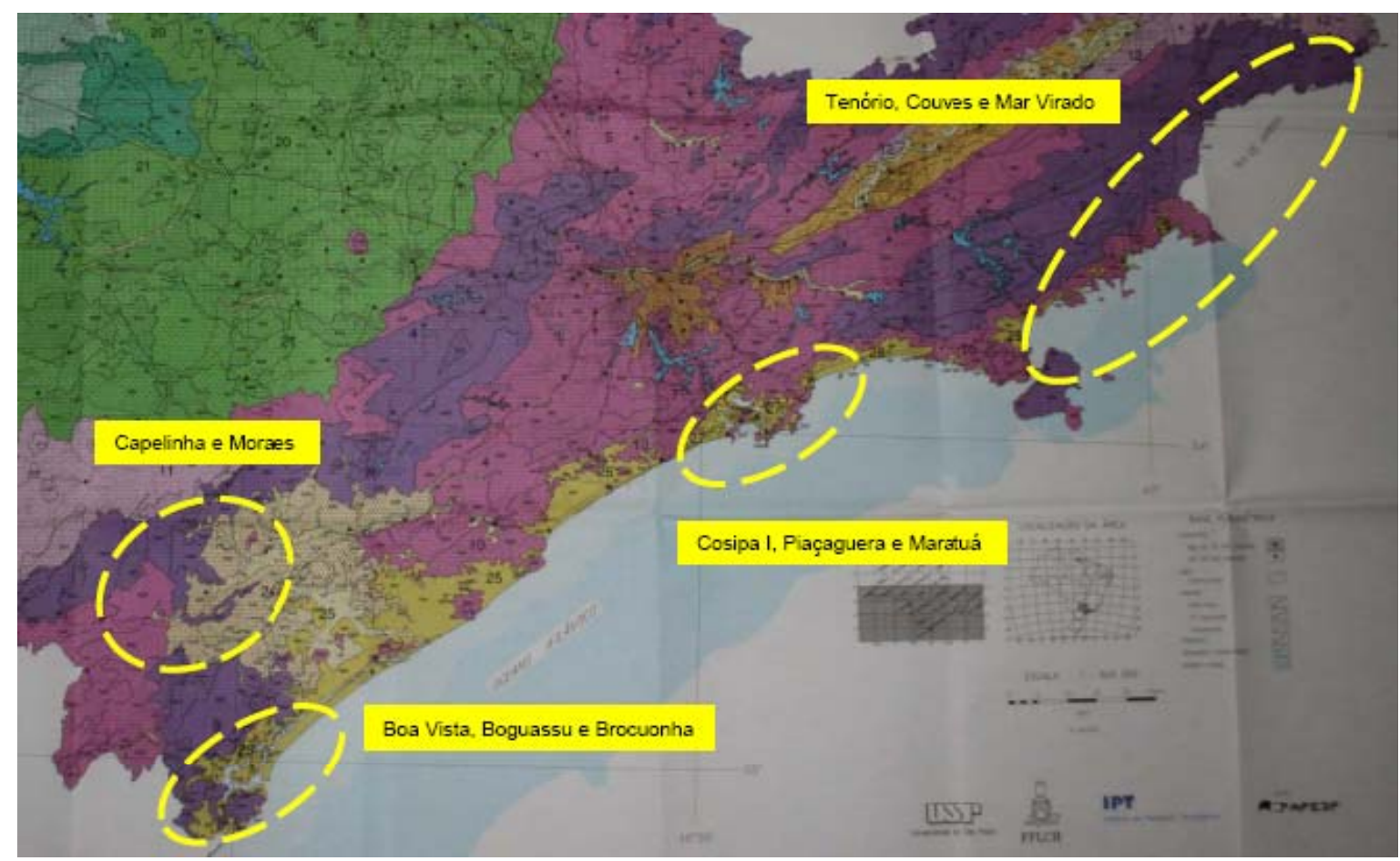

Figura 0.02 - Mapa do estado de São Paulo com a localização aproximada dos sambaquis estudados através da análise das razões isotópicas do estrôncio.

Embora tal pesquisa tenha se desenvolvido a partir da construção de um modelo de predição de sítios pré-históricos submersos (proposto por WATERS, 1992) que enfatiza, em maior detalhe, o Vale do Ribeira e o litoral do estado de São Paulo, essa abordagem foi também utilizada para analisar e propor hipóteses a respeito das lacunas existentes entre as principais áreas de concentração de sambaquis ao longo do litoral brasileiro.

Assim, com o intuito de desenvolver uma Tese que contribua tanto para uma melhor compreensão do contexto em que se deu a ocupação sambaquieira do baixo Vale do Ribeira como para o estabelecimento de uma abordagem marítima a respeito das percepções ambientais e da organização sócio-cultural dos povos dos 
sambaquis, foi desenvolvida uma estrutura subdividida em duas partes. As quais, juntas, abrangem um total em seis capítulos.

Na primeira delas, intitulada Encaminhamentos da Pesquisa, são apresentados, respectivamente, em dois capítulos iniciais (recorte amostral e proposta analítica), os pressupostos teóricos que norteiam a Tese e as estratégias de pesquisa utilizadas para estabelecer uma análise dos dados que tenha como elemento norteador uma relação indissociável em teoria, método e técnica.

De um modo geral, ao longo dos pressupostos teóricos são apresentadas as compreensões que nos permitem pesquisar e discutir os sambaquieiros como parte de uma sociedade marítima, investigando a percepção que tinham de seu meio e identificando as evidências que possibilitam compreendê-los arqueologicamente sob essa perspectiva.

No que tange à proposta analítica, além da apresentação da metodologia empregada e da breve caracterização da área de pesquisa, são explicitadas, também, as intervenções realizadas nos sambaquis da região de Cananéia e a proveniência das amostras utilizadas para o estudo da composição isotópica dos sítios do estado de São Paulo.

Em uma segunda parte, que se encontra subdivida em três capítulos (quarto, quinto e sexto capítulos), são apresentados e discutidos os principais resultados da Tese. No primeiro desses capítulos (Capítulo 4 - Intervenções Arqueológicas), encontram-se os resultados das intervenções arqueológicas e das datações por radiocarbôno realizadas nos sambaquis.

No quinto e sexto capítulos, são apresentados e discutidos os resultados das análises dos isótopos estáveis (carbono e oxigênio) e radiogênicos (estrôncio), realizadas, respectivamente, com o intuito de compreender os modos através dos quais os sambaquieiros relacionar-se-iam com os ambientes aquáticos e, também, os seus padrões de mobilidade e territorialidade ao longo do litoral.

No sexto e último capítulo, é apresentado o modelo de predição de sambaquis submersos, o qual se encontra subdivido em duas partes: uma mais geral, abordando toda a costa brasileira, e, outra, mais específica, que diz respeito somente ao estado de São Paulo. 
Embora tal modelo fundamente-se, principalmente, na análise da porção submersa da plataforma continental e na distribuição das áreas mais prováveis para a ocorrência de sítios submersos pré-históricos, são propostos (a partir da correlação dessas informações com o resultado de praticamente todas as análises realizadas) novos argumentos e hipóteses a respeito das descontinuidades entre as principais concentrações de sambaquis e sobre as fronteiras culturais que surgiriam entre as diversas comunidades sambaquieiras (marítimas ou não) responsáveis pela construção desses sítios. 


\section{OBJETIVOS}

OBJETIVO GERAL

Desenvolver e testar a hipótese de que, embora houvesse uma unidade cultural que permitisse o estabelecimento de uma ampla sociedade sambaquieira, os povos dos sambaquis estariam organizados em comunidades costeiras regionais. Em conseqüência dos diferentes modos com que se relacionariam (dialeticamente) com o ambiente, tais comunidades teriam se desenvolvido e organizado em comunidades marítimas, costeiras e fluviais.

\section{OBJETIVOS ESPECÍFICOS}

Apresentar, discutir e propor novas abordagens teóricas, focadas em perspectivas marítimas (MUCKELROY, 1978; DELGADO, 1997; ADAMS, 2002) e sócio-ambientais (HERRERA, 2002; MAYORGA, 2006; INGOLD, 2000) que nos permitam identificar e contextualizar novas evidências a respeito das relações socioambientais desenvolvidas pelos povos dos sambaquis.

Desenvolver e testar a possibilidade de que os povos dos sambaquis possam ter se organizado em uma sociedade sambaquieira diversa, formada tanto por comunidades fluviais e costeiras quanto marítimas. Esta possibilidade está fundamentada, principalmente, no estudo de Malinowski (1986) [1922] a respeito de sociedades marítimas e nas abordagens transigualitárias de sociedades pecadorascoletoras (HAYDE, 1995; TENÓRIO, 2004). 
Adaptar métodos e técnicas de análise já comumente utilizados em outras áreas científicas, a fim de ampliar os tipos de evidências e os estudos que possam contribuir com novos argumentos e hipóteses a respeito da compreensão dos povos dos sambaquis.

Aumentar o número de datações por radiocarbôno para os sambaquis do baixo Vale do Ribeira, bem como o conhecimento a respeito de seus processos formativos.

Ampliar o conhecimento arqueológico produzido a respeito da percepção ambiental dos sambaquieiros e dos modos através dos quais eles explorariam os recursos dessa região, tendo como referência a análise da composição isotópica de elementos estáveis (carbono e oxigênio) (KEITH et al, 1964; COSTA, 2000; MIZUTA, 2007) presentes nos sambaquis de Cananéia.

Propor uma hipótese inicial a respeito da mobilidade e dos territórios estabelecidos pelos povos dos sambaquis, partindo da realização de análises da composição isotópica do estrôncio (isótopo radiogênico) (HÖLZL, 1997; PRICE et al., 2000; BENTLEY et al, 2003; HODELL, 2004) presente em ossos e dentes humanos provenientes de sambaquis do litoral do estado de São Paulo e, também, do médio vale do rio Ribeira de Iguape.

Desenvolver um modelo de predição de sambaquis submersos que possa apontar a localização de prováveis sítios mais antigos do que 8.000 anos AP, utilizando-se, principalmente, dados provenientes de estudos oceanográficos e de geologia marinha (Projeto REMAC, 1979; KOWSMANN e COSTA, 1979; FURTADO et. al, 1998; KLEIN, 2005; CONTI, 2004). 
Propor um modelo de ocupação sambaquieira que seja capaz de explicar as descontinuidades, as semelhanças e as diferenças entre os diversos conjuntos de sambaquis e, a partir do modelo de predição de sítios arqueológicos submersos (WATERS, 1992), possa também apontar tanto as possíveis rotas de chegada à costa brasileira como a influência dos últimos grandes eventos holocênicos de flutuação do nível relativo do mar.

Correlacionar os resultados do modelo de ocupação sambaquieira com as informações sobre a mobilidade e a territorialidade apontadas pela análise dos isótopos de estrôncio, com a finalidade de se propor o estabelecimento de diferentes comunidades ou subsistemas sambaquieiros ao longo da região que hoje abrange o estado de São Paulo. 


\section{PARTE I - ENCAMINHAMENTO DA PESQUISA}

Por quase 8.000 anos os povos dos sambaquis distribuíram-se ao longo de uma extensa área litorânea, dominando grande parte das regiões costeiras que atualmente compõe o litoral brasileiro e deixando o registro de sua presença. Visando a compreensão da presença desses povos em meio a um espaço que se encontra em contínuo processo de transformação, foi adotado um posicionamento teórico que entende os povos dos sambaquis como um conjunto de comunidades que, em diferentes graus, estabeleceram relações materiais e simbólicas com o mar. Compreensão que aqui é estabelecida a partir de um olhar marítimo e sócioambiental, onde se procura compreender os sambaquieiros como uma sociedade que vive tanto o mar quanto vive a terra.

Do mesmo modo que esses olhares requerem a construção de um posicionamento teórico específico, demandam, por outro lado, o estabelecimento de uma abordagem metodológica que possa servir de elo entre os olhares marítimos e os vestígios materiais deixados pelos povos dos sambaquis. Embora entendamos que essas duas esferas, teóricas e metodológicas, devam ser consideradas de forma integrada, a fim de facilitar a compreensão do leitor, elas são aqui dispostas em dois momentos distintos.

Em uma primeira parte são discutidos os pressupostos teóricos que dizem respeito à construção desse olhar marítimo. Em uma outra, intitulada As estratégias de pesquisa, é apresentada a metodologia adotada para a análise dos sambaquis e as suas correlações com os posicionamentos teóricos assumidos. 


\section{PRESSUPOSTOS TEÓRICOS}

\subsection{OS SAMBAQUIS SOB O PONTO DE VISTA DA ARQUEOLOGIA MARÍTIMA}

Para desenvolver a hipótese de que a sociedades sambaquieira pode ser concebida como uma sociedade marítima, foi necessário, em primeiro lugar, estabelecer uma proposta teórica e metodológica que fosse capaz de levar em consideração tanto as especificidades dos ambientes aquáticos como a dos ambientes terrestres. Isso porque, mesmo entendendo que os povos dos sambaquis desenvolviam práticas sócio-culturais diferenciadas em conseqüência do distinto valor social, econômico ou simbólico que, segundo Geistdoerfer (1989, p. 7 apud DIEGUES, 1998, p. 57), as sociedades marítimas dão ao mar ou a seus recursos, no caso dos sambaquieiros, parte dessas práticas também envolve ambientes ou estão associadas a um universo que não está, necessariamente, ligado ao mar.

Assim, a construção desta Tese teve inicio a partir do estabelecimento de um arcabouço teórico que se fundamenta em uma Arqueologia marítima preocupada em identificar e compreender quais os comportamentos e elementos materiais do modo de vida sambaquieiro se encontram associados ao universo marítimo dos povos dos sambaquis.

Essa compreensão dos sambaquieiros como uma sociedade marítima, cujo universo cultural extrapola os limites do ambiente marinho, encontra similaridades em uma proposta de Arqueologia marítima sugerida por Adams (2002), para quem a Arqueologia marítima é o estudo da interação humana e das manifestações materiais de culturas marítimas com os diversos tipos de ambientes aquáticos.

The study of human interaction with the sea, lakes, and rivers through the archaeological study of material manifestations of maritime culture, including vessels, shore-side facilities, cargoes, and even human remains (DELGADO, 1998, p. 259).

Embora a compreensão de Adams (op. cit.) constitua-se como uma proposição ainda pouco explorada pela própria Arqueologia marítima, ela é aqui adotada e desenvolvida pois suscita novas possibilidades para a construção de uma 
interpretação a respeito de um modo de vida cujas práticas sociais, culturais ou simbólicas possam estar associadas tanto ao mar quanto à terra.

Do ponto de vista teórico, tal proposta pode ser entendida como uma continuidade da Arqueologia marítima criada por Keith Muckelroy que, no final dos anos de 1970, procurando superar a visão histórico-culturalista então predominante na Arqueologia praticada no mar, propôs que os arqueólogos começassem a estabelecer como principal objetivo o homem e não mais os artefatos (navios, cargas, etc.) perdidos no mar. Muckelroy enfatizava que, nesse processo, também fosse levado em consideração tudo aquilo que está conectado com a vida no mar e não somente os restos dos navios e dos barcos que nele se encontram.

Above all, it should be noted that the primary object of study is man [...] and not the ships, cargoes, fittings, or instruments with which the researcher is immediately confronted (MUCKELROY, 1978, p. 03)

Com base na Arqueologia marítima desenvolvida por Muckelroy - na época definida como sendo "o estudo científico dos vestígios materiais do homem e de suas atividades do mar" (MUCKELROY, 1978, p. 05), Adams (2002) sugere uma abordagem mais abrangente, a qual, ao mesmo tempo em que supera a "compreensão da pesca e da faina do mar como uma sub-cultura distinta" (HASSLÖF, 1972, p. 15-17), permite que tanto as evidências marítimas (apontadas por Muckelroy), como as terrestres sejam utilizadas para entender o universo marítimo e as relações que os povos estabeleciam com o mar.

Nesse sentido, a proposta de Adams se alinha com uma nova corrente da Arqueologia Marítima que, segundo Duran (2008, p. 92), busca o rompimento com as limitações geográficas do mundo submarino (como impostas por Muckelroy, op. cit.), com o foco específico nos sítios de naufrágios (como sugerido por este e desenvolvido por Gibbins, 1990), e a inclusão dos elementos terrestres associados, de uma maneira ou de outra, ao universo marítimo. Assim, os sítios abordados pela Arqueologia marítima se encontrariam tanto em terra como no mar, e, mais do que o ambiente onde ocorrem (ou da maneira que devemos utilizar para acessá-los), o que mais importa são as compreensões dos processos e as correlações com o universo marítimo que estão preservadas em seu interior (FONTENOY, 1998). 
Sites pertinent to the sub discipline of maritime archaeology exist both on land and underwater [...] Maritime archaeologists need to appreciate that it is the subject matter of sites that is distinctive, not that diving is necessary to reach them. (FONTENOY, 1998: 47, 49).

Sob esse ponto de vista, os desdobramentos de uma cultura marítima não terminariam exatamente no último resquício de água salgada que banha a praia ou a linha de costa de diferentes ilhas e continentes. Ela estenderia sua influência terra adentro, englobando também equipamentos, estruturas produtivas, religiosas e mesmo cidades inteiras (DURAN, op. cit., p. 92).

[...] those 'related objects on the shore' and 'coastal communities' explicitly ruled out by Keith Muckelroy would just as explicitly be ruled in today. Indeed, it is through them that coastal and sea-born maritime concerns articulate with society at large. Today, then, maritime archaeology is the study of material (ADAMS, 2002: 328).

Além das questões inerentes aos limites entre terra e mar, existem ainda duas outras que devem ser levadas em consideração antes que possamos estabelecer uma compreensão marítima dos sambaquieiros, as quais estão ligadas, principalmente, aos significados dos conceitos marítimos e marinhos.

A primeira diz respeito aos ambientes associados ao universo marítimo sambaquieiro. No que tange a proposta de Arqueologia marítima aqui desenvolvida, devem compor o universo marítimo dos povos dos sambaquis não só os ambientes oceânicos e marinhos, mas, também, todos aqueles ambientes aquáticos associados à região costeira. Deste modo, são também concernidos como intrínsecos ao universo marítimo todos os ambientes percebidos e, culturalmente, apropriados pelos povos dos sambaquis, independentemente de quão próximos ao mar aberto eles se encontrem.

Tal compreensão é aqui adotada, pois, embora os ambientes possam ser realmente diferenciados e classificados em conseqüência da influencia da água marinha, a subdivisão desses ambientes (como oceânicos, marinhos, estuarinos, lacustres, fluviais, lagunas, lagoas, mangues, marismas, etc) está fundamentada em 
parâmetros ecológicos, científicos e culturais, estabelecidos por nossa sociedade a partir de um ponto de vista científico ocidental moderno.

Apesar de acreditarmos que uma diferenciação entre esses ambientes fosse estabelecida pelos sambaquieiros, é pouco provável que ela tenha sido percebida a partir da identificação de diferentes parâmetros físicos e químicos (como acontece atualmente). O mais provável é que um "mapeamento" desse espaço tenha sido desenvolvido com base na importância econômica, social, cultural e simbólica de seus elementos para a sociedade sambaquieira.

Nesse sentido, para a adoção de uma perspectiva marítima é preciso antes, segundo Bava de Camargo (2006), compreender que a Arqueologia marítima constitui uma disciplina (ou subdisciplina) voltada para o estudo da relação do ser humano com os cursos d'água, estando aí abrangidos os aspectos materiais e simbólicos dessa relação, expressa tanto em jazidas submersas, emersas ou na interface desses ambientes.

Sob tal ponto de vista, tem-se na Arqueologia marítima uma forma de investigação mais abrangente do que em outros ramos "úmidos", a saber, a Arqueologia náutica e a Arqueologia subaquática. A primeira focada na tecnologia naval do material flutuante antigo e a segunda direcionada para os vestígios depositados em ambientes aquáticos. Apesar do termo marítimo ter uma relação direta com mar, hoje se engloba nele, também, a análise dos vestígios presentes nas águas interiores.

Embora aqui se acredite que os sambaquieiros pudessem constituir suas próprias concepções a respeito desses diferentes compartimentos "molhados" e, também, das diversas regiões emersas, é importante ressaltar que a atual subdivisão dessas áreas (em marinhos, oceânicos, lacustres, estuarinos, etc) e os "preconceitos" interpretativos que se criam em relação a elas, são, de certo modo, influenciados pela maneira como nós, arqueólogos, compreendemos os ambientes aquáticos.

Segundo Blot (1999) e Read (1996 apud RAMBELLI, 2003), em sua maioria, essas compreensões devem ser reflexo da influência de como nossa sociedade concebe culturalmente o mar. Concepção essa que não se restringe somente às 
questões brasileiras, pois a separação entre marítimos e continentais perpetua-se devido ao fato de que "nas sociedades ocidentais, o mar permanece ainda como um espaço mal conhecido, perigoso, fora da cultura terrestre, fora da lei que impera no continente" (DIEGUES, 1998, p.58). Nesse processo, pode-se identificar uma espécie de "resistência" em se voltar olhares para o mar e, principalmente, para o fundo do mar, pois "a região submarina se torna, dessa forma, símbolo do inconsciente" (DIEGUES, 2000, p.159; RAMBELLI, 2003, p.12).

A segunda dessas questões inerentes aos limites entre terra e mar, diz respeito aos contextos que historicamente vem sendo associados à Arqueologia marítima. Pois, embora esta sub-disciplina da Arqueologia, por vezes, se confronta com vestígios arqueológicos pré-históricos ou com sociedades menos complexas, ela sempre esteve, mesmo antes de Muckelroy (1972), predominantemente vinculada a problemáticas históricas, econômicas e políticas de sociedades clássicas e modernas.

No âmbito da presente Tese, entretanto, procura-se estabelecer uma abordagem Arqueológica marítima que caminha justamente na direção contrária, procurando fundamentar-se mais em questões de cunho antropológico, sociológico e etnográfico do que nos processos e valores mercantis e capitalistas que permeiam as sociedades históricas modernas. Desta maneira, ao invés de adotarmos uma perspectiva focada na eficiência da captação dos recursos ou na utilização prática dos ambientes aquáticos, o que procuramos investigar, com base na análise dos vestígios arqueológicos, é a possibilidade dos povos dos sambaquis terem atribuído significados a esses ambientes e a seus elementos (fauna, flora, paisagens, etc). Pois, como apontado por Diegues (2003):

[...] somente para uma ciência reducionista o oceano é uma realidade somente material, despovoada de seres humanos e seus símbolos. Essa concepção totalizante ainda subsiste entre as populações marítimas que mantém um estreito contato com o mar e dele retiram sua subsistência. Essas populações humanas têm uma percepção complexa do meio marinho e seus fenômenos naturais. De um lado há um vasto conhecimento empírico adquirido pela observação continuada dos fenômenos físicos e biológicos (e.g. ventos, marés, reprodução dos cardumes de peixes)... De outro lado as explicações para tais fenômenos também passam pela representação simbólica e pelo imaginário dos povos do mar (DIEGUES, 2003, p.3). 
Assim, mais do que considerá-las como simples áreas de captação de recursos, onde os ambientes marinhos teriam sido explorados sobre a perspectiva da máxima eficiência e do mínimo gasto de energia (intrínseca a uma ótica capitalista), eles são aqui compreendidos como um espaço culturalmente percebido e apropriado pelos povos dos sambaquis. Um universo em que nem sempre as escolhas são lógicas e práticas, mas, sim, tomadas a partir de aspectos culturais.

Com base nesse entendimento, acreditamos ser possível estabelecer uma compreensão da Arqueologia marítima que, ao mesmo tempo, extrapola as fronteiras do ambiente marinho e permite o desenvolvimento de uma proposta analítica e interpretativa a respeito da maritimidade dos povos dos sambaquis, ainda mais quando levamos em consideração a importância do estabelecimento de um contexto histórico (pré-histórico, pré-colonial, pescador-coletor, etc) específico à complexidade e à natureza das sociedades em questão. Nesse sentido, o entendimento do universo marítimo dos povos dos sambaquis passa a se focar tanto na interpretação dos significados e dos valores que podemos atribuir a determinada cultura ou nível de organização social, como em nossa compreensão (marítima) dos modos através do quais as sociedades sambaquieiras e os indivíduos podem perceber, compreender e se apropriar do ambiente.

Sob esse ponto de vista, objetivamos que a perspectiva de uma cultura sambaquieira passe a ser entendida também a partir de uma visão antropológica, relacionada a grupos étnicos (BEATTIE, 1977; ROUSE, 1968 apud TENÓRIO, 2004), através da qual a cultura material pode expressar significados traduzidos pelo arqueólogo (SHANKS e HODDER, 1995, p. 17 apud TENÓRIO, op. cit.).

\subsection{O UNIVERSO MARÍTIMO DOS POVOS DOS SAMBAQUIS}

Tendo como referencial uma abordagem arqueológica marítima pela qual os ambientes marinhos, lacustres e terrestres constituem um espaço culturalmente percebido e assimilado pelo sistema sócio cultural dos povos dos sambaquis, em um 
segundo momento, foram estabelecidas correlações entre as evidências materiais preservadas no registro arqueológico e o universo marítimo dos povos dos sambaquis.

Com a intenção de estabelecer tais correlações, foi criado um quadro para uma compreensão inicial do universo marítimo dos sambaquieiros a partir de um ponto de vista propiciado pela Antropologia marítima. Elaborado principalmente a partir dos estudos realizados por Diegues (1998) e Malinowski (1986) [1922], tal enfoque foi estabelecido com o objetivo de propor um outro referencial através do qual poderíamos entender os povos dos sambaquis com base em suas relações com o ambiente marinho.

Antes de avançarmos nessa direção é importante ressaltar que a preocupação em apontar a possibilidade de uma perspectiva teórica complementar para o estudo dos sambaquieiros não foi estabelecida, exclusivamente, em conseqüência da escolha de um ponto de vista marítimo. Desde os primeiros trabalhos publicados a respeito de sociedades que hoje são entendidas, no âmbito da Antropologia marítima, como sociedades marítimas, tornou-se claro que existem certos comportamentos sociais e culturais que não poderiam ser simplesmente concebidos a partir da aplicação de conceitos próprios das sociedades cujo modo de vida está diretamente relacionado ao universo terrestre.

Um exemplo dessa compreensão específica para as sociedades marítimas pode ser encontrado já na clássica monografia de Malinowski (op. cit.), "Os Argonautas do Pacífico", onde, segundo Diegues (op. cit, p. 60), sob um ponto de vista funcionalista, o autor analisava as funções das crenças religiosas, dos mitos e da magia para a sociedade dos insulares tobriandeses, a partir do kula (troca ritual de bens) realizado no âmbito da navegação entre as ilhas da Polinésia.

Neste estudo, que contribuiu decisivamente para a consolidação da Antropologia como um novo campo do conhecimento humano, Malinowski criticava os antropólogos evolucionistas que viam na pesca um estágio civilizatório anterior à agricultura e a sedentarização (DIEGUES, op. cit, p. 55 e 56). Apesar de ser relativo aos estágios iniciais da Etnologia, esse estudo já apontava o surgimento de uma 
preocupação em relação às particularidades das sociedades marítimas e do meio em que vivem.

Mesmo tendo passado quase um século, essa preocupação (aqui também norteadora da construção de uma compreensão marítima a respeito das sociedades sambaquieiras) continua sendo reforçada no âmbito dos estudos de Antropologia marítima. Fato que evidencia ainda mais a importância de tal singularidade das culturas marítimas. Como pode ser observado em Diegues (op. cit.), além de assumirem a existência real de uma particularização das sociedades marítimas, os antropólogos defendem que para um entendimento mais específico dessas sociedades faz-se necessária, também, uma reavaliação das próprias compreensões e conceitos desenvolvidos no meio científico.

[...] os conceitos utilizados até hoje para se analisar as sociedades camponesas, como a função da família na reprodução social, o salário e a propriedade, dificilmente se aplicariam à realidade social marítima e às práticas da gente do mar. No entanto, afastando-se o perigo do determinismo geográfico, Geistdoerfer (1989) afirma que os homens do mar souberam colocar em prática sistemas sociais, econômicos e religiosos destinados a ocupar, explorar, gerir e imaginar o mar e os seus recursos (DIEGUES, 1998, p. 57).

Ainda em relação à questão da particularização do meio marítimo, Diegues propõe que além do surgimento de sistemas sociais diferenciados aos das comunidades que não vivem o ambiente marítimo, tais sistemas atribuem às características naturais do oceano uma dimensão antropológica.

As práticas socioculturais da gente do mar [...] são marcadas, de maneira original, por essas "propriedades naturais" do mar, socializadas pela aplicação dos diferentes sistemas. Mas, segundo o valor social, econômico ou simbólico que as comunidades dão ao mar e aos seus recursos, o conjunto de praticas sócio-culturais dessas comunidades pode ser marcado de forma diferenciada (GEISTDOERFER, 1989, p.7).

Embora esse particularismo social e cultural tenha sido identificado a partir do estudo de sociedades modernas, ele é aqui adotado para o estudo das sociedades sambaquieiras porque diversos elementos da cultura material (como, por exemplo, zoólitos, adornos, acompanhamentos funerários e outros) desses povos evidenciam 
que as propriedades naturais do mar também atingiram, entre os sambaquieiros, tal dimensão antropológica.

Um exemplo desses valores simbólicos em relação ao mar pode ser percebido na diferenciação de status social que, segundo Pinheiro e Peixoto (2003, p. 177), era dada a homens e mulheres em enterramentos de alguns sambaquis do Rio de Janeiro. Onde, em geral, são encontrados ossos de baleia como acompanhamento funerário masculino e evidências de tubarões acompanhando os corpos femininos.

Ainda que não possamos apontar um significado específico para tal associação com tubarões e baleias, as associações desses ossos de animais marinhos a contextos mortuários indicam, assim como ocorre com os zoólitos, a existência de uma relação simbólica com o mar e com os seres que nele habitam.

Para Tenório (2004), essa associação não se restringe somente aos artefatos, mas, também, a todos os outros elementos de ordem faunística que compõe o próprio sambaqui. Fundamentada em Lévi-Strauss (1962), para quem membros de sociedades não-estratificadas são conduzidos pelo impulso de classificar, exaustivamente, os elementos do ambiente explorado para garantir a sua sobrevivência, o que fornece a cada elemento um lugar em sua cosmologia (LUBY e GRUBER, 1999, p 102 apud TENÓRIO 2004, p. 53); a autora sugere que muitos grupos caçadores coletores estariam conectados com o reino sagrado em seu ambiente explorado. Nesse contexto, segundo uma abordagem estruturalista, os "shellmounds" deveriam ter significado simbólico envolvido por ampla cosmologia; o conteúdo simbólico desse centro doméstico, com certeza, estaria imbuído pelo lado sagrado do alimento (LUBY e GRUBER, op. cit., p 102 apud TENÓRIO, id ibidem).

Luby \& Gruber (id ibid) chamam a atenção para a interpretação de LéviStrauss (1962:10 apud id ibidem) que confere à parte não digerível dos alimentos um grau especial de interpretação simbólica e lembra que esses elementos - conchas, ossos, dentes - constituem as camadas formadoras dos shellmounds o que, segundo os autores, deveria impedir que continuassem a ser vistos apenas como montes de lixo.

Essas duas categorias, casa e comida, estão entre os mais poderosos símbolos de qualquer sistema cultural. A adição de enterramentos dedica aos sambaquis uma terceira poderosa associação sagrada. Gaspar (1991, p. 260) já havia atentado para ela nos sambaquis brasileiros e propôs que a constante associação de moradia, alimento e enterramento configuraria uma cosmologia própria a uma única cultura sambaquiana. 
De certo modo, essa associação encontra apoio em Diegues (1998), o qual defende que dentre os vários aspectos componentes do particularismo da gente do mar sobressaem os aspectos simbólicos, mágicos e rituais dos quais se reveste, em muitas culturas marítimas, a relação homem/mar. Aspectos que, segundo ele, variam de cultura para cultura:

\begin{abstract}
Enquanto nos países ocidentais, o oceano constitui um objeto de medo e terror, em algumas sociedades do sul do Pacífico o espaço marítimo é o locus da vida, um ser vivo com o qual é preciso se conciliar antes de nele se adentrar. As sociedades marítimas do Pacífico, mais do que outras, desenvolveram mitos e ritos relativos ao mar e aos seres vivos que nele habitam (DIEGUES, 1998, p.58).
\end{abstract}

De um lado, há rituais de acesso ao mar e de outro, os de acesso aos recursos que nele existem. Na polinésia, por exemplo, o mar está na origem das ilhas e das sociedades. Cada lugar no oceano, cada ilha, é marcada pelo aparecimento ou moradia de ancestrais míticos (GEISTDOERFER, 1989 apud DIEGUES, 1998, p.58).

No entanto, para Diegues (op. cit), essa relação com o mar não é, porém, algo dado, imutável, mas uma inter-relação que se constrói historicamente. Em geral, as comunidades marítimas constituem-se pela prática da gente do mar num ambiente natural marcado pelo risco, pelo perigo e pela instabilidade, e dadas essas incertezas cria-se, entre as sociedades de pescadores, um certo apego à vida no mar, dificultando, muitas vezes, sua inserção em terra.

No âmbito da Antropologia marítima, a configuração dessa dimensão antropológica do mar e de seus recursos e, também, a compreensão de que os aspectos inerentes a ela variam de cultura para cultura, são as questões mais prementes para este trabalho. Porém, de maneira alguma se procura atribuir significados específicos às relações da cultura material e dos povos sambaquieiros com o mar, mas, sim, visa-se à oportunidade de investigar e discutir se prováveis diferenças e semelhanças nas relações identificadas entre os diversos contextos arqueológicos poderiam ser interpretadas como conseqüência da existência de diferentes ou semelhantes valores sociais, econômicos e simbólicos que os sambaquieiros atribuiriam ao mar e a seus recursos. Suscitando, nesse sentido, uma 
discussão a respeito da possibilidade do estabelecimento de diferentes conjuntos (ou comunidades sambaquieiras) ao longo do atual litoral brasileiro.

No que tange às características que poderiam permitir a constituição de diferentes sociedades, Diegues (op. cit.) indica os seguintes exemplos:

[...] a valorização positiva ou negativa do mar, o modo de organização econômica e social, o lugar reservado às atividades pesqueiras na economia, o modo de integração das comunidades litorâneas na sociedade mais ampla e o caráter simbólico das relações com o mar (DIEGUES, op. cit., p. 55).

Tomando por base o modelo funcionalista, Malinowski (1922), enfatizando os aspectos psicológicos do comportamento social, afirmava que os povos "primitivos" tinham um comportamento racional, baseado num grande conhecimento empírico do mundo em que viviam. Estudando a religião, o pensamento mágico, os mitos e os ritos, o autor propôs que a magia floresce quando o homem não pode controlar o imprevisível por meio de seu conhecimento. Uma idéia que surgiu a partir da constatação de que, nas lagunas tranqüilas, os tobriandeses não usavam os ritos mágicos que antecediam a pesca, como faziam em mar aberto, onde estavam sujeitos a perigos e incertezas (DIEGUES, op. cit.).

Assim, independente do significado e das relações atribuídos por Malinowski a esses diferentes tipos de pesca, o que interessa para o estudo dos sambaquieiros é a constatação de que podem existir entre as sociedades marítimas diferentes tipos de pesca e a cada um desses tipos podem ser atribuídos valores sociais, econômicos e simbólicos diferenciados.

Embora uma analogia direta entre os tobriandeses e os sambaquieiros não seja possível, afinal os tobriandeses e as outras diversas sociedades da costa das ilhas periféricas da Nova Guiné não podem ser simplesmente considerados como povos pescadores coletores, pois praticavam agricultura e o kula (um tipo de "comércio primitivo") entre as ilhas, as sociedades da melanésia são aqui utilizadas como exemplos por meio dos quais se possa estabelecer novas hipóteses a respeito do que viria a ser o universo marítimo dos povos sambaquieiros. 
Um referencial a partir do qual a cultura material sambaquieira pode ser repensada e interpretada com base em exemplos, relações e valores que não se encontram, necessariamente, associados a uma visão capitalista; onde a obtenção dos recursos e a organização social dos povos pescadores coletores são simplesmente um resultado direto da máxima eficiência da coleta e do menor gasto de energia. Para essas sociedades da melanésia (assim como pode ter acontecido entre os sambaquieiros), a coleta, a pesca e a produção de alimentos não estavam exclusivamente vinculadas a uma perspectiva de produção de excedentes, acúmulo e comercialização lucrativa, mas, sim, ligados a um contexto de trocas, inerente ao seu sistema de crenças e valores.

No que tange aos valores econômicos, uma das primeiras contribuições do estudo dos trobriandeses diz respeito à voraz crítica tecida por Malinowski (1986, p. 56) em relação à noção da existência de um homem econômico primitivo: uma espécie de homem primitivo ou selvagem imaginário, movido em todas as suas ações por uma concepção racionalista do interesse pessoal, atingindo seus objetivos de maneira direta e com os mínimos esforços. Para ele,

[...] o nativo de Trobriand trabalha movido por razões de natureza social e tradicional altamente complexos; seus objetivos certamente não se referem ao simples atendimento de necessidades imediatas nem a propósitos utilitaristas. Muito pelo contrário, em sua realização são despendidas grandes parcelas de tempo e energia que, do ponto de vista utilitário, são extremamente desnecessárias (MALINOWSKI, op. cit, p. 56).

[...] a magia também impõe à tribo muito trabalho extra e estabelece regras e tabus que são aparentemente desnecessários e dificultosos. No fim das contas, porém, não resta dúvida de que, por sua influência no sentido de ordenar, sistematizar e regular o trabalho, a magia constitui elemento de inestimável valor econômico para os nativos (MALINOWSKI, op. cit, p. 56).

Segundo esse autor, o trabalho e o esforço não constituem apenas meios para atingir certos fins, mas sob certo ponto de vista, um fim em si mesmo. Nas ilhas Trobriand, por exemplo, o prestígio de um bom agricultor é diretamente proporcional à sua capacidade de trabalho e à quantidade de terra que consegue lavrar.

Se ficarmos na ilusão de que o nativo é o filho folgado e preguiçoso da natureza, que evita na medida do possível qualquer trabalho ou que não faz outra coisa se não esperar que frutas maduras lhe caiam na boca, de modo 
algum poderemos compreender seus propósitos e os motivos que os levam a executar o kula ou qualquer outro tipo de empreendimento. Muito pelo contrário: a verdade é que o nativo pode trabalhar e, em dadas circunstancias, realmente trabalha bastante. Com objetivos bem definidos e de maneira sistemática e persistente. Tão pouco fica ele à espera que suas necessidades imediatas lhe forcem ao trabalho.

Na lavoura, por exemplo, os nativos produzem muito mais do que realmente necessitam e, em média, no decorrer de um ano normal, chegam a colher o dobro do que precisam para alimentar-se. Nos dias atuais, esse excedente de alimentos é exportado por europeus para o consumo de trabalhadores agrícolas de outras regiões da Nova Guiné. Antigamente, simplesmente apodrecia (MALINOWSKI, op. cit, p. 54-55).

Além do mais, os nativos conseguem esse excedente por meio de um trabalho muito maior do que o estritamente necessário à obtenção de uma boa colheita. [...]. O elemento não utilitário do seu trabalho agrícola torna-se ainda mais evidente se analisarmos as diversas tarefas a que eles se dedicam com fins exclusivamente ornamentais, em conexão com cerimônias de magia e em obediência aos costumes da tribo (MALINOWSKI, op. cit, p. $55)$.

Nesse sentido, apesar de também realizarem a agricultura e produzirem excedentes, os trobriandeses não possuíam, pelo menos no mar, uma propriedade real sobre os meios naturais de produção. Condição que, para Bate (1989, p. 19), constitui, sob um ponto de vista focado no materialismo histórico, uma das principais características das comunidad primitiva de cazadores recolectores. Embora estejamos tratando, neste momento, de grupos com diferentes status, seria interessante avançar nesta discussão, pois ela reforça ainda mais as singularidades das sociedades marítimas ${ }^{4}$ e nos faz refletir sobre a possibilidade, sugerida por De Blasis et. al. (2007, p. 33), de começarmos a investigar e considerar os sambaquieiros como caçadores coletores complexos.

Lo distintivo de la misma [comunidade de coletores], encuanto a los contenidos de la propriedad, es que ésta se establece sobre la fuerza de trabajo y los instrumentos de producción. No se há establecido la propriedad real sobre los medios naturales de producción. La apropriación de medios naturales es resultado del trabajo y no uma condición necesaria para La producion (BATE, 1989, p. 19).

\footnotetext{
${ }^{4} \mathrm{O}$ fato dos tobriandeses estabelecerem, nas ilhas, territórios e propriedade sobre os meios naturais e, não se preocuparem em se apropriar, no mar, de tais meios, é, por si só, uma condição que reforça a singularidade das comunidades marítimas, entre as quais, talvez, seja necessário repensar, inclusive, a própria maneira como, tradicionalmente, categorizamos as sociedades em simples e complexas.
} 
No que se refere à organização social, talvez, possamos sugerir uma série de paralelos com os povos dos sambaquis. Segundo Malinowski (op. cit., p. 63), embora todos os aspectos da vida dos nativos (magia, religião e economia) estivessem inter-relacionados, era a organização social que fundamentava a todos. Os povos das ilhas Trobriand formavam uma unidade cultural e lingüística, tinham as mesmas instituições, obedeciam às mesmas leis e regulamentos, estavam sob a influência das mesmas crenças e convenções.

Os distritos em que se subdividem o território Trobriand distinguem-se entre si somente do ponto de vista político e não do ponto de vista cultural. Embora possuam o mesmo tipo de nativo, cada um deles reconhece o seu próprio chefe e defende seus próprios interesses e objetivos e, em caso de guerra, cada um se empenha em sua própria luta.

As diversas comunidades existentes em de cada distrito são independentes umas das outras. Cada aldeia tem um líder que a representa, seus membros organizam trabalhos em conjunto, suas próprias festas e cerimônias, pranteiam seus mortos em comum e realizam, em memória deles, uma série interminável de distribuições de alimentos. Em todos os assuntos importantes da tribo ou do distrito os membros de cada comunidade se mantêm unidos e atuam como um grupo independente dos demais.

Interpondo-se através das divisões políticas e territoriais há também a divisão em clãs totêmicos, cada um deles com uma série de totens relacionados. Os membros desses clãs estão espalhados por toda a tribo e, em cada comunidade, podem ser encontrados representantes de todo eles. Existe certa solidariedade entre os membros do mesmo clã, baseada num sentimento muito vago de afinidade comunal com os animais totêmicos, que se manifesta, principalmente, nos diversos deveres sociais, como a execução de determinadas cerimônias, especialmente as funerárias, que mantêm unidos os membros do mesmo clã.

Nessa questão, creio que o estudo dos sambaquieiros também possa ir buscar elementos de reflexão na organização social dos trobriandeses e nos tipos de símbolos e significados que desenvolveram. Embora não tenhamos aqui a pretensão de afirmar que os sambaquieiros articulavam-se a partir de clãs totêmicos, 
não podemos negar que existe uma série de significados e simbolismos implícitos nos zoólitos, nos acompanhamentos funerários e, também, nas singularidades regionais que acabam por compor a sociedade sambaquieira.

Analisando, por exemplo, os sambaquis da região da paleolaguna de Santa Marta, localizada na porção do litoral do estado de Santa Catarina, De Blasis et. al. (op. cit, p.48) aponta uma série de evidências que sugerem o estabelecimento de práticas sociais que muito se assemelham aos tipos de práticas desenvolvidas pelos tobriandeses. Além da presença de restos de madeira provenientes de áreas de restinga aberta e Mata Atlântica (as quais indicariam que o território dos sambaquieiros incluiria também áreas terrestres), ocorrem diversos restos vegetais que parecem apontar para o surgimento de atividades relacionadas à horticultura e para uma possível sedentarização dessas sociedades.

Em relação ao estabelecimento de territórios, os autores acreditam que não existe uma individualização para grupos de sítios e, sim, uma superposição de territórios que aponta uma clara interação e articulação dessas comunidades no entorno da laguna, centro do universo econômico e social sambaquieiro. Nesse sentido, cada agrupamento de sítios constituiria um foco nuclear-social, não apenas geográfico, de ocupação e adensamento geográfico, marcos territoriais, referências locacionais e de identidade para comunidades sambaquieiras no entorno da laguna.

\footnotetext{
Esta configuração circum-lagunar, juntamente com a cronologia disponíveis que atesta a longa duração destes sambaquis, aponta para a existência de comunidades sedentárias que, com o tempo, foram crescendo e se desenvolvendo no entorno da laguna, espaço e domínio comum e epicentro da vida (e da morte) sambaquieira (DE BLASIS et. al, op. cit, p. 48).
}

Os autores reiteram, ainda, o aspecto sagrado desses sítios, o qual acreditam representar um vinculo essencial entre a sociedade sambaquieira e seus antepassados e territórios, apontado pelo modo intencional, recorrente e incremental com que esses sítios foram construídos ao longo de extensos períodos. Sacralidade essa manifestada através de cerimônias funerárias fortemente ritualizadas que constituíam referências de profundo significado simbólico para seus construtores, 
onde também perpetua-se uma visão de mundo própria da cultura sambaquieira (DE BLASIS et. al, op. cit, p. 48).

Para eles, a onipresença dos sambaquis aponta o caráter domesticado da paisagem lagunar, onde a presença diuturna dos mortos e suas conexões cosmológicas imiscuem-se na vida cotidiana da sociedade sambaquieira. De certo modo, essa presença é representada pelos zoólitos. Esculturas com forma animal, esculpidas segundo regras estilísticas rígidas e que se constituem como parafernália de uso ritual relacionado a animais e entidades mitológicas específicas - parte essencial de uma estrutura ideológica religiosa de expansão macro-regional entre as sociedades sambaquieiras do litoral. Artefatos que, por serem ocasionalmente encontrados em associação a sepultamentos específicos, sugerem algum tipo de diferenciação social (DE BLASIS et. al, op. cit, p. 49-50).

Segundo Lima e Mazz (1977, p. 43), essas esculturas parecem ter sido destinadas à produção de estímulos sensoriais e emocionais. Fuertemente simbólicas, cargadas de um significado dificilmente alcanzable, fueron realmente elementos de comunicación ritual. A rusticidade dos objetos de uso cotidiano frente ao esmero na fabricação dos zoólitos vincula, segundo esses autores, o domínio da arte ao uso ritual.

Além desse forte apelo simbólico atribuído aos zoólitos, existe outra questão em relação a eles que também encontra similaridades entre as sociedades tobriandesas. Questão essa que está ligada ao fato de existir um grande número de zoólitos representando animais exclusivamente marinhos: mamíferos marinhos, tubarões, peixes e outros. Embora não existam evidências de que os zoólitos estejam relacionados ao estabelecimento dos clãs totêmicos entre os sambaquieiros, essa ocorrência reforça a hipótese de que os povos dos sambaquis poderiam compor uma sociedade formada por diferentes comunidades fluviais, lagunares e marítimas (umas mais marítimas do que outras), articuladas e integradas a partir de crenças e convenções comuns. Algumas, inclusive, intimamente ligadas ao universo marítimo. 


\subsection{SOCIEDADE SAMBAQUIEIRA, COMUNIDADES MARÍTIMAS}

Embora a emergência de uma complexidade social entre os sambaquieiros seja um tema ainda controverso, tanto no Brasil, como no contexto norte americano (Lima, 1999/2000), mais freqüentemente se tem aceito que grupos caçadorescoletores não podem mais ser genericamente rotulados de "bandos igualitários", de maneira especial, os que teriam habitado ambientes ricos e complexos (TENÓRIO, 2004, p. 50).

Tal perda de prestígio científico deve-se, principalmente, ao desenvolvimento, nas últimas décadas, de diversos modelos de mobilidade e de organização social que foram elaboradas com base em estudos etnográficos de populações pescadoras não horticulturas; cuja principal crítica é a utilização de parâmetros intrínsecos a grupos caçadores e horticultores, desconsiderando o aspecto pescador. Uma aproximação equivocada, já que a atividade da pesca pode implicar em um padrão de mobilidade e um contato social completamente diferentes daqueles encontrados ou estabelecidos para caçadores-coletores (TENÓRIO, op. cit., p. 50).

Segundo a autora, tal compreensão vem sendo substituída por uma visão transigualitária de complexidade, a partir da qual, segundo Hayden (1995), esses grupos não seriam considerados nem igualitários nem estratificados, mas, sim, formados por sociedades de diferentes tamanhos e graus de complexidade, num contínuo de comunidades compostas por famílias independentes que controlariam os mecanismos de obtenção dos recursos. Nesse tipo de organização, segundo a autora, podem coexistir tanto trabalho cooperativo, como donos corporativistas dos recursos. Uma compreensão de sociedade que extrapola a categorização antropológica baseada em estágios.

Shallins (1979) e Service (1971) concordam que na costa noroeste americana são encontrados grupos caçadores-coletores que, mesmo sem agricultura, transcendem em muito o nível de bando. Murdock (1968) também informa sobre grupos que subsistem basicamente da pesca e têm uma cultura tão complexa quanto grupos agricultores vizinhos, citando, como exemplo, os índios da Costa Norte do Pacífico, os Calusa, na Flórida, e numerosas sociedades ao longo dos rios Negro e Congo, na África. Este autor também relata que, no norte da Ásia, os Ainu, os Chukchee marinhos, os Gilyak, os Kamchadal e os Koryac marinhos provavelmente também estejam na mesma categoria (TENÓRIO, op. cit, p. 51). 
Dessa maneira, procurou-se um entendimento que visa à adequação dessa compreensão transigualitária ao conjunto de evidências materiais que compõe o registro arqueológico dos sambaquis estudados. Entendimento esse que se apóia fundamentalmente na concepção dos povos dos sambaquis a partir das categorias sociológicas de comunidade e sociedade.

De um modo informal, os parâmetros que norteiam essa categorização já vêm sendo utilizados por alguns autores para contextualizar os conjuntos de sambaquis, enquanto artefatos, em uma perspectiva sociológica dos povos que os construíram. Contudo, somente em alguns poucos trabalhos tal conceituação é aplicada com a intenção de entender os modos através dos quais os sambaquieiros se organizavam como grupos sociais. No âmbito da presente Tese, adota-se essa categorização, pois, a partir dela, podemos atribuir uma perspectiva sociológica inicial para as hipóteses de origem e estabelecimento das sociedades sambaquieiras, as quais são formuladas com base em análises isotópicas (de elementos químicos presentes nos vestígios dos sambaquis) e em modelos de predição de sítios arqueológicos.

Segundo Albuquerque (1999), o par comunidade-sociedade indica configurações sociais contrastantes (tais como arcaico e moderno, afetivo e racional, sagrado e secular), que, embora fizessem parte da tradição sociológica (sobretudo weberiana), só foram sistematizados no século XIX por Tönnies. Aqui, no entanto, ele é utilizado a partir de uma outra perspectiva, segundo a qual as noções de comunidades e sociedade não são mais vistas como conflitantes e integram-se de modo a englobar os dois principais tipos de relações sociais (primárias e secundárias) que, segundo a Sociologia, explicam as maneiras através das quais os grupos sociais se relacionam.

Tal perspectiva fundamenta-se, principalmente, no entendimento de que os indivíduos que compõem uma comunidade compartilham um núcleo aglutinado de valores que lhes são comuns, ao passo que nas sociedades, os membros devem aceitar um conjunto de normas que regula a relação entre eles (BUELA, 1987). Sob esse ponto de vista, os povos dos sambaquis poderiam ser vistos sob ambas as categorias. Quando abordados a partir de um conjunto regional de sítios, onde os 
indivíduos compartilham normas de convivência e conduta marcadas pela tradição, religião, consenso e respeito mútuo (contatos primários), podem ser entendidos no âmbito de uma comunidade.

\begin{abstract}
O conceito de comunidade é empregado, no século XIX e XX, para todas as formas de relacionamento caracterizadas por intimidade, profundeza emocional, engajamento moral e continuidade no tempo. Para Durkheim (1960) esse tipo de solidariedade é denominada mecânica, já que os indivíduos se ligam ao todo sem intermediário e participam de crenças coletivas idênticas. [...]. A esse tipo de contato dá-se o nome de primário, nas classificações sociológicas (ALBUQUERQUE, 199, P. 51).
\end{abstract}

No entanto, quando vistos a partir de uma perspectiva mais ampla, onde mais do que as relações de parentesco, afetividade e informalidade, predominem relações impessoais, racionais, formais (contatos secundários), diferentes grupos sociais podem ser considerados como intrínsecos a uma sociedade. Sob essa perspectiva, tanto as diversas comunidades sambaquieiras regionais como os diferentes contextos sambaquieiros (e.g. fluviais, costeiros, marinhos, etc) poderiam ser estabelecidos como grupos sociais de uma única sociedade sambaquieira.

[...] os indivíduos [ou as comunidades] se ligariam às partes que compõe o todo coletivo e participam de crenças diferentes entre si. [...]. No jargão sociológico esse tipo de conduta é chamado de secundário (ALBUQUERQUE, 1999, P. 51).

Nesse sentido, assim como identificado por Malinowski (1986, p. 56), embora as embarcações que participavam do kula fossem geralmente compostas por membros de cada comunidade, em determinadas situações, indivíduos de outras comunidades (do interior das ilhas eram ou de outros locais) ou de outras sociedades, integravam-se às expedições. Fato que evidencia não só a articulação entre diferentes grupos sociais de uma mesma região e de diferentes tipos de comunidades (costeiras, marítimas, litorâneas, etc), mas, principalmente, o papel do kula na relação e integração dessas comunidades e da sociedade trobriandesa com seus vizinhos.

Há no circuito inteiro do kula um encadeamento de relações que naturalmente fazem dele um todo entrelaçado. Pessoas que vivem centenas de milhas uma das outras se relacionam através da parceria direta ou indireta, realizam trocas, passam a conhecer-se e, às vezes, se encontram 
em grandes reuniões intertribais. Os objetos dados por um nativo - não só os artigos do kula, mas também vários outros de uso doméstico e pequenos presentes - chegam, com o tempo, a parceiros indiretos muito distantes. É fácil observar que, no fim das contas, não só os objetos da cultura material, mas também costumes, canções, temas artísticos e influencias culturais gerais também viajam ao longo das rotas do kula. O que se verifica, então, é um vasto encadeamento de relações intertribais numa grande instituição que incorpora milhares de pessoas, todas elas unidas por uma paixão comum pelas transações do kula e, em segundo plano, por muitos pequenos laços e interesses (MALINOWSKI, 1986, p. 78).

Assim, como o kula teve um papel fundamental de articulação e integração entre as diversas comunidades tobriandeses, favorecendo a disseminação e a manutenção desse sistema de regras, convenções e crenças, é preciso estarmos atentos para a possibilidade de que esse mesmo processo, fundamentado na prática navegação costeira, pudesse ter atuado como um elemento de ligação entre as diversas regiões litorâneas e ilhas costeiras ocupadas pelos sambaquieiros, interligando comunidades e fortalecendo os laços e as convenções que uniriam as comunidades marítimas, litorâneas e fluviais em uma única e hegemônica sociedade. Uma navegação praticada por comunidades que deveriam conceber o mar e os corpos d'água costeiros como muito mais do que um local de passagem e extração de recursos. Um ambiente percebido e apropriado, ao qual era atribuída enorme importância e significado em conseqüência de seu poder de conexão entre populações aparentadas, isoladas por grandes distâncias de terra.

Referindo-se a essa mesma questão, Meghan (1982, p. 40 apud TENÓRIO, 2004, p. 57) apresenta o caso de uma comunidade de pescadores, coletores, caçadores do norte da Austrália, os Gidjingali, que pode exemplificar o modo através do qual poderia ter se dado o contato entre as diversas comunidades dos povos dos sambaquis.

A comunidade Gidjingali engloba quatro subgrupos (os Anbarra, os Matai, os Marawuraba e os Gullala) que tem como base de sua alimentação a coleta de moluscos. Embora possuam a mesma filiação cultural, esses quatro subgrupos apresentam diferenças em sua cultura material, que, segundo Meghan (op. cit, 40), estão relacionadas ao fato de habitarem ambientes distintos. 
Os Gullala percorrem a costa de canoa, chegando ao mar alto; eles seriam, segundo o informante de Meghan, os soberanos do mar.

Os Matai tinham medo do mar aberto e gastavam mais tempo nas florestas, manguezais, terra preta e planícies lodosas; seriam o povo da floresta.

Os Anbarra se estabeleciam no estuário do rio, ambiente de muita fartura, vivendo com maior abundância de recursos; seriam também mais sedentários, dando grande importância à coleta de moluscos, valorizando o seu sabor e orgulhando-se de ter disponíveis algumas espécies que também utilizavam para presentear seus parentes do interior (TENÓRIO, 2004, p. 58)

Além de se visitarem constantemente, em determinadas épocas, os Gidjingali realizam cerimônias que concentram grande quantidade de pessoas acampadas. Nesses momentos, geralmente associados a cerimônias de iniciação, a atividades mortuárias e a chegada de parentes, as atividades de coleta e preparação do alimento mudavam consideravelmente. Nessas ocasiões, enquanto os homens se ocupam dos rituais, a coleta passa a ser uma tarefa das mulheres (TENÓRIO, 2004, p. 58).

\subsection{POVOS SAMBAQUIERIOS, POVOS NAVEGADORES}

Ao desenvolvermos uma abordagem que procura entender a maneira pela qual os povos dos sambaquis relacionavam-se com o mar, não podemos deixar de considerar a importância das embarcações para a navegação e também para todas as praticais sociais e culturais desenvolvidas pelos sambaquieiros.

Para Malinowski (op. cit, p. 87), por exemplo, a canoa não era somente um artefato ou um veículo através do qual os nativos locomoviam-se entre as ilhas. Ela está envolvida em uma atmosfera de romance, constituída de tradições e experiências pessoais. É um objeto de culto e admiração, uma coisa viva que possui personalidade própria. Para o nativo, a canoa representa o instrumento poderoso que lhe permite tornar-se senhor da natureza, capaz de singrar mares perigosos em demanda a terras distantes. Está associada a viagens [...] que ele expressa em cantigas e estórias.

Segundo esse autor, por mais que houvesse uma organização social subjacente à construção das embarcações, ela não se constitui somente de 
indivíduos (líder, especialistas e trabalhadores) cuja função é construir as canoas, navegá-las e dar apoio ao kula. O especialista (que pode ser mais de um), da mesma forma que tem os conhecimentos para construir a canoa e fazer os entalhes, é responsável também por executar a magia. Para os trobriandeses, além da construção das canoas, é a magia que propicia a navegação, o salvamento, o kula, as trocas, a pesca e a coleta dos recursos mais importantes (MALINOWSKI, op. cit, p. 94).

São ambas [a eficácia mágica e os resultados da capacidade técnica] consideradas imprescindíveis; entende-se, porém, que ajam independentemente. Em outras palavras, os nativos entendem que a magia, por mais eficiente que seja, não compensa uma construção defeituosa. Cada uma das duas tem a sua própria função; o artesão, através de sua habilidade e conhecimentos, constrói a canoa de modo que ela seja estável e veloz; a magia Ihe dá estabilidade e velocidade adicionais. Se a canoa é visivelmente mal construída, os nativos saberão por que ela navega vagarosamente e é difícil de navegar. No entanto, se duas canoas parecem estar igualmente bem construídas mas uma supera a outra em algum aspecto, o fato será atribuída à magia (MALINOWSKI, op. cit, p. 94).

Nesse sentido a canoa não é somente um artefato usado para a navegação, ela representa o poderoso instrumento que Ihes permite tornarem-se senhores da natureza, capaz de singrar mares perigosos em demanda a terras distantes. (MALINOWSKI, op. cit, p. 88).

Embora ainda não tenham sido encontrados vestígios concretos de quaisquer tipos de embarcações, existem evidências que indicam a adoção desse tipo de tecnologia pelos povos dos sambaquis. De um modo geral, essas evidências relacionam-se a dois principais conjuntos de dados: estudos bioarqueológicos e evidências da utilização de embarcações na América do Sul em momentos que superam as idades dos sambaquis mais antigos da costa brasileira.

\subsubsection{Evidências bioarqueológicas}

O primeiro desses conjuntos diz respeito a dados provenientes de estudos bioarqueológicos, os quais, com base na análise de anomalias ósseas presentes em 
indivíduos sambaquieiros, sugerem o estabelecimento de atividades náuticas ligadas à prática de mergulhos e à utilização de embarcações a remo. Especificamente em relação às anomalias, essas podem ser de três tipos: exostoses auriculares (anomalias ósseas que se formam na base do canal auditivo externo), modificações nas estruturas de inserção dos feixes musculares e desgastes ósseos irregulares.

Segundo Okumura et al (2006) e Schell-Ybert et al. (2003), as exostoses auriculares estão relacionadas, principalmente, a constantes imersões em águas frias e salgadas ou exposição ao vento. O que indicaria certa adaptabilidade e domínio de técnicas associadas ao mergulho livre por parte dos sambaquieiros. Ao analisar as exostoses do sambaqui Jabuticabeira II (em Santa Catarina), Okumura (op. cit, p. 275) indica que tais anomalias seriam mais comuns em indivíduos do sexo masculino. Estabelecendo, também, uma possível associação da prática dessas atividades náuticas a questões de gênero.

Auditory exostoses can be interpreted as an indicator of sex specific activities in the Jabuticabeira II population. A higher frequency of auditory exostoses in men than women was observed in this and other Sambaquis populations (MENDONÇA DE SOUZA, 1995). This type of exostoses is reported to be caused by frequent dives in cool (CHAPLIN e STEWART, 1998; KENNEDY, 1986) or salt water (PEIXOTO, 1989) and may therefore be related to the people's subsistence strategies. In several other populations, high frequencies of this trait are found in the sex which is responsible for the capture of aquatic resources (KENNEDY, 1986; STANDEN et al, 1997). This might also be true for the Sambaqui people (OKUMURA et al, 2006).

No que tange à modificação das estruturas de inserção dos feixes musculares e dos desgastes ósseos irregulares, Carvalho (2004) aponta uma associação dessas anomalias à prática de atividades ligadas à natação, à utilização de remos (em pé e sentando) e, indiretamente, à fabricação de canoas.

Com base na análise das articulações de sambaquis de Santa Catarina e do Rio de Janeiro, Carvalho (op. cit, p. 152) aponta que os conjuntos articulares mais afetados são, respectivamente, pulso e cotovelo. Entre as populações pré-históricas, segundo a autora, o grande acometimento do pulso deve estar ligado, principalmente, a movimentos que envolvam ao mesmo tempo, firmeza, e mobilidade da região, [...], como, ocorre, por exemplo, na confecção de artefatos 
(polimento, raspagem), em atividades envolvendo redução de matéria-prima ou [na preparação] de alimentos (raspagem, moagem). Atividades também realizadas ao longo do processo de fabricação de canoas e embarcações.

No caso do estresse articular do cotovelo, o mais provável é que estaria associado ao transporte de peso ou à flexão/extensão do antebraço contra algum tipo de resistência, como pode ocorrer na remada e no arrastar redes, por exemplo (CARVALHO, op. cit, p. 152).

A seguir ao pulso e ao cotovelo, a articulação que apresenta maior desgaste é a do ombro. Embora em segundo plano, entende-se, com base no resultado dessas análises, que tais alterações articulares indicam também certa relação com a prática de atividades náuticas (arremesso de arpões e lanças), a fabricação de canoas (machados e enxós ${ }^{5}$ ) e aquelas relacionadas aos ambientes aquáticos (natação), pois:

O ombro é particularmente sensível a atividades que envolvam movimentos de grande extensão acima da cabeça como o arremesso de objetos, a natação moderna e a aplicação de diferentes golpes acompanhados de ferramentas diversas (como machados, marretas, porretes, etc.) e associados a movimentos amplos (CARVALHO, op. cit., p. 155 apud WHITING e ZERNICKE, 2001).

O tornozelo foi uma das articulações menos afetadas nas séries estudada e, como possui [...] um papel imprescindível na marcha e no suporte do peso corporal (CARVALHO, op. cit., p. 156), a autora sugere que possa ter havido um menor esforço decorrente de atividades de caminhada em relação à utilização de embarcações.

No que tange aos marcadores de estresse muscular, Carvalho aponta a manutenção do mesmo padrão, que, de uma maneira geral, está relacionado a uma maior utilização dos membros superiores em relação inferiores. Nos membros superiores, movimentos envolvendo o conjunto braço/ombro devem ter sido freqüentes em todas as séries, enfatizados pelo desenvolvimento da inserção do deltóide e peitoral maior. Segundo a autora, o desenvolvimento das áreas

\footnotetext{
${ }^{5}$ Ferramentas normalmente utilizadas para a escavação do interior de canoas monóxilas (ver figura 6.22).
} 
correspondentes de fixação muscular está associado a diversas atividades como [...] a utilização de remos duplos, a retirada de peles animais, ao manuseio de ferramentas como machados [para a fabricação de canoas], enxadas, picaretas, à utilização de grandes pilões, na natação (especialmente nos movimentos da natação moderna), no lançamento de objetos, entre outros (CARVALHO, op. cit., p. 156).

Outro músculo bastante solicitado foi o bíceps, o qual também está relacionado à utilização de remos. Capasso (1999) e Carvalho (op. cit, p. 162 apud Hawkey e Merbs, 1995) apontam que o desenvolvimento [...] bilateral desse músculo é freqüentemente relacionado ao carregamento de pesos com o braço flexionado e a utilização de remos duplos. A atividade - remada - também é indicada em conseqüência dos índices de robusticidade obtidos nos sambaquieiros em relação ao músculo pronador quadrado. A autora relaciona, ainda, a utilização desses músculos em atividades ligadas ao [...] processamento de alimentos pela moagem ou raspagem, ao polimento de diferentes artefatos [como as laminas de machado] $e$ a outros movimentos que podem ser realizados com o cotovelo flexionado e o antebraço em pronação.

No caso do tríceps, [...] mais uma vez o manejo de remos pode ser uma explicação ${ }^{6}$, juntamente com a utilização de [...] machados, [...] lanças longas ou arpões, acompanhados de um arremesso rápido e a pouca distância do alvo, o que poderia ser associado a pesca em águas calmas e com boa visibilidade (CARVALHO, op. cit., p. 163). A autora chama a atenção, ainda, para:

[...] o uso de embarcações que se utilizassem de longas hastes como propulsores [para jangadas e canoas] e remos, tipo de transporte comum em águas calmas e com poucas correntes, onde o condutor geralmente se posiciona de pé e o esforço é compartilhado entre ambos os braços. Não se deve descartar, porém, o emprego de machados (CARVALHO, op. cit., p. 163).

\footnotetext{
${ }^{6} \mathrm{~A}$ extensão do antebraço contra resistência pode ocorrer, por exemplo, em contraposição à flexão do braço oposto na remada e na manutenção do equilíbrio e mudanças de orientação da embarcação, que estariam em concordância com a navegação em águas agitadas e com correntes fortes (CARVALHO, op. cit., p. 163).
} 
Embora essas evidências tenham sido aqui apresentadas como uma tendência geral entre os sambaquieiros, Carvalho (op. cit.) destaca que ocorrem diferenças entre os diversos sítios, apontando certa diversificação das atividades entre os conjuntos regionais de sítios e, em um mesmo sítio, entre homens e mulheres.

\begin{abstract}
A maior solicitação do extensor radial longo do carpo nestas séries é uma característica masculina. Este músculo estende e abduz o punho (desvio radial), ajuda a flexionar o cotovelo e é importante na preensão de objetos (Palastanga et al., 2000). Esta última poderia ter sido sua função principal nas séries fluminenses, já que as alterações nas articulações também apontam para uma sobrecarga nos pulsos e nas mãos. O manuseio e transporte de objetos pesados, associados a outras atividades onde a preensão firme fosse requerida, explicariam a grande utilização desse músculo. É possível ainda sugerir que a confecção de determinados artefatos fosse atribuição masculina, como, por exemplo, o preparo de peças líticas (CARVALHO, op. cit., p. 164).
\end{abstract}

O abdutor longo do polegar foi muito solicitado entre as mulheres do Sambaqui da Beirada. Este músculo abduz, aduz e opõe o polegar, sendo também flexor do punho (Palastanga et al., 2000). Com uma ação importante na oposição do polegar, provavelmente estava envolvido em alguma atividade motora fina que implique na movimentação intensa deste, como em movimentos relacionados ao trabalho em fibras, na cestaria, na confecção de redes, esteiras, adornos (especialmente de pequenas dimensões), e outros artefatos (CARVALHO, op. cit., p. 164).

Em geral, as atividades que demandam maior esforço físico foram realizadas por homens, com algumas possíveis exceções. Parecem ter sido atividades masculinas o uso de redes de pesca, o transporte de grandes quantidades de matéria-prima lítica, o uso de embarcações, a coleta de madeiras para confecção destas embarcações e de estruturas habitacionais, a confecção, pelo menos em parte de peças líticas, entre outras. É necessário lembrar essas atividades poderiam ser também executadas pelas mulheres, porém em menor escala (CARVALHO, op. cit., p. 170).

Um padrão que nos faz refletir não somente a respeito da diversidade e especialização de comunidades marítimas, litorâneas e fluviais em relação à prática da navegação, mas, também, quanto ao estabelecimento de diferentes funções e especialidades entre indivíduos de uma mesma comunidade, sugerindo, assim, diferenças de atividades ou demandas entre indivíduos de mesma idade, de idades diferentes e entre homens e mulheres.

Esta variabilidade é facilmente observada, por exemplo, pela persistência de indivíduos com o mesmo nível de comprometimento em diferentes intervalos etários, sugerindo que as demandas exercidas sobre as articulações não eram as mesmas para todos os indivíduos. Isto é, as 
atividades, ou pelo menos a carga de esforço solicitada por estas era desigual entre os sexos e entre os indivíduos do mesmo sexo (CARVALHO, op. cit., p. 168).

Ao concluir sua análise, a autora indica, ainda, que o esforço dedicado à utilização de arpões, propulsores, arcos, lanças e etc., não sobrepujou o esforço dedicado a atividades como o uso de embarcações e redes de pesca (CARVALHO, op. cit., p. 170). Sugerindo que, embora todas as comunidades sambaquieiras tenham mantido contato com os ambientes aquáticos, tal relação não tenha se dado apenas a partir de suas margens. É provável que, efetivamente, os sambaquieiros tenham rompido o limite terra-mar, aventurando-se em meio às águas lagunares e costeiras.

\subsubsection{As mais antigas evidências de navegação na América do Sul}

Embora Carvalho (2004) tenha sugerido (às vezes, indiretamente) a utilização de diferentes tipos de embarcações (canoas e balsas) e propulsores (remos, remos duplos, varas e hastes), existem outros tipos de artefatos náuticos, alguns tecnologicamente mais simples, que podem indicar não só a adoção de uma tecnologia náutica, mas, também, o seu desenvolvimento pelos povos sambaquieiros.

Tal perspectiva é difícil de ser considerada quando tratamos de embarcações mais complexas, as quais são formadas a partir da articulação de diversas inovações tecnológicas que as transformam em artefatos, cuja construção e utilização requerem o trabalho de especialistas. Entretanto, quando nos referimos a peças náuticas mais simples, talvez, a possibilidade do desenvolvimento da navegação possa ser comparada ao desenvolvimento de qualquer outro tipo de tecnologia pré-histórica.

Quando pensamos em uma embarcação pré-histórica brasileira a imagem mais comum é a de uma canoa. No entanto, existem diversos outros tipos artefatos flutuadores que poderiam ser empregados na pesca e no cotidiano dos 
sambaquieiros que não requerem, necessariamente, o mesmo grau de domínio tecnológico empregado nas canoas. Alguns, inclusive, nem poderiam ser considerados embarcações.

Embora não haja uma divisão precisa entre eles, Hornell (1970) sugere uma subdivisão dos flutuadores em duas categorias: flutuadores de natação (swimming floats) e flutuadores propulsionados (riding floats).

Os flutuadores de natação são acessórios mais simples, como pequenos pedaços de madeira, toras, bolsas de pele, etc, utilizados para auxiliar a flutuação do corpo enquanto o individuo permanece parado, ou segue ao sabor da correnteza ou desloca-se com uma propulsão e direção gerada por suas penas e braços (figura 1.01). Uma árvore seguindo corrente abaixo, segundo Hornell (op. cit, p. 1.), foi o primeiro estímulo para a inventividade do homem nessa direção.

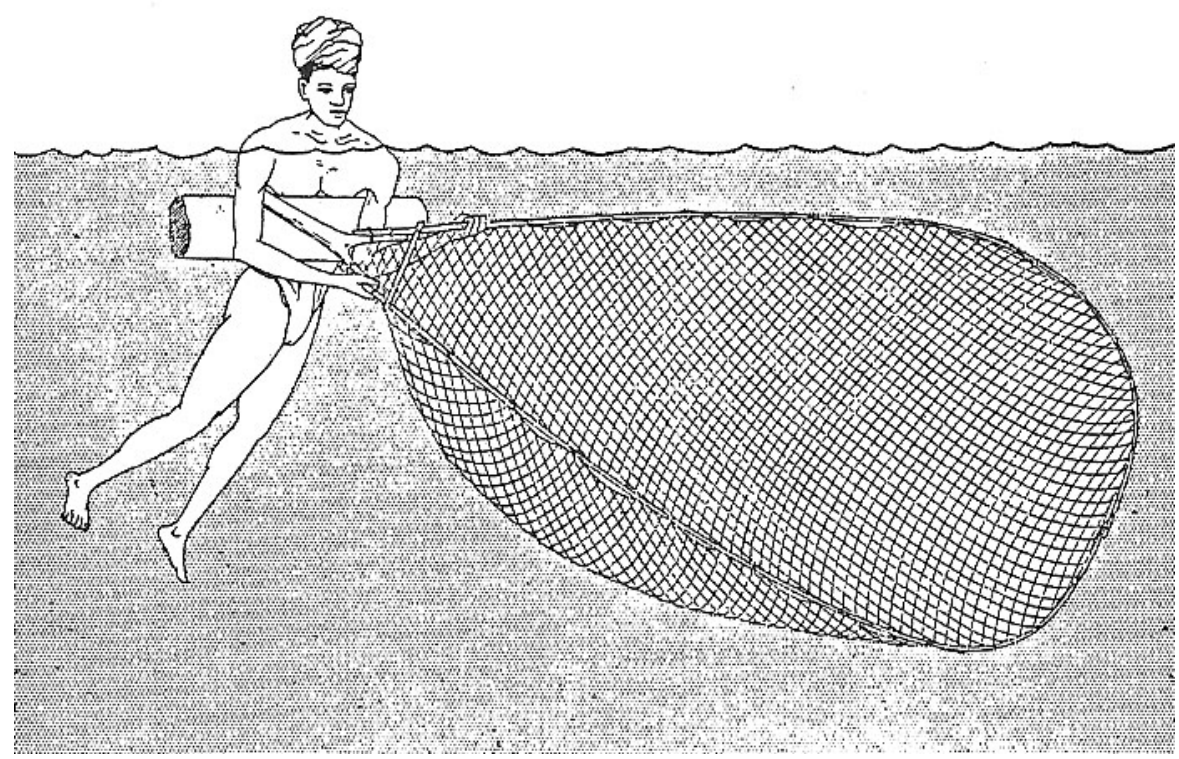

Figura 1.01 - Representação de um pescador do Rio Kaveri (sul da Índia) usando um flutuador de natação

Nos flutuadores propulsionados, por outro lado, em vez de ficarem imersos os indivíduos (e apenas um) permanecem sobre uma tora ou feixe de junco e, além dos membros, utilizam como propulsores varas, hastes, remos, etc.

Existem diversos exemplos da utilização de flutuadores por populações pescadoras tradicionais, indígenas e aborígenes ao longo de todo o mundo. $\mathrm{Na}$ 
Austrália, por exemplo, segundo Stokes (1846, p. 11, 15-16), existem inúmeros exemplos aborígenes da utilização de toras como flutuadores de natação. Eles são, freqüentemente, encontrados ao longo da costa norte australiana, onde os aborígenes utilizam uma pequena tora ou um pedaço de madeira, preso ao peito, para fazer longas jornadas entre as ilhas e o continente. Na América, Mason (1895, p. 334) indica o uso de um flutuador de madeira como uma prática de tribos do Golfo da Califórnia para descansar seus braços quando nadam.

Hornell (op. cit.) afirma que uma definição mínima sobre flutuadores não pode ser apresentada sem uma referência sobre as pranchas havaianas. Embora elas sejam hoje utilizadas para a prática de esporte, Lisiansky (1814 apud HORNELL, op. cit, p. 4), que visitou a ilha em 1804, não viu canoas lá, mas muitos nativos vieram ao barco utilizando, cada um, uma prancha de madeira.

Do ponto de vista tecnológico, não seria impossível que os sambaquieiros tivessem desenvolvido e utilizado flutuadores e, a partir dessa experimentação náutica (realizada, principalmente, nos primeiros momentos da ocupação sambaquieira, onde estariam se adaptando aos ambientes costeiros), desenvolvido inovações que levaram à construção de balsas e à transformação de flutuadores em canoas. Além de possuírem conhecimentos suficientes para a sua construção, os padrões de desgaste articular e de estresse muscular, indicados por Carvalho (2004), descritos no item anterior, também condizem com a utilização de ambos os tipos de flutuadores, de elementos de propulsão e da construção de canoas.

Embora ainda não existam muitas evidências materiais que nos permitam discutir o desenvolvimento de uma tecnologia náutica sambaquieira, em função desses argumentos, não podemos negá-la. Pois, assim fazendo, assumimos uma perspectiva difusionista, através da qual somente poderiam existir artefatos náuticos sambaquieiros se os conhecimentos para o seu desenvolvimento tivessem sido trazidos por povos ou indivíduos de regiões distantes.

Nesse sentido, defendemos que tanto a navegação (entendida como arte ou a habilidade de se deslocar e se localizar nos ambientes aquáticos) como a construção de flutuadores, balsas e canoas poderiam ter sido desenvolvidas pelos 
povos dos sambaquis, assim como também foram desenvolvidas por outros povos ao longo do atual território brasileiro, sul americano e do mundo todo.

Uma vez estabelecida, entre os sambaquieiros, as tecnologias necessárias para a preparação dos flutuadores, o próximo passo no sentido do desenvolvimento tecnológico das embarcações deveria estar associado à transformação desses em balsas, jangadas e canoas monólixas (escavadas em uma única arvore). Hornell (1970, p. 1) aponta que para o surgimento de balsas ou jangadas, bastaria apenas que as toras ou feixes de juncos fossem amarrados juntos, lado a lado. Como já mencionado (item anterior), esses tipos de embarcação também condizem com os padrões bioarqueológicos identificados por Carvalho (2004).

No que tange a artefatos náuticos mais complexos, elaborados a partir de técnicas que suplantam a escavação, modelagem e agregação de flutuadores (como ocorre, por exemplo, na construção de barcos, onde diferentes tipos de estruturas são unidos para formar um casco), o mais provável é que tal desenvolvimento tecnológico não tenha sido atingido pelos sambaquieiros. Além de não ser encontrado um ferramental que permitisse a construção desses tipos de embarcações, tais barcos não são encontrados mesmo entre as sociedades que, posteriormente, vieram a habitar as áreas antes ocupadas pelos sambaquieiros. Como em determinado momento houve certa coexistência entre os sambaquieiros e os tupiguaranis, se os sambaquieiros tivessem desenvolvido tal tecnologia, seria de se esperar que, de algum modo, os tupiguaranis poderiam ter aprendido ou se apropriado de técnicas de construção desses artefatos náuticos mais complexos.

Voltando a questão dos artefatos náuticos mais simples, Carabias (2000) destaca uma série de evidências pré-hispanicas de navegação ao longo da costa norte do Chile. O mais antigo vestígio material dessa navegação diz respeito a uma miniatura de balsa de totora (junco) encontrada em um [...] cementerio de túmulos, ubicado $6 \mathrm{~km}$ al sur de la desembocadura del rio Loa, fechada em 215 d.C.(figura 1.02) (LLAGOSTERA, 1990 apud CARABIA, 2000, p.34). 


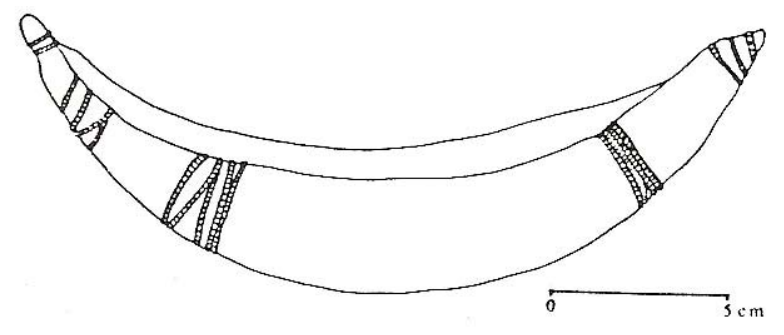

Figura 1.02 - Miniatura de balsa de junco encontrada, no norte do Chile (CARABIAS, op. cit.)

No entanto, é no interior do Brasil que pode existir a mais antiga evidência de fabrico e construção de canoas, a qual acabaria, de vez, com as compreensões difusionistas que entendem que a tecnologia náutica só poderia ter chegado à América do Sul após ser desenvolvida por povos tecnologicamente e culturalmente mais avançados. Na realidade, mesmo que a navegação não tenha surgido de maneira independente, o mais provável é que em cada comunidade ou aldeia, onde novos grupos começavam a utilizar tal tecnologia, ela era sempre adaptada com inovações e significados desenvolvidos com base na experimentação de cada indivíduo e dos grupos a que pertenciam.

\begin{abstract}
En um comienzo, el tema de ela navegación en América sirvió para alimentar inconsistentes hipótesis difusionistas de poblamiento; largos viajes "oceánicos" fueran señalados como un mecanismo mediante el cual agentes "civilazadores" venidos desde tierras distantes, com un mayor nivel de desarrollo sociocultural, hicieron entrega de aparataje tecnológico y empleo de técnicas a otros grupos com niveles supuestamente más "atrasados" (CARABIAS, 2000, p. 31)
\end{abstract}

Essas evidências dizem respeito a uma série de representações de pirogas (figura 1.03 a 1.07) classificadas como da tradição nordeste, que foram pintadas em abrigos sob rocha da região do Seridó, no interior do estado do Rio Grande do Norte. Tradição que, segundo Borges (2008, p. 12), teria permanecido na região entre 12.000 e 6.000 anos AP. 


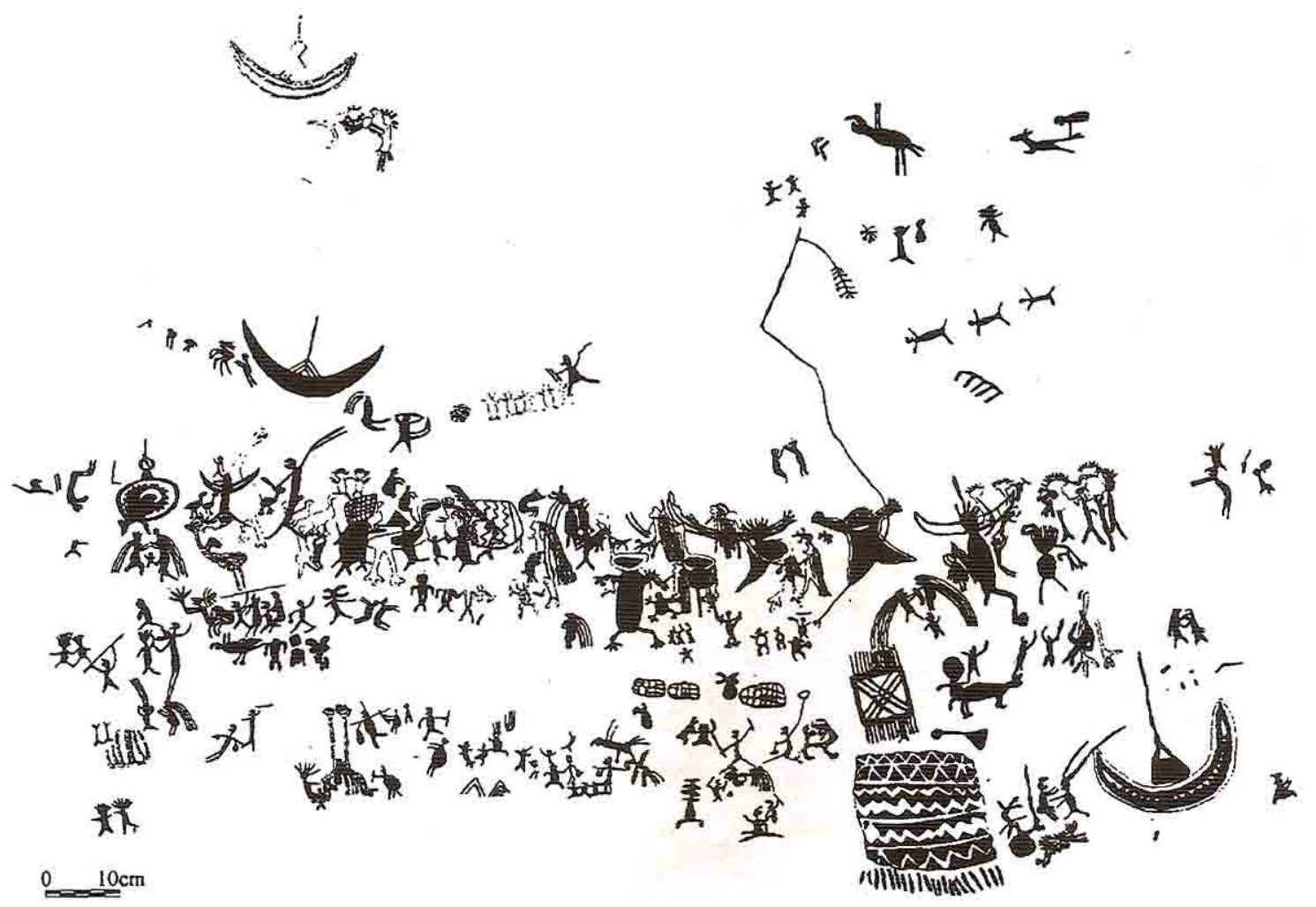

Figura 1.03 - Painel Casa Santa, Carnaúba dos Dantas, RN (Borges, 2008)
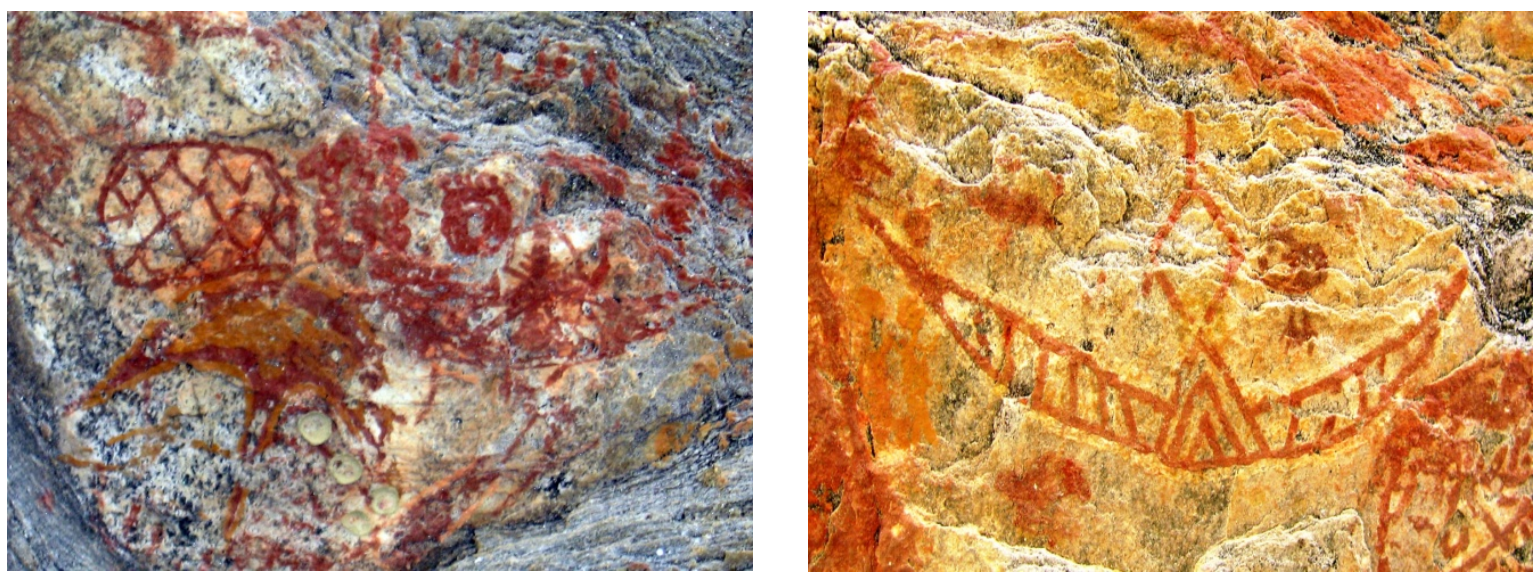

Figuras 1.04 e 1.05 - Prováveis representações de pirogas (classificadas como da tradição nordeste) pintadas em abrigos sob rocha da região do Seridó, interior do Rio Grande do Norte (foto: Flávio Calippo). 

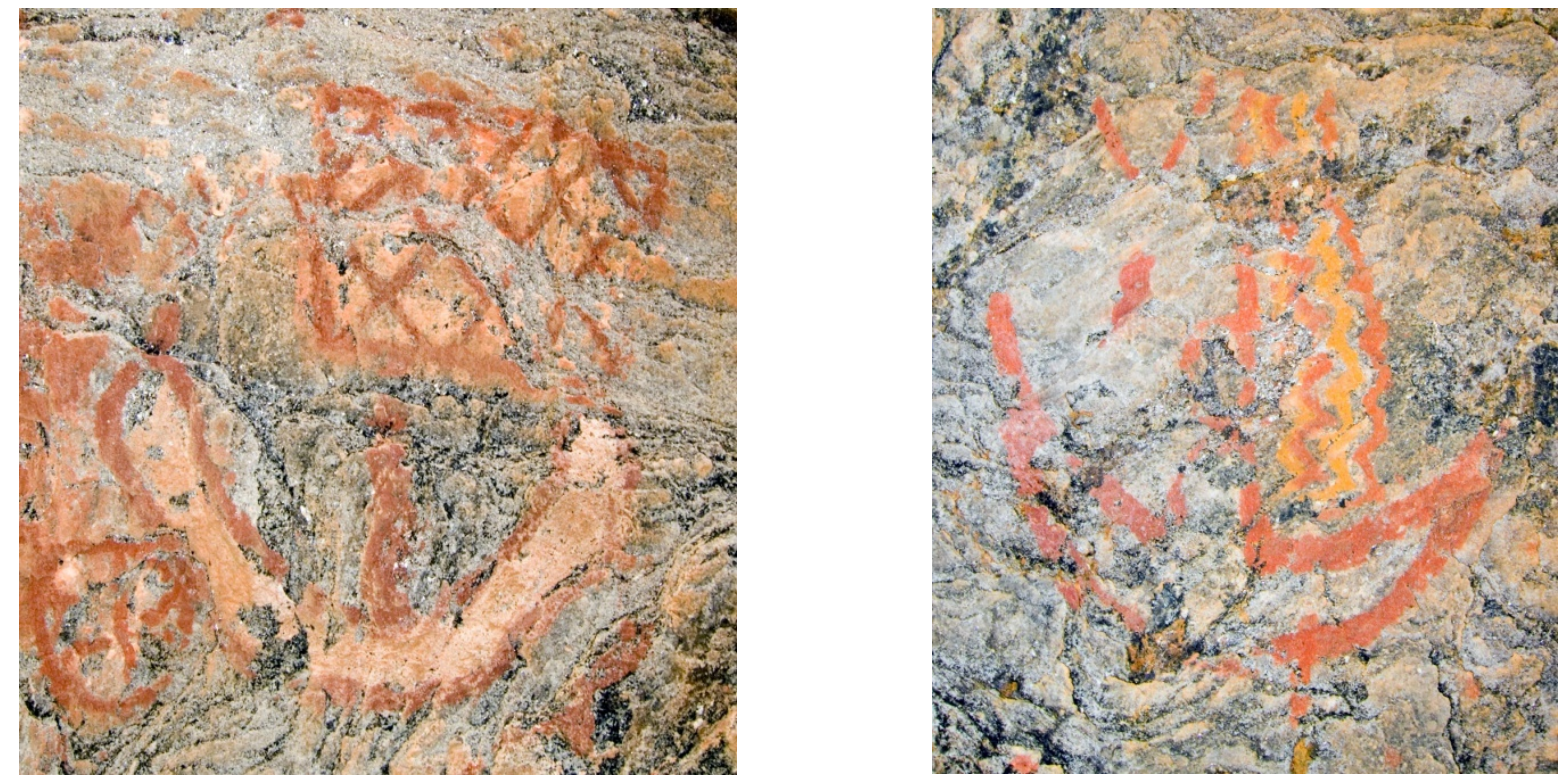

Figuras 1.06 e 1.07 - Prováveis representações de pirogas (classificadas como da tradição nordeste) pintadas em abrigos sob rocha da região do Seridó, interior do Rio Grande do Norte (foto: Flávio Calippo).

Ainda que a autora Martin (1997) faça referência a pirogas, uma análise direcionada ao tema náutico sugere não somente a possibilidade de tais pinturas representarem canoas monóxilas, mas, principalmente, em função de seu formato semi-lunar, indicarem canoas de feixes de junco ou de casca de árvore. Nestas representações é possível ainda identificar uma recorrência de elementos acessórios, os quais poderiam estar relacionados a adaptações ou inovações tecnológicas decorrentes da experimentação e contínuo desenvolvimento destas embarcações.

Além de possíveis mastros e de uma utilização que não está, necessariamente, vinculada à subsistência (figura 1.08 - c), as representações sugerem ainda a possibilidade da utilização de algum tipo de velame (figura 1.08 - g). Mesmo que esse tipo de forma de representação geométrica seja comum nos sítios da região e, nesse sentido, uma interpretação equivocada possa ser estabelecida a partir da sobreposição de diferentes figuras, a sua associação com um dos mastros reforça ainda mais a hipótese deste elemento representar uma canoa com algum tipo de propulsão a vela. 


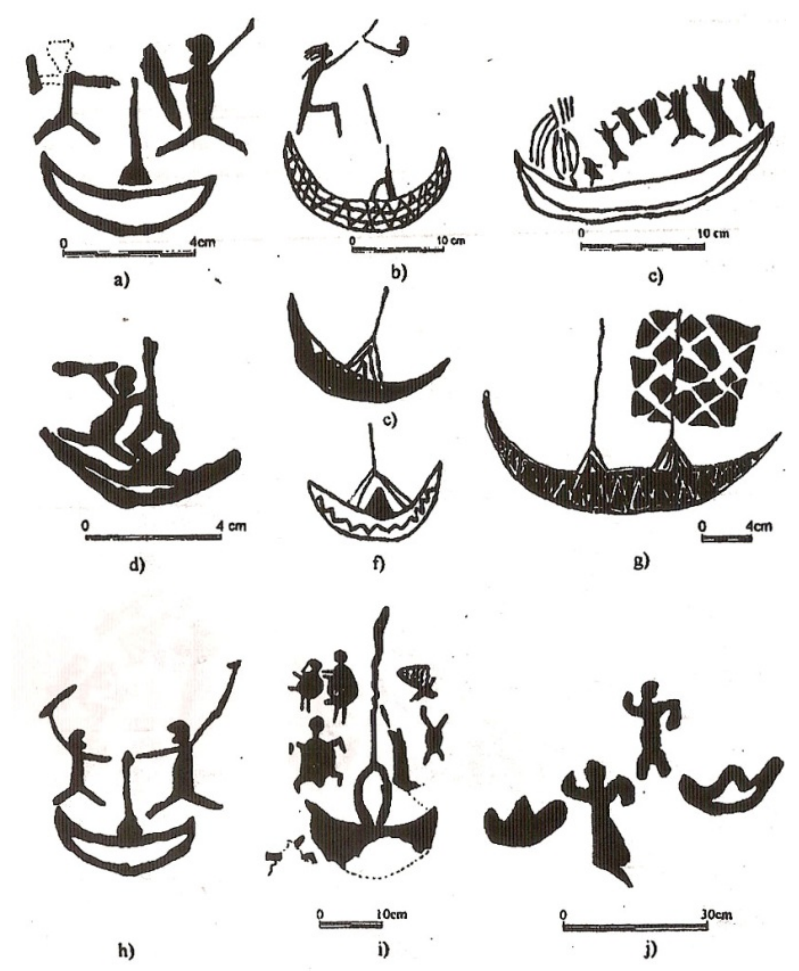

Figura 1.08 - Representações de pirogas encontradas no sítio Pedra do Alexandre, em Carnaúba dos Dantas (c - representação de uma piroga que carrega sete indivíduos guiados por um chefe que ostenta longo cocar de penas; g: provável representação de uso de vela) (MARTIN, 1997, p. 255).

Embora aqui se defenda a possibilidade dessas representações serem relativas a canoas já com certos tipos de inovações (mastros, velas, etc) ou com adaptações desenvolvidas para a realidade local, anos mais tarde, segundo Borges (2008, p.52), Gabriela Martin e Anne Marie Pessis apontam, com base em análises etnográficas comparativas, a possibilidade dessas imagens também serem representações de redes funerárias.

Apesar da atribuição de significados a esse tipo de grafismo ser uma questão bastante controversa, que, no mínimo, demandaria um estudo específico dessa questão, existem algumas características que nos permitem hipotetizar a respeito da utilização de embarcações associadas ao contexto arqueológico da região do Seridó. Além das prováveis representações de velas se encontrarem recorrentemente associadas às canoas e a possíveis mastros, essas velas apresentam aparentemente um padrão diferenciado do encontrado nas outras figuras 
geométricas (com franjas) que se distribuem pelos painéis dos sítios da região (figura 1.03). Por outro lado, ainda que tais figuras não pudessem ser assim consideradas, tendo o tema náutico como referência, talvez possam representar a utilização de redes de pesca.

Mesmo que ainda não se possa ter uma noção mais específica e precisa para essa questão, existe um outro fator que fomenta o entendimento de representações como canoas: o contexto paleoambiental da região do Seridó. Segundo Borges (op. cit, p. 66), a região do Seridó é marcada por um relevo acentuado, através do qual se desenvolve uma hidrografia (figura 1.09) intermitente, pela qual os rios da região só assumem seus volumes máximos ao longo das épocas chuvosas. No entanto, segundo essa autora, diversas evidências arqueológicas (registros rupestres e vestígios alimentares) sugerem a predominância, no passado, de um ambiente entremeado por um regime hídrico mais proeminente do que o atual.

Quando aborda a questão da origem da ocupação do sertão do Seridó (que engloba os municípios de Parelhas e de Carnaúba dos Dantas), em ambas as hipóteses que propõe (via rio Piranhas-Acú e, depois, via rio Seridó; ou a partir do litoral via a porção leste do estado do Rio Grande do Norte), o ambiente aquático é sempre o principal elemento de conexão, pois, independente das rotas escolhidas, elas são sempre baseadas nos principais rios que cortam a região e ligam-na ao mar. $\mathrm{Na}$ realidade, as hipóteses de ocupação apresentadas por Borges (op. cit, p. 67) partem do ponto que esses grupos vieram de áreas que foram dominadas pelo avanço do nível do mar, a partir do qual as populações direcionaram-se ao interior em busca da manutenção de suas condições ambientais ideais.

Essa questão fica mais clara quando a autora analisa o processo de ocupação do atual território do Rio Grande do Norte:

[...] considerando a mobilidade dessas populações, a variação climática, a umidade do solo e as características da vegetação e da fauna devem levar em conta dois fatores: primeiro, a ocupação desse território não ter se realizado somente pelas vias litorâneas [pois essas estariam sendo submersas no período de transição entre pleistoceno e holoceno], mas também pela capacidade de interiorização; e segundo, pelas próprias condições ambientais o homem ter optado habitar áreas mais favoráveis à sua sobrevivência (BORGES, op. cit, p. 66). 


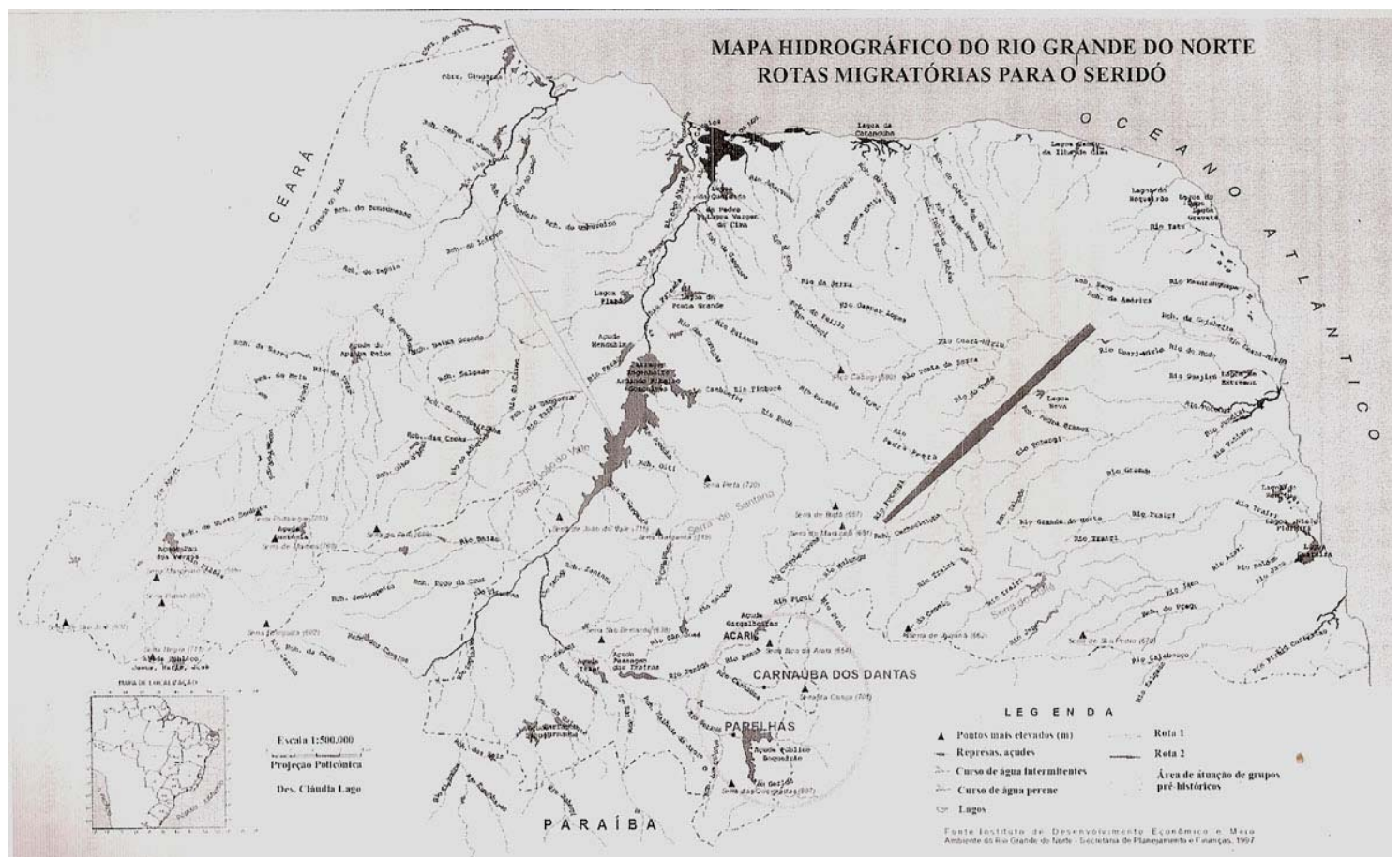

Figura 1.09 - Mapa hidrográfico do Rio Grande do Norte

Independente do sentido em que esse processo tenha se dado (litoral em direção ao interior ou vice-versa), o importante para a questão do estabelecimento desse contexto náutico é o fato de que tal processo é semelhante aos que parecem ter ocorrido ao longo de outros locais da costa pacífica e atlântica sul-americanas, onde se estabeleceram populações humanas que desenvolveram e/ou utilizaram a tecnologia da navegação. Ao longo da costa atlântica, por exemplo, pode-se citar o caso da ocupação do vale do Rio Ribeira de Iguape. Como veremos (nos capítulos finais desta Tese), ao tratarmos do Modelo de Predição elaborado para a costa brasileira, as evidências arqueológicas e paleoambientais indicam a possibilidade de também terem ocorrido fluxos de populações humanas do litoral para o interior. No caso específico do vale do Ribeira, não só do litoral para o interior, mas, provavelmente, também, um primeiro e mais antigo fluxo, do interior para o litoral, em meio ao qual as populações que deram origem aos povos dos sambaquis podem ter iniciado sua experimentação náutica.

No caso da costa pacífica, uma situação específica desses fluxos ligados à navegação é apresentada por Carabias (2000, p. 40), ao abordar a questão da 
origem das balsas utilizadas para navegação oceânica pré-histórica ao longo da costa pacífica:

\begin{abstract}
Establecer el origen de este tipo de embarcaciones resulta complejo. Evidencias arqueológicas apuntam a contactos marítimos periódicos entre el litoral ecuatoriano y Mesoamérica desde el Período Formativo Temprano, em tempos tan antiguos como La fase Valdivia Tardia (ca. 2.000-1.500 a.C.), pero se cree que los pré-cerámisco Valdivia que arribaron al lugar, yaposeían embarcaciones de alta mar (ca. 3.400 a.C.)(Zeidler, 1986). Buse (1973), há postulado que las balsas de madera se genaron em los rios interiores Del Perú, sufriendo uma posterior adaptacion marítima.
\end{abstract}

\title{
1.5. A PERCEPÇÃO DO AMBIENTE
}

Uma vez estabelecidas compreensões a respeito do universo marítimo sambaquieiro e dos povos dos sambaquis como uma sociedade marítima, o passo seguinte está vinculado à definição dos conceitos que nos permitem identificar, investigar e interpretar os modos, os processos, as correlações e os padrões através dos quais poderíamos inferir como os sambaquieiros compreenderiam e interagiriam com os ambientes. Nesse sentido, a abordagem aqui desenvolvida está calcada em uma perspectiva focada principalmente nos estudos de percepção ambiental propostos por Ingold (2000) e em concepções provenientes da Sociologia Ambiental (Herrera, 2002; Mayorga, 2006)..

No entanto, antes de estabelecermos hipóteses a respeito da percepção ambiental dos povos dos sambaquis, é importante também fazermos uma reflexão a respeito de algumas questões sobre a maneira como atualmente entendemos as relações entre homem e meio.

A primeira dessas reflexões diz respeito à dicotomia que se estabelece entre homem e natureza. onde, normalmente, os indivíduos são concebidos como externos e em oposição ao meio natural. Uma perspectiva que, de um modo ou de outro, tende a conduzir-nos a interpretações deterministas ambientais ou culturais. A segunda refere-se à maneira como entendemos a transformação da natureza pelo homem. No âmbito desta Tese, a relação homem versus natureza é compreendida a partir de um ponto de vista dialético, em que indivíduo e natureza transformam-se 
mutuamente. A experiência de transformar o meio modifica o indivíduo, que, por sua vez, modifica a relação que estabelece com a natureza e, nesse sentido, com si mesmo.

Um dos principais motivos que nos leva a analisar os sambaquieiros a partir dessa perspectiva, focada nas relações entre os indivíduos e o meio natural, tem suas raízes na idéia de que coletores e pescadores são sempre tecnologicamente mais "atrasados" e menos complexos que povos agricultores. Embora isso (que para alguns autores ainda é uma premissa) possa ser verificado em algumas sociedades, ela não é uma lei universal. Como já foi apontado no item 1.3, existem diversos casos em que esta estrutura (coletores, caçadores, pescadores, agricultores, etc) não é suficientemente flexível e complexa para explicar a realidade e a diversidade das práticas e das relações sócio-culturais.

Para um melhor entendimento de algumas dessas sociedades, que não podem ser consideradas nem puramente simples e nem explicitamente complexas (onde incluímos os povos sambaquieiros), o desenvolvimento de uma apurada percepção ambiental (a qual envolve um preciso mapeamento dos elementos ambientais, no espaço e ao longo das épocas do ano) e o estabelecimento de técnicas e estratégias específicas para a contínua exploração do ambiente, também devem ser compreendidos como intrínsecos aos modos de produção de conhecimento e ao desenvolvimento tecnológico.

O fato de não serem assim concebidos é, no mínimo, um contra-censo; pois, o desenvolvimento de tais tecnologias demanda, no mínimo, o mesmo nível de conhecimento acumulado e de esforços necessários para o domínio das épocas de plantio e para o desenvolvimento e elaboração de ferramentas e instrumentos específicos (enxós para a preparação de canoas, artes de pesca, redes, machados, zoólitos, etc).

De certo modo, essa compressão do meio natural como algo acessório e passivo em relação ao estabelecimento das sociedades sambaquieiras é, também, uma conseqüência da visão dicotômica que durante muito tempo estabelecemos entre natureza e cultura. Como, sob esse ponto de vista, existe sempre uma necessidade de atribuir uma causa cultural ou natural para explicar a ação de 
agentes, escolhas e processos, acabamos interpretando natureza e cultura de forma isolada, distanciando as relações entre essas duas esferas do centro das discussões. Direcionando, desta maneira, as questões centrais dessas discussões para a periferia das problemáticas.

É importante ressaltar que não se pretende com essa argumentação negar a importância da utilização das esferas ambientais e culturais, mas, sim, propor uma discussão a respeito desses conceitos de modo que, pelo menos, partes destas duas esferas possam, em momentos específicos, serem abordadas também de uma forma mais integrada e não excludente. Talvez, sob essa perspectiva muito discutida no âmbito da Sociologia Ambiental (e, mais recentemente, nos estudos de Arqueologia Simétrica), seja possível iniciarmos um processo de reflexão a respeito de tal dicotomia.

Segundo Buttel (1996, p. 65) esse salto é extremamente necessário, pois, normalmente, as estruturas tradicionalmente utilizadas para explicar uma sociedade (classes, estados, etc) nem sempre são suficientes quando o que se quer é compreender as relações ambientais. Assim, se conseguirmos superar a dicotomia homem versus ambiente em, pelo menos, alguns pontos do processo arqueológico analítico e interpretativo, é provável que possamos também melhor compreender os limites estabelecidos pela Arqueologia entre ambiente e sociedade.

$\mathrm{Na}$ medida em que isto se tornar possível, maior será o conjunto de dados que poderemos analisar a partir de um referencial comum. Em alguns casos, talvez, nem faça mais sentido discutir se um indivíduo, grupo, ou sistema sociocultural toma suas decisões e faz suas escolhas em conseqüência de pressões ambientais ou a partir de costumes, tradições ou de outros aspectos considerados eminentemente culturais.

A fim de avançarmos nessa questão, é importante também compreender que tal dicotomia não tem uma origem exclusivamente ligada à Arqueologia. Durante muito tempo esta separação entre homem e natureza foi de extrema importância para que as ciências humanas pudessem se estabelecer como um universo distinto das ciências naturais, onde, normalmente, só são aceitos como científicos os estudos que conseguiam ser hipotetizados e empiricamente comprovados. Embora 
esta concepção normativa do que é científico ainda persista em certas áreas, é preciso pensar que as ciências humanas já assumiram um grau de desenvolvimento e reconhecimento que não mais justifica a manutenção de tal dicotomia.

Segundo Mayorga (2006, p. 50), hoje o conhecimento científico encontra nos processos irreversíveis uma chave diferente para compreender e explicar tanto a natureza como a sociedade, entendidas como âmbitos habitados por seres com capacidade para modificar, modificar-se e inovar, cujo comportamento não se pode considerar absolutamente previsível e controlável, tal como acreditava o pensamento científico clássico. Uma das conseqüências inevitáveis dessa reconceitualização da noção de leis científicas é a superação da tradicional divisão entre as chamadas ciências ditas "duras" e "brandas".

O combate a tal segmentação também pode ser encontrado em Herrera (2002), que afirma ser necessário questionar porque normalmente compreendemos as esferas do natural, do social, do econômico e do cultural em um estado particular de (relativo) equilíbrio em uma sociedade, região ou civilização? E, mesmo que isso pudesse acontecer, como é que poderíamos diagnosticar e lidar com os limites desses compartimentos?

No sentido de superar tal dicotomia, Ingold (1994, 2000 e 2001), Descola (1992, 1998, 2001 e 2002) e Viveiros de Castro (2002) propõem a necessidade de uma revisão da teoria social de forma a se avançar na construção de um instrumental analítico que nos permita falar em termos de trans-ecologia e multinaturalismo, superando o dualismo natureza-cultura que marcou a Antropologia moderna e serviu para definir o próprio campo de atuação dessa disciplina. Afinal, além de tais questões serem de extrema importância para alinhar as interpretações arqueológicas aos novos paradigmas das ciências humanas e ambientais, essa proposta, onde se estabelecem de maneira simbiôntica natureza e sociedade, não é nova nas humanidades e no próprio materialismo histórico.

Segundo Trigger (2004, p. 221), embora novas tecnologias (onde incluo os modos através dos quais o homem se apropria do meio natural) acarretem mudanças políticas e sociais, elas são, em si mesmas, produtos de contextos sociais específicos que influenciam quais inovações têm ou não probabilidade de acontecer. 
Era isso que Engels tinha em mente quando escreveu que em última análise, o elemento determinante do processo histórico é a produção e a reprodução da vida. Se alguém distorcer este princípio transformando-o na crença de que o elemento econômico é o único determinante, terá transformado a concepção materialista da história em uma sentença vazia e abstrata (MARX e ENGELS, 1962, 2, p. 488 apud TRIGGER, 2004, p. 221).

\subsubsection{A construção de uma percepção ambiental sambaquieira}

A partir dos anos 40, quando, segundo Klökler (2001), surge um consenso dos pesquisadores a respeito da artificialidade dos sambaquis e sobre o caráter de descarte (através do qual os moluscos eram simplesmente entendidos como restos de alimentação), inicia-se, na Arqueologia brasileira, o desenvolvimento de uma perspectiva teórica para o estudo dos sambaquis, influenciada, sobretudo, pela Ecologia Cultural e por abordagens evolucionistas.

Se, por um lado, essa perspectiva permitiu o desenvolvimento de novas compreensões como padrão de assentamento, captação de recursos, estudos de tecnologia, etc, por outro, acabou atribuindo aos ambientes um significado que restringe seu entendimento ao mero espaço onde as populações humanas viveriam e dele obteriam seus recursos. Negando, de certa forma, a possibilidade de que viessem a ser compreendidos como parte indissociável de seu meio (enquanto indivíduos e sociedades que se relacionam com a natureza de uma forma dialética), e atribuindo a eles (os sambaquieiros) valores e percepções modernas, intrínsecos a um contexto histórico capitalista. Resultando, por vezes, em interpretações normativas e deterministas de sua relação com a natureza.

Essa visão do ambiente como algo externo a sociedade sambaquieira pode ser entendida como uma conseqüência dos modos através dos quais a própria Arqueologia brasileira vem se relacionando com as correntes teóricas internacionais. Influenciada pelo fortalecimento de uma Arqueologia norte-americana (que, cada vez mais, destacava a importância do caráter quantitativo em detrimento do qualitativo), 
aumenta, na Arqueologia brasileira, uma preocupação com a identificação de unidades culturais, a partir das quais a cultura é entendida muito mais como um conjunto de objetos (culturas arqueológicas) do que como um complexo de conhecimentos, crenças, arte, moral, leis, costumes ou qualquer outra capacidade ou hábitos adquiridos pelo homem como membro de uma sociedade (TENÓRIO, 2004, p. 72).

Embora calcada em pressupostos da antropologia, a arqueologia americana se apropria do conceito de cultura com uma visão muito particular, na medida em que destitui a humanidade do conceito básico de unidade cultural formulado por como: "todo complexo que inclui conhecimentos, crenças, arte, moral, leis, costumes ou qualquer outra capacidade ou hábitos adquiridos pelo homem como membro de uma sociedade" (Tylor, 1970 apud Laraia 1989).

Percebendo a cultura como um conjunto de objetos e não de crenças e costumes expressos no discurso, a arqueologia passa a trabalhar com "culturas arqueológicas", evidenciadas, segundo Childe, por: "uma pluralidade de bens definidos, tipos, diagnósticos, que são repetidamente e exclusivamente associados com outros, e que, quando plotados nos mapas, exibem um reconhecido padrão de distribuição" (Childe 1981:112).

Entre essas duas definições apresentadas acima, existe uma grande distância entre o conceito de cultura e o que pode ser revelado através do estudo da cultura material. Pontos referentes à ideologia, estruturadores de cultura, passaram a ser evitados, devido à dificuldade de serem recuperados a partir do estudo da cultura material.

Nesse contexto, baseados nos princípios da Escola do Histórico Culturalismo americano, elementos da cultura material, encontrados nos sítios litorâneos brasileiros, foram tipologizados, com o objetivo da identificação das unidades culturais, sua evolução e dispersão.

Posteriormente, princípios da Ecologia Cultural foram acrescentados às interpretações para explicar mudanças observadas na cultura material, que passaram a ser entendidas como evidências de adaptações funcionais às alterações ambientais (TENÓRIO, op. cit, p. 72).

Sob essa ótica todos aqueles conjuntos de comportamentos e práticas sociais que não ficam preservados no registro arqueológico e, portanto, não podem ser quantificados, correlacionados entre si e utilizados como diagnósticos, a fim de estabelecer padrões, passam a ser desconsiderados da análise da cultura material. Nesse sentido, a relação com o ambiente passa a ser considerada primordialmente como uma fonte econômica de obtenção de recursos.

[...] baseados nos princípios da Escola do Histórico Culturalismo americano, elementos da cultura material, encontrados nos sítios litorâneos brasileiros, foram tipologizados, com o objetivo da identificação das unidades culturais, sua evolução e dispersão. 
Posteriormente, princípios da Ecologia Cultural foram acrescentados às interpretações para explicar mudanças observadas na cultura material, que passaram a ser entendidas como evidências de adaptações funcionais às alterações ambientais

A multilinearidade evolutiva, proposta por Boas (1965), colocada por Steward (1955) e White (1943) como resposta a pressões ambientais, passou a ser a principal responsável pelas mudanças culturais, apresentando à arqueologia a possibilidade de testar modelos que explicariam alterações culturais. Assim sendo, o Histórico Culturalismo passou a influenciar decididamente a interpretação arqueológica.

(TENÓRIO, op. cit, p. 73).

Em resposta a essa compreensão, surge na Arqueologia uma tendência que postulava um homem muito mais influenciável por um ambiente/natureza de percepção mentalista do que um ser delineado por fatores ambientais, mostrando que o "ambiente" social pode exercer tanta influência como o "natural" e que o social deve ser visto como suporte e modelador de ações humanas (TENÓRIO, op. cit, p. 74).

Para a antropologia, a visão da cultura como um instrumento adaptativo foi muito usada até ser colocada em discussão, quando Shallins (1979) demonstrou, através de resultados de estudos etnográficos que, no comportamento humano, a ideologia pode prevalecer sobre as causas ambientais. A posição de Shallins vem reforçar a proposta de Lévi-Strauss (1955) que já postulava um homem muito mais influenciável por um ambiente/natureza de percepção mentalista do que um ser delineado por fatores ambientais, mostrando que o "ambiente" social pode exercer tanta influência como o "natural" e que o social deve ser visto como suporte e modelador de ações humanas (TENÓRIO, op. cit, p. 74).

Com o estabelecimento dessa crítica estruturalista [a qual aponta que, no comportamento humano, a ideologia pode prevalecer sobre as causas ambientais], arqueólogos, que tinham seu trabalho baseado na Ecologia Cultural Neofuncionalista, passam a ser criticados como reducionistas e deterministas. Tentando fugir a essa rotulação, os arqueólogos procuram outras abordagens, mas, acabaram, como a maior parte, utilizando causas ambientais para explicar o que não conseguem responder somente com base na tipologização da cultura material. Tal fato se dá principalmente porque a Ecologia Humana tem uma grande capacidade de fornecer modelos testáveis pela Arqueologia (TENÓRIO, op. cit, p. 74). 
Ainda segundo essa autora, surgem no Brasil duas vertentes interpretativas principais: uma evolucionista, que se expressa através do materialismo histórico, combinando a evolução das formas de cultura com mudanças na economia, a partir da qual surgem trabalhos (MENDONÇA DE SOUZA, 1981; DIAS, 1983/84) que caracterizam a cultura e a mudança a partir do modus econômico de extração; e outra, funcionalista, mais ligada à Ecologia Cultural, que, além da identificação de mudanças, busca o entendimento da capacidade de adequação funcional da cultura em relação ao meio.

[...] a funcionalista, mais relacionada à Ecologia Cultural, procura associar os mecanismos elaborados para adaptação com as escolhas culturais. Essa abordagem é encontrada nos trabalhos de Heredia (1980,1981/82, 1989), Carvalho (1984) Dias Jr (1972), Kern (1989), Schmitz (1984), Kneip (1994). Schmitz e Kneip, embora tenham uma preocupação com as respostas ambientais, estão mais voltados para detalhar exaustivamente o "modus vivendi" do grupo estudado, enquanto Kern também se preocupa com a história da paisagem, observando o homem a partir de sua interação com um ambiente mutável no tempo. Nesse aspecto, difere de Heredia que não tem como enfoque a contextualização do objeto de estudo no tempo; os sítios são analisados como se fossem estáticos, atemporais, o que exemplifica uma abordagem mais próxima da Antropologia do que da História. Essa tendência de focalizar o sítio isoladamente dá origem a um outro tipo de abordagem na arqueologia do litoral desenvolvida no Brasil, os estudos isolados (TENÓRIO, op. cit, p. 75).

Essa tendência de analisar os sítios de forma isolada dá origem, para Tenório, a um outro tipo de abordagem arqueológica sobre a ocupação do litoral brasileiro: o estudos isolados. Motivados pelas dificuldades em delimitar as unidades culturais, muitos pesquisadores passam a adotar abordagens interdisciplinares que procuram entender os sítios de forma isolada, através da reconstituição de seus elementos (dieta alimentar, área de captação de recursos, padrão de assentamento, etc). Uma postura que representa um certo retorno à abordagem metodológica francesa, na medida em que se aprofunda o conhecimento em um sítio em detrimento do enfoque regional, acrescida por uma abordagem tecnológica americana (TENÓRIO, op. cit, p. 74).

Trata-se de uma influência da Arqueologia Processual americana que vem sendo desenvolvida desde a década de 70 e que é bastante criticada por impregnar a arqueologia de uma postura demasiado positivista (Hodder et al, 
1995:5) e normativa (Claissen 1991:249) para uma Ciência Social (TENÓRIO, op. cit, p. 76 e 77).

Com isso, a partir da década de 90, de acordo com a autora, intensificam-se as pesquisas interdisciplinares, utilizando, principalmente, uma perspectiva focada na biologia, na botânica e na geomorfologia para se reconstruir a dieta alimentar, entender a mobilidade e reconstituir o meio ambiente explorado.

\begin{abstract}
Essa abordagem caracteriza um momento em que a questão do povoamento do litoral brasileiro é trocada por outras de menor amplitude, mas de maior profundidade. Chega-se a detalhes da dieta, porém fala-se pouco de províncias culturais. Provavelmente, isso é decorrente de estar a ciência influenciada também pelo pensamento pós-moderno que ressalta a importância em se considerar o fator diversidade e que mostra a fragilidade do conceito de cultura e a artificialidade na criação de fronteiras culturais. Ao mesmo tempo, essa postura constitui um impasse no desenvolvimento da pesquisa arqueológica, na medida em que a arqueologia tem como principal preocupação a identificação, a caracterização de culturas e o entendimento das mudanças (TENÓRIO, op. cit, p. 77).
\end{abstract}

Ainda que essas perspectivas tenham contribuído de modo significativo para o estabelecimento de um panorama a respeito da economia e dos recursos naturais explorados pelos sambaquieiros, pouco foi produzido sobre as relações sociais e sócio-ambientais que esses povos estabeleceram entre si e com o seu meio. Além de tais estudos, em geral, fundamentarem-se em conceitos de cultura que estariam ligados mais a padrões de ocorrência de artefatos (classificados, ordenados e quantificados) do que a conjuntos de conhecimentos, práticas, significados, costumes e relações estabelecidas entre os indivíduos (enquanto integrantes de uma comunidade ou sociedade), também se apoiavam em uma frágil compreensão do ambiente, onde os sambaquieiros eram entendidos mais como organismos do que indivíduos, e a natureza mais como um conjunto passivo de recursos do que como um espaço culturalmente percebido, que poderia ser transformado ou ter atuado como agente catalisador de transformações nas sociedades.

Destoando desse contexto, numa reaproximação com as Ciências Sociais, surge uma série de trabalhos, como os de Wust, De Blasis e Gaspar, que utilizam pressupostos da geografia, para o estabelecimento das áreas de captação de recursos e os padrões de assentamento; da antropologia social, para entender a 
organização e a identidade social. Dentre eles, apenas Gaspar (1991) desenvolve esse tipo de pesquisa no litoral (TENÓRIO, op. cit, p. 77 e 78).

Como conseqüência desse reposicionamento, desenvolve-se uma corrente que procura reconstituir as atividades desenvolvidas nos sítios com base na investigação do processo de formação de suas camadas. Tenório (op. cit, p. 80) aponta duas vertentes principais: a primeira, que considera o sítio como um artefato, parte do pressuposto de que o sítio foi construído por opções culturais e não apenas como resultado indireto de atividades que nele foram desenvolvidas. Em determinados casos, é proposto, inclusive, que o sítio foi realmente construído no sentido arquitetônico.

A segunda corrente (relacionada ao trabalho de Tenório), que considera o sítio como resultado de atividades especiais que implicam na formação de locais de destaques na paisagem, procura:

[...] compreender os motivos que fizeram com que alimentos fossem carregados e acumulados e considera que, dependendo da inserção do sítio no sistema de assentamento, ele apresenta contextos diferenciados e que, a partir de repetições sistematizadas pela Arqueologia Comportamental, podem-se inferir diferentes contextos atuantes na sua construção (SCHIFFER, 1976, p. 3 apud TENÓRIO, op. cit, 79).

Compartilhando, em certos aspectos, com ambas vertentes, a presente Tese também se fundamenta nos trabalhos e em re-leituras de Schiffer (1972) para compreender os processos naturais e culturais que fundamentam a formação do registro arqueológico; levando em consideração tanto os processos associados ao sítio como os que se relacionam com uma abordagem espacial mais ampla. Nesta são também considerados, sob os pontos de vista natural e cultural, os conjuntos locais/regionais de sambaquis e sua articulação em relação à toda ocupação sambaquieira.

Como veremos mais adiante, sob a perspectiva ambiental, serão levados em consideração, principalmente, as diversas modificações ambientais contemporâneas à ocupação sambaquieira do litoral e mesmo aquelas que ocorreram após o desaparecimento das sociedades sambaquieiras. No que tange ao cultural, o entendimento dos comportamentos sociais (para Schiffer, contexto sistêmico) que 
acabaram por moldar o contexto arqueológico é estabelecida a partir da correlação das evidências arqueológicas, presentes nos sambaquis e nos ambientes por eles apropriados, com o estudo etnográfico (a respeito das sociedades marítimas da Melanésia) desenvolvido por Malinowski (1922) e com as percepções ambientais apontadas por Ingold (2000), para as sociedades coletoras.

Embora a utilização desses referenciais etnográficos, antropológicos e sociológicos sejam aqui utilizados para atender a proposta de Schiffer (1972), que procura resgatar, a partir de estudos etnográficos com sociedades atuais, comportamentos gerais observáveis em quaisquer sociedades e que deixam marcas perceptíveis na cultura material (SHIFFER, 1978), a escolha dos estudos de Malinowski e Ingold deu-se, principalmente, em conseqüência da relação dialética (e intrínseca ao sistema sociocultural) com que as sociedades tobriandesas e os grupos analisados por Ingold compreendem o ambiente.

Com isso, nosso principal objetivo não é criticar a proposta de Schiffer, mas, sim, desenvolver uma estratégia de pesquisa que possa contribuir com novas hipóteses e abordagens a respeito do fenômeno dos sambaquis. As quais venham preencher algumas das lacunas que se estabeleceram em decorrência de perspectivas ambientais que consideram os indivíduos como externos à natureza e o ambiente como extrínseco ao sistema sócio-cultural.

Para isso, segundo Ingold (2000), é preciso superar a noção de que as relações natureza-cultura possam ser entendidas simplesmente como uma construção cultural da realidade. Ao invés disso, é preciso pensar de que modo nós compreendemos as ações, percepções e a cognição dos povos dos sambaquis; e em que medida essas concepções são, por nós, arqueólogos, influenciadas ou moldadas com base nas percepções e valores de nossa sociedade.

$\mathrm{Na}$ verdade, independente da maneira como classificamos essas questões, em processos naturais ou culturais, o importante é que, de alguma maneira, elas sejam efetivamente consideradas, sob uma perspectiva dialética, quando o comportamento de um indivíduo ou de uma sociedade estiver sob análise. 


\subsubsection{Reinterpretando os processos de formação do registro arqueológico}

Assumindo uma perspectiva que defende a indissociabilidade entre as esferas teóricas, metodológicas e técnicas para a produção de conhecimento arqueológico a partir do estudo da cultura material, foi desenvolvida uma abordagem metodológica que realmente atuasse como um elo de ligação entre as propostas teóricas (marítimas e ambientais) e as evidências arqueológicas.

A fim de sustentar tal conexão, estabeleceu-se uma proposta metodológica fundamenta principalmente em uma adaptação do estudo dos processos de formação do registro arqueológico propostos por Schiffer (1972) e em uma releitura, desenvolvida por Stein (2000), de tais processos no âmbito das pesquisas em sítios do tipo sambaqui.

A adoção de tal proposta tem diversas justificativas. Em primeiro lugar, permite uma concreta correlação das evidências arqueológicas com 0 posicionamento teórico (marítimo e ambiental) assumido. Correlação que se estabelece em conseqüência da capacidade da proposta de Schiffer (op. cit.) em reconhecer, como evidências arqueológicas, os diversos elementos ambientais, de ordem natural e cultural (como, a fauna, a flora, as paisagens, os rios, as praias, a matéria-prima, etc) associados aos sítios arqueológicos. Sob essa perspectiva, tanto artefatos como os elementos naturais, coletados ou capturados pelos sambaquieiros, podem ser entendidos como indicadores das relações que os indivíduos estabeleciam com o seu meio.

Em segundo lugar, compreende, de forma integrada, a formação do registro arqueológico a partir de macro, meso e micro escalas. As quais, aliadas às abordagens marítimas e de percepção ambiental, podem ser aplicadas para a análise de relações ambientais (estabelecidas a partir de um ponto de vista dialético) materializadas em um único sítio, entre conjuntos de sítios e em uma perspectiva regional. Levando-nos, inclusive, a uma reflexão a respeito das categorias (natural e cultural) que foram estabelecidas para o estudo de tais processos.

Assim, do mesmo modo que as relações entre sociedade e natureza podem ser interpretadas e discutidas com base nos artefatos encontrados nos sambaquis (e, 
em algumas vezes, em re-interpretações dos usos e funções desses artefatos), essa proposta permite também que a relação do homem com o universo marítimo possa ser investigada com base nas conchas, nos otólitos, nos ossos de peixes e de outros animais, que, em geral, configuram-se como evidências arqueológicas que não foram fisicamente e quimicamente modificadas pela ação direta do homem (ecofatos).

A principal diferença dessas evidências em relação aos artefatos reside no fato de que não são as modificações feitas pelo homem que as tornam indicadores de processos ou ações. A sua presença no sítio é que a torna uma evidência. Antes de ser depositado o futuro vestígio foi lembrado, procurado, localizado, selecionado, preparado, utilizado, descartado e, possivelmente, reutilizado antes de ser definitivamente descartado ou de ter um fim específico como material construtivo, oferenda ou acompanhamento funerário.

Uma vez entendidos nesse sentido, a essas evidências pode ser atribuída também a capacidade de atuarem como indicadores de eventos e processos (naturais e culturais), pois, a análise específica de elementos de sua anatomia e constituição permite que apontem, por exemplo, épocas e locais de crescimento, de captura e os ambientes (naturais) de sua ocorrência. Fomentando, assim, interpretações a respeito de territórios, áreas de coleta, sazonalidade das coletas e pescarias, mobilidade, etc. Questões fundamentais para o estabelecimento das especificidades e dos particularismos que, sob a ótica da Antropologia marítima e da Sociologia Ambiental, poderiam indicar o surgimento, a distinção e a correlação de diferentes sociedades ou comunidades sambaquieiras no tempo e no espaço.

A medida que compreendemos as relações dos sambaquieiros com a natureza e com os diferentes compartimentos e ambientes marinhos, é possível, também, que se possa contextualizar as diferenças e semelhanças culturais existentes entre as diversas áreas de ocorrência de sambaquis (conjuntos de sítios de Cananéia, Baixada Santista, litoral norte, etc), entre os principais compartimentos ambientais (fluviais, costeiros, marinhos, em ilhas, etc) e em relação aos diversos tipos de sítio (sambaquis propriamente ditos, acampamentos conchíferos, sítios habitação, funerários, etc). 
Como a compreensão marítima do modo de vida sambaquieiro aqui proposta se desenvolve a partir da correlação de questões que envolvem tanto a interpretação da cultura material dos povos dos sambaquis como o seu relacionamento com o universo marítimo, buscou-se estabelecer uma proposta analítica e interpretativa que fosse capaz de permitir o desenvolvimento de correlações entre as principais evidências arqueológicas encontradas (conchas, otólitos e ossos humanos), a evolução dos contextos ambientais a que os sambaquieiros estiveram associados e os modos através dos quais as sociedades sambaquieiras se relacionavam com o ambiente.

Para a elaboração de tal proposta adotou-se a análise dos processos de formação do registro arqueológico desenvolvida, por Stein (2000), com a intenção de compreender a estratigrafia de sambaquis da costa noroeste dos Estados Unidos. A qual foi desenvolvida a partir de um enfoque geoarqueológico calcado nos processos formação propostos por Schiffer (1972) e na Arqueologia Ambiental estabelecida por Butzer (1964).

A partir da abordagem teórica de Schiffer (1972), que se preocupa mais em obter informações a partir do registro arqueológico do que da classificação e da ordenação dos artefatos, Stein (op. cit.) apresenta uma análise que leva em consideração três conjuntos de fatores.

O primeiro deles é relativo aos processos culturais que considera como responsáveis pela formação do registro arqueológico, onde se incluem as maneiras como os objetos são procurados, utilizados, consertados e descartados. Eles envolvem as atividades através das quais se criaram e se utilizaram os artefatos, bem como aquelas que resultaram em sua deposição.

O segundo trata dos processos culturais que alteram ou obscurecem a interpretação das evidências. Nesses processos são levadas em consideração tanto as ações humanas contemporâneas à formação do sítio como as que ocorreram em períodos posteriores à deposição dos vestígios arqueológicos. Nesse conjunto, Stein (op. cit.) inclui também as alterações que os próprios arqueólogos causam sobre o registro arqueológico. 
O terceiro desses conjuntos engloba todos os processos naturais, os quais, são considerados, pela autora, como os eventos não culturais que alteram, obscurecem ou preservam o comportamento original das evidências arqueológicas.

No caso desta Tese, a justificativa da ação da abordagem de Stein (op. cit) está diretamente associada à sua capacidade em reconhecer como evidências de comportamentos e processos, vestígios arqueológicos de diferentes naturezas e magnitudes. No entanto, em conseqüência do posicionamento teórico adotado, procurou-se aqui desenvolver uma análise complementar que objetiva a adequação das problemáticas ambientais e marítimas em meio ao estudo dos processos de formação, repensando o que Stein (op. cit.) define como processos culturais e naturais.

Em relação ao primeiro dos conjuntos (processos culturais responsáveis pela formação do registro), além de considerar as maneiras através da qual os objetos são selecionados, coletados, transportados e depositados no sítio, são aqui consideradas também as intenções e as escolhas assumidas para a realização dessas ações. Nesse sentido, mais do que investigar o modo pelo qual as conchas de uma determinada camada foram coletadas, objetiva-se entender o porquê e com que intenção elas foram levadas ao sítio. Haveria apenas uma explicação prática para tais comportamentos (maior disponibilidade ambiental, proximidade do banco de moluscos, etc) ou eles seriam unicamente reflexo dos padrões culturais?

No que tange ao segundo conjunto (processos culturais que alteram ou obscurecem a interpretação das evidências), além da influência das ações humanas contemporâneas à ocupação dos sítios arqueológicos (como seleção, descarte, perda, etc.) e das alterações geradas por agentes humanos em períodos posteriores ao seu abandono (reocupação, reutilização das conchas, ações dos arqueólogos, etc.), também são levados em consideração, no âmbito desta Tese, a concepção que os próprios arqueólogos têm dos sítios e das sociedades que estudam.

Em nosso entendimento, as ações práticas sobre os sítios arqueológicos não podem ser entendidas como os únicos processos, ocasionados pelos arqueólogos, que alterariam ou obscureceriam o registro arqueológico. Além das interferências de ordem física, devem ser também consideradas as questões teóricas e 
metodológicas que norteiam desde os objetivos da pesquisa até a interpretação das evidências arqueológicas. Afinal, toda interpretação, por mais parametrizada que seja, é subjetiva.

Nesse sentido, as questões decorrentes do posicionamento teórico e das posturas interpretativas adotadas por seus interlocutores são aqui entendidas como intrínsecas ao estudo dos processos formativos. Desta maneira, tão ou mais importante que as modificações físicas realizadas pelos arqueólogos, consideramos que são as concepções que desenvolvem sobre os sítios, a respeito de seus construtores e em relação à maneira como os sambaquieiros se organizavam (e percebiam a si mesmos e ao seu meio), que acabam por alterar ou obscurecer a compreensão do registro arqueológico dos povos dos sambaquis.

É a partir dessa perspectiva mais abrangente de processos culturais que procuramos estabelecer uma correlação entre as evidências arqueológicas e as outras diversas faces do sistema sócio cultural (para Schiffer, contexto sistêmico) que extrapolam a cultura material dos povos dos sambaquis. Desta maneira,, inclusive, empregamos o estudo dos processos de formação do registro arqueológico como ele foi inicialmente proposto por Schiffer: ou seja, não como uma abordagem teórica em si, mas, sim, no âmbito de uma teoria de médio alcance, a qual se estabelece para construir uma ligação entre as teorias de alto nível (materialismo histórico, funcionalismo, estruturalismo, etc) e as evidências arqueológicas.

Para subsidiar o entendimento das outras diversas faces do sistema sóciocultural dos povos dos sambaquis (as quais extrapolam a análise direta da cultural material e incluem, por vezes, questões relacionadas a significados e simbolismos), serão aqui considerados os exemplos de percepção ambiental de grupos coletores, estabelecido por Ingold (2000) e o referencial etnográfico marítimo descrito por Malinowski (1922) - esse último já apresentado. Nosso intuito com isso não é o estabelecimento de analogias que permitam a interpretação dos aspectos simbólicos e culturais dos povos dos sambaquis com base em valores e significados atribuídos ao mar e aos recursos marinhos por outras sociedades, mas, sim, o 
desenvolvimento de hipóteses que não estejam limitadas por visões normativas da relação com o ambiente.

Embora separados por quase um século e abordando sociedades que apresentam diferentes graus de complexidade (pescadores/agricultores e caçadores coletores), Malinowski (op. cit.) e Ingold (op. cit.) compartilham da compreensão de que ambos os tipos de sociedades entendem natureza e cultura de uma forma integrada.

Nessa questão, Ingold vai além. Para ele, não existem dois mundos (natureza e sociedade), mas somente um, saturado de poderes pessoais, que abarca tanto os humanos, os animais e as plantas dos quais todos dependem e as feições da paisagem na qual todos vivem e morrem. Neste único mundo, os humanos figuram não como corpo e mente, mas como um ser indivisível que se relaciona tanto com entidades e agentes humanos e não-humanos, não existindo uma separação absoluta entre eles e os agentes naturais (INGOLD, op. cit, p 47).

As Bird-David observes, hunter-gatherers 'do not inscribe into the nature of things a division between the natural agencies and themselves, as we [Westerners] do with our "nature-culture" dichotomy. They view their world as an integrated entity' (BIRD-DAVID, 1992, p. 29-30 apud INGOLD, op. cit, p 47).

Citando o caso dos Waswanipi, do norte do Canadá, o autor aponta que no mundo culturalmente construído dessa sociedade, tanto animais, como o vento e muitos outros fenômenos são entendidos como indivíduos que agem de forma inteligente; têm desejos e idiossincrasias; compreendem e são compreendidos pelos homens. Para eles a causalidade é pessoal e não biológica ou mecânica. Quando questionam algo a respeito da causalidade dos fenômenos naturais, costumam perguntar mais "quem fez isso" ou "porque" do que "como isso aconteceu".

Embora existam elementos materiais que nos permitam discutir 0 estabelecimento de uma natureza culturalmente percebida, apropriada e incorporada pelos povos dos sambaquis em meio ao sistema sócio-cultural, essa não é a questão principal que objetivamos aqui analisar. Nosso propósito em utilizar os estudos de Ingold como referência é a construção de um arcabouço que nos 
possibilite tecer interpretações a respeito da maneira como os sambaquieiros relacionam-se com os seus ambientes. As quais passam a assumir um novo significado quanto se compreende que para os grupos caçadores coletores 0 ambiente não seria somente um espaço de obtenção de recursos e de comida. $O$ ato de coleta não representa apenas um tempo gasto para a manutenção de uma vida simples, mas significa a própria vida (INGOLD, 1986, p. 211 e 212). Como a estocagem de comida reduz sua mobilidade e as fontes de alimento são abundantes e distribuídas por todo o território, os caçadores coletores tratam o ambiente em si como um armazém (INGOLD, op. cit., p. 66).

Para Ingold, no entanto, não existe apenas um único sistema econômico de caçadores coletores. Apoiado nos estudos de James Woodburn, com os Hadza da Tanzania (WOODBURN, 1980, 1982, 1988 apud INGOLD, op. cit., p. 66), discute pelo menos duas maneiras através das quais a economia de grupos caçadorescoletores pode ser discutida: sistema de retorno imediato (immediate-return) e sistema de lento retorno (delayed-return). No primeiro, os indivíduos ficariam fora por dias para obter comida e consomeriam-na ao longo desses dias ou em um curto período de tempo. O equipamento seria simples e feito de modo ligeiro, sem o envolvimento de muito tempo e esforço, e seriam investidos na busca pelo recurso. Já no sistema de lento retorno, por outro lado, haveria um substancial investimento na elaboração e na construção de instalações e armadilhas ou (no caso de pescadores) barcos e redes. Em geral, os indivíduos devotariam também consideráveis esforços para gerenciar seus recursos e estocá-los.

Para Woodburn o significado dessa diferenciação está no compromisso que estabelecem com o ambiente não humano e com os outros indivíduos - o qual é muito maior entre os de lento retorno. Enquanto entre os do sistema de retorno imediato existe uma quase ausência de compromissos e investimento em recursos ou pessoas (os indivíduos relacionam-se de uma maneira geral com as pessoas e com os recursos: as pessoas não dependem de outras pessoas em especial para acessar as necessidades básicas), no sistema de lento retorno as relações são construídas principalmente com pessoas e ambientes em particular. 
Independente da forma como que uma sociedade ou individuo perceba o seu ambiente e com ele se relacione, existe, para Ingold (ibidem), uma idéia de ambiente que é recorrente, na qual ele é quase sempre entendido como um passivo recipiente de recursos que se encontra saturado de diversos tipos de poderes pessoais, e onde existe uma enorme abundância de coisas a serem coletadas. Um meio em que, para que sobrevivam e prosperarem, os caçadores-coletores devem manter relações com esses poderes assim como mantém com outras pessoas.

Segundo Ingold, é importante compreender que essa preocupação em estabelecer uma relação mais integrada ao poderes personificados do ambiente, embora aponte certa prudência e cuidado no uso dos recursos, não esta necessariamente associada à compreensão ocidental de conservação da vida selvagem. Na realidade, em geral, para caçadores coletores a responsabilidade é inversa. Em última instância são os poderes que animam o ambiente os responsáveis pela sobrevivência e extinção dos humanos.

Para ilustrar essa situação Ingold utiliza o trabalho de Richard Nelson sobre os Koyukon do Alaska, para quem, a existência humana depende de um relacionamento moral com os poderes dominantes da natureza. Eles devem interagir com as forças que os circundam, não tentando controlá-los, dominá-los ou fundamentalmente alterá-los. Eles não confrontam a natureza, eles rendem-se a ela (NELSON, 1983, p.40 apud INGOLD, 2000, p. 68).

Dentre as várias conseqüências dessa percepção dos caçadores coletores, existe uma que é de extrema importância para a presente Tese, a qual está ligada à maneira como os caçadores-coletores mapeiam e navegam através de seu meio. Segundo Ingold (2000, p. 68), de forma a estabelecerem uma compreensiva representação espacial de seu ambiente habitual, constroem, utilizando a mente em vez das mãos, uma espécie de mapa mental ou cognitivo que, a qualquer momento, pode ser acessado e utilizado para reconhecer sua localização.

Esse mapa, no entanto, não permite que um indivíduo caçador possa apontar sua posição no espaço (pelo menos, não em termos de qualquer sistema de coordenadas). Isso acontece porque esses locais não têm localização, mas, sim, histórias. Atrelados aos itinerários de seus habitantes, os locais não existem como 
espaço, mas em uma matriz em movimento, cujo conhecimento da região e a habilidade para situar-se em meio ao contexto histórico obtido em jornadas anteriores, distinguem um nativo de um estrangeiro (INGOLD, 2000, p. 218).

Nesse sentido, esse conhecimento (entendido aqui como resultado de uma específica percepção do ambiente) é resultante da experimentação de suas rotas ou caminhos, não sendo possível a ninguém conhecê-los sem antes viajar nele. Entretanto, para Ingold, o ambiente não é percebido a partir de múltiplos pontos de vista. Com base em Gibson (1979, p. 198), propõe que a navegação ao longo do território só pode ser realizada a partir de uma ordem específica, na qual as diversas paisagens e superfícies do ambiente funcionam como uma espécie de roteiro.

Esse é o caso, por exemplo, dos pescadores da Micronésia, que se localizam a partir de uma pré-formulada decisão de navegação, que, a todo o momento, durante uma viagem, fica atento a uma combinação de movimentos, sons, à sensação do vento, à posição das estrelas, etc. As quais compara com as lembranças de suas observações em experiências passadas e usa-as para aumentar ou diminuir a pressão nos remos ou corrigir a direção do leme (GLADWIN, 1964, p. 171).

É sob essa perspectiva que pretendemos pesquisar e discutir a percepção ambiental dos sambaquieiros. Correlacionando os dados arqueológicos e os resultados das análises isotópicas, obtidas para os sambaquis de Cananéia, poderemos apontar algumas hipóteses a respeito de como os sambaquieiros se relacionavam com o seu meio. 


\section{AS ESTRATÉGIAS DE PESQUISA}

Uma vez estabelecidos os pressupostos teóricos que subsidiam a construção de uma abordagem marítima em relação aos povos dos sambaquis, buscou-se estabelecer uma metodologia que fosse capaz de correlacionar tal posicionamento teórico às evidências arqueológicas encontradas no registro arqueológico dos povos construtores deste tipo de sítio na região.

A abordagem escolhida para o estabelecimento dessa construção está fundamentada no estudo dos processos de formação do registro arqueológico, desenvolvido por Schiffer (1972). Foi realizada uma releitura que, mais do que pesquisar toda a complexa cadeia de processos envolvidos na formação do registro arqueológico dos sambaquis, procura compreender o estudo dos processos formativos como uma teoria de médio alcance (middle range theory). Através da qual se pode estabelecer uma real articulação entre a cultura material e as principais correntes teóricas (teorias substantivas ou de alto nível) ou as teorias arqueológicas delas decorrentes.

Assim, embora não se tenha adotado o estudo dos processos de formação com o detalhamento proposto inicialmente por Schiffer (op. cit.), muitos de seus princípios e conceitos foram utilizados como estrutura para a análise e com a finalidade de se estabelecer uma relação concreta entre a abordagem arqueológica marítima dos sambaquis e as evidências arqueológicas em macro, meso e micro escalas.

Nesse sentido, a primeira ação tomada foi a de instituir um panorama geral a respeito do espaço vivenciado pelos sambaquieiros e sua modificação ao longo do tempo, onde o foco principal foiram os processos naturais envolvidos na formação do registro arqueológico. Embora entendamos que a percepção dos espaços (paisagens) é inerente ao sistema sócio-cultural, neste primeiro momento, a meta foi compreender como a evolução do litoral e a configuração do sistema hídrico poderiam ter influenciado a origem e o estabelecimento dos povos dos sambaquis, bem como a origem de sua relação com as questões marítimas. 
Assim, com esse propósito, foi desenvolvido, a partir de uma perspectiva macro-espacial, um modelo inicial de predição que pudesse apontar novas hipóteses a respeito dos locais e períodos de origem dos sambaquieiros, das rotas utilizadas por eles e pelos grupos humanos que os originaram e, também, da correlação entre esses primeiros momentos e a atual distribuição dos sambaquis. Modelo esse, fundamentado, principalmente, no modelo preditivo de sítios submersos, elaborado por Watters (1992), e aqui adaptado para o estudo dos sambaquis submersos.

Uma vez compreendida a dinâmica do espaço onde se fixaram e habitaram os povos dos sambaquis, foram pesquisados os elementos que viessem subsidiar um entendimento de como esses povos relacionaram-se com esse ambiente em contínua transformação. Procurando não somente entender como as alterações climáticas e ambientais modificaram os sambaquieiros, mas, principalmente, buscando compreender em que medida eles se adaptaram aos novos ambientes gerados e como os processos culturais influenciaram no estabelecimento de uma relação entre estes grupos e o seu meio.

Pois, embora as questões ambientais exerçam grandes pressões sobre os indivíduos e as sociedades, no final das contas, a maneira como estes percebem tais pressões e como reagem a elas (adaptando-se, modificando-se, migrando, fugindo e, até, escolhendo a morte) está diretamente associada aos valores, às crenças e à compreensão de mundo que desenvolvem e transmitem a seus descendentes. Como postulado por Gaspar (1998), a relação homem-ambiente é inerente ao próprio sistema sociocultural.

Para tanto, foram investigadas e testadas várias metodologias, algumas ainda inéditas na Arqueologia brasileira (ou utilizadas para outros fins), que pudessem apontar novos indicadores para essa relação. Dentre elas, ressalta-se a análise de polens, de nanofósseis calcários ${ }^{7}$, de ostracodes $^{8}$, de foraminíferos ${ }^{9}$, de

\footnotetext{
${ }^{7}$ Segundo Seyve (1990), os nanofósseis calcários são fósseis de algas planctônicas que vivem nos primeiros 50 a 100 metros da superfície d'água. Eminentemente marinhos, compõe junto com as diatomáceas a maior parte do fitoplâncton oceânico. Apresentam uma variedade muito grande de estruturas, formadas, em geral, por pequenas peças calcíticas, com forma circular ou oval, de diâmetro médio de 5 a 15 micrômetros.

${ }^{8}$ Os ostracodes são pequenos crustáceos aquáticos cujas carapaças bivalves (que, em geral, medem entre 0,4 a $0,15 \mathrm{~mm}$ ) podem ser encontradas em variados sedimentos desde o Cambriano Superior (SEYVE, op. cit.).
} 
diatomáceas ${ }^{10}$ e de isótopos estáveis (carbono e oxigênio - presentes nas conchas e otólitos de peixes) e radiogênicos (estrôncio em ossos e dentes humanos). Sendo, os últimos, decorrentes de análises da composição isotópica dos elementos carbono, oxigênio e estrôncio, os indicadores que apresentaram os resultados mais favoráveis, acabando, assim, por integrar a presente Tese.

De um modo geral, as análises isotópicas tiveram dois objetivos principais. Com a análise da composição isotópica do estrôncio buscou-se estabelecer um referencial inicial de mobilidade e territorialidade entre os conjuntos de sambaquis que compõe o litoral do estado de São Paulo e, também, dos que se localizam ao longo do médio curso do Rio Ribeira de Iguape (sambaquis fluviais) - abordagem em meso-escala.

No caso dos isótopos de carbono e oxigênio, buscou-se, por outro lado, compreender se existe uma recorrência das áreas (barras, regiões mais próximas ao mar, porções de menor salinidade e outras) exploradas pelos sambaquieiros em meio aos diversos compartimentos dos ambientes costeiros (abordagem que tende do meso para micro-escala).

Embora essas metodologias tenham propósitos diferentes, existe um potencial na correlação entre elas que aqui é explorado. Pois, é possível que, juntas, essas duas metodologias possam apontar evidências a respeito da relação dos sambaquieiros com o seu meio. Contribuindo não só para o estabelecimento de novas hipóteses a respeito da mobilidade, da territorialidade, da percepção ambiental e das práticas sociais realizadas pelos povos dos sambaquis, mas, principalmente, permitindo que possamos identificar diferenças e similaridades entre os diversos conjuntos de sambaquis que se distribuem ao longo da costa brasileira.

Contudo, apesar de trazerem à luz novas linhas de investigação científica para os sambaquis e permitirem a formulação de novas hipóteses a respeito da organização dos sambaquieiros, é importante salientar que tais metodologias não

\footnotetext{
${ }^{9}$ Os foraminíferos são microfósseis de protozoários da classe Rizópode, cuja carapaça interna (mineralizada no interior do citoplasma) é constituída de sucessivas câmaras, ligadas entre si, e caracterizadas por furos: os foramens (SEYVE, op. cit.).

${ }^{10}$ As diatomáceas são algas crisófitas unicelulares que possuem uma carapaça ou frústula formada por duas valvas encaixadas e muito finamente ornamentadas, cujo tamanho vai de 2 até 3.000 micrometros. Segundo Seyve (op. cit.), as diatomáceas estão presentes em todos os meios aquáticos continentais e marinhos.
} 
tinham sido, até então, testadas e aplicadas à pesquisa arqueológica. Se por um lado essa perspectiva adiciona certo grau de ineditismo, por outro, demanda também alguns cuidados que, até então, não haviam sido considerados para o estudo dessa região.

No que tange aos isótopos de carbono e oxigênio, tal preocupação restringese, principalmente, ao estabelecimento desses isótopos como precisos indicadores de paleosalinidade e paleotemperatura. Para que isso acontecesse, seria necessário, antes, a obtenção de mais conhecimento a respeito de alguns parâmetros paleoambientais e da relação desses com a formação das conchas. Como para a região de Cananéia tais parâmetros ainda não foram estabelecidos, são aqui utilizados indicadores relativos de paleotemperatura e paleosalinidade, definidos com base em dados atuais provenientes de regiões ecologicamente equivalentes.

Como as possíveis distorções geradas com essas aproximações se mantêm dentro de um limite aceitável (pois, de um modo geral, valores semelhantes foram verificados em diversos outros ambientes e paleoambientes) e as interpretações a respeito desses isótopos são aqui tratadas mais em nível hipotético (ou como indicadores de uma tendência) do que como dados absolutos, sua utilização é justificada. Ainda mais quando são entendidas como um "primeiro passo" ${ }^{11}$ para a adoção de uma metodologia que pode contribuir de forma significativa, com novos dados e hipóteses, ao estudo das sociedades sambaquieiras.

Em relação ao estrôncio, a situação não é muito diferente. Além de, no Brasil, ter sido realizado apenas um outro recente estudo (BASTOS, 2008) a partir da composição isotópica desse elemento (que se iniciou concomitantemente à pesquisa realizada no âmbito desta Tese), tal estudo foi feito com base em uma metodologia parcialmente diferenciada da aqui proposta.

O estudo realizado por Bastos (op. cit.), no sambaqui do Forte Marechal Luz (norte de Santa Catarina), teve como objetivo uma interpretação focada na correlação da composição isotópica do estrôncio presente nos esqueletos humanos

\footnotetext{
${ }^{11}$ Embora análises isotópicas de carbono e oxigênio (DE MASI, 2001; PLENS, 2008) já tenham sido realizadas, no Brasil em alguns poucos estudos, sua utilização enfocou a análise da composição isotópica desses elementos em ossos humanos. A utilização desses isótopos como indicadores da paleosalinidade e da paleotemperatura dos ambientes de coleta e pesca, a partir da análise de conchas provenientes de sambaquis, ainda é uma metodologia inédita no Brasil.
} 
(em ossos e dentes) com as assinaturas isotópicas locais e regionais. No âmbito desta Tese, por outro lado, a interpretação dos resultados das análises isotópicas foi realizada de modo comparativo, a partir do qual diferentes classes de valores (aferidas com base no contexto geológico em que se inserem os sítios) foram interpretadas como relativas a diferentes agrupamentos de sítios.

Deste modo, se valores isotópicos semelhantes fossem identificados em indivíduos provenientes de sambaquis associados a diferentes contextos geológicos (e, portanto, espacialmente distantes), esses sítios poderiam ser entendidos como intrínsecos a um mesmo território ou padrão de mobilidade. Isso porque, para que tal condição se configurasse, esses indivíduos precisariam ter absorvido o estrôncio ambientalmente disponível em ambas as áreas, gerando, dessa maneira, valores intermediários da composição isotópica desse elemento nos restos humanos.

De maneira similar ao apontado para a análise isotópica do carbono e do oxigênio, além desta nova proposta interpretativa não objetivar resultados extremamente precisos (sendo tratada mais hipoteticamente do que de uma forma absoluta) e de ser também uma das pioneiras na adaptação de tal método para a realidade dos contextos brasileiros (cuja geologia é heterogênea e, portanto, permite interpretações comparativas seguras), o resultado de tal metodologia foi também confrontado com o resultado de duas outras linhas de pesquisa: a análise, propriamente dita, da cultura material (estabelecida com base em referências bibliográficas) e a conformação do sistema hídrico contemporâneo aos primeiros momentos da presença sambaquieira no litoral (apontado pelo modelo de predição elaborado no âmbito desta Tese).

\subsection{O RECORTE AMOSTRAL}

A fim de verificar a possibilidade de que os povos dos sambaquis poderiam ter se organizado em comunidades marítimas, foram analisados, de forma diferente, dois conjuntos de dados complementares. No primeiro deles, para a realização das análises isotópicas de carbono e oxigênio, foram considerados somente os sítios 
que dizem respeito à ocupação sambaquieira da região de Cananéia, no baixo Vale do Ribeira, extremo sul do litoral do estado de São Paulo. Trata-se de um conjunto de sítios arqueológicos do tipo sambaqui, pesquisado ao longo de minha dissertação de mestrado, no âmbito do mesmo projeto de pesquisa em que se desenvolve a presente Tese, intitulado Programa Arqueológico do Baixo Vale do Ribeira ${ }^{12}$.

No segundo desses conjuntos, além dos sambaquis da região de Cananéia, foram analisadas, também, amostras de ossos e dentes humanos provenientes de sambaquis (costeiros e fluviais) localizados em diversos pontos do litoral do estado de São Paulo (planície costeira de Cananéia e Iguape, Baixada Santista e litoral norte) e ao longo do médio Vale do Ribeira. Com o propósito de compreender as conexões do sistema de Cananéia em relação à ocupação sambaquieira regional, foram selecionadas, em meio à reserva técnica do Museu de Arqueologia e Etnologia (MAE/USP), amostras de sambaquis dessas outras regiões.

\subsubsection{Os sambaquis do Baixo Vale do Ribeira}

A presença sambaquieira na região do baixo Vale do Ribeira foi analisada, em um primeiro momento, a partir de uma compreensão focada no estudo dos processos de formação em macro escala. Sob essa perspectiva, o propósito inicial foi entender quais seriam os processos naturais responsáveis pela formação e modificação do registro arqueológico, sendo, posteriormente, analisados os processos culturais.

Tal proposição pode ser compreendida como uma continuidade das pesquisas desenvolvidas, em Cananéia, ao longo da dissertação de mestrado, onde, através de uma correlação das idades dos sambaquis com as curvas relativas aos últimos grandes eventos holocênicos de variação do nível relativo do mar (VNRM), foi possível apontar a existência de diferentes contextos arqueológicos aos quais podem ser atribuídos momentos de relativa estabilidade ambiental (CALIPPO, 2004).

\footnotetext{
${ }^{12}$ Projeto realizado com apoio financeiro da Fundação de Amparo à Pesquisa Científica do Estado de São Paulo (FAPESP), sob a coordenação da Profa. Dra. Maria Cristina Mineiro Scatamacchia (MAE/USP).
} 
Embora esses contextos estivessem associados a períodos em que o nível relativo do mar e os ambientes costeiros da região do baixo Vale do Ribeira encontravam-se em modificação, cada um deles corresponde a fases (de elevação ou rebaixamento do nível relativo do mar) em que tais modificações estavam em um processo contínuo (equilíbrio dinâmico) de progradação ou regradação da linha de costa.

Nesses momentos, pelo menos no que se tange às modificações do espaço em macro escala, a influência dos processos naturais de formação do registro arqueológico pode ser minimizada. Como cada um deles se encontra associado a um momento de relativo equilíbrio ambiental, o comportamento dos sambaquieiros em relação a seu meio (em cada contexto) pode ser analisado dando-se maior ênfase aos processos culturais. Neste sentido, qualquer mudança, que não apresente uma correlação direta com a elevação ou rebaixamento do nível relativo do mar, foi aqui interpretada como decorrente da ação de processos culturais.

\subsubsection{A formação do baixo Vale do Ribeira e o estabelecimento dos sambaquis}

Após percorrer quase $500 \mathrm{~km}$ desde a cabeceira, as águas do rio Ribeira de Iguape atingem o mar. Desse encontro, que ocorre em meio a uma ampla planície sedimentar, denominada Planície Costeira de Cananéia-Iguape, desenvolve-se um extenso complexo estuarino-lagunar, marcado pela presença de montanhas e escarpas da Serra do Mar, morros e morrotes isolados, rios, restingas, manguezais, corpos lagunares, mares interiores, numerosas ilhas e uma considerável rede hídrica, além de um dos mais ricos conjuntos de vida do planeta (MAGALHÃES, 1997) e uma das maiores concentrações de sambaquis ao longo da costa brasileira. Segundo Uchôa e Garcia (1983), ao longo dessa área podem ser encontrados mais de uma centena de sambaquis.

Inserida em meio a esse vasto complexo de terras e águas, historicamente conhecido como Lagamar, encontra-se a cidade de Cananéia que, juntamente com os municípios de Pariquera-Açu, Iguape e Ilha Comprida, formam a região do Baixo 
Vale do Ribeira. Área de grande importância ecológica, essa porção final do vale do rio Ribeira faz parte da maior faixa contínua de Mata Atlântica ainda existente, de um dos mais conservados bancos genéticos do país e da mais importante reserva de água doce dos estados de São Paulo e Paraná (MAGALHÃES, op. cit.).

É muito provável que a grande concentração dos sambaquis da região do Baixo Vale do Ribeira seja decorrente também da importância ecológica dessa região. Segundo Figuti (1999), "os povos construtores de sambaquis preferiam áreas estuarinas-lagunares, manguezais e lagoas salobras, ricas em peixes, moluscos e crustáceos, e nesse tipo de ambiente é que se encontra com maior freqüência esses sítios". Porém, para que se possam estabelecer quaisquer outros paralelos com outras áreas, é importante levar em consideração o impacto da presença humana na região do Baixo Vale. Talvez, o desenvolvimento econômico tardio dessa área e conseqüentemente uma menor degradação dos espaços naturais e dos sítios arqueológicos sejam também responsáveis pela grande quantidade de sambaquis que ainda podem ser encontrados.

Atualmente, a região de Cananéia situa-se em uma área de transição entre os climas tropical e subtropical. Contudo, a proximidade com o oceano, a dinâmica atmosférica regional e os traços do relevo contribuem para tornar o clima predominantemente quente e úmido, com uma distribuição de chuvas bastante irregular. Nessa questão, a região apresenta, de um modo geral, um período menos chuvoso, que vai de abril a setembro, e um outro mais chuvoso, de outubro a março. No verão ocorrem temperaturas máximas de até $40^{\circ} \mathrm{C}$ e chuvas em $50 \%$ dos dias, enquanto no inverno, as temperaturas mínimas podem chegar aos $10^{\circ} \mathrm{C}$ e chove, em média, em 33 \% dos dias (MAGALHÃES, op. cit.). Segundo Wainer et al. (1996), essa região apresenta temperatura média anual de $21,4^{\circ} \mathrm{C}$ (que varia de $17,7^{\circ} \mathrm{C}$ em julho a $25,2^{\circ} \mathrm{C}$ em fevereiro $)^{13}$, uma umidade relativa de $87 \%$ a $89 \%$, com uma precipitação média de $2.269 \mathrm{~mm}$.

Segundo Magalhães (op. cit.), tais condições climáticas permitem 0 estabelecimento de uma densa cobertura vegetal composta principalmente por

\footnotetext{
${ }^{13}$ Dados calculados com base nas medições realizadas entre 1956 e 1994, na Base Dr. João de Paiva Carvalho,do Instituto Oceanográfico da Universidade de São Paulo, em Cananéia.
} 
Florestas de Planície. Sobre solos pobres (normalmente arenosos, com camada de húmus superficial e lençol freático profundo), desenvolve-se uma formação vegetal com predominância de árvores altas (15 a 20 metros), com sub-bosque rico em palmito e araticum e chão forrado por bromélias.

Nas áreas compreendidas principalmente entre os ambientes marinhos/estuarinos e as Florestas de Planície, ocorre uma vegetação de transição de menor porte, conhecida como Restinga. Essa vegetação mista é composta principalmente por árvores, arbustos, epífitas, trepadeiras e muitas bromélias de chão e samambaias resistentes. Em áreas próximas às faces praiais ocorrem arbustos (1,5 a 2,0 metros); mais para o interior, árvores pequenas; e, sobre os terraços marinhos, exemplares arbóreos que chegam a atingir os 15 metros. Desenvolvem-se também nesta região, sobre as áreas que normalmente encontramse sob a influência das marés, extensos manguezais.

Além dessa densa cobertura vegetal, faz parte também desses ambientes uma abundante fauna. Nas áreas de Floresta de Planície ocorrem, principalmente, antas, bugios, macacos-prego, tatus, morcegos, veados, quatis, gambás, tamanduás-mirins, cachorros-do-mato, sanhaços, sabiás, jacutingas, papagaios, anfíbios e borboletas; na Restinga, macacos-prego, quatis, morcegos, pequenos roedores, gambás, saíras, gaviões, lagartos, aranhas, libélulas e borboletas; nas praias e dunas, maçaricos, gaivotas, gaviões, aves migratórias, tatuíras, moluscos, bolachas-da-praia, marias-farinhas e pulgas-da-praia; nos costões rochosos, peixes, cracas, ostras, mariscos, ouriços-do-mar, estrelas-do-mar, pepinos-do-mar, caranguejos, esponjas, corais, caramujos e anêmonas; nas áreas de mangue, lontras, graxinins, garças, socós, biguás, peixes, jacarés-do-papo-amarelo, martinspescador, siris, caranguejos, camarão e ostras; e nos ambientes marinhos e estuarinos, golfinhos, tartarugas, peixes, camarão, estrela-do-mar e águas-viva.

Porém, durante os diversos períodos da ocupação sambaquieira, nem sempre a região litorânea do Baixo Vale do Ribeira apresentou essa mesma configuração. Segundo Martin et al. (1985), que propuseram um modelo de evolução para a Planície Costeira de Cananéia-Iguape, há cerca de 120.000 anos AP, o nível relativo 
do mar encontrava-se aproximadamente $8 \pm 2$ metros acima do atual, no ápice de um período transgressivo, denominado “Transgressão Cananéia” (figura 1.01).

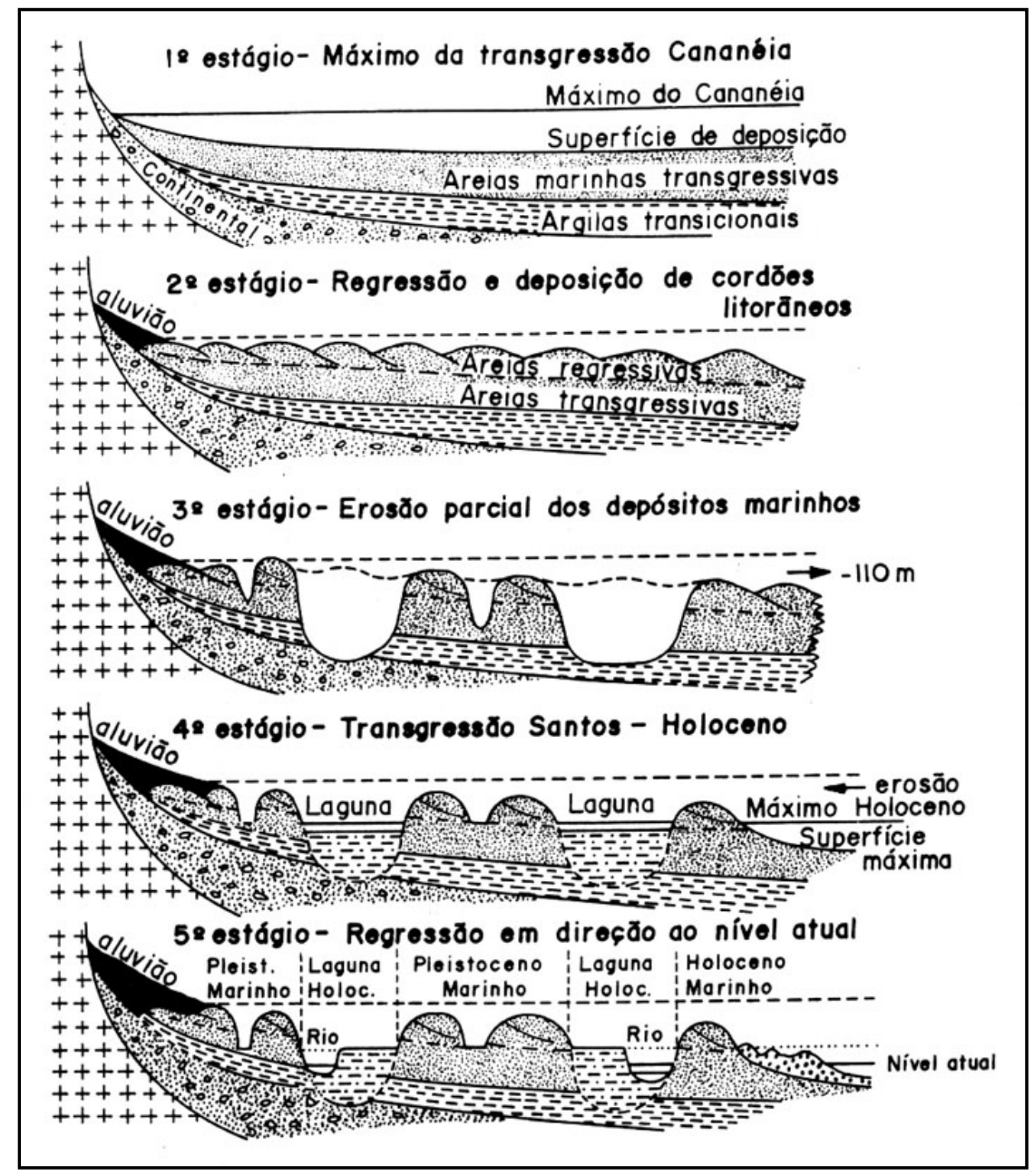

Figura 2.01 - Estágios evolutivos propostos para explicar a origem da planície costeira de Cananéia ao Morro da Juréia (MARTIN e SUGUIO, 1978)

Entre o final desse período e o início da regressão que se seguiu, foi gerada uma primeira linha de cordões arenosos. Durante o período seguinte de nível mais baixo, foi estabelecida uma rede hidrográfica sobre esses depósitos, formando vales (alguns deles muito largos e profundos). O rebaixamento máximo foi atingido por volta de 17.500 anos AP, quando o nível marinho apresentava-se de 120 a 130 metros mais baixo que o atual. Nesse instante, uma extensa planície costeira (com mais de $100 \mathrm{Km}$ de largura) foi gerada. 
Após esse máximo regressivo, o Nível Relativo do Mar voltou novamente a subir, passando por uma posição semelhante à do nível atual entre 7.000 e 6.500 anos AP, até atingir, há cerca de 5.000 anos $A P$, uma cota entre os 4 e 5 metros. Durante tal evento, denominado "Transgressão Santos", as zonas mais baixas foram invadidas pelo mar, formando assim sistemas lagunares muito extensos (MARTIN, op. cit.). Ambiente muito propício ao estabelecimento de grupos pescadores, coletores e caçadores (denominados sambaquieiros) e à formação dos sambaquis.

Gaspar (1998), em uma primeira tentativa de visualizar temporalmente o processo de ocupação dos sambaquis, com base na análise das datações radiocarbônicas obtidas ao longo da costa brasileira, indica a presença de grupos sambaquieiros há pelos menos 7.000 anos e aponta a possibilidade dessa ocupação já ter se iniciado por volta dos 10.000 anos AP (figura 2.02). Além disso, propõe que a ocupação sambaquieira já se encontraria, entre 5.000 e 4.500 anos AP, em plena expansão, a qual parece ter atingido o seu auge entre 4.500 e 4.000 anos AP.

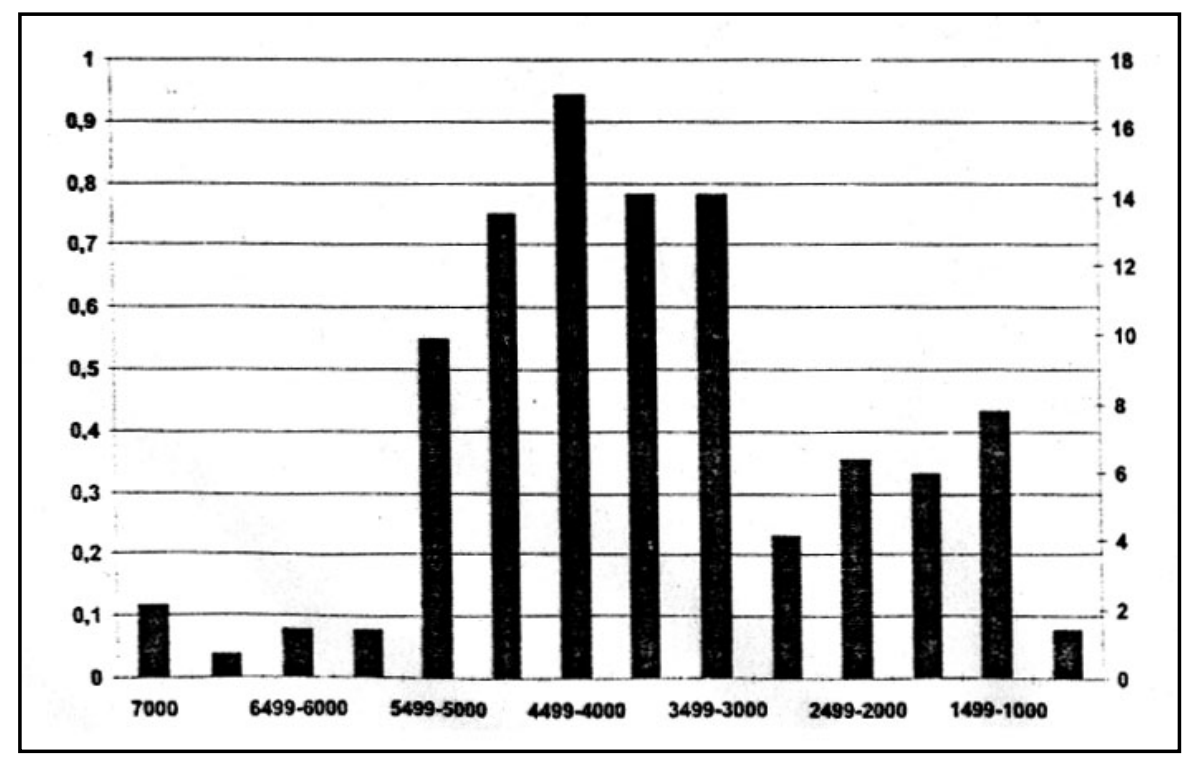

Figura 2.02 - Datações dos sambaquis da costa brasileira por classes de idade (GASPAR, 1998)

Portanto, baseado no proposto por Gaspar (op.cit.) para toda a costa brasileira (inclusive o litoral de São Paulo), é provável que as populações sambaquieiras tenham iniciado a ocupação da Planície Costeira de Cananéia- 
Iguape em algum ponto do evento transgressivo que ocorreu entre 17.500 e 5.100 anos AP. Além disso, com base na posição do nível do mar entre 7.000 e 6.500 anos AP (semelhante ao atual), pode-se esperar também que outros desses sambaquis mais antigos possam se encontrar hoje submersos ou parcialmente submersos.

Após 5.100 anos AP, o nível do mar voltou novamente a baixar. Ao contrário do que pensam Angulo e Lessa (1997), que acreditam que essa regressão foi gradual até o nível do mar atual (figura 2.03), Suguio (1999) propõe dois momentos em que o nível do mar esteve abaixo do atual. Um primeiro, entre 4.100 e 3.600 anos AP, em que o nível do mar desceu até 1,5 ou 2,0 metros abaixo do atual. $E$, um segundo, de menor escala, entre 3.000 e 2.500 anos AP, em que o nível do mar também chegou a atingir uma cota abaixo da atual (figura 2.04) ${ }^{14}$.

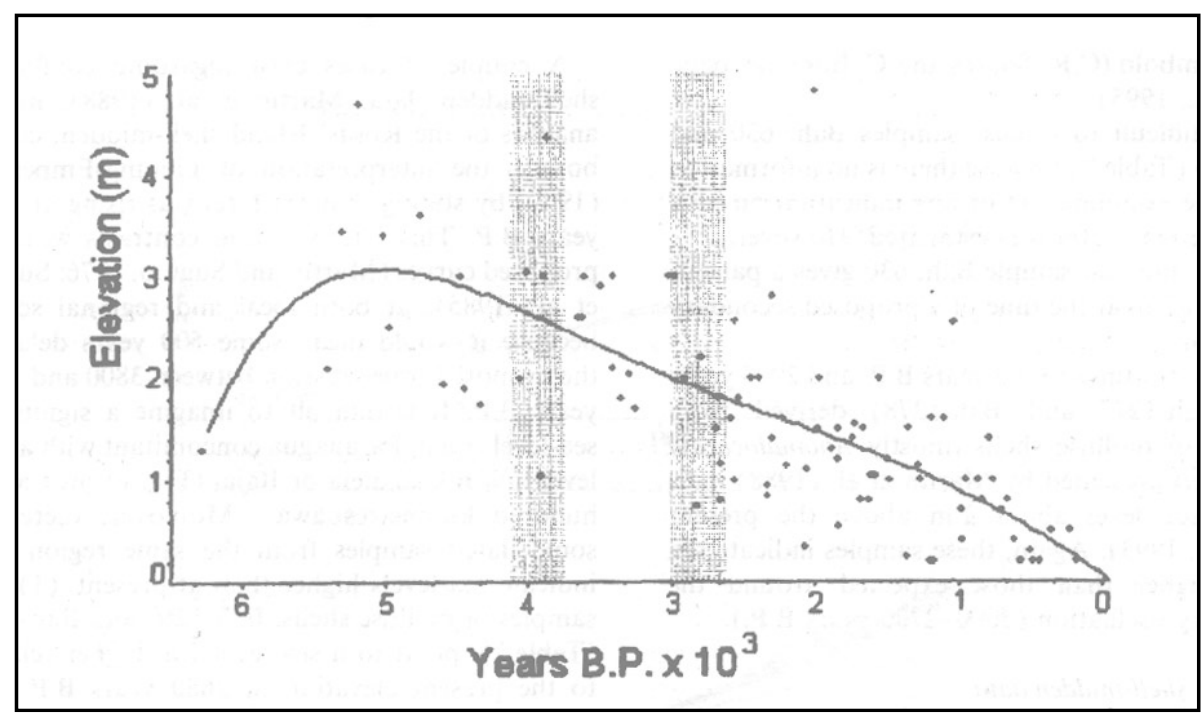

Figura 2.03 - Curva de Variação do Nível Relativo do Mar para a costa brasileira (ANGULO e LESSA, 1997)

\footnotetext{
${ }^{14}$ Ainda que existam diferenças significativas entre os modelos desenvolvidos Suguio (op.cit.) e Angulo e Lessa (op.cit.), neste momento, mais importante do que adotar um desses modelos é compreender que foi no contexto de intensas modificações ambientais, decorrentes de flutuações do nível relativo do mar, que se deu grande parte do período intermediário e final da ocupação sambaquieira em Cananéia.
} 


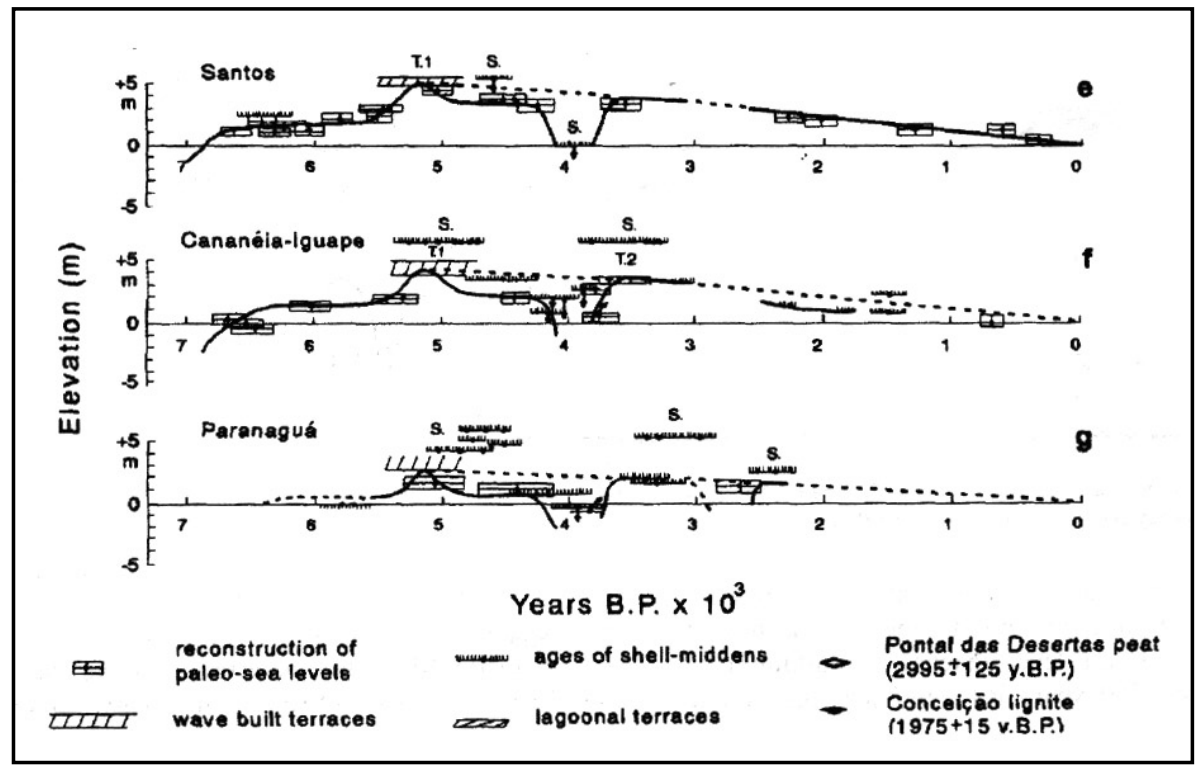

Figura 2.04 - Curvas de Variação do Nível Relativo do Mar para a região de Cananéia, SP (SUGUIO, 1999)

Gaspar (1998) sugere, como hipótese de trabalho, que o declínio do sistema cultural dos sambaquieiros (que fica evidente a partir de 3.500 anos AP) deva estar associado a causas internas relacionadas ao próprio funcionamento dos pescadores, coletores e caçadores, uma vez que, por volta dessa época, não existiria nenhum outro grupo cultural que também tivesse dispersão semelhante.

Nesse sentido, é importante ressaltar que, embora analisemos a questão da origem e do declínio da sociedade sambaquieira a partir de um ponto de vista focado nas modificações ambientais holocênicas, nossa compreensão vai ao encontro do entendimento de Gaspar que considera a relação homem/natureza inerente ao próprio sistema sócio-cultural. No âmbito desta Tese não compartilhamos de um posicionamento determinista ambiental, onde as pressões do meio regem diretamente o comportamento humano. Mas, sim, acreditamos em uma relação ambiental dialética, onde os indivíduos tanto sofrem a influência do ambiente como modificam o meio; e, nesse processo, modificam-se e agem de acordo com sua percepção do ambiente e com base em aspectos culturais. 
No entanto, embora compartilhemos da compreensão de que o comportamento humano não pode ser simplesmente entendido como uma resposta às pressões ambientais, nesta questão específica, que enfoca as ocupações sambaquieiras a partir de uma macro-perspectiva, parece haver indícios de que algumas das principais forças exercidas pelo meio natural poderiam ter realmente influenciado as escolhas tomadas pelos sambaquieiros. Principalmente porque se tratam de eventos de grande magnitude (variação do nível relativo do mar) e de longa duração (ciclos de centenas a milhares de anos), muitos dos quais, provavelmente, não teriam sido percebidos pelos sambaquieiros ou ocorreriam em intervalos superiores ao período de ocupação da maioria dos sambaquis.

O primeiro desses indícios pode ser verificado quando correlacionamos a distribuição temporal dos sambaquis proposta por Gaspar (1998) com a curva de variação do nível relativo do mar proposta por Suguio (figura 2.05). Embora Gaspar já aponte a existência de uma antiguidade de 7.000 anos AP (que acreditamos ser maior), uma marcante diferença na freqüência dos sambaquis só pode ser notada a partir de 5.500 anos AP. Anteriormente a essa data, a quantidade de sítios apresenta-se muito baixa se comparada à que parece ocorrer em associação ao momento em que a elevação do nível relativo do mar atingiu o seu máximo durante o holoceno (5.100 anos AP).

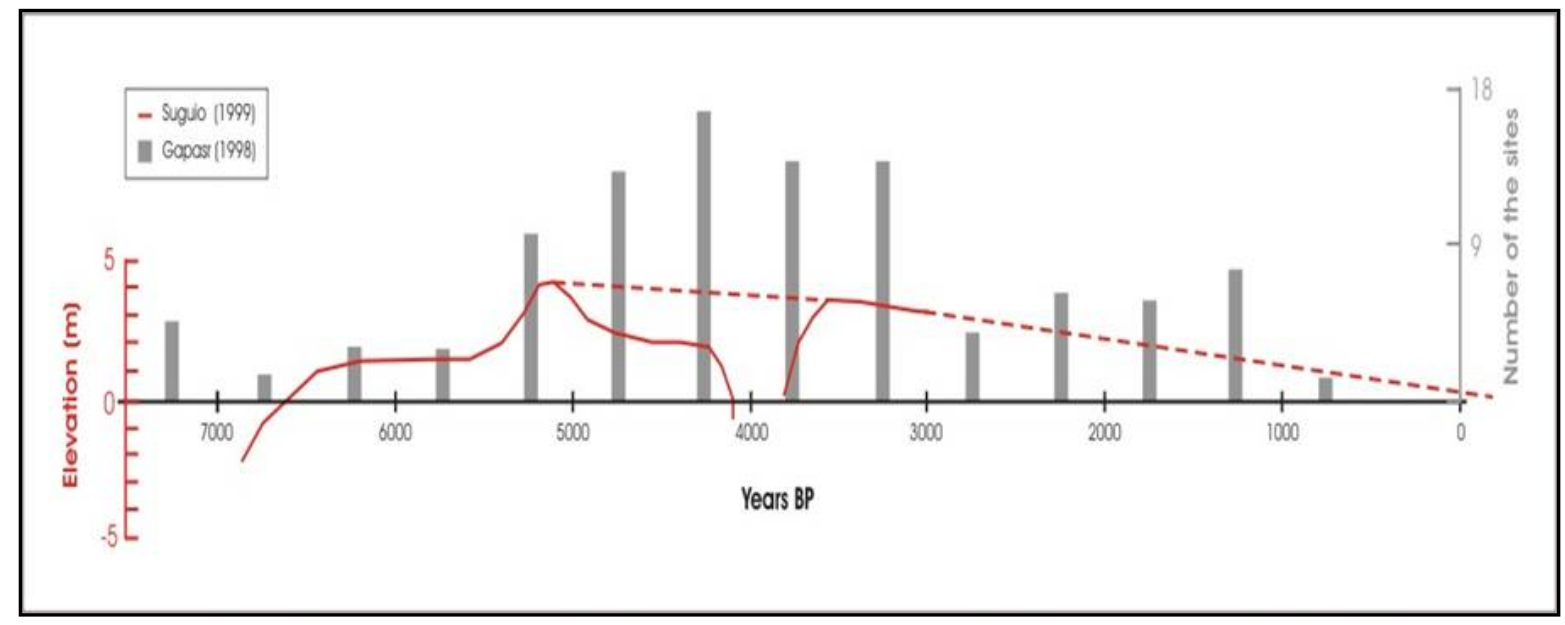

Figura 2.05 - Correlação da distribuição temporal dos sambaquis proposta por Gaspar (1998) com a curva de variação do nível do mar elaborado por Suguio (1999) (CALIPPO, 2006, 2008). 
Quando analisamos a data de 7.000 anos AP, uma associação entre esses sítios e o momento em que o nível do mar em ascensão passou pela última vez sobre a posição em que atinge atualmente não pode ser evitada. Talvez sítios mais antigos que 5.500 anos AP sejam pouco numerosos, pois, se sambaquis mais antigos a essa data foram construídos, deviam estar associados a linhas de costa que se encontram atualmente abaixo do nível do mar. Provavelmente, se tal nível hoje fosse mais baixo, evidências de sítios mais antigos poderiam ser encontradas em áreas emersas.

O fato da mínima ocorrência de sambaquis entre 7.000 e 5.500 anos AP também pode ser analisado com base na elevação do nível do mar. Os dados apresentados na distribuição proposta por Gaspar (op. cit.) podem muito bem ser relativos a apenas parte dos sambaquis que um dia foram construídos, referindo-se particularmente àqueles que se estabeleceram sobre áreas de cotas mais altas ou que, por algum motivo, não foram destruídos pelos agentes costeiros característicos de um evento transgressivo.

Tal associação parece se confirmar quando se analisa o nível do mar ao qual o período da máxima ocorrência dos sambaquis é relativo. Quanto mais próximo ao momento em que o nível do mar não mais se elevava, passando, conseqüentemente, a não mais destruir os sambaquis que então eram formados, maior passa a ser o potencial de preservação dos sítios nesta fase.

O segundo indício diz respeito ao período final da ocupação sambaquieira, quando, as amplas áreas lagunares, que permitiram o desenvolvimento do modo de vida pescador-coletor, começam a ser substituídas por manguezais e pântanos salgados. Segundo Ybert et al. (2003), com o rebaixamento do nível do mar, as extensas áreas lagunares da Planície Costeira de Cananéia-Iguape começaram a ficar cada vez mais rasas, contribuindo, assim, para a expansão dos pequenos manguezais já existentes as margens dessas lagunas. Através de análises palinológicas realizadas em Iguape, esses autores evidenciaram que entre 3.740 e 2.750 anos AP uma extensa área lagunar desapareceu em conseqüência do rebaixamento do nível do mar, dando lugar a uma densa floresta tropical, muito 
provavelmente um manguezal. Após esse período, o clima tornou-se um pouco mais seco, gerando uma retração desse manguezal. Tal modificação ocorre até 1300 anos AP, na época em que um pântano salgado se estabeleceu na área (não necessariamente um manguezal), mantendo-se assim até 675 anos AP, quando então o mangue se restabelece.

Se comparada à distribuição temporal dos sambaquis proposta por Gaspar (figura 2.02 e 2.05), o padrão da retração lagunar e a conseqüente formação do manguezal indicam uma relação inversa à diminuição na freqüência dos sambaquis entre os 3.000 e 2.500 anos AP. Essa mesma relação parece continuar existindo também quando se faz uma comparação entre o comportamento da freqüência dos sambaquis após 2.500 anos AP (que lentamente se eleva até cair de maneira abrupta por volta de 1.000 anos AP) com a diminuição das áreas de mangue, entre 2.750 e 675 anos AP.

\subsubsection{Hipóteses para a ocupação do baixo Vale do Ribeira}

O modelo da ocupação humana da região de Cananéia (CALIPPO, 2004) indica que os sambaquis da porção sul do Baixo Vale do Ribeira podem ser relativos a, pelo menos, dois momentos (figura 2.06). 


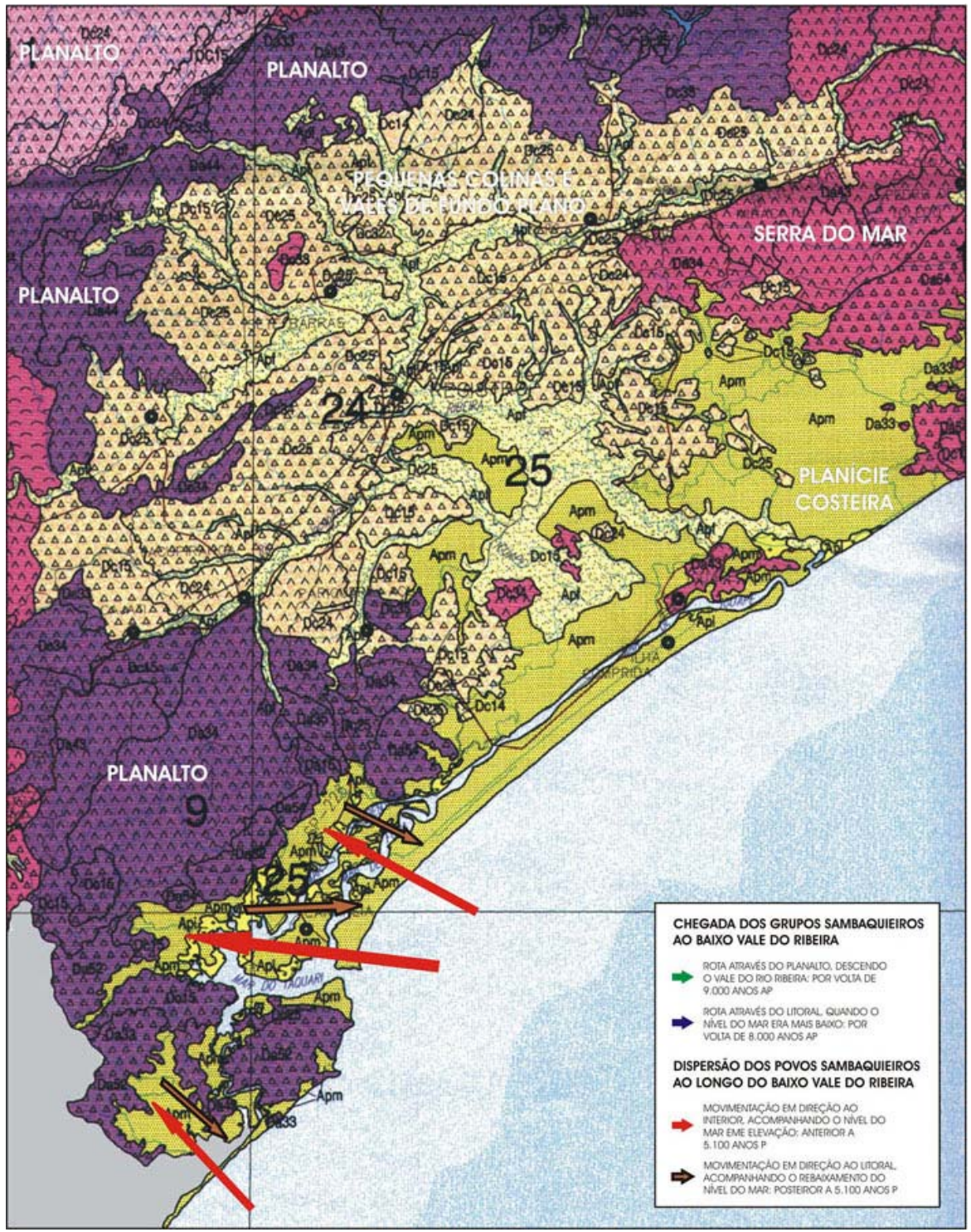

Figura 2.06 - Hipótese para a ocupação da porção sul do baixo vale do Ribeira (mapa: elaborado a partir do mapa geológico de ROSS e MOROZ, 1997)

No primeiro desses momentos (ocorrido entre aproximadamente $8.000 \mathrm{e}$ 5.100 anos), fica evidente uma tendência dos sambaquis começarem a ser construídos sobre as porções mais altas da região de Cananéia, cada vez mais em direção ao interior do continente. Evidência interpretada como uma resposta dos sambaquieiros frente à elevação do nível do mar que atingiu a região, a qual, provavelmente, acabou por alterar significativamente a distribuição espacial desses sítios. Tal conjunto de sítios foi denominado Sambaquis da Fase Transgressiva II e 
entre seus representantes podem ser citados os sambaquis do Cambriu Grande e Pequeno.

Sucedendo essa primeira fase, verificou-se também a presença de um segundo momento da ocupação sambaquieira de Cananéia, onde a distribuição espacial dos sambaquis parece estar associada ao rebaixamento do nível do mar, iniciado após 5.100 anos AP. Quanto mais recente é a datação dos sítios relacionados a esse conjunto (Sambaquis da Fase Regressiva), maior a tendência deles se localizarem sobre as áreas mais baixas e/ou mais próximas à atual linha de costa. Como representantes desse momento podem ser indicados os sambaquis Branco e Cachoeira Mirim.

Embora essas evidências refiram-se exclusivamente à porção sul do baixo Vale do Ribeira, é possível extrapolar as tendências da distribuição das evidências da ocupação sambaquieira para toda a área do Baixo Vale do Ribeira. Afinal, além dos eventos de flutuação marinha terem atingido a região como um todo, ambas as áreas são dominadas pela ocorrência de sambaquis.

A única diferença marcante dessa tendência entre os sambaquis de Cananéia e os encontrados em todas as outras porções do baixo Vale do Ribeira é relativa à forma assumida pela distribuição espacial desses sítios. Em Cananéia, os sambaquis de ambas as fases (Transgressiva II e Regressiva) estão agrupados. Fato que deve estar provavelmente relacionado à formação de uma antiga região lagunar menos extensa em direção ao continente, ocorrida em conseqüência da maior proximidade da Serra do Mar neste ponto.

Já em todo restante da região ocorreu o contrário. Quanto mais próximo do atual baixo curso do rio Ribeira de Iguape, maior é a dispersão dos sambaquis. $O$ mais provável é que esta outra configuração da distribuição espacial dos sambaquis seja resultante de uma maior extensão da região lagunar (em direção ao interior do continente) nos períodos contemporâneos à construção desses sítios. A qual chegou a atingir, em alguns pontos, mais de 30 quilômetros (figura 2.07). Nessa região, com exceção de alguns sítios que se localizavam sobre feições atualmente próximas da linha de costa (de cota mais elevada), os sambaquis associados aos períodos 
relativos ao máximo transgressivo devem apresentar uma tendência de agrupar-se em direção ao interior da planície.

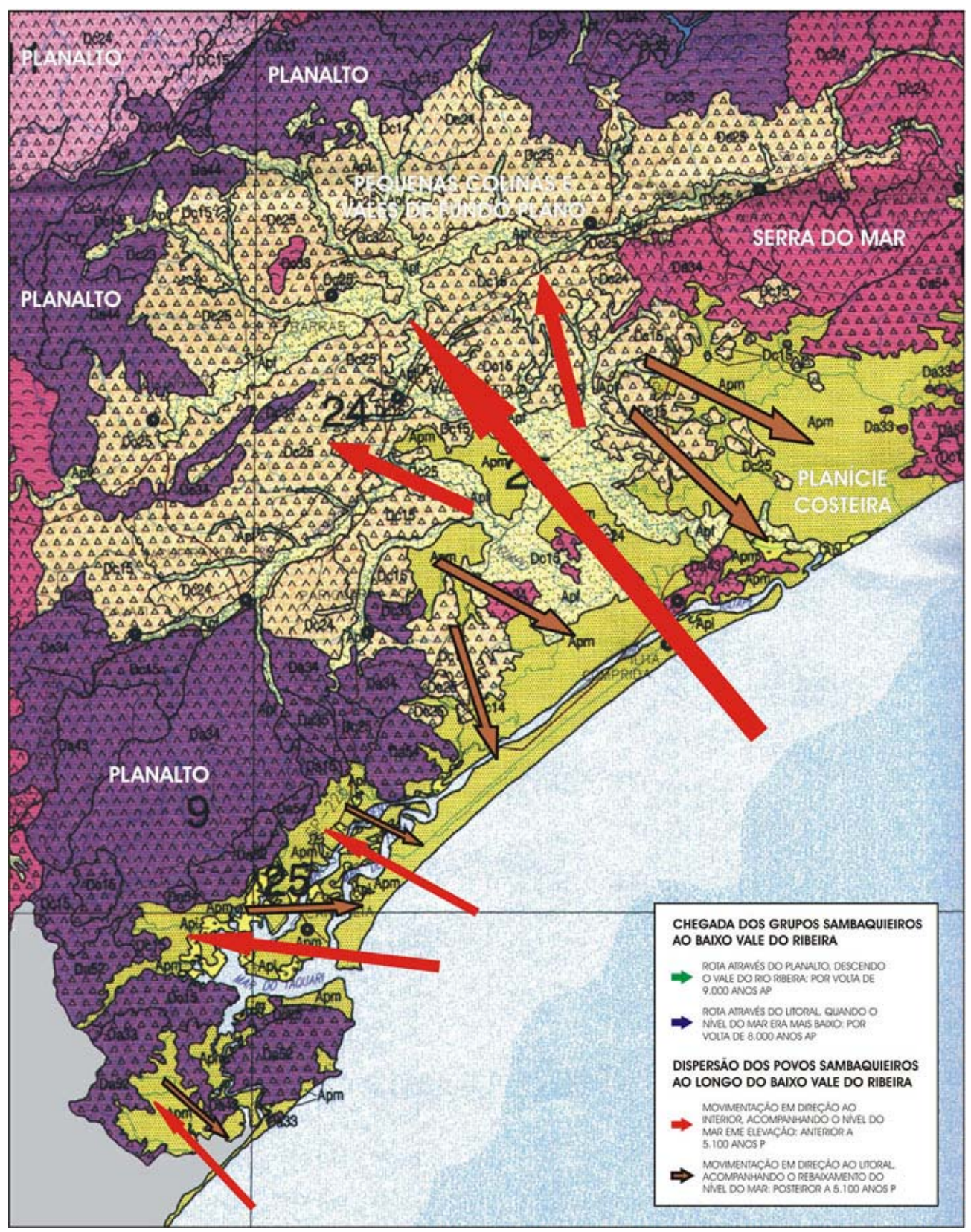

Figura 2.07 - Hipótese para a ocupação de todo o baixo vale do Ribeira (elaborado por Flávio Calippo a partir de ROSS e MOROZ, 1997)

Assumindo que esses dois momentos da ocupação sambaquieira de Cananéia possam ser extrapolados para todo Baixo Vale do Ribeira, foi possível iniciar, com maior segurança, uma discussão a respeito do processo de ocupação 
dessa região (CALIPPO, 2004). Principalmente no que tange às rotas utilizadas pelos grupos humanos construtores de sambaquis para chegarem à região do Baixo Vale e sobre onde se encontrariam as evidências deixadas por esses grupos.

Nesse sentido, como hipótese de trabalho, na época, propôs-se que a chegada dos grupos sambaquieiros ao Baixo Vale fosse pesquisada levando-se em consideração que a mesma possa ter se dado através de duas vias: com os grupos humanos migrando através do Vale do Ribeira, a partir do planalto, e/ou através de deslocamentos realizados ao longo de zonas costeiras que atualmente se encontram submersas (figura 2.08). 


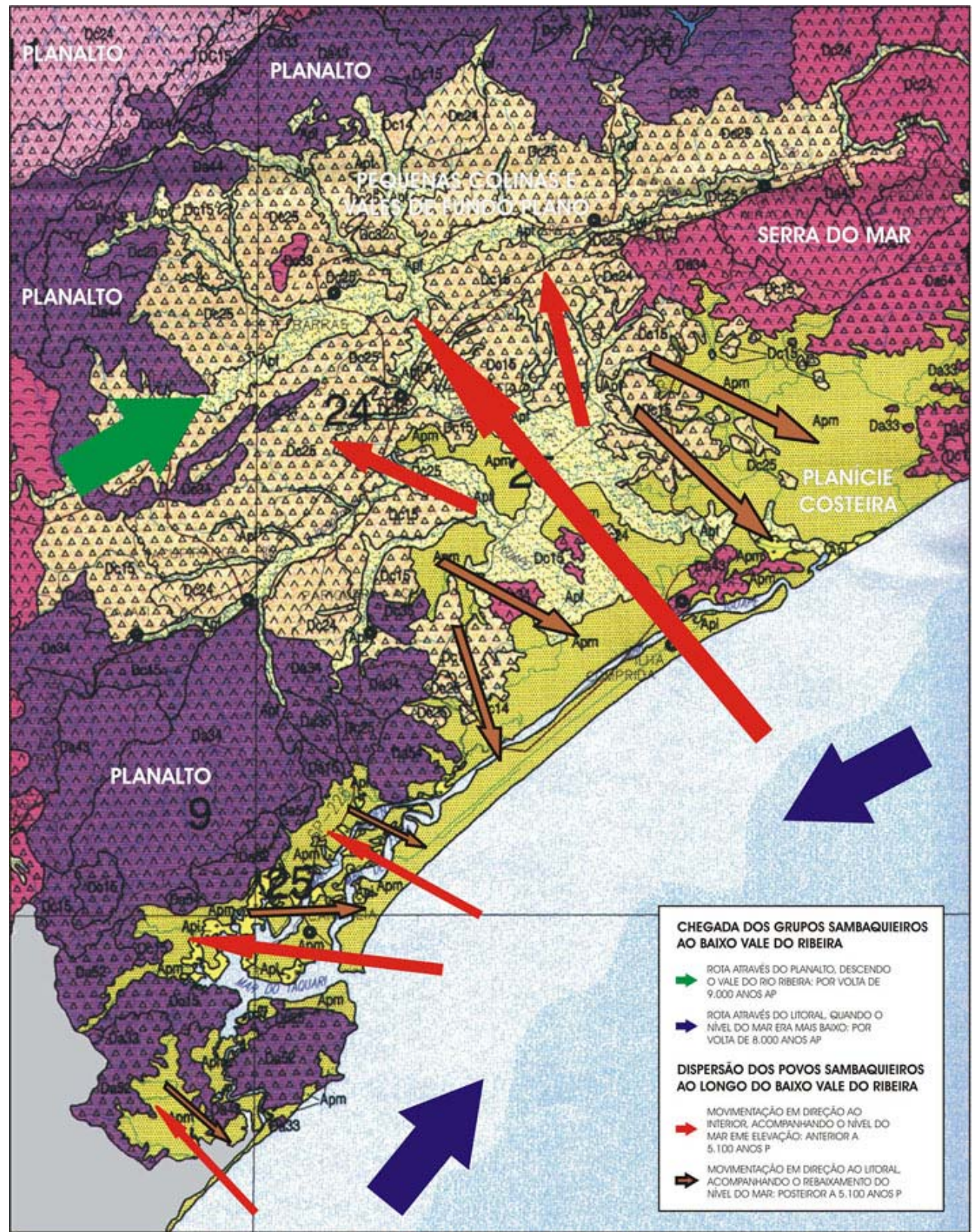

Figura 2.08 - Hipótese para a chegada dos sambaquieiros à atual área do Baixo vale do Ribeira (elaborado por Flávio Calippo a partir de ROSS e MOROZ, 1997)

A migração a partir do planalto fundamenta-se na ocorrência de sambaquis fluviais identificados e datados em 10.000 anos AP, por Collet e Loebl (1988), no Médio Vale do Ribeira, e, mais recentemente, por Plens et al. (2001), em $8770 \pm 60$ BP (Beta 153.988). Se os grupos responsáveis pela formação desses sítios fossem os mesmos que construíram os sambaquis encontrados na Planície Costeira de Cananéia-Iguape (constituídos principalmente por conchas marinhas e estuarinas), é 
provável que os sambaquieiros tenham descido o Vale do Ribeira, ocupando áreas costeiras que hoje se encontram submersas.

Embora na época da elaboração desta proposta tenha se trabalhado com a hipótese de que os sambaquieiros tenham somente descido o Vale do Ribeira, no âmbito desta Tese, a existência de deslocamentos em um único sentido está sendo revista. Principalmente porque, embora existam, ao longo do médio Ribeira, sítios concheiros mais antigos que 8.000 anos AP, ainda não há um consenso dos pesquisadores a respeito de quem foram os responsáveis por sua formação.

Além de sítios do tipo sambaqui (como o pesquisado por Plens, op. cit.), distribuem-se pela região um outro tipo de sítio conchífero, caracterizado por De Blasis (1988) como abrigos sob rocha e sítios a céu aberto, onde predominam grandes quantidades de conchas de moluscos terrestres e artefatos líticos de caçadores-coletores (figura 2.09). No entanto, são estes últimos, e não os sambaquis fluviais (figura 2.10) (e.g. sítio Moraes, com por volta de 6.000 anos), os sítios que, de um modo geral, apresentam as datações mais antigas (e.g. sítio Capelinha, com aproximadamente 9.000 anos AP) (figura 2.11).
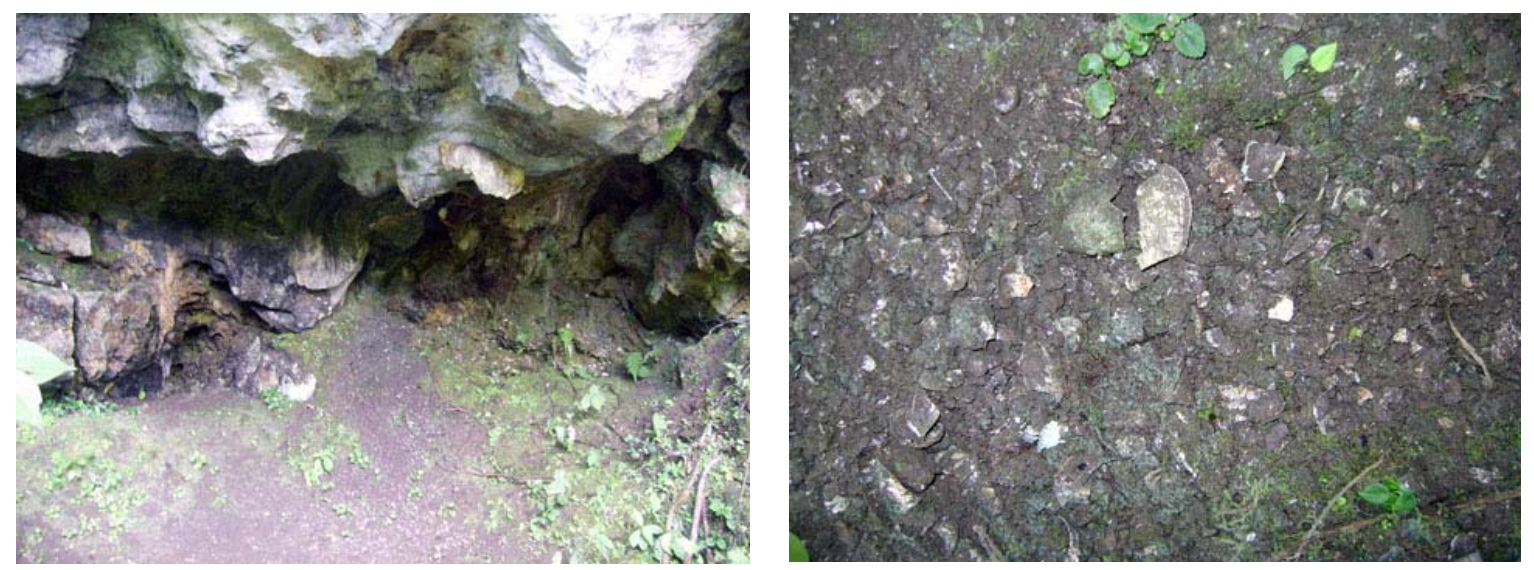

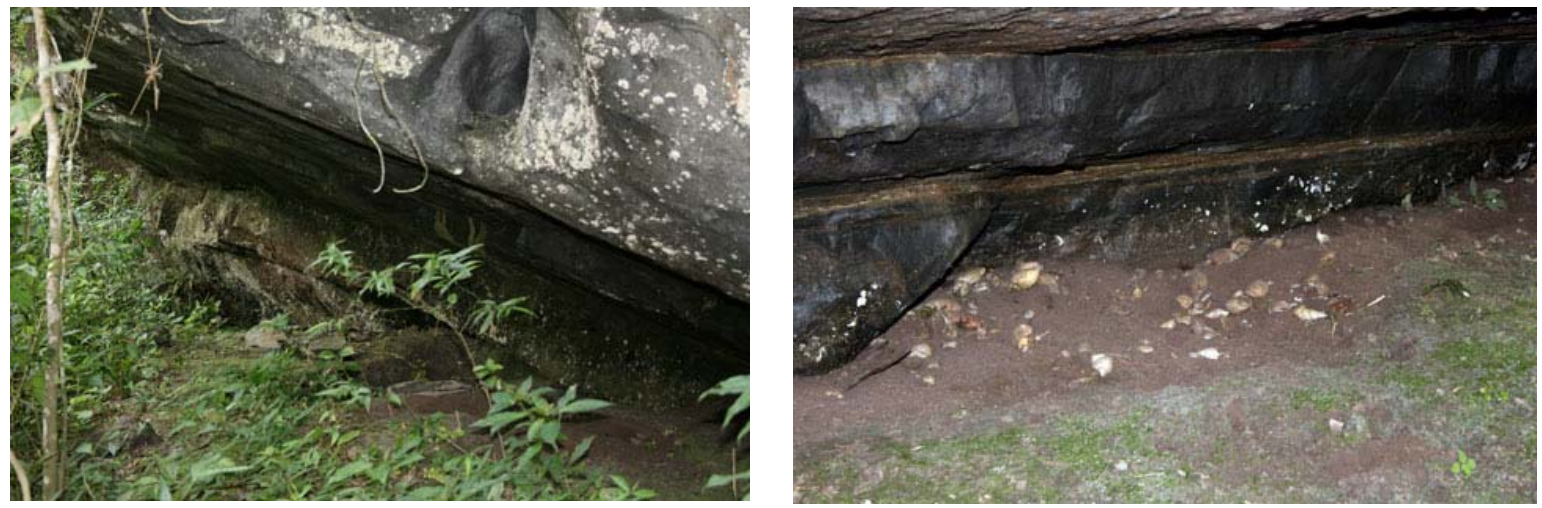

Figura 2.09 - Sítio conchífero Espírito Santo (porção superior) e abrigo Maximiniano (porção inferior), localizados, respectivamente, nos municípios de Apiaí e Iporanga, SP (médio Vale do Ribeira)
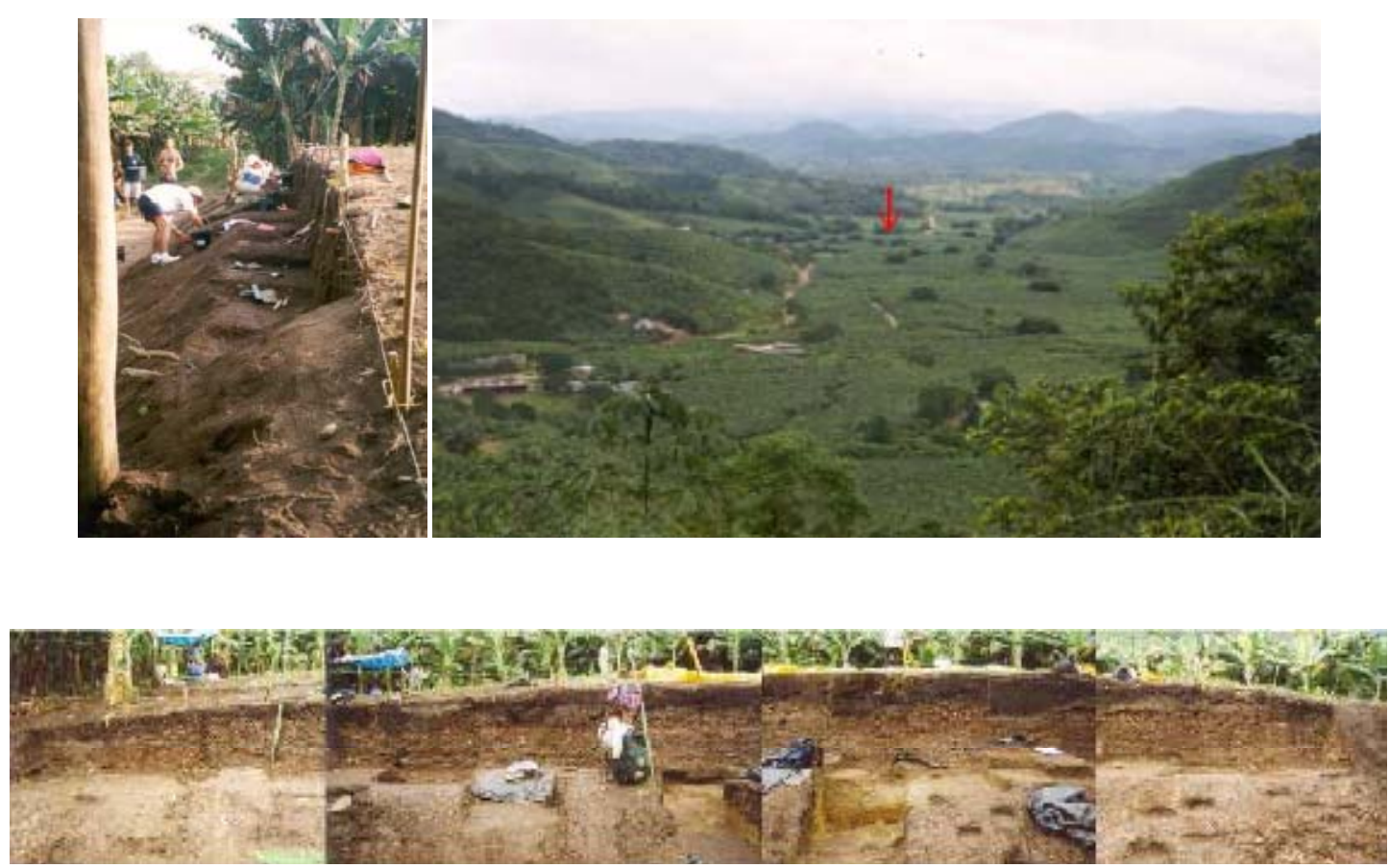

Figura 2.10 - Implantação (canto superior esquerdo) e vistas do perfil (superior direito e inferior) do sambaqui Moraes, localizado no município de Miracatu, SP (coord. UTM 23 J 0256908 7313340) (FIGUTI et. al., 2004) 

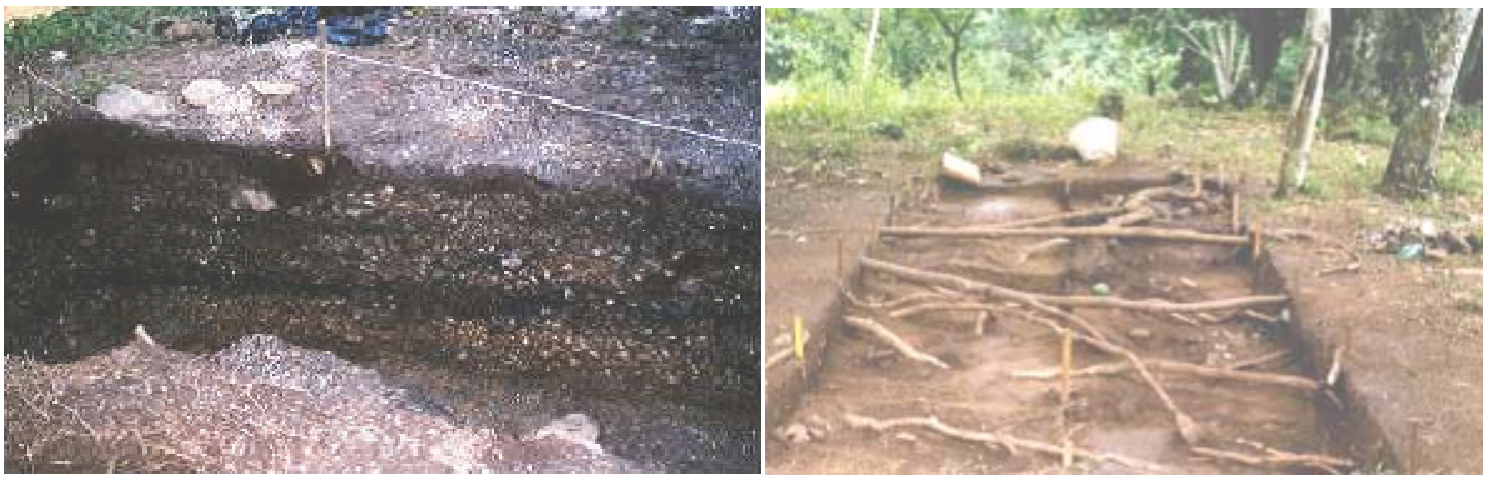

Figura 2.11 - Imagens de um dos perfis (esquerda) e área de escavação (direita) do sambaqui Capelinha, localizado no município de Cajati, SP, a uma altitude aproximada de 310/320 metros (coord. UTM 22J 0778967 7249040) (FIGUTI et. al., 2004)

Além disso, independente das diferenças entre os sítios do médio Ribeira, as únicas evidências que sugerem que eles tenham descido e não subido o vale do Ribeira são relativas a ausência de datações mais antigas ao longo do litoral. Como a idade mais recuada para Cananéia, obtida no sambaqui Cambriu Grande (CALIPPO, 2004), não ultrapassa os 8.000 anos AP, trabalhou-se, na época, principalmente com a hipótese de que a origem dessas ocupações teria se dado no interior.

Em relação à outra hipótese, que diz respeito aos sambaquieiros terem ocupado regiões litorâneas atualmente submersas, basta analisar a migração da linha de costa, que, entre 10.000 anos e 7.000 anos AP, encontrava-se deslocada em direção ao oceano. Nesse período, apesar do nível do mar se encontrar abaixo do atual e em ascensão, haveria ainda à disposição dos sambaquieiros uma extensão da zona litorânea e uma planície fluvial que só posteriormente seria retrabalhada pela dinâmica costeira e recoberta pela elevação do nível do mar.

Vale ressaltar aqui que, apesar da maior probabilidade de localização de sambaquis submersos estar relacionada às áreas atualmente recobertas pelas águas do oceano, não se pode negar que parte desses sítios possa ser encontrada em meio às atuais regiões estuarinas e fluviais. Pois, apesar do nível do mar estar, em épocas anteriores, acima ou abaixo do atual, grande parte dos sedimentos que compõe essas áreas ainda não tinha sido depositada e apresentava cotas inferiores às atuais, o que poderia permitir, mesmo em um nível de mar inferior, uma penetração do oceano sobre essas áreas que hoje são estuarinas e fluviais. 
Para que a hipótese da chegada via planalto possa ser verificada, além de sambaquis submersos intactos ou desagregados (em função dos processos destrutivos gerados pelos eventos de variação do nível mar) que devem estar localizados ao longo da plataforma continental, precisam ser identificados também, em áreas atualmente emersas, sambaquis que tenham sido retrabalhados e/ou recobertos por sedimentos costeiros depositados em conseqüência da variação do nível do mar que ocorreu na região. Ou seja, se os grupos sambaquieiros realmente migraram do planalto em direção ao litoral utilizando como rota o Vale do Ribeira, é provável que as evidências arqueológicas desta migração possam hoje estar total ou parcialmente destruídas pela ação da antiga dinâmica costeira e/ou recobertas pelos sedimentos que foram depositados sobre as mesmas durante o último grande evento holocênico de variação do nível do mar.

Já para se verificar a hipótese da chegada dos sambaquieiros através do litoral, deve-se procurar principalmente por sambaquis atualmente situados em locais de cota mais elevada (associados ou às margens de áreas antes ocupadas por corpos d'água) ou sítios que estejam submersos ao longo da plataforma continental e/ou de áreas estuarinas e fluviais.

O mais provável é que esses sambaquis possam assumir uma antiguidade de no mínimo 7.000 anos AP, devendo estar recobertos por sedimentos costeiros mais recentes, parcialmente ou totalmente destruídos pela ação da dinâmica costeira que se estabelecia em função da variação do nível relativo do mar e associados principalmente às paleolinhas de costa e aos paleocanais submersos, que um dia configuravam e drenavam toda a região que hoje constitui o baixo Vale do Ribeira.

\subsubsection{Os sambaquis pesquisados no baixo Vale do Ribeira}

Com o intuito de consolidar uma proposta que também compreenda os processos de formação em menores escalas, foi analisado, em detalhe, um desses cenários, comparando-o a um cenário mais antigo. O escolhido foi o cenário relativo à fase Regressiva, o qual se desenvolveu de maneira associada ao rebaixamento do 
nível relativo do mar, iniciado após o máximo transgressivo holocênico, em 5.100 anos AP, e findado com o desaparecimento do modo de vida pescador coletor na região, por volta de 2000 anos AP.

Neste caso, a escolha de tal cenário deu-se, principalmente, em conseqüência da quantidade de sítios analisados e da informação arqueológica produzida a respeito desses cenários para a região do baixo Vale do Ribeira. Ao total foram analisados, da Fase Regressiva, três sítios arqueológicos. São eles, os sambaquis Branco (coordenada UTM 7214409 0194260), Cachoeira Mirim (UTM 7211914 0198461) e Ilha do Cambriu (UTM 7213579 0206318) (tabela 2.01) (figura 2.12).

Tabela 2.01 - Idade dos sambaquis analisados do baixo Vale do Ribeira

\begin{tabular}{|c|c|c|c|}
\hline síTIO & $\begin{array}{c}\text { IDADE CONVENCIONAL } \\
\text { (anos AP) }\end{array}$ & $\begin{array}{l}\text { REFERÊNCIA DA } \\
\text { AMOSTRA }\end{array}$ & $\begin{array}{l}\text { REFERÊNCIA } \\
\text { BIBLIOGRÁFICA }\end{array}$ \\
\hline Branco & $3790 \pm 110$ & Gif-3437 & Uchôa e Garcia (1983) \\
\hline Branco & $4400 \pm 110$ & Gif-3439 & Uchôa e Garcia (1983) \\
\hline Branco & $4150 \pm 50$ & BETA-190991 & Calippo (2004) \\
\hline Branco & $4160 \pm 50$ & BETA-199992 & Calippo (2004) \\
\hline Branco & $4460 \pm 60$ & BETA-190993 & Calippo (2004) \\
\hline Cachoeira Mirim & $4715 \pm 95$ & I-9596 & Uchôa e Garcia (1983) \\
\hline Cachoeira Mirim & $4715 \pm 95$ & Ba-290 & Uchôa e Garcia (1983) \\
\hline Cambriu Grande & $7870 \pm 80$ & CENA -481 & Calippo (2004) \\
\hline Cambriu Grande & $5390 \pm 70$ & CENA -480 & Calippo (2004) \\
\hline Ilha do Cambriu & $4360 \pm 60$ & BETA -190999 & Calippo (2004) \\
\hline Ilha do Cambriu & $4340 \pm 50$ & BETA -191000 & Calippo (2004) \\
\hline
\end{tabular}




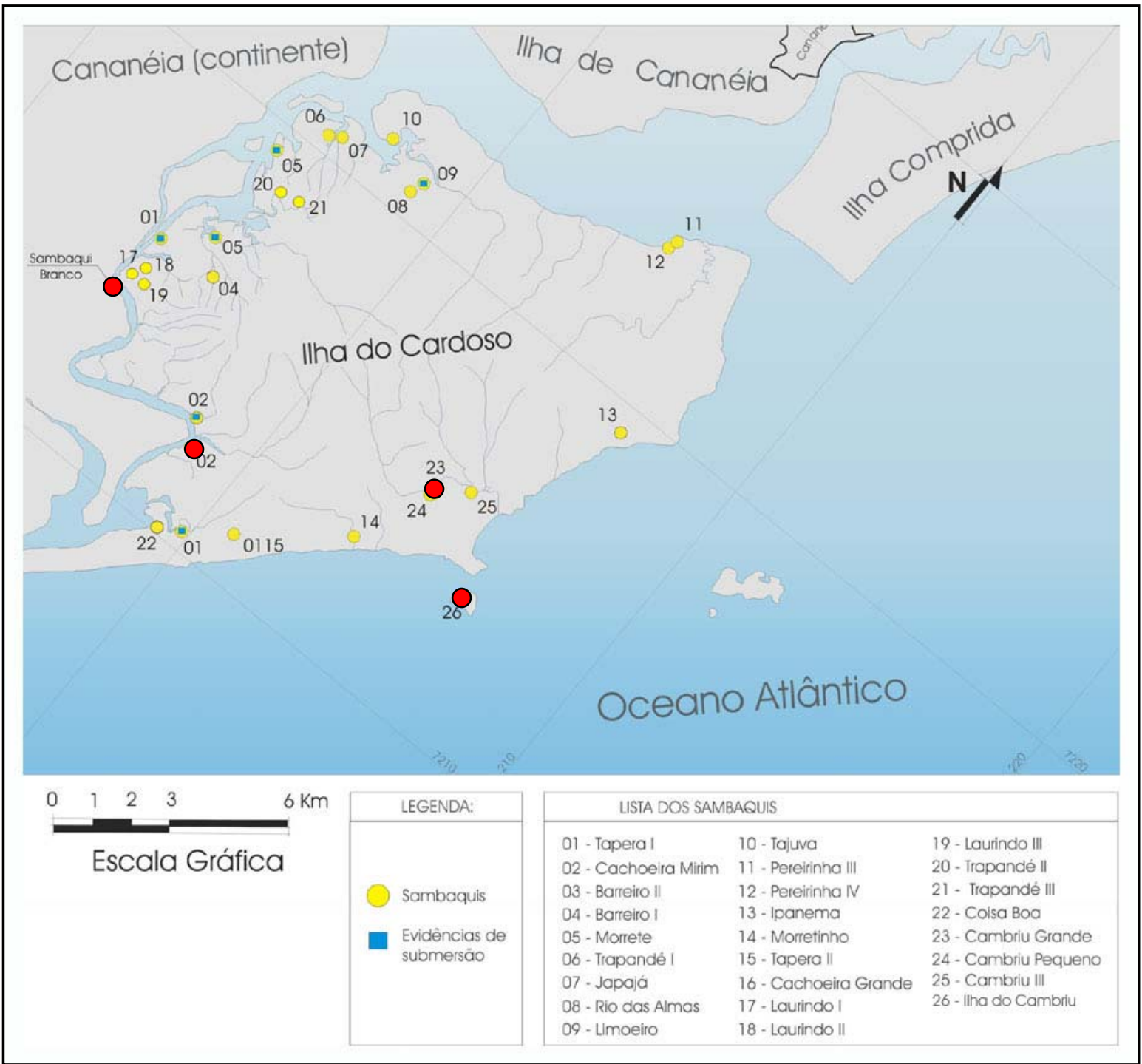

Figura 2.12 - Mapa de localização dos sambaquis analisados em Cananéia (em destaque na cor vermelha)

Com a intenção de estabelecer um referencial comparativo, foi também analisado um sítio referente aos primeiros momentos da fase transgressiva. $O$ escolhido foi o sambaqui Cambriu Grande (UTM 7216076 0204325) (tabela 2.01) (figura 2.12), o qual, além de ser um dos sítios mais antigos da costa brasileira, está inserido em um contexto paleoambiental semelhante ao dos sítios da fase regressiva. Contexto que diz respeito a momentos em que o mar, embora em níveis diferentes e deslocando-se em sentido contrário, encontrava-se próximo ao sítio (CALIPPO, 2004). 


\subsection{O sambaqui Cambriu Grande}

Durante a Fase Transgressiva I, apesar do nível do mar já se encontrar em franca ascensão, ele ainda não havia ultrapassado a cota em que se encontra atualmente. Portanto, até por volta de 7.000 anos AP, se existissem populações sambaquieiras ocupando o litoral, seus vestígios deveriam hoje estar submersos. Entretanto, existem exceções, que, provavelmente, devem estar associadas a sambaquis que foram construídos sobre áreas de cota mais elevada do que a atingida pela elevação do nível do mar ou a locais que tenham sido protegidos da ação da dinâmica costeira.

Nos sambaquis de Cananéia existem pelos menos dois sítios que podem ser enquadrados nessas condições: os sambaquis Cambriu Grande (figura 2.13) e Pequeno (figura 2.14). Datados em, respectivamente, 7.870 080 (CENA 481) e 5.940 \pm 80 anos AP (CENA 483) (CALIPPO, 2004), esses sambaquis só se preservaram em função de estarem situados em uma área um pouco mais alta e protegida por um grande afloramento rochoso (Ponta do Cambriu) (figura 2.15). Tal condição atuou como uma zona de sombra, evitando que a feição sobre a qual esses sambaquis se assentavam fosse destruída durante a elevação do nível do mar.

Atualmente esses sítios localizam-se em meio à face marinha (leste) da Ilha do Cardoso, imediatamente atrás de uma área hoje recoberta por uma densa mata de Restinga e um manguezal, mas que, provavelmente, na época da formação desses sambaquis, deveria ser uma baía ou área lagunar (figura 2.16). 

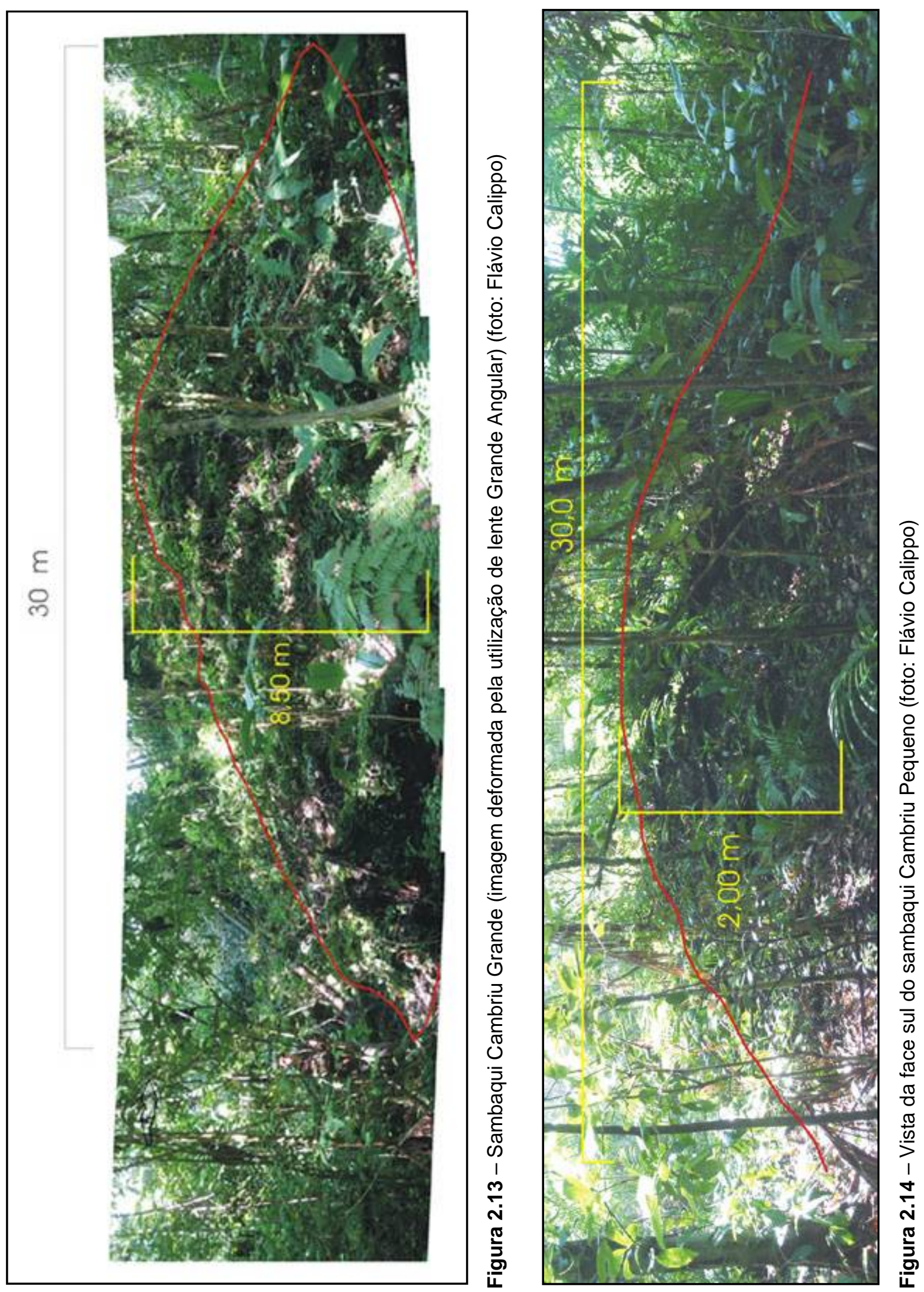


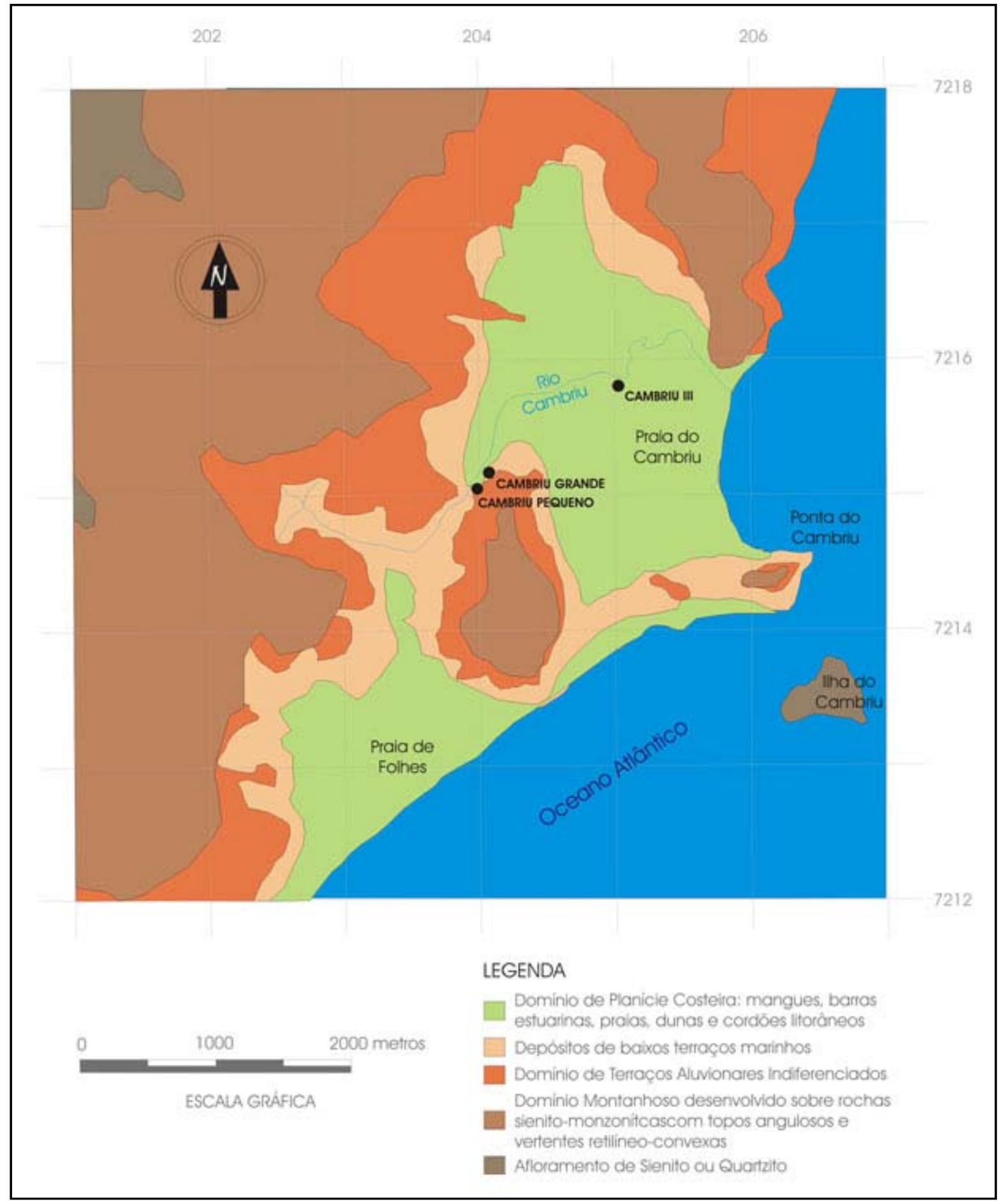

Figura 2.15 - Mapa geomorfológico da região do Cambriu com a posição dos sambaquis (modificado a partir de Landim et al., 2000) 


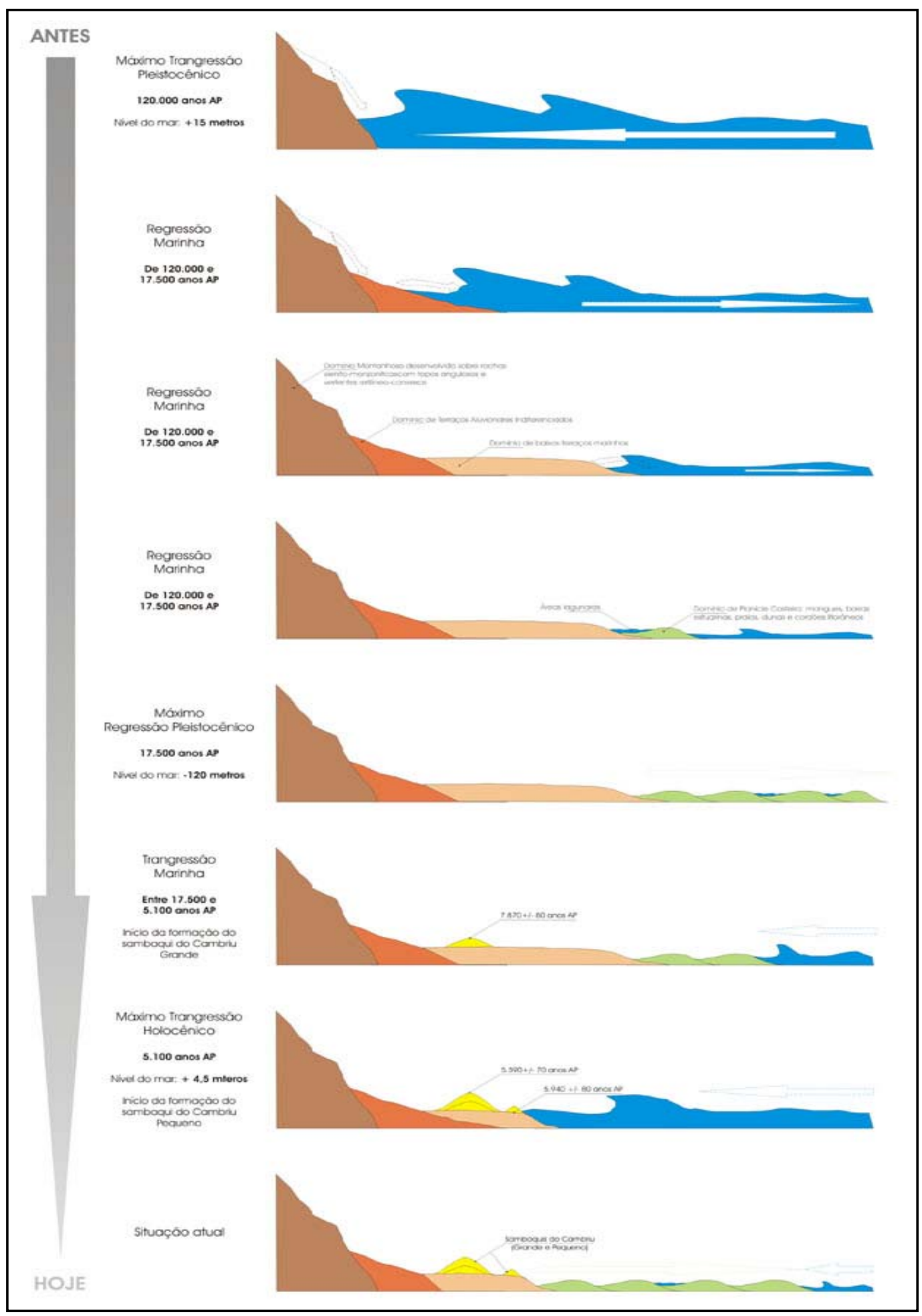

Figura 2.16 - Hipótese da ocorrência dos sambaquis Cambriu Pequeno e Grande em meio à formação da região (elaborado por Flávio Calippo com base em Suguio et al. 1978) 
Os sambaquis estão localizados sobre os sedimentos depositados por leques aluviais $^{15}$ formados a partir da erosão marinha das bordas do maciço central da Ilha do Cardoso e durante as oscilações do nível do mar que ocorreram no Pleistoceno (figura 2.17). A oeste dos sítios, cortando os leques aluviais, as matas de Restinga e os manguezais, está o rio Cambriu.

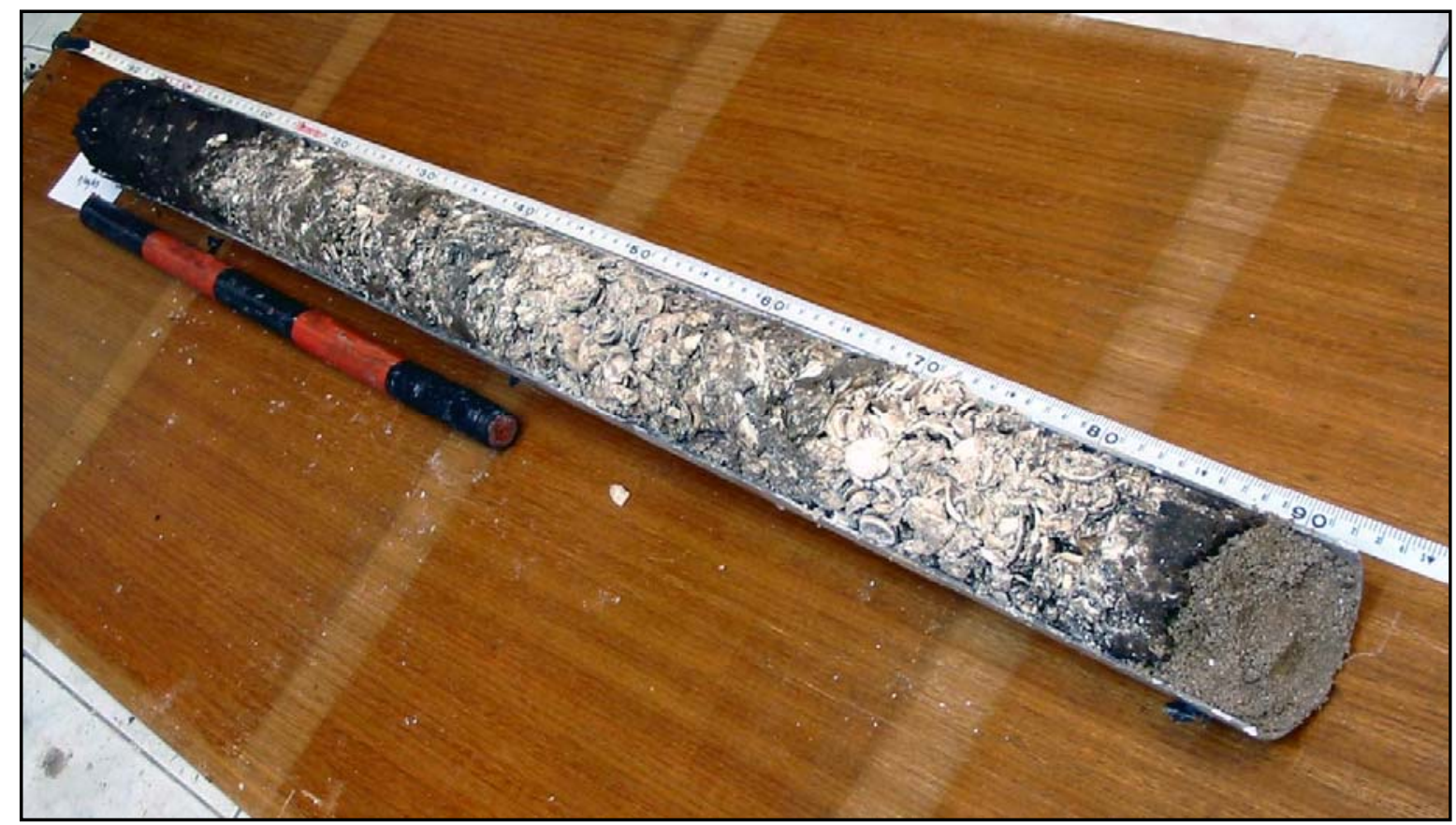

Figura 2.17 - Testemunho realizado no sambaqui Cambriu Grande, cuja base está assentada sob um depósito associado a um leque aluvial. Na porção inferior do testemunho (à direita) pode-se verificar a presença de sedimentos relativos a esse depósito (foto: Flávio Calippo).

Tanto o sambaqui Cambriu Grande como o Pequeno foram formados pelo acúmulo de diversas camadas de Ostrea sp. (ostra) e Anomalocardia brasiliana (berbigão). Apesar de ambos apresentarem uma forma circular, assumem um tamanho bastante diferenciado: 8,5 metros no Grande e, no máximo, 2,0 no Pequeno.

${ }^{15} \mathrm{O}$ sedimento foi identificado a partir de uma análise preliminar qualitativa realizada pelo Prof. Dr. Moisés Tessler (IO/USP), que, ao constatar a presença de micas e pequenos fragmentos de rocha em meio a uma matriz composta por areia grossa, concluiu que essas evidências não poderiam ser provenientes de um depósito intensamente retrabalhado pela dinâmica costeira (como o caso de um terraço marinho). O mais provável é que esse sedimento fosse oriundo de alguma feição geológica semelhante a um leque aluvial, pouco distante do local do sítio (fragmentos de rocha estariam indicando uma proximidade da rocha fonte). 
Em função das datações mais antigas obtidas para os sambaquis Cambriu

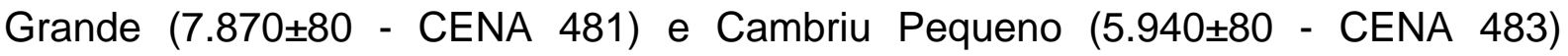
(CALIPPO, 2004) e do modelo de formação da planície costeira proposto para a região de Cananéia, estima-se que esses sambaquis começaram a ser formados a partir de recursos extraídos tanto da face praial como da área lagunar, na época próximas aos sítios (evidenciada pela presença das conchas de ostra e berbigão). Estas condições parecem ter se mantido até por volta do máximo transgressivo holocênico, quando houve a invasão da água do mar por todo interior da baía.

Essa tendência que pode ser verificada quando se analisam os valores da razão de ${ }^{12} \mathrm{C} /{ }^{13} \mathrm{C}$ presentes nas conchas do sambaqui Cambriú Grande: $-0,7$ \%o (CENA - 481) e -0,1 \%o (CENA - 480), respectivamente datadas em 7.870 $5.390 \pm 70$ anos AP. Levando-se em consideração que os valores da razão de ${ }^{12} \mathrm{C} /{ }^{13} \mathrm{C}$ podem variar de 13\%o (água doce) a, por volta, de 0\%o (água marinha) (Martin et al., 1984), as razões obtidas na amostras dos sambaquis Cambriú Grande indicam uma coleta associada a áreas de intensa influência marinha. Além disso, se esses valores pudessem ser diretamente $\operatorname{comparados}^{16}$, como indicam uma tendência na diminuição da razão ${ }^{12} \mathrm{C} /{ }^{13} \mathrm{C}$ entre a primeira e a última datação, poder-se-ia supor que tais sítios fossem contemporâneos a um momento em que a influência marinha, apesar de intensa, estaria diminuindo.

Essa modificação ambiental parece ter sido a responsável pelo abandono dessa área, pois a datação mais recente do sambaqui Cambriu Grande (topo) é relativa a 5.390 70 anos AP (CENA 480) - período que coincide com o do máximo transgressivo. Após esse momento, à medida que o nível do mar rebaixava, essas áreas eram paulatinamente ocupadas por sedimentos. Sobre eles desenvolve-se uma cobertura vegetal que dá origem às matas de Restinga e aos manguezais que hoje dominam a região (figura 2.18).

Além da análise realizada com base em fotos aéreas, levantamentos geomorfológicos e geológicos já existentes para essa região, no âmbito da

\footnotetext{
${ }^{16}$ Para que essa comparação entre os valores da razão de ${ }^{12} \mathrm{C} /{ }^{13} \mathrm{C}$ possa ser estatisticamente confiável, seria necessário que houvesse um maior controle sobre as outras variáveis envolvidas no processo da coleta, como, por exemplo, a espécie dos organismos capturados, a localização e a distância das áreas de coleta ao longo do tempo.
} 
dissertação de mestrado (CALIPPO, 2004), que permitiu a proposição de tais hipóteses, foram realizados testemunhos a percussão principalmente a volta do sambaqui Cambriu Grande ${ }^{17}$. Essas coletas tiveram dois objetivos principais: primeiro, verificar se o solo sobre o qual o sambaqui está assentado era realmente relativo a leques aluviais e, segundo, investigar o processo de formação desses sambaquis.

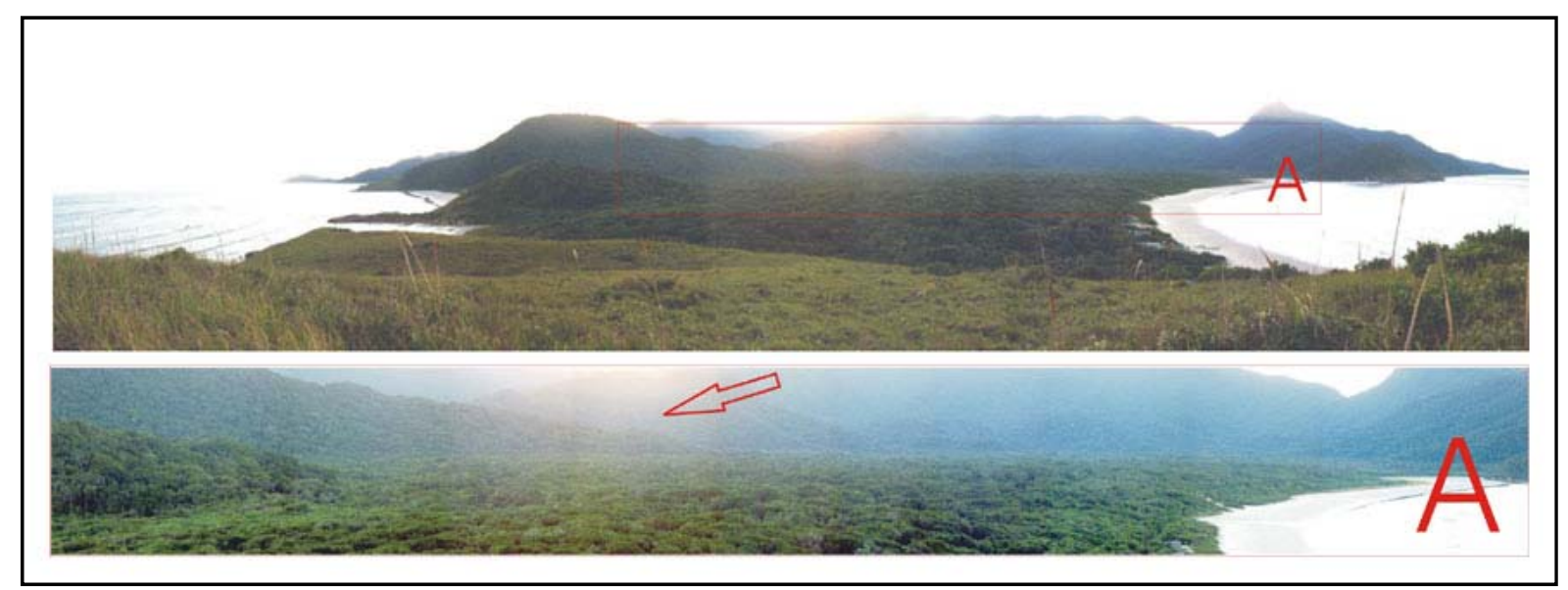

Figura 2.18 - Vista a partir da Ponta do Cambriu. Imagem superior (deformada pela utilização de uma lente Grande Angular): praia do Fole (esquerda), planície do rio Cambriu (centro) e praia do Cambriu (direita). Detalhe: vista da região do rio Cambriu, com a seta indicando o local (entre os dois morros) onde se localizam os sambaquis do Cambriu Grande e Pequeno (foto: Flávio Calippo)

No sambaqui Cambriu Grande foram realizados dois testemunhos (figura 2.19). O primeiro foi retirado de sua borda oeste (figura 2.20), com o objetivo de obter-se uma amostra do contato entre a base do sambaqui e o solo. E o segundo, na face leste do sambaqui (figura 2.21), a 2,8 metros abaixo do topo, em uma área que já havia sido impactada pela queda de uma árvore (figura 2.22).

\footnotetext{
${ }^{17}$ Em função da pequena espessura do pacote arqueológico do sambaqui Cambriu Pequeno, as amostras coletadas através dos Testemunhos à Percussão não permitiram uma investigação estratigráfica mais detalhada das evidências arqueológicas. Dessa maneira, acabaram propiciando somente a obtenção de amostras da porção mais inferior e central do sambaqui, cujas conchas foram datadas em $5.940 \pm 70$ anos AP.
} 


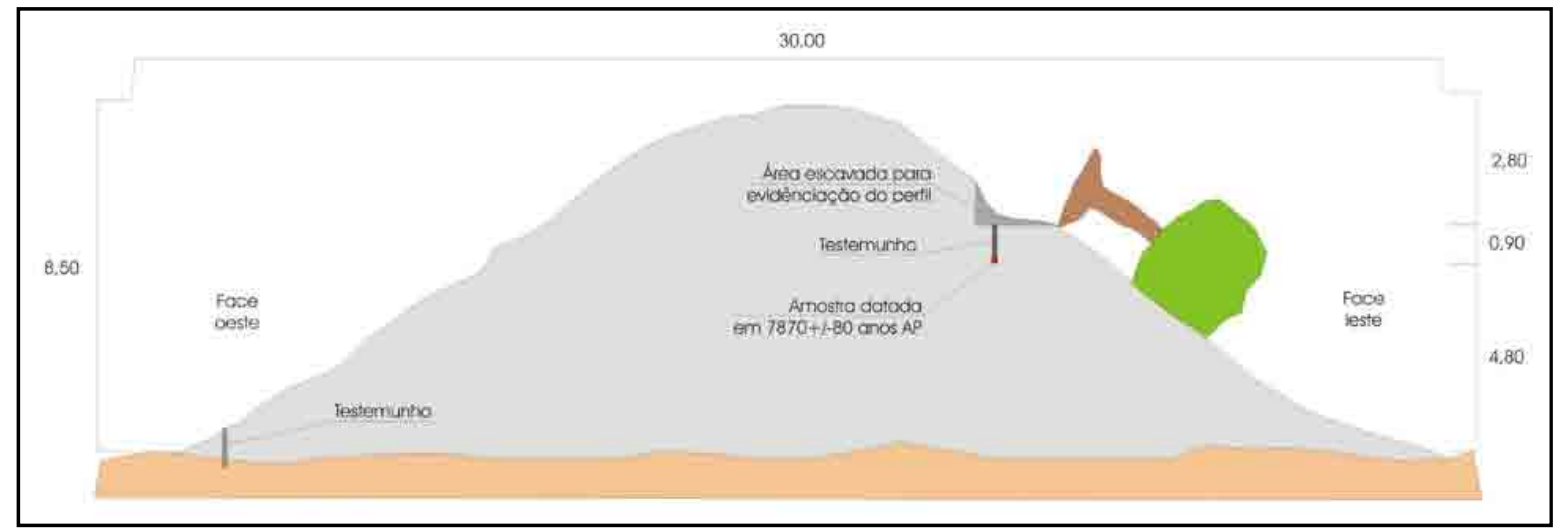

Figura 2.19 - Perfil esquemático do sambaqui Cambriu Grande (autor: Flávio Calippo)

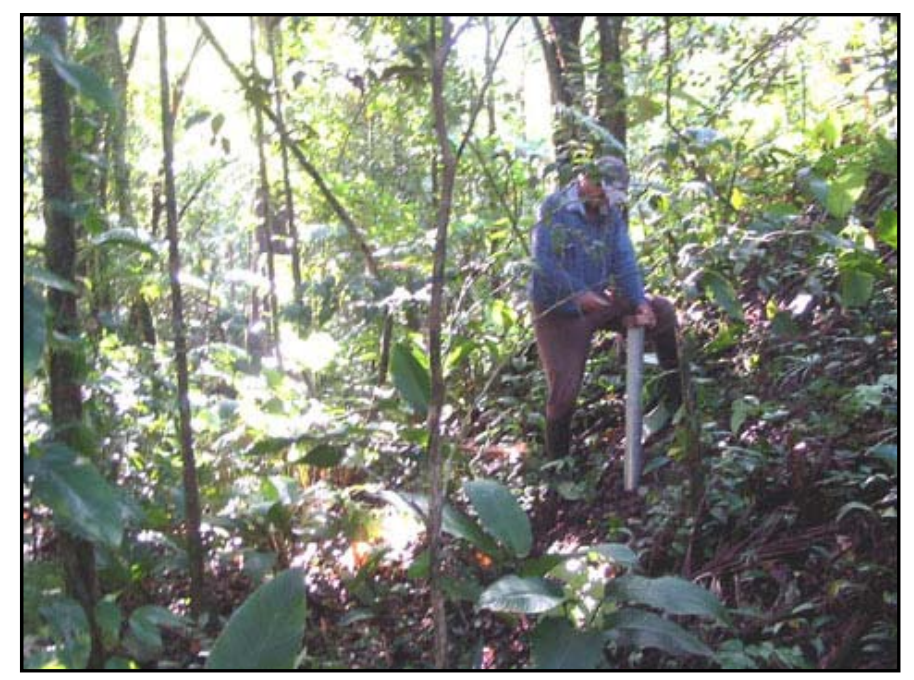

Figura 2.20 - Testemunhagem junto à base do perfil oeste do sambaqui Cambriu Grande (foto: Célia M. C. Demartini )

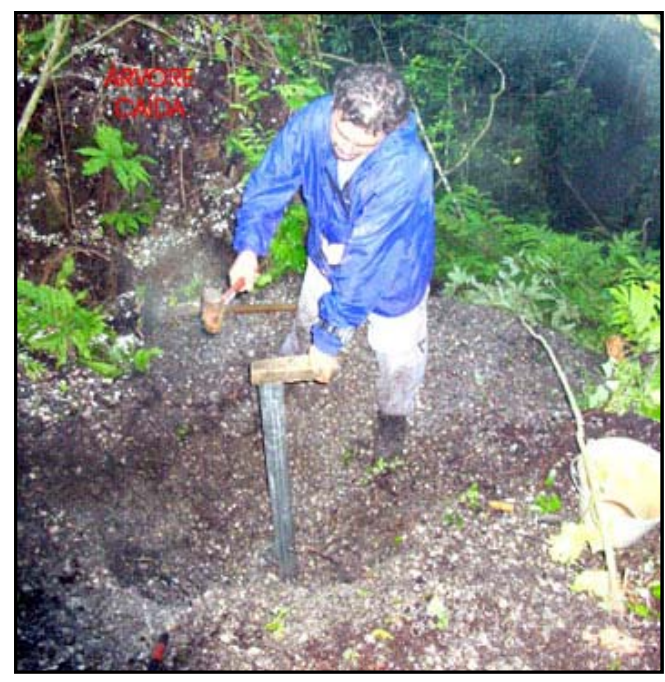

Figura 2.21 - Testemunhagem do perfil leste do sambaqui Cambriu Grande (foto: Célia M. C. Demartini) 


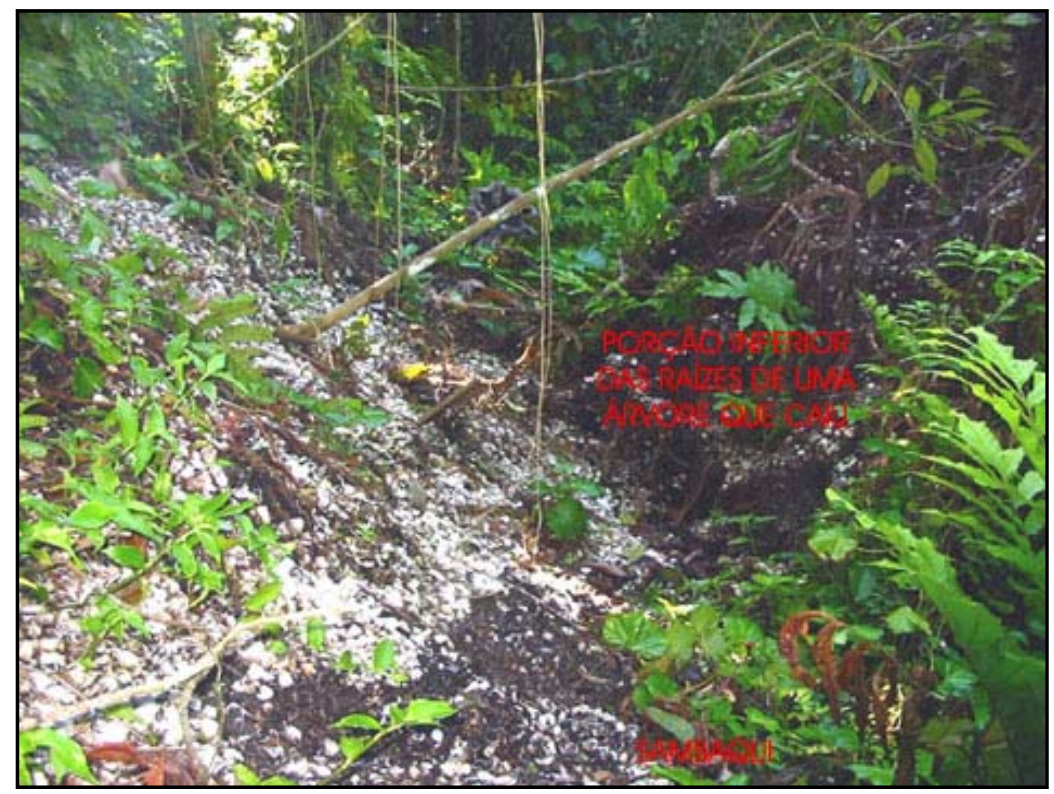

Figura 2.22 - Porção impactada pela queda da árvore antes da intervenção arqueológica (foto: Flávio Calippo)

Além de objetivar a obtenção de uma amostra da parte central do sambaqui, esse testemunho foi utilizado também para se obter uma idéia inicial da estratigrafia do sítio. Por isso, antes de se iniciar a obtenção do testemunho, realizou-se a elaboração de um perfil ${ }^{18}$ (figura 2.23) ao longo da parte do sambaqui que foi remobilizada pela queda da árvore. Como a amostra de conchas foi retirada de um ponto acima da metade da altura do sítio (aproximadamente a 4,8 metros acima do nível da base), pode-se inferir que a idade inicial do mesmo seja mais antiga que os $7.870 \pm 80$ anos AP.

\footnotetext{
${ }^{18} \mathrm{O}$ objetivo da realização desse perfil foi compreender a influência da movimentação das raízes da árvore (no momento da queda) sobre o registro arqueológico, garantindo assim que o testemunho fosse retirado de uma região não perturbada por esse tipo de alteração pós-deposicional.
} 


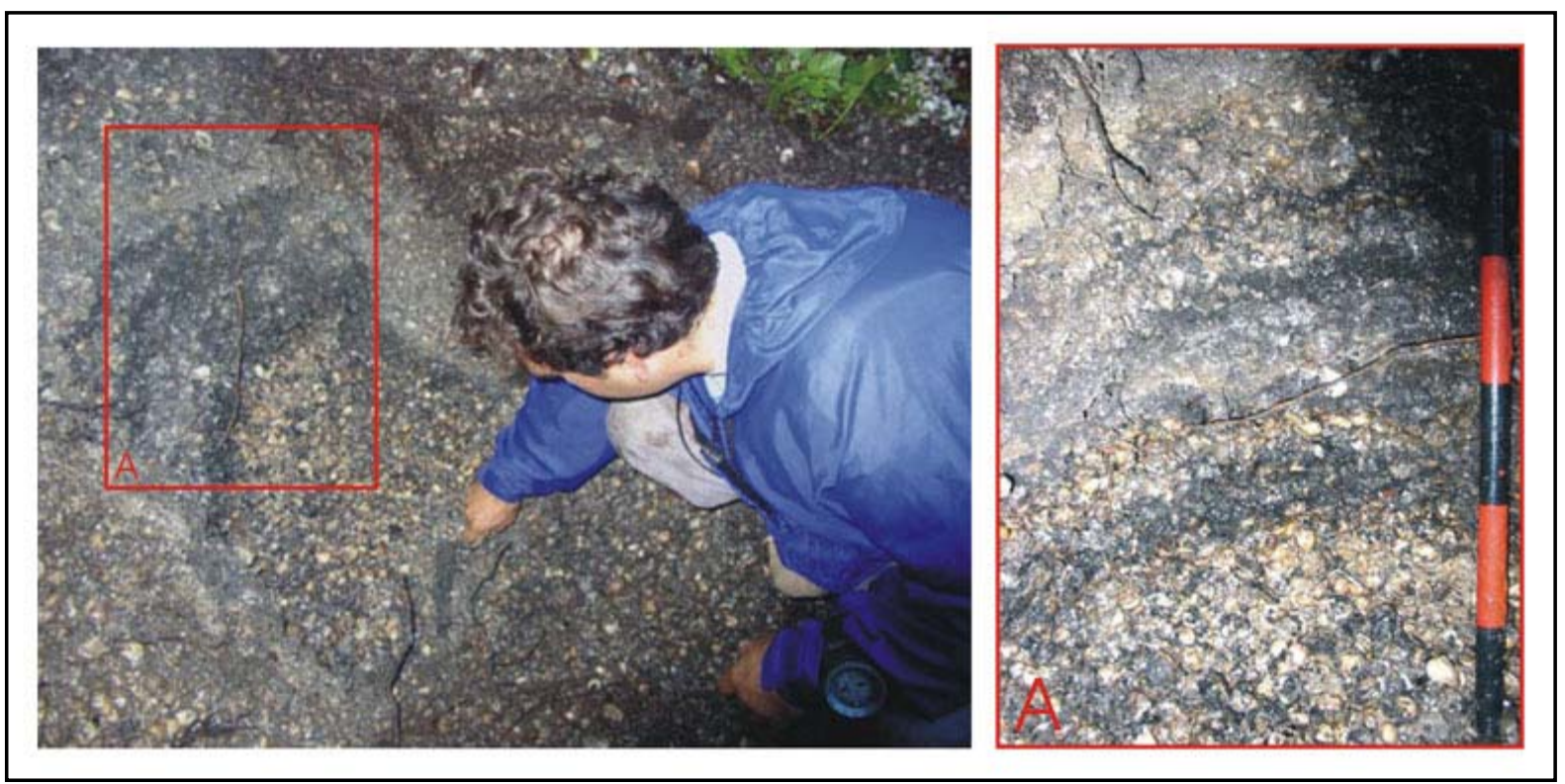

Figura 2.23 - Evidenciação do perfil (esquerda) e detalhe da seqüência estratigráfica evidenciada (foto: Célia M. C. Demartini e Flávio Calippo)

Quanto ao Processo de Formação do sambaqui Cambriu Grande, verificou-se, através do perfil da análise do testemunho (figura 2.24), que existe, nesse ponto, uma alternância de dois tipos de camadas: uma, mais desagregada, muitas vezes formada por conchas fechadas; e outra, mais compacta, onde as conchas se encontram aglutinadas em meio a um sedimento de cor escura, que pode ser relativo à uma concentração de matéria orgânica.

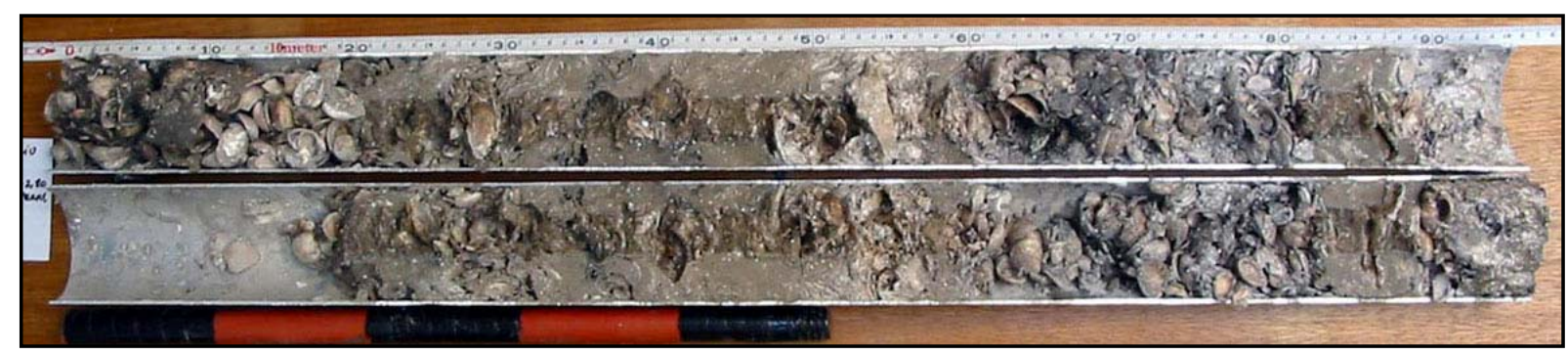

Figura 2.24 - Vista superior das duas metades do testemunho retirado da base do perfil evidenciado na face leste do sambaqui Cambriu Grande (o topo do testemunho encontra-se à esquerda da figura) (foto: Flávio Calippo)

Apesar de ser uma amostra pontual e pouco representativa, a ocorrência dessa sucessão de diferentes camadas pode ser compreendida como um indício de que a construção do sambaqui Cambriu Grande (pelos menos em um determinado 
momento) foi realizada a partir de eventos alternados de diferentes naturezas, possivelmente associados a fases de rápida (episódica) e lenta acumulação.

\subsection{O sambaqui Cachoeira Mirim}

O sambaqui Cachoeira Mirim localiza-se na Ilha do Cardoso, à margem leste do Canal do Ararapira, sobre uma feição arenosa que atualmente aflora em meio à área de influência das marés e encontra-se recoberta por um manguezal (figuras 2.25 e 2.26).

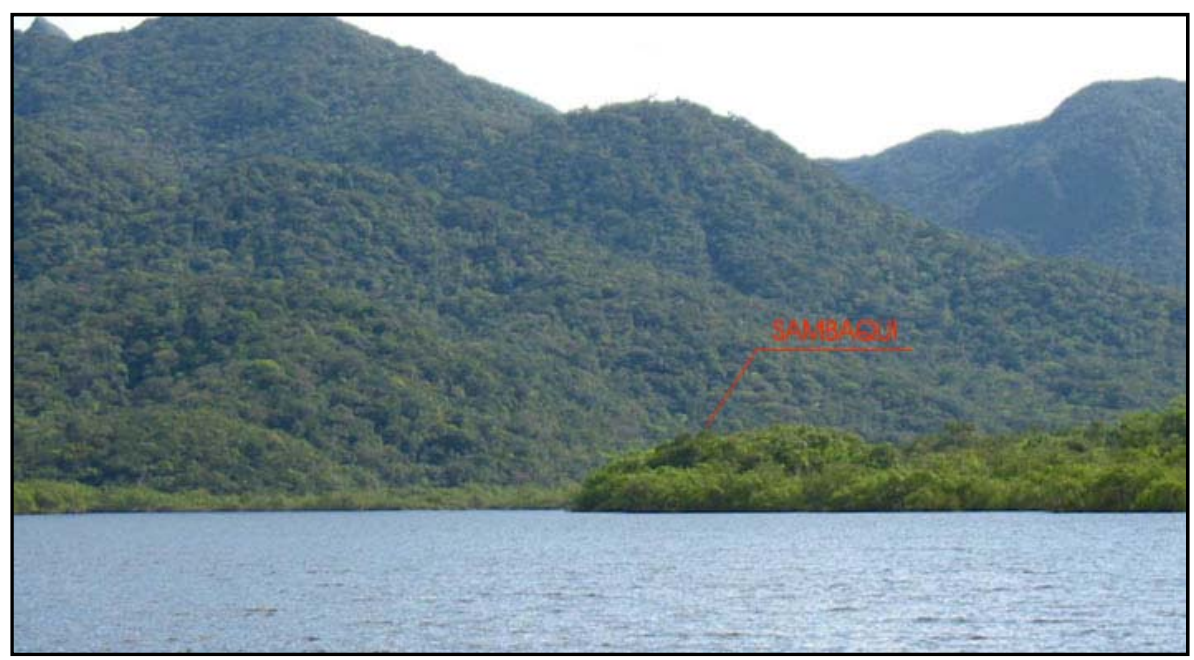

Figura 2.25 - Detalhe da localização do sambaqui Cachoeira Mirim, que se encontrada recoberto pela vegetação (foto: Flávio Calippo) 


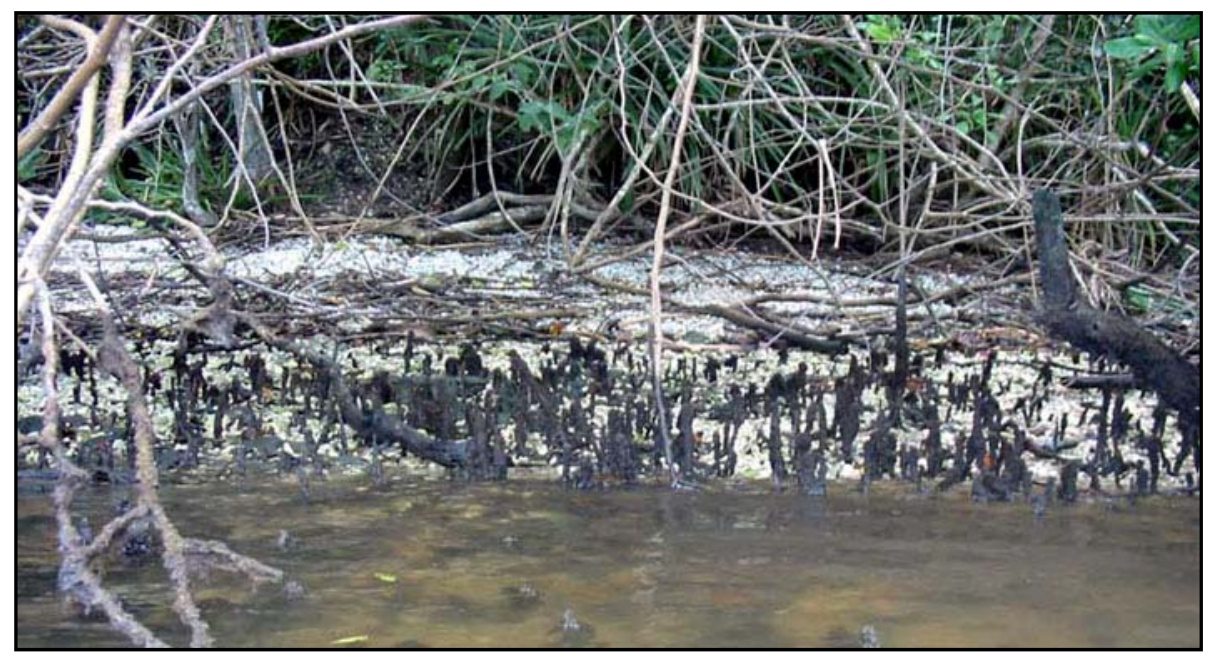

Figura 2.26 - Detalhe do mangue que recobre a feição arenosa e parte dos vestígios erodidos (foto: Flávio Calippo)

Como esse sambaqui também apresentou vestígios arqueológicos subaquáticos em suas adjacências, foram realizados, além de um testemunho por Percussão, três testemunhagens (vibracoring) e em porções subaquáticas (figura 2.27). Além de evidenciarem que os vestígios arqueológicos ocorrem superficialmente sobre o fundo (sendo provavelmente relativos a eventos erosivos), esses testemunhos revelaram também que a feição arenosa sobre a qual o sambaqui foi construído, a partir de certa profundidade, sobrepõe-se a uma camada de sedimentos argilosos que, provavelmente, também deve estar associada a um paleocanal (figura 2.28). 


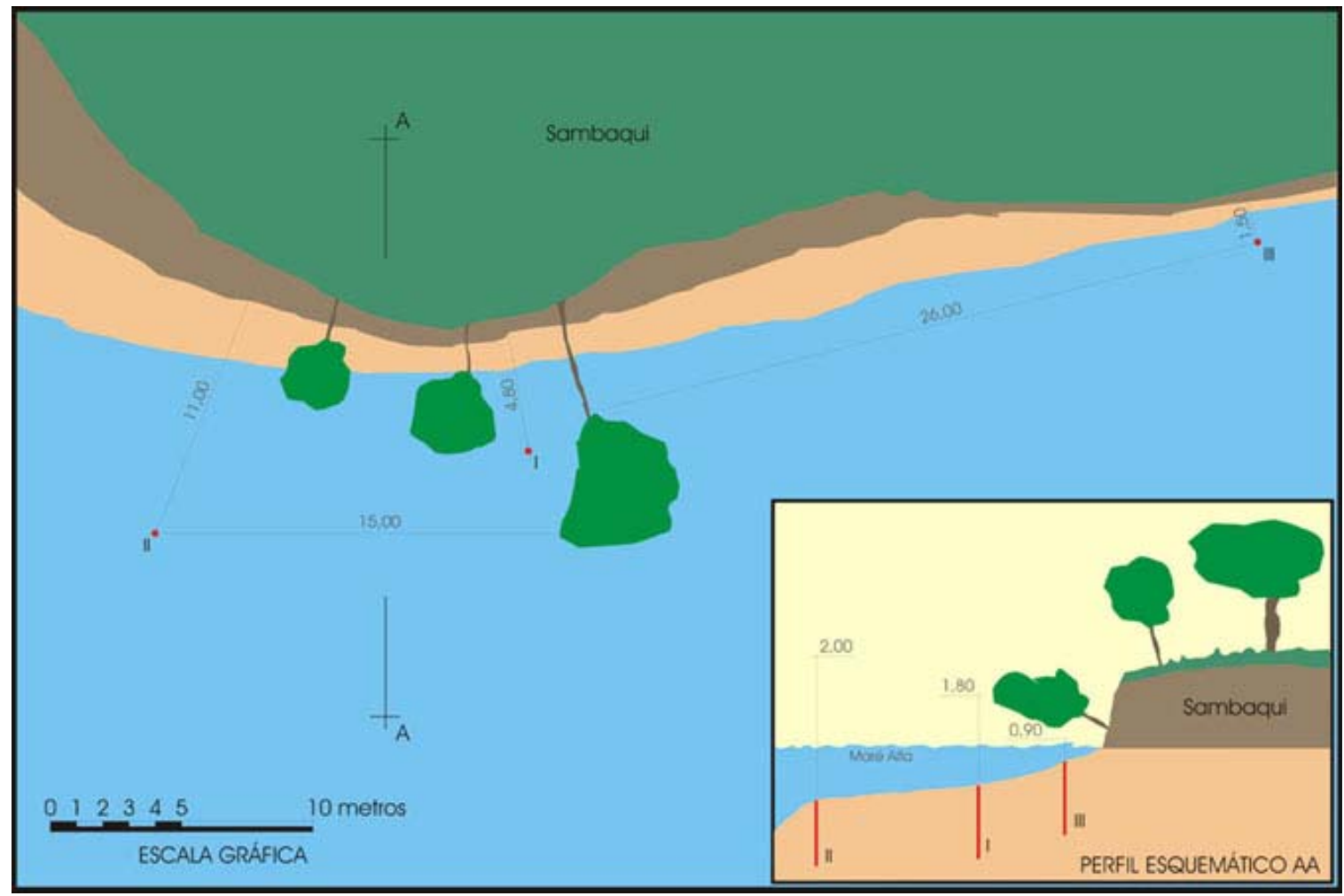

Figura 2.27 - Croquis do sambaqui Cachoeira Mirim, com a posição dos testemunhos subaquáticos (autor: Flávio Calippo) 


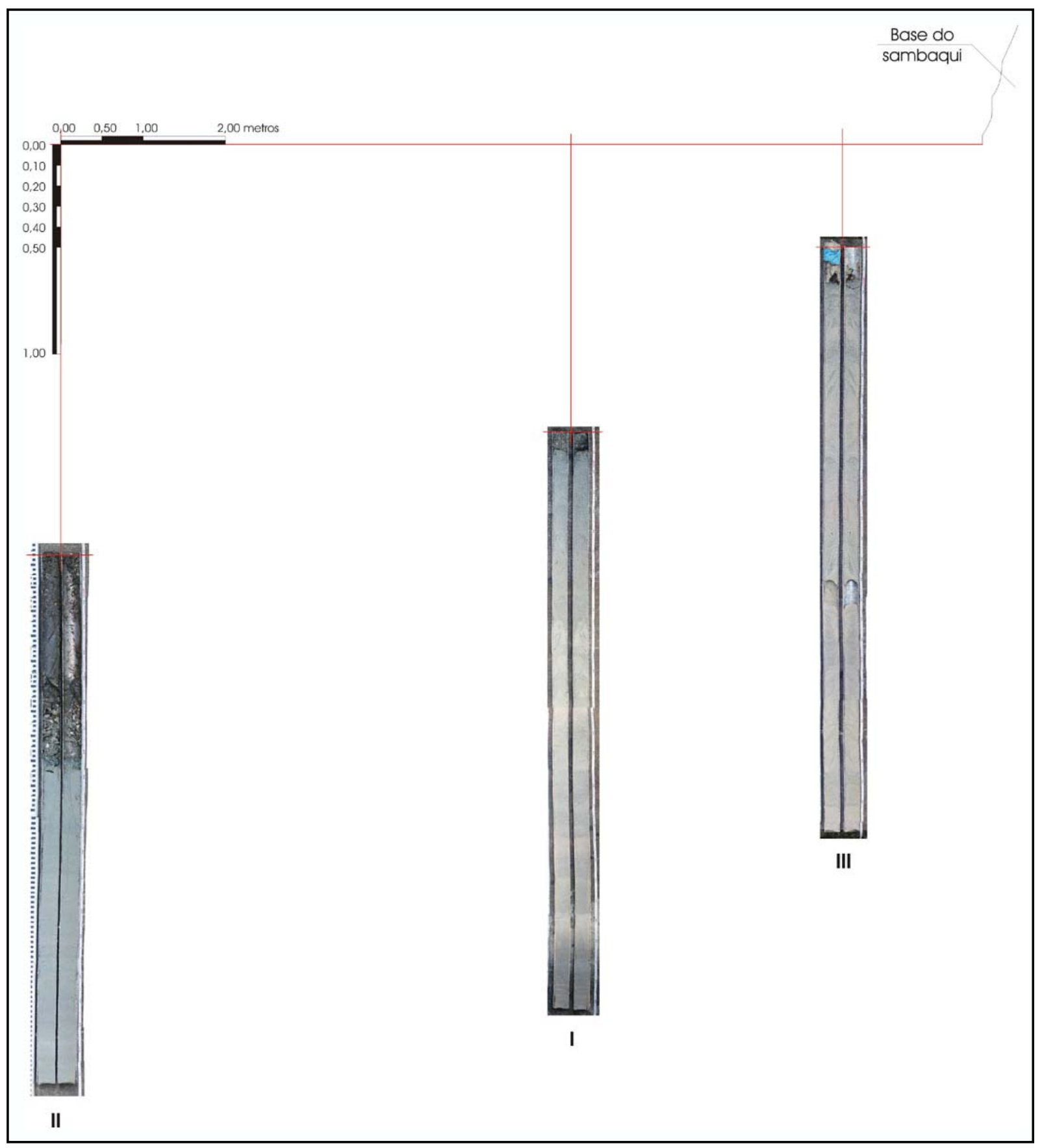

Figura 2.28 - Testemunhos subaquáticos realizados no sambaqui Cachoeira Mirim (autor: Flávio Calippo)

Apesar das medições e análises estratigráficas não terem sido realizadas neste sítio com o mesmo detalhamento daquelas que foram feitas no sambaqui Branco (onde uma nova metodologia de interpretação foi testada), as evidências encontradas no sambaqui Cachoeira Mirim indicam que este sítio também foi 
construído sobre uma feição arenosa provavelmente relacionada à Transgressão Santos, sob a qual existe um pacote sedimentar passível de causar subsidência em suas feições estratigraficamente superiores.

No caso do sambaqui Cachoeira Mirim, o argumento da subsidência é ainda mais forte, pois, além da idade de suas porções mais inferiores (4.715 \pm 95 anos AP I-9596) (UCHÔA e GARCIA, 1983) coincidirem com um momento em que o nível do mar encontrava-se aproximadamente 3 metros mais alto, a base deste sítio encontra-se em uma posição muito semelhante a ocupada hoje pelo nível do mar. Isso indica que deve existir uma defasagem de aproximadamente 3 metros entre a cota altimétrica que ocupa atualmente e a que deveria ocupar durante o início de sua formação.

É bastante provável que um evento de subsidência possa realmente ter atuado sobre o sambaqui Cachoeira Mirim, porém, antes que se empenhem esforços em compreender a sua influência, é preciso confirmar se a datação obtida por Uchôa e Garcia (op. cit.) junto à base do sítio, realmente corresponde ao início de sua formação. É verdade que no sambaqui Branco as idades das amostras obtidas a partir do perfil erodido coincidem com a idade das amostras coletadas com o vibracorer, mas é preciso lembrar que aquele sítio provavelmente se encontra seccionado em sua porção central, expondo assim uma porção inferior que é relativa ao início de sua formação.

Buscando investigar o processo de formação do sambaqui Cachoeira Mirim e solucionar a dúvida referente à data do início de sua formação, foram realizados um corte experimental e três testemunhos por Percussão (figura 2.29). O corte experimental foi feito na porção central de uma das duas feições colinares que compõe o sambaqui, até uma profundidade de aproximadamente 1,30 metros. A partir desse ponto, as amostras foram obtidas por meio de uma testemunhagem por percussão, pois o poço teste teve de ser encerrado em função da desagregação natural do pacote arqueológico e da conseqüente instabilidade de suas paredes. Os outros dois testemunhos foram obtidos junto às porções mais inferiores de dois perfis que se encontram expostos em função de erosões provocadas pelas águas do Canal do Ararapira. Além de coletar amostras que pudessem ser datadas e 
comparadas às idades obtidas por Uchôa e Garcia (1983), essas intervenções objetivaram também compreender se a feição arenosa identificada ao longo dos testemunhos subaquáticos também ocorria sob o sambaqui. Fato que foi mais tarde comprovado com a abertura desses testemunhos (figura 2.30). 


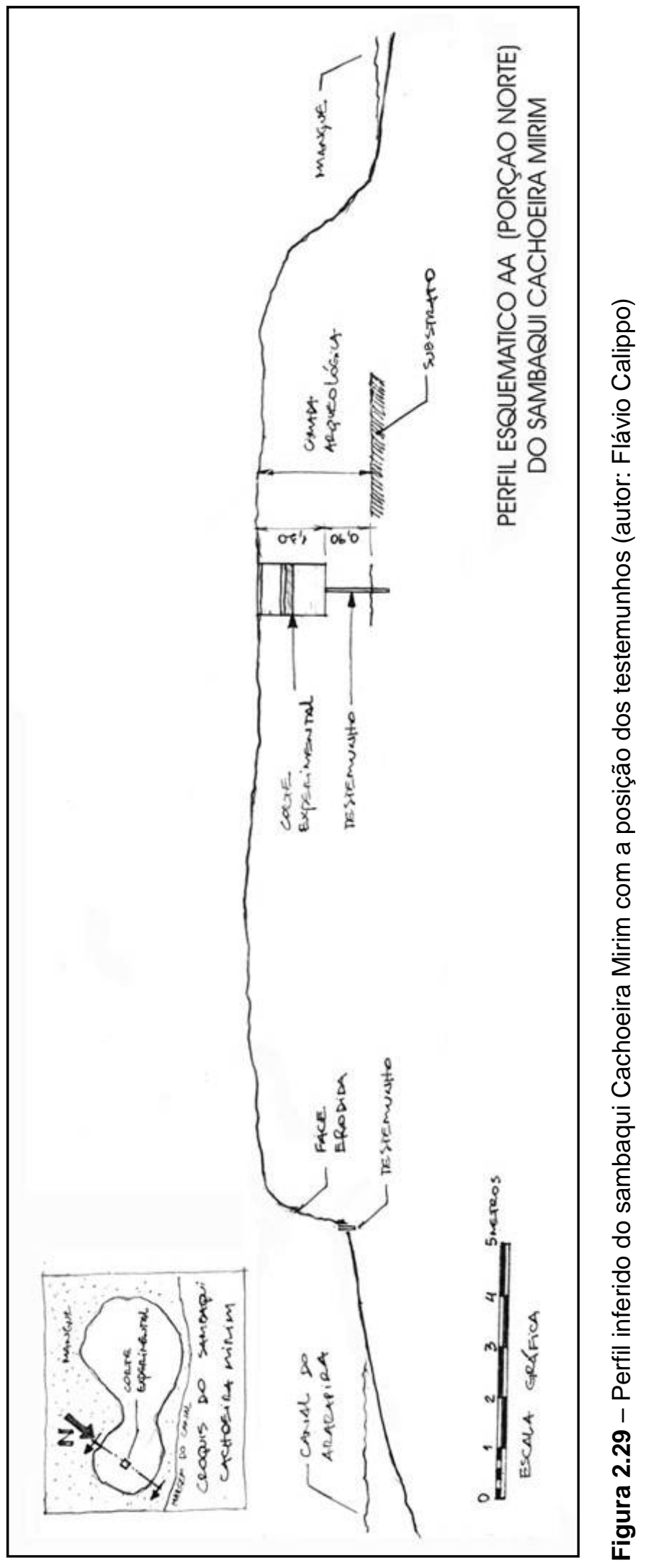



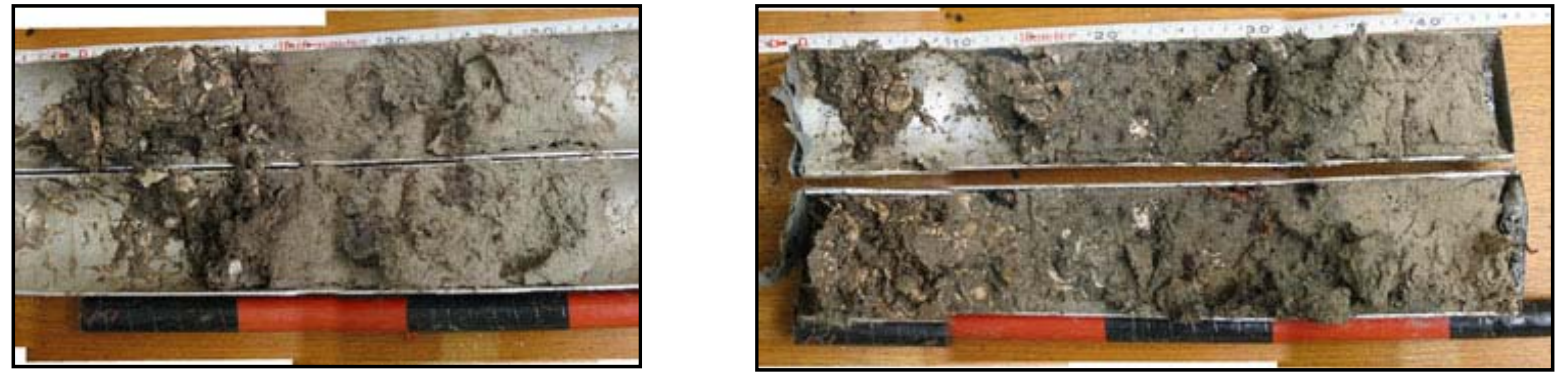

Figura 2.30 - Testemunhos retirados junto à base do sambaqui Cachoeira Mirim (autor: Flávio Calippo)

O poço teste foi realizado em níveis artificiais de dez centímetros, evidenciando pelo menos quatro diferentes camadas arqueológicas (figuras 2.31 e 2.32). Apesar de apresentar uma estrutura deposicional bem marcada, não foram encontradas evidências arqueológicas que, em uma primeira análise, pudessem diretamente ser associadas a uma mudança no processo de formação. De qualquer maneira, em cada uma dessas camadas foram coletadas amostras de conchas para datação.

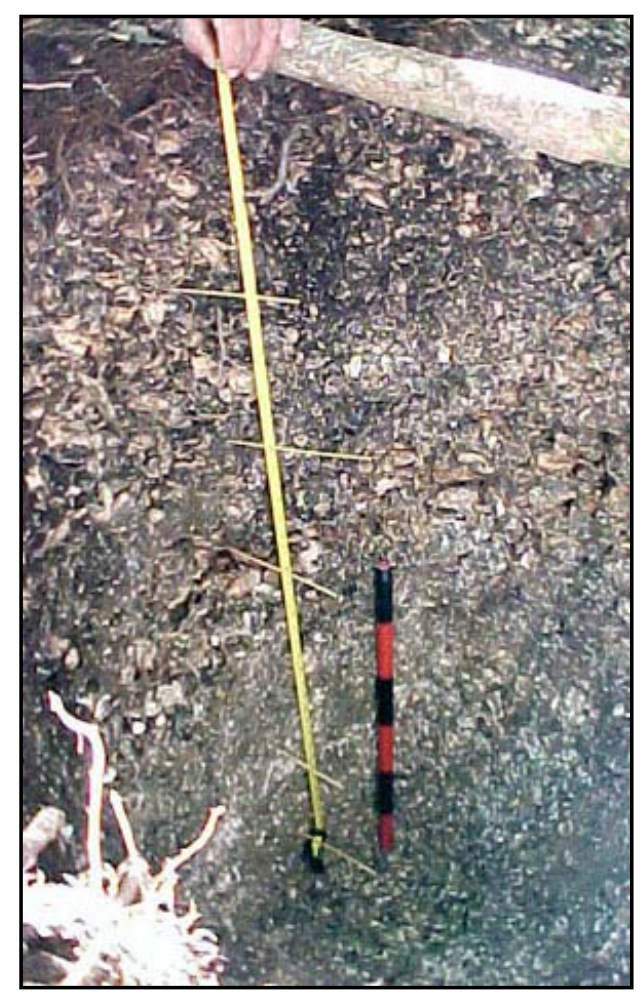

Figura 2.31 - Imagem vértice do perfil nordeste do poço teste (as estacas amarelas indicam os pontos de coleta (foto: Flávio Calippo) 


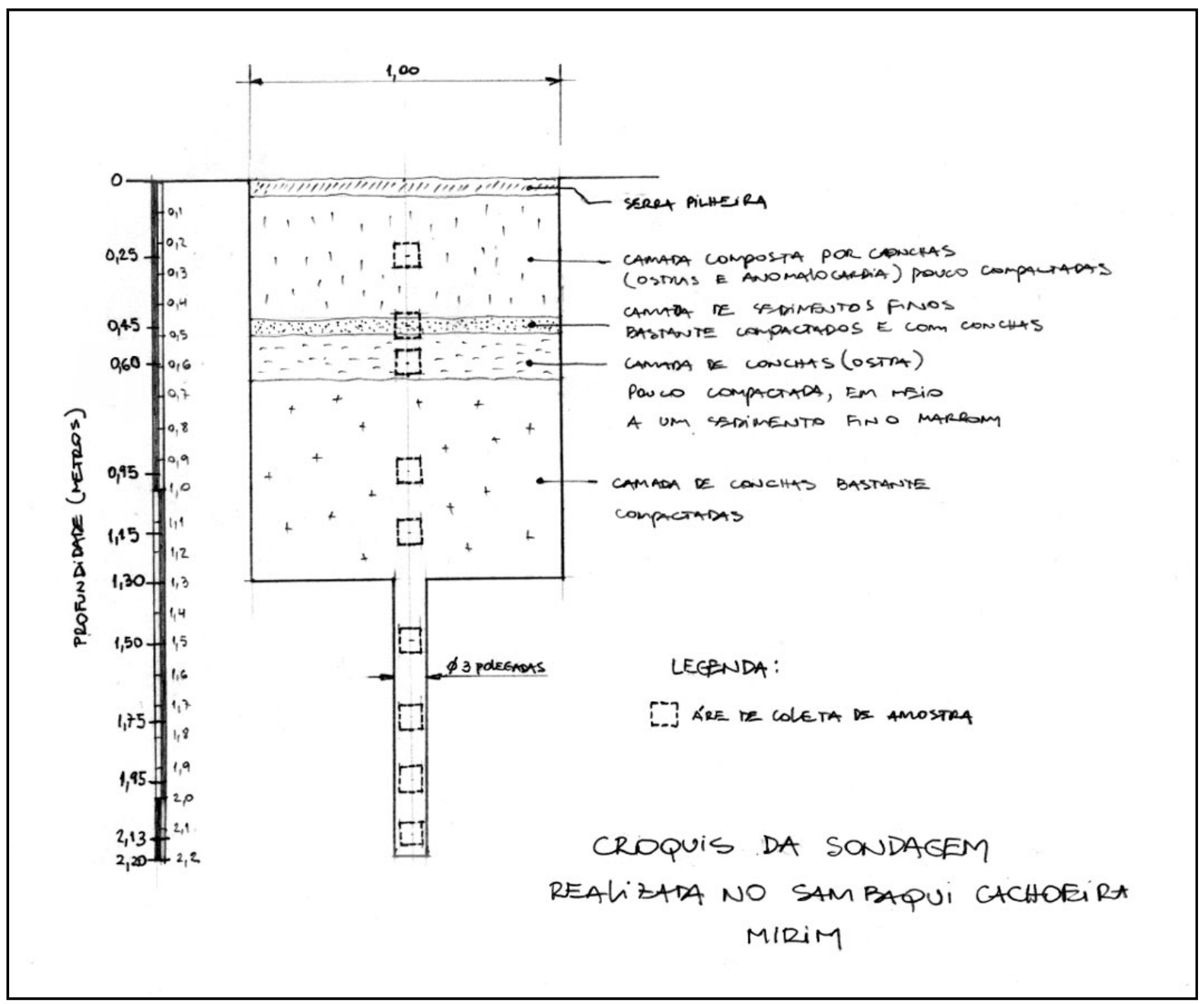

Figura 2.32 - Perfil do poço teste (autor: Flávio Calippo)

Assim como aconteceu com o poço teste, apesar de algumas mudanças na composição, coloração, compactação e texturas terem sido diagnosticadas; não foram encontradas evidências que pudessem sustentar uma segura interpretação do processo formativo. Com exceção da camada arqueológica mais próxima à base do testemunho, onde, após uma marcada face de contato com o topo da feição arenosa que suporta o sambaqui, as conchas ocorrem em meio a uma matriz sedimentar composta principalmente por sedimentos arenosos e argilosos (figura 2.33). Condição nada semelhante a que foi encontrada na porção mais central e inferior do sambaqui Branco (Camada III), onde se estima que tal camada tenha atuado como uma base ou plataforma para a ocupação inicial do local. 


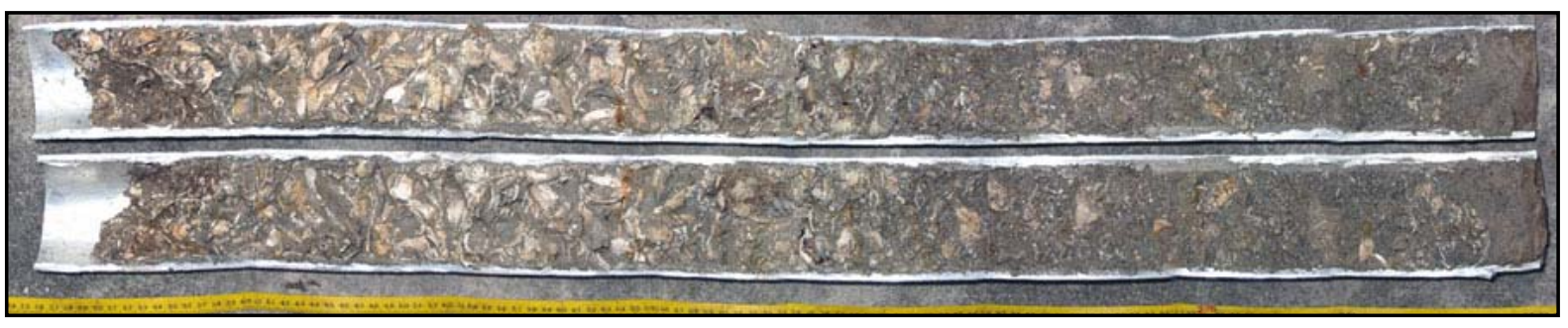

Figura 2.33 - Testemunho retirado da base da sondagem (autor: Flávio Calippo)

Entretanto, ainda que não tenha sido possível compreender por completo o processo de formação do sambaqui Cachoeira Mirim, algumas partes da seqüência estratigráfica desse sítio sugerem que os processos envolvidos em sua formação são bastante diferentes daqueles associados ao sambaqui Branco. Embora ambos estão associados aos contextos ambientais e geológicos semelhantes, possuírem bases com idades semelhantes, serem cercados por áreas de mangue que se estabeleceram após a sua formação e se encontrarem assentados sobre feições arenosas (provavelmente regressivas), a diversa composição e estrutura de suas camadas mais centrais e inferiores indicam que poderia existir uma heterogeneidade interna a um mesmo conjunto de sítios e a seus respectivos processos formativos. Um comportamento que, provavelmente, estaria associado ao estabelecimento de diferentes funções para os sítios ou a coexistência de diversas práticas culturais.

\subsection{O sambaqui Branco}

O sambaqui Branco (figura 2.34) localiza-se a beira de uma das grandes curvas do Canal do Ararapira, na margem oposta à Ilha do Cardoso, sobre a borda de uma feição arenosa que vem sendo continuamente erodida pela migração do curso desse canal em direção noroeste. Devido a esse processo, o sambaqui já teve grande parte de sua porção leste erodida ${ }^{19}$, fazendo-nos acreditar que o que hoje se

\footnotetext{
${ }^{19}$ Como atualmente o sambaqui Branco apresenta-se seccionado justamente sobre a sua parte mais alta e pressupondo que apresentava uma forma elíptica, é provável que o perfil agora exposto seja relativo à porção central da forma original do sambaqui. Um outro fato que corrobora a essa idéia é a grande quantidade de vestígios arqueológicos que podem ser encontrados submersos em suas adjacências.
} 
vê a partir do canal é uma grande secção relativa à porção central do sítio (figura 2.35).

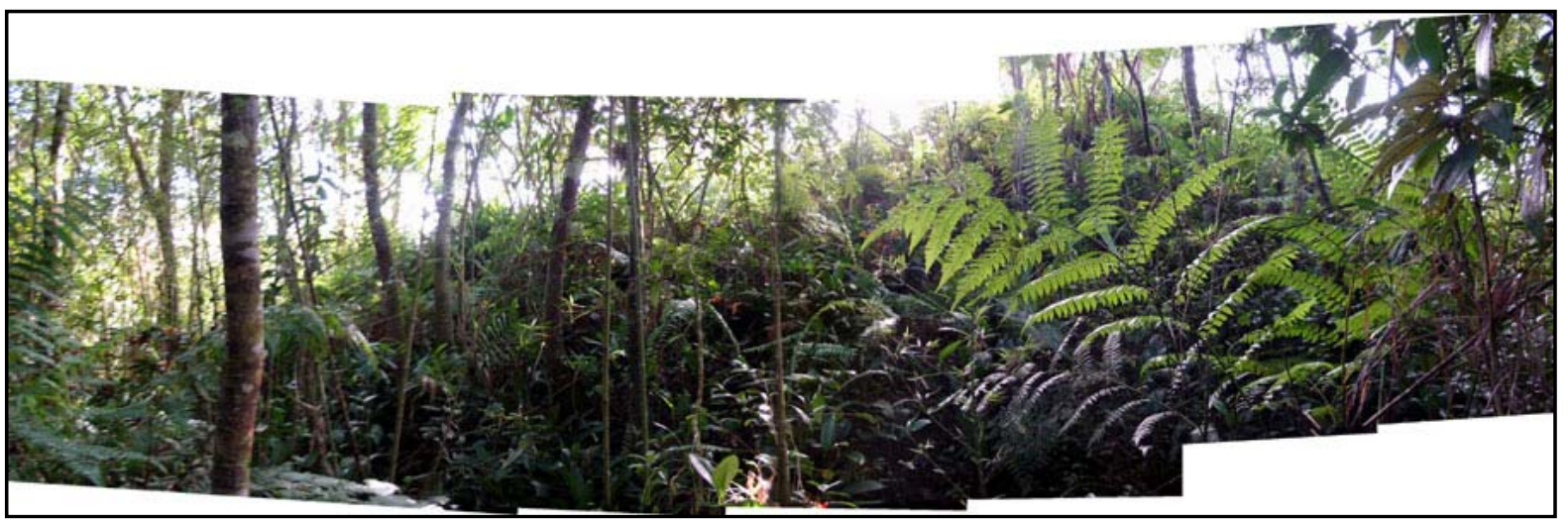

Figura 2.34 - Vista da porção sudoeste do sambaqui Branco (foto: Flávio Calippo)

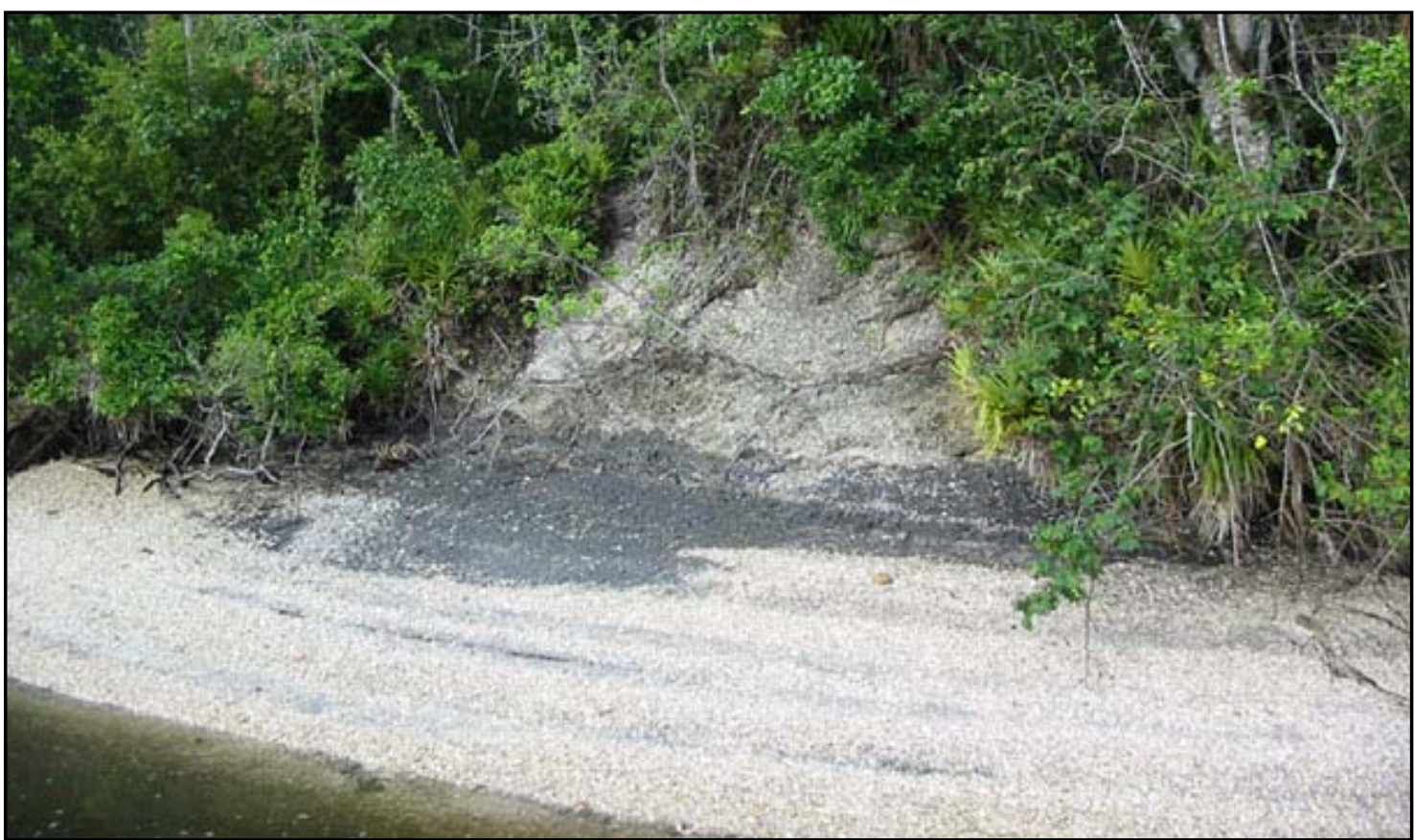

Figura 2.35 - Vista do perfil exposto do sambaqui Branco a partir do Canal do Ararapira (foto: Flávio Calippo)

Ao longo de sua face sudeste (que margeia o Canal do Ararapira) o sambaqui Branco apresenta atualmente, aproximadamente, cinco metros de altura, por treze metros de largura e vinte e quatro metros de comprimento. A norte do sambaqui existe um manguezal (figura 2.36) - parcialmente inundado durante as marés de 
maior amplitude - e, a sul, sobre a formação arenosa onde foi construído, desenvolve-se uma mata de restinga (figura 2.37).

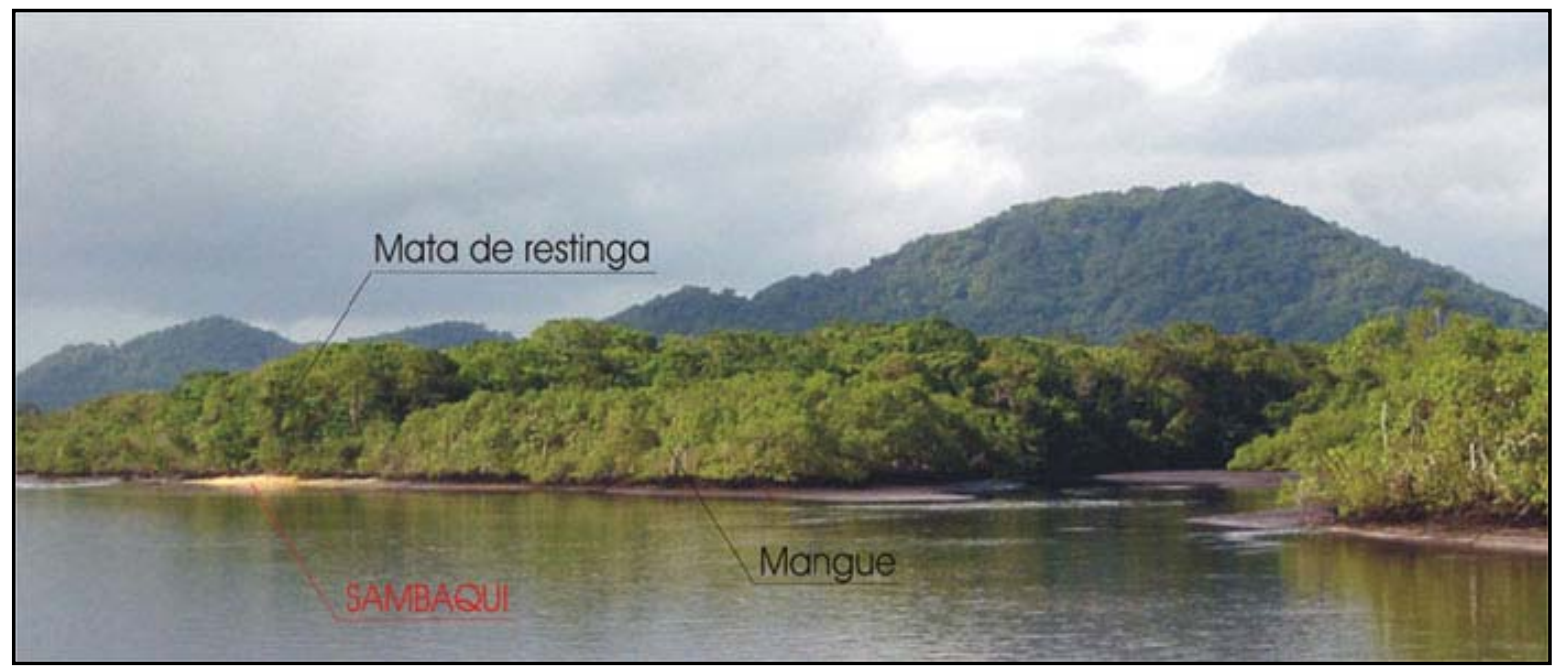

Figura 2.36 - Área de mangue que margeia o sambaqui Branco, a norte (foto: Flávio Calippo)

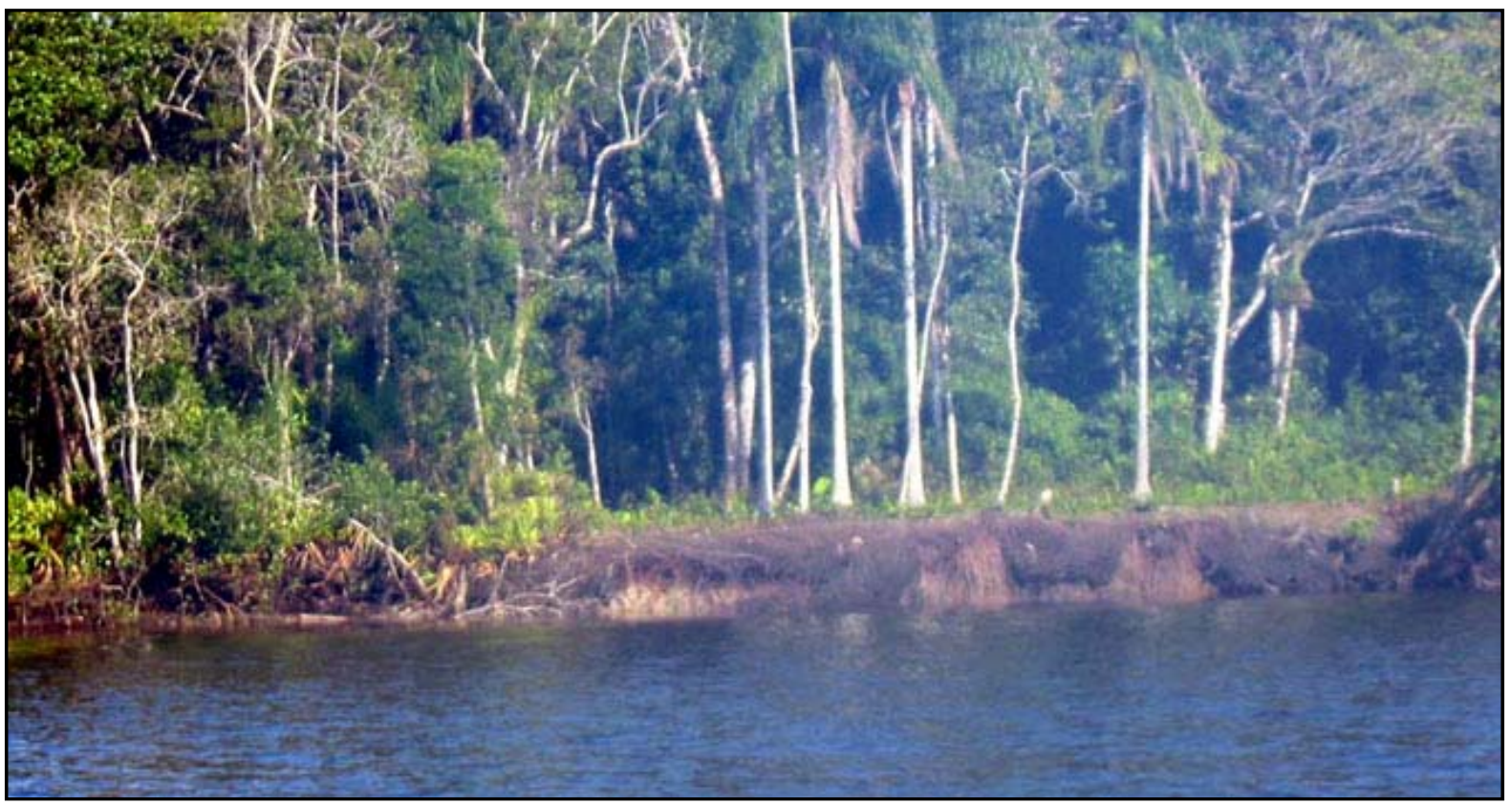

Figura 2.37 - Vista da feição arenosa sobre a qual o sambaqui Branco foi construído, a partir do Canal do Ararapira (foto: Flávio Calippo)

Durante as pesquisas realizadas nesse sambaqui foram obtidos doze testemunhos estratigráficos (figura 2.38), sendo sete por vibracore e cinco por percussão (figura 2.39). Com exceção de três testemunhagens por vibracorer 
realizadas na porção submersa do sambaqui, todas as outras prospecções foram executadas em áreas emersas.

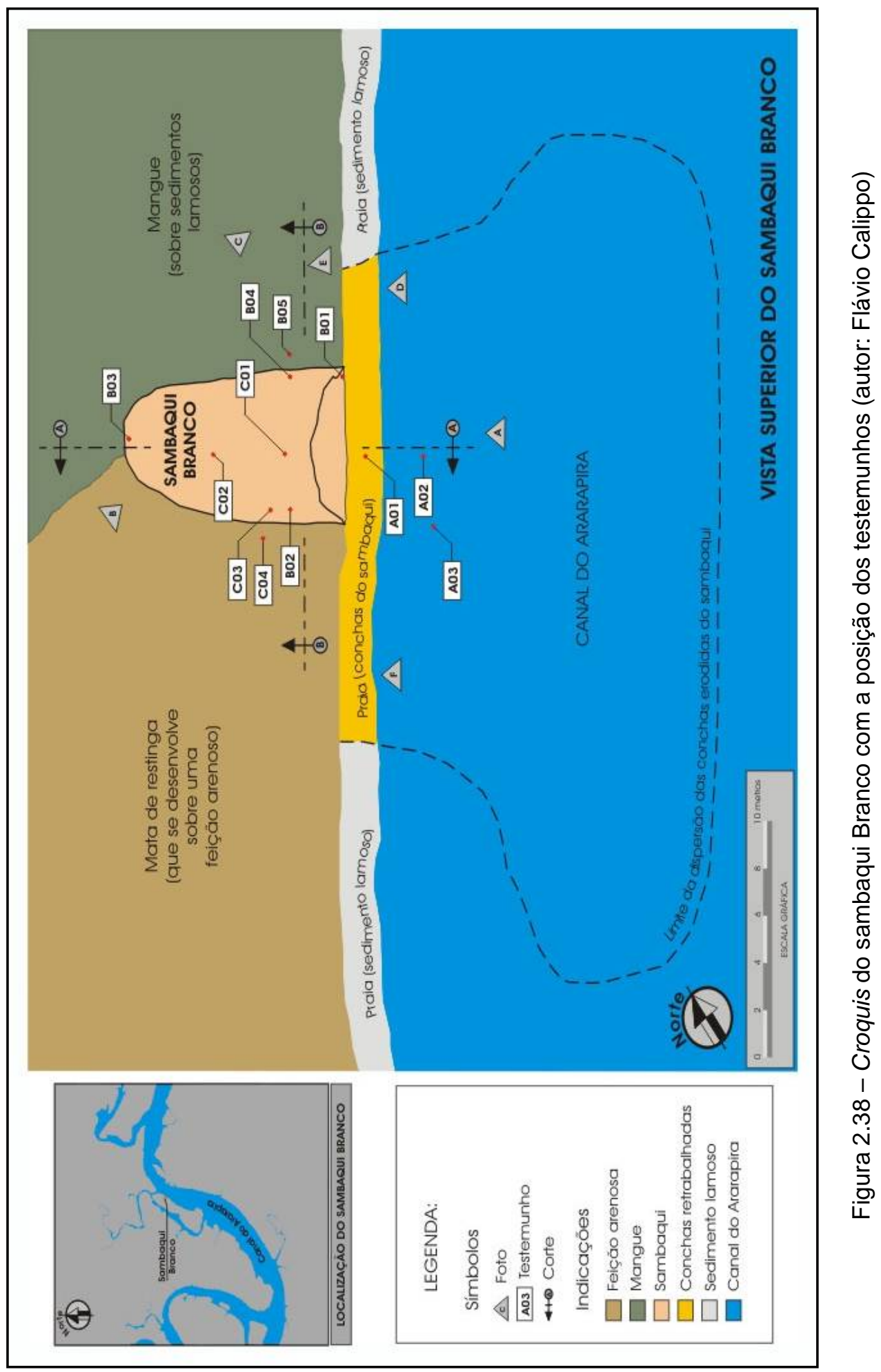




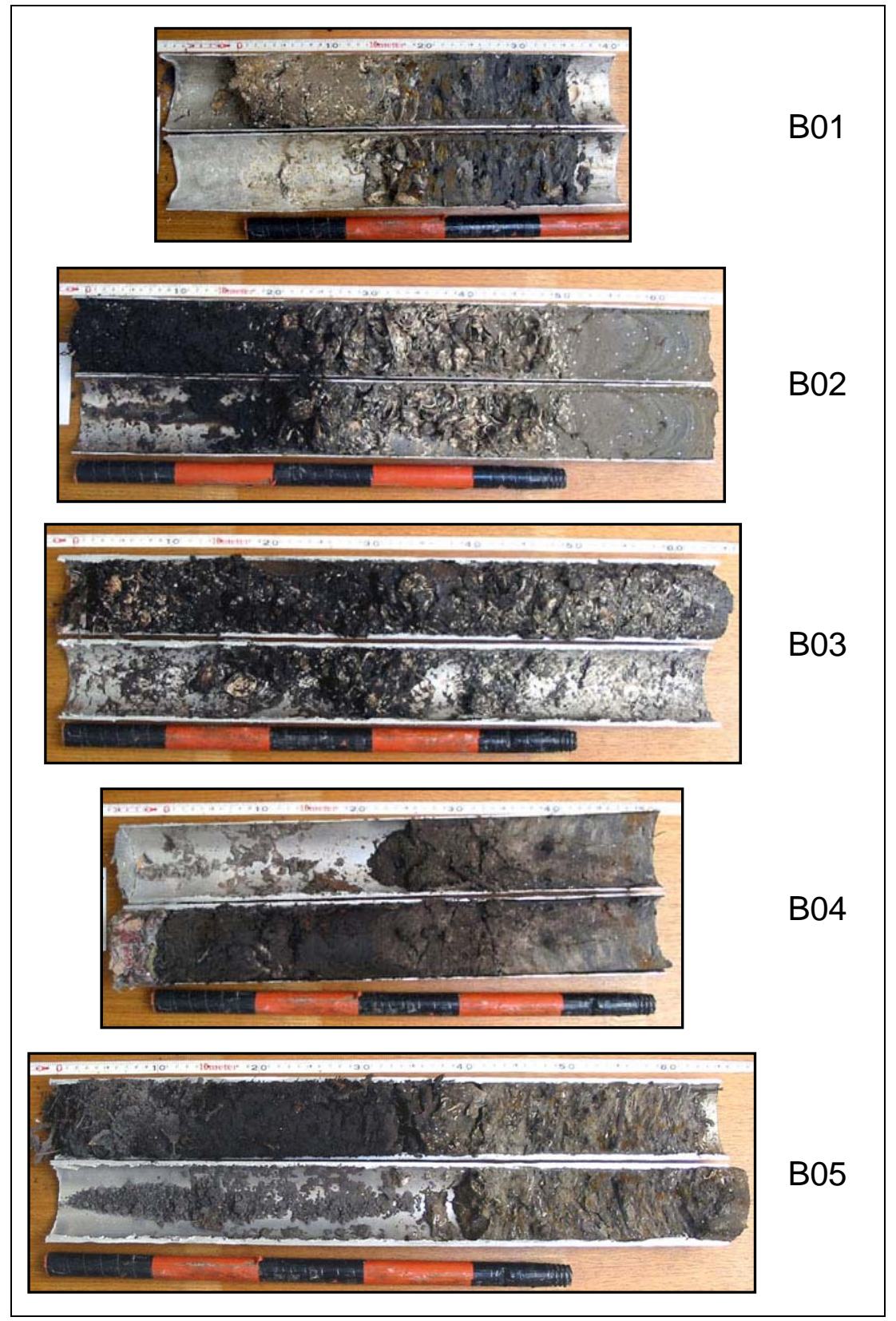

Figura 2.39 - Testemunhos a percussão realizados no sambaqui Branco (topo sempre à esquerda) (fotos: Flávio Calippo)

A análise ${ }^{20}$ e correlação ${ }^{21}$ dos testemunhos indicaram que pelo menos três diferentes momentos ocorreram ao longo do Processo de Formação do sambaqui

\footnotetext{
${ }^{20}$ A análise dos testemunhos foi realizada a partir de uma diferenciação visual das camadas presentes nos testemunhos e, posteriormente, de uma comparação qualitativa das valvas e do teor de sedimentos, levando-se em consideração principalmente a composição e o grau de integridade.
} 
Branco, os quais se manifestam através de uma seqüência deposicional marcada pela existência de três principais conjuntos de camadas arqueológicas, denominadas aqui: Camada I, Camada II e Camada III (figura 2.40/anexo I). Dessas, apenas a Camada I se distribui por todo o sítio; as Camadas II e III encontram-se restritas à parte central do sambaqui.

\footnotetext{
${ }^{21}$ Afim de que as diversas amostras da seqüência deposicional do sambaqui Branco pudessem ser comparadas, foram utilizados como referência a cota da superfície do sambaqui no ponto onde se realizou o testemunho e o comprimento do tubo que efetivamente penetrou no sambaqui. Além de permitirem que o efeito da compactação gerada pelo testemunhador pudesse ser identificado e um comprimento inferido pudesse ser calculado, a realização dessas medidas possibilitou que os testemunhos fossem posicionados (na vertical e na horizontal) a partir de um sistema referenciado. A técnica utilizada para isso foi bastante elementar: com estaca, trena, linha de Nylon, fio de prumo e um nível de bolha, foram determinadas as distâncias verticais e horizontais entre os diversos pontos de testemunhagem.
} 


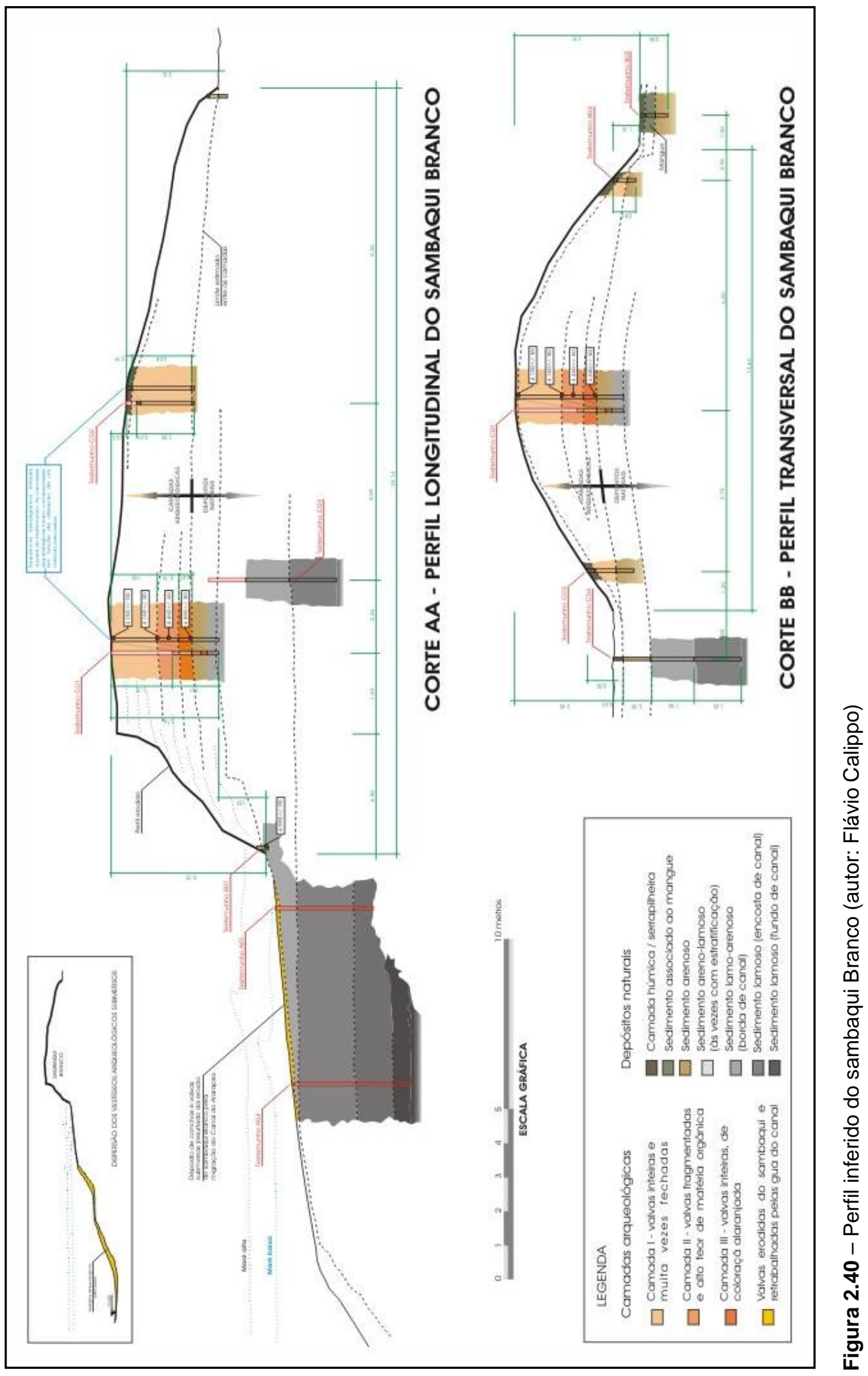


Para a identificação dessas camadas e uma interpretação inicial do Processo de Formação do sambaqui Branco, tal pesquisa fundamentou-se, principalmente, no testemunho C01 (por vibracorer). Este método permitiu amostrar uma coluna estratigráfica de quase quatro metros, obtendo informações que vão do topo (na parte central do sítio) até os depósitos naturais sobre os quais o sambaqui foi construído. Nele, estão presentes as três seqüências de camadas que compõe o registro arqueológico do sambaqui Branco, o qual foi datado em quatro pontos: topo e base da Camada I, porção intermediária da Camada II e base da Camada III (figura 2.40/anexo I).

As datações evidenciaram que o processo de formação do sambaqui Branco mudou ao longo do período em que foi formado (400 anos). A primeira camada (Camada III) provavelmente levou menos de 100 anos para ser constituída, pois essa é a diferença entre a datação de sua base (4.550 50 anos AP - Beta 190994)

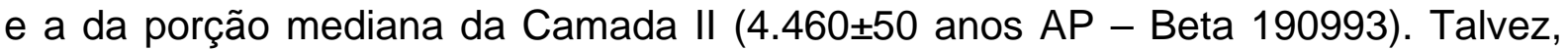
esse intervalo possa ter sido bem menor. Se considerarmos que toda a Camada II foi constituída à mesma taxa que a sua metade superior (300 anos), é muito provável que a Camada III seja relativa a um curto momento ou talvez a um único instante de construção (evento episódico).

É verdade que estatisticamente essa extrapolação não apresenta uma grande significância, porém, para efeito de análise, ela desperta a possibilidade de que a Camada II poderia ter se iniciado antes mesmo da data obtida para o início da Camada III. O que em um primeiro momento parece não fazer muito sentido, ganha importância na medida em que tal incongruência estratigráfica pode indicar uma alteração na velocidade de formação da Camada II. Talvez, além de essa camada ter sido acumulada de uma forma mais lenta, esse processo pode não ter ocorrido de maneira constante. Provavelmente, sua parte inferior formou-se de maneira mais acelerada que a sua porção mais recente ${ }^{22}$.

\footnotetext{
${ }^{22}$ Se esse raciocínio puder ser confirmado com novas datações e escavações mais amplas, talvez a própria definição dessas camadas acabem sendo revista, uma vez que, inicialmente, foi estabelecida a partir de critérios e analises texturais, tafonômicas e granulométricas qualitativas e não com base em momentos arqueológicos cronologicamente estabelecidos.
} 
Diferentemente do que ocorreu na Camada II, que tem uma diferença de 300

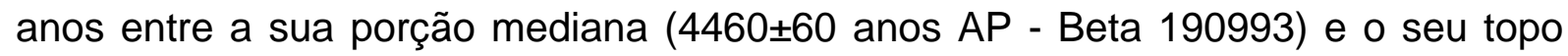
(4160 \pm 50 anos AP - Beta 190992), toda a Camada I levou provavelmente apenas dez anos para ser constituída ${ }^{23}$, mesmo sendo mais espessa que as Camadas II e III juntas. Além dessas evidências indicarem que a Camada I também se formou a partir de um evento episódico, sugere que esse processo ocorreu de maneira mais intensa do que o associado à Camada III.

Ao longo da interpretação do testemunho C01 algumas características tafonômicas, texturais e granulométricas de cada uma das três camadas também puderam ser identificadas e comparadas, contribuindo, assim (em conjunto com as datações), para o estabelecimento de uma seqüência cronológica relativa à formação do registro arqueológico do sambaqui Branco. A seguir, é apresentada uma caracterização preliminar e qualitativa de cada uma dessas camadas.

\section{Camada III:}

A Camada III é composta principalmente por valvas inteiras ou pouco fragmentadas (mecanicamente), onde não foram encontradas laminações ou quaisquer outras estruturas que indicassem que a mesma tenha sido formada por eventos crônicos de ocupação (figuras 2.41), pois, se assim fosse, deveriam ser encontradas, também, camadas mais finas, mais compactadas, com maior teor de matéria orgânica e com conchas bastante fragmentadas, resultantes da atividade humana sobre a superfície do sítio. Portanto, é provável que esta camada esteja realmente associada a um evento episódico, possivelmente relacionado à formação de uma base para a ocupação do local pelos sambaquieiros. Interpretação que vem reafirmar a "leitura" do sítio obtida por meio de datações desta camada.

\footnotetext{
${ }^{23}$ Diferença obtida a partir das datas relativas entre o topo da Camada II (4160 \pm 50 anos AP - Beta 190992) e o topo da Camada I (4150 \pm 50 anos AP - Beta 190991)
} 


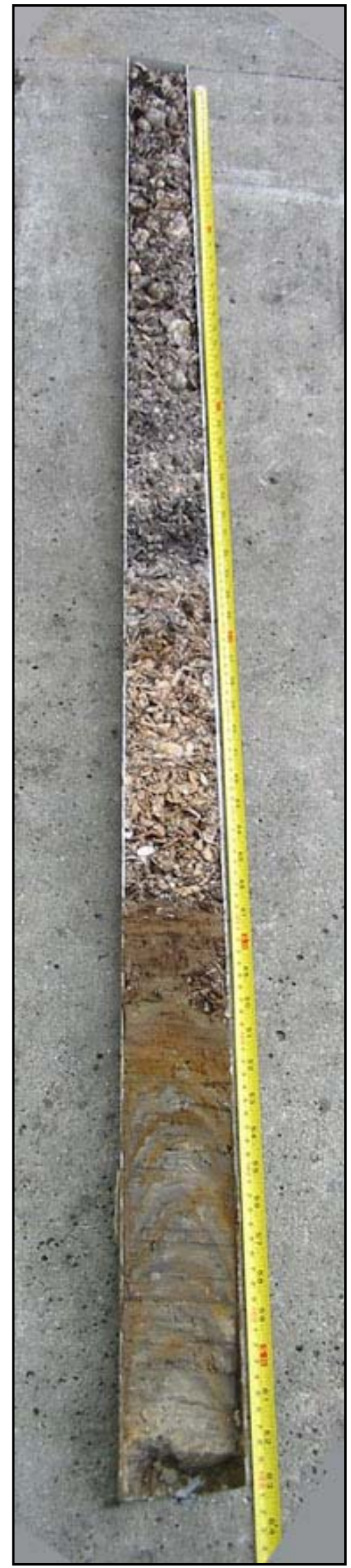

Figura 2.41 - Uma das metades do testemunho C01 (foto: Flávio Calippo) 
Além das características granulométricas e deposicionais, a coloração e o grau de dissolução das valvas presentes na Camada III também podem ser interpretados como evidências da construção de uma base. Em comparação com as outras camadas (II e I), as valvas da Camada III apresentaram uma coloração ferruginosa ${ }^{24}$ e certo grau de dissolução do carbonato de cálcio ${ }^{25}$. Como ambos são decorrentes principalmente de reações químicas com a água marinha e estuarina, existe a possibilidade de que essa camada tenha atuado como uma área de isolamento, que, tanto impediria a umidade presente no solo de atingir as Camadas II e I, como facilitaria o escoamento da água da chuva. Funções possíveis em razão da maior granulometria da Camada III, que dificulta o aprisionamento e percolação da água por capilaridade 26 .

Por si só essas evidências não seriam suficientes para justificar a intencionalidade da construção de uma base que protegesse os ocupantes do sambaqui da umidade, porém assumem essa condição à medida que são associadas à seqüência de datações e à estrutura deposicional de todas as camadas.

\section{Camada II:}

A Camada II é composta principalmente por valvas bastante fragmentadas, distribuídas uniformemente em meio à bandas de sedimentos finos, com uma coloração que varia de cinza claro à preto, da base à porção intermediária da

\footnotetext{
${ }^{24} \mathrm{~A}$ coloração ferruginosa encontrada em meio às conchas e aos sedimentos da Camada I é provavelmente relativa à adsorção de compostos ferrosos (presentes em grande quantidade nas águas marinha e estuarina) e a sua conseqüente oxidação. Nesse processo, o oxigênio tende a transformar compostos ferrosos (ricos em $\mathrm{Fe}^{2+}$ ) em férricos $\left(\mathrm{Fe}^{3+}\right)$, de cor alaranjada. $\mathrm{O}$ que normalmente ocorre em áreas que estão em contato direto com os ambientes aéreos, inundadas periodicamente pelas águas ou que um dia já foram, pois, nos estuários, a quantidade de oxigênio dissolvido tende a ser baixa em função de sua absorção no processo de degradação e mineralização da matéria orgânica.

${ }^{25} \mathrm{Em}$ ambientes lagunares e estuarinos a alta quantidade de matéria orgânica em decomposição propicia a formação de um ambiente ácido, que altera a estabilidade e a dissolução do carbonato de cálcio das conchas.

${ }^{26} \mathrm{Em}$ meio a sedimentos de granulometria baixa, devido à sua tensão superficial, a água tem a capacidade de migrar verticalmente de espaços aéreos em espaços aéreos, mesmo contra a força da gravidade. A essa migração dá-se o nome de percolação por capilaridade.
} 
camada, a partir da qual passa novamente a diminuir de tom, até tornar-se cinza em sua porção superior (figura 2.41). Apesar de já ter sido possível inferir (com base nas datações) que a formação dessa camada não se deu de maneira uniforme, ainda não se conseguiu (com base na análise qualitativa preliminar que foi realizada) verificar se essas bandas formam diferentes camadas arqueológicas. Por enquanto, a única associação que pode ser estabelecida em relação à coloração da Camada II é que essa seja decorrente de uma grande quantidade de matéria orgânica, possivelmente gerada em função da atividade humana.

Emperaire e Laming (1956 apud DE BLASIS et al., 1998), Piazza (1966), Prous (1992) e Afonso e De Blasis (1994), fundamentados na correlação de datas e de seqüências estratigráficas de sítios de pescadores-coletores, indicam que o registro arqueológico relativo à construção de um sambaqui é composto por alternâncias de episódios de rápida acumulação e momentos deposicionais de longa duração. Os primeiros são compostos geralmente por camadas mais espessas, pouco compactadas e de composição homogênea (freqüentemente uma única espécie de molusco), e os últimos formados normalmente por finas camadas de materiais heterogêneos, onde se incluem argilas, areias e misturas de conchas fragmentadas. Na maioria das vezes essas camadas apresentam uma coloração muito escura e encontram-se misturadas com finas lentes de carvão (relacionados a fogueiras).

Com exceção da espessura da Camada II (que não é propriamente uma camada fina), todas as outras características são semelhantes às descritas por De Blasis et al. (op. cit.) para a um momento deposicional de longa duração. Assim, como existe a possibilidade de que a Camada II seja composta por diversas camadas, talvez a sua grande espessura possa ser compreendida como a somatória de diversos momentos deposicionais de longa duração.

Camada I:

Assim como a Camada III, a Camada I é provavelmente o resultado de uma formação episódica, pois, como acima foi proposto por De Blasis et al. (op. cit.), esse 
tipo de processo formativo se verifica pela presença de um único e espesso pacote de conchas que aparentemente não apresenta laminações ou qualquer tipo de estrutura indicadoras de eventos crônicos de ocupação (figuras 2.40 e 2.41). Além da Camada I ser mais espessa, a principal diferença entre ela e a Camada III é o fato de não é raro encontrar na Camada I bivalves fechados, indicando que esses moluscos poderiam ter sido coletados e levados ao sambaqui principalmente com a intenção de elevar a cota de sua superfície.

A Camada I apresenta também uma outra característica relacionada à sua cor: em sua porção superior apresenta uma coloração diferenciada, que vai do cinza escuro a um marrom quase preto. Apesar de argilas e areias finas ocorrerem em todas as porções da Camada I, é somente próximo ao topo que esses sedimentos encontram-se misturados a um outro, de constituição arenosa mais grosseira, provavelmente mais rico em matéria orgânica e que deve estar relacionado a uma penetração dos sedimentos da camada húmica que atualmente recobre o sambaqui Branco.

\subsection{O sambaqui Ilha do Cambriu}

Em conjunto com os sambaqui do Pereirinha III $^{27}$ (figura 2.42), o sambaqui da Ilha do Cambriu ${ }^{28}$ (figura 2.43) assume uma maior importância na presente pesquisa pois é um dos poucos sítios da região que se encontra em ilhas um pouco mais isoladas do continente. Nesses sítios, em uma análise preliminar, diagnosticouse que, além de serem os únicos sambaquis encontrados isolados em pequenas ilhas ${ }^{29}$, foram também os únicos onde, até o momento, se encontrou ossos de animais de maior porte (como, por exemplo, tartaruga e baleia). Além disso, em ambos, a matriz sedimentar que os compõe é diferente das encontradas no restante

\footnotetext{
${ }^{27} 3.170 \pm 35$ (I-9878) e $3.250 \pm 90$ anos AP (Ba-286), segundo UCHÔA e GARCIA (1983).

${ }^{28} 3950 \pm 60$ (Beta - 190999) e 3940 \pm 50 (Beta - 191000) (CALIPPO, 2004)

${ }^{29}$ Atualmente o sambaqui do Pereirinha III localiza-se na Ilha do Cardoso sobre um morro que se encontra à beira do canal da barra de Cananéia. Porém, segundo o modelo de evolução da Barra de Cananéia proposto por Suguio e Tessler (1992) e as datações obtidas para esse sambaqui por Uchôa e Garcia (1983) e Demartini (2004), existe a possibilidade de que na época de sua formação o morro do Pereirinha fosse uma ilha que se localizava bem no centro do canal (figura 3.16).
} 
dos sambaquis visitados: visualmente, a quantidade de conchas em relação aos sedimentos finos é bem menor do que a razão encontrada em outros sítios.

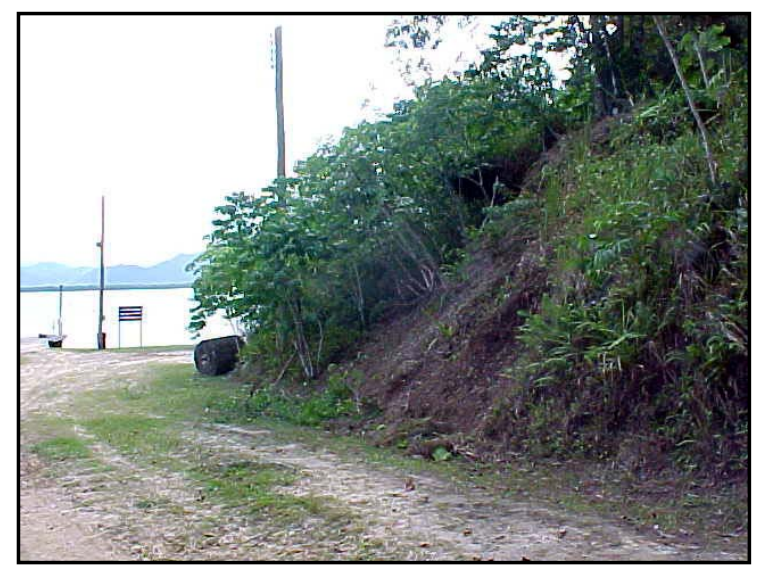

Figura 2.42 - Sambaqui do Pereirinha $\mathrm{II}^{30} \mathrm{com}$ o canal da barra de Cananéia ao fundo (foto: Célia M. C. Demartini)

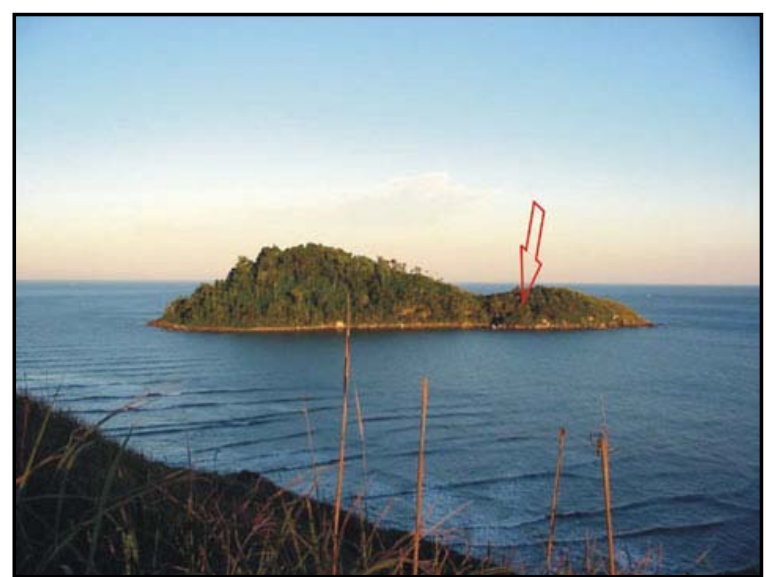

Figura 2.43 - Ilha do Cambriu, com o local do sambaqui indicado pela seta (foto: Flávio Calippo)

A interpretação das evidências arqueológicas presentes no sambaqui da llha do Cambriú torna-se ainda mais complexa na medida em que se analisam os valores da composição isotópica do carbono presentes nas conchas (razão $C^{13} / C^{12}$ obtida ao longo do processo de datação por radiocarbôno): -0,6 \%o (Beta - 190999) e -0,7 \%o (Beta - 191000). Segundo Martin et al. (1984), esses valores indicam que os organismos cujas conchas estão presentes nos sambaquis são provenientes de ambientes com uma forte influência marinha. Indicando, talvez, que a coleta associada a ocupação e à construção desses sambaquis fosse realizada em um ambiente externo à região lagunar.

\subsubsection{Os sambaquis do estado de São Paulo}

Para a realização do estudo da mobilidade dos sambaquieiros ao longo do litoral de São Paulo e Vale do Ribeira (análises de estrôncio), foram contemplados tanto sambaquis de Cananéia (associados à Fase Regressiva) como aqueles

\footnotetext{
${ }^{30}$ A estrada que pode ser vista foi construída sobre a face oeste do sambaqui.
} 
localizados nas porções central e norte do litoral do estado e ao longo do médio Ribeira. Em Cananéia, foram analisados os sambaquis Boguassu, Boa Vista e Brocuonha (tabela 2.02) (figura 2.44). No médio Ribeira, os sambaquis fluviais Moraes e Capelinha. Os sambaquis costeiros Piaçaguera, Cosipa I e Maratuá, na Baixada Santista, e os sítios Couves, Mar Virado e Tenório, no litoral norte (tabela 2.02) (figura 2.44).

Tabela 2.02 - Idade e localização dos sambaquis ao longo do litoral do estado de São Paulo e Vale do Ribeira

\begin{tabular}{|c|c|c|c|c|c|c|}
\hline SÍTIO & COORDENADA & $\begin{array}{c}\text { IDADE } \\
\text { CONVENCIONAL } \\
(\text { anos AP })\end{array}$ & $\begin{array}{c}\text { IDADE } \\
\text { CALIBRADA } \\
\text { (anos AP) }\end{array}$ & $\begin{array}{c}\text { REFERÊNCIA } \\
\text { DA } \\
\text { AMOSTRA }\end{array}$ & $\begin{array}{l}\text { REFERÊNCIA } \\
\text { BIBLIOGRÁFICA }\end{array}$ & REGIÃO \\
\hline Capelinha & $\begin{array}{c}22^{\circ} 27^{\prime} 8^{\prime \prime} \mathrm{S} \\
45^{\circ} 34^{\prime} \mathrm{W}\end{array}$ & $9250 \pm 50$ & $\begin{array}{l}10560 \mathrm{a} \\
10250\end{array}$ & Beta 189331 & $\begin{array}{l}\text { Figuti et al. } \\
\text { (2004) }\end{array}$ & \multirow{3}{*}{$\begin{array}{l}\text { médio } \\
\text { Ribeira } \\
\text { (interior) }\end{array}$} \\
\hline \multirow{2}{*}{ Moraes } & $\begin{array}{c}\text { (23J) } 256908 \\
7313340\end{array}$ & $5895 \pm 45$ & 6777 a 6665 & KIA 15561 & $\begin{array}{l}\text { Figuti et al. } \\
\text { (2004) }\end{array}$ & \\
\hline & $\begin{array}{c}\text { (23J) } 256908 \\
7313340 \\
\end{array}$ & $5420 \pm 30$ & 5200 a 5048 & KIA 20843 & $\begin{array}{l}\text { Figuti et al. } \\
\text { (2004) }\end{array}$ & \\
\hline Brocuonha & - & $3900 \pm 450$ & - & SPC-116 & Uchôa (1982) & \multirow{2}{*}{$\begin{array}{c}\text { baixo } \\
\text { Ribeira } \\
\text { (litoral } \\
\text { sul) }\end{array}$} \\
\hline Boguassu & - & $3080 \pm 55$ & - & Ba-285 & Uchôa (1982) & \\
\hline Piaçaguera & $\begin{array}{l}23^{\circ} 52^{\prime \prime} \mathrm{S} \\
46^{\circ} 22^{\prime} \mathrm{W}\end{array}$ & $4930 \pm 110$ & - & I-4481 & $\begin{array}{l}\text { Garcia e Uchôa } \\
\text { (1980) }\end{array}$ & \multirow{3}{*}{$\begin{array}{l}\text { Litoral } \\
\text { centro }\end{array}$} \\
\hline Cosipa I & $\begin{array}{l}23^{\circ} 52^{\prime} 29^{\prime \prime} \mathrm{S} \\
46^{\circ} 22^{\prime} 212^{\prime \prime}\end{array}$ & $4310 \pm 180$ & - & SPC-15 & Uchôa (1982) & \\
\hline Maratuá & - & $3865 \pm 95$ & - & I-9185 & Garcia (1979) & \\
\hline Mar Virado & $\begin{array}{c}\text { (23K) } 484708 \\
7393740\end{array}$ & $2640 \pm 70$ & 2840 a 2140 & - & Nishida (2002) & \multirow{2}{*}{$\begin{array}{l}\text { Litoral } \\
\text { norte }\end{array}$} \\
\hline Tenório & $\begin{array}{c}(23 K) 493206 \\
7406637\end{array}$ & $1875 \pm 90$ & - & I-5306 & Garcia (1972) & \\
\hline
\end{tabular}




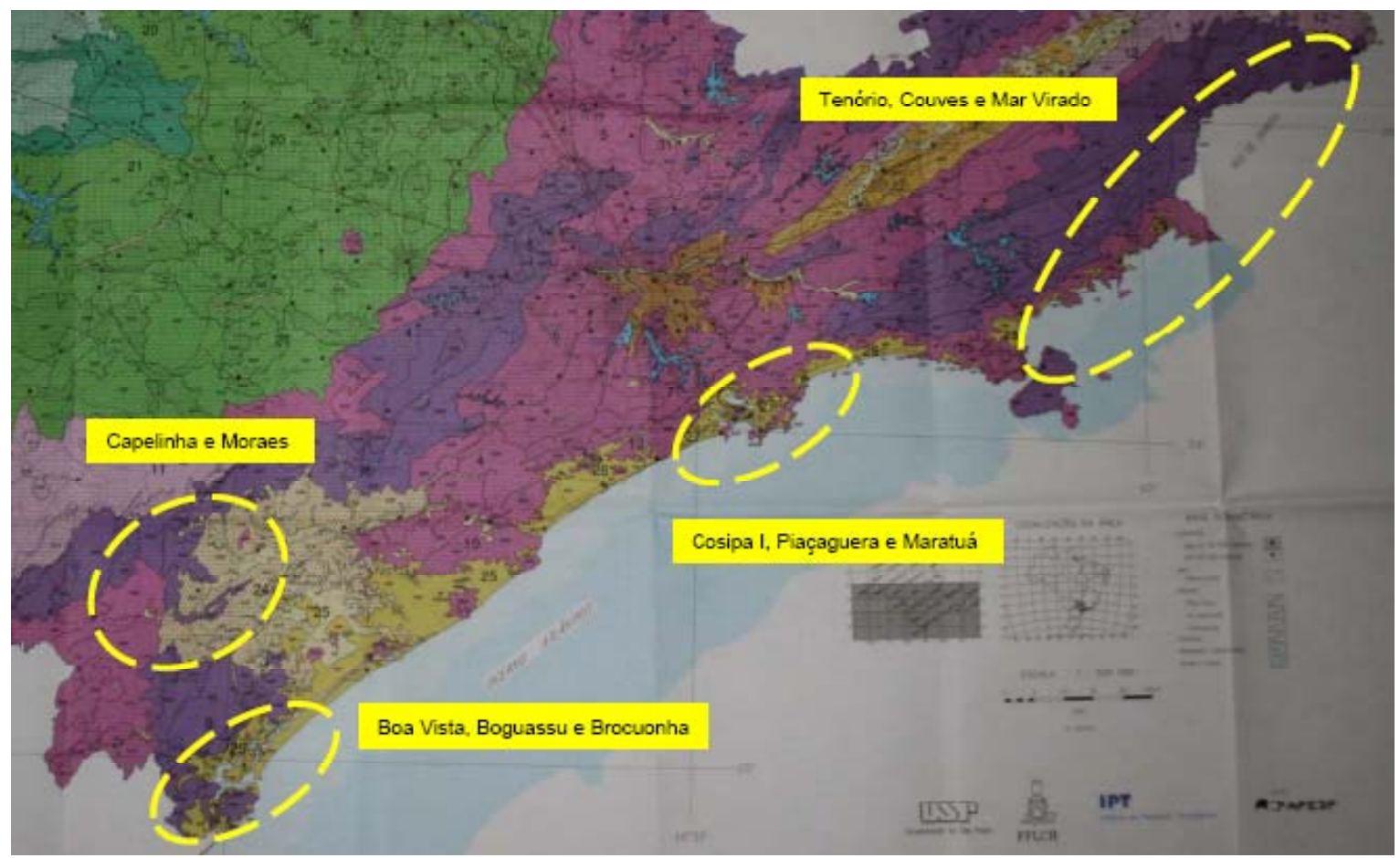

Figura 2.44 - Mapa com a localização aproximada dos sambaquis analisados ao longo do litoral do estado de São Paulo e Vale do Ribeira

Embora a distribuição espacial dos sambaquis analisados tenha sido elaborada com a intenção de permitir a comparação das relações ambientais estabelecidas entre os sambaquieiros de Cananéia com os de regiões adjacentes (gerando, assim, bases para a discussão de uma organização social articulada em comunidades marítimas), por outro lado, tal distribuição também permite a retomada de uma antiga discussão. A qual diz respeito à existência de fronteiras sambaquieiras, internas e externas a uma única e abrangente sociedade sambaquieira.

Nesse sentido, tomou-se aqui o cuidado de que tal conjunto de dados fosse desenhado de forma a permitir a inclusão de outros três contextos fundamentais para a discussão de tais limites: os sambaquis fluviais do médio Ribeira e os sambaquis do litoral centro e norte. 


\subsection{A PROPOSTA ANALÍTICA}

Tendo como norte um referencial focado principalmente na Arqueologia Marítima e nos Estudos de Percepção Ambiental, desenvolveu-se, no âmbito da presente Tese, uma proposta analítica que, embora se fundamente em um corpo consistente de dados, ao mesmo tempo busca atender ao posicionamento teórico adotado. Nesse sentido, mesmo preocupados em fazer uma Arqueologia apoiada em um rigor analítico e científico, entendemos que tal rigor não é, necessariamente, fruto de uma proposta metodológica que depende, exclusivamente, de análises quantitativas numericamente precisas e parametrizadas.

Mais do que o estabelecimento de uma análise estatística levada aos seus mínimos detalhes, primou-se aqui por uma análise que, embora qualitativa, fosse marcada por um profundo equilíbrio da representatividade, da precisão e da exatidão das análises com os limites das conclusões e hipóteses aqui apresentadas.

Com isso, é importante ressaltar que não negamos a importância das análises quantitativas, pois, elas também são utilizadas para a elaboração da presente Tese. No entanto, elas aqui são entendidas não como capazes de estabelecer "verdades" apontadas pelos dados, mas, sim, como um referencial a partir do qual se pode estabelecer hipóteses e traçar correlações e conclusões que se alinhem aos pressupostos assumidos.

Embora, sob um ponto de vista processualista tradicional, esse posicionamento possa ser entendido como um subjetivismo, ele não é. Na realidade, tal postura é reflexo da compreensão de que, por mais que se façam esforços para atingir uma imparcialidade interpretativa, esta busca é utópica e, em si mesma, uma postura subjetiva. Toda interpretação é subjetiva. Na realidade, a busca por essa imparcialidade, por mais que não se tenha consciência, é, antes de mais nada, decorrente de um posicionamento teórico que procura desvincular teoria e método. A escolha ou a negação de uma abordagem teórica ou do próprio objeto de estudo reflete um posicionamento. Na maioria das vezes, inclusive, político e ideológico.

Nesse sentido, buscou-se, logo de inicio, assumir um posicionamento comprometido e alinhado com a problemática das sociedades marítimas, cujas 
metodologias empregadas foram selecionadas e aplicadas com 0 intuito de estabelecer reflexões e de propor novas hipóteses a respeito da relação dialética que os diversos povos sambaquieiros estabeleceram com o mar, com os ambientes aquáticos e entre si.

Embora para a elaboração desta Tese tenham sido selecionadas duas propostas analíticas principais (relacionadas, principalmente, ao desenvolvimento de um modelo de predição de sítios submersos e de análises isotópicas), devido aos pressupostos teóricos assumidos, tornou-se necessário estabelecer um conjunto de dados que, por um lado, atendesse a tais perspectivas; e, por outro lado, preenchesse as lacunas decorrentes do estabelecimento de um corpo amostral que, em parte, foi organizado a partir de amostras coletadas no âmbito de outros projetos de pesquisa ou em etapas de campo anteriores.

\subsubsection{Coleta e seleção de amostras para determinação de idades}

A primeira ação no sentido de transformar o recorte amostral em um conjunto consistente de dados foi a de identificar as lacunas de informação (camadas inferiores e superiores sem idades determinadas, camadas não amostradas, camadas com amostras insuficientes para a realização de análises isotópicas, etc) existentes e completá-las com novas amostragens. Nesse sentido, realizou-se um levantamento de todas as amostragens já realizadas no âmbito do Projeto Arqueológico do Baixo Vale do Ribeira.

Uma vez identificadas, tais lacunas foram correlacionadas aos propósitos da Tese. Dessa maneira, constatou-se que ainda havia a necessidade de se realizar algumas datações, relativas a sítios e a contextos específicos, e, principalmente, obter amostras de camadas arqueológicas ainda não contempladas em coletas anteriores.

Assim, tendo como propósito obter amostras para o estabelecimento de uma cronologia mais concreta e, também, para a elaboração de um conjunto de dados, coeso e representativo, para a realização das análises isotópicas, realizou-se uma 
etapa de campo na Ilha do Cardoso, Cananéia, SP. Nessa etapa, utilizando-se um testemunhador à vibração (vibrocorer), foram retiradas duas colunas estratigráficas do sambaqui Cambriu Grande (figuras 2.45 e 2.46).
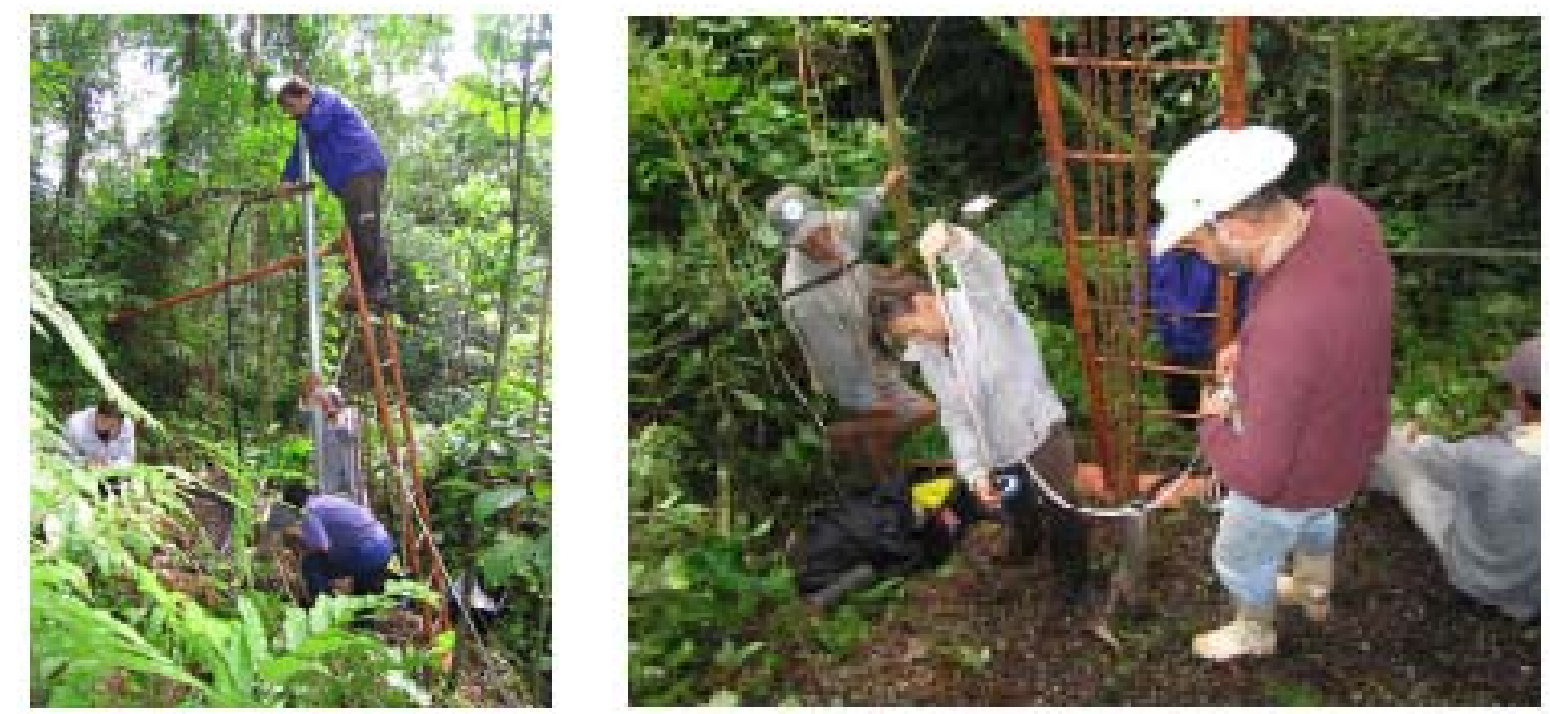

Figura 2.45 e 2.46 - Amostragem com a utilização de amostrador tipo vibracorer

Além de obter novas amostras, que serviram para se confirmar a antiguidade de quase 8.000 anos AP inicialmente atribuída a esse sambaqui, tais amostragens corroboraram também com o estabelecimento de uma compreensão inicial a respeito do processo de formação desse sítio.

Do ponto de vista do estabelecimento de um conjunto amostral, essas amostras somaram-se a um outro conjunto de dados, previamente coletado e parcialmente analisado, no âmbito de minha dissertação de mestrado. Conjunto esse, também proveniente de Cananéia, onde diversas amostras, referentes aos sambaquis em estudo, já haviam sido coletadas com o intuito de, na época, ampliar os dados cronológicos para a região e, assim, propor novas hipóteses acerca dos processos formativos e de questões referentes à monumentalidade e à intencionalidade intrínsecas à ocupação sambaquieira do baixo Vale do Ribeira.

Além de tais propósitos, essa primeira etapa teve também como objetivo a coleta de amostras para a realização de uma primeira análise (ensaio) da composição isotópica do carbono e do oxigênio presente nas conchas dos sambaquis. Análise que, mais tarde, subsidiou a elaboração de um trabalho de 
conclusão do curso de Oceanografia (MIZUTA, 2007), realizado no Instituto de Oceanografia (IO/ USP), sob a orientação do Prof. Dr. Felipe Toledo (LaPAS/IO). Tal trabalho desenvolveu as bases para a análise e a interpretação da composição isotópica do carbono e do oxigênio presentes nas conchas dos sambaquis de Cananéia.

Com o resultado positivo apresentado por esse ensaio, buscou-se ampliar o número de sítios e camadas contempladas. Configurando, assim, um esforço amostral que fosse capaz de permitir o estabelecimento de hipóteses a respeito da relação que os sambaquieiros de Cananéia promoviam com os ambientes costeiros e marinhos. Um quadro detalhado dessas novas amostragens é apresentado no item 2.2.4. (Análises Isotópicas).

De modo similar, também no item 2.2.4, são apresentados os dados que subsidiaram o estudo de mobilidade e territorialidade, baseado na análise isotópica do estrôncio, aqui elaborada. Dados que não foram obtidos a partir de intervenções arqueológicas realizadas no âmbito da presente Tese ou do Projeto Arqueológico do Baixo Vale do Ribeira, mas, sim, a partir de um levantamento realizado ${ }^{31}$ na reserva técnica do Museu de Arqueologia e Etnologia (MAE/USP) e em amostras provenientes de escavações realizadas, pelo Prof. Dr. Levy Figuti (MAE/USP), em sambaquis fluviais do médio Vale do Ribeira.

\subsubsection{Datações radiocarbônicas}

No intuito de complementar as lacunas cronológicas existentes entre os sambaquis analisados de Cananéia, de confirmar a maior antiguidade do sambaqui Cambriu Grande e de propor novas hipóteses a respeito de sua formação, foram realizadas (no laboratório Beta Analytic Inc - Miami, Flórida, EUA) um total de três datações radiocarbônicas em conchas, provenientes das amostras mais próximas à base dos sambaquis Cachoeira Mirim e Cambriu Grande, que foi possível coletar.

\footnotetext{
${ }^{31}$ Levantamento e seleção das amostras realizado com apoio de Silvia Piedade, Paulo Jacob e Daria Barreto (técnicos e ex-técnicos da instituição), após a obtenção da autorização da diretoria do MAE.
} 
Obtidas, respectivamente, a partir de uma amostra da camada superior e central do sambaqui Cachoeira Mirim (figura 2.47) e de duas amostras retiradas das camadas intermediárias do sambaqui Cambriu Grande (na profundidade máxima alcançada pelo vibracorer a partir da região do topo do sítio (figura 2.48).

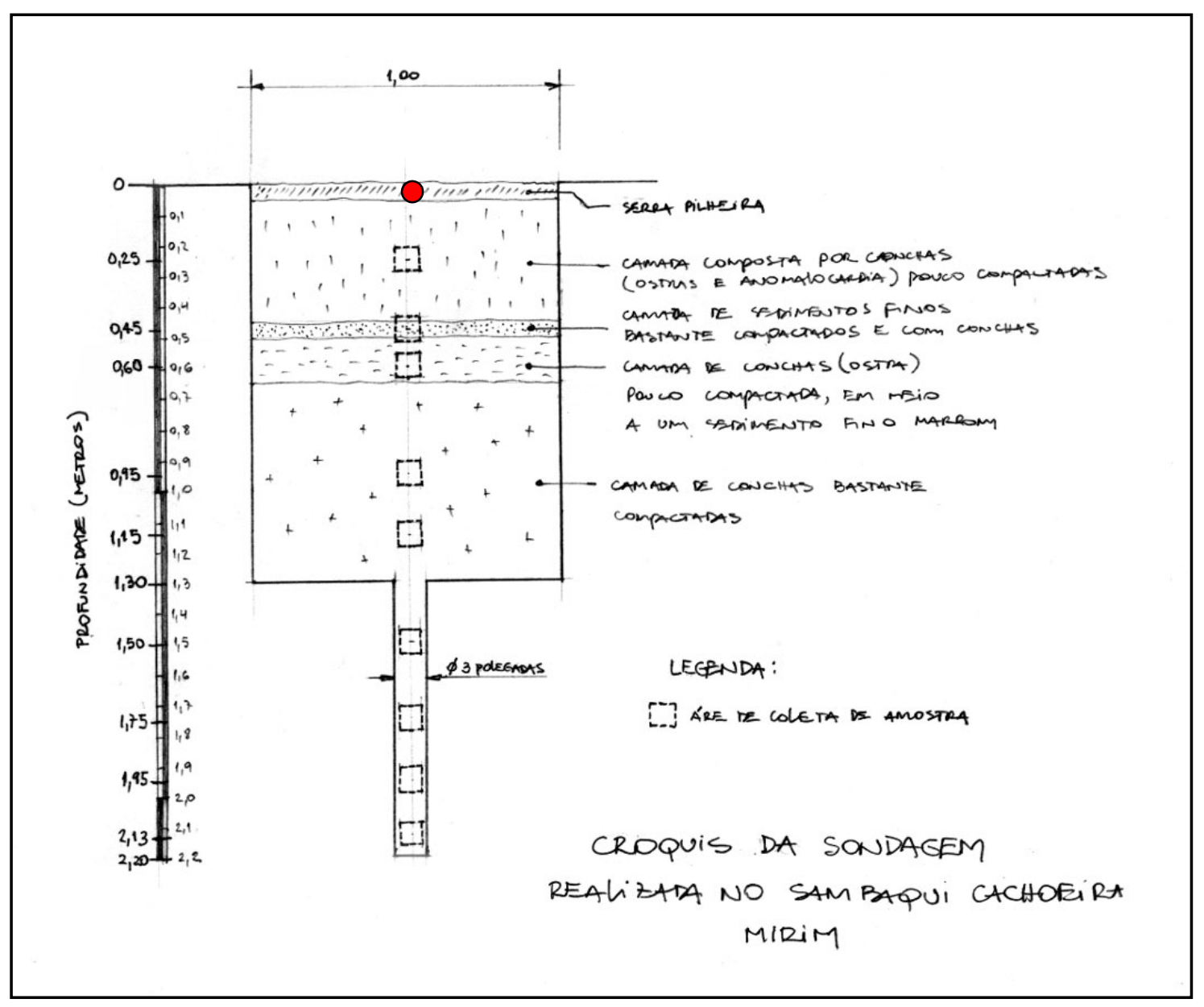

Figura 2.47 - Croquis da posição da amostra coletada (em vermelho), no sambaqui Cachoeira Mirim, para a realização de datação radiocarbônica 


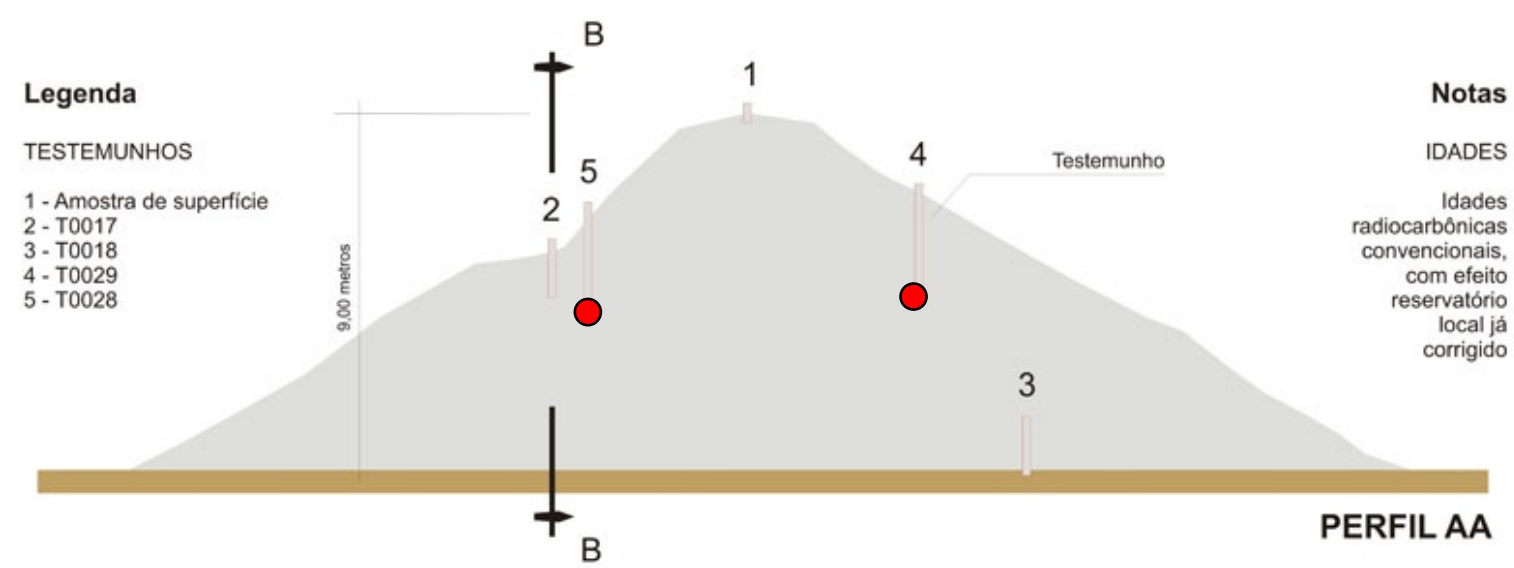

Figura 2.48 - Croquis da localização das amostras coletadas, no sambaqui Cambriu Grande, para a realização das duas datações radiocarbônicas (base dos testemunhos 4 e 5)

\subsubsection{Modelo de Predição}

Como existem diversos sambaquis mais antigos que 7.000 anos AP (Calippo, 2004; LIMA et. al, 2004) e evidências de sítios desse tipo que apresentam evidências de submersão decorrentes da elevação do nível relativo do mar (Calippo, op. cit.; DEPINÉ, 2005), as quais apontam para uma antiga presença de populações humanas vivendo ao longo de uma extensa planície fluvial que se desenvolveu em meio à atual porção submersa da plataforma continental brasileira, desde, pelo menos, o período final do pleistoceno até, por volta, de 7.000 anos AP (quando o nível do mar atingiu a cota que assume atualmente), elaborou-se, no âmbito desta Tese, um modelo de predição que fosse, ao mesmo tempo, capaz de apontar as áreas mais prováveis para se encontrar os vestígios materiais (sambaquis submersos) deixados por essas populações mais antigas e de, também, propor hipóteses para explicar as lacunas existentes entre os diversos conjuntos de sambaquis da costa brasileira.

Para dar inicio a esse modelo de predição utilizou-se como referência o modelo desenvolvido por Waters (1992), para a costa do Golfo do México, da Geórgia e da Carolina, a partir do qual as localizações dos sítios foram inferidas com base na correlação das idades dos sítios conhecidos com as datas atribuídas às paleolinhas de costa (figura 2.49). 


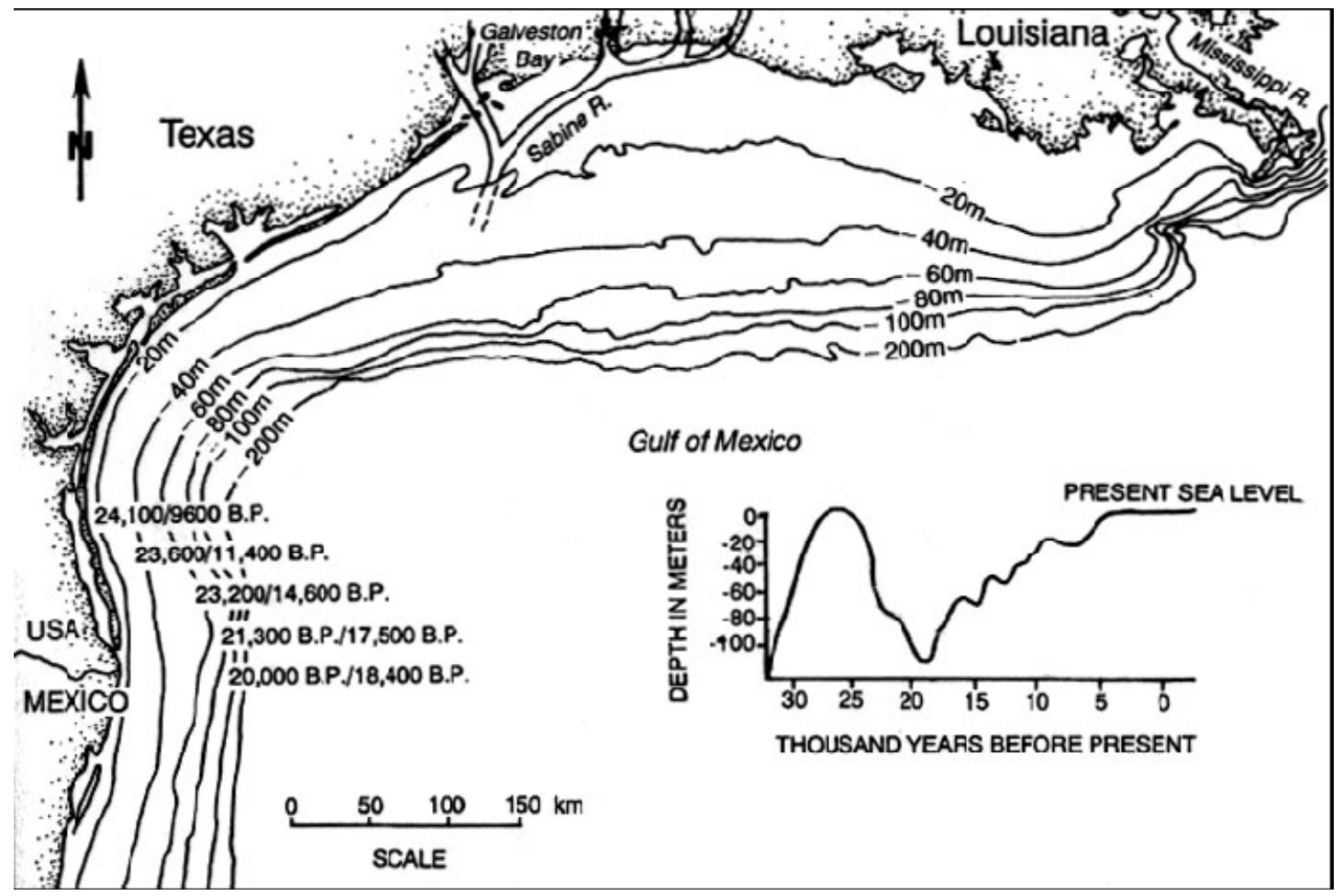

Figura 2.49 - A costa do Golfo e posição aproximada das paleolinhas de costa. Modificado de Stright (1986) por Waters (1992)

Embora, anteriormente à construção de tal modelo, as curvas de variação do nível relativo do mar para essas regiões e as idades dos sítios arqueológicos emersos apontassem para uma presença humana que não superava os 4.000 ou 6.000 anos AP (ATEN, 1983 e GAGLIANO, 1984 apud WATERS, 1992), foram localizados, com base na proposta, ao longo da plataforma submersa diversos sítios mais antigos, encontrados mar adentro, submersos além da moderna linha de costa e tipicamente recobertos por sedimentos costeiros mais recentes (BRYAN, 1977 apud WATERS, 1992; EMERY e EDWARDS, 1966).

Com base em tal metodologia, sambaquis do Arcaico, atribuídos a paleoíndios, por exemplo, foram encontrados submersos na baía Tampa, na Flórida (WARREN, 1964; GOODYEAR e WARREN, 1972 apud WATERS, 1992;). Entre eles, um sambaqui de 8.000 anos foi descoberto enterrado sob sedimentos estuarinos a 12 quilômetros da costa da Louisiana, a uma profundidade de 18 metros (PEARSON et. al., 1986 apud WATERS, 1992). Além desses, outros sítios 
submersos têm sido encontrados ao longo da costa do Golfo, Atlântica e Pacífica dos Estados Unidos ${ }^{32}$.

Levando em conta a utilização das paleolinhas e as curvas de variação do nível relativo do mar como referência e o fato de que com esse tipo de abordagem foram encontrados sítios submersos muito mais antigos do que aqueles que se encontram em terra, o presente modelo de predição foi desenvolvido a partir de duas perspectivas principais. Em uma primeira, que engloba o litoral e a porção submersa da plataforma continental adjacente à costa do estado de São Paulo, além das curvas de variação do nível relativo do mar e das paleolinhas de costa, foram levadas em consideração, também, algumas referências acerca da idade dos paleoníveis marinhos (evidências de antigos níveis de mar) (KOWSMANN e COSTA, 1979; FURTADO et. al, 1998; KLEIN, 2005) e um mapeamento dessas feições e da porção submersa dos vales dos principais rios (paleovales marinhos) que deságuam ao longo do litoral (figura 2.50), realizado por CONTI (2004).

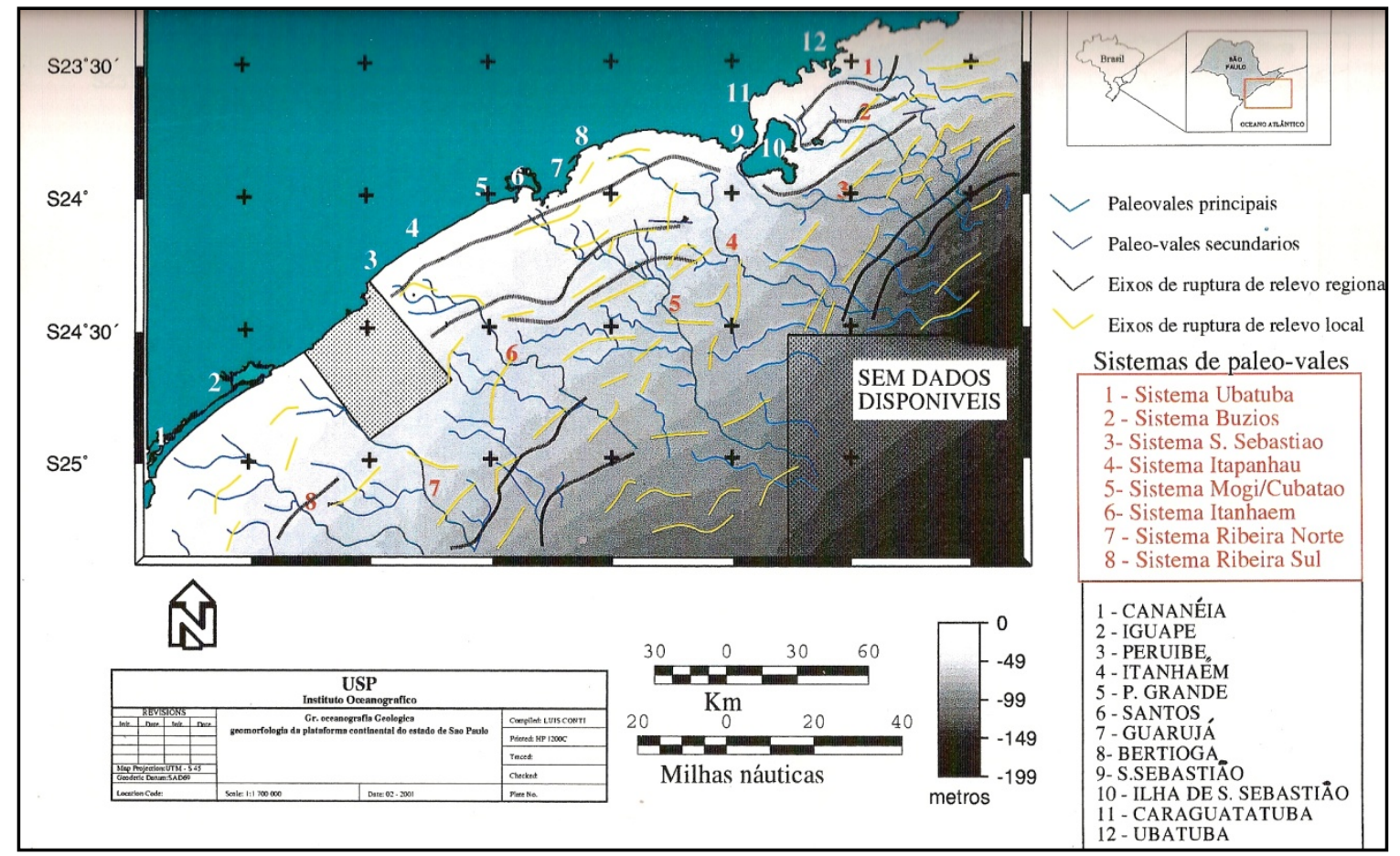

Figura 2.50 - Distribuição dos paleovales e paleoníveis marinhos ao longo da plataforma continental submersa adjacente ao litoral do estado de São Paulo

\footnotetext{
${ }^{32}$ Uma lista completa desses sítios arqueológicos submersos pode ser encontrada em Stright (1990).
} 
Na segunda dessas perspectivas, extrapolando-se as informações obtidas a partir da costa do estado de São Paulo, aos paleoníveis datados (acima citados) foram correlacionados (porém, em menor detalhe) as cartas batimétricas (de profundidade) (figura 2.51) e os mapas dos paleovales (figura 2.52) identificados ao longo de toda a plataforma continental brasileira, no âmbito do Projeto REMAC (1979).

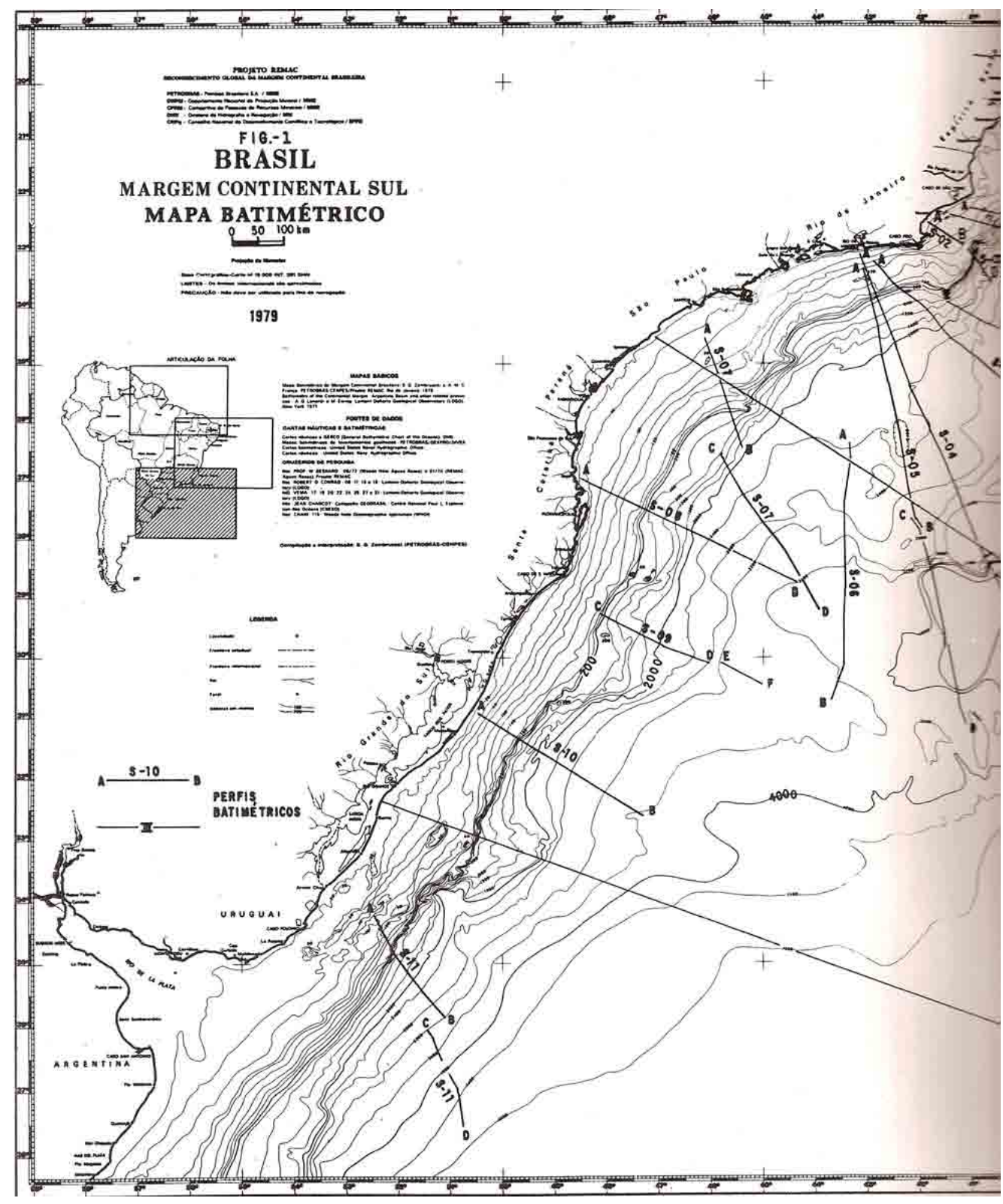

Figura 2.51 - Exemplo da série de mapas utilizados para a elaboração do modelo de predição: Mapa Batimétrico da Margem Sul da Plataforma Continental Brasileira (REMAC, 1979) 


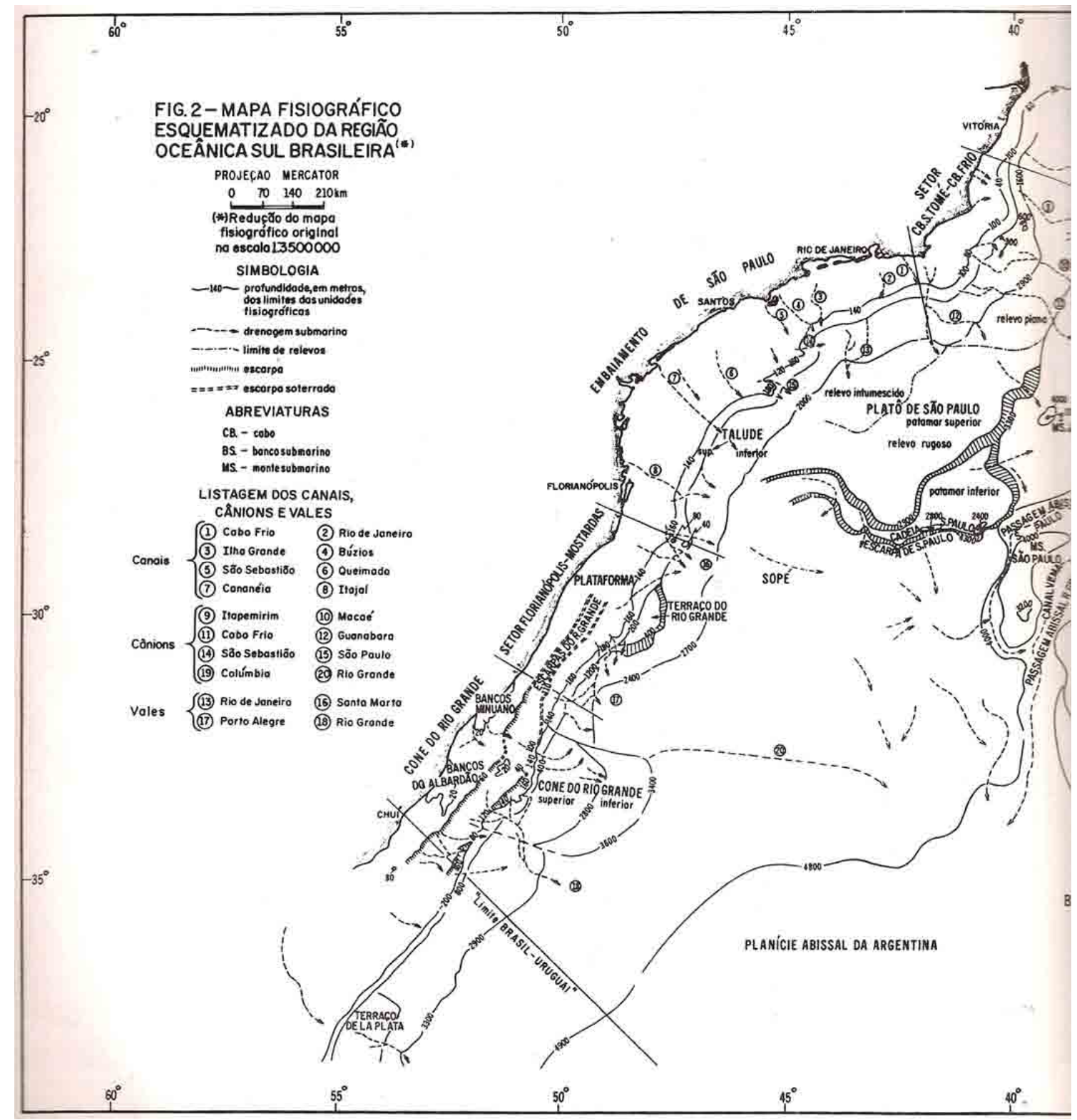

Figura 2.52 - Exemplo da série de mapas utilizados para a elaboração do modelo de predição: Mapa Fisiográfico Esquematizado da Região Oceânica Sul da Plataforma Continental Brasileira (REMAC, 1979)

No que tange à adoção do modelo de Waters (op. cit.) é importante ressaltar que, embora existam diferenças significativas entre as curvas de variação do nível relativo do mar estabelecidas para a costa brasileira e para a costa leste norte americana (geradas, principalmente, em conseqüência da atuação de diferentes processos que regulam o equilíbrio oceano/continente, tais diferenças não eliminam a possibilidade da existência desses sítios mais antigos ao longo da costa brasileira. Ainda mais quando esse mesmo tipo de sítio vem sendo encontrado em uma costa 
cujos processos de variação relativa do nível do mar são semelhantes aos que atuaram na costa brasileira ${ }^{33}$, como começa acontecer na Austrália. Um local onde, segundo Bonhomme (1999), começam a surgir evidências de sítios arqueológicos (também formados por aterros de concha) que vêm sendo encontrados em regiões submersas. Alguns, inclusive, atingindo idades próximas aos 10.000 anos AP (Hall, 1999).

Especificamente em relação às curvas de variação do nível relativo do mar estabelecidas para a costa brasileira, ressalta-se ainda que foram utilizadas, como referência tanto as curvas propostas por Martin e Suguio (SUGUIO, 1999) como as desenvolvidas por Ângulo e Lessa (1997), pois, no que diz respeito às cotas positivas, para a elaboração do presente modelo, mais importante do que o nível atingido é a tendência e as idades apontadas para os eventos de oscilação do nível relativo do mar. Parâmetros que, ambos os grupos, em geral, parecem concordar. Nesse sentido, quando as curvas de um ou outro autor são utilizadas em casos específicos é apontada a devida referência.

Entretanto, neste modelo, uma maior precisão é requerida para as cotas negativas do nível relativo do mar (profundidade). Desta maneira, como referência da idade de cada paleonível marinho foram utilizadas as datações apontadas por Kowsmann e Costa (1979), Furtado et. al. (1998) e Klein (2005). Ambas, apresentadas na tabela abaixo (tabela 2.03).

Tabela 2.03 - Idade e profundidade dos paleoníveis marinhos utilizados como referência

\begin{tabular}{|c|c|c|}
\hline \multicolumn{3}{|c|}{ PALEONÍVEIS MARINHOS } \\
\hline $\begin{array}{c}\text { Profundidade } \\
\text { (metros em relação ao nível } \\
\text { marinho atual) }\end{array}$ & $\begin{array}{c}\text { Idade } \\
\text { (anos AP) }\end{array}$ & Referência \\
\hline-130 & 15.000 & Kowsmann e Costa (1979) \\
-110 & 14.000 e 13.000 & Kowsmann e Costa (1979) \\
-90 a -75 & 12.000 e 11.000 & Kowsmann e Costa (1979) \\
-60 & 11.000 & Kowsmann e Costa (1979)
\end{tabular}

\footnotetext{
${ }^{33}$ Uma comparação mais detalha entre as curvas de variação do nível relativo do mar da costa brasileira, australiana e norte americana, bem como dos principais processos atuantes em cada uma delas, pode ser encontrada em Calippo (2004).
} 


\begin{tabular}{|c|c|c|}
-40 & 9.000 & Kowsmann e Costa (1979) \\
-13 & 8.000 & Furtado et. al. (1998); \\
Klein (2005)
\end{tabular}

\subsubsection{Análises Isotópicas}

Os isótopos são átomos ou nuclídeos de um mesmo elemento químico que, ainda que contenham igual número de prótons, apresentam, em seus núcleos, diferentes números de nêutrons. Embora esses diferentes isótopos de um mesmo elemento se encontrem em uma mesma posição da tabela periódica, as diferenças de massa, geradas pela ocorrência de diversos números de prótons, fazem com que eles apresentem leves modificações em suas propriedades. E, uma vez sujeitos a ação de processos físico-químicos específicos (como evaporação, condensação e difusão), esses isótopos podem acabar perdendo nêutrons, gerando assim novos isótopos. A esse processo dá-se o nome fracionamento isotópico (HÖLZL, 1997).

Segundo esse mesmo autor, a ocorrência e o grau das alterações isotópicas dependem, principalmente, da diferença relativa de massa entre os isótopos. Embora o fracionamento isotópico ocorra de forma natural, as alterações desse tipo estão restritas a elementos de baixa massa atômica, pois, neles, a diferença relativa de massa é mais elevada. Em geral, isótopos desses elementos que não apresentam um decaimento radioativo, são denominados isótopos estáveis. Exemplo de elementos que naturalmente geram fracionamento isotópico são o oxigênio (e.g. ${ }^{16} \mathrm{O}$ e ${ }^{18} \mathrm{O}$ ) e o carbono $\left({ }^{14} \mathrm{C},{ }^{13} \mathrm{C}\right.$ e ${ }^{12} \mathrm{C}$ ).

Entretanto, variações isotópicas também são observadas em muitos elementos pesados, os quais não são suscetíveis ao efeito isotópico. No caso desses elementos de maior massa, a causa da variabilidade isotópica está geralmente associada a um decaimento radioativo - o Rubídio $\left({ }^{87} \mathrm{Rb}\right)$, por exemplo, leva em torno de $4,88 \times 10^{10}$ anos (meia vida) para decair a Estrôncio ( ${ }^{87} \mathrm{Sr}$ ). Em geral, esses isótopos gerados através de um decaimento que dependem da radioatividade de um isótopo mãe são denominados isótopos radiogênicos. Normalmente a abundância desses isótopos radiogênicos é determinada em relação a um isótopo 
não radiogênico. Esse é o caso da razão isotópica do próprio estrôncio $\left({ }^{87} \mathrm{Sr} /{ }^{86} \mathrm{Sr}\right)$, onde a abundância do isótopo radiogênico $\left({ }^{87} \mathrm{Sr}\right)$ é obtida relativamente ao do isótopo estável $\left({ }^{86} \mathrm{Sr}\right)$.

Com a intenção de melhor compreender a maneira como os povos dos sambaquis se relacionavam com os antigos ambientes do litoral do estado de São Paulo e se distribuíam ao longo de suas paisagens naturais e culturais, procurou-se utilizar a composição da razão isotópica dos elementos carbono $\left({ }^{13} \mathrm{C} /{ }^{12} \mathrm{C}\right)$, oxigênio $\left({ }^{18} \mathrm{O} /{ }^{16} \mathrm{O}\right)$ e estrôncio $\left({ }^{57} \mathrm{Sr} /{ }^{56} \mathrm{Sr}\right)$, presentes nas conchas (carbono e oxigênio) e nos ossos e dentes humanos (estrôncio) depositados nos sambaquis, como indicadores das condições paleoambientais e da dispersão dos sambaquieiros ao longo do litoral.

Nesse sentido, os isótopos dos elementos carbono e oxigênio foram analisados com o intuito de se determinar em que condições de paleotemperatura e paleosalinalidade as conchas presentes nos sambaquis se formaram. Como essas conchas, mesmo no momento de sua captura, ainda continuavam a formar suas valvas (pois só parariam de secretar sua carapaça a partir de mortas), pressupomos que a salinidade e a temperatura da água em que foram coletadas podem indicar, de um modo aproximado, que tipos de ambientes (marinho, estuarino, lagunar, lacustre ou fluvial) e águas (água marinha, mista ou doce) os sambaquieiros as coletariam.

Em relação ao estrôncio, o processo ocorre de modo semelhante. Com base nas razões isotópicas de estrôncio presentes nos ossos e dentes humanos, procurou-se, inicialmente, correlacionar a localização dos sambaquis considerados com a distribuição das razões isotópicas naturalmente encontradas ao longo do litoral do estado de São Paulo e também do Vale do Ribeira. Em segundo momento, de modo complementar, procurou-se identificar diferentes conjuntos de sítios a partir da análise da dispersão dos valores das razões isotópicas de estrôncio.

\subsubsection{Isótopos radiogênicos: estrôncio}

Embora o estrôncio tenha quatro isótopos que ocorrem naturalmente $\left({ }^{88} \mathrm{Sr}\right.$, ${ }^{87} \mathrm{Sr},{ }^{86} \mathrm{Sr}$ e ${ }^{84} \mathrm{Sr}$ ), os quais são primordiais e estáveis, um deles, o ${ }^{87} \mathrm{Sr}$, também 
possui uma origem radiogênica, que é produto do decaimento isotópico ${ }^{87} \mathrm{Rb}$. Em conseqüência desse decaimento e da extrema longa vida desses isótopos, eles podem ser utilizados para se determinar a idade das rochas em um espectro que chega a atingir milhões de anos (HODELL, 2004, p.3).

Por si só essa característica já apresentam um grande potencial para a sua aplicação em estudos arqueológicos, pois, uma vez que tal fracionamento aconteça, as razões isotópicas presentes nas rochas e nos sedimentos que delas se originaram, permanecerão as mesmas por um período de tempo muito superior ao relativo à ocupação humana das regiões em questão. Nesse sentido, mesmo que as populações humanas absorvam esses isótopos (através do consumo de água e de alimentos) ao longo de sua vida, eles continuam atuando, segundo Hölzl (op. cit.), como traçadores naturais das regiões de onde a água era proveniente, o alimento cresceu ou foi plantado e onde os animais foram abatidos.

Com base em um estudo a respeito da variação espacial dos isótopos de estrôncio $\left({ }^{87} \mathrm{Sr} /{ }^{86} \mathrm{Sr}\right)$ ao longo do território maia, Hodell et al.(2004) afirmam que é possível estudar migrações e processos de sedentarismo de populações e indivíduos pré-históricos a partir de ossos e dentes humanos, pois:

Strontium isotope ratios reflect the geologic substrate, or bedrock, from the landscape where an individual obtained foodand water, and these ratios are incorporated into theskeleton and dentition during tissue formation without isotopic fractionation. Differences in Sr isotopic ratios of tooth enamel and bone sampled from one individual may be used to infer movement across different geologic terrains over an individual's lifetime (HODELL, 2004, p.1).

Ainda que alguns estudos, como o de Price et al. (2002), apontem que nem sempre existe uma relação direta entre os isótopos de estrôncio presente nas rochas e as razões encontradas nesses alimentos, é importante ressaltar que no âmbito da presente pesquisa a diferenças de valores geradas em conseqüência dessas alterações não influenciam nossa interpretação. Isso porque não se procura aqui estabelecer um estudo quantitativo com base na identificação das assinaturas isotópicas, como, por exemplo, realizado por Bentley et al. (2003), em comunidades 
da Europa Central, e, por Price et al. (2000), em grupos do sudoeste da América do Norte.

Nesse sentido, mais do que caracterizar as razões presentes ao longo dos diversos tipos de rochas, sedimentos, alimentos e águas, o que se objetiva aqui é analisar comparativamente, entre diferentes grupos de sítios e locais, as razões isotópicas "médias" entre os indivíduos. Ou seja, como a diferenciação entre esses grupos é inferida a partir da análise da dispersão dos valores das razões isotópicas, não buscamos diferenciar as razões isotópicas do estrôncio relativas às diferentes fases da vida dos indivíduos (nascimento, últimos anos, etc), nem às precisas correlações com as assinaturas isotópicas locais.

Embora reconheçamos a contribuição desses estudos, é importante ressaltar também que tais objetivos não se encontram entre os propostos no âmbito da presente Tese. Na qual, a análise das razões isotópicas do estrôncio é utilizada principalmente para fundamentar a proposição de novas hipóteses a respeito das descontinuidades, semelhanças e diferenças entre as diversas concentrações de sambaquis. Quando discutimos a possibilidade de mobilidade entre os grupos sambaquieiros, o fazemos através do distanciamento de determinado valor em relação à tendência principal da dispersão dos dados de um grupo ou da aproximação com outro.

Com esse propósito, foram selecionadas diversas amostras de ossos e dentes humanos, depositadas na reserva técnica do Museu de Arqueologia e Etnologia (MAE/USP), referentes às principais áreas de concentração de sambaqui ao longo do estado de São Paulo: baixo Vale do Ribeira, médio Vale do Ribeira, litoral centro e litoral norte. Dando-se preferência a amostras cujas camadas apresentavam idades conhecidas.

Embora neste estudo tenhamos optado por não utilizar as assinaturas isotópicas locais e de fauna como controle de nossas análises, é importante ressaltar que em hipótese alguma abandonamos a preocupação com a precisão e a exatidão dos dados. No sentido de identificar discordâncias entre os dados e apontar possíveis contaminações decorrentes da absorção diferencial dos diversos tipos de 
estruturas osteológicas, adotamos como estratégia a análise de diversos tipos de ossos (compactos e porosos) e de diferentes partes dos dentes (esmalte e dentina).

Assim, sob tal perspectiva, foram enviadas para análise, no Laboratório de Isotopia Geológica (LIG) da Universidade Federal do Rio Grande do Sul (UFRGS) (coordenado pelo Prof. Dr. Farid Chemale), um total de 23 amostras. As quais são apresentadas no quadro abaixo (tabela 2.04).

Tabela 2.04 - Amostras de ossos e dentes humanos utilizadas para a realização das análises isotópicas de estrôncio

\begin{tabular}{|c|c|c|c|c|c|c|c|c|c|}
\hline & AMOSTRA & $S$ DE DE & VTES E OSS & SS HUMANOS & ARA ANÁ & ISE ISOTÓP & ICA DE & STRÔNCIC & \\
\hline $\begin{array}{l}\text { NÚMERO } \\
\text { AMOSTRA }\end{array}$ & sítıo & TIPO & DESCR. & OBSERVAÇÃO & $\begin{array}{l}\text { IDADE } \\
\text { APROX. } \\
\text { (anos AP) }\end{array}$ & ORIGEM & Locus & MUNICÍPIO & REGIÃO \\
\hline 19 & \multirow{2}{*}{ Moraes } & Osso & Costela & & 6000 & Escavação & $\begin{array}{c}X X X V- \\
A\end{array}$ & Miracatu & \multirow{3}{*}{$\begin{array}{c}\text { Médio } \\
\text { Ribeira } \\
\text { (interior) }\end{array}$} \\
\hline 20 & & Osso & Costela & & 5400 & Escavação & VI-A & Miracatu & \\
\hline 21 & Capelinha & Osso & Costela & & 9000 & Escavação & II & Miracatu & \\
\hline 02 & \multirow{4}{*}{ Boguassu } & Dente & Molar & & 3430 & & & Cananéia & \multirow{10}{*}{$\begin{array}{l}\text { Baixo Ribeira } \\
\text { (Litoral Sul) }\end{array}$} \\
\hline 03 & & Dente & Molar & & 3430 & & & Cananéia & \\
\hline 04 & & Osso & Mandíbula & & 3430 & & & Cananéia & \\
\hline 05 & & Osso & Mandíbula & & 3430 & & & Cananéia & \\
\hline 06 & \multirow{3}{*}{ Boa Vista } & Dente & Incisivo & & & & & Cananéia & \\
\hline 07 & & Dente & Pré-Molar & & & & & Cananéia & \\
\hline 08 & & Osso & Mandíbula & & & & & Cananéia & \\
\hline 09 & \multirow{3}{*}{ Brocuonha } & Dente & Molar & & 4387 & & & Cananéia & \\
\hline 10 & & Dente & Molar & & 4387 & & & Cananéia & \\
\hline 11 & & Osso & Mandíbula & & 4387 & & & Cananéia & \\
\hline 12 & Piaçaguera & Dente & Incisivo & & 4930 & Escavação & & Cubatão & \multirow{5}{*}{ Litoral Centro } \\
\hline 13 & & Osso & Costela & & 4930 & Escavação & & Cubatão & \\
\hline 14 & Cosipa I & Dente & Incisivo & & 4300 & Escavação & & Cubatão & \\
\hline 15 & \multirow[b]{2}{*}{ Maratuá } & Dente & Molar & \multirow[b]{2}{*}{$\begin{array}{c}\text { Ocorre tumor } \\
\text { ou patologia } \\
\text { óssea }\end{array}$} & 3865 & & & Guarujá & \\
\hline 16 & & Osso & & & 3865 & & & Guarujá & \\
\hline $01 \mathrm{a}$ & \multirow[b]{2}{*}{ Couves } & Dente & Molar & & & & & Ubatuba & \multirow[b]{2}{*}{ Litoral Norte } \\
\hline $01 b$ & & Dente & Molar & $\begin{array}{l}\text { Raiz sem } \\
\text { esmalte }\end{array}$ & & & & Ubatuba & \\
\hline
\end{tabular}




\begin{tabular}{|c|c|c|c|c|c|c|c|}
\hline 17 & Mar Virado & Dente & Incisivo & & 2640 & Escavação & Ubatuba \\
\hline $18 a$ & Tenório & Dente & Incisivo & $\begin{array}{c}\text { Esmalte e } \\
\text { parte interna }\end{array}$ & 1875 & & Ubatuba \\
\hline $18 \mathrm{~b}$ & & Dente & Molar & Só esmalte & 1875 & & Ubatuba \\
\hline
\end{tabular}

Como a maioria das amostras estava depositada na reserva técnica do MAE há, pelo menos, mais de uma década, por não haverem registros precisos das condições em que foram encontradas e por terem sido manipuladas de diferentes formas ao longo das etapas de registro (aplicação de tinta nanquim e grafite), restauro (utilização de diferentes tipos de cola), conservação, documentação (utilização de massas plásticas e adesivos químicos para dar sustentação à peça), os ossos e dentes passaram por um segundo processo de limpeza em ultra-som (por diversas vezes consecutivas). Imersas em água deionizada (dentro de um aparelho de lavagem ultrasônico - figura 2.54), as impurezas de menor tamanho, aderidas na superfície das amostras, foram separadas em conseqüência da forte vibração gerada pelas ondas sonoras de alta freqüência emitidas.

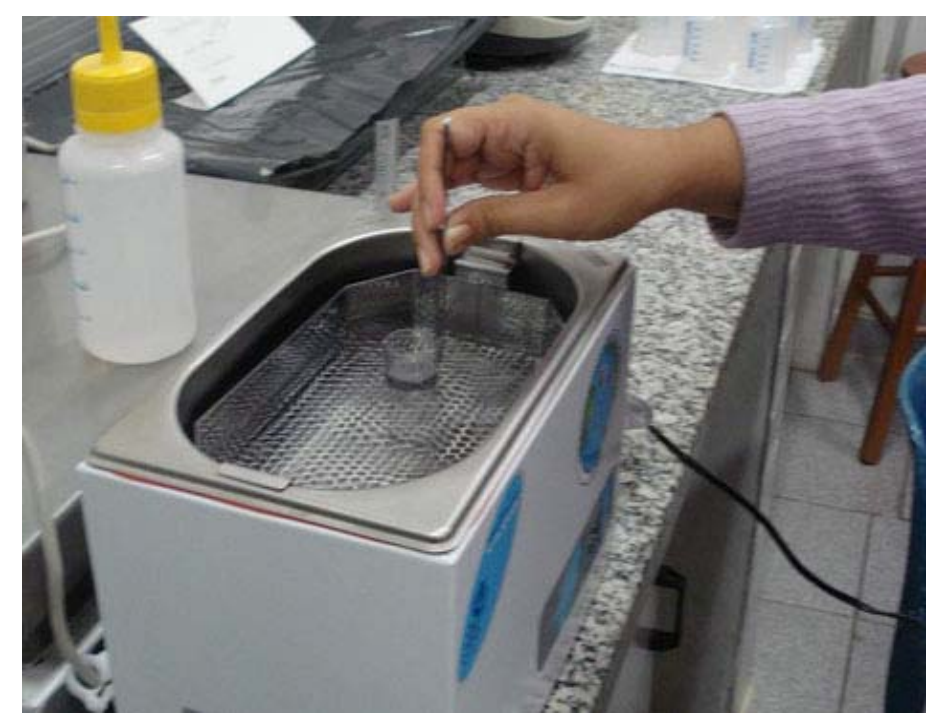

Figura 2.53 - Processo de limpeza através de ultra-som

Uma vez realizada a limpeza superficial das amostras, buscou-se separar as porções das amostras a serem analisadas. Com o auxílio de uma broca odontológica, foram selecionadas diversas porções das estruturas anatômica que mais interessavam ao estudo (figura 2.55). Em algumas dessas estruturas foram, 
inclusive, selecionadas e analisadas mais de uma porção. De um único dente, por exemplo, retirou-se fragmentos de esmalte e de dentina para a realização de diferentes análises, as quais, mais tarde, seriam comparadas entre si a fim de se verificar qual o melhor indicador e possíveis absorções diferenciais das razões isotópicas (figura 2.56). Tais processos foram realizados no Laboratório de Paleoceanografia do Atlântico Sul (LaPAS), do Instituto Oceanográfico (IO/USP).

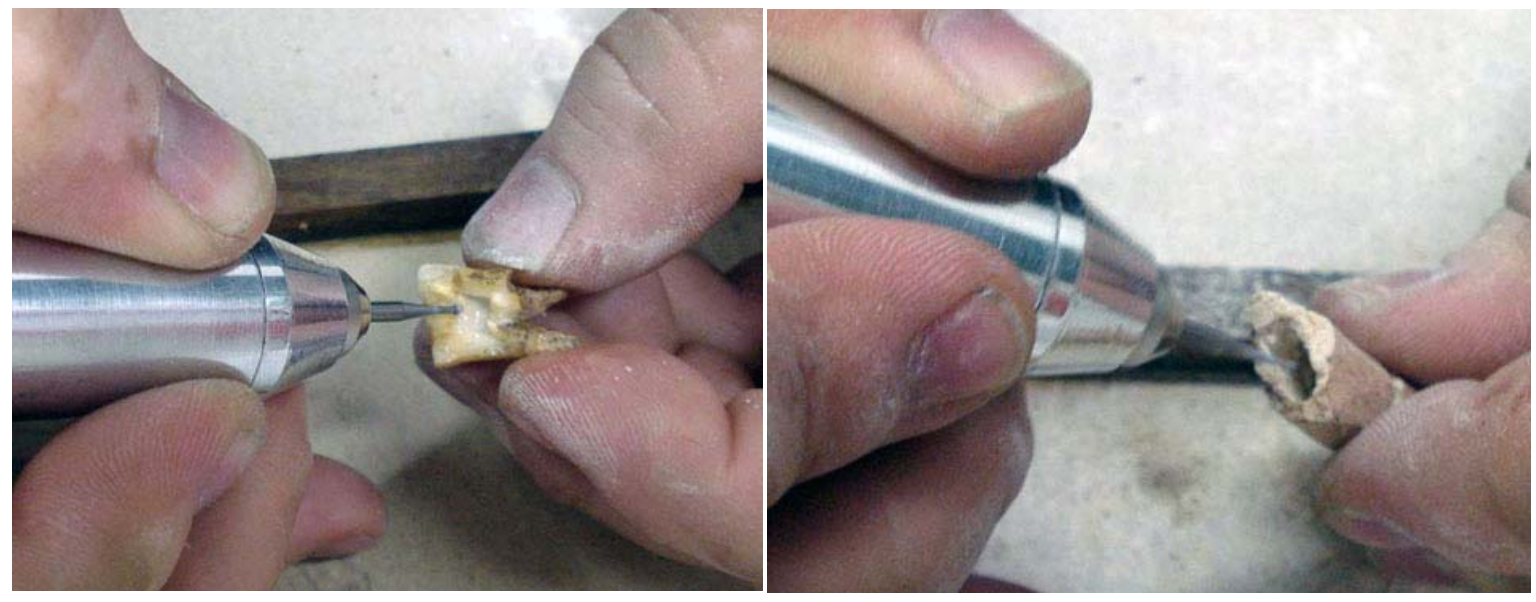

Figura 2.54 - Utilização de broca odontológica para a preparação das amostras (dentes e ossos)
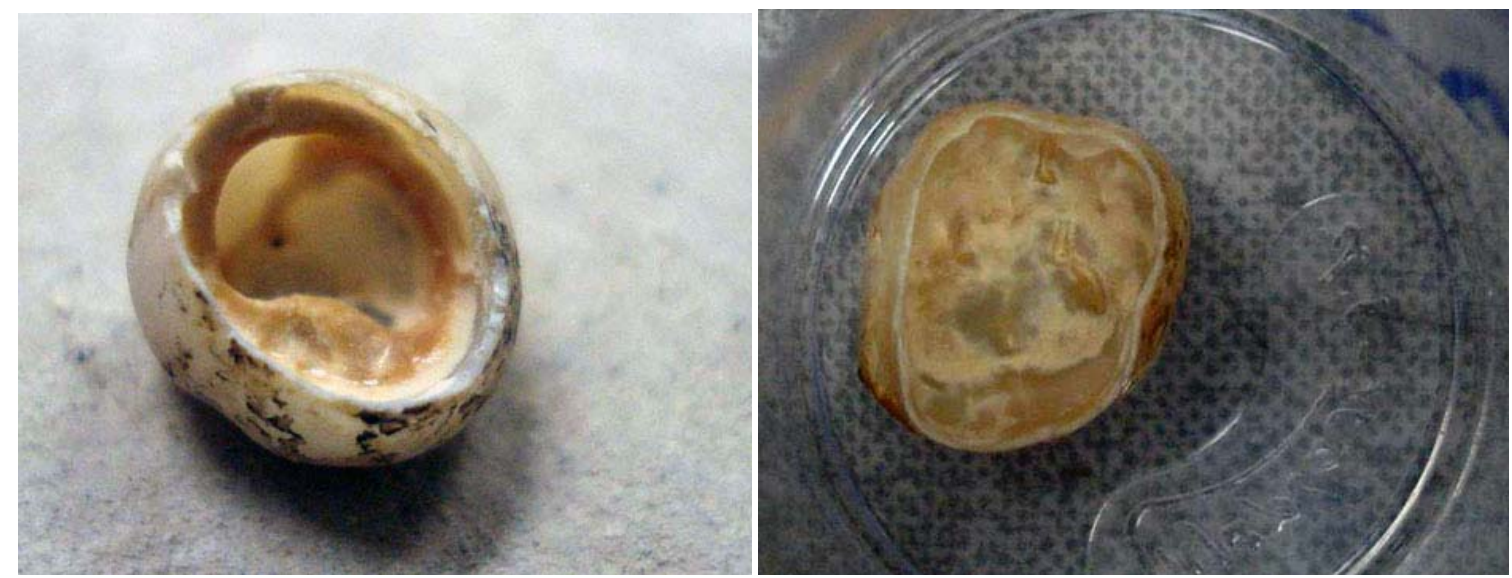

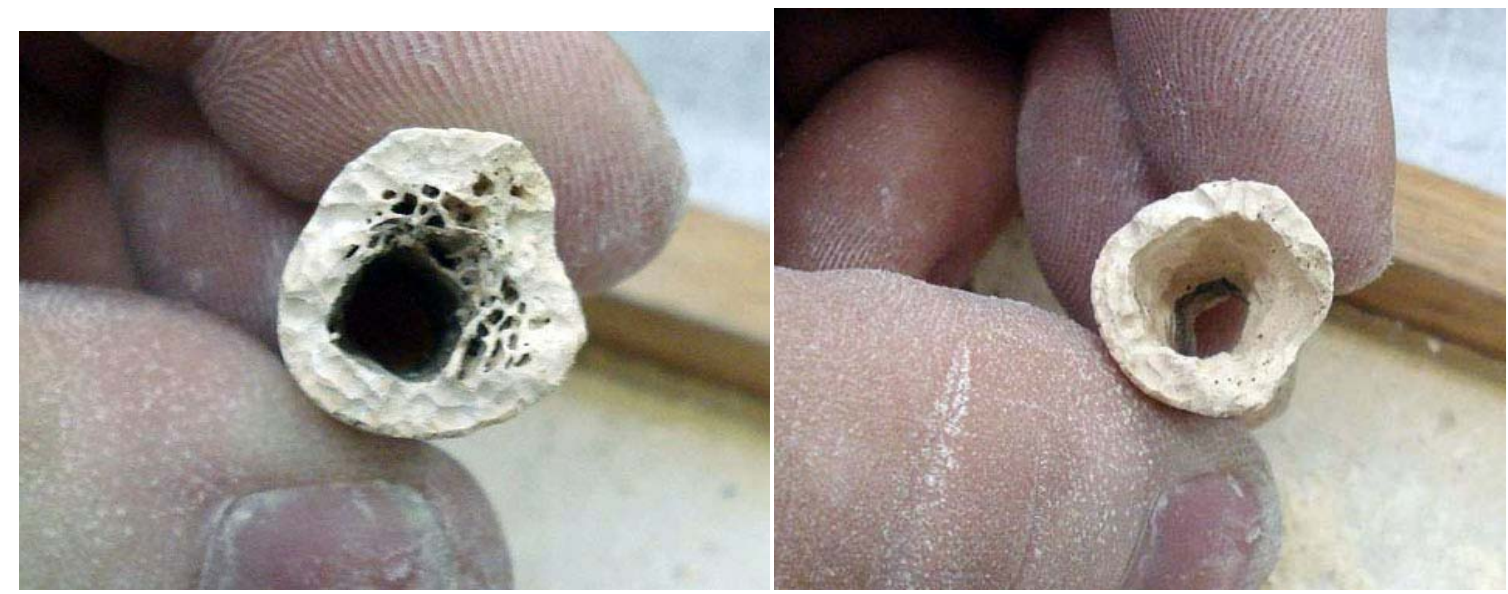

Figura 2.55 - Dentes (fotos no topo da figura) e ossos (na porção inferior) antes e depois do processo de preparação das amostras. No dente à esquerda, pode-se visualizar as camadas concêntricas de dentina (branco/opaco) e esmalte; no da direita, vê-se somente o esmalte (a dentina já havia sido retirada, restando somente a capa de esmalte). No fragmento de osso à esquerda, vê-se duas camadas de ossos: uma compacta e outra porosa. No osso à direita, a camada porosa (mais suscetível a contaminações) foi retirada.

Uma vez selecionadas, as amostras foram acondicionadas em sacos plásticos (acompanhadas de uma numeração impressa em etiqueta de papel, a qual, por sua vez, encontrava-se inserida em sacos plásticos menores) e enviadas ao Laboratório de Isotopia Geológica (LIG) da Universidade Federal do Rio Grande do Sul (UFURGS). Onde, segundo Machado (com. pess, 2009), técnica responsável pelas análises, foram empregadas técnicas grosserias de raspagens para a remoção de possíveis corpos estranhos ainda remanescentes e lavagem com água deionizada.

Após a secagem em estufa, os fragmentos resultantes foram novamente lavados com água Milli-Q e ultrassom durante duas horas, sendo inspecionados a cada 30 minutos em microscópio binocular (Olympus-SZ1145) para verificação de eventuais impurezas aderidas. Após novo processo de secagem em estufa, as amostras foram pulverizadas em moinhos de ágata e submetidas a um processo químico similar ao descrito por Machado (2003) para a realização de análises isotópicas de estrôncio em foraminíferos.

Desta maneira, em primeiro lugar, procedeu-se a digestão e separação química do estrôncio. Aproximadamente $100 \mathrm{mg}$ da amostra pulverizada foram dissolvidas em $500 \mu \mathrm{L}$ de ácido nítrico $\left(\mathrm{HNO}_{3}\right)$ 5,0N bi-destilado em cápsulas Savilex 
de $7 \mathrm{~mL}$, mantidas, com tampa, em uma chapa quente $\left(60^{\circ} \mathrm{C}\right)$ por um período de uma hora. Após a secagem (com Savilex aberto) a uma temperatura da ordem de $100^{\circ} \mathrm{C}$, as amostras foram dissolvidas em $3 \mathrm{~mL}$ de ácido clorídrico (HCL) 2,0N e transferidas para um tubo de centrifugação de $5 \mathrm{~mL}$.

A fim de eliminar a eventual presença de sólidos insolúveis, as amostras foram centrifugadas por 10 minutos a 3000 rpm. Da solução sobrenadante foram retiradas cerca 1,0 mL para posterior separação cromatográfica (usando-se colunas de resina catiônica do tipo Sr Spec, com granulometria entre 50 e 100 mesh). Para a dissolução do estrôncio foram utilizados 2 microlitros de $\mathrm{H}_{3} \mathrm{PO}_{4}$ (super puro), os quais foram depositados sobre um filamento simples de rênio e secados por meio de uma fonte de corrente.

Para a determinação da composição isotópica do estrôncio, utilizou-se um espectrômetro de fonte sólida (abreviadamente conhecido como TIMS - Thermal Ionization Mass Spectrometer) da marca Micromass (Reunido Unido), modelo VG Sector, através do qual as amostras foram analisadas no modo estático e os íons do

${ }^{86} \mathrm{Sr}$ medidos com detector Faraday na posição axial (utilizando-se como padrão um carbonato de estrôncio de valor 0,71025 - NBS-987). Em geral, para a determinação de cada valor utilizou-se como referência a média de 100 razões isotópicas (divididas em 10 blocos de 10 ciclos), sendo que as razões espúrias (outliers) além do critério 2DP foram rejeitadas automaticamente. Para a composição dos resultados, nenhuma correção (conhecida como "bias" ou desvio sistemático) foi aplicada.

\subsubsection{Isótopos estáveis: carbono e oxigênio}

A realização de análises isotópicas de carbono e oxigênio para o estudo de paleoambientes é uma técnica amplamente difundida e utilizada no mundo inteiro (KEITH et al, 1964). No Brasil, desde, pelo menos, o final da década de 1970 (SILVA, 1978), essas análises já vinham sendo realizadas com o propósito de utilizar a composição isotópica dos elementos presentes nas carapaças dos moluscos como 
indicadores dos ambientes em que tais organismos se formaram (Freitas, 1983; Martin et al.,1986).

Embora muitos desses trabalhos tenham utilizado amostras provenientes de sítios arqueológicos, na realidade não tinham como propósito a realização de estudos com enfoque na relação das sociedades com o seu meio. Freitas (1983), por exemplo, ainda que tenha realizado análises provenientes de sambaquis, empregou-as somente com os propósitos de determinar paleoambientes e estudar 0 fracionamento isotópico em diferentes espécies. Nesse sentido, o vestígio arqueológico só foi utilizado com a idéia de que é antigo e poderia contribuir com dados a respeito de um ambiente diferente do atual.

De modo similar, com o objetivo de determinar as razões isotópicas de carbono e oxigênio que definem os diversos tipos ambientes, Silva (1978) realizou um estudo com conchas provenientes de diferentes ambientes e idades. Sendo que, para a análise das idades mais antigas, utilizou conchas provenientes de sambaquis.

Nesta mesma linha, não se pode deixar de apontar o clássico trabalho de Martin et al. (1986) que, para corroborar o estudo das paleolinhas de costa que desenvolvem para toda o Brasil, utilizam as análises isotópicas de oxigênio e carbono, obtidas a partir de conchas de sambaquis, como um indicador da antiga influência marinha dentro das regiões lagunares onde se formavam os sambaquis.

Por último, é importante ressaltar o trabalho de Mizuta (2007). O qual, embora se trate de um trabalho de conclusão de curso $^{34}$, além de desenvolver todas as bases (critério para a seleção das amostras, técnicas de limpeza, seleção e adequação da metodologia de análise e parâmetros para a interpretação dos resultados) para a realização das análises realizadas no âmbito da presente Tese ${ }^{35}$; teve como principal objetivo a caracterização de paleoambientes da região de Cananéia com uso de indicadores isotópicos.

\footnotetext{
${ }^{34}$ Trabalho de conclusão do curso de Oceanologia realizado, no Instituto Oceanográfico (IO/USP), sob a orientação do Prof. Dr. Felipe Toledo (LaPAS/IO).

${ }^{35}$ Para a realização do trabalho de Mizuta, estabeleceu-se uma parceria entre o Laboratório de Paleoceanografia do Atlântico Sul (LaPAS/IO) e o Projeto Arqueológico do Baixo Vale do Ribeira (no qual a presente Tese se insere). Onde a coleta das amostras ficaria a cargo do Projeto, a análise sob a responsabilidade do LaPAS e a interpretação dos dados seria feita de forma conjunta.
} 
No entanto, na Arqueologia brasileira sua aplicação ainda é restrita. Embora alguns pesquisadores (como DE MASI, 2001; PLENS, 2008) já tenham realizado análises isotópicas de carbono e oxigênio, em geral, além de utilizarem-nas somente a partir de amostras de ossos humanos e de solos, não tinham como principal objetivo a correlação do comportamento humano com os dados paleoambientais.

2.2.4.2.1. Composição isotópica dos elementos carbono e oxigênio

\section{Carbono}

Conforme apontado por Mizuta (2007), o carbono tem um único isótopo radioativo $\left({ }^{14} \mathrm{C}\right.$ ) e dois isótopos estáveis $\left({ }^{12} \mathrm{C} \mathrm{e}{ }^{13} \mathrm{C}\right.$ ), sendo o ${ }^{12} \mathrm{C}$ (carbono 12) o mais abundante, constituindo aproximadamente $99 \%$ do carbono na natureza. No entanto, existem flutuações em tal abundância, que, embora de baixa magnitude, implicam em diferenças significativas na abundância relativa dos isótopos de carbono em seus diferentes reservatórios (COSTA, 2000).

Tais diferenças existem porque as variações entre esses isótopos decorrem principalmente do fracionamento isotópico do ${ }^{14} \mathrm{C}$, que, segundo Bigg (1998) dá origem aos outros dois isótopos em conseqüência do fracionamento gerado por uma variedade de processos naturais. Onde inclui, principalmente, a fotossíntese e as reações de troca isotópica entre os compostos carbonosos.

No que tange especificamente aos isótopos presentes nas carapaças dos moluscos, Mizuta (op. cit.) aponta que a composição isotópica de suas carapaças registra valores de $\partial^{13} \mathrm{C}$ que condizem com a água do ambiente em que foram formadas. Em regiões costeiras, o valor de $\partial^{13} \mathrm{C}$ registrado na concha é uma conseqüência direta do local (ou posição em relação a influência marinha) em que o organismo se desenvolveu. Ou seja, quanto mais próximo do continente e protegido da influência marinha, maior será o espectro de valores controlado pelo fornecimento de carbono a partir de fontes continentais (Martin, 2003). 
Nesse sentido, como os valores de $\partial^{13} \mathrm{C}$ são mais altos nas águas marinhas do que em relação às continentais, os valores registrados nas conchas dos moluscos podem ser utilizados como indicadores do grau das influências marinhas e continentais sobre um determinado ambiente ou paleoambiente. Podendo, segundo Martin et al. (1986, 2003), inclusive, fornecer indiretamente evidências das flutuações do nível relativo dos mares. Supondo-se, para isso, que durante um período de nível relativo do mar mais alto, a influência marinha seria maior e os valores de $\partial^{13} \mathrm{C}$ seriam mais elevados em relação a um período de nível do mar mais baixo.

Como os valores de $\partial^{13} \mathrm{C}$ obtidos a partir de conchas carbonáticas (provenientes de regiões costeiras) podem apresentar diferentes razões isotópicas (que são decorrentes do grau de aporte de carbono continental), os organismos lagunares apresentariam valores de $\partial^{13} \mathrm{C}$ intermediários entre os valores apontados por organismos de que se formaram em águas totalmente doce e os que se desenvolveram em um ambiente francamente marinho. Valores que, segundo Martin et al. (1986, 2003), distribuem-se, respectivamente, entre 13\% (água doce) e 0\% (água marinha).

\section{Oxigênio}

Segundo Nier (1950), existem na natureza três tipos de isótopos de oxigênio $\left({ }^{16} \mathrm{O},{ }^{17} \mathrm{O}\right.$ e $\left.{ }^{18} \mathrm{O}\right)$ que podem ser encontrados na forma de diferente compostos, cujas disponibilidades são de, respectivamente, 99,76\%, 0,04\% e 0,20\%.

Nos oceanos, por exemplo, podemos encontrar dois desses isótopos formando um mesmo tipo de composto. Segundo Mizuta (2007), em momentos de intensa evaporação, as moléculas de água, formadas por isótopos mais leves de oxigênio $\left(\mathrm{H}_{2}{ }^{16} \mathrm{O}\right)$, tendem a ser evaporados mais facilmente. Fazendo com que ao longo de determinados períodos os oceanos aumentem sua concentração em água isotopicamente mais pesada $\left(\mathrm{H}_{2}{ }^{18} \mathrm{O}\right)$. Na precipitação do vapor d'água o contrário ocorre. A água isotopicamente mais pesada se concentra primeiro e cai sob a forma de chuva. 
Como as taxas de evaporação e precipitação ao longo do planeta não são as mesmas, surgem em meio a esse processo zonas de diferentes concentrações de água leve e pesada. Com o vapor d'água sendo transportado do sentido dos trópicos para os pólos, forma-se na atmosfera dos pólos uma massa de vapor rica em isótopos de ${ }^{16} \mathrm{O}$ (formada em decorrência das altas taxas de evaporação no equador). A qual, ao atingir os pólos, se condensa na forma de gelo (em conseqüência da queda de temperatura) (MIZUTA, op. cit).

Em períodos mais quentes, quando a temperatura global se eleva, o derretimento das geleiras faz com que grande parte desses isótopos de ${ }^{16} \mathrm{O}$ (antes aprisionados no gelo dos pólos), retorne aos oceanos, tornando a água dos oceanos isotopicamente mais leve (COSTA, 2000). Processo que se repete, de maneira diferenciada, a cada novo ciclo de flutuações climáticas.

Segundo Shackleton (1967), o registro dos isótopos de oxigênio é dominado, principalmente, pelas variações na composição isotópica da água do mar, causadas pelo acúmulo e derretimento do gelo nos continentes. Deixando, assim, diversos tipos de evidências ao longo do registro geológico (e.g. isótopos de ${ }^{16} \mathrm{O}$ e ${ }^{18} \mathrm{O}$ capturados no momento da formação da carapaça de moluscos). As quais, uma vez adotadas as variações nas características isotópicas da água como referência, permitem a utilização dos isótopos de oxigênio como um indicador paleoambiental e paleoclimático.

Emiliani $(1954,1955)$ indica que os moluscos registram a temperatura e o $\partial^{18} \mathrm{O}$ da água do ambiente em que se encontram por meio da deposição de carbonato de cálcio em suas conchas. Por isso, podem ser utilizados em estudos das variações isotópicas de oxigênio. Segunda Mizuta (op. cit.), o registro de isótopos de oxigênio em moluscos, para o Holoceno, é caracterizado por variações quasi-periódicas e globalmente sincrônicas.

Por convenção, a composição isotópica do oxigênio é geralmente expressa como o desvio da razão ${ }^{18} \mathrm{O} /{ }^{16} \mathrm{O}$, a partir de um padrão arbitrário, e o resultado é registrado por meio de valores $\partial^{18} \mathrm{O}$. Sendo que, valores negativos de $\partial^{18} \mathrm{O}$ significam que a amostra é empobrecida em ${ }^{18} \mathrm{O}$; e valores positivos indicam um enriquecimento em ${ }^{18} \mathrm{O}$, o qual reflete uma água isotopicamente mais pesada. $\mathrm{A}$ 
equação abaixo indica o algoritmo através do qual a composição isotópica do oxigênio de uma amostra pode ser calculada.

$$
\partial^{18} \mathrm{O}\left(\%_{\mathrm{oo}}\right)=1000 \times \frac{(18 \mathrm{O} / 16 \mathrm{O}) \text { amostra }-(18 \mathrm{O} / 16 \mathrm{O}) \text { padrão }}{\left(\mathrm{O} /{ }^{16} \mathrm{O}\right)_{\text {padrão }}}
$$

Para a determinação da composição isotópica do oxigênio existem dois padrões de referência, os quais apresentam uma razão isotópica padrão para a água do mar. São eles, o padrão VSMOW (Vienna Standard-Mean-Ocean-Water) e o padrão PDB (Pee Dee Beleminites).

\subsection{O processo analítico}

Após a seleção das amostras (que se encontram especificadas no item 2.2.4.2.3 - Conjunto amostral), procedeu-se a preparação das amostras. Seguindo a metodologia descrita por Mizuta (2007), abaixo apresentada, as conchas (figura 2.57 a, b, c), provenientes de cada nível, foram lavadas uma a uma em água deionizada, utilizando-se uma escova com cerdas plásticas macias.

Removida as impurezas mais grossas, as amostras passaram por um segundo processo de limpeza em ultra-som (por diversas vezes consecutivas). Imersas em água deionizada (dentro de um aparelho de lavagem ultrasônico), as impurezas de menor tamanho, aderidas na superfície das amostras, foram separadas em conseqüência da forte vibração gerada pelas ondas sonoras de alta freqüência emitidas (figura 2.57 d, e, f). 


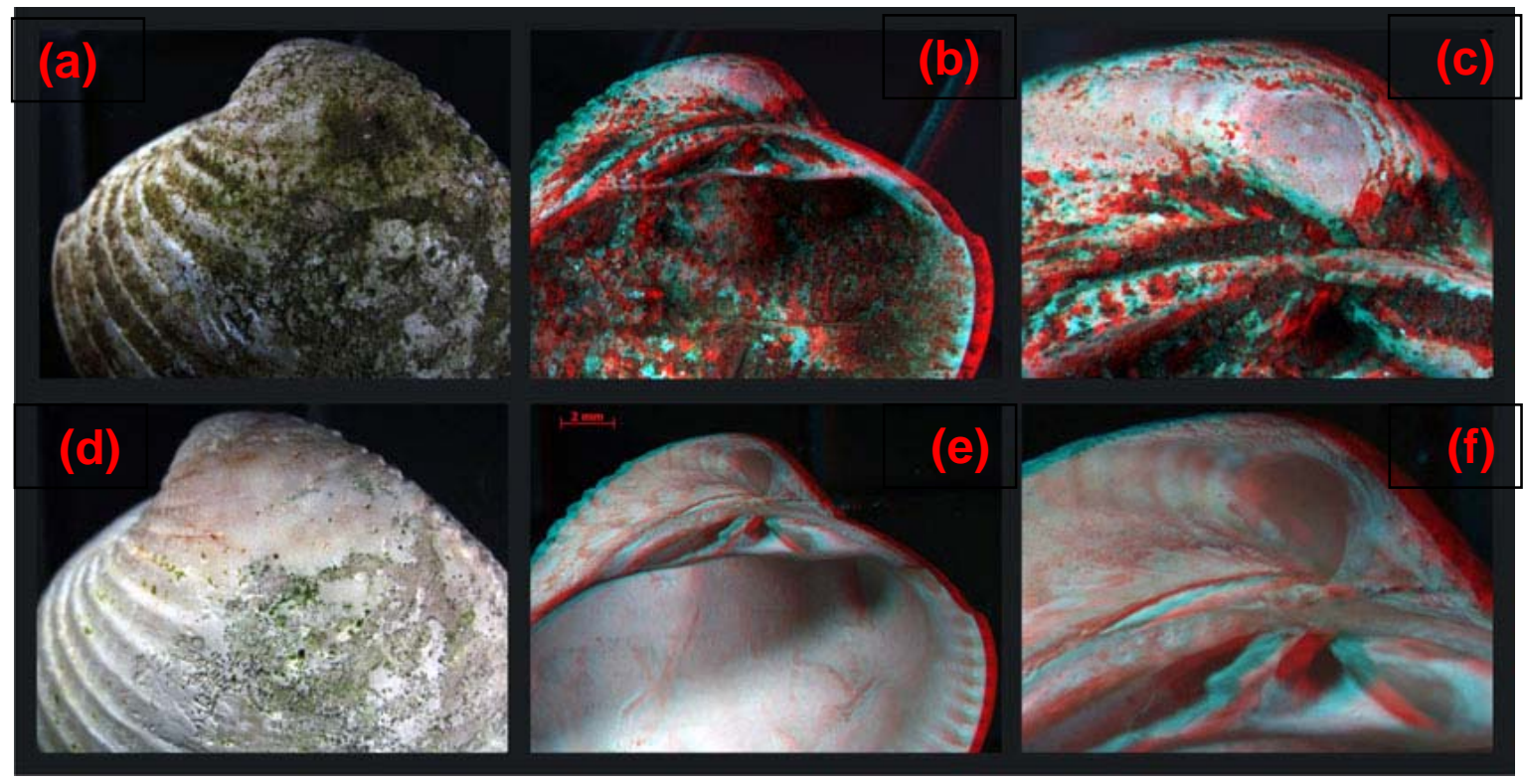

Figura 2.56 - Conchas antes $(a ; b ; c)$ e depois do processo de lavagem com água deionizada e ultra-som (d; e; f). As imagens "b", "c", "e" e "f" foram tiradas em estereoscopia (3D). Para uma melhor visualização utilizar os óculos que se encontram no verso da contracapa da Tese.

No ultra-som, as amostras foram lavadas por sucessivas vezes. Entre as sessões, as superfícies das conchas foram novamente lavadas utilizando-se uma escova de cerdas macias e água. Após esse segundo ciclo de lavagem, as amostras foram acondicionadas em béqueres de plástico e lavadas com peróxido de oxigênio $\left(\mathrm{H}_{2} \mathrm{O}^{2}\right)$, em concentração de $10 \%$, de modo a quimicamente eliminar qualquer resíduo restante de matéria orgânica.

Uma vez eliminadas quaisquer impurezas, as amostras foram então secas em estufa com temperatura controlada à $60^{\circ} \mathrm{C}$, impedindo, assim, que houvesse perdas isotópicas para a atmosfera (o que ocorre em temperaturas acima de $100^{\circ} \mathrm{C}$ ). Após essa primeira secagem, as amostras foram novamente lavadas e secas em estufa. Processo repetido com o objetivo de evitar que possíveis resíduos de matéria orgânica remanescentes permanecessem depositados nas conchas. Quando secas, as amostras passaram, então, por um processo completo de moagem (realizado com almofariz e pistilo de cerâmica), até que se formasse um pó fino (amostra homogeneizada).

Embora Keith et al.(1964) tenha demonstrado que variações isotópicas podem ser encontradas ao longo das diversas camadas das conchas (que se 
formam umas sobrepostas às outras ao longo do crescimento dos moluscos), não foram aqui selecionadas ou desprezadas quaisquer partes das conchas; pois, o tempo de vida dos bivalves estudados é muito menor do que a margem de erro de cada datação radiocarbônica.

Do total de cada amostra, foi selecionada (em balança de precisão) uma alíquota de $300 \mathrm{mg}$. A qual, assim que devidamente acondicionada e identificada, foi enviada ao Laboratório de Isótopos Estáveis (LIE) do Instituto de Geociências (IG/USP) para análise da composição isotópica dos elementos carbono e oxigênio.

No Laboratório de Isótopos Estáveis, de cada amostra foi retirada uma alíquota de $5 \mathrm{mg}$ a 10mg. Utilizando-se reagentes químicos, um sistema a vácuo de eliminação de gás atmosférico (910-3 Torr), uma linha de extração off-line (com garrafas térmicas DEWAR, mantido em baixo-vácuo: $2.10^{-3}$ Torr) e um espectrômetro de massa tipo Delta ${ }^{\text {Plus }}$ Advantage (da ThermoFinningan), foram determinadas os valores de $\partial^{13} \mathrm{C}$ e $\partial^{18} \mathrm{O}$.

Segundo Mizuta (op. cit.), a referência utilizada para a determinação é proveniente de um padrão interno (amostra de mármore - padrão CM-1) com a seguinte composição isotópica: $\partial^{13} \mathrm{C}=2,12 \%$ (PDB) e $\partial^{18} \mathrm{O}=-1,51 \%$ (PDB). Composição essa semelhante à do padrão SMOW, indicado pela Agência Internacional de Energia Atômica (IAEA).

\subsubsection{Conjunto amostral}

A fim de estabelecer um conjunto amostral que fosse capaz de sustentar as análises isotópicas de carbono e oxigênio e o estabelecimento de correlações entre as relações ambientais desenvolvidas pelos sambaquieiros de Cananéia, foram utilizadas tanto amostras coletadas em etapas de campo anteriores à elaboração da presente Tese (através de amostradores tipo Vibracoring) como amostragens realizadas no âmbito do presente doutoramento.

De um modo geral, essas novas coletas (já descritas no item 2.1.1.1) tiveram como objetivo principal complementar algumas lacunas de dados existentes nos 
sambaquis Cambriu Grande, cujo processo de formação até então era completamente desconhecido.

A seguir, na tabela 2.05, é apresentado um quadro com as origens e as idades de cada uma das 75 amostras analisadas (provenientes tanto de antigas intervenções como das realizadas no âmbito da presente Tese).

Tabela 2.05 - Conjunto amostral das análises isotópicas de carbono e oxigênio (de cada nível foram retiradas uma concha para a realização das análises)

\begin{tabular}{|c|c|c|c|c|c|c|c|}
\hline \multirow{3}{*}{ Sítio } & \multirow{3}{*}{ Intervenção } & \multirow{3}{*}{ Camada } & \multirow{3}{*}{ Nível } & \multicolumn{4}{|c|}{ Concha } \\
\hline & & & & \multicolumn{3}{|c|}{ C14 } & \multirow{2}{*}{$\begin{array}{l}\text { Idade } \\
\text { Inferida }\end{array}$} \\
\hline & & & & Conv. & $\delta 13 C$ & Obs & \\
\hline \multirow{27}{*}{ Branco } & \multirow{7}{*}{ T007 } & \multirow{7}{*}{ III } & 002 & \multirow{7}{*}{\multicolumn{2}{|c|}{$4590 \pm 90$}} & \multirow[b]{7}{*}{ Calippo (2004) } & 4550 \\
\hline & & & 010 & & & & 4557 \\
\hline & & & 015 & & & & 4563 \\
\hline & & & 020 & & & & 4570 \\
\hline & & & 027 & & & & 4577 \\
\hline & & & 032 & & & & 4583 \\
\hline & & & 034 & & & & 4590 \\
\hline & \multirow{13}{*}{ T019 } & \multirow{7}{*}{ I } & $000 / 010$ & $4150 \pm 50$ & $-0,8$ & Calippo (2004) & 4150 \\
\hline & & & 010/020 & & & & 4151 \\
\hline & & & 020/030 & & & & 4153 \\
\hline & & & $030 / 040$ & & & & 4154 \\
\hline & & & $040 / 050$ & & & & 4156 \\
\hline & & & $050 / 060$ & & & & 4157 \\
\hline & & & 060/070 & & & & 4159 \\
\hline & & \multirow{4}{*}{ II } & 070/080 & $4160 \pm 50$ & $-0,7$ & Calippo (2004) & 4160 \\
\hline & & & 080/090 & $4460 \pm 60$ & $-0,5$ & Calippo (2004) & 4258 \\
\hline & & & 090/100 & & & & 4331 \\
\hline & & & $100 / 110$ & & & & 4385 \\
\hline & & \multirow{2}{*}{ III } & $110 / 120$ & $4550 \pm 50$ & $-0,4$ & Calippo (2004) & 4550 \\
\hline & & & $120 / 130$ & $4550 \pm 50$ & $-0,4$ & Calippo (2004) & 4550 \\
\hline & \multirow{7}{*}{ T021 } & \multirow{7}{*}{ I } & 020 & & & & 4150 \\
\hline & & & 030 & & & & 4151 \\
\hline & & & 040 & & & & 4153 \\
\hline & & & 050 & & & & 4154 \\
\hline & & & 060 & & & & 4156 \\
\hline & & & 064 & & & & 4157 \\
\hline & & & 070 & & & & 4159 \\
\hline
\end{tabular}




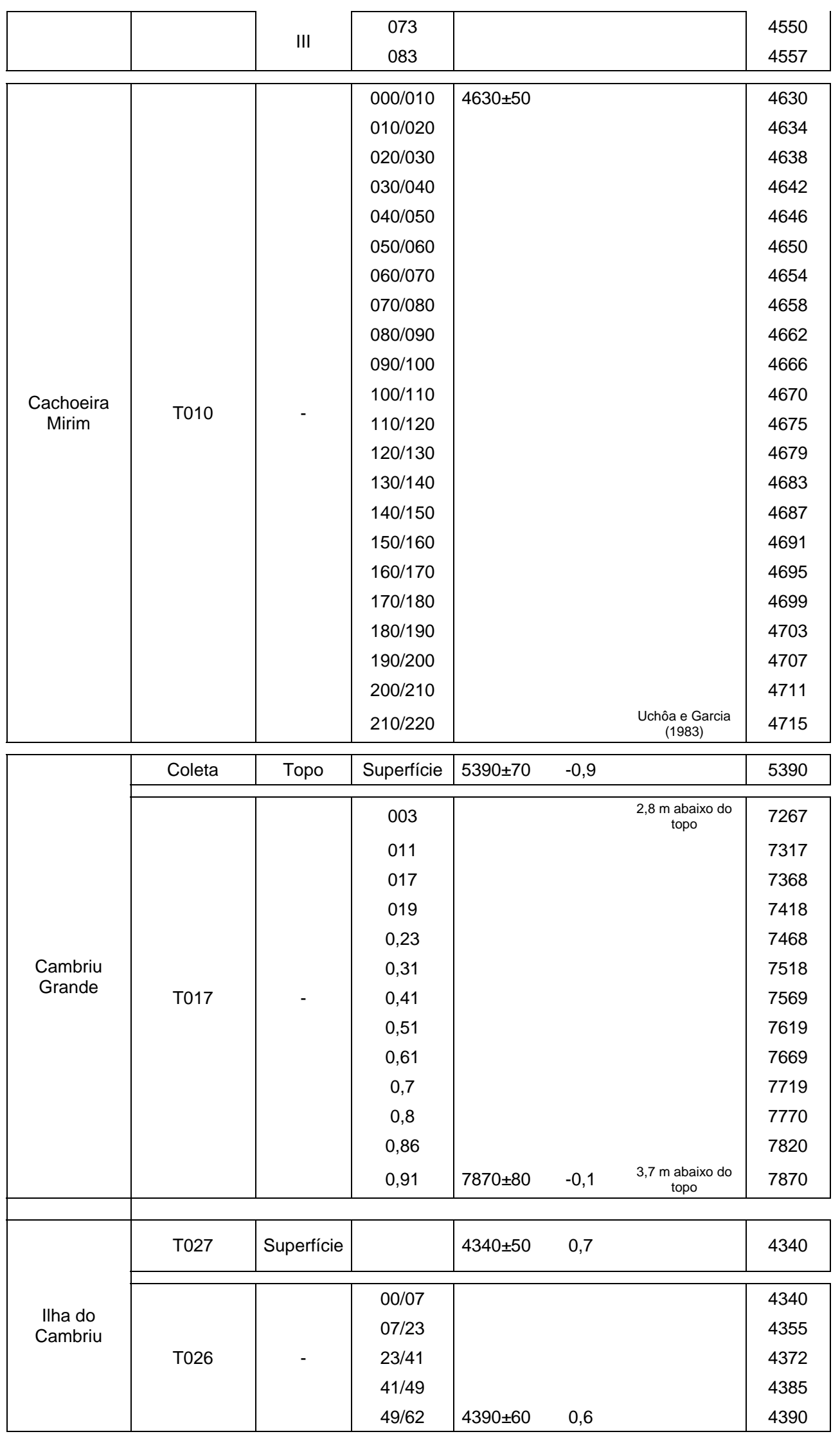


Como pode ser visto na tabela acima, procurou-se, para a realização das análises de carbono e oxigênio, estabelecer um quadro cronológico que viesse a contextualizar no tempo todas as amostras. No entanto, principalmente em conseqüência dos altos custos envolvidos para isso, em vez de realizar datações absolutas, estabeleceu-se uma série de idades relativas para cada uma das amostras. As quais foram inferidas a partir da profundidade de cada amostra em relação à espessura do extrato ou camada datada, cujas idades (base e topo) foram obtidas no âmbito desta Tese e em outras pesquisas do Projeto Arqueológico do Baixo Vale do Ribeira, ou obtidas através de datações realizadas por outros pesquisadores.

Embora tenhamos consciência de que tal inferência possa não representar a exata velocidade de formação e deposição das micro-camadas arqueológicas, a precisão resultante de tal processo (controlada pela utilização das idades de topo e base como referência) é suficiente para que possamos estabelecer uma seqüência temporal mínima. Em alguns casos, como, por exemplo, o sambaqui Cambriu Grande, onde as camadas apresentam diferentes velocidades de formação, em vez de utilizarmos como pacote sedimentar todo o extrato do sítio, optou-se por estabelecer como limites os topos e bases de cada camada que compões o sítio. Minimizando, assim, prováveis distorções cronológicas.

Além da preocupação em se estabelecer uma seqüência temporal para a contextualização dos resultados, existe ainda uma outra questão que deve ser revista antes de podermos utilizar, com segurança, os dados isotópicos. Questão essa que está diretamente vinculada às espécies de moluscos utilizadas. Ainda que alguns sítios apresentem diversos tipos de conchas, optou-se aqui por utilizar, como principal elemento para a determinação da composição isotópica do carbono e do oxigênio, o molusco Anomalocardia brasiliana (berbigão). Não somente por sua abundância, mas, principalmente, por sua recorrência em praticamente todos os sítios e também por sua grande dispersão ao longo dos diversos ambientes estuarinos.

Embora, em alguns casos específicos tenha-se utilizado também conchas de mais de uma espécie (Cassostrea sp. - ostra), é importante ressaltar que a 
utilização de dois tipos diferentes de concha em nada influencia o resultado e as interpretações. Pois, mesmo que diferentes espécies possam apresentar diferentes fracionamentos isotópicos biológicos no momento em que secretam suas conchas (ou seja, a preferência na utilização de um isótopo a outro por parte dos bivalves); Keith et al. (1964) e Freitas (1983) constataram que o fracionamento biológico em bivalves não é significativo se comparado com o fracionamento ambiental.

Portanto, para a realização de estudos de análises isotópicas não é necessário fazer qualquer tipo de correção nos dados isotópicos e tão pouco distinções por espécies. Podendo, assim, serem utilizadas conchas de diferentes localidades e idades (MIZUTA, 2007).

Nesse sentido, considera-se aqui que as conchas são secretadas em equilíbrio isotópico com a água do mar - ou seja, as razões de carbono e oxigênio descrevem as características da água na época de vida dos bivalves coletados. Não necessitando a realização de correções dos valores ${ }^{36}$ resultantes das análises.

Em relação à adoção de espécies diferentes, resta ainda uma última dúvida. Ainda que o fracionamento isotópico não represente um problema, será que a distribuição dessas duas espécies ao longo das áreas lagunares poderia gerar possíveis distorções na interpretação dos resultados? Essa é uma preocupação que surge de termos, como uma das principais propostas desta Tese, a intenção de estudar as relações ambientais desenvolvidas pelos sambaquieiros com os diferentes tipos de ambientes apontadas pelas razões isotópicas das conchas dos moluscos presentes nos sambaquis.

De modo similar ao que ocorre com o fracionamento isotópico de origem biológica, essa é uma questão que também não interferirá no estabelecimento das interpretações, pois, tanto Anomalocardia brasiliana como Cassostrea sp. são conchas que apresentam uma ampla distribuição ao longo do estuário.

Segundo Boehs e Magalhães (2004), a Anomalocardia brasiliana habita a faixa entre marés e o infralitoral, ocorrendo geralmente em regiões protegidas (áreas

\footnotetext{
${ }^{36}$ Se durante a secreção dessas conchas ocorresse um significativo fracionamento isotópico biológico, os valores obtidos pelo uso de material biogênico para estudos de isótopos de carbono e oxigênio como indicadores paleoambientais, teriam de ser corrigidos. Pois, os molusco não secretariam suas conchas em equilíbrio isotópico com a água do mar.
} 
de baixa energia, livre de ação de ondas e correntes). Embora em geral se distribuam em águas com temperaturas que vão dos $21^{\circ} \mathrm{C}$ aos $34^{\circ} \mathrm{C}$ e salinidades entre os $21,6 \%$ e $34,7 \%$, não apresentam preferência por qualquer intervalo de temperatura e salinidade e toleram variações nas condições ambientais em que vivem (SCHAEFFER-NOVELLI, 1976). Condição semelhante à da Crassostreas sp., que pode ser encontrada em uma ampla faixa de valores de salinidade (8\% a 34\%) e temperatura $\left(8^{\circ} \mathrm{C}\right.$ e $\left.33^{\circ} \mathrm{C}\right)$ (WAKAMATSU, 1973). 


\section{PARTE II - RESULTADOS e DISCUSSÕES}

Uma vez apresentadas as principais propostas desta Tese, as abordagens teóricas e metodológicas desenvolvidas e o conjunto amostral utilizado para se compreender a sociedade sambaquieira a partir de um ponto de vista marítimo, agora, nesta segunda parte, são apresentados e discutidos, em quatro capítulos, os principais resultados obtidos ao longo da elaboração desta Tese.

No primeiro capítulo (Capítulo 3) são abordados os resultados que dizem respeito às intervenções arqueológicas realizadas nos sambaquis de Cananéia e as análises radiocarbônicas obtidas para eles. Nos dois capítulos seguintes (Capítulos 4 e 5) são, respectivamente, apresentados e discutidos os resultados referentes à análise da composição isotópica estrôncio (isótopo radiogênico) e do carbono e oxigênio (isótopos estáveis).

Com o propósito de correlacionar todos esses resultados, contextualizando-os no espaço e no tempo, são apresentados e discutidos, em um último capítulo (Capítulo 6), em consonância com todos os outros, os resultados do modelo de predição de sambaquis submersos. O qual se encontra subdividido em duas partes principais: a primeira aborda o estabelecimento de um modelo geral para toda a costa brasileira; e a segunda diz respeito ao desenvolvimento de um modelo mais detalhado, específico para a porção submersa da plataforma continental do estado de São Paulo. 


\section{AS INTERVENÇÕES ARQUEOLÓGICAS}

Como as intervenções arqueológicas realizadas nos sambaquis da região de Cananéia tiveram o propósito de complementar o conjunto amostral já desenvolvido em etapas anteriores, houve somente a necessidade de executar intervenções arqueológicas em apenas dois sítios: os sambaquis Cambriu Grande e Cachoeira Mirim.

\subsection{SAMBAQUI CAMBRIU GRANDE}

Embora já tivessem sido propostas duas datas (porção intermediária e topo) para o sambaqui Cambriu Grande (CALIPPO, 2004), as quais atribuíam a esse sítio uma das maiores antiguidades do litoral brasileiro, ainda não havia sido estabelecida uma compreensão inicial a respeito de seus processos formativos. Com o intuito de confirmar tal antiguidade e de estabelecer um entendimento inicial da formação de suas camadas, procurou-se, no âmbito desta Tese, obter amostras relativas às camadas intermediárias desse sítio. Tornando possível, assim, a elaboração de hipóteses a respeito do processo de formação do sambaqui.

Com essa intenção foram, então, executadas duas novas testemunhagens, à vibração (método Vibracoring), nas faces leste e oeste do sambaqui (figura 3.01), a partir das quais se obteve duas novas colunas estratigráficas, cujas bases foram datadas em, respectivamente, $5730 \pm 60$ e $5620 \pm 60$ anos AP (tabela 3.01).

Tabela 3.01 - Datações radiocarbônicas realizadas nos sambaqui Cambriu Grande

\begin{tabular}{|c|c|c|c|c|c|c|c|}
\hline \multirow{2}{*}{ Sítio } & \multicolumn{2}{|c|}{ Idade (anos AP) } & \multirow{2}{*}{$\begin{array}{l}\text { Tipo de } \\
\text { Amostra }\end{array}$} & \multirow{2}{*}{ Testemunho } & \multirow{2}{*}{ Posição } & \multirow{2}{*}{ Laboratório } & \multirow{2}{*}{ Referência } \\
\hline & Convenc. & Calibrada & & & & & \\
\hline $\begin{array}{l}\text { Cambriu } \\
\text { Grande }\end{array}$ & $5620 \pm 60$ & $\begin{array}{c}6170 \mathrm{a} \\
5890\end{array}$ & Concha & T0028 & $\begin{array}{l}\text { Base do } \\
\text { testemunho }\end{array}$ & Beta Analytic & Beta 219093 \\
\hline $\begin{array}{l}\text { Cambriu } \\
\text { Grande }\end{array}$ & $5730 \pm 60$ & $\begin{array}{c}6270 a \\
5980\end{array}$ & Concha & T0029 & $\begin{array}{l}\text { Base do } \\
\text { testemunho }\end{array}$ & Beta Analytic & Beta 219094 \\
\hline
\end{tabular}



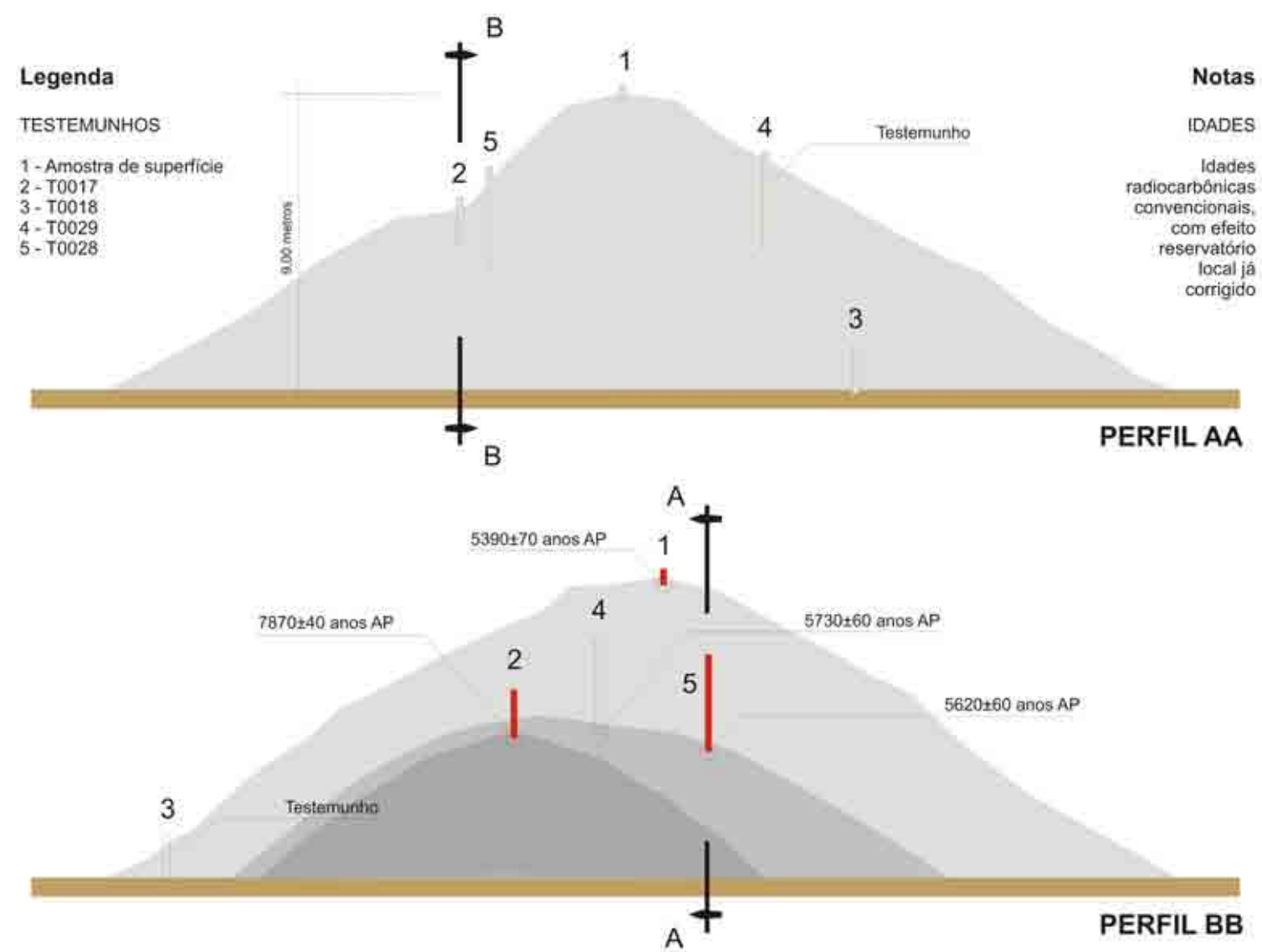

Figura 3.01 - Localização e posicionamento dos testemunhos coletados no sambaqui Cambriu Grande. As amostras datadas ao longo da Tese são as referentes às bases dos testemunhos T0028 e T0029

Além de ampliarem o entendimento da estrutura das camadas estratigráficas do sambaqui Cambriu Grande, as novas idades, obtidas a partir da datação da base desses últimos testemunhos, confirmaram a maior antiguidade desse sítio. Mesmo que ainda não tenha sido possível atingir as camadas mais basais do sambaqui, as datas (intermediárias às anteriores) sugerem um tipo de padrão de construção ainda não detectado na região. No qual, com base na deposição de consecutivas camadas de conchas que se intercalam às lentes de sedimentos ricos em matéria orgânica ou vestígios de carvão (figura 3.02), sugere-se que, nesses momentos mais antigos, parece não haver indícios de períodos de intenso acréscimo de material. Indicando, assim, que a formação do sítio se daria de uma forma mais contínua (ou crônica) do que episódica e que durante a construção desse sítio os sambaquieiros não estariam ainda preocupados com a elaboração de estruturas mais representativas, 
como bases, montículos funerários e espessas camadas de acresção associadas a perspectivas de monumentalidade.

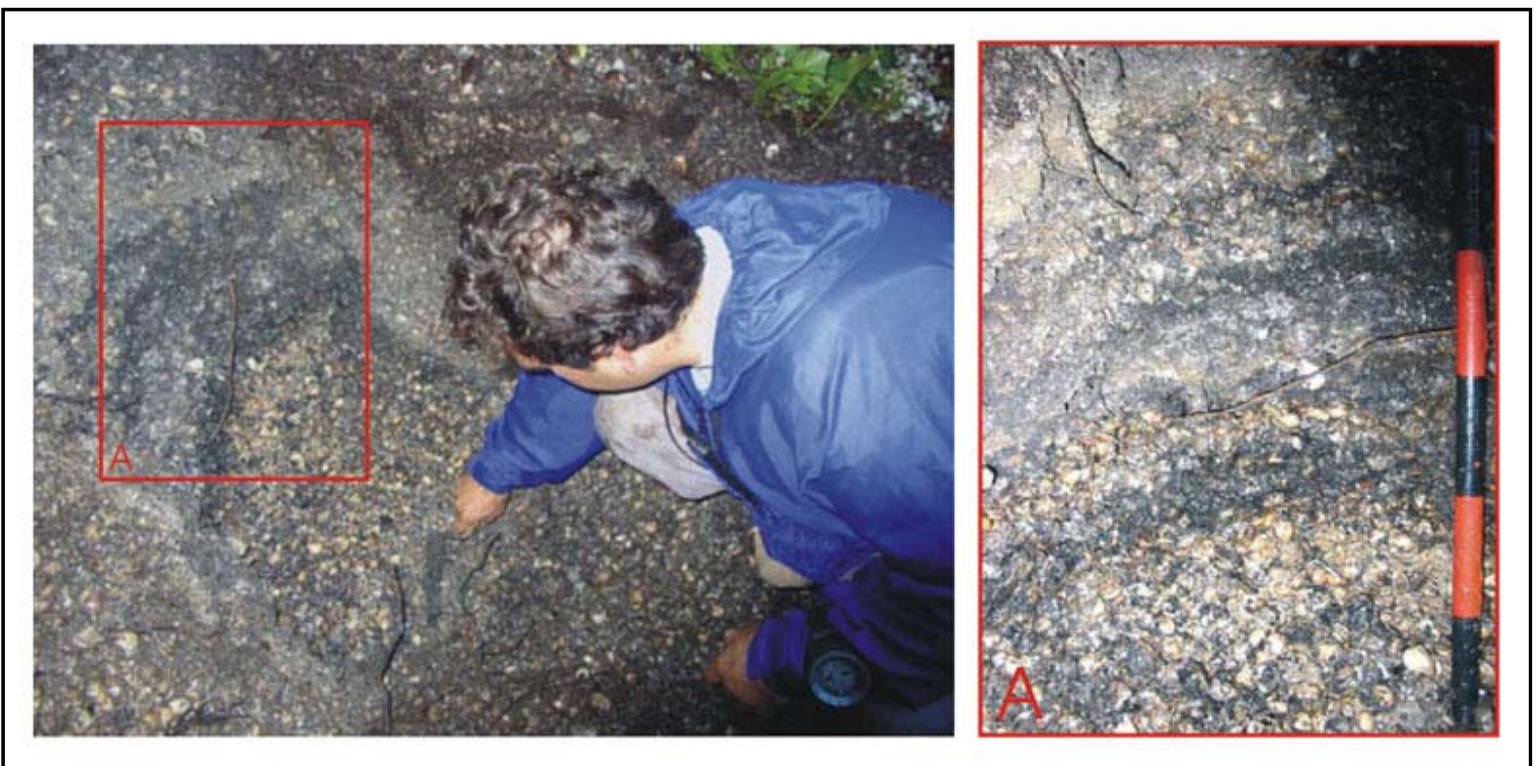

Figura 3.02 - Detalhes da seqüência de camadas arqueológicas identificadas no sambaqui Cambriu Grande

A interpretação desse padrão é reforçada, ainda, pela idade das camadas analisadas, as quais, de maneira concomitante ao crescimento vertical dos depósitos, parecem apontar, também, uma expansão lateral do sítio (figura 3.01). Mais do que uma preocupação com a altura do monte acumulado (afinal, esse sítios tem pelo menos nove metros em relação à sua base), talvez, esse padrão represente uma preocupação com a necessidade de se ampliar o espaço de ocupação, seja ele utilizado para moradia, habitação ou como lugar de culto aos mortos. Quem sabe, nesses primeiros momentos, apesar da dimensão vertical atingida pelo sambaqui, ainda não estivesse implícita na concepção dos sambaquis os referenciais de monumentalidade.

Embora tal hipótese esteja alinhada a uma abordagem calcada nos processos culturais de formação do registro arqueológico, ela não pode, pelo menos aqui, ser vista de forma dissociada da evolução do contexto natural (onde atuam os processos naturais de formação do registro) contemporâneo à formação desse sambaqui. Principalmente, porque é possível que essa expansão horizontal do sambaqui esteja também relacionada ao surgimento de um contexto ambiental cada 
vez mais favorável (entrada de água salgada no interior das áreas lagunares) ao aumento da disponibilidade das conchas, causado pela elevação do nível relativo que, por volta de 8.000 anos, atinge uma cota próxima à do sambaqui. O qual, nesse momento, possuía uma altitude quase três metros abaixo do que a atingida por volta de 5.500 anos AP (Calippo, 2004).

\subsection{SAMBAQUI CACHOEIRA MIRIM}

O sambaqui Cachoeira Mirim localiza-se na face interna da Ilha do Cardoso, às margens do Canal do Ararapira, em uma região próxima à desembocadura do estuário de Cananéia. Assim como ele, existe um outro sítio, o sambaqui Branco, que apesar de contemporâneo a ele e se localizar a menos de dois quilômetros de distância, apresenta um processo de formação completamente diferente.

Para que tal diferença pudesse ser analisada, realizando-se, inclusive, um estudo comparativo a respeito da composição isotópica (carbono e oxigênio) das conchas das camadas de ambos os sítios, foi necessário realizar uma datação radiocarbônica em sua camada superior; pois, até então, só havia sido obtida apenas uma única data para o topo desse sítio (UCHÔA e GARCIA, 1983).

Para a determinação da idade dessa camada foi utilizada uma amostra que já havia sido coletada em uma etapa anterior ao inicio da presente Tese, a partir da realização de uma sondagem realizada na porção central do sambaqui (ver itens 2.1.1.2 e 2.2.2) (CALIPPO, 2004). O resultado da análise radiocarbônica dessa amostra apontou uma idade (convencional) de 4630 550 anos AP (Beta 258663) (tabela 3.02).

Tabela 3.02 - Datações radiocarbônicas realizada no sambaqui Cachoeira Mirim

\begin{tabular}{|c|c|c|c|c|c|c|c|}
\hline \multirow{2}{*}{ Sítio } & \multicolumn{2}{|c|}{ Idade (anos AP) } & \multirow{2}{*}{$\begin{array}{c}\text { Tipo de } \\
\text { Amostra }\end{array}$} & \multirow{2}{*}{ Testemunho } & \multirow{2}{*}{ Posição } & \multirow{2}{*}{ Laboratório } & \multirow{2}{*}{ Referência } \\
\hline & Convenc. & Calibrada & & & & & \\
\hline $\begin{array}{c}\text { Cachoeira } \\
\text { Mirim }\end{array}$ & $4630 \pm 50$ & $\begin{array}{c}4960 \mathrm{a} \\
4780\end{array}$ & Concha & T0010 & $\begin{array}{l}\text { Topo do } \\
\text { testemunho }\end{array}$ & Beta Analytic & Beta 258663 \\
\hline
\end{tabular}


Além de contribuir para o estabelecimento do período de construção desse sítio (que tem por volta de 100 anos), essa nova data permitiu também que pudéssemos estabelecer uma nova compreensão de seu processo formativo, o qual, se comparado ao sambaqui Branco, parece ter sido construído a partir de um estilo diferente ou ter assumido uma outra função; pois, embora próximos e contemporâneos, não foram identificados em sua estratigrafia estruturas que possam ser interpretadas como concebidas pelos sambaquieiros com base em aspectos imbuídos de intencionalidade e monumentalidade.

Em relação à análise dos isótopos estáveis (carbono e oxigênio) apresentadas no (capítulo 5), essa nova data foi de fundamental importância para a inferência das idades relativas de cada um dos níveis analisados. Propiciando, nesse sentido, bases para a elaboração de hipóteses a respeito das relações que os sambaquieiras estabeleciam com o seu ambiente. 


\section{ISÓTOPOS RADIOGÊNICOS}

Do ponto de vista do estudo dos processos de formação do registro arqueológico, a análise das razões isotópicas de estrôncio pode ser considerada um dos principais indicadores (em macro-escala) dos processos culturais discutidos no âmbito desta Tese. Através dessa análise foi possível, pela primeira vez, produzir dados que viessem corroborar com a hipótese da existência de uma possível fronteira cultural entre as populações sambaquieiras do norte e do sul do estado de São Paulo, bem como em relação as do médio Ribeira.

Entretanto, no intuito de ser fiel à estrutura e às propostas teóricas da Tese, as questões que dizem respeito, principalmente, à origem e ao estabelecimento de tais fronteiras serão discutidas mais tarde, ao longo do Capítulo 6 (Modelo de Predição). Onde, a fim de se propor o estabelecimento de diferentes conjuntos de comunidades marítimas ao longo da costa do estado de São Paulo, o resultado da análise da composição isotópica do estrôncio é correlacionado com as evidências arqueológicas presentes em cada uma dessas três áreas.

Assim, neste quarto capítulo, são apresentados e discutidos os resultados que se referem, exclusivamente, às questões metodológicas e técnicas da utilização do método analítico do estrôncio, bem como o seu potencial e correlação com estudos já realizados.

Embora neste projeto piloto tenham sido analisadas apenas 22 amostras de dentes e ossos humanos (sendo, três relativas a sítios do médio Vale do Ribeira; dez a sítios do baixo Vale do Ribeira; cinco de sítios da Baixada santista; e quatro do litoral norte), devido à heterogeneidade da geologia regional (e, portanto, da existência de diferentes fontes de estrôncio), foi possível, de uma forma simples e precisa (gráficos de dispersão), identificar um padrão inicial a respeito da mobilidade e da territorialidade dos grupos sambaquieiros ao longo do atual estado de São Paulo. Um quadro detalhado dos resultados da análise de tais amostras é apresentado abaixo, na tabela 4.01 . 
Tabela 4.01 - Composição isotópica do estrôncio presente em ossos e dentes humanos provenientes de sambaquis do litoral de São Paulo e vale do Ribeira

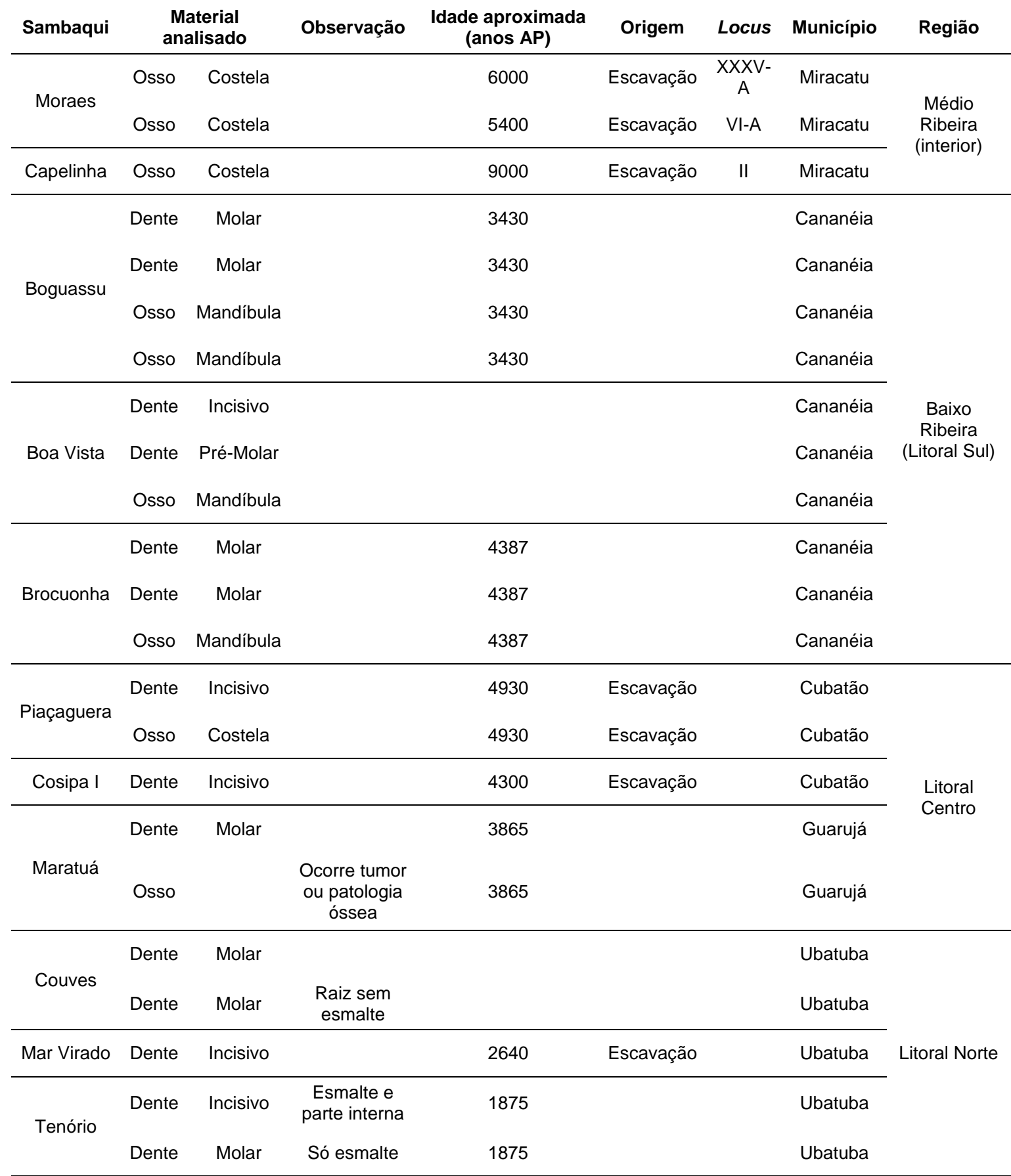

Um padrão que, muito provavelmente, está associado a uma forte territorialidade (interna a cada a cada conjunto) e a uma baixa mobilidade entre os três conjuntos principais de sítios: sambaquis do médio Vale do Ribeira (conjunto 1), 
do baixo Vale do Ribeira e da Baixada Santista (conjunto 2) e do litoral do norte do estado de São Paulo (conjunto 3).

Como pode-se perceber através da figura 4.01, mesmo em uma primeira análise (gráfico de simples dispersão), os valores das razões isotópicas se distribuem de forma a agruparem-se em pelo menos dois conjuntos principais. Os quais dizem respeito aos sambaquis costeiros (à esquerda) e aos sítios fluviais do médio Ribeira (à direita).

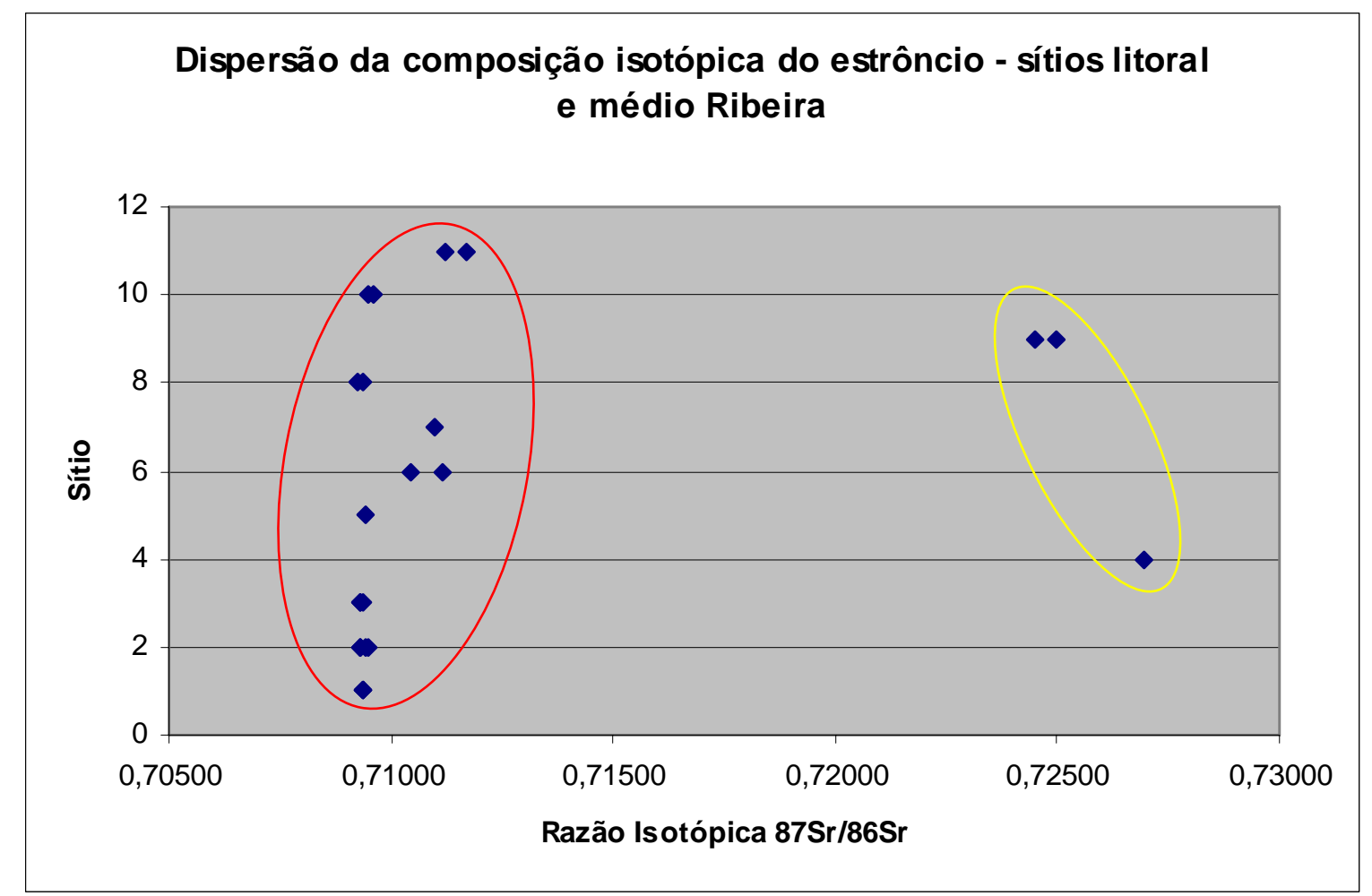

Figura 4.01 - Dispersão das razões isotópicas do estrôncio presentes nos sambaquis do litoral (esquerda) e do médio vale do Ribeira ( direita). Sítios: (1) Boa Vista; (2) Boguassu; (3) Brocuonha; (4) Capelinha; (5) Cosipa I; (6) Couves; (7) Mar Virado; (8) Maratuá; (9) Moraes; (10) Piaçaguera; (11) Tenório

No entanto, se olharmos com mais atenção para o conjunto da esquerda poderemos perceber, ainda nesta escala, que as razões isotópicas relativas aos sítios do litoral também parecem subdividir-se em dois subconjuntos. Localizados ligeiramente à direita do conjunto que se agrupa em torno da razão isotópica 
0,71000, estão posicionados os valores relativos aos sítios do litoral norte (que apresentam valores um pouco mais altos que os dos litorais centro e sul).

A fim de melhor ilustrar essa diferenciação entre os sítios do litoral, foi elaborado um outro gráfico (figura 4.02), cuja abscissa (eixo x) encontra-se subdivida em intervalos menores.

Visando uma melhor compreensão dessa figura, é importante ressaltar que, nesse tipo de gráfico, a distância ao longo da ordenada (eixo Y) não apresenta qualquer significado analítico. Os sítios foram distribuídos ao longo deste eixo somente com a intenção de facilitar a compreensão do leitor. Do contrário, devido a amplitude da dispersão dos valores das razões isotópicas (entre, aproximadamente, 0,708 e 0,710), os dados relativos a cada um dos sítios apareceriam plotados praticamente em apenas um único ponto do gráfico.

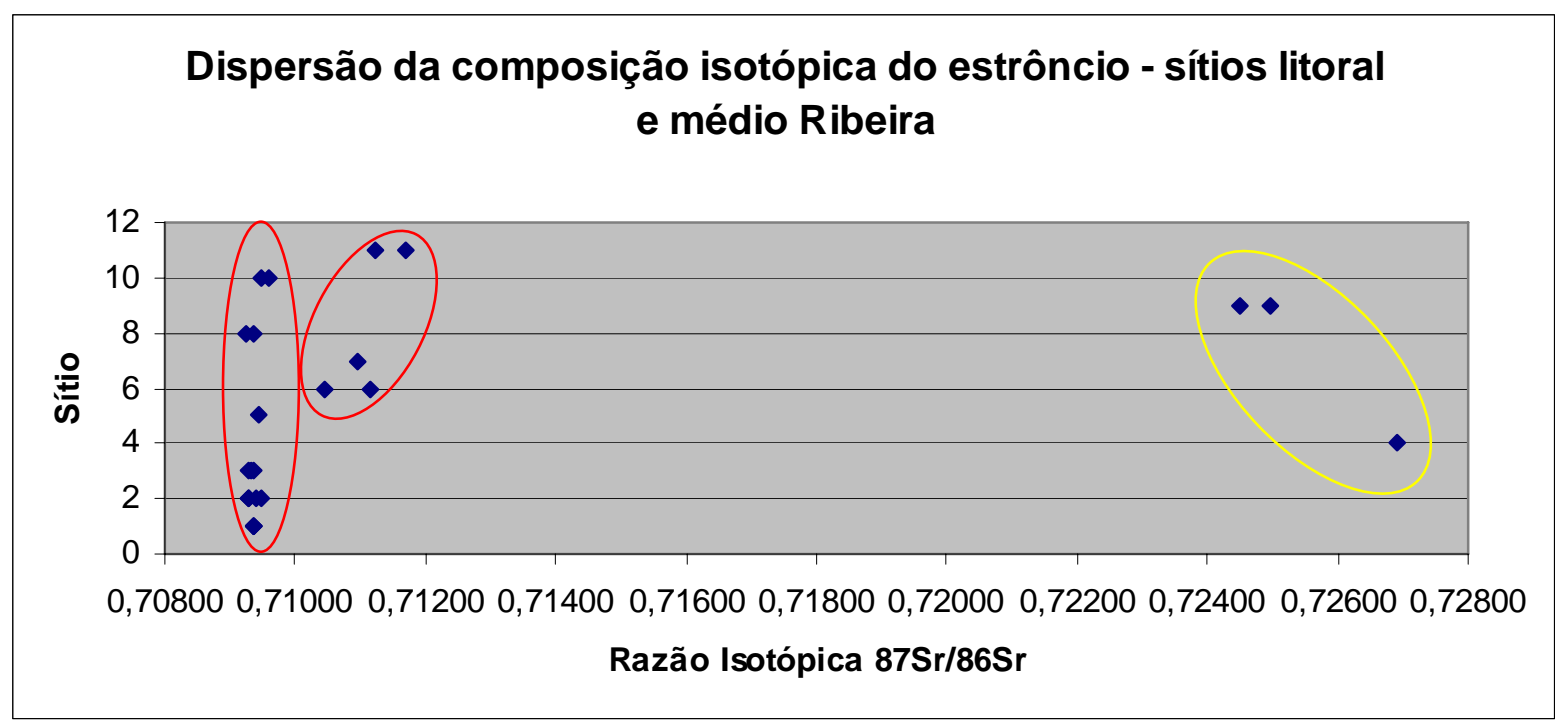

Figura 4.02 - Dispersão das razões isotópicas do estrôncio presentes nos sambaquis do litoral (dois conjuntos à esquerda) e do médio vale do Ribeira (direita). Sítios: (1) Boa Vista; (2) Boguassu; (3) Brocuonha; (4) Capelinha; (5) Cosipa I; (6) Couves; (7) Mar Virado; (8) Maratuá; (9) Moraes; (10) Piaçaguera; (11) Tenório

Antes de avançarmos na discussão da mobilidade e da territorialidade dos grupos sambaquieiros, é preciso ainda fazer duas rápidas considerações. A primeira é relativa ao que entendemos por mobilidade e territorialidade. Quando propomos o estabelecimento de uma baixa mobilidade e uma forte territorialidade, não estamos 
necessariamente afirmando que os sambaquieiros desses diferentes locais não interagissem entre si. Existem, nesse sentido, diversas evidências na bibliografia arqueológica de que os grupos do médio Ribeira manteriam contatos com os povos do litoral. Como exemplo, podemos citar o caso de dentes de tubarão e conchas marinhas encontrados em sítios do médio Ribeira (BARRETO, 1998; FIGUTI et al, 2004; PLENS, 2008; DE BLASIS, com. pess, 2009).

Nosso entendimento, neste caso, é que a freqüência dos deslocamentos e a interação dos indivíduos entre esses três conjuntos seriam menores do que os praticados internamente a cada conjunto, subsistema ou comunidade local. Ou seja, ainda que indivíduos do litoral sul, do litoral norte e do média Ribeira se visitassem esporadicamente, essa freqüência seria muito do menor do que a praticada entre os indivíduos de um único conjunto.

A segunda diz respeito aos diferentes intervalos dos valores isotópicos encontrados para cada uma dessas regiões. Embora não se tenha aqui estabelecida uma relação direta entre os indivíduos e a geologia local (com base na análise isotópica de sedimentos e de rochas adjacentes aos sítios), foi possível estabelecer uma diferenciação inicial dos conjuntos de sítios porque cada um desses agrupamentos encontra-se associado a contextos geológicos completamente distintos entre si; cuja composição isotópica é semelhante às aqui obtidas para as amostras dos ossos e dentes humanos analisados.

A fim de melhor ilustrar essa situação, abaixo, na figura 4.03, a localização desses três conjuntos principais foi correlacionada aos compartimentos geológicos apontados no Mapa Geológico do Estado de São Paulo (ROSS e MOROZ, 1997). 


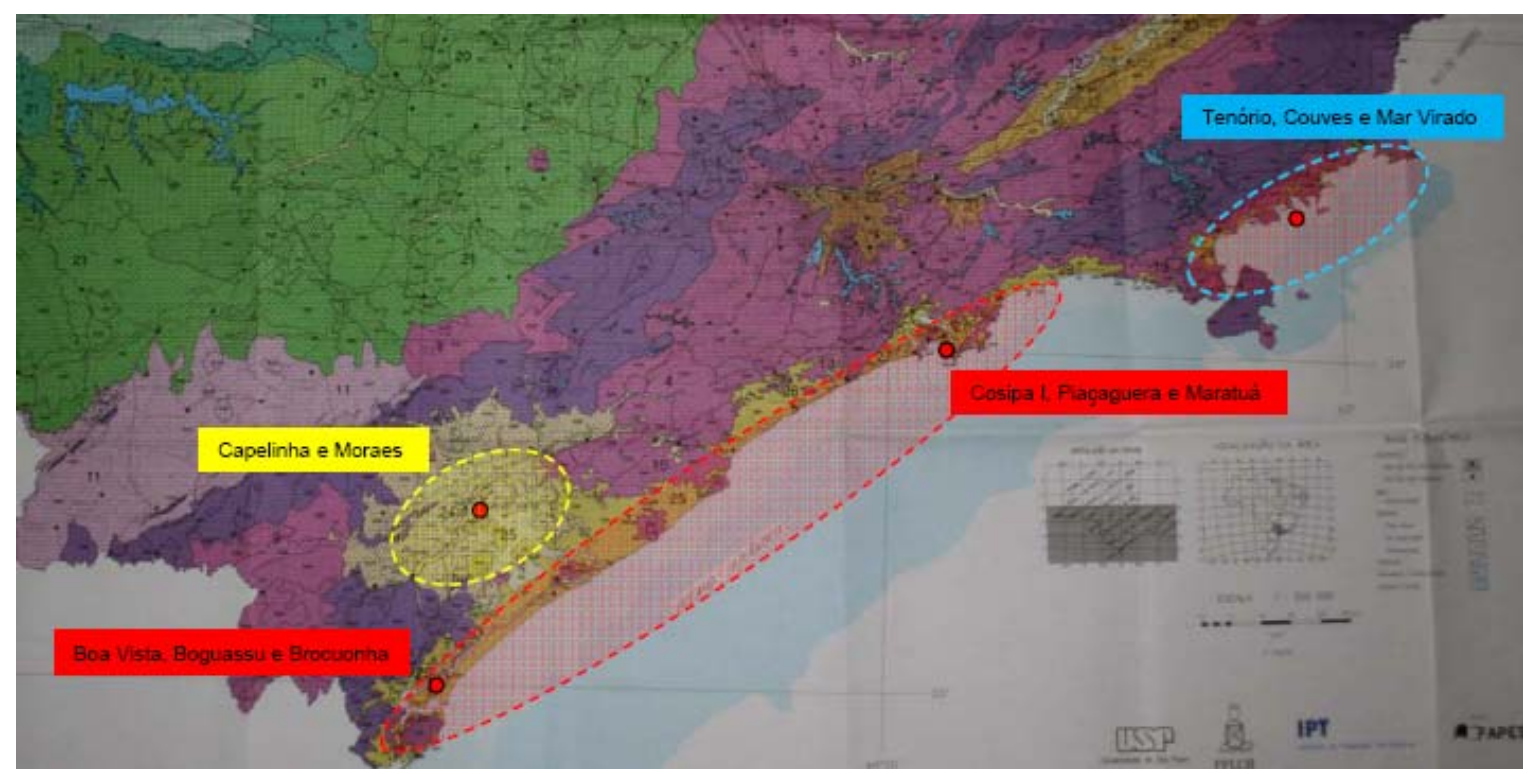

Figura 4.03 - Mapa da porção sul/sudeste do estado de São Paulo, com a correlação dos conjuntos de sambaquis (pertencentes à mesma faixa de razão isotópica de estrôncio) com os compartimentos geológicos do litoral e do Vale do Ribeira

\subsection{AS RAZÕES ISOTÓPICAS DE SÃO PAULO}

\subsubsection{As razões isotópicas do litoral de São Paulo}

Com o intuito de verificar se a análise da composição isotópica do estrôncio realmente aponta para uma separação entre os sítios do litoral, procurou-se analisar a dispersão dos conjuntos de dados relativos aos sítios do litoral (baixo Vale do Ribeira, Baixada Santista e litoral norte) a partir de uma maior resolução dos valores (figura 4.04).

Como se pode perceber no gráfico abaixo, em uma maior resolução as diferenças entre os conjuntos de sítios do litoral não só se mantém, mas tornam-se ainda mais significativas. Além de reforçar a existência de dois distintos conjuntos de sítios (litoral norte à direita e centro-sul à esquerda), os diferentes distanciamentos entre os valores internos a cada conjunto indicam, inclusive, que, entre os sítios do litoral norte e os do litoral central e sul do estado de São Paulo poderiam também ocorrer diferenciados padrões de mobilidade. 


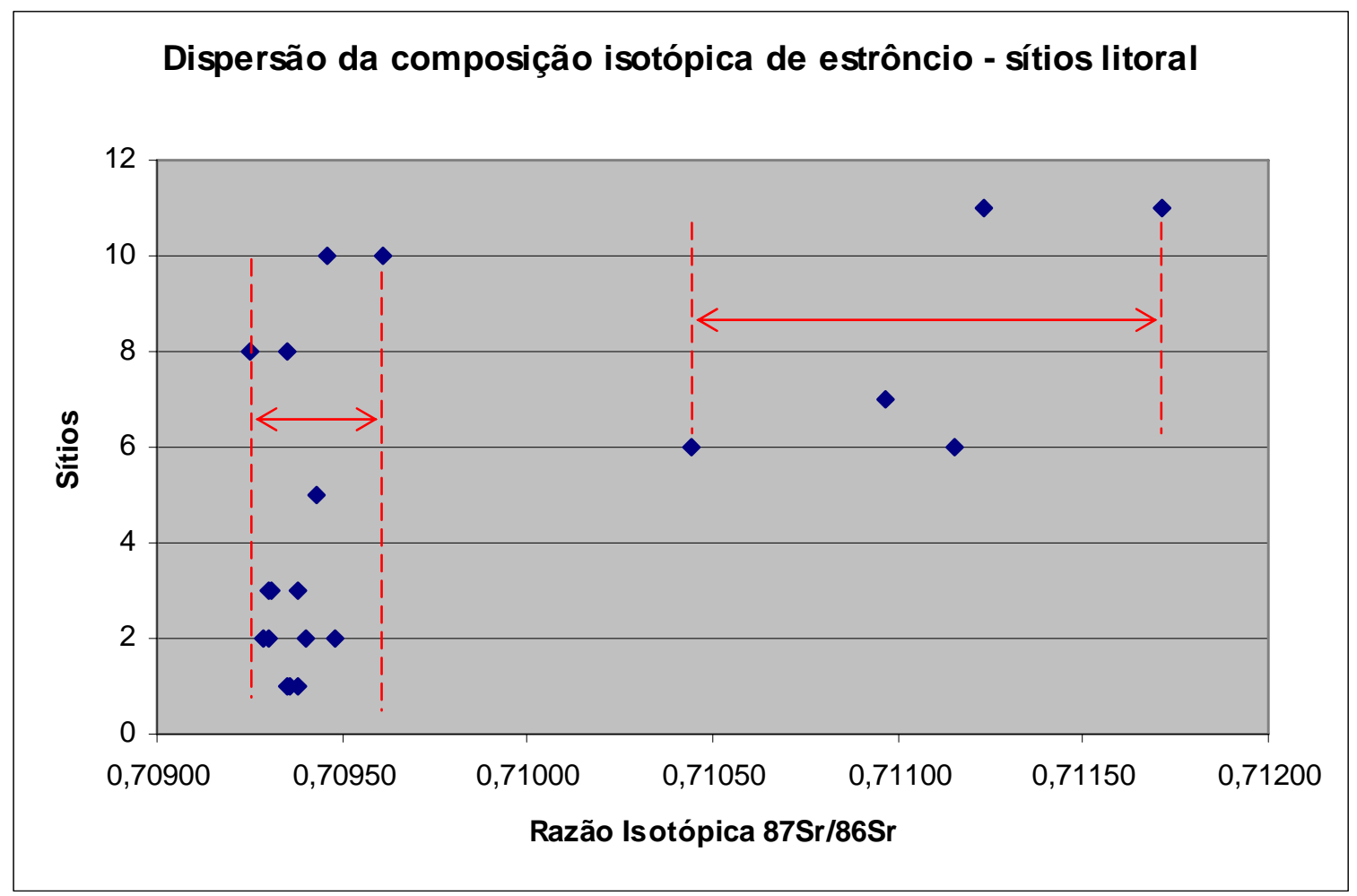

Figura 4.04 - Dispersão das razões isotópicas do estrôncio presentes nos sambaquis do litoral sul (baixo Vale do Ribeira e Baixada Santista, à direita) e do litoral norte (à esquerda). Sítios: (1) Boa Vista; (2) Boguassu; (3) Brocuonha; (5) Cosipa I; (6) Couves; (7) Mar Virado; (8) Maratuá; (10) Piaçaguera; (11) Tenório

Além disso, como a amplitude dos valores de cada um desses conjuntos é menor do que a distância entre os seus pontos médios, seria pouco provável que os padrões de mobilidade entre os indivíduos dessas diferentes áreas fossem resultado dos mesmos processos e contextos. Para que ambos pudessem ser entendidos como parte de um único contexto sócio-cultural (onde, pelo menos, houvesse a predominância de contatos mais freqüentes e duradouros), os valores referentes a ambos deveriam apresentar uma distribuição mais linear e verticalizada. Indicando, assim, que compartilhariam com mais freqüência fontes comuns de estrôncio.

No entanto, como isso não acontece, permanecendo a distribuição das razões isotópicas bem diferentes (ao menos duas vezes menor que a distância entre elas), o mais provável é que o contato entre essas diferentes comunidades ou populações (incluindo aqui também os povos do médio Ribeira) se daria principalmente através 
de poucos indivíduos, de forma esporádica ou ao longo de períodos relativamente curtos.

\subsubsection{As razões isotópicas a partir de uma perspectiva temporal}

Embora a identificação desses três conjuntos tenha sido elaborada com base na distribuição espacial dos sítios, houve também uma preocupação em garantir a esse modelo uma dimensão temporal. Com esse propósito, as idades disponíveis de cada sítio foram correlacionadas aos valores das razões isotópicas. Quando houve possibilidade, tomou-se ainda a precaução de se diferenciar cronologicamente diferentes camadas de um mesmo sambaqui. Abaixo, na figura 4.05, é apresentado um gráfico que representa a distribuição temporal dessas razões isotópicas.

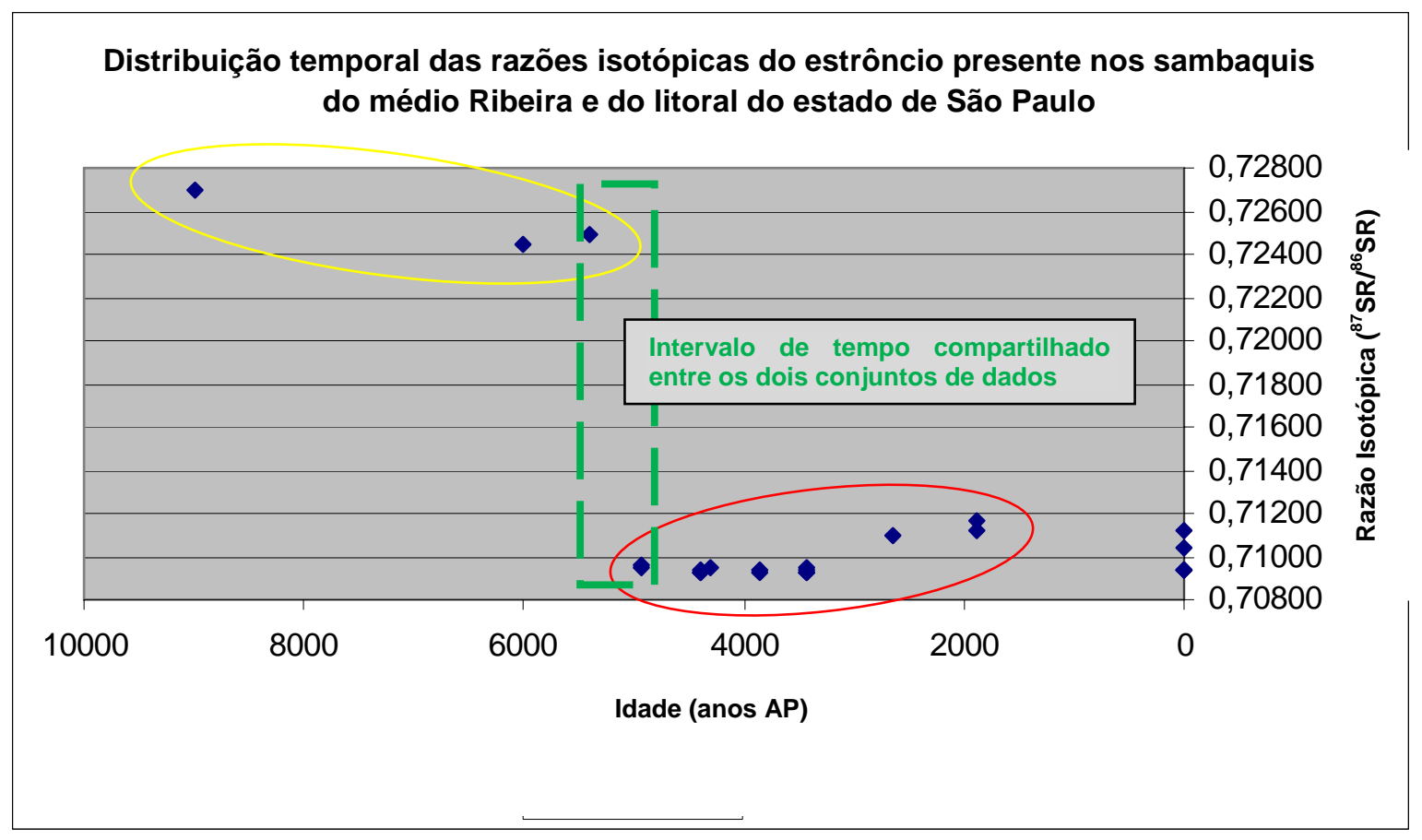

Figura 4.05 - Distribuição temporal das razões isotópicas de estrôncio: os pontos na parte superior do gráfico representam os sítios do médio Ribeira e os da porção inferior são relativos aos do litoral (norte e sul). Os pontos plotados junto ao eixo das razões isotópicas (idade igual a zero) representam as amostras não datadas.

Com base nessa figura, pode-se perceber a existência de um período em que os conjuntos do médio Ribeira e do litoral são contemporâneos. Ainda que o número 
de amostras sincrônicas a eles seja baixo (ocorrendo somente entre aproximadamente 5.000 e 6.000 anos AP), elas existem; corroborando, dessa maneira, com a hipótese de que mesmo com o passar do tempo os grupos do litoral e do médio Ribeira pertenceriam a diferentes unidades culturais ou comunidades. As quais, ainda que compartilhassem traços culturais comuns, desenvolveriam, entre si, um fluxo de mobilidade pouco significativo.

Embora a ausência de dados mais antigos ao longo do litoral e de sambaquis mais recentes no médio Ribeira possam sugerir também uma possível migração dos povos do médio Ribeira para o litoral, o mais provável é que, se tal migração realmente ocorreu, quando os sambaquieiros do médio Ribeira atingiram o litoral lá encontraram uma outra comunidade já estabelecida desde, pelos menos, 8.000 anos AP (idade do sambaqui mais antigo do litoral).

$\mathrm{Na}$ realidade, como a maioria dos sambaquis do médio Ribeira apresentam idades mais antigas que 5.000 anos AP e os sítios do litoral (pelo menos os que resistiram à elevação do nível relativo do mar do mar) começam a aumentar de número por volta dessa data, somos, em um primeiro momento, levados a acreditar que a melhor hipótese para o desaparecimento dos sambaquis fluviais estaria relacionada à migração de seus construtores para o litoral.

No entanto, a força dessa associação reside unicamente na compreensão de que os sambaquieiros do litoral fazem parte de uma única e homogênea sociedade sambaquieira, onde os povos do médio Ribeira seriam somente uma porção (inicial ou secundária) dessa sociedade que se instala em um ambiente mais elevado e longe do mar.

Em nossa compreensão, que, nesse caso, se fundamenta principalmente no estudo das últimas grandes variações holocênicas do nível do mar e na idéia de que essa sociedade sambaquieira maior seria formada por diversas comunidades ou subsistemas regionais, a idéia de uma migração não é a única opção a ser considerada. Pois, além da possibilidade de que dos povos dos sambaquis do interior terem migrado em direção ao litoral, existe também chances de que tenham sido absorvidos ou, a partir de diversos fatores, razões e modos, dado origem a outros povos. 
Embora existam poucos dados isotópicos referentes ao período entre 6.000 e 5.000 anos $\mathrm{AP}$, em teoria, os sítios relativos a esse período comum deveriam apresentar valores de razão isotópica mais próximos. Isso porque, se uma migração dessa magnitude tivesse ocorrido, parte dos indivíduos do litoral (a qual se originou no médio Ribeira) deveria apresentar razões isotópicas de estrôncio mais altas.

Como isso não acontece, não temos como afirmar ou negar a possibilidade de tal migração. Na realidade, para que possamos avançar nessa questão deveríamos ampliar o número de sítios analisados (pois, talvez, nossa amostragem tenha sido insuficiente para que um desses indivíduos tenha sido selecionado) e, nesse processo, coletar amostras de sambaquis costeiros mais antigos do que 6.000 anos AP (pois existem) e sambaquis fluviais mais recentes.

Procurando verificar se a subdivisão entre os conjuntos de sambaquis do litoral norte e do centro-sul também se mantém a partir de uma perspectiva temporal, as razões isotópicas dos sambaquis costeiros foram correlacionadas às suas idades (figura 4.06). Como resultado, encontrou-se um comportamento gráfico bastante semelhante ao identificado na correlação entre os sítios do médio Ribeira e do litoral.

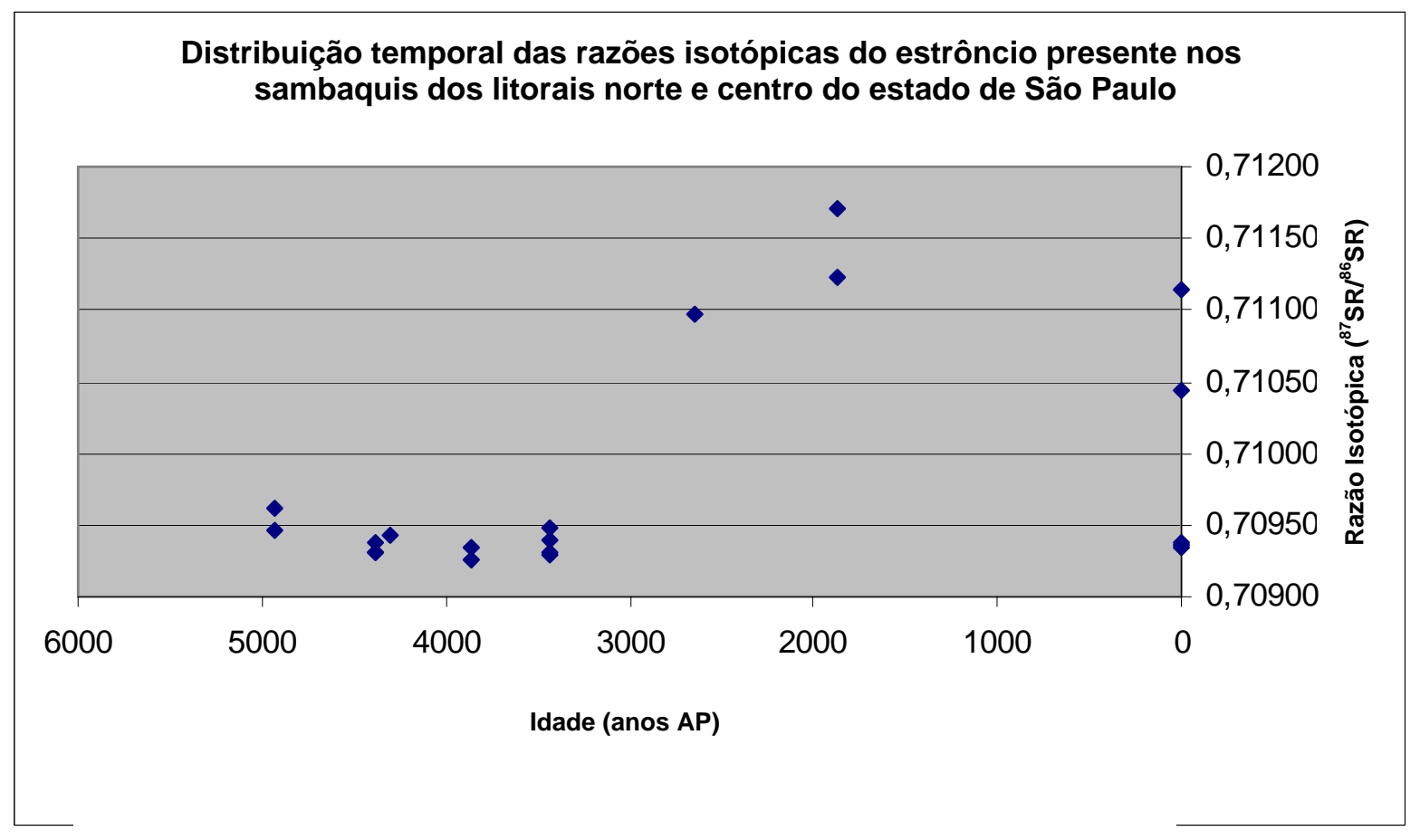

Figura 4.06 - Distribuição temporal das razões isotópicas de estrôncio: os pontos na parte superior 
do gráfico (esquerda) representam os sítios do litoral norte e os da porção inferior (direita) são relativos aos do litoral centro e sul. Os pontos plotados junto ao eixo das razões isotópicas (idade igual a zero) representam as amostras não datadas.

Nesse caso, no entanto, a situação é um pouco mais complexa. Embora as razões isotópicas de ambos os conjuntos sejam diferentes, devido ao número reduzido de amostras datadas obtidas para o litoral norte e à amplitude das idades de ambos os conjuntos, o intervalo de tempo referente ao contato entre os dois conjuntos é muito grande (em relação aos períodos de tempo apontados pelas idades dos sítios. Nesse sentido, torna-se complicado estabelecer qualquer consideração a respeito da possibilidade dos sítios do litoral norte terem se originado a partir dos sítios do litoral central.

Embora, em uma primeira análise, a maior antiguidade dos sítios da porção centro-sul possa sugerir a ocupação sambaquieira de Cananéia como a origem da presença sambaquieira no litoral norte, é importante ressaltar que a ausência de sambaquis mais antigos nessa porção possa ser uma decorrência do processo de formação do registro arqueológico dessa região (destruição de sítios pela densa ocupação litorânea e/ou pela ação dos eventos de variação do nível relativo do mar). Além disso, como veremos mais adiante, no Capítulo 6 (Modelo de Predição) é importante termos em mente que, talvez, a ocupação do litoral norte pode estar mais associada à presença sambaquieira do litoral sul e centro do estado do Rio de Janeiro do que a São Paulo.

\subsubsection{A dispersão das razões isotópicas de cada conjunto}

Além da análise temporal das razões isotópicas existe ainda outra questão que deve ser explorada no âmbito das correlações entre os conjuntos de sambaquis do estado de São Paulo, a qual diz respeito aos diferentes padrões de dispersão entre os valores das razões isotópicas dos sambaquis do médio Ribeira, do litoral centro-sul e do litoral norte.

Antes de avançarmos nessa questão, é importante ressaltar que qualquer discussão a respeito da possibilidade de migrações é aqui vista com cautela. Isso 
porque, além do reduzido número de amostras analisadas, não foi o propósito desta Tese estabelecer um preciso controle das assinaturas isotópicas das rochas e dos sedimentos do entorno dos sambaquis - condição que nos permitiria identificar um padrão para cada sambaqui e apontar aqueles indivíduos que mais se distanciariam do sítio.

Entretanto, ainda que não possamos estabelecer dados conclusivos em relação à interação entre os conjuntos de sambaquis, por outro lado, em conseqüência das regiões em que se inserem configurarem-se como ambientes costeiros completamente diferentes, podemos também utilizar as distâncias entre os valores das razões isotópicas como um indicador dos padrões de mobilidade internos a cada conjunto de sambaquis.

Assim, quando analisamos a distribuição das razões isotópicas para o litoral do estado de São Paulo (figura 4.07) podemos perceber, mesmo em uma análise visual, que o padrão de dispersão dos valores do litoral norte é diferente dos sítios do restante do litoral. Enquanto os sítios do litoral sul e centro (à esquerda) encontram-se agrupados (o espalhamento vertical, no caso desse gráfico, foi introduzido somente com a idéia de diferenciar os sítios), os sambaquis do norte encontram-se distribuídos ao longo de uma faixa mais horizontal. Sugerindo, dessa maneira, uma maior mobilidade interna na região entre as ilhas ou talvez uma maior presença dos sambaquieiros nos ambientes mais ao sul.

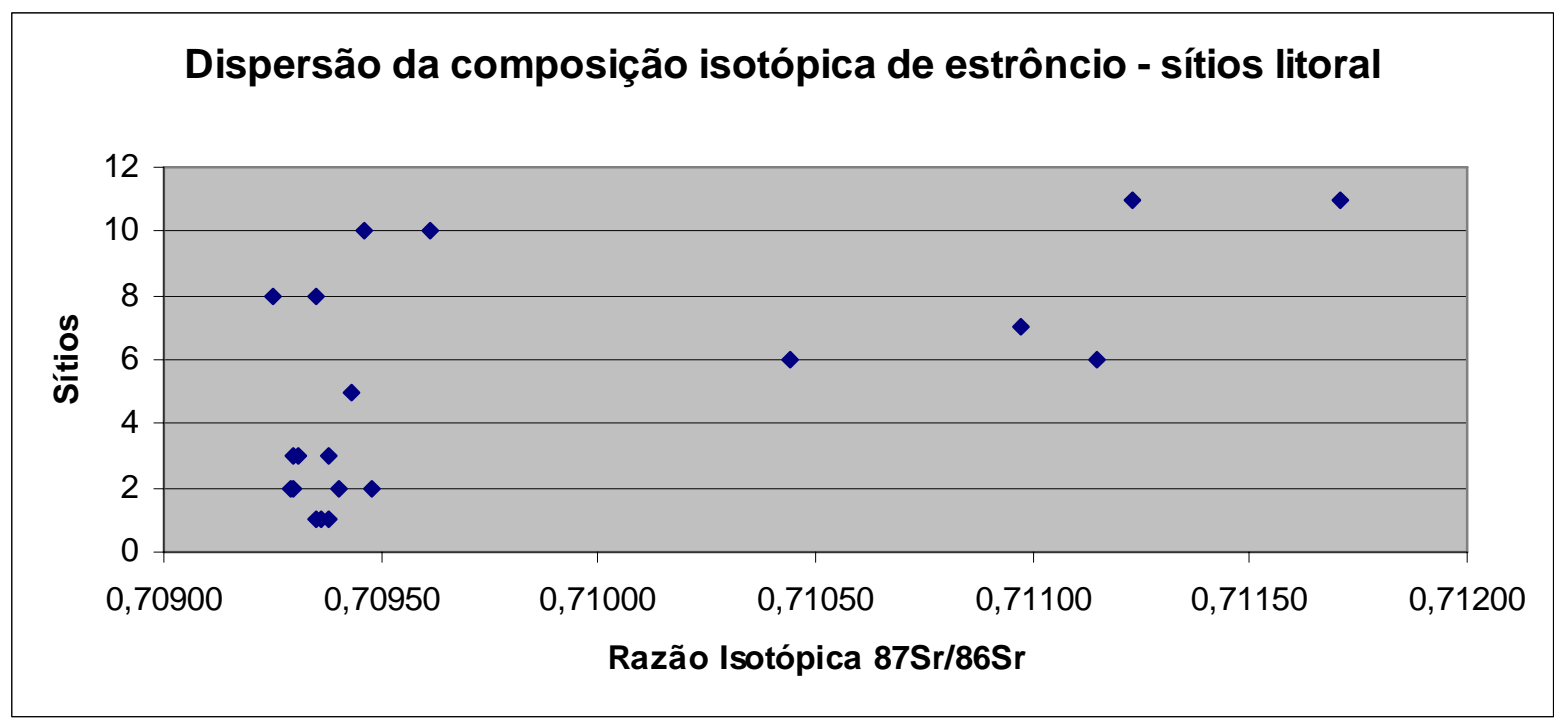


Figura 4.07 - Dispersão das razões isotópicas do estrôncio presentes nos sambaquis do litoral norte (direita) e centro-sul (esquerda). Sítios: (1) Boa Vista; (2) Boguassu; (3) Brocuonha; (5) Cosipa I; (6) Couves; (7) Mar Virado; (8) Maratuá; (10) Piaçaguera; (11) Tenório

Uma Interpretação que condiz com a própria configuração geomorfológica do litoral norte, onde, em vez de extensas praias arenosas, desenvolvem-se inúmeras ilhas e pequenas praias. As quais, em um primeiro olhar (de quem vê esses ambientes somente a partir de uma perspectiva de quem está em terra), podem ser entendidas como uma barreira natural que viria a isolar, cada vez mais, as diversas pequenas comunidades de sambaquieiros do litoral norte.

Em relação a essa questão, existe ainda outra possibilidade para explicar essa dispersão diferencial do litoral norte. Como os ambientes do litoral norte apresentam uma configuração mais heterogênea, é provável que esta distribuição dos valores isotópicos possa ser condicionada pela própria distribuição natural das razões isotópicas do estrôncio na região.

Embora a correlação das razões isotópicas do estrôncio ao longo do litoral possa propiciar diferentes hipóteses a respeito da territorialidade e da mobilidade dos sambaquieiros (algumas até, de certo modo, contraditórias), neste momento, não procuramos adotar ou defender apenas uma delas. Pois, como veremos no Capítulo 6 (Modelo de Predição), é possível que grande parte delas esteja relacionada também a uma maior exploração e domínio dos ambientes marinhos mais abertos. Tal exploração, provavelmente, teria ocorrido em conseqüência da adoção, desenvolvimento ou aprimoramento das técnicas e tecnologias de construção naval e de navegação utilizadas nas incursões ao longo do litoral norte do estado de São Paulo.

Procurando investigar se um comportamento semelhante poderia ser atribuído aos sítios do litoral sul, abaixo (figura 4.08), são apresentadas as razões isotópicas do estrôncio presente nos sambaquis do baixo Vale do Ribeira e da Baixa Santista. 


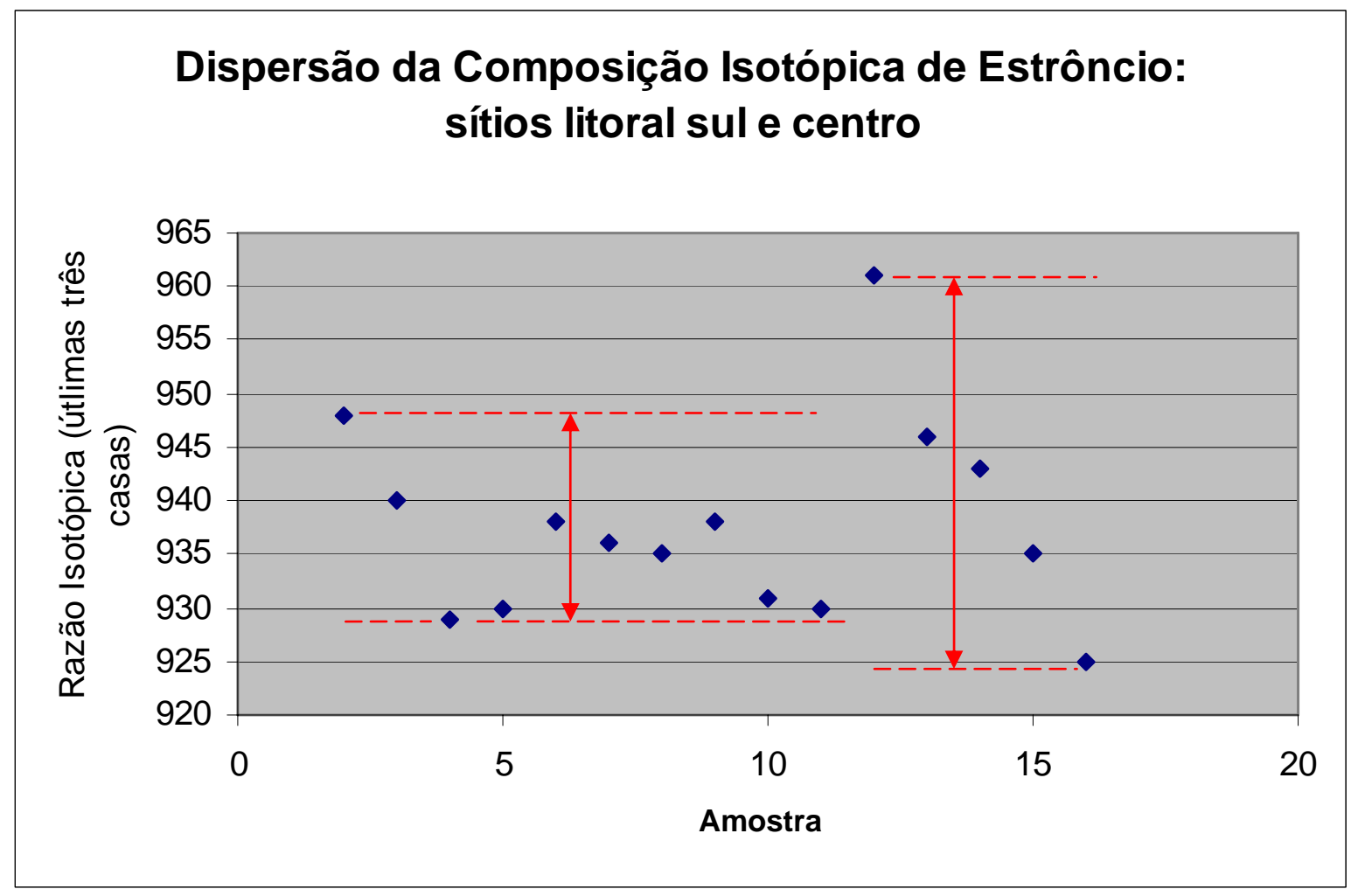

Figura 4.08 - Amplitude dos valores das razões isotópicas do estrôncio presente nos sítios do litoral sul e centro do estado de São Paulo. No gráfico, o conjunto da esquerda refere-se às amostras provenientes dos sítios do litoral sul e o da direita diz respeito às do litoral centro

Como podemos perceber a partir da distribuição das razões isotópicas na figura 4.08, parece não haver (sem a realização de testes estatísticos) uma substancial diferença (se comparada a do litoral norte) entre os sítios do baixo Vale do Ribeira (esquerda: amostras 2 a 11) e da Baixa Santista (direita: amostras 12 a 16).

Embora existam diferenças entre os dois conjuntos, em média as distancias entre os valores isotópicos são semelhantes. Indicando, assim, que o padrão de mobilidade entre esses dois agrupamentos de sambaquis é maior do que o padrão identificado internamente no conjunto de sambaquis do litoral norte. Abordando essas questões em uma perspectiva hipotética, com base em tais comparações, talvez, possamos começar a discutir a possibilidade de que os sambaquis do sul poderiam vir a compor um conjunto mais coeso de pequenas comunidades costeiras, não tão adaptadas aos ambientes marítimos como os sambaquieiros do litoral norte. 
No que tange especificamente à comparação entre os dois subconjuntos do litoral centro-sul (baixo Ribeira e Baixada Santista) (figura 4.08, acima), veremos que as dispersões de suas razões isotópicas, mais do que de serem aproximadamente semelhantes (sendo somente um pouco maior no caso da Baixada Santista), apresentam, também, uma maior proximidade do que se comparadas as do litoral norte. Evidenciado que, em ambos os conjuntos do sul, os sambaquieiros relativos às essas pequenas comunidades poderiam apresentar menores territórios (se deslocando menos ao longo de toda a sua região) e/ou, então, estariam circunscritos a uma região em que as fontes de estrôncio poderiam ser mascaradas pela homogeneidade dos depósitos geológicos.

\subsection{AS RAZÕES ISOTÓPICAS DE SÃO PAULO VERSUS SANTA CATARINA}

No intuito de aprofundar a discussão da hipótese da existência de três comunidades sambaquieiras (duas costeiras e uma fluvial) ao longo do litoral do estado de São Paulo e do Vale do Ribeira, foram também utilizados, como elemento comparativo, os dados produzidos por Bastos (2009) a respeito das razões isotópicas de estrôncio registradas ao longo das diversas camadas do sambaqui Forte Marechal Luz e de seu entorno (litoral norte do estado de Santa Catarina) (figura 4.09). 


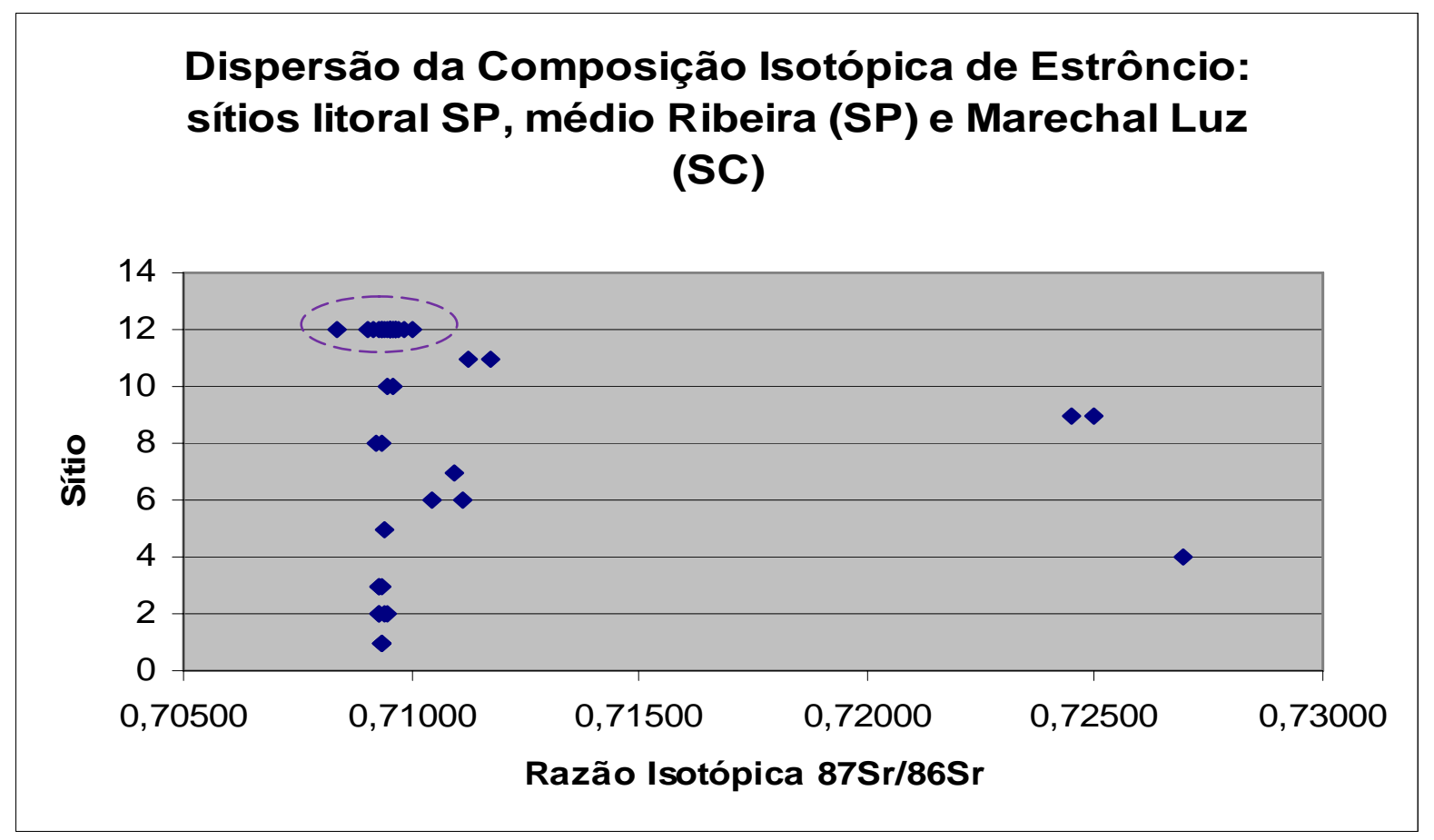

Figura 4.09 - Dispersão da razão isotópica do estrôncio presentes nos sambaquis do estado de São Paulo e do litoral de Santa Catarina (esquerda - sítios do litoral de São Paulo e Santa Catarina; direita - sítios do médio Ribeira). Os dados referentes ao sítio forte Marechal Luz se encontram dentro da área tracejada

Tendo como a base a figura 4.09, podemos perceber, de imediato, uma forte semelhança no comportamento dos dados referentes aos sítios do litoral de São Paulo e de Santa Catarina (à esquerda do gráfico) em contraposição aos sambaquis fluviais do médio Vale do Ribeira (à direita). Distribuição que, de imediato, reforça a idéia de que haveria uma real separação entre os povos dos sambaquis da costa e os fluviais.

Embora, nesse caso, pareça não haver sentido em se estabelecer uma correlação mais precisa entre as razões isotópicas do Forte Marechal Luz com as dos sambaquis fluviais do Ribeira (pois, é pouco provável que tivessem mantido um contato maior do que com os sambaquieiros do baixo Ribeira), são as semelhanças com os grupos do litoral (identificadas em oposição às razões isotópicas dos sambaquis fluviais) o que mais nos interessa.

Em primeiro lugar, porque, de modo contrário à análise realizada no âmbito desta Tese, que enfatizou uma análise com número restrito de amostras e sítios de diversas regiões, Bastos (2009, p. 53) realizou um total de 32 análises isotópicas no 
esmalte dentário de diversos indivíduos (sendo 21 referentes a níveis pré-cerâmicos e 11 a uma ocupação ceramistas mais recente) de apenas um sítio. Um conjunto amostral que permitiu estabelecer considerações mais precisas em relação ao comportamento dos indivíduos daquele sítio. As quais, por assumirem um padrão semelhante aos dos sambaquis do litoral do estado de são Paulo, reforçariam as hipóteses que foram estabelecidas a partir dos sítios paulistas.

Assim, quando analisamos somente a distribuição das razões isotópicas referentes à ocupação sambaquieira do sítio do Forte Marechal Luz, vemos que esse padrão de baixa mobilidade (razões isotópicas semelhantes), que foi inferido para os sambaquis de São Paulo, também se confirma quando um maior número de dados é levado em consideração. Ou seja, embora tenhamos realizado um pequeno número de amostras para estabelecer as hipóteses de mobilidade ao longo do litoral do estado de São Paulo, elas são confirmadas por uma análise similar realizada com um número bem maior de dados.

Em segundo lugar, porque Bastos (op. cit.) analisou razões isotópicas referentes a dois contextos arqueológicos distintos (pré-ceramistas e ceramistas), cuja distribuição indica um padrão de mobilidade diferenciado entre os sambaquieiros e à ocupação associada a níveis cerâmicos mais recentes (figura 4.10). Um comportamento esperado, afinal, tradicionalmente se acredita, na Arqueologia brasileira, que os sambaquieiros, coletores pescadores ou pescadores coletores possuiriam uma mobilidade maior que a de grupos ceramistas.

No entanto, não é bem isso que os dados apresentados por Bastos mostram. Embora haja uma real diferença na dispersão entre esses dois conjuntos, a maior amplitude dos valores das razões isotópicas relativa aos indivíduos ceramistas indica que esses (ao contrário do que tradicionalmente se espera) desenvolveriam uma maior mobilidade. Reforçando, nesse caso, a hipótese de comunidades sambaquieiras estáveis, adaptadas aos ambientes marinhos e com territórios definidos e compartilhados entre seus membros. 


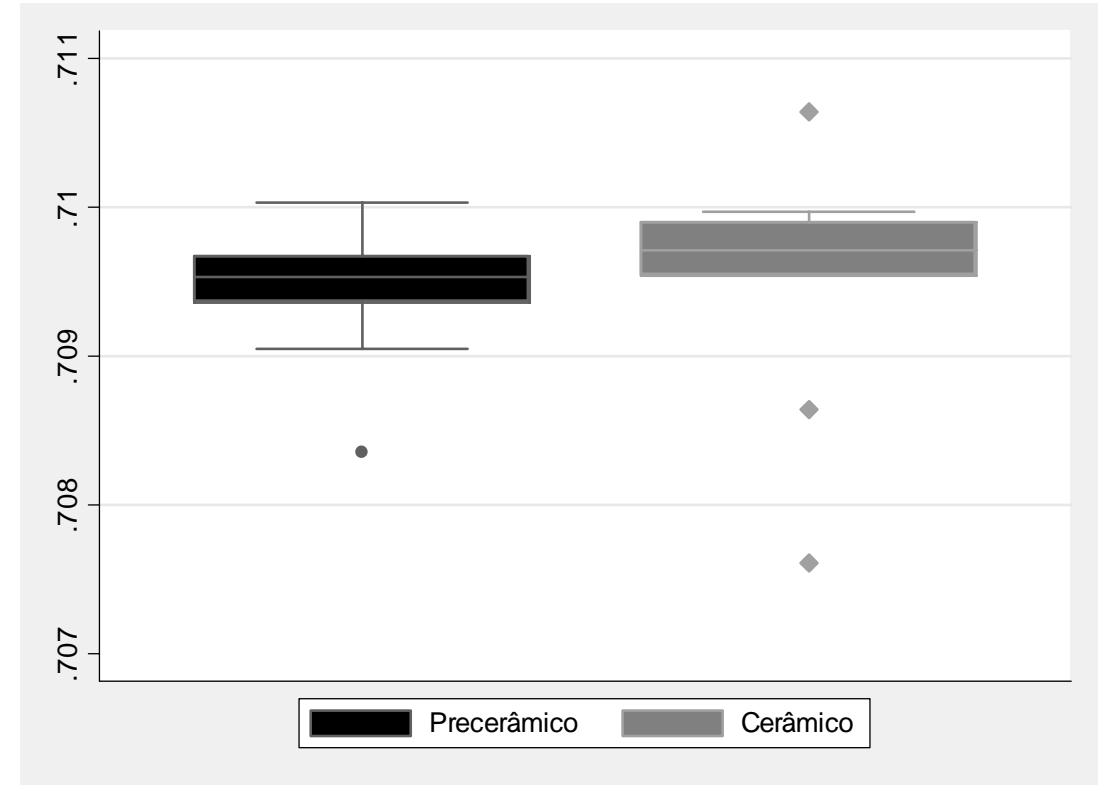

Figura 4.10 - Boxplot das razões isotópicas dos indivíduos sepultados nos níveis cerâmicos e pré-cerâmicos do sítio Forte Marechal Luz (BASTOS. 2009, p. 60).

Uma vez analisadas as semelhanças com todos os sambaquis (costeiros e fluviais), e identificadas as diferenças entre o sambaqui do Forte Marechal Luz, procurou-se aqui correlacionar, em um segundo momento, os dados desse sítio somente com os dos sambaquis do litoral do estado de São Paulo (figura 4.11). 


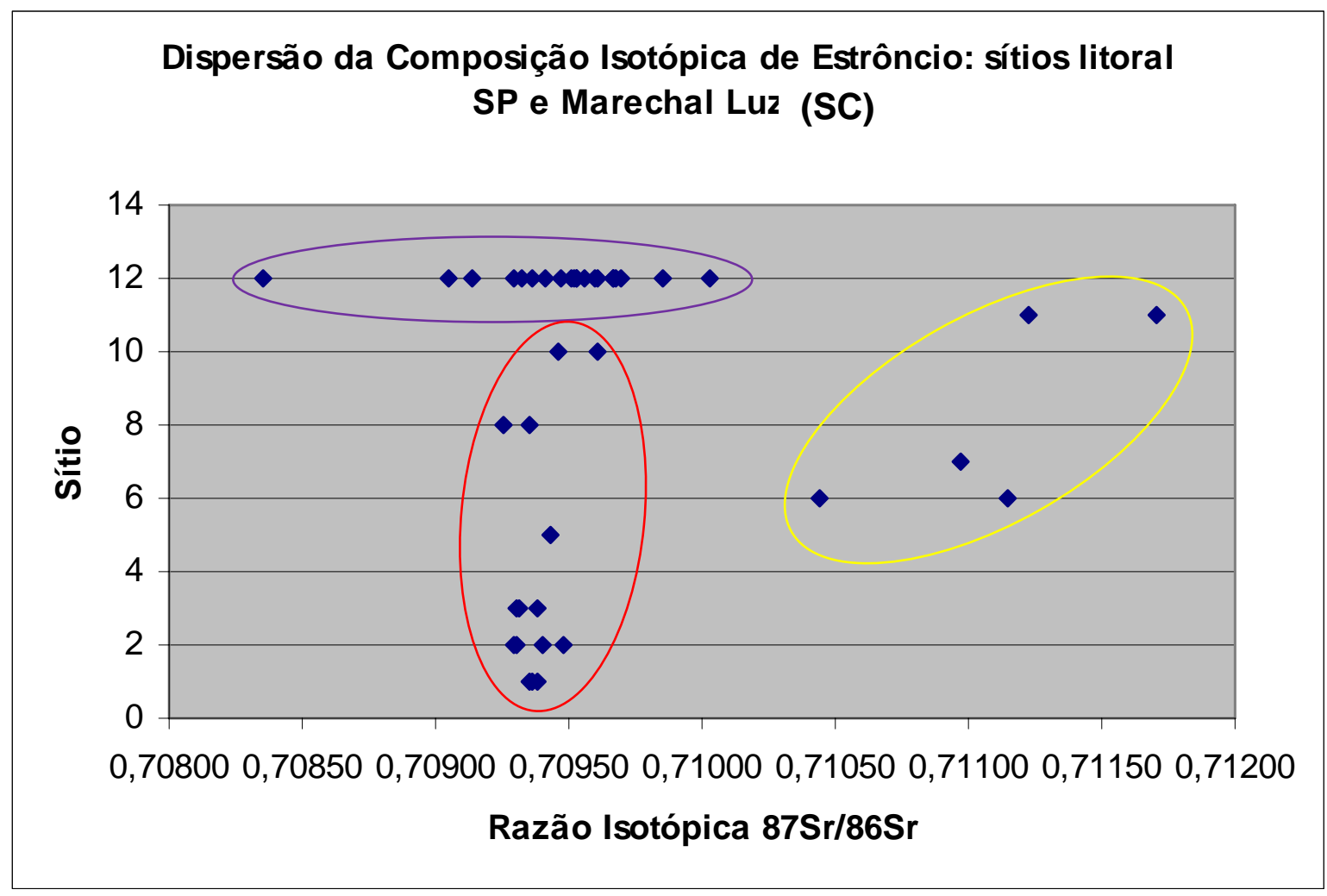

Figura 4.11 - Dispersão das razões isotópicas do estrôncio presentes nos sambaquis do litoral do estado de São Paulo (litoral norte - direita; litoral centro-sul - esquerda) e do estado de Santa Catarina (forte Marechal Luz - posição superior). Sítios de São Paulo: (1) Boa Vista; (2) Boguassu; (3) Brocuonha; (5) Cosipa I; (6) Couves; (7) Mar Virado; (8) Maratuá; (10) Piaçaguera; (11) Tenório

$\mathrm{Na}$ figura acima, pode-se identificar uma maior proximidade entre as razões isotópicas dos indivíduos do sambaqui Forte Marechal Luz (porção superior) com as dos sambaquis do litoral sul e centro do estado de São Paulo (agrupamento à esquerda), do que com os do litoral norte (à esquerda).

Embora esses dados pareçam apontar para a configuração de uma unidade populacional que se estendia da Baixada Santista até, pelo menos, o norte do estado de Santa Catarina, entendemos que esta compreensão deve ser tratada como uma hipótese a ser verificada. Isso porque, na realidade, para o estabelecimento da presente análise não estão sendo levadas em consideração as razões isotópicas das rochas e sedimentos de cada região. Assim, não temos como saber (com a precisão necessária para o estabelecimento dessa correlação) se essa semelhança é fruto de uma real convivência entre as populações do sul de São 
Paulo, Paraná e norte de Santa Catarina ou se assim configura-se em conseqüência da homogeneidade das planícies costeiras que se desenvolvem ao longo de todo esse trecho de litoral.

Por outro lado, mesmo não podendo traçar correlações diretas entre essas áreas, podemos discutí-las a partir de suas diferenças em relação ao contexto dos sambaquis do litoral norte de São Paulo. Como a região sul de são Paulo e a planície costeira norte do Paraná apresentam uma dispersão das razões isotópicas que não coincidem em nenhum momento com a região norte do estado de São Paulo, essa diferença reforça a compreensão da existência de, pelo menos, dois distintos conjuntos de sambaquis (ou, talvez, de duas comunidades marítimas) ao longo do litoral de São Paulo. Não somente pela inclusão, nessa análise, de um outro conjunto de sítios (norte de SC), mas, sobretudo, pela inclusão de um conjunto com um número muito maior de dados (32 amostras).

Com base na figura 4.11, verifica-se também que, embora os valores máximos e mínimos das razões isotópicas do Forte Marechal Luz excedam os limites de distribuição dos valores dos sítios da região sul de São Paulo, em nenhum momento eles assumem valores semelhantes aos do sítio do litoral norte. Reforçando, assim, o entendimento de que, mesmo aumentando o número de amostras na região sul de São Paulo (o que, provavelmente, aumentaria os valores mínimos e máximos), os valores das razões isotópicas dos conjuntos do norte e do sul do litoral de são Paulo não se fundiriam.

\subsection{ANÁLISE COMPARATIVA ENTRE OS TIPOS DE VESTíGIOS ANALISADOS}

Embora a análise das razões isotópicas do estrôncio presente nos esqueletos dos sambaquieiros tenha permitido o estabelecimento de correlações entre as diversos conjuntos de sítios e de novas hipóteses a respeito da organização dos povos dos sambaquis, tal análise foi inicialmente desenvolvida de modo experimental. Desde o princípio de seu desenvolvimento, nossa principal proposta 
consistia na avaliação e adequação de tal metodologia para sua utilização ao longo do litoral brasileiro.

A aplicação de tal metodologia resultou em dados que superaram as expectativas iniciais, os quais se devem, principalmente, à diversidade das formações geológicas da região sudeste do Brasil e do mosaico de razões isotópicas de estrôncio por elas gerado. Se tal diversidade não existisse, o mais provável é que, mesmo os conjuntos de sambaquis não compartilhando áreas comuns, as razões isotópicas de estrôncio apresentariam dados uniformes. Indicando, assim, um resultado falso.

Devido ao caráter experimental e adaptativo dessa metodologia para a situação brasileira, além da analise de sítios localizados em diferentes contextos geológicos, buscou-se, também, utilizar como amostra, elementos de diferentes naturezas (ossos densos, ossos porosos e diferentes partes dos dentes). Esses, mesmo estando associados a populações humanas circunscritas a uma mesma região, poderiam vir a apresentar razões isotópicas mais ou menos diferentes.

Em geral, existem duas possibilidades que poderiam estar associadas à ocorrência de razões isotópicas diferentes a um único local. Em primeiro lugar, as amostras poderiam ter sido contaminadas por razões isotópicas de sedimentos trazidos para os sítios ou de sedimentos dos próprios sítios (no caso de indivíduos vindos de outros locais). Situações que, na realidade, não se aplicam a análise em questão, pois, os dados, em geral, apresentam-se muito coesos e associados a conjuntos distintos.

Em segundo lugar, poderia haver razões isotópicas diferentes em conseqüência da perda ou ganho do elemento estrôncio em conseqüência da capacidade diferencial de cada tipo de osso em realizar trocas com os sedimentos do sítio. Como aqui não estamos levando em consideração que um mesmo individuo possa ter estado em diferentes áreas ao longo de sua vida (capturando razões isotópicas diferentes em ossos e dentes), pois, os dados sugerem um baixo padrão de mobilidade inter-regional; a única possibilidade de distorção dos dados que necessita ainda ser avaliada diz respeito ao estabelecimento de uma comparação 
entre as razões isotópicas dos diferentes tipos de ossos (densos e porosos) e partes dos dentes (esmalte, dentina, raiz).

Abaixo, na figura 4.12, é apresentado um gráfico de dispersão das razões isotópicas referentes a esses diferentes tipos de ossos e dentes. 


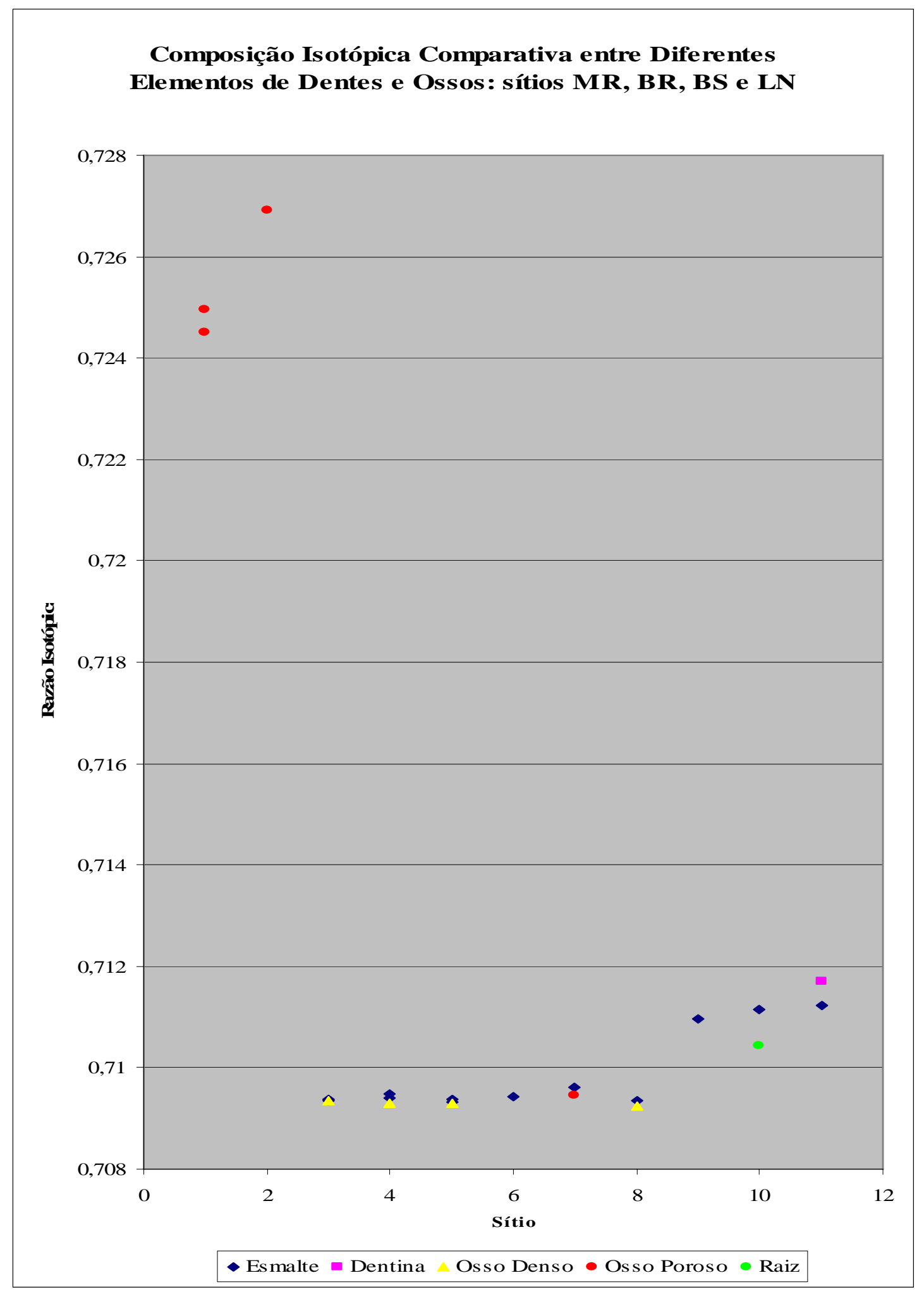

Figura 4.12 - Razões isotópicas do estrôncio relativo aos diferentes tipos de ossos e dentes analisados (sítios do litoral e médio ribeira). Sítios: (1) Moraes; (2) Capelinha; (3) Boa Vista; (4) Boguassu; (5) Brocuonha; (6) Cosipa I; (7) Piaçaguera; (8) Maratuá; (9) Mar Virado; (10) Couves; (11) Tenório 
Com base nesse gráfico (figura 4.12), podemos perceber que, embora haja diferenças entre os tipos de ossos e dentes (de um mesmo conjunto de sambaquis), as diferenças entre seus valores isotópicos são inferiores às que as que se estabelecem entre os conjuntos de sítio. Ou seja, apesar de existirem variações nas razões isotópicas dentro de um mesmo sítio ou interna aos conjuntos de sítios, tais variações não se aproximam das razões identificadas nos outros conjuntos (conjunto acima, médio Vale do Ribeira; à esquerda, litoral sul e centro; à direita, litoral norte). Reforçando, assim, o entendimento de que realmente se estabeleceu um padrão de baixa mobilidade entre os sambaquis.

Analisando (em outra escala) somente os dados referentes aos sítios do litoral, podemos verificar a repetição desse padrão (figura 4.13). Embora haja diferenças entre os sítios de um mesmo conjunto, elas são muito menores do que as diferenças entre os conjuntos de sítio (litoral sul, à esquerda; litoral norte, à direita). 


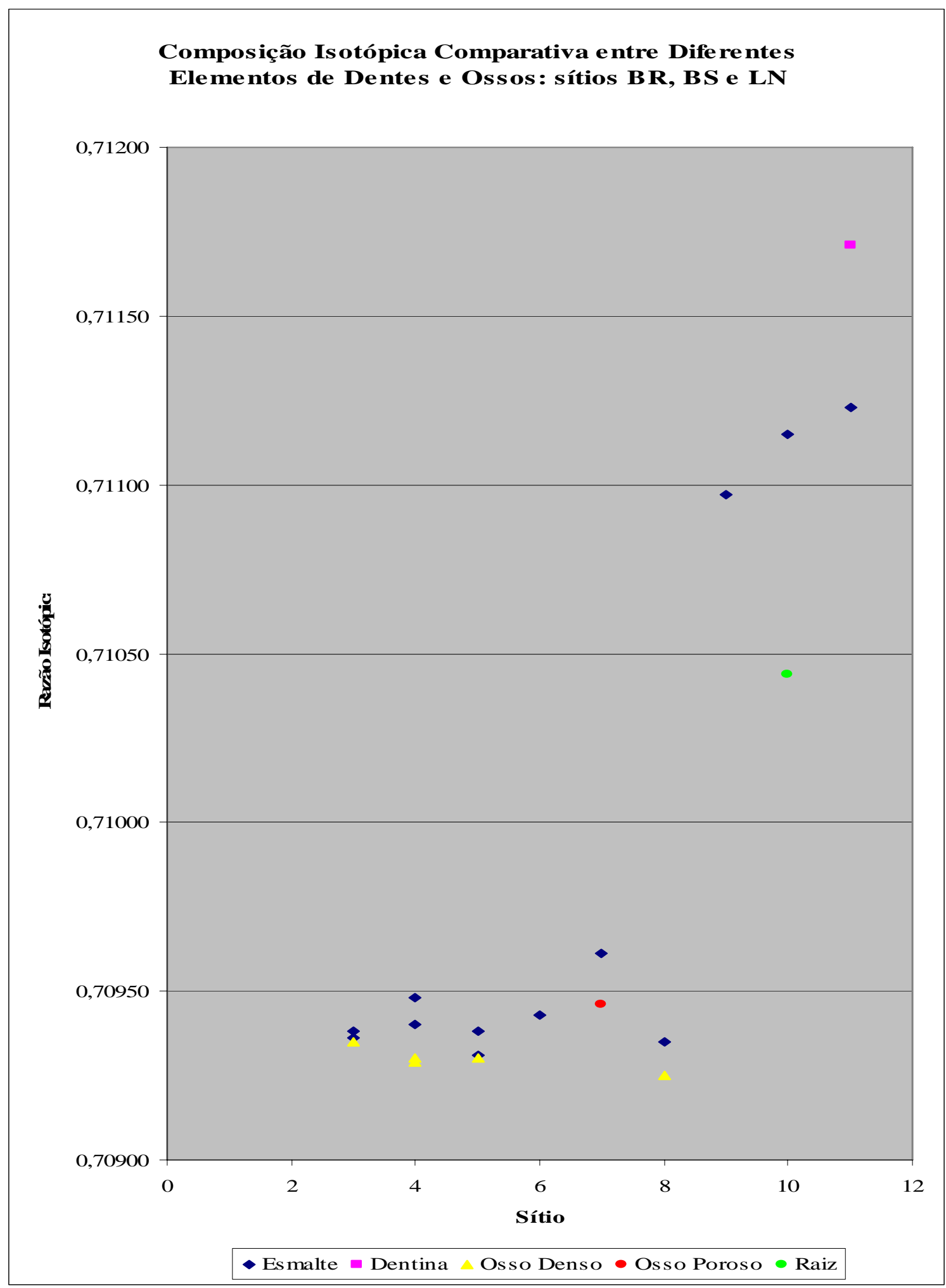

Figura 4.13 - Razões isotópicas do estrôncio relativo aos diferentes tipos de ossos e dentes analisados (sítios do baixo Ribeira, Baixada Santista e litoral norte). Sítios: (3) Boa Vista; (4) Boguassu; (5) Brocuonha; (6) Cosipa I; (7) Piaçaguera; (8) Maratuá; (9) Mar Virado; (10) Couves; (11) Tenório 
No sentido de compreender o comportamento dessas variações nos valores das razões isotópicas, foram plotados no gráfico a seguir (figura 4.14) somente os dados referentes a um conjunto de sambaquis (Baixada Santista e do baixo Vale do Ribeira). Os quais, de um modo geral, indicaram que parece haver um padrão diferencial de absorção das razões isotópicas de estrôncio. Pois, ainda que flutuações sejam comuns de sítios para sítio, os dados indicam uma tendência dos valores mais elevados em cada sítio serem encontrados no esmalte e depois nos ossos densos ${ }^{37}$.

\footnotetext{
${ }^{37}$ Nessa interpretação foram considerados somente os dados referentes ao esmalte e aos ossos densos. Embora tenham também sido identificados valores isotópicos em ossos porosos e dentina, não há uma mínima recorrência desses indicadores que possa sustentar uma correlação segura entre eles e as partes anatômicas adotadas como referência.
} 


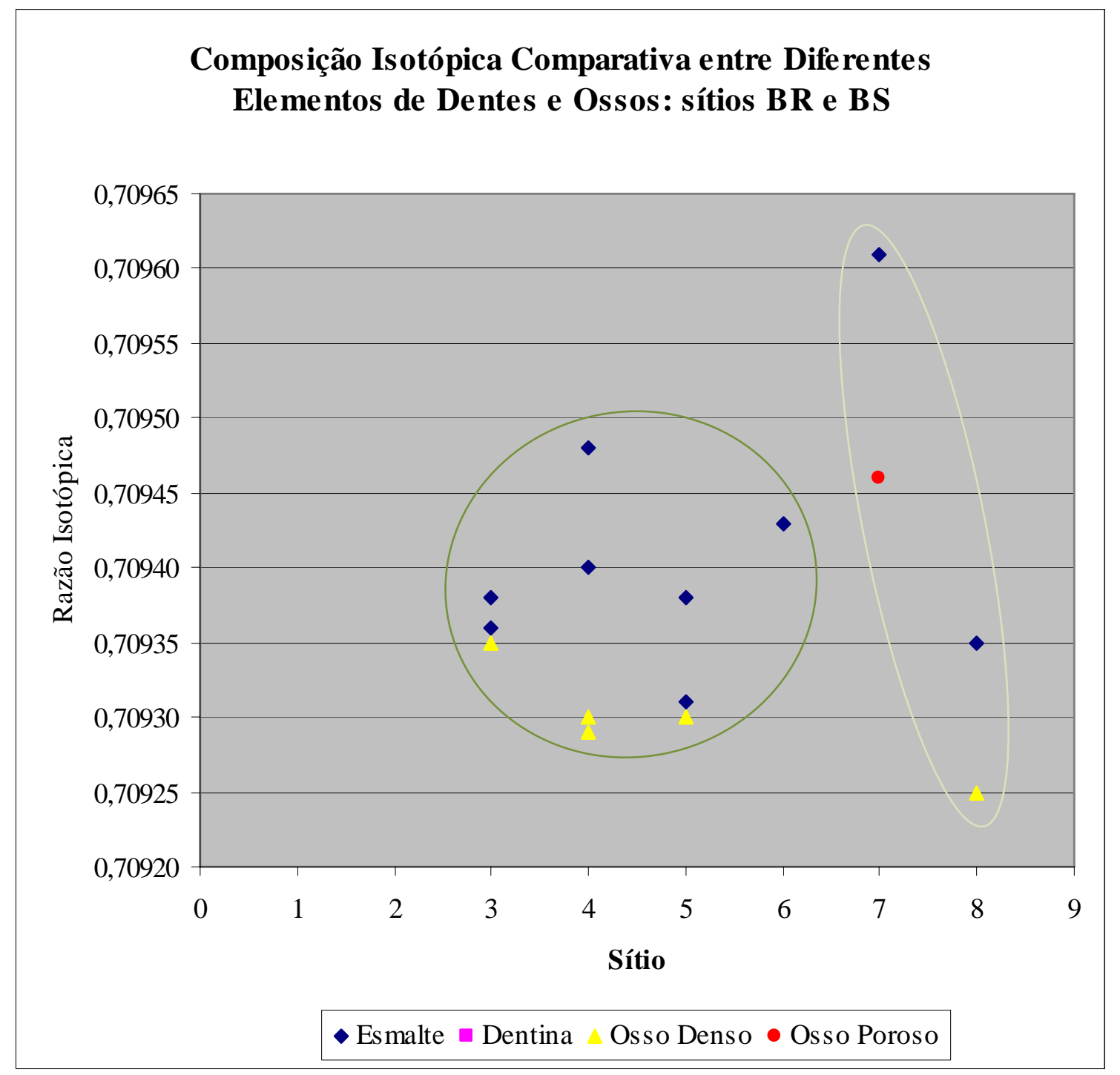

Figura 4.14 - Razões isotópicas do estrôncio relativo aos diferentes tipos de ossos e dentes analisados (sítios do baixo Ribeira e Baixada Santista). Sítios: (3) Boa Vista; (4) Boguassu; (5) Brocuonha; (6) Cosipa I; (7) Piaçaguera; (8) Maratuá

Um comportamento que parece indicar que tais flutuações (intra-sítio e internas aos conjuntos) devam estar mais associadas a uma absorção diferencial de cada tipo anatômico (dentes, ossos e suas partes) do que a contaminações provenientes da intrusão de sedimentos externos ao contexto geológico do sítio ou a indivíduos que absorveram razões isotópicas provenientes de outras regiões. 


\section{ISÓTOPOS ESTÁVEIS}

Procurando dar continuidade à análise de evidências relativas aos processos culturais de formação do registro arqueológico que, no âmbito desta Tese, se iniciaram com a discussão da mobilidade dos povos dos sambaquis (estabelecida a partir das razões isotópicas do estrôncio), serão aqui apresentados e discutidos os resultados referentes à análise dos isótopos estáveis de carbono $\left({ }^{13} \mathrm{C} /{ }^{12} \mathrm{C}\right)$ e oxigênio $\left({ }^{18} \mathrm{O} /{ }^{16} \mathrm{O}\right)$, utilizados, principalmente, com a intenção de se investigar as percepções ambientais desenvolvidas pelos povos dos sambaquis.

Como estratégia de pesquisa, buscamos analisar somente um dos três conjuntos de sambaquis apontados pela análise da composição isotópica do estrôncio. O conjunto selecionado se refere ao Baixo Vale do Ribeira, e sua escolha deu-se, principalmente, em conseqüência do grande número de amostras que já haviam sido coletadas na região de Cananéia em projetos e etapas anteriores (CALIPPO, 2004).

No total foram analisados quatro sambaquis (Cambriu Grande, Branco, Cachoeira Mirim e Ilha do Cambriu), os quais localizam-se no município de Cananéia (extremo sul do litoral do estado de São Paulo) e encontram-se associados a dois diferentes períodos da ocupação sambaquieira. Abaixo, na tabela 5.01, são caracterizadas todas essas amostras e apresentados os resultados das análises isotópicas de carbono e oxigênio.

Tabela 5.01 - Caracterização das amostras e apresentação dos resultados das análises isotópicas de carbono e oxigênio

\begin{tabular}{|c|c|c|c|c|c|c|c|c|c|}
\hline \multirow{3}{*}{ Sítio } & \multirow{3}{*}{ Testemunho } & \multirow{3}{*}{ Camada } & \multirow{3}{*}{ Nível } & \multicolumn{4}{|c|}{$\begin{array}{l}\text { Idades obtidas a partir da análise de } \\
\text { conchas }\end{array}$} & \multicolumn{2}{|c|}{$\begin{array}{c}\text { Razão } \\
\text { Isotópica }\end{array}$} \\
\hline & & & & \multicolumn{3}{|c|}{ Datação Radiocarbônica } & \multirow{2}{*}{$\begin{array}{l}\text { Idade } \\
\text { inferida }\end{array}$} & \multirow{2}{*}{$\delta 13 C$} & \multirow{2}{*}{$\begin{array}{l}\delta 180 \\
\text { (PDB) }\end{array}$} \\
\hline & & & & Conv. & $\delta 13 C$ & Obs & & & \\
\hline \multirow{6}{*}{ Branco } & \multirow{6}{*}{ T007 } & \multirow{6}{*}{ III } & 002 & \multirow[t]{6}{*}{$4550 \pm 90$} & & \multirow[t]{6}{*}{ Calippo (2004) } & 4550 & $-1,20$ & $-1,20$ \\
\hline & & & 010 & & & & 4557 & $-0,40$ & $-1,80$ \\
\hline & & & 015 & & & & 4563 & $-2,60$ & $-0,90$ \\
\hline & & & 020 & & & & 4570 & $-0,70$ & $-0,40$ \\
\hline & & & 027 & & & & 4577 & $-1,20$ & $-1,40$ \\
\hline & & & 032 & & & & 4583 & $-0,10$ & $-1,40$ \\
\hline
\end{tabular}




\begin{tabular}{|c|c|c|c|c|c|c|c|c|c|}
\hline & & & 034 & $4590 \pm 90$ & & Calippo (2004) & 4590 & 0,20 & $-1,20$ \\
\hline & & 1 & $\begin{array}{l}000 / 010 \\
010 / 020 \\
020 / 030 \\
030 / 040 \\
040 / 050 \\
050 / 060 \\
060 / 070\end{array}$ & $4150 \pm 50$ & $-0,8$ & Calippo (2004) & $\begin{array}{l}4150 \\
4151 \\
4153 \\
4154 \\
4156 \\
4157 \\
4159\end{array}$ & \begin{tabular}{l|}
$-0,17$ \\
0,19 \\
0,38 \\
0,40 \\
0,28 \\
0,44 \\
0,77 \\
0,15 \\
0,39
\end{tabular} & $\begin{array}{l}-1,78 \\
-2,06 \\
-1,80 \\
-1,72 \\
-1,76 \\
-2,02 \\
-1,19 \\
-1,64 \\
-1,68\end{array}$ \\
\hline & T019 & II & $\begin{array}{l}070 / 080 \\
080 / 090 \\
090 / 100 \\
100 / 110\end{array}$ & $\begin{array}{l}4160 \pm 50 \\
4460 \pm 60\end{array}$ & $\begin{array}{l}-0,7 \\
-0,5\end{array}$ & $\begin{array}{l}\text { Calippo (2004) } \\
\text { Calippo (2004) }\end{array}$ & $\begin{array}{r}4160 \\
4258 \\
4331 \\
4385\end{array}$ & $\begin{array}{l}0,94 \\
0,65 \\
0,58 \\
1,06 \\
0,81 \\
0,29\end{array}$ & $\begin{array}{l}-1,20 \\
-1,26 \\
-2,04 \\
-1,74 \\
-1,16 \\
-1,80\end{array}$ \\
\hline & & III & $\begin{array}{l}110 / 120 \\
120 / 130\end{array}$ & $\begin{array}{l}4550 \pm 50 \\
4550 \pm 50\end{array}$ & $\begin{array}{l}-0,4 \\
-0,4\end{array}$ & $\begin{array}{l}\text { Calippo (2004) } \\
\text { Calippo (2004) }\end{array}$ & $\begin{array}{l}4550 \\
4550\end{array}$ & $\begin{array}{l}1,00 \\
1,02\end{array}$ & $\begin{array}{l}-1,48 \\
-1,27\end{array}$ \\
\hline & T021 & 1 & $\begin{array}{l}020 \\
030 \\
040 \\
050 \\
060 \\
064 \\
070\end{array}$ & $4150 \pm 50$ & $-0,8$ & Calippo (2004) & $\begin{array}{l}4150 \\
4151 \\
4153 \\
4154 \\
4156 \\
4157 \\
4159\end{array}$ & $\begin{array}{l}0,10 \\
-0,30 \\
-0,20 \\
-0,20 \\
-0,90 \\
-0,30 \\
-0,40\end{array}$ & $\begin{array}{l}-1,40 \\
-1,90 \\
-1,30 \\
-2,20 \\
-1,70 \\
-2,20 \\
-2,70\end{array}$ \\
\hline & & III & $\begin{array}{l}073 \\
083\end{array}$ & $4550 \pm 50$ & $-0,4$ & Calippo (2004) & $\begin{array}{r}4550 \\
4557\end{array}$ & $\begin{array}{r}0,10 \\
-1,40\end{array}$ & $\begin{array}{l}-1,60 \\
-1,80\end{array}$ \\
\hline $\begin{array}{c}\text { Cachoeira } \\
\text { Mirim }\end{array}$ & T010 & - & $\begin{array}{l}000 / 010 \\
010 / 020 \\
020 / 030 \\
030 / 040 \\
040 / 050 \\
050 / 060 \\
060 / 070 \\
070 / 080 \\
080 / 090 \\
090 / 100 \\
100 / 110 \\
110 / 120 \\
120 / 130 \\
130 / 140\end{array}$ & $4630 \pm 50$ & & & $\begin{array}{l}4630 \\
4634 \\
4638 \\
4642 \\
4646 \\
4650 \\
4654 \\
4658 \\
4662 \\
4666 \\
4670 \\
4675 \\
4679 \\
4683\end{array}$ & $\begin{array}{l}1,58 \\
0,78\end{array}$ & $\begin{array}{l}-1,57 \\
-1,23\end{array}$ \\
\hline
\end{tabular}




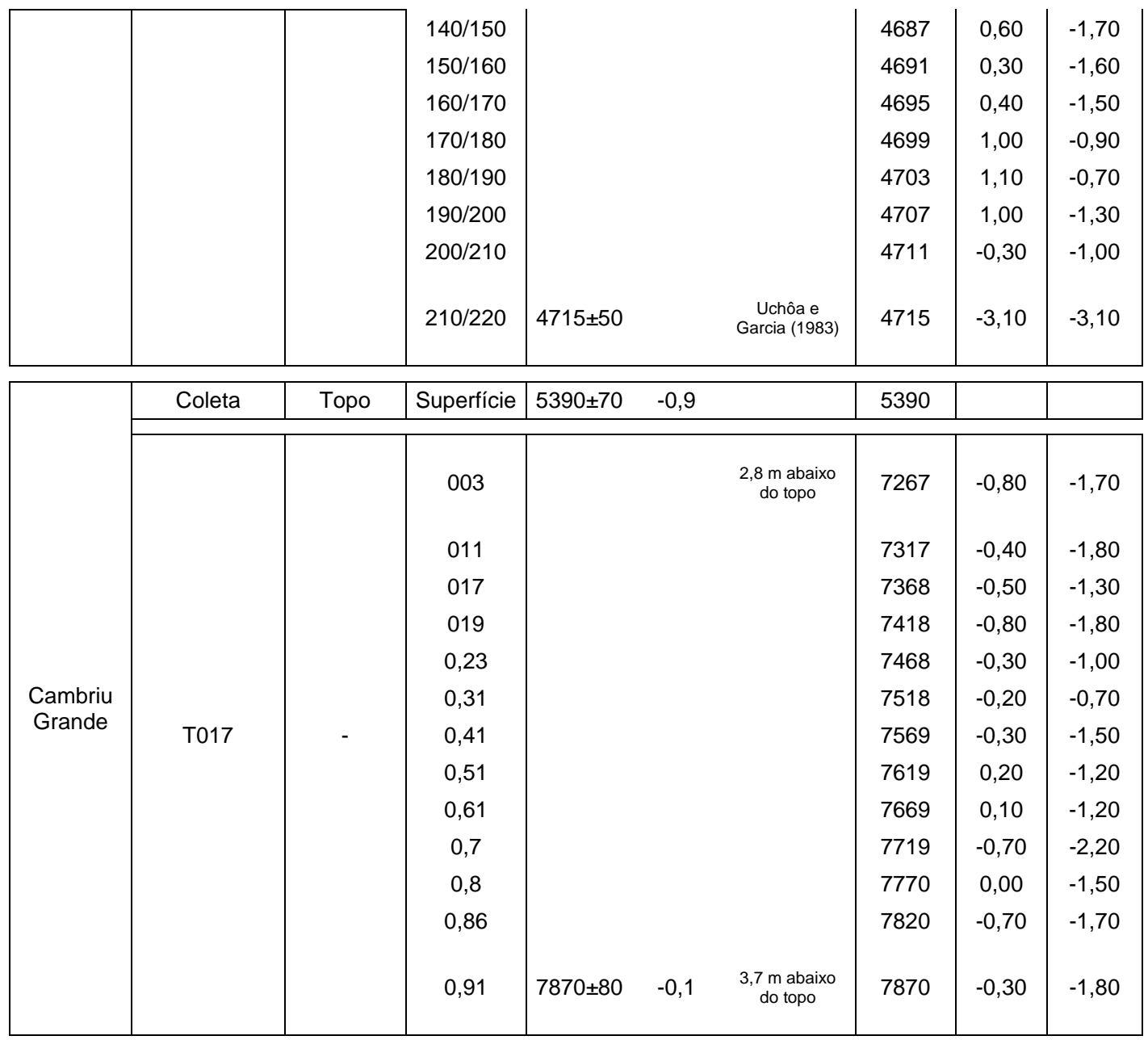

\begin{tabular}{|c|c|c|c|c|c|c|c|c|c|}
\hline \multirow{6}{*}{$\begin{array}{l}\text { Ilha do } \\
\text { Cambriu }\end{array}$} & T027 & Superfície & & $4340 \pm 50$ & 0,7 & & 4340 & & \\
\hline & \multirow{5}{*}{ T026 } & \multirow{5}{*}{-} & 00/07 & & & & 4340 & 0,25 & $-2,05$ \\
\hline & & & $07 / 23$ & & & & 4355 & $-1,25$ & $-1,65$ \\
\hline & & & $23 / 41$ & & & & 4372 & $-0,76$ & $-2,19$ \\
\hline & & & $41 / 49$ & & & & 4385 & $-1,31$ & $-1,56$ \\
\hline & & & $49 / 62$ & $4390 \pm 60$ & 0,6 & Calippo (2004) & 4390 & 1,05 & $-1,15$ \\
\hline
\end{tabular}

O primeiro desses períodos da ocupação sambaquieira é representado pelo sambaqui Branco (que possui idades entre 8.000 e 5.500 anos AP), o qual está relacionado a um momento em que os sambaquieiros, embora já adaptados à exploração dos recursos costeiros, provavelmente ainda desenvolveriam uma estratégia fundamentada, principalmente, na coleta de moluscos.

Ainda que existam poucas informações a esse respeito, o mais provável é que nesses primeiros momentos, os ambientes lagunares propícios à pesca ainda não teriam se formado por completo (CALIPPO, op. cit.). Apesar da zona costeira 
ser cada vez mais inundada pela elevação do nível relativo do mar, foi só a partir do final da fase transgressiva, com o rebaixamento do nível relativo do mar, que começaram a se estabelecer os grandes estuários e as extensas áreas lagunares, responsáveis pelo desenvolvimento dos ambientes propícios ao surgimento de densas populações de peixes.

\subsection{A DISTRIBUIÇÃO TEMPORAL DAS RAZÕES ISOTÓPICAS DE CARBONO E OXIGÊNIO}

Antes de estabelecermos uma correlação entre as razões isotópicas dos elementos carbono e oxigênio (presentes nas conchas dos sambaquis de Cananéia) e os ambientes em que foram coletados, procurou-se aqui contextualizar as razões isotópicas em relação às idades das amostras e dos sítios arqueológicos (figuras 5.01 e 5.02). Com isso, além de visualizarmos a distância temporal que separa esses dois momentos, podemos investigar também se existem evidências dessa mudança na estratégia das atividades de coleta e nos ambientes onde as conchas eram capturadas. 


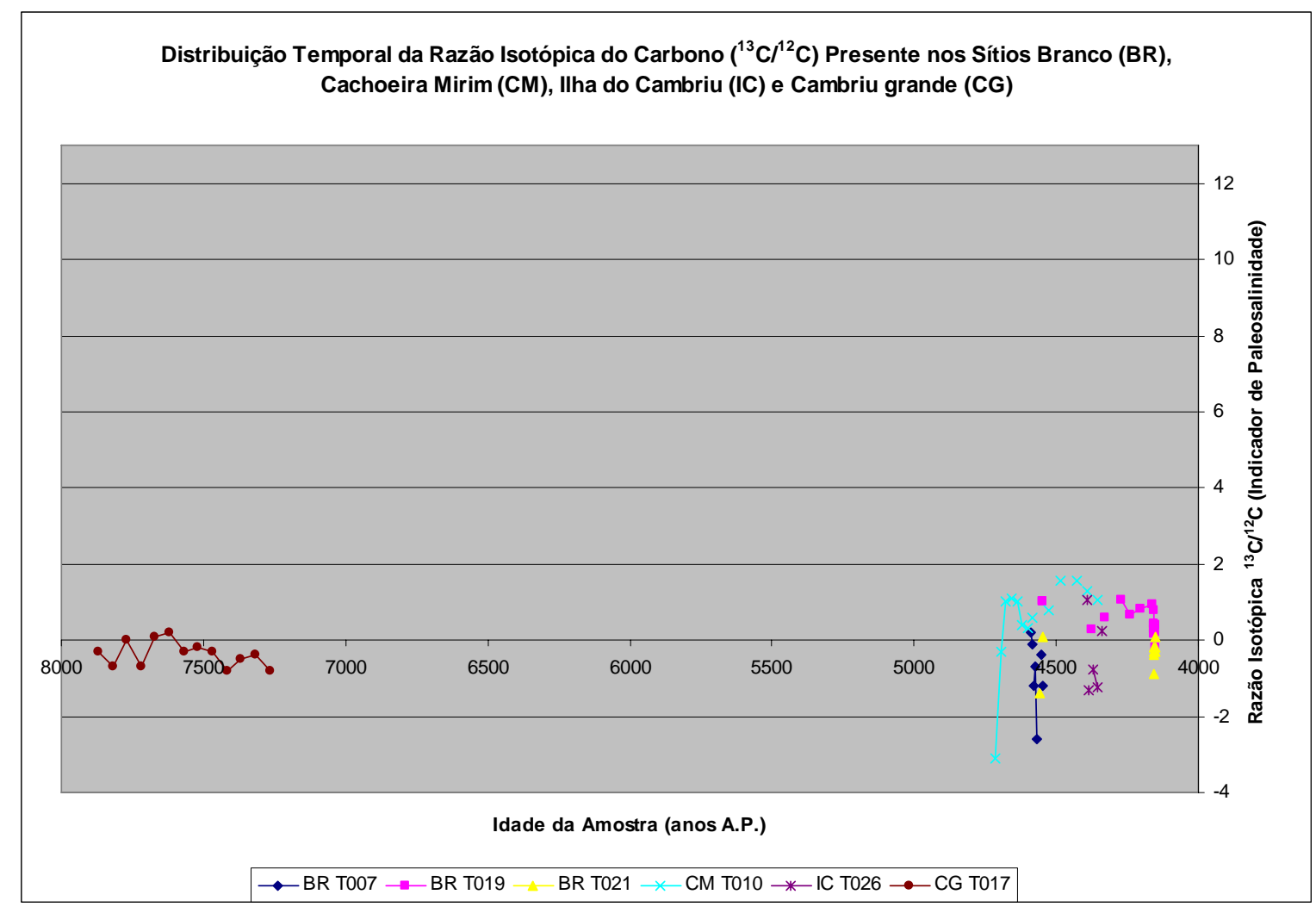

Figura 5.01 - Razão isotópica do Carbono $\left({ }^{13} \mathrm{C} /{ }^{12} \mathrm{C}\right)$ presente nas conchas dos quatro sítios analisados. Os valores do eixo $Y$ indicam a formação de carapaça em ambientes que vão da água doce $(13 \%)$ à água marinha $(0 \%)$.

De um modo geral, podemos perceber que existe certa similaridade entre os locais de coleta, pois, todas as amostras apresentam razões isotópicas que indicam uma proveniência associada a uma parte das regiões lagunares que recebem forte influência de águas marinhas ${ }^{38}$. Embora existam diferenças entre as paleosalinidades identificadas nas conchas desses sítios, tais flutuações são mínimas se comparadas à salinidade suportada pelo molusco Anomalocardia brasiliana, cujas carapaças predominam nesses sítios.

Como a Anomalocardia brasiliana tolera salinidades que vão dos 34\%o (águas oceânicas) a 8\% (águas salobras a doces) (WAKAMATSU, 1973), as razões isotópicas das conchas provenientes dos sambaquis indicam que os ambientes de coleta das conchas são sempre muito próximos aos ambientes marinhos.

\footnotetext{
${ }^{38}$ Segundo Martin et al. (1984), as razões isotópicas do Carbono $\left({ }^{13} \mathrm{C} /{ }^{12} \mathrm{C}\right)$ indicam salinidades que distribuem-se, aproximadamente, da água marinha (valores próximos zero) à água doce (valores em torno de 13).
} 
Independente da idade dos sítios e dos momentos de variação do nível relativo do mar a que cada camada arqueológica está associada, a salinidade dos ambientes em que as conchas foram coletadas permanece semelhante a encontrada junto à interface marinha. Padrão que parece indicar uma escolha que não estaria, necessariamente, ligada à busca de uma maior rentabilidade da coleta, e, sim, a questões associadas à tradição e à percepção de seu ambiente. Do contrário, os sambaquieiros teriam explorado todos os outros ambientes onde essas conchas também ocorreriam em abundância.

O mais interessante sobre essa questão é que ela não se mantém somente para os outros sambaquis da região, mas, também, ao longo do tempo. Mesmo atravessando um período de intensas modificações ambientais, em que a influência da água marinha dentro das áreas lagunares e estuarinas teria se modificado drasticamente, os sambaquieiros continuaram a explorar, logo após o máximo transgressivo, os mesmos ambientes que exploravam por volta de 8.000 anos AP (não os mesmos locais, mas os mesmos tipos de ambientes). Os quais, nesse contexto de rebaixamento, passariam cada vez mais a se afastar dos sítios, obrigando os indivíduos a se deslocarem a novos locais para continuarem obtendo recursos dos mesmos tipos de ambientes. Indicando, provavelmente, que tanto a escolha do local dos sítios como as áreas de coleta não seriam uma conseqüência direta da disponibilidade alimentar.

Além da questão da disponibilidade alimentar e dos esforços para a obtenção do alimento, podemos perceber ainda, na manutenção da estratégia de coleta, duas questões extremamente importantes para o entendimento das relações que os sambaquieiros estabeleciam com o seu ambiente: em primeiro lugar, tinham um razoável conhecimento da ecologia de seu ambiente, pois, embora não explorassem todas as possibilidades para a obtenção dessas conchas, mantinham a coleta restrita a áreas em que a disponibilidade do recurso era constante.

Em segundo lugar, havia, nesse sentido, uma forma de tradição de exploração desses recursos. Mesmo passados milhares de anos, a estratégia da exploração dos ambientes costeiros mais próximos ao mar não se altera, reforçando a idéia que a escolha de tais locais não seria somente definida em função da 
capacidade desse ambiente em prover recursos. Se houvesse entre eles uma preocupação em identificar e explorar as áreas de maior disponibilidade de recursos, é bem provável que, em pelos menos 4.000 anos, algum avanço nesse sentido teria sido registrado ao alongo do registro arqueológico dos sambaquieiros.

De modo semelhante, o mesmo padrão parece ocorrer quando analisamos a distribuição temporal da razão isotópica do oxigênio (paleotemperatura) (figura 5.02). Embora ainda não tenha sido possível estabelecer, para a região, uma relação direta entre as temperaturas da água do mar e as razões isotópicas de oxigênio (que dependem de análises paleoambientais mais precisas), podemos usar o comportamento dessas razões no gráfico como um indicador. Assim como para a paleosalinidade, a paleotemperatura das águas em que as conchas se desenvolveram também se mantém ao longo de uma faixa de valores (com valores de zero a aproximadamente -3). Mesmo ainda não sendo possível indicar uma temperatura absoluta para o ambiente da coleta das conchas, o comportamento de seu indicador (razão isotópica ${ }^{18} \mathrm{O} /{ }^{16} \mathrm{O}$ ) também indica que os sambaquieiros continuaram explorando o mesmo tipo de ambiente ao longo do tempo. 


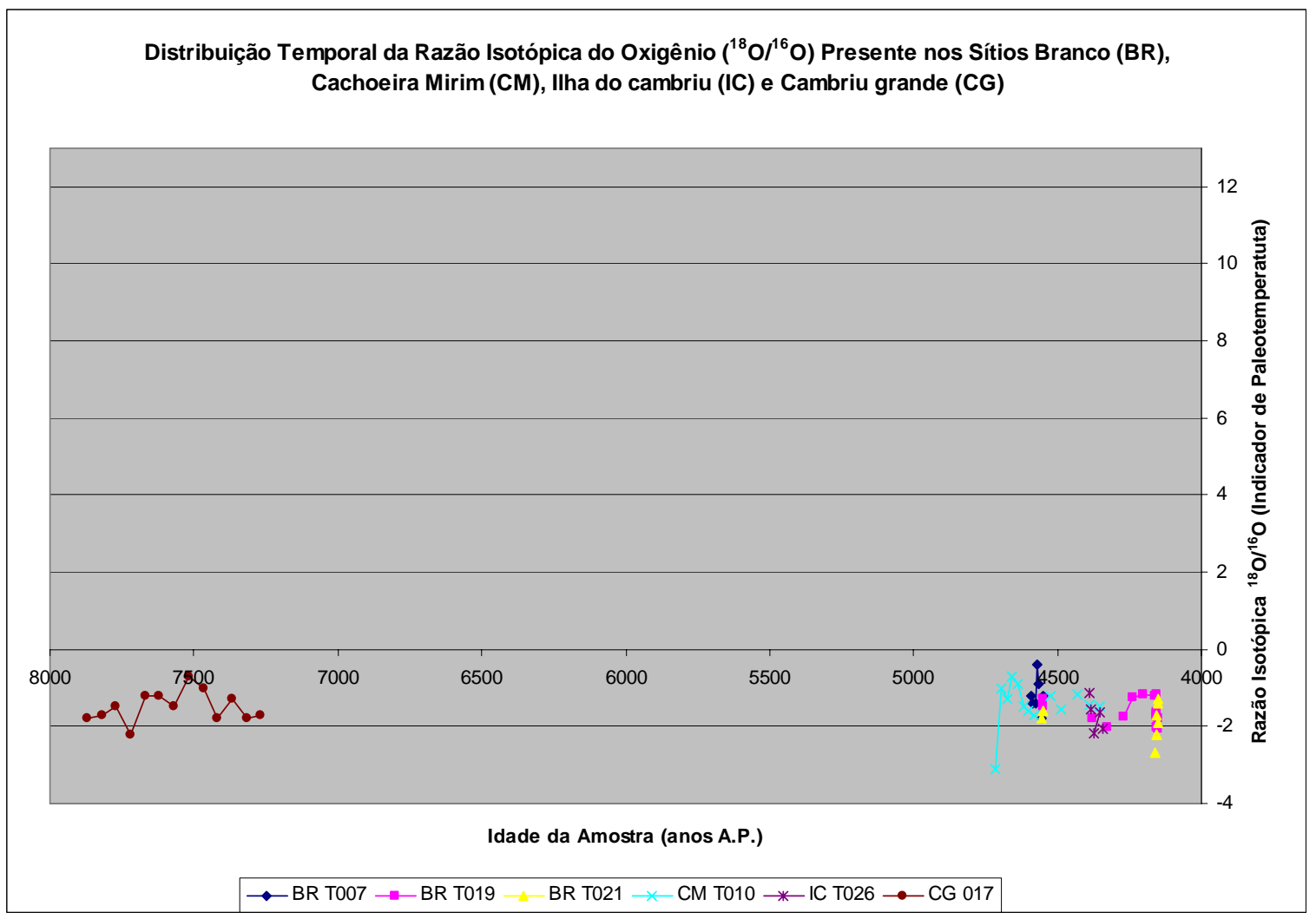

Figura 5.02 - Razão isotópica do Oxigênio $\left({ }^{18} \mathrm{O} /{ }^{16} \mathrm{O}\right)$ presente nas conchas dos quatro sítios analisados.

Para ilustrar o predomínio e a continuidade de tal relação com o ambiente marinho, as razões isotópicas de carbono (paleosalinidade) e oxigênio (paleotemperatura) destes três sambaquis foram correlacionadas entre si (gráficos da figura 5.03), de modo a serem comparadas com as relações ideais, propostas por Keith et. al. (1964), entre o ambiente e a composição isotópica das conchas dos moluscos (figura 5.04). 

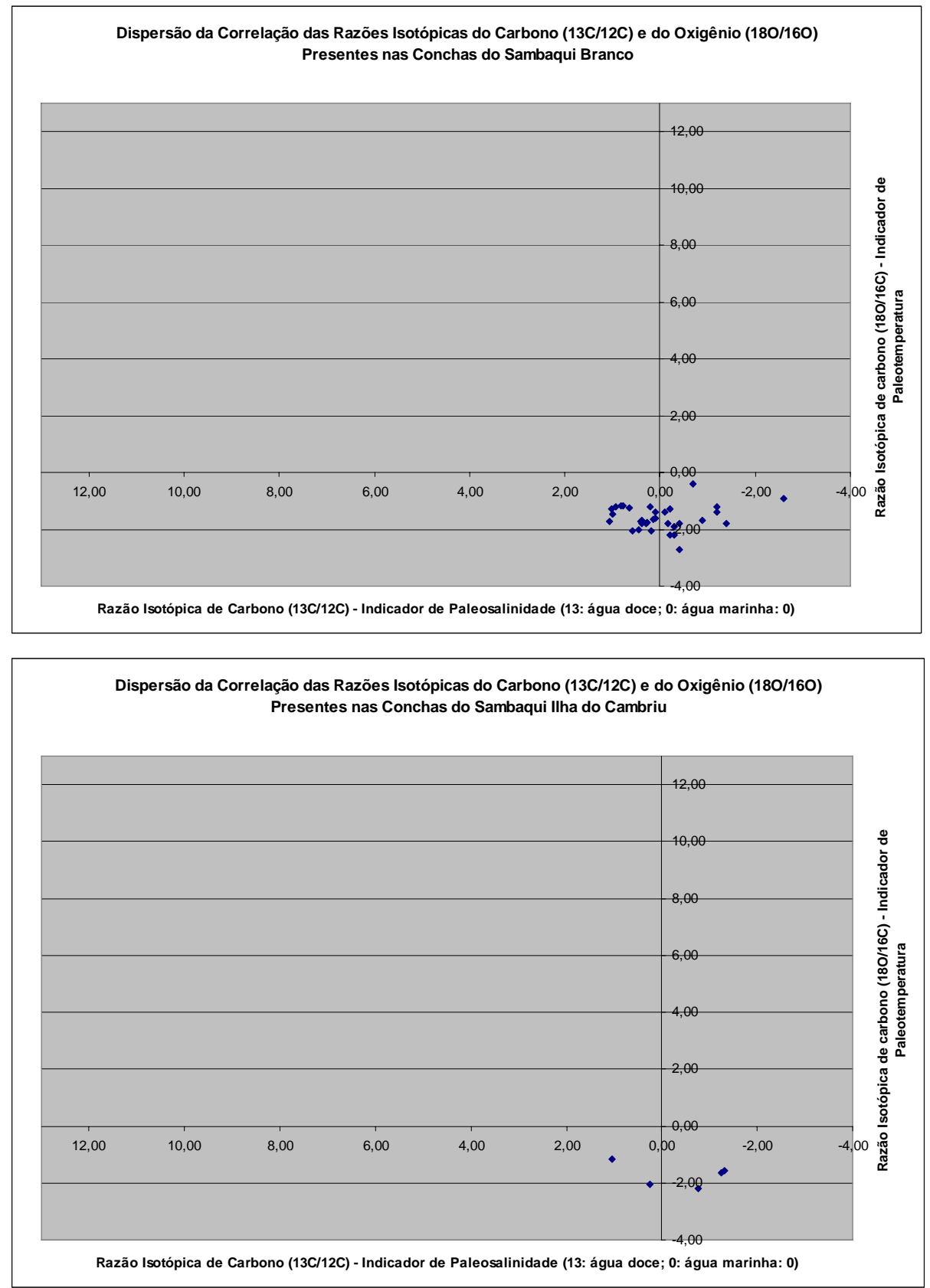

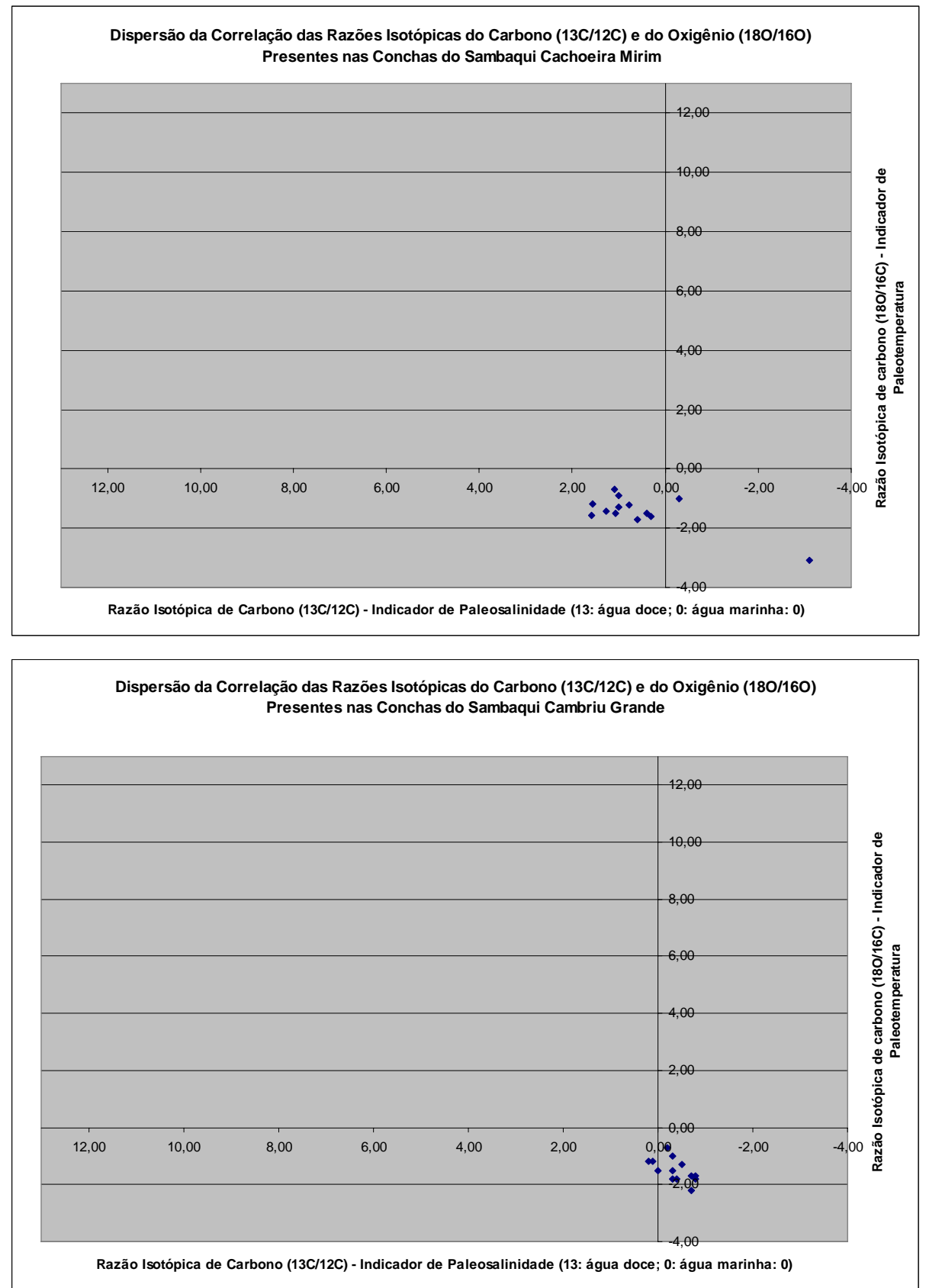

Figura 5.03 - Correlação das razões isotópicas do Carbono $\left({ }^{13} \mathrm{C} /{ }^{12} \mathrm{C}\right)$ e do Oxigênio $\left({ }^{18} \mathrm{O} /{ }^{16} \mathrm{O}\right)$ presente nas conchas dos sambaquis Branco, Ilha do Cambriu, Cachoeira Mirim e Cambriu Grande. No gráfico, quando maior o valor de " $x$ " menor é salinidade do ambiente de crescimento das conchas; quanto maior o valor de "y", mais elevada é a temperatura.

Com base na comparação da correlação das razões isotópicas dos quatro sítios analisado na região de Cananéia, apresentada na figura acima, podemos também perceber que, independente dos locais e das idades dos sítios, a maior 
parte dos dados encontra-se concentrados em uma região muito próxima ao cruzamento do eixo de ambas as razões isotópicas (valores muito próximos a zero; sendo um pouco mais negativos no eixo relativo à temperatura).

Comparando-se esses resultados com a relação proposta por Keith et. al. (1964) (figura 5.04, abaixo), confirma-se a hipótese de que as conchas coletas pelos sambaquieiros de Cananéia eram, em sua maioria, provenientes de ambientes com grande influência marinha.

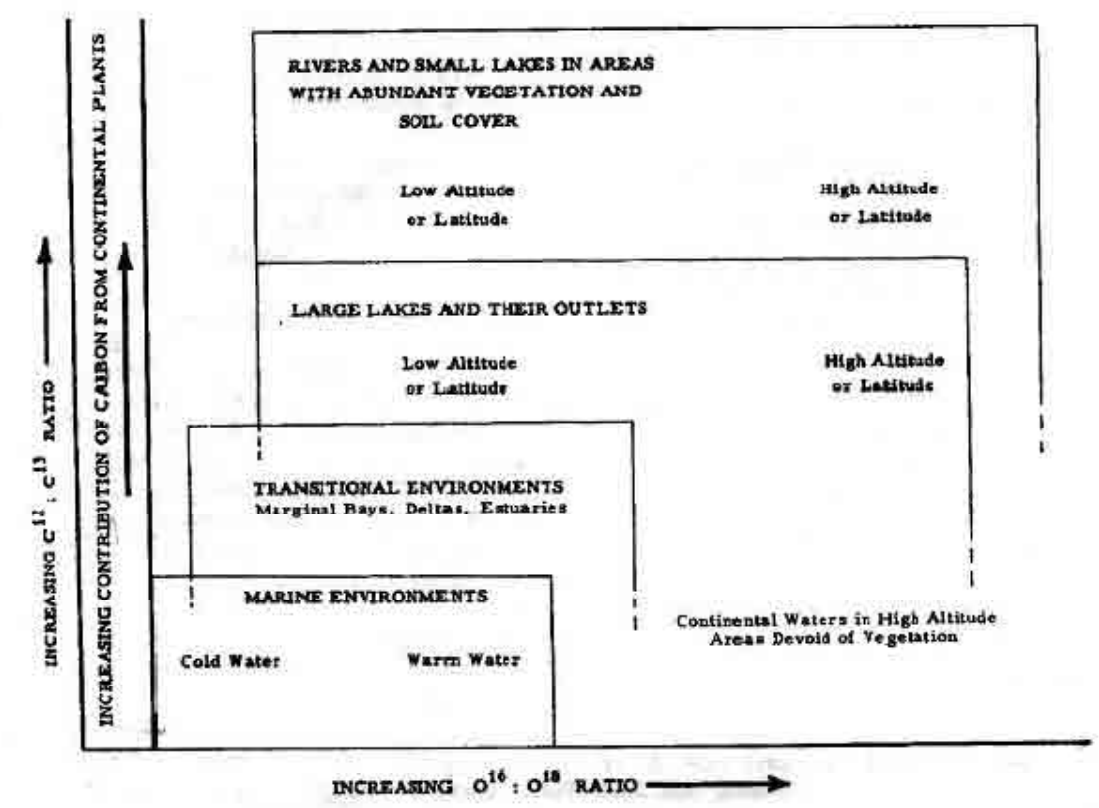

Figura 5.04 - Relações idealizadas entre o ambiente e a composição isotópica das conchas dos moluscos (KEITH et. al., 1964).

\subsection{O SIGNIFICADO DA VARIAÇÃO DAS RAZÕES ISOTÓPICAS}

Uma vez estabelecido o ambiente em que os sambaquieiros de Cananéia realizam suas principais atividades de coleta, buscamos agora analisar as variações das razões isotópicas relativas aos sambaquis. Com base na figura 5.05, podemos perceber que existem dois principais padrões de comportamento gráfico: um horizontal e outro vertical. 


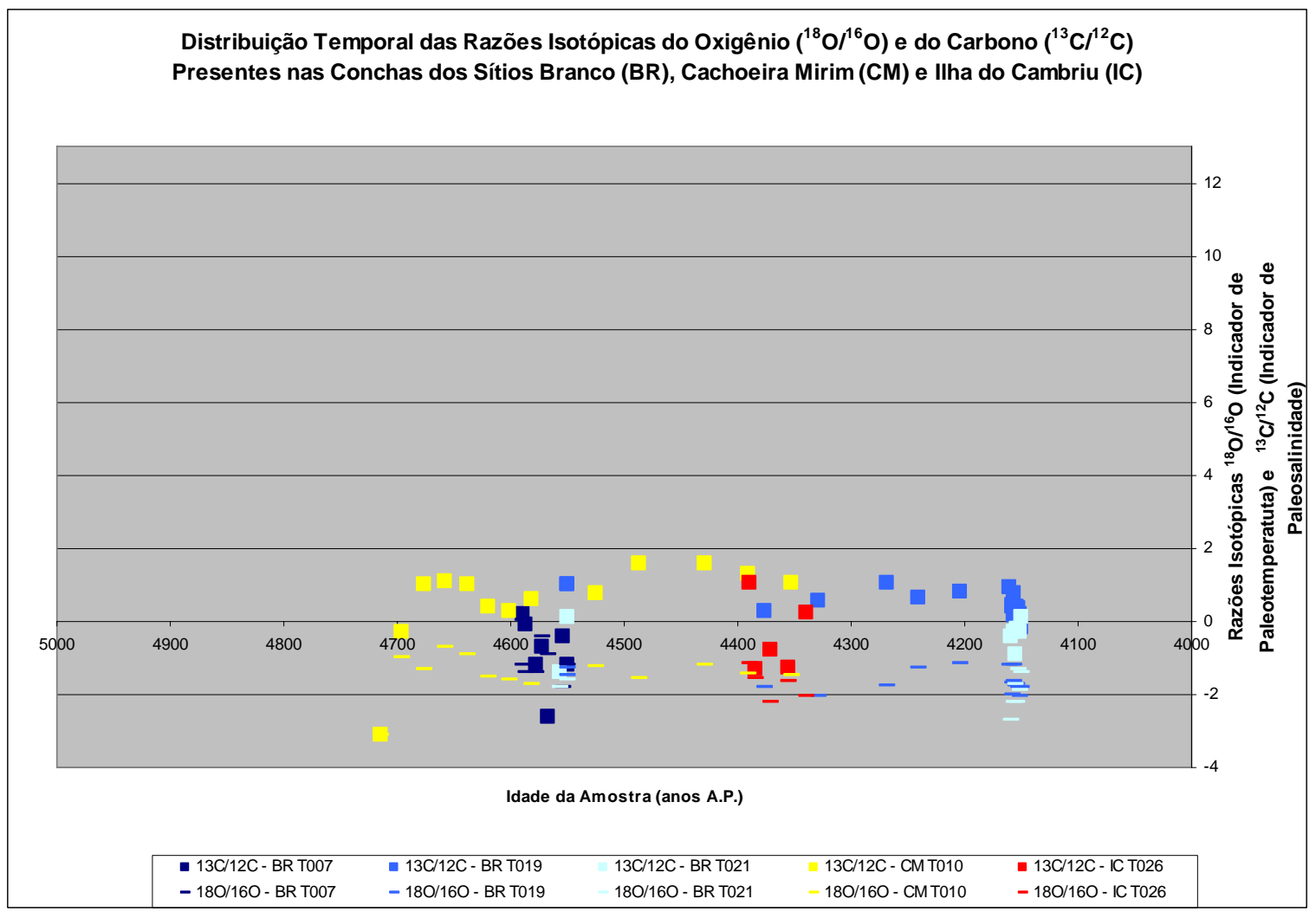

Figura 5.05 - Razões isotópicas do Carbono $\left({ }^{13} \mathrm{C} /{ }^{12} \mathrm{C}\right)$ e do Oxigênio $\left({ }^{18} \mathrm{O} /{ }^{16} \mathrm{O}\right)$ presentes nas conchas dos três sítios contemporâneos ao último grande máximo transgressivo holocênico (5100 anos AP).

De um modo geral, uma distribuição horizontal evidencia a manutenção de uma coleta de conchas que se desenvolveram em ambientes com salinidades médias aproximadamente semelhantes (por isso o espalhamento dos dados não é completamente linear). No entanto, em alguns pontos, isso não acontece. Em determinados momentos existe uma tendência de verticalização, a qual reflete a exploração de ambientes com maior salinidade.

Por si só essa flutuação não expressaria grandes mudanças de comportamento. Afinal, os dados ainda estão associados a uma faixa de alta salinidade. Talvez, no máximo, um pequeno aumento na diversidade dos ambientes marinhos de coleta ou reflexos de modificações ambientais de baixa amplitude. Entretanto, quando comparadas ao processo de formação dos sambaquis, ganha 
uma nova dimensão. Todos esses pontos onde existe uma verticalização gráfica estão relacionados a uma importante mudança no processo de formação dos sambaquis. Nesses momentos, os sambaquis estão sendo formados de uma maneira muito mais rápida.

No caso do sambaqui Branco (figura 5.06), por exemplo, foram definidos três momentos principais de formação (CALIPPO, 2004): um primeiro, referente à construção de uma base (com aproximadamente meio metro de altura), onde a diferença entre as idades de topo e da base é de dez anos (inferior ao desvio padrão da datação, que é de \pm 40 anos); um intermediário, com espessura de 0,75 metros, relacionado a uma camada de ocupação de 400 anos; e, por final, uma camada de 1,60 metros, formada, também em um intervalo aproximado de dez anos (com erro de \pm 50 anos).

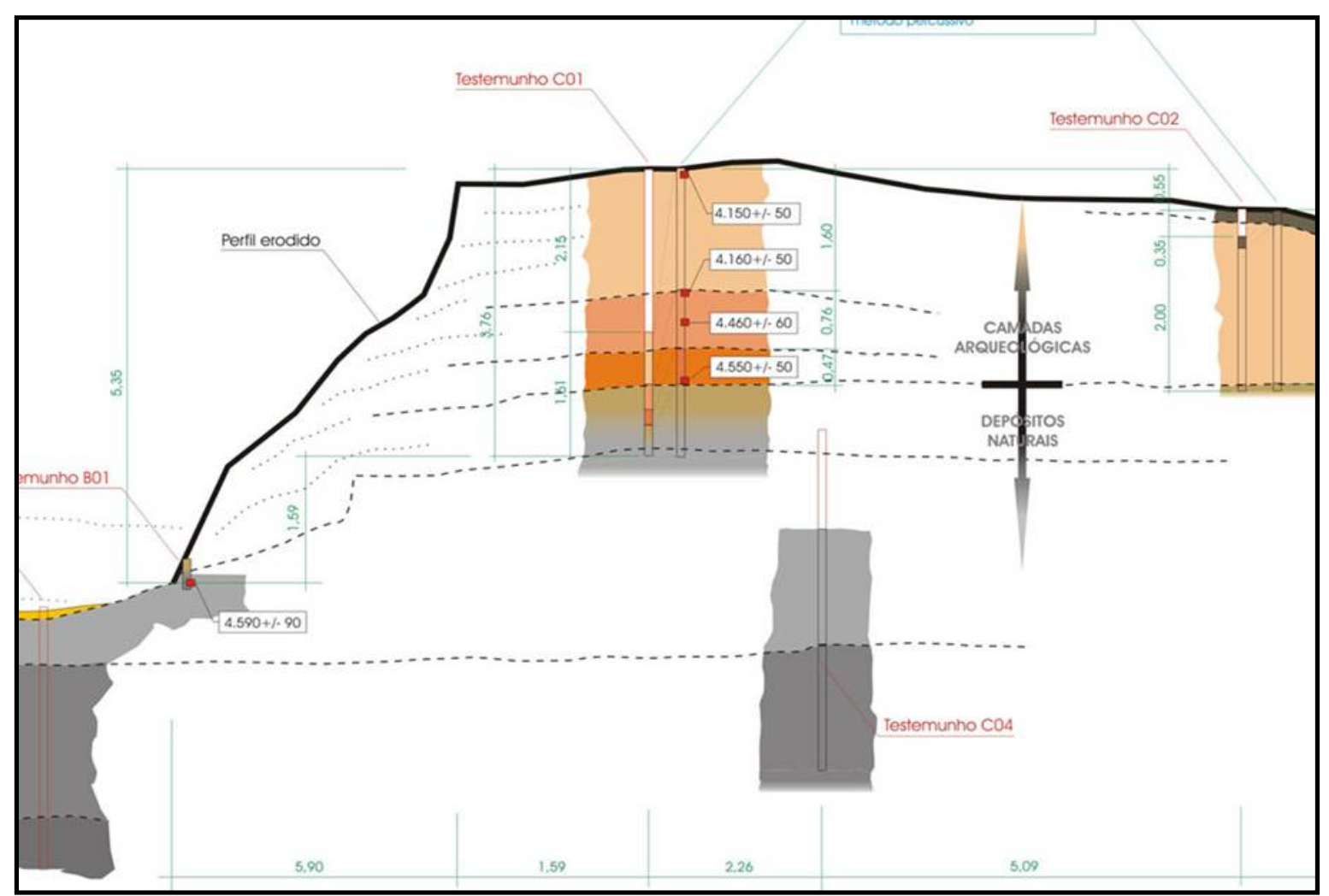

Figura 5.06 - Perfil esquemático do sambaqui branco.

São a esses momentos de rápida acresção (que, na prática, devem ser até mais rápidos, mas não foram assim diagnosticados em conseqüência da própria 
precisão do método de datação) que se relacionam os dados de salinidade e temperatura que apresentam um comportamento predominantemente verticalizado nos gráficos das razões isotópicas de carbono e oxigênio (figura 5.07). Correlação que aqui interpretamos como um padrão de formação diferenciado, imbuídas possivelmente de significados, decorrente da construção de estruturas que são, ao mesmo tempo, funcionais e simbólicas.

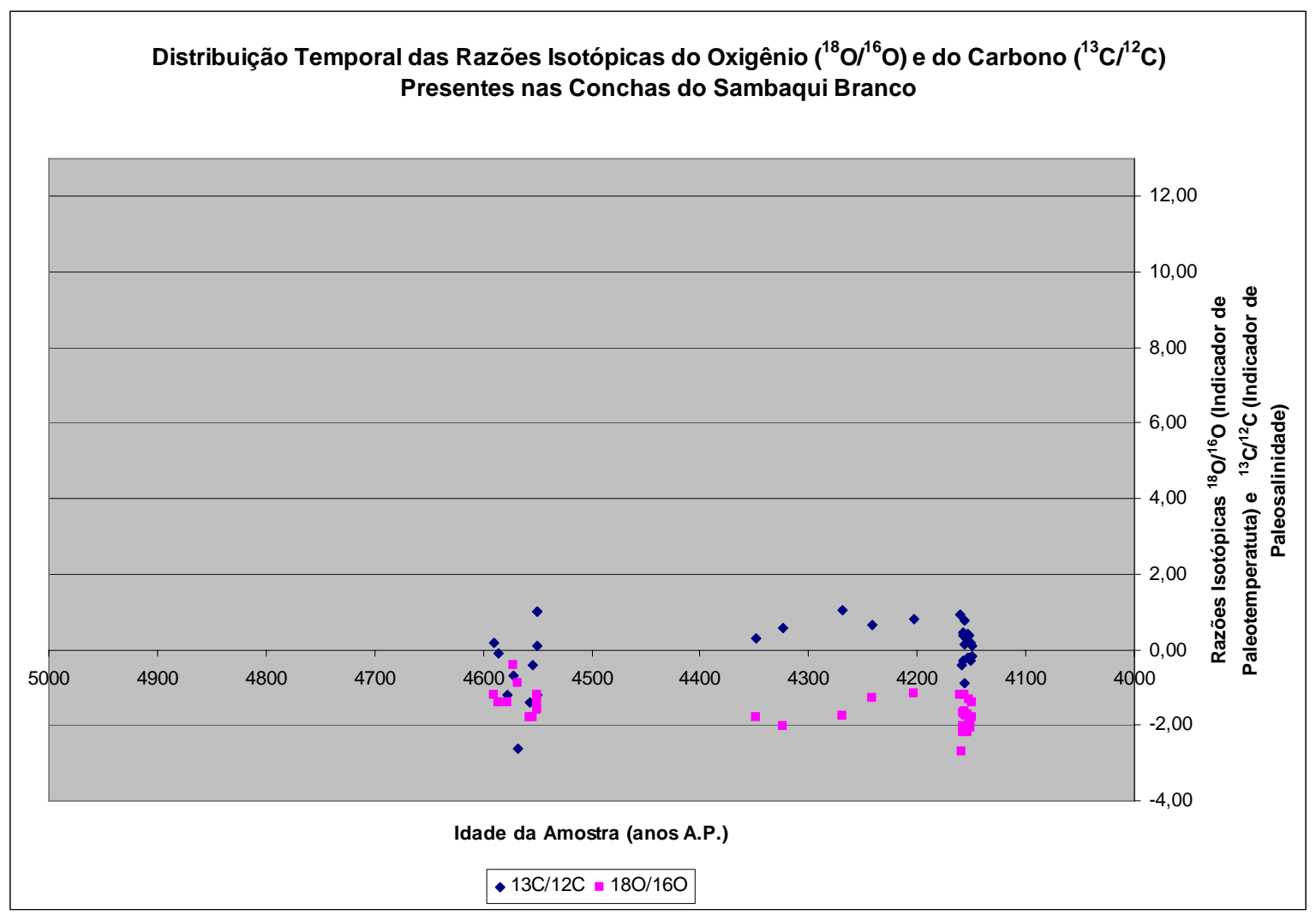

Figura 5.07 - Razões isotópicas do Carbono $\left({ }^{13} \mathrm{C} /{ }^{12} \mathrm{C}\right)$ e do Oxigênio $\left({ }^{18} \mathrm{O} /{ }^{16} \mathrm{O}\right)$ presente nas conchas do sambaqui Branco.

Funcionais porque foram construídas, inicialmente, como base para a ocupação do local e, posteriormente, com o provável propósito de destacar o sítio na paisagem. Simbólicas porque, através da presença de conchas coletas em ambientes marinhos (em ilhas) ou mais próximos da interface estuário/mar, podemos supor uma reafirmação de sua ligação com esses ambientes e com o universo marítimo. Seja ela em conseqüência do significado das conchas e desses ambientes na cosmologia dos sambaquieiros ou em decorrência da importância cultural que 
esses locais tiveram para seus ancestrais e que, com o passar do tempo e das gerações, foram a eles transmitidas.

Se essa ligação cultural ou simbólica com o ambiente marinho não ocorresse, deveria haver não só um aumento na freqüência das conchas que se formaram em um ambiente de maior salinidade, mas, principalmente, das conchas provenientes de regiões de menor salinidade ao longo do estuário. Afinal, existe nas áreas estuarinas um maior número de locais de coleta (com grande abundância) se comparados às praias que sofrem uma maior influência marinha e às pequenas ilhas costeiras da região.

Assim, como os ambientes de coleta não se encontram necessariamente vinculados a uma maior disponibilidade do recurso, acreditamos que uma interpretação menos normativa da atividade de coleta possa aqui ser estabelecida. Uma interpretação que entenda a coleta não só como uma atividade de subsistência, mas, principalmente, como um rito que permeia o universo cultural e simbólico dos povos dos sambaquis.

Embora todas essas interpretações sejam aqui compreendidas mais como hipóteses a serem verificadas do que como um resultado concreto, existe uma recorrência no comportamento nos dados que, cada vez mais, nos leva a acreditar que podemos identificar, ao longo do registro arqueológico dos sítios, uma sucessão de processos cotidianos relacionados à busca pelo alimento e à lenta construção do sítio, bem como aqueles associados à monumentalidade e a possíveis formas rituais de culto aos mortos.

Além do já citado sambaqui branco, onde esses processos se sucedem ao longo do tempo, podemos identificar, com base nas razões isotópicas dos sambaquis Cambriu Grande, Cachoeira Mirim e Ilha do Cambriu, que existe uma recorrência de tais processos. Recorrência esta que deve estar, provavelmente, associada à função do sítio para aquela comunidade.

No caso do sambaqui Ilha do Cambriu (figura 5.08), por exemplo, a distribuição dos valores de paleotemperatura e paleosalinidade é praticamente verticalizada. Uma dispersão que nos leva a interpretar que a principal função desse sítio não estaria necessariamente ligada a práticas de subsistência. Ainda que 
entendamos que as práticas rituais possam ser realizadas cotidianamente, de modo integrado a todas as atividades diárias dos sambaquieiros, o mais provável é que nesses sítios as principais atividades fossem resultantes de práticas rituais. Pois, além de ser o único sambaqui localizado em uma ilha mais afastada (cujo acesso demanda, necessariamente, a utilização de embarcações), é um dos poucos sítios, associado ao conjunto da llha do Cardoso, onde se encontram vestígios de uma fauna marinha de maior porte (tartaruga, mamíferos marinhos, etc).

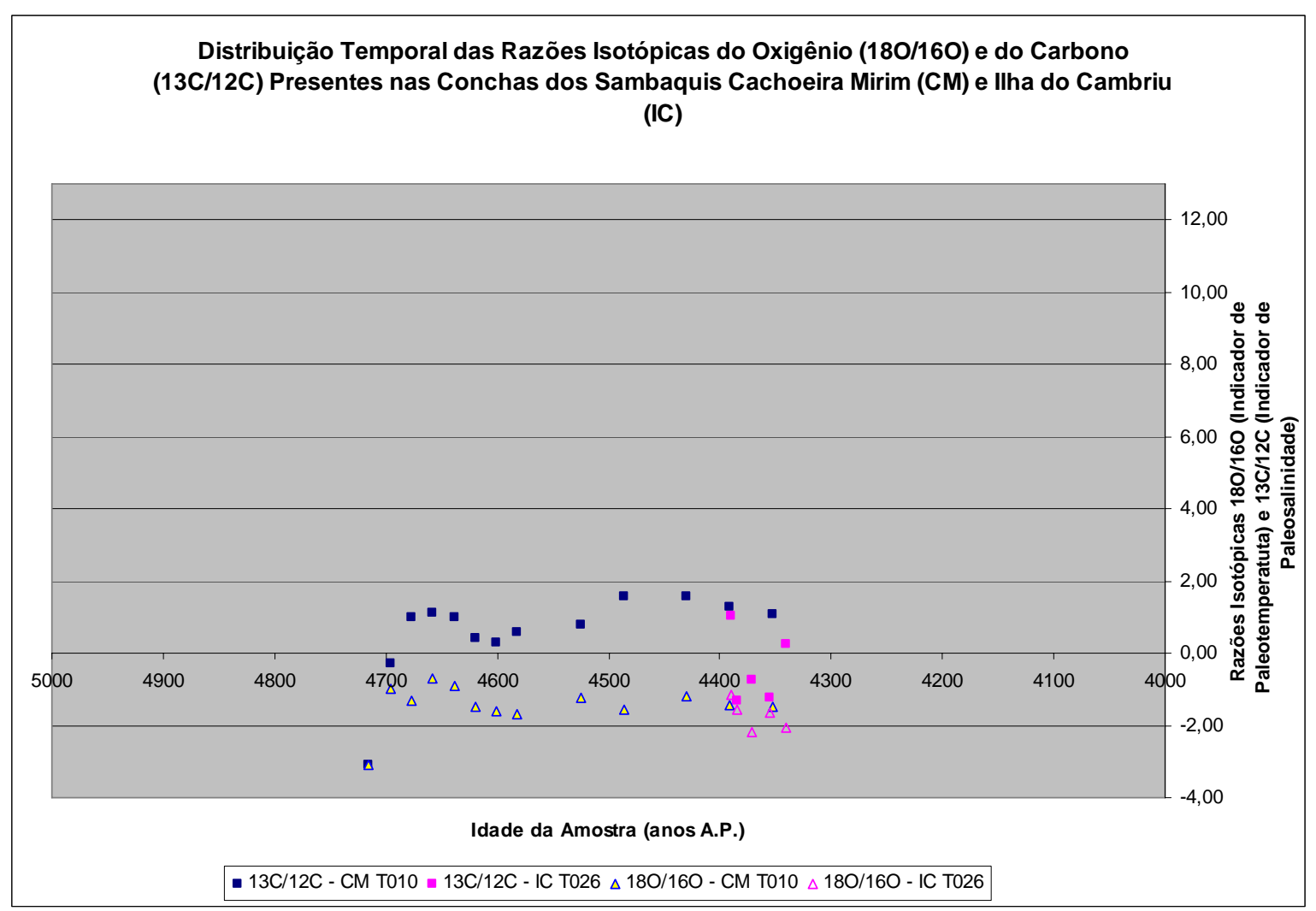

Figura 5.08 - Razões isotópicas do Carbono $\left({ }^{13} \mathrm{C} /{ }^{12} \mathrm{C}\right)$ e do Oxigênio $\left({ }^{18} \mathrm{O} /{ }^{16} \mathrm{O}\right)$ presente nas conchas dos sambaquis Cachoeira Mirim (CM) e Ilha do Cambriu (IC).

Embora essa associação entre a localização em ilhas isoladas e a abundância de animais de maior porte não possa ser necessariamente considerada uma indicação absoluta de práticas rituais e simbólicas, configura-se um padrão que recentemente vem sendo apontado tanto para o litoral sul (sambaquis Ilha do Cambriu e Pereirinha, na Ilha do Cardoso) (CALIPPO, 2004) como em sítios do litoral norte (AMENOMORI, com. pess. 2009). 
No caso do sambaqui Cachoeira Mirim (figura 5.08), no entanto, a situação é completamente oposta. Mesmo sendo contemporâneo e estando inserido em um contexto ambiental semelhante ao do sambaqui Branco, nesse sítio a distribuição dos valores isotópicos de carbono e oxigênio é praticamente horizontalizada, levando-nos a acreditar que esse sítio estivesse principalmente associado à realização de práticas sociais de subsistência. Ao longo da construção desse sambaqui, provavelmente, houve uma menor preocupação com a elevação da altura desse sítio (tendência monumental) ou com a intensificação da coleta de conchas provenientes do ambiente marinho.

De certo modo, esse padrão de distribuição horizontal dos valores isotópicos também é verificado no sambaqui Cambriu Grande (figura 5.09). Embora separados por milhares de anos, parece haver entre esses sítios uma tendência de constantemente explorar os mesmos tipos de ambiente, independente de como e quanto eles se deslocavam na paisagem em conseqüência das flutuações do nível relativo do mar. Um conhecimento que, nesses primeiros momentos, deveria ser resultante principalmente das práticas de coleta. 


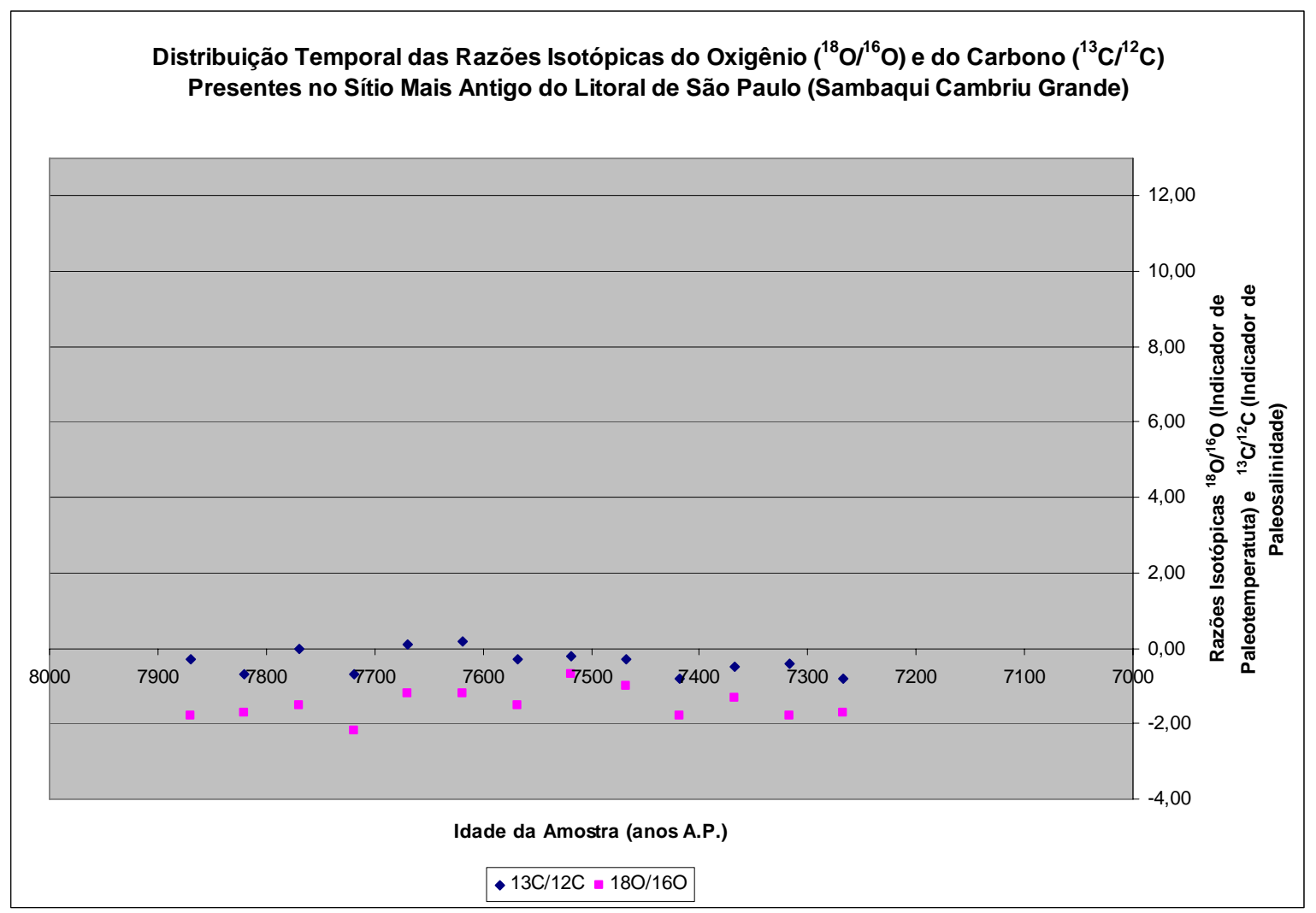

Figura 5.09 - Razões isotópicas do Carbono $\left({ }^{13} \mathrm{C} /{ }^{12} \mathrm{C}\right)$ e do Oxigênio $\left({ }^{18} \mathrm{O} /{ }^{16} \mathrm{O}\right)$ presente nas conchas do sambaqui Cambriu Grande

Como indicado no item 2.1 (Recorte Amostral), o processo de formação do sambaqui Cambriu Grande esteve fortemente associado a um intenso processo de elevação do nível do mar (muito bem caracterizado ao longo do Plano de Manejo do Parque Estadual da Ilha do Cardoso - INSTITUTO FLORESTAL, 2000) que mudou por completo a configuração do contexto ambiental e geomorfológico adjacente a ele. No entanto, a análise das conchas coletadas em seu interior mostra um padrão de salinidade e temperatura que não se modifica ao longo do tempo, levando-nos a inferir que, muito provavelmente, mesmo por volta de 8.000 anos AP, os sambaquieiros de Cananéia já conheciam muito bem os ambientes costeiros e ao invés de mudarem a posição do sítio acompanhando a migração dos ambientes, paulatinamente modificariam (intencionalmente ou não) os seus territórios de forma a explorar aqueles mesmo ambientes que vinham sendo explorado por seus ancestrais. 
Sugerindo, assim, que a percepção ambiental desenvolvida pelos primeiros sambaquieiros não foi simplesmente transformada. Muito pelo contrário, além do conhecimento adquirido a respeito desse ambiente fronteiriço com o mar, agregaram-se os resultados das experiências da relação com um ambiente francamente marítimo, cujos elementos passaram, provavelmente, a integrar a cosmologia das comunidades sambaquieiras da região. Processo esse que acreditamos deva estar relacionado com a prática da pesca e o desenvolvimento do conhecimento náutico.

Ainda que os dados isotópicos sejam capazes de subsidiar, com segurança, interpretação a respeito das relações que os sambaquieiros desenvolveram com os ambientes costeiros, existe um fator que pode influenciar tal interpretação: a influência das variações do nível relativo do mar.

A fim de verificar se essas variações poderiam ter influenciado de modo significativo a coleta realizada pelos sambaquieiros, as distribuições temporais das razões isotópicas do carbono e do oxigênio (de todos os quatros sítios) foram correlacionadas às curvas de variação do nível relativo do mar apontadas por Martin et. al. (1985) e Angulo e Lessa (1997) (figuras 5.10 e 5.11). 


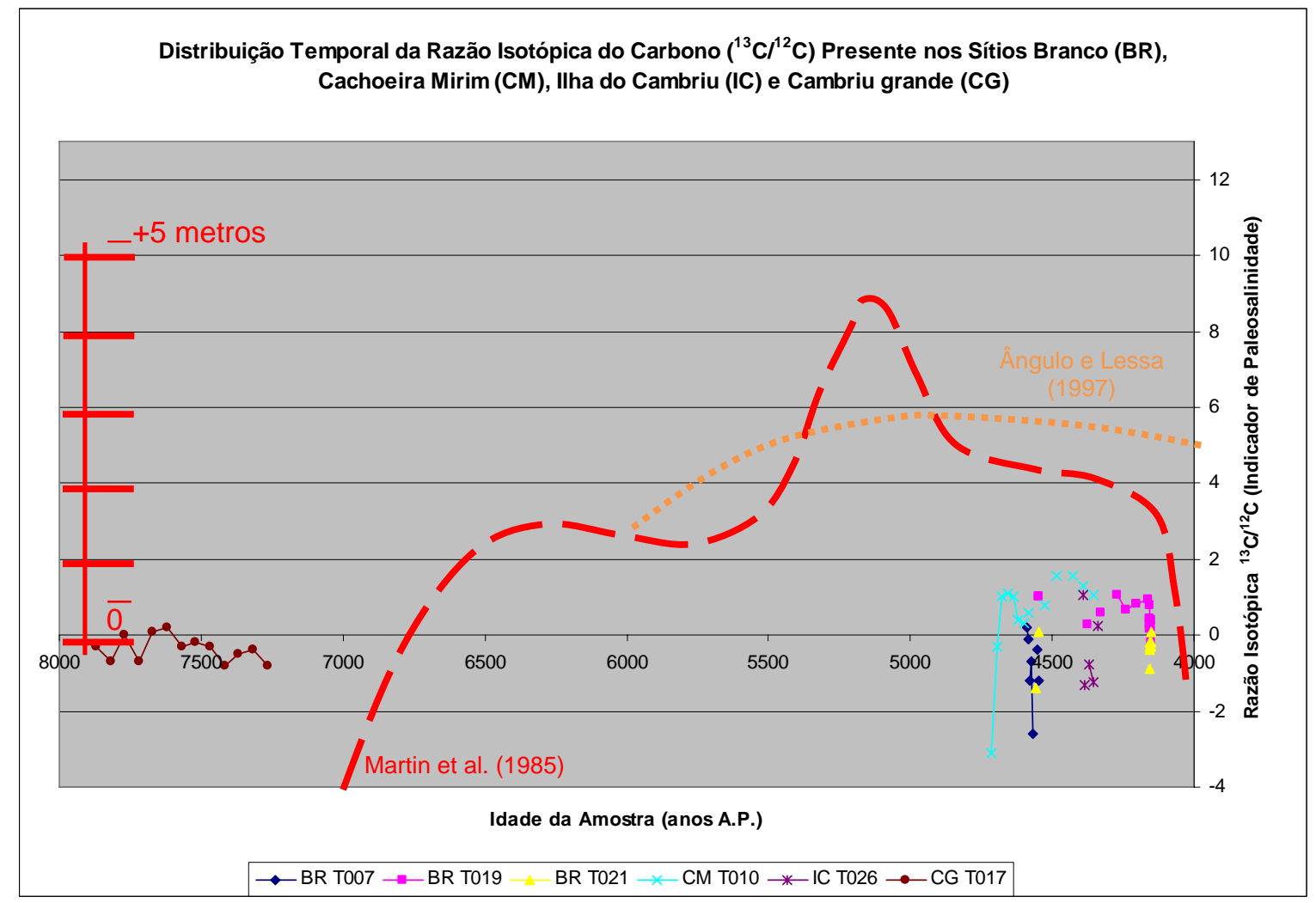

Figura 5.10 - Correlação das curvas de variação do nível relativo do mar (MARTIN et al, 1985; ÂNGULO e LESSA, 1997) com as distribuição temporal das razões isotópicas do Carbono $\left({ }^{13} \mathrm{C} /{ }^{12} \mathrm{C}\right)$ presente nas conchas dos quatro sítios analisados. Os valores do eixo $\mathrm{Y}$ indicam a formação de carapaça em ambientes que vão da água doce (13\%) à água marinha (0\%) 


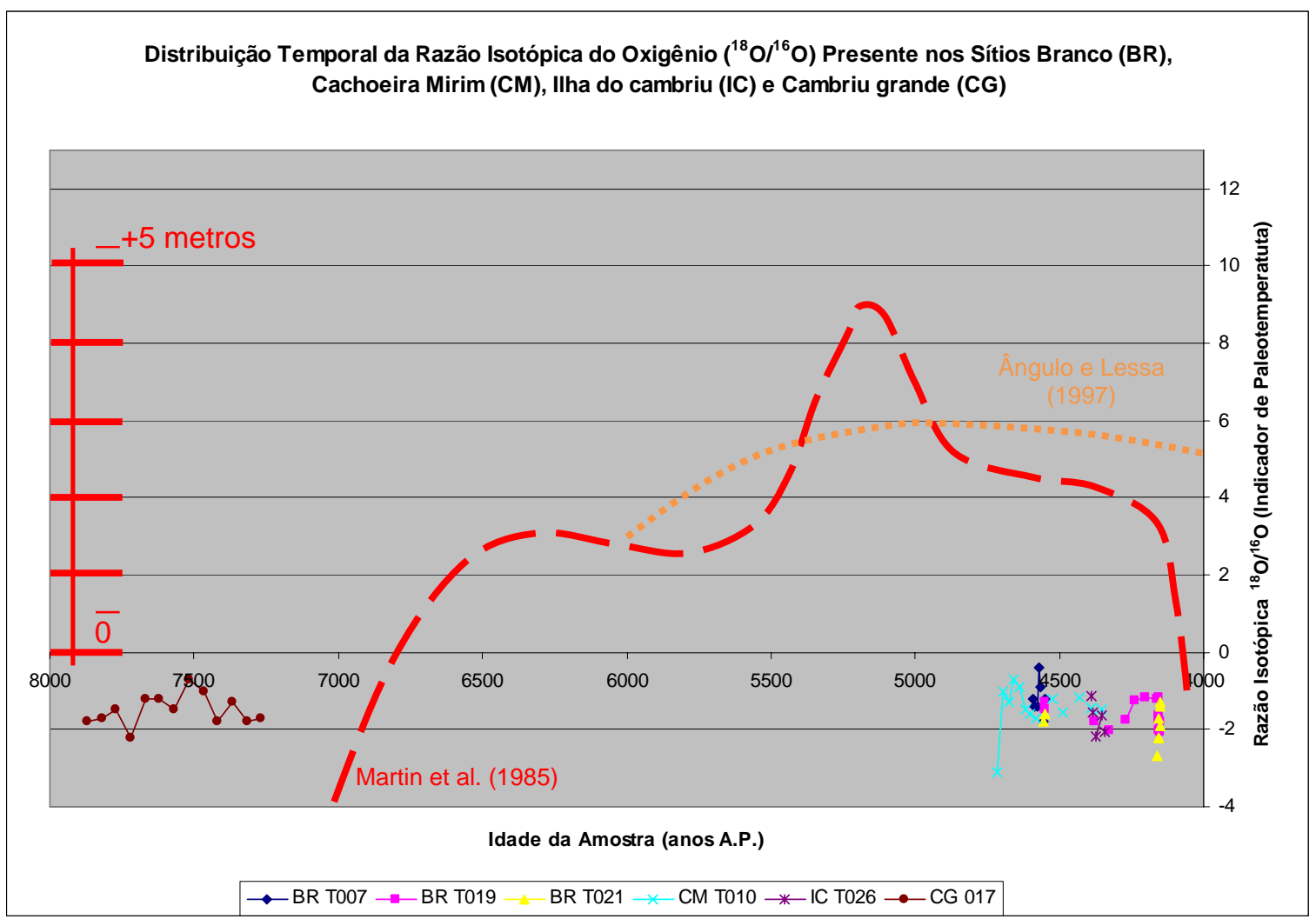

Figura 5.11 - Correlação das curvas de variação do nível relativo do mar (MARTIN et al., 1985; ÂNGULO e LESSA, 1997) com as distribuição temporal das razões isotópicas do Oxigênio $\left({ }^{18} \mathrm{O} /{ }^{16} \mathrm{O}\right)$ presente nas conchas dos quatro sítios analisados. Os valores do eixo $Y$ indicam a formação de carapaça em ambientes que vão da água doce $(13 \%)$ à água marinha $(0 \%)$

Com base em ambas as figuras, podemos perceber que não existe uma correlação direta entre a subida e a descida do nível relativo do mar (pelos menos, não em relação aos grandes ciclos de flutuação) e a distribuição temporal dos indicadores dos locais onde as conchas formam coletadas. Tanto nos momentos contemporâneos à ocupação do sambaqui Cambriu Grande como à construção dos outros sambaquis mais recentes, a maioria dos valores parece não ter sido diretamente influenciada pela variação do nível relativo do mar e das conseqüentes modificações ambientais decorrentes de tal processo. Reforçando, assim, a compreensão de que seriam os processos culturais os responsáveis pela determinação das estratégias de coleta.

Existe somente um momento, relativo ao topo do sambaqui Branco (dados mais à direta do gráfico), onde a extrema inflexão da curva de Martin (por volta de 4.000 anos AP) poderia sugerir uma correlação. No entanto, se analisarmos com 
mais cuidado as tendências de ambos os gráficos perceberemos que essa associação não faria qualquer sentido, pois, pela curva, o nível relativo do mar nesse momento estaria em profundo de declínio e as conchas, por outro lado, estariam sendo coletadas em ambientes cada vez mais salinos. Ambientes esses que, pela curva, afastar-se-iam cada vez mais das adjacências do sambaqui. Neste caso específico, tal associação reforçaria ainda mais a interpretação de que as estratégias de coleta tenham sido tomadas com base em aspectos culturais. 


\section{MODELO DE PREDIÇÃO}

Com o intuito de localizar feições submersas que pudessem explicar as lacunas e continuidades na presença sambaquieira ao longo do atual litoral, foi desenvolvido um modelo de predição de sambaquis submersos. No sentido de tecer correlações a partir desse modelo, em diferentes escalas, os resultados referentes à sua elaboração foram subdivididos em duas perspectivas: uma macro-regional, relativa a toda costa brasileira e adjacências; e outra, regional, que aborda, principalmente, e em maior detalhe, a ocupação sambaquieira de parte da região sudeste.

\subsection{UM MODELO GERAL PARA A COSTA BRASILEIRA}

O propósito de se desenvolver um modelo de predição de sambaquis submersos, em macro escala, estava, inicialmente, relacionado com a possibilidade de se explicar as descontinuidades existentes entre as áreas de ocorrência de sambaquis ao longo da costa brasileira. Tal propósito não só foi alcançado como extrapolado. Além de explicar a existência de tais lacunas, o modelo acabou permitindo ainda a proposição de duas novas hipóteses a respeito da chegada e da dispersão dos povos dos sambaquis ao longo da costa brasileira.

Em um primeiro momento, a partir da correlação entre as principais características topográficas da plataforma continental submersa, as feições de fundo (com idades conhecidas) e as posições dos antigos vales de rios (paleovales) submersos, o modelo de predição indicou as áreas mais prováveis (cruzamento dos eixos dos paleovales com as regiões mais largas das antigas bordas da margem continental) para a ocorrência de sítios submersos relativos aos primeiros momentos da ocupação sambaquieira (figura 6.01/anexo 02 e figura 6.02). 


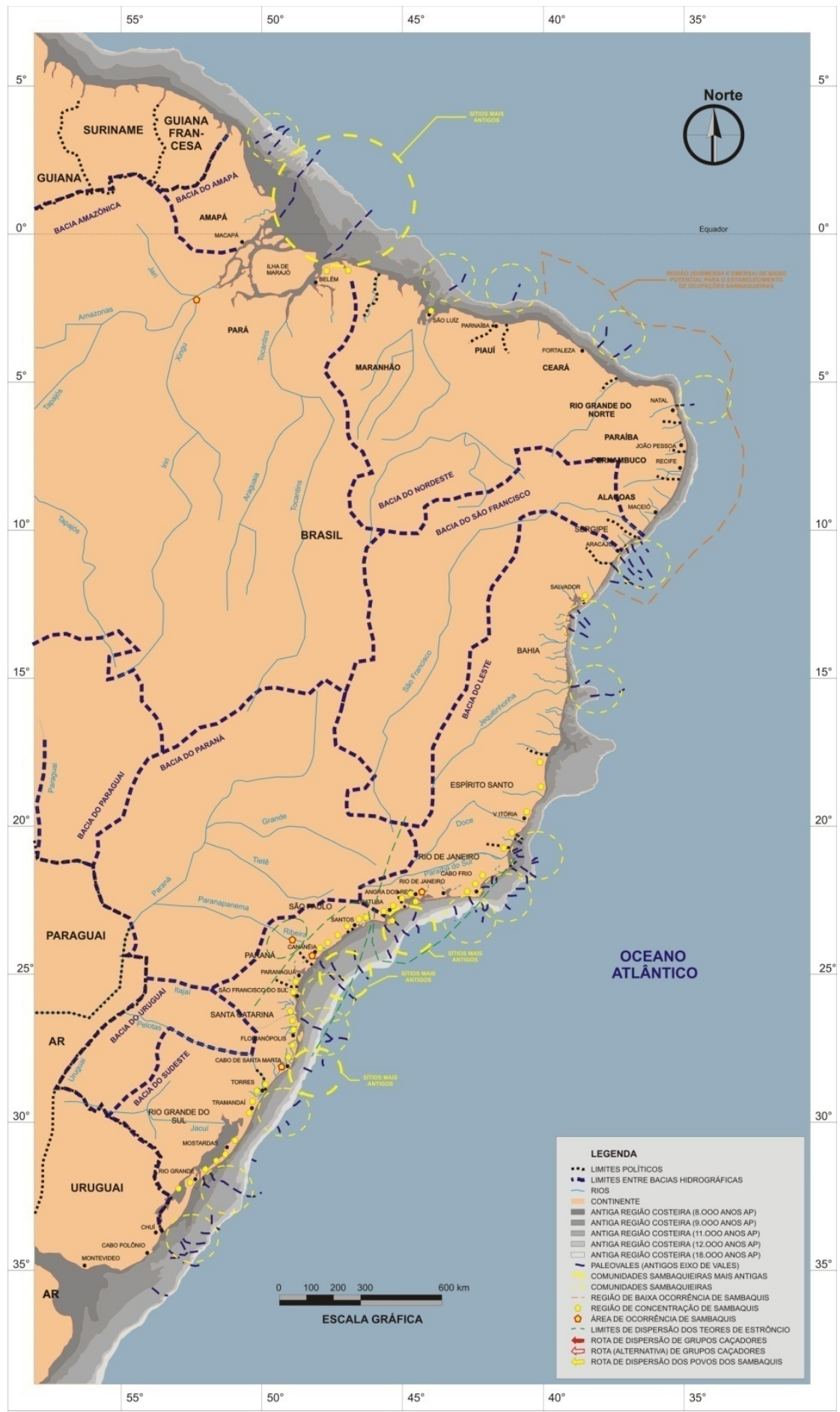

Figura 6.01 - Modelo de predição de sambaquis submersos ao longo da plataforma continental brasileira 


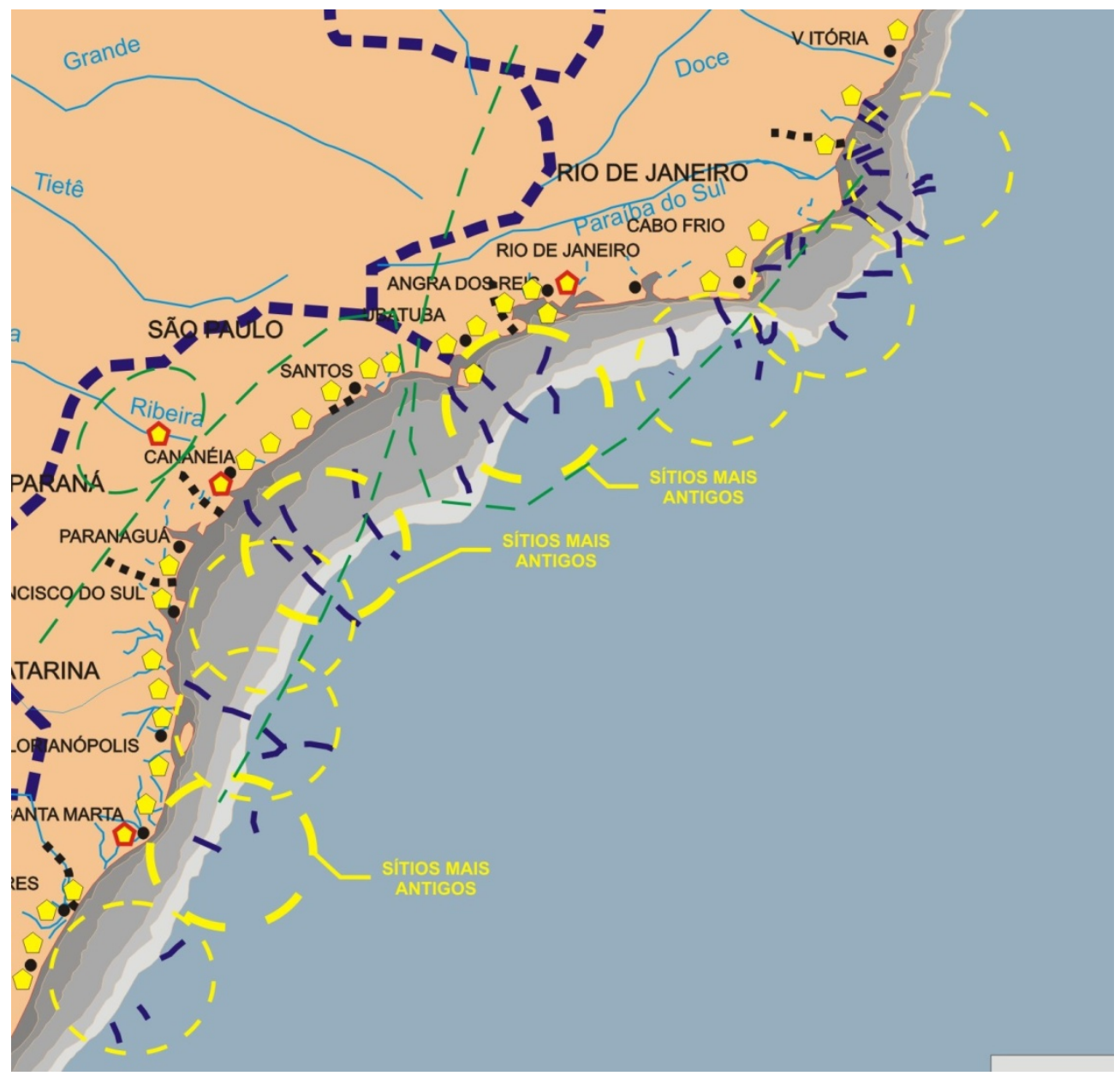

Figura 6.02 - Detalhe do modelo de predição de sambaquis submersos para a costa da região sudeste

Essa maior probabilidade da ocorrência de sambaquis submersos está fundamentada em dois pontos principais: em primeiro lugar, na ocorrência de sítios do tipo sambaqui que possuem datas anteriores a oito mil anos (sambaquis Cambriu Grande, em São Paulo, do Algodão, no Rio de Janeiro, e Taperinha, no Maranhão), cujos pares encontram-se, provavelmente, associados a um litoral hoje submerso; e, em segundo, na recorrência dos locais de assentamentos dos povos dos sambaquis, que, para a escala aqui analisada, é relativa à ocupação das regiões de foz dos principais rios que deságuam no mar (cruzamento dos vales dos rios com a zona costeira).

Mais do que fundamentar discussões a respeito de uma maior antiguidade da ocupação sambaquieira da costa brasileira, tal correlação visa também a proposição 
de novas alternativas para se explicar o estabelecimento de diferentes conjuntos de sambaquis. Uma vez que diferentes paleovales divergem a partir de um único provável vale original ou formam um provável sistema de vales (microbacias) mais antigo, surge a possibilidade de analisarmos as particularidades regionais da ocupação sambaquieira com base na organização desse sistema de vales submersos.

Em um segundo momento, com base nessa mesma modelagem, foi possível perceber ainda uma correlação entre a distribuição dos sambaquis ao longo da região nordeste e a mínima extensão da plataforma continental submersa entre, aproximadamente, o norte do estado da Bahia e o Ceará. Em conseqüência da pequena largura da plataforma, é bem provável que os povos sambaquieiros não teriam conseguido (ou não tivessem escolhido) permanecer muito tempo ao longo dessa região. Pois, tanto em áreas atualmente emersas como submersas, os amplos sistemas estuarinos e lagunares responsáveis pela oferta de recursos naturais que sustentariam o surgimento, o estabelecimento e a difusão do modo de vida coletor ou pescador não teriam a possibilidade de se formar.

Desta forma, independente das rotas de chegada à região (via continente ou via um litoral hoje submerso), mesmo que populações paleoíndias, caçadoras, coletoras ou horticultoras-ceramistas (neste último caso, provenientes da foz do Amazonas) tivessem passado e se estabelecido ao longo da região nordeste, em períodos de nível de mar mais baixo, devido à maior inclinação e menor extensão da plataforma continental dessa área, não teriam encontrado, nessa região, as condições necessárias à sobrevivência e ao desenvolvimento de comunidades sambaquieiras.

No entanto, apesar de fundamental para explicar a descontinuidade na distribuição dos sambaquis ao longo da costa brasileira, tal proposta não é capaz de, sozinha, apontar as origens, os locais e as rotas de chegada dos sambaquieiros ao litoral. Nesse sentido, com o intuito de avançar no entendimento de tais questões, foram elaboradas duas hipóteses a respeito dessas possíveis rotas: uma via o interior do continente e outra seguindo através de uma região hoje submersa. 
Sob o ponto de vista do estudo dos processos de formação do registro arqueológico, a proposição de ambas as hipóteses está diretamente associada à análise e interpretação dos processos naturais em macro escala. Nesse sentido, tais propostas podem ser compreendidas como um "pano de fundo", de ordem natural, que permitiu a ocupação dessa região e subsidia a construção de uma interpretação a respeito do surgimento dos povos dos sambaquis.

Embora tais hipóteses sejam contraditórias em relação às rotas de acesso a um litoral hoje submerso, elas não são necessariamente excludentes, pois, mais do que procurar apontar uma única rota de dispersão povos que construíram os sambaquis (através da costa ou pelo interior), sua proposição visa ao estabelecimento e à fundamentação de compreensões que contribuam para um melhor entendimento a respeito da origem dos povos dos sambaquis.

Independente da postura marítima da Arqueologia aqui defendida, que nos leva a analisar a possibilidade dos sambaquieiros terem se originado e, posteriormente, ocupado uma extensa porção da plataforma continental brasileira, hoje submersa, não acreditamos que houve um único caminho possível até ela. $\mathrm{Na}$ realidade, é possível que tal processo de ocupação possa ter se dado de forma concomitante ao longo desses dois eixos principais. Perspectiva que nos permite, inclusive, analisar e comparar as singularidades entre os sambaquis de diferentes regiões.

Para a elaboração dessas hipóteses, compreende-se que havia, em algumas partes do atual território brasileiro e países vizinhos, populações de caçadores coletores contemporâneas aos períodos em que os níveis relativos do mar, associados aos diversos pontos da costa brasileira, se encontravam mais baixos (18.000 a 7.000 anos AP).

Em um artigo em que discute a variabilidade cultural no período paleoíndio (11.000-8.000 anos AP), fundamentados nas pesquisas de Bate (1990), Dillehay (2000), Politis (1993) e Suárez e López (2003), Araujo (2004) aponta uma série de, pelo menos, 25 recuadas idades para a América do Sul. As quais apresentam antiguidades que distribuem-se desde os 30.000 anos AP (sítio Monte Verde, norte 
do Chile) e 25.000 anos AP (Pikimanchay, no Peru) até por volta de 8.600 anos AP (abrigo Quirihuac, norte do Peru).

Ainda que essas datações (localizadas, em geral, ao longo da costa pacífica), reforcem o modelo tradicional da dispersão do homem na América do Sul, Dixon (1999; 2001) defende uma rota costeira para a dispersão das populações humanas paleoindígenas (figura 6.03). Nessa mesma linha, Neves et al. (2003) propõe um outro modelo, a partir do qual, ao chegarem à América do Sul, as populações humanas teriam se dispersado pela costa e seguido dois ramos, um atlântico e outro pacífico (figura 6.04). No ramo pacífico, existem diversas evidências (acima apresentadas) que sustentam esse movimento. No ramo atlântico, no entanto, esses sítios mais antigos (que poderiam recuar a antiguidades de 30.000 a 8.000 anos AP) encontrar-se-iam submersos.

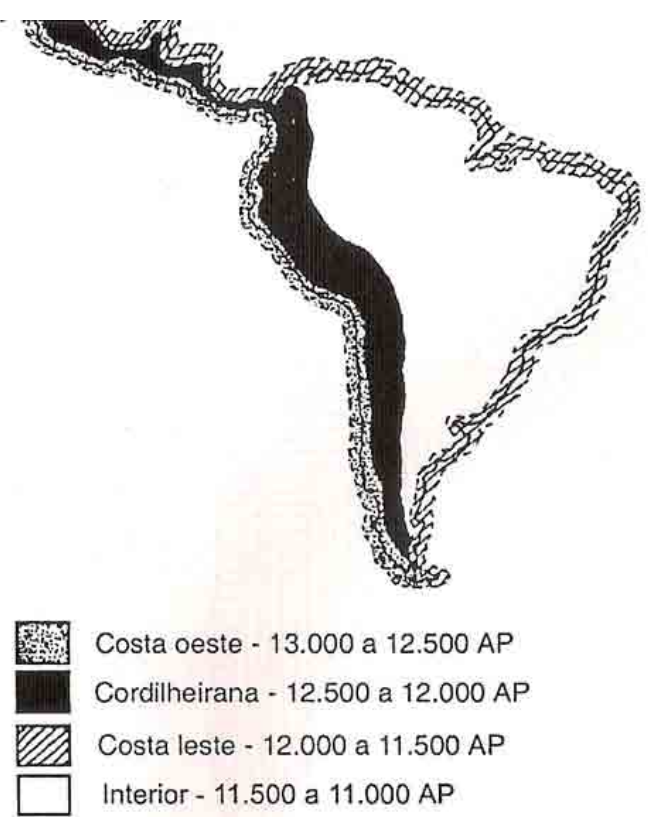

Figura 6.03 - Rota costeira de dispersão de populações paleoindígenas (DIXON, 1999; 2001)

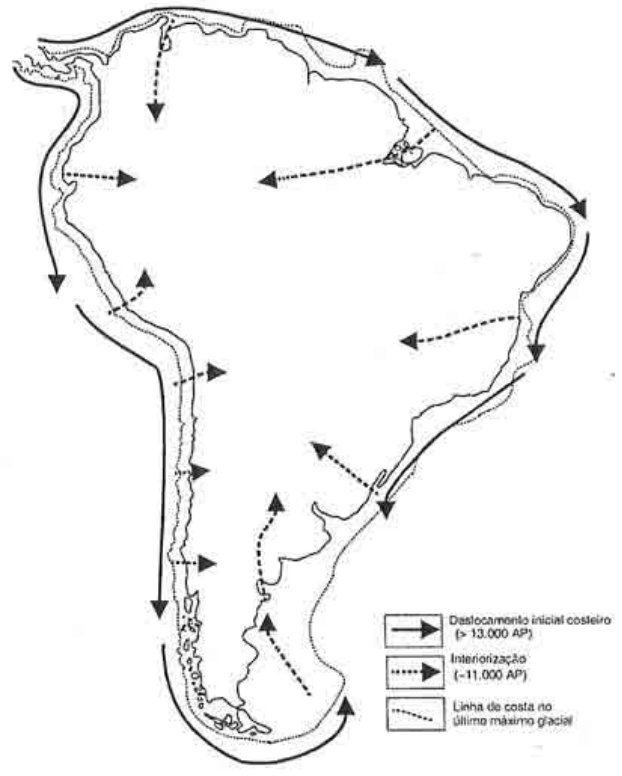

Figura 6.04 - Rota costeira de dispersão de populações paleoindígenas (NEVES et al, 2003)

Apesar da controvérsia a respeito da antiguidade e do processo de ocupação da América do Sul, Bueno (2005) aponta que, cada vez mais, o debate sobre essas questões tem caminhado no sentido de reconhecer que houve uma entrada inicial no continente em momentos anteriores há, pelo menos, 13.000 anos AP; e que um dos 
pontos amplamente aceito nesse debate é que, por volta dos 10.000 anos AP, todo o continente já se encontrava ocupado. Argumentos que reforçam a hipótese de que o período inicial da ocupação do litoral brasileiro e, também, da presença sambaquieira, encontram-se submersos.

Há uma série de sítios na Venezuela, Colômbia, Peru, Chile, Argentina e Brasil que apresentam datas para confirmar essa hipótese e, até mesmo, recuar ainda mais esse momento de ocupação (DILLEHAY, op. cit; ROOSEVELT, 2002) (BUENO, 2005, p. 38)

No que tange aos sítios arqueológicos em território brasileiro, pode-se citar, ainda, os assentamentos de caçadores relacionados à Tradição Itaparica (abrangendo, entre 10.750 e 9.000 anos AP, os estados de Minas gerais, Goiás, Mato Grosso, Bahia, Pernambuco e Piauí) (SCHMITZ, 1987; BUENO, 2005); o sítio Caverna da Pedra Pintada, em Monte Alegre, Pará (11.200 anos AP) (ROOSEVEL, 1999); os sítios da Tradição Umbu, na região sul do Brasil, com idades entre 12.000 e 7.000 anos AP (MENTZ RIBEIRO, 1999); os sítios de Lagoa Santa, em Minas Gerais, onde existem ocupações que remontam a, pelo menos, 11.000 anos AP; e, também, o abrigo Santa Helina, no Mato Grosso, cuja idade atinge os 23.000 anos AP (VIALOU, 2005). Assentamentos cujos ocupantes tanto poderiam ter chegado à antiga região costeira através da ocupação das diversas bacias hidrográficas brasileiras como através de uma região submersa (que na época, não seria, necessariamente, próxima à costa) entre o atual e o antigo litoral brasileiro (figura 6.05). 


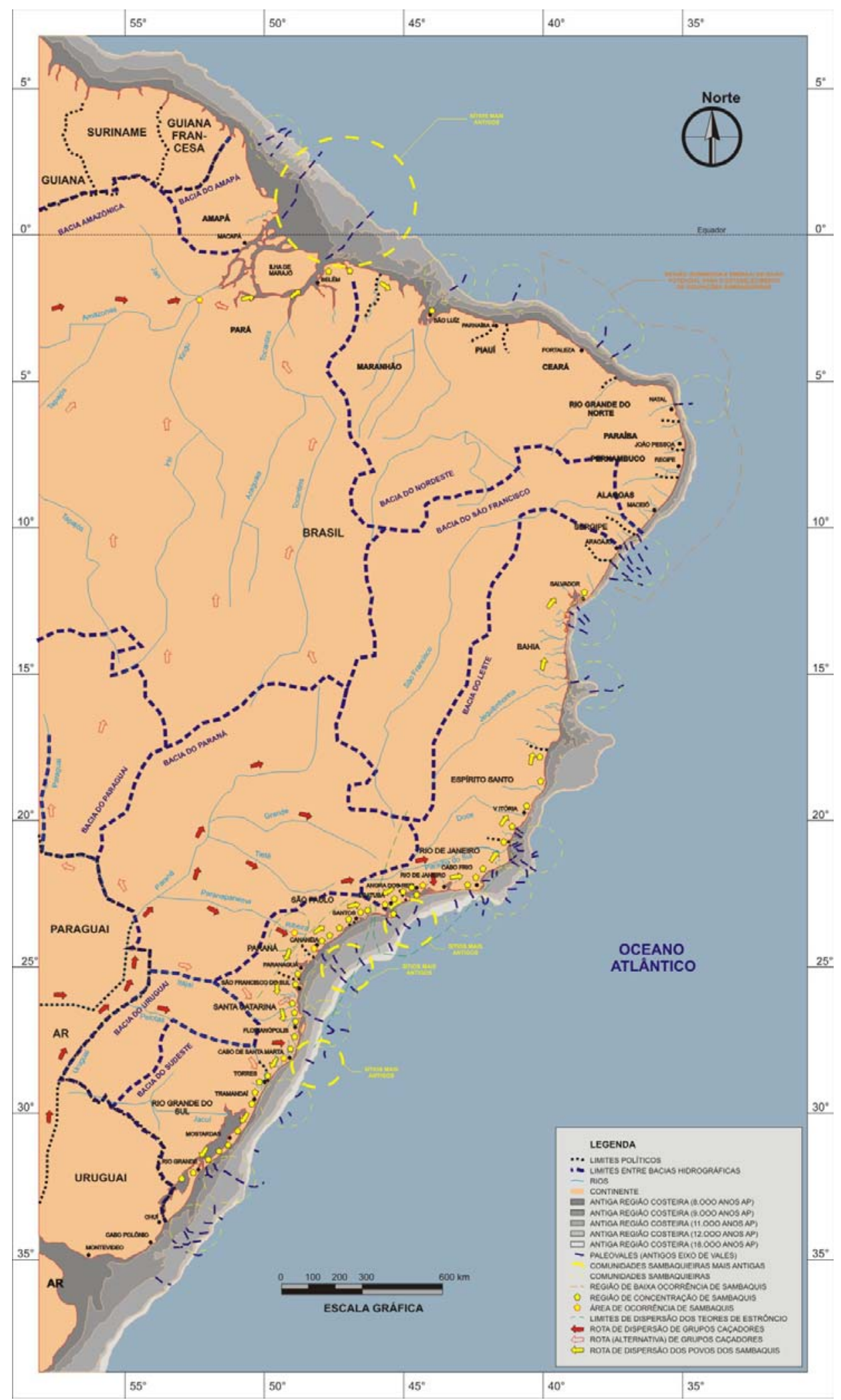

Figura 6.05 - Mapeamento dos antigos e atuais limites da costa brasileira, com as prováveis rotas de migração ao longo do litoral e das bacias hidrográficas. Estão plotados também os paleovales submersos e as ocupações sambaquieiras mais antigas. 
Apesar de raras, existem pelo menos duas indicações no Brasil que apontam para a existência de vestígios arqueológicos de caçadores associados a esses contextos submersos. A primeira é uma ocorrência relatada pelo arqueólogo Paulo Tadeu, da $5^{\mathrm{a}}$ SR IPHAN (com. pess, 1997), que teve acesso a testemunhos submarinos realizados há mais de 30 metros de profundidade, na plataforma continental submersa de Pernambuco, onde foram encontrados fragmentos de pontas de projétil líticas.

A segunda é referente a uma ponta de projétil, característica da tradição Umbu (figura 6.06), encontrada, por Mentz Ribeiro e Vaz (1999), na região dos Concheiros do Albardão (sul do RS) - um depósito geológico onde predominam conchas e fósseis de megafauna pleistocênica que são continuamente transportados à face praial pela intensa dinâmica costeira atuante na região.

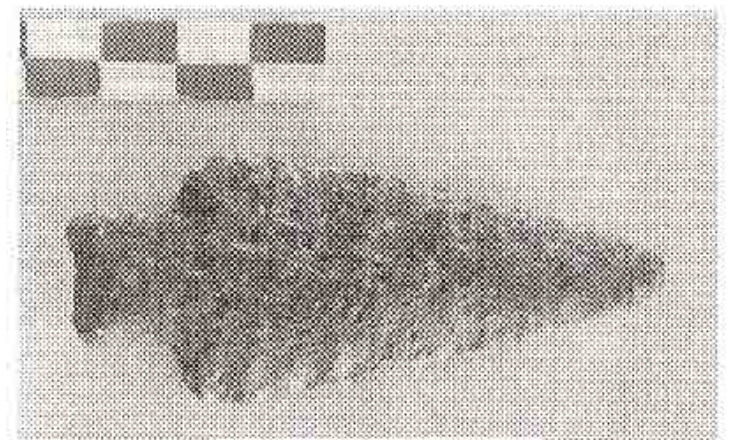

Ponta-de-projétil:

lado "a"

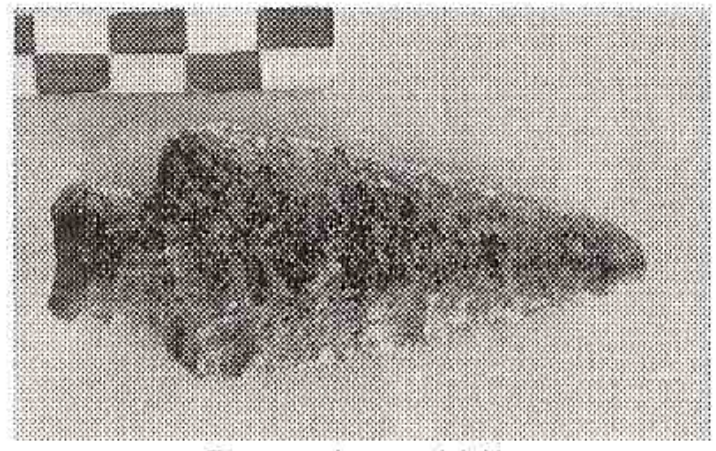

Ponta-de-projétil:

lado "b"

Figura 6.06 - Ponta de projétil da tradição Umbu encontrada em uma praia atlântica da região dos Concheiros do Albardão, entre os municípios de Chuí e Rio Grande (RS)

Embora esse tipo de evidência seja, de certo modo, ainda uma novidade para a comunidade arqueológica brasileira, a ocorrência desses vestígios já vem sendo, há décadas, destacada na bibliografia arqueológica internacional. Como exemplo, podemos citar os diversos sítios pré-históricos submersos de caçadores-coletores (paleoíndios) encontrados próximo à foz do rio Aucilla (ao sul da cidade de Tallahasee, Flórida) (figura 6.07 a), onde, segundo Wisner (1997), em meio a ossos 
de mamutes, foram encontrados, em contexto preservado, anzóis em osso (figura $6.07 \mathrm{~b}, \mathrm{c}$ ), pontas de projétil (figura $6.08 \mathrm{a}, \mathrm{b}$ ), fragmentos de estacas de madeira e artefatos em marfim (figura 6.08 c), datados em $10.000 \pm 80$ e $9.960 \pm 60$ anos AP (Beta 21750 e 58858).

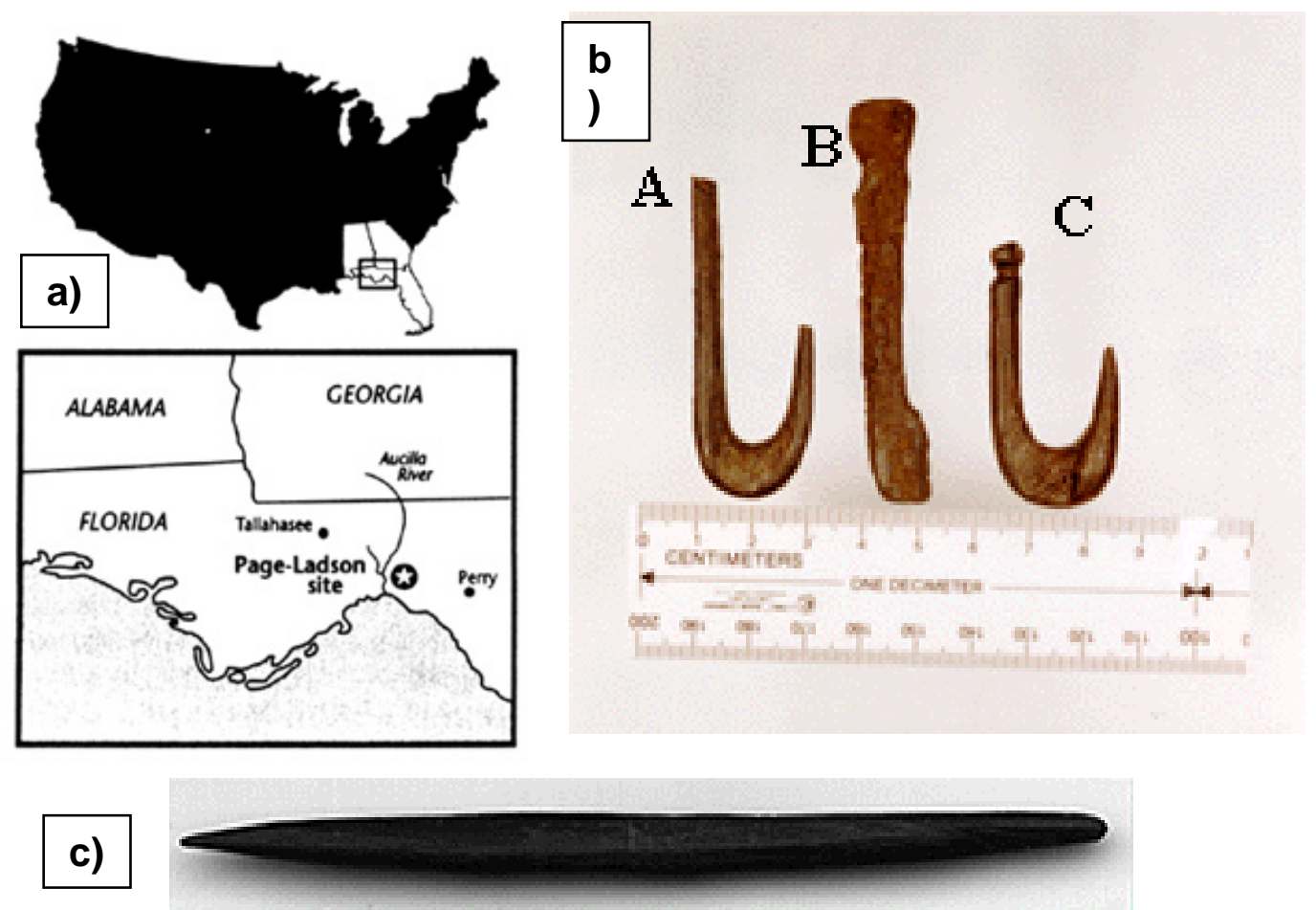

Figura 6.07 - Mapa de localização do rio Aucilla (a) e dos anzóis em osso (b, c) encontrados em contexto (WEBB et. al, 1990)
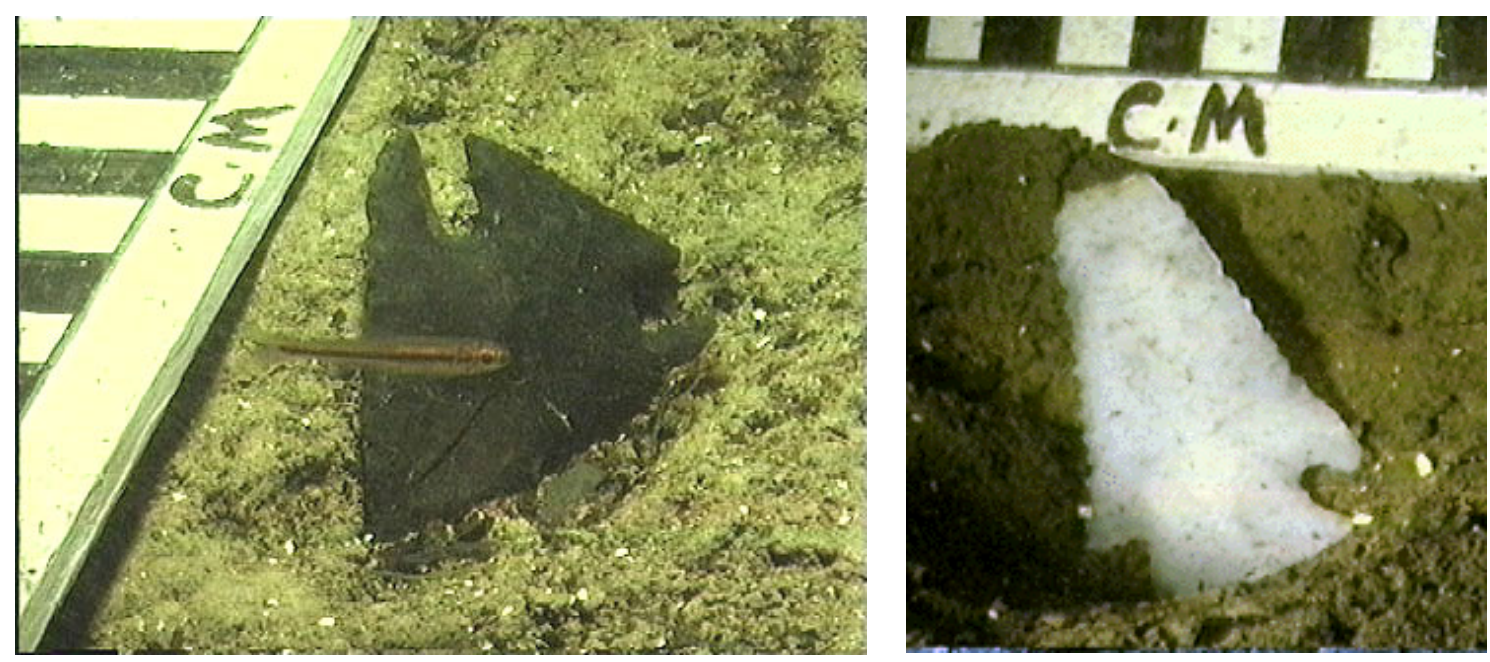


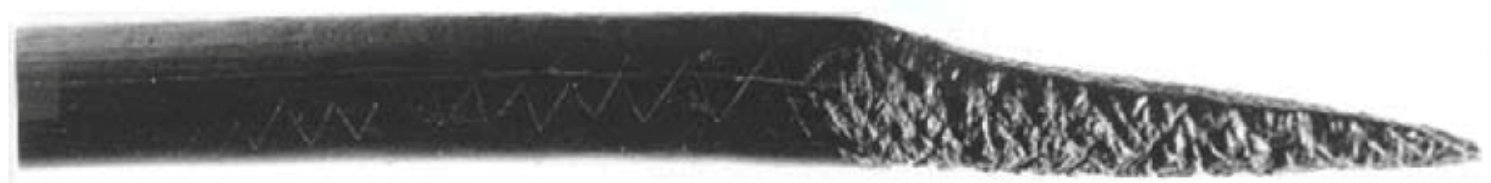

Figura 6.08 - Pontas de projétil (a, b) e artefato em marfim (c) encontrados em sítios arqueológicos submersos no rio Aucilla, Tallahasee, Flórida (WEBB et. al, 1990)

\subsubsection{A chegada ao litoral através de uma região atualmente submersa}

Esta primeira hipótese fundamenta-se no entendimento de que os povos dos sambaquis têm uma origem mais antiga do que se acredita atualmente, a qual é contemporânea a um período entre 18000 e 7.000 anos AP, em que o nível relativo do mar se encontrava abaixo do atual. Período no qual, provavelmente, grupos caçadores coletores ocupariam uma região situada entre o atual litoral e a cota de 120 metros.

A partir de 18.000 anos AP, quando o nível do mar entra em uma nova fase transgressiva, essas áreas passam, segundo Martin et al. (1985), a ser afogadas pela elevação do nível das águas marinhas, gerando estuários e grandes corpos d'águas costeiros ao longo dos principais rios que cortavam as regiões litorâneas daquela época. Novos ambientes que, por sua vez, propiciavam, a partir da interação entre os meios aquáticos marinhos e fluviais, o surgimento de uma região de maior diversidade e riqueza de espécies.

Apesar do contexto de mudança do espaço natural e do ambiente percebido por essas populações, esse novo ambiente apresenta as condições necessárias para a transformação de um modo de vida caçador-coletor para coletor-pescador. A partir de 18.000 anos AP, as extensas planícies fluviais que até então eram cobertas por florestas entremeadas por uma extensa rede hídrica fluvial, passam, cada vez mais, a dar lugar a planícies costeiras onde predominam corpos de água salgada e mixohalinos (com mistura de água doce e salgada), ricos em moluscos e peixes.

No que tange às populações humanas, não existe uma única resposta em relação a tal evolução da paisagem e do meio. Assim como devem ter existido 
parcelas dessa população que escolheram ficar, adaptando-se a esse novo meio, devem ter havido também grupos que resolveram migrar em direção ao interior em busca da manutenção das condições ambientais a que estavam acostumados.

Com base nas evidências levantadas até o momento, o mais provável é que o surgimento dos povos dos sambaquis tenha se dado a partir de uma transformação do modo de vida caçador coletor a um modo de vida coletor pescador, onde mais do que se adaptar a novas condições ambientais, parte das populações humanas tenham escolhido mudar o seu modo de vida, transformando-se em coletores e pescadores costeiros.

Desta maneira, cada conjunto de paleovales (figura 6.09) poderia ter atuado como um cenário específico para o surgimento de diferentes comunidades sambaquieiras marítimas. Onde, dependendo das questões sociais e culturais intrínsecas a seus integrantes, a vivência de um ambiente semelhante poderia resultar no estabelecimento de diferentes formas de perceber, modificar, modificarse e transmitir seus conhecimentos sobre o meio em que viviam.

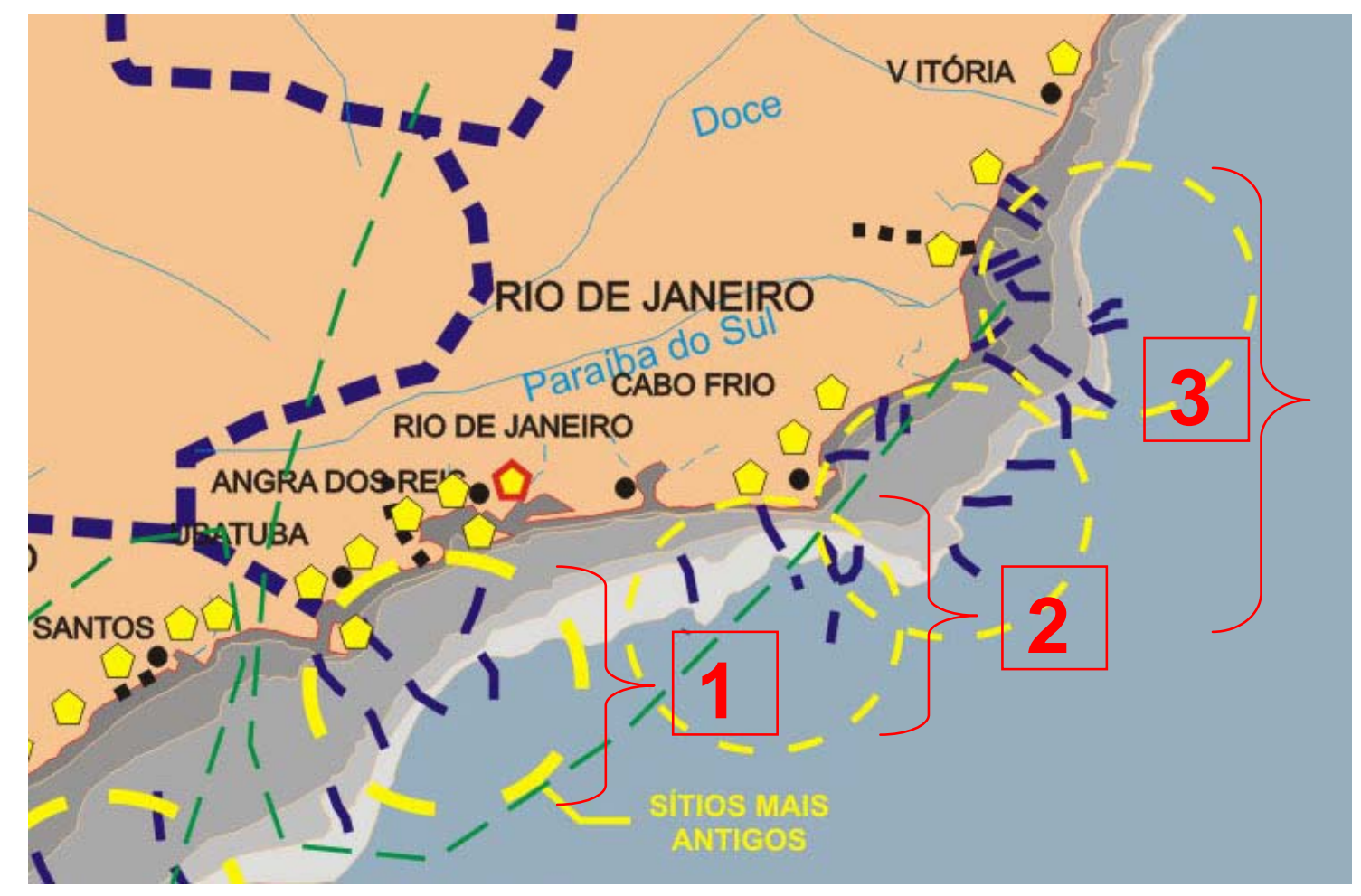

Figura 6.09 - Conjuntos de paleovales entre Santos e Vitória, os quais podem apresentar certa correlação com atual distribuição dos diferentes agrupamentos de sambaquis ao 
longo da costa (1 - litoral norte de São Paulo e sul do Rio de Janeiro; 2 - região central do litoral do Rio de Janeiro; 3 - litoral norte do Rio de Janeiro e sul do Espírito Santo).

É importante ressaltar que deste ponto, em diante, devem ser considerados não só os processos naturais de formação do registro arqueológico, mas, também, os culturais, pois, a medida que todas esses grupos de caçadores estariam sujeitos aos mesmos tipos de ambiente, o resultado da mudança de seu modo de vida estaria ligado principalmente aos processos culturais que se desenrolariam.

Processos esses que devem ser entendidos sob a perspectiva dos estudos de percepção ambiental de Ingold (2000), como ocorridos de uma forma dialética, onde a relação com o meio não se constrói de maneira unilateral. Como apontado por esse autor, à medida que as populações humanas e os indivíduos interagem com o seu meio e o modificam, acabam transformando-se a si próprias.

Existe um outro fator que também ajuda a sustentar a hipótese de que a distribuição dos antigos vales dos rios (hoje submersos) influenciou a dispersão dos sambaquis ao longo da costa, e, também, o estabelecimento das diversas comunidades sambaquieiras. Fator que está relacionado à localização dos sambaquis conhecidos mais antigos. Os quais se encontram, respectivamente, ao longo dos atuais litorais do estado do Rio de Janeiro (sambaqui do Algodão: $7.860 \pm$ 80 anos AP - LIMA et al, 2004) e São Paulo (7.870 \pm 80 anos AP - CALIPPO, 2004).

Além destes sambaquis apresentarem idades contemporâneas e localizaremse em regiões da costa ligadas a diferentes paleovales submarinos, como cada um deles encontra-se associado a um dos conjuntos de sambaquis (ou comunidades sambaquieiras) apontados pela análise da composição isotópica do estrôncio (Capítulo 4), é possível que deva haver entre os seus construtores uma origem comum. Seja ela proveniente de uma migração através de uma área submersa ou via interior (através do sistema hídrico que chega a costa).

Em relação ao período final da ocupação sambaquieira, ainda existem poucas evidências que possam sustentar uma hipótese a esse respeito. Na realidade, a adaptação aos ambientes costeiros deve ter ocorrido ao longo de diversos pontos da costa brasileira até, aproximadamente, 5.100 anos AP, quando o nível relativo do 
mar atinge seu máximo e começa a regredir. Embora ainda seja possível que, desse ponto em diante, outros grupos de caçadores continuassem a se adaptar a um modo de vida coletor pescador, é provável que os povos dos sambaquis começaram a se especializar na pesca somente após o máximo transgressivo. Isso porque é somente a partir de 5.100 anos AP, com o rebaixamento do nível do mar, que começam a se formar os amplos complexos estuarinos (antes dominados pelas águas marinhas costeiras), responsáveis pela grande abundancia dos recursos pesqueiros em ambientes protegidos da intensa dinâmica costeira.

Uma das evidências que leva-nos a essa interpretação foi obtida no âmbito desta Tese. Mais especificamente, como resultado da análise da composição isotópica do carbono e do oxigênio (Capítulo 5), a qual aponta para um aumento na diversidade das estratégias de coleta realizadas após o máximo transgressivo. Ainda que a coleta se concentrasse na fronteira dos ambientes lagunares e marinhos costeiros, parece haver, nos sítios de Cananéia, em momentos específicos, uma expansão nos ambientes de coleta.

Embora seja preciso reconhecer que essas evidências sejam ainda tênues (e, por isso, são aqui tratadas sob uma perspectiva hipotética), elas não são evidências isoladas. Recentemente, Lessa (2005) apontou para o fato de que parece existir um momento a partir do qual a coleta passa a ter cada vez menos importância, migrando de uma intensa exploração de frutos do mar (principalmente moluscos e peixes) para uma maior diversificação alimentar (que inclui, além da pesca, a caça de um grande número de mamíferos terrestres e aquáticos) - o que, para a autora, (com base em TIBURTIS et al, 1950/51; BECK, 1972; SILVA et al, 1990; BANDEIRA, 1992; SCHMITZ et al, 1993; SCHMITZ, 1996), se reflete na proliferação das pontas ósseas. Pontas essas que, como veremos logo adiante, com base na literatura internacional, acreditamos também possam ser interpretadas como um tipo de anzol mais simples.

Aliado a esse processo de adaptação e desenvolvimento de novas estratégias associadas aos ambientes costeiros que se formavam, existe também outra possibilidade de aquisição de tecnologias náuticas e saberes marítimos que deve ser considerada. Afinal, é justamente nesse período regressivo, entre, 
aproximadamente, 4.000 e 2.000 anos, que se estabelecem, na região sudeste e sul, as populações Tupiguarani ${ }^{39}$. Populações com as quais os povos dos sambaquis, em algum momento, devem também ter interagido (pacifica ou violentamente) e trocado conhecimentos, recebendo e passando novas tecnologias relacionadas à pesca e ao domínio dos ambientes marinhos.

Ainda que existam poucas referências a respeito do contato entre os povos dos sambaquis e as populações ceramistas que os sucederam, algumas evidências começam a apontar que os conhecimentos tecnológicos dos ceramistas podem ter despertado o interesse de algumas comunidades sambaquieiras, dando origem ao estabelecimento de contatos violentos ${ }^{40}$.

Com base no estudo cerâmico do sambaqui Tapera (Santa Catarina), Lessa (2005) sugere que, a partir de um determinado momento, embora não produzissem cerâmica, os habitantes desse sambaqui faziam uso de tal inovação tecnológica. A qual deveria ser a causa de ataque dos homens da Tapera a aldeias ceramistas para o rapto de mulheres, as quais seriam preservadas de ataque mortais (pois seriam as portadoras dos conhecimentos da confecção desses artefatos). Hipótese que propõe com base na ausência de ferimentos (por pontas de flecha) nos ossos da amostra feminina analisada.

Como causa do surgimento dessa agressividade, Lessa (op. cit.) sugere uma mudança no comportamento dos sambaquieiros que deve ter ocorrido, principalmente, em conseqüência da extinção da ideologia subjacente à atividade construtiva dos montes de concha, os quais obedeciam a um projeto ideologicamente determinado (GASPAR, 1992; LIMA, 1999/2000)

Paralelamente à falência do sistema sambaquiano e surgimento de uma nova ordem, onde já não importavam mais as premissas associadas à acumulação de conchas e observa-se a introdução de uma importante inovação tecnológica como a cerâmica, é possível que a agressividade

\footnotetext{
${ }^{39}$ A data mais antiga para um sítio da tradição Tupiguarani no litoral da região sul/sudeste é apresentada por Buarque et al. (2003), a qual diz respeito ao sítio Morro Grande (2600 \pm 160 anos AP), localizado no município de Araruama, RJ.

${ }^{40}$ Traumas agudos associados à violência na amostra esquelética no sítio Praia da Tapera (SC) só ocorrerem a partir de um segundo momento de ocupação, quando passam a ocorrer evidências da utilização da cerâmica, sendo os homens mais afetados do que as mulheres (17,2\% contra 3,8\%) (LESSA, 2005)
} 
tenha adquirido uma nova dimensão e importância entre as populações litorâneas (LESSA, 2005, p. 204).

\subsubsection{A chegada através do interior}

Do mesmo modo que a primeira proposta, a hipótese da chegada dos sambaquieiros fundamenta-se, principalmente, no entendimento de que os povos dos sambaquis se originaram a partir de uma mudança no modo de vida de populações caçadoras e coletoras que habitavam uma região da margem continental brasileira que atualmente se encontra submersa.

A diferença entre elas surge na medida em que se propõe uma outra possibilidade para a chegada dessas populações a essa região. Uma rota que, em vez de seguir ao longo de uma área próxima à costa, se desenvolve acompanhando algumas das principais bacias hidrográficas brasileiras, utilizando os rios como elementos de conexão entre os sítios de caçadores mais antigos e os primeiros sambaquis de nosso atual litoral (figura 6.10). 


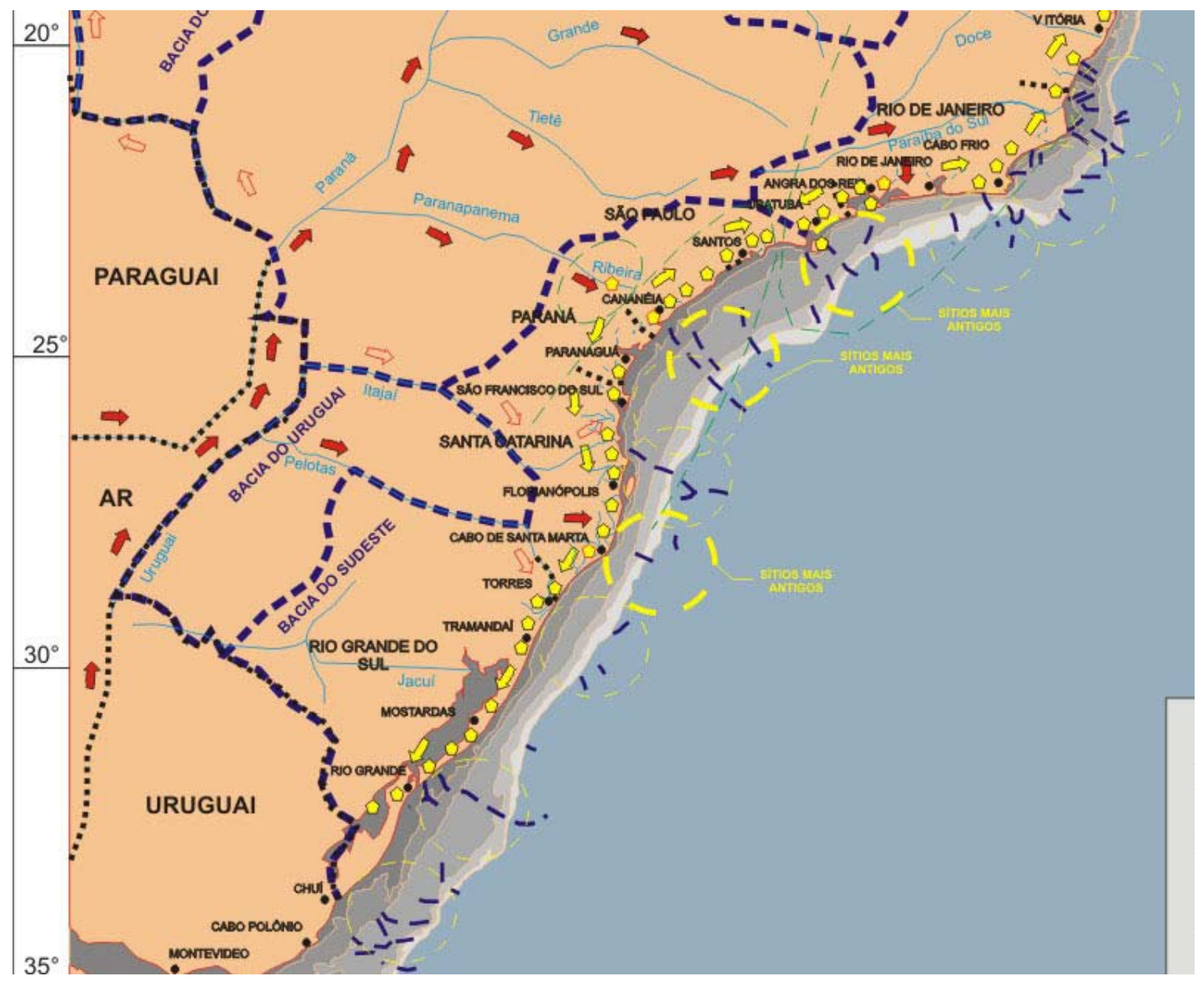

Figura 6.10 - Modelo de predição com as principais rotas de chegada ao litoral via interior (setas vermelhas) e posterior dispersão ao longo do litoral (setas amarelas)

Do ponto de vista teórico, tal interpretação também pode ser compreendida como um desdobramento da abordagem marítima aqui desenvolvida, a qual considera como parte do universo marítimo todos os outros contextos aquáticos. Nesse sentido, rios e bacias são entendidos como os eixos principais através dos quais as populações caçadoras-coletoras chegaram ao litoral via o interior.

Mesmo ainda não sendo possível estabelecer um quadro cronológico de sítios que apontem essa migração em direção ao litoral, existem ao longo do registro arqueológico dessas populações caçadoras alguns indícios (abaixo apresentados) que podem sugerir o desenvolvimento de uma adaptação, cada vez maior, ainda em locais distantes do litoral, aos ambientes aquáticos. Resultado, provavelmente, do contato que esses grupos caçadores acabaram desenvolvendo a partir da exploração dos ambientes dos vales e dos rios que utilizavam para se deslocar (ou 
migrar) em direção ao litoral ou às extensas planícies fluviais do início do holoceno. Em meio às quais, mais tarde, desenvolveu-se um novo e promissor ambiente costeiro.

Dentre essas evidências de captação de recursos aquáticos, podemos destacar, por exemplo, a ocorrência de pontas serrilhadas (figura 6.11), específicas para a prática de pescarias, localizadas no interior do Rio Grande do Sul (abrigo sob rocha Garivaldino - RS-TQ:58). Segundo Mentz Ribeiro (1999), apesar do uso dessas pontas atingirem seu ápice por volta do ótimo climático, sua produção já havia se iniciado em períodos anteriores aos 8.000 anos AP. Nos primeiros momentos do sítio (Período I), cujas idades estão entre 9.000 e 8.000 anos AP, as pontas serrilhadas equivalem a apenas $1,3 \%$ do total das pontas de projétil. A partir do qual, aumentam de número em direção ao presente, chegando a representarem $4 \%$ e 18\%, entre, respectivamente, aproximadamente 8.000 e 7250 (ou 6000) anos AP (Período II) e entre 6000 e 1000 anos AP (Período III).

No caso deste sítio, com datas que remetem sua ocupação a por volta de 9.430 \pm 360 anos AP (Beta-44739), ocorrem ainda dentes de tubarão, pinças de crustáceos (figura 6.12) e conchas de origem marinha. Indicando assim, já nesses primeiros momentos, algum contato (por mínimo que seja) entre esses grupos, os ambientes aquáticos do interior e os ambientes costeiros.
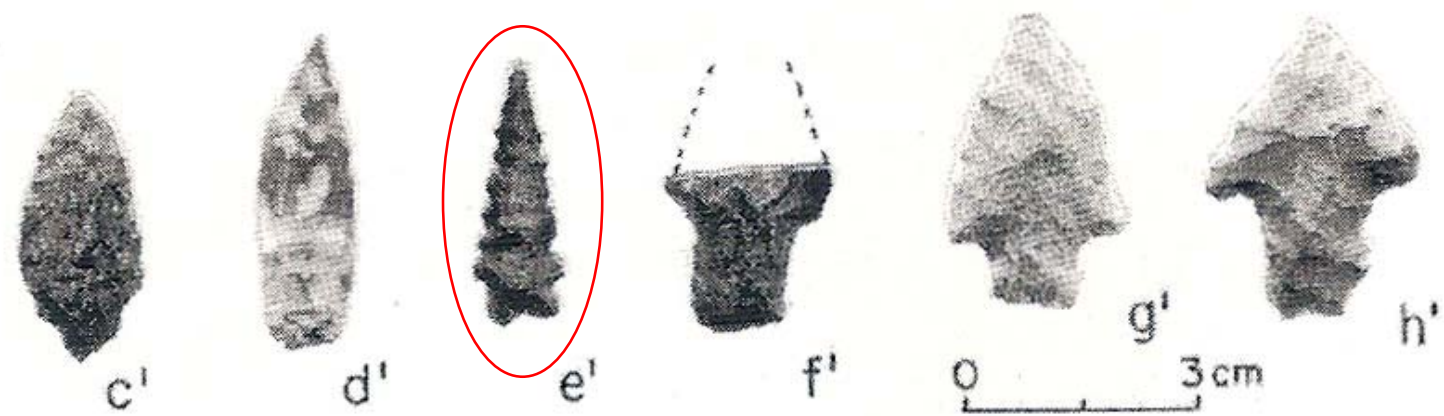

Figura 6.11 - Ponta de projétil (e) serrilhada encontrada entre as camadas arqueológicas associadas ao Período I 


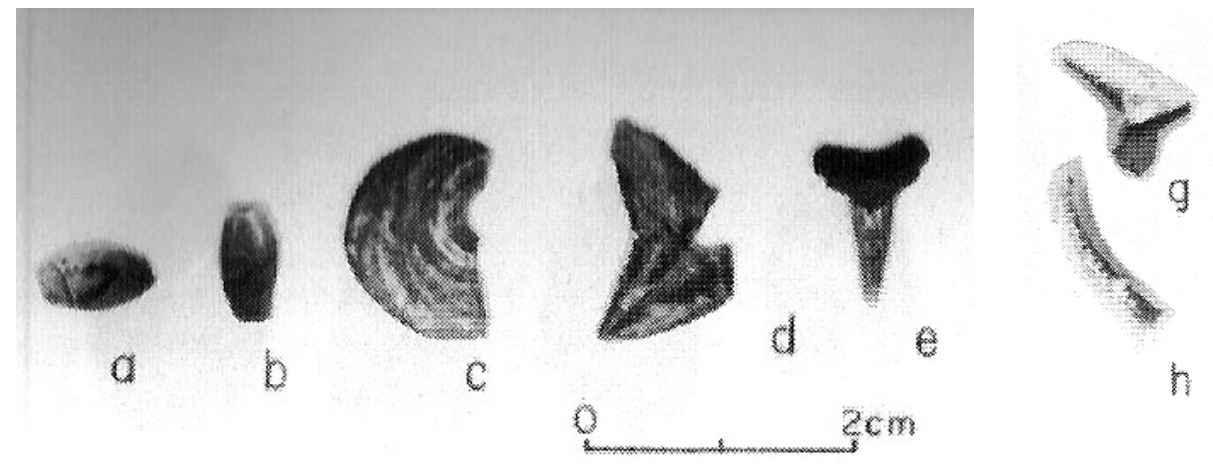

Figura 6.12 - Dentes de Tubarão (d, e) e conchas costeiras ( $a, b, c)$ associados ao Período III e pinças de crustáceos marinhos (g, h) relativos ao Período II

Além do caso das pontas serrilhadas, existem também outros instrumentos, característicos de grupos caçadores, que podem estar sendo interpretados de forma equivocada ou a partir de um contexto mais simples do que na realidade ele é (no qual, o mesmo instrumento poderia assumir outras funções). Nesse sentido, Stewart (1982) aponta, por exemplo, com base no estudo de artefatos dos índios da costa noroeste dos Estados Unidos, que existe uma série de instrumentos, comumente atribuídos a caçadores, que são atualmente utilizados em atividades de pesca por populações indígenas atuais (figura 6.13). Esse é o caso de bolas de boleadeira, pingentes e outros artefatos, que tanto poderiam servir para a função que Ihes dá o nome como serem utilizados (ou também utilizados) como pesos de rede e de anzóis. 


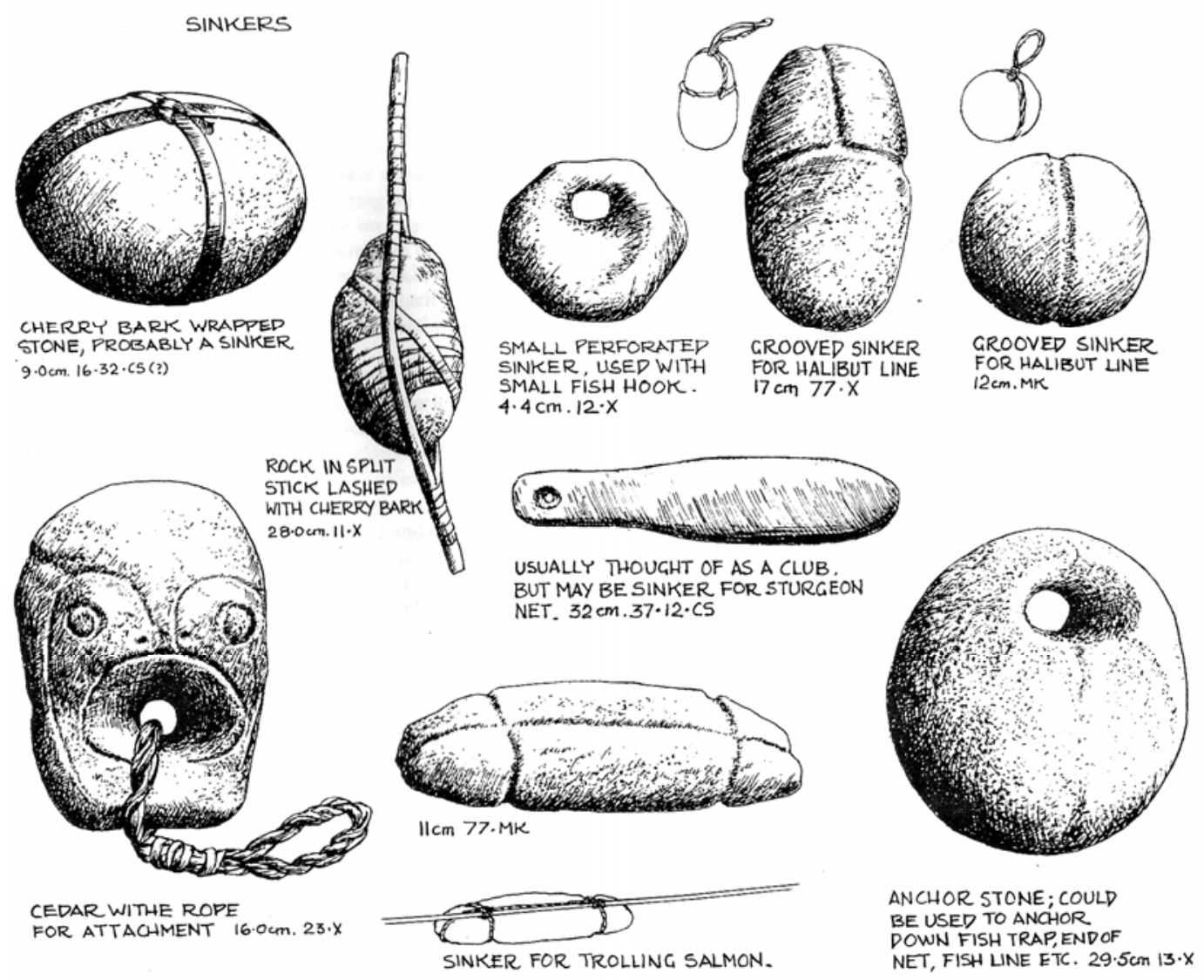

Figura 6.13 - Pesos de rede, utilizados por populações indígenas norte americanas. Os quais apresentam similaridades com artefatos tradicionalmente associados, na Arqueologia brasileira, a instrumentos de caça.

Uma situação que não é verificada somente por Stewart (op. cit) nas Américas. Cleyet-Merle (1990) descreve, também, uma situação semelhante para sítios pré-históricos e para o período greco-romano francês (figura 6.14).
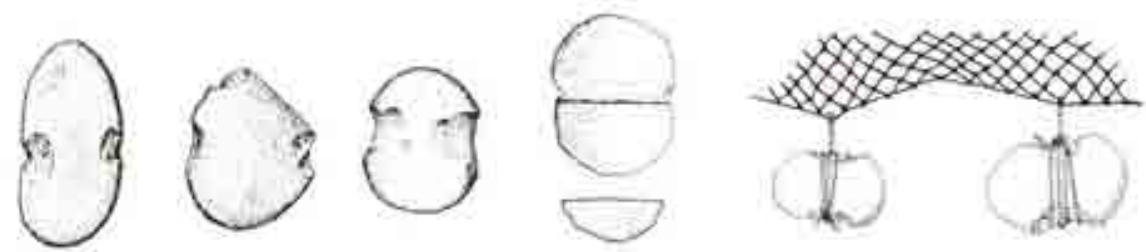

Figura 6.14 - Diferentes tipos de peso de rede (dos períodos pré-histórico, galo romano e atual) provenientes da França (CLEYETMERLE, 1990) 
Exemplos desse tipo também são encontrados no Brasil. Em Mentz Ribeiro e Calippo (2000) podemos também encontrar uma série de tipos de pontas em osso (figura 6.15), que, na realidade, tanto poderiam ser utilizadas como pontas (pontas de projétil, furadores, etc) ou de modo a servirem para a confecção de anzóis, como indicado (abaixo) por Cleyet-Merle (1990) para os sítios franceses (figura 6.16). De modo similar, nos sítios dessa região, é provável ainda que alguns machados, pingentes e peças de uso desconhecido também pudessem ser utilizados, no âmbito náutico e pesqueiro, como pesos de rede, pesos para anzóis e enxós (figuras 6.17).

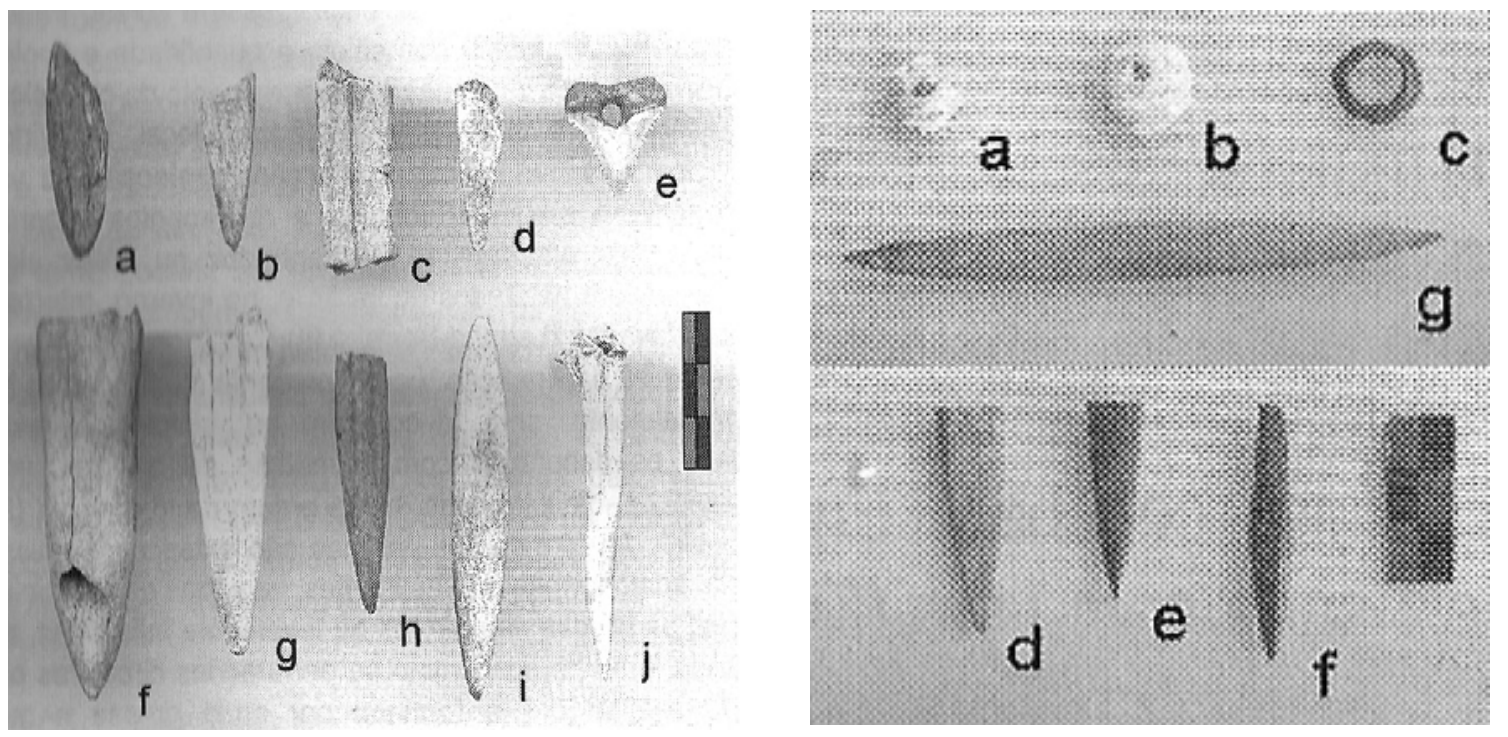

Figura 6.15 - Artefatos em osso (polido), inicialmente identificadas como pontas em osso, que, no entanto, poderiam ser utilizadas como anzóis (sambaquis do litoral centro e sul do Rio Grande do Sul) (Mentz Ribeiro e Calippo, 2000)
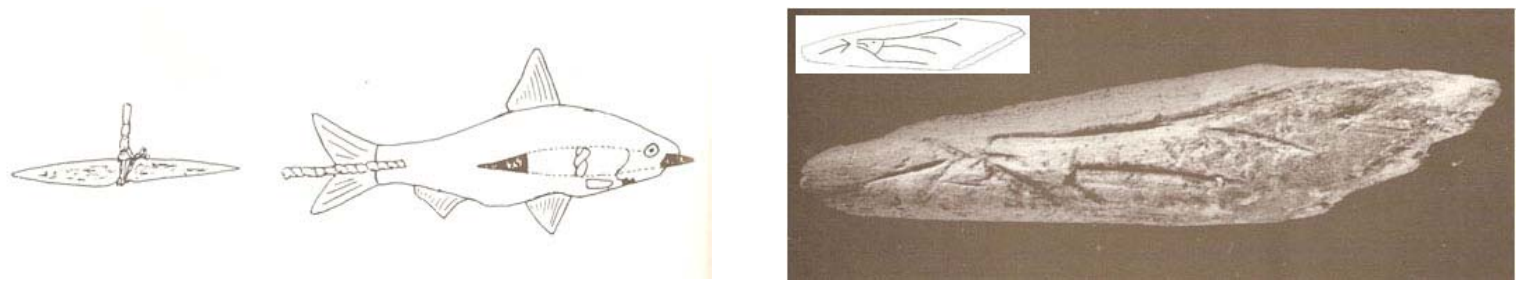

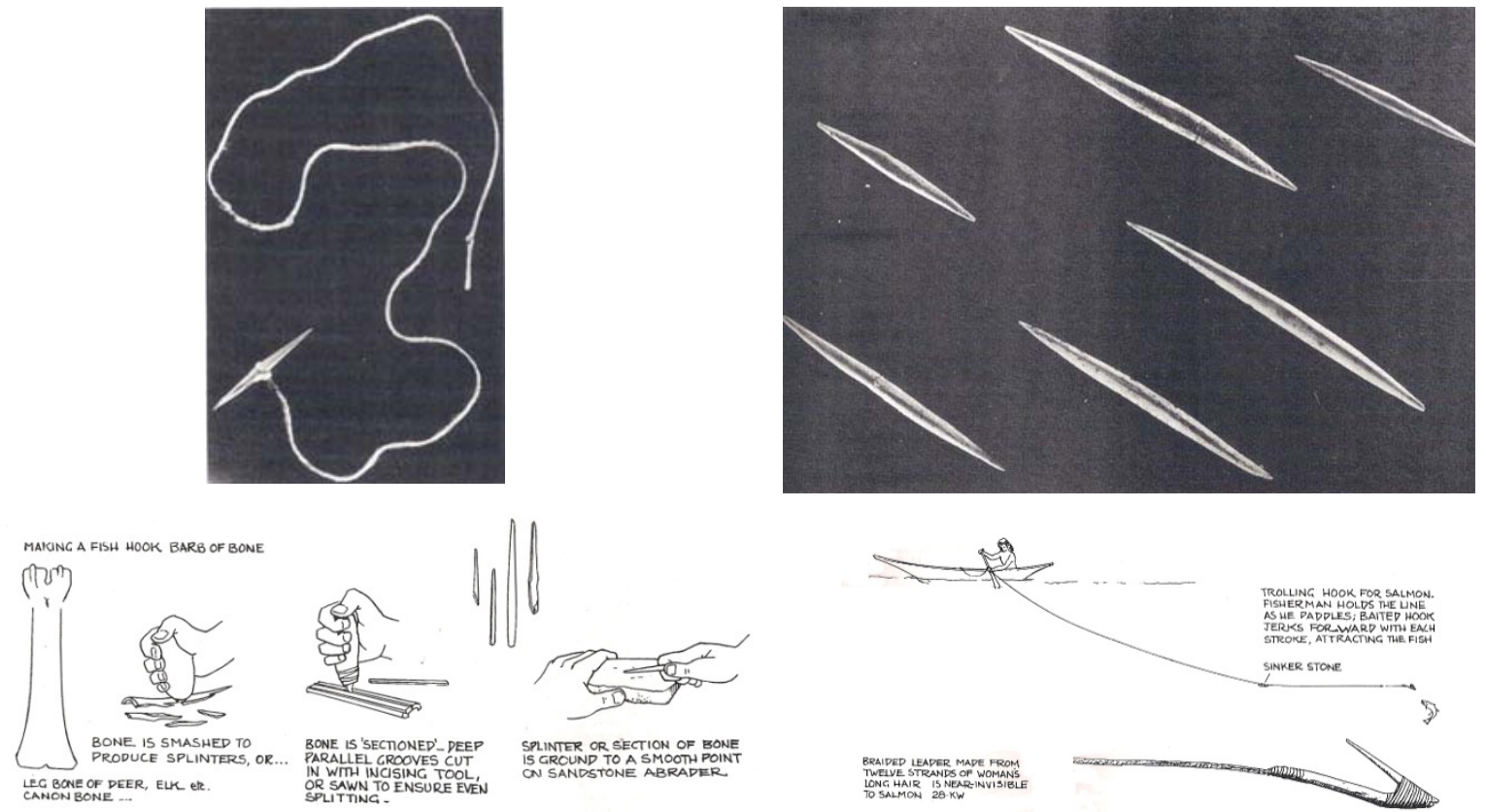

Figura 6.16 - Acima, esquema para utilização em anzol (esquerda) e gravura, sobre galhada de rena, que representa um peixe engolindo um anzol, relativa ao magdaleniense francês (direita)e (CLEYET-MERLE, 1990); No meio, anzol em madeira atualmente utilizado no sudoeste da França (CLEYET-MERLE, 1990); Abaixo, esquema para a preparação de anzóis em osso (STEWART, 1982).

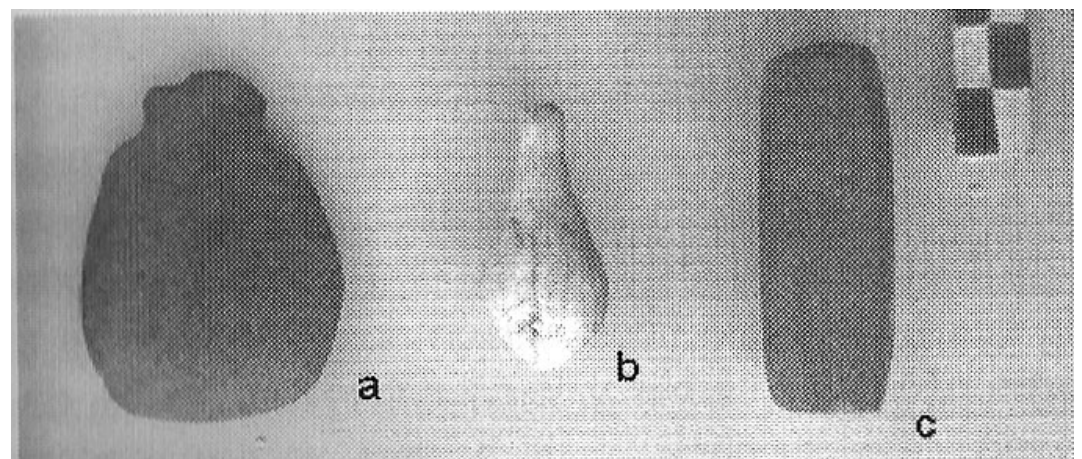

Figura 6.17 - Pingentes (a e b) e peças de uso desconhecido (c), encontrados nos sambaquis do litoral centro e sul do Rio Grande do Sul, que também poderiam ser utilizados na atividade pesqueira como pesos de rede (a), pesos para anzóis (a e b) e como enxós (c) (para a fabricação de canoas)

Embora migrando através dos rios em direção ao mar, não acreditamos que nesse primeiro momento o foco dos caçadores fosse o ambiente costeiro, pois, nessa época, a costa brasileira não apresentava a riqueza e a diversidade de espécies que começou a apresentar após o máximo transgressivo (onde ocorre um 
processo de rejuvenescimento e expansão dos estuários). Nessa fase, o que os caçadores buscavam seria a abundancia de recursos naturais disponíveis nas amplas planícies fluviais (que mais tarde, com a elevação do nível do mar, se tornariam áreas costeiras).

O mais provável é que nesse período contemporâneo ao evento transgressivo, as populações caçadoras que viviam nessas extensas planícies (com até por volta de 120 quilômetros de largura) começariam a se deparar com um ambiente e um espaço em plena transformação. Onde, cada vez mais, os recursos costeiros passariam a ser mais abundantes.

No que tange a ocupação dessa ampla planície fluvial, é importante ainda fazermos uma consideração a respeito de seu relevo. Embora fosse uma planície, possuía uma diferença de altura entre seus extremos que atingia por volta de 120 metros. Ou seja, os grupos que a ocupavam, muito provavelmente, não estariam próximos ao litoral. De um modo geral, podemos inferir que os habitantes de tal planície ocupariam uma cota em relação ao mar semelhante (ou até maior, dependendo da época) a que os sambaquieiros do médio Ribeira ocuparam quando o nível do mar atingiu o seu máximo no holoceno.

Se extrapolarmos essa possibilidade para a toda a costa, é provável que possamos também estabelecer um contexto a partir do qual algumas das principais descontinuidades e diferenças entre os principais conjuntos de sambaquis. Nesse sentido, como exemplo, podemos propor uma hipótese para explicar a ausência de sambaquis ao longo da plataforma continental do nordeste.

$\mathrm{Na}$ figura 6.03 podemos perceber que em nenhum momento a plataforma continental adjacente a essa região propiciou o desenvolvimento de condições sedimentares e de relevo apropriados para o desenvolvimento de um modo de vida sambaquieiro, no qual os grandes corpos lagunares e os ambientes marinhos protegidos seriam os principais atrativos.

Entretanto, é importante ressaltar que, embora esse ambiente não apresentasse as condições que identificamos como ideais para um modo de vida sambaquieiro, não estamos querendo dizer que essa região não poderia ter sido ocupada por populações coletoras e pescadoras. Nesse caso específico, poderia ter 
se estabelecido nessa porção da costa uma outra sociedade que também explorasse os recursos costeiros. Porém, em um ambiente completamente diferente dos escolhidos pelas populações das regiões sul e sudeste, onde o fator determinante para o seu desenvolvimento, e similaridade ou diferença em relação aos povos dos sambaquis dependeria, principalmente, da maneira como essa sociedade teria percebido-se, modificado-se, transformado seu meio e relacionadose com o ambiente.

Com base nessa mesma perspectiva, talvez possamos discutir a questão dos sambaquis da região norte. Ainda que não exista um consenso se os aterros de concha dessa região possam ou não ser chamados de sambaquis (sendo, dessa maneira, compreendidos como membros da grande sociedade sambaquieira que dominou o litoral), sob tal abordagem eles são aqui entendidos como evidências deixadas por populações pertencentes a uma outra sociedade coletora pescadora.

Não somente em conseqüência da distancia que assumem da região sudeste, mas, principalmente, em decorrência de suas prováveis origens culturais. Embora aqui não se procure discutir com profundidade os povos que poderiam os ter originado, existem apenas duas possibilidades: grupos caçadores-coletores (provenientes do interior ou migrantes ao longo de uma plataforma hoje submersa) ou populações horticultoras que começaram também a explorar os recursos costeiros em conseqüência dos eventos decorrentes da elevação do nível relativo do mar.

Sob esse contexto, talvez, possamos, por exemplo, melhor discutir as problemáticas associadas à compreensão do sambaqui Taperinha (datado em aproximadamente 10.000 anos AP) e da própria cerâmica (Mina) - que caracteriza grande parte dos aterros de concha da região norte. Os quais, provavelmente, teriam sido construídos não só por um povo que se originou de populações caçadoras-coletoras que se adaptaram aos novos ambientes costeiros, mas, também, devem ter sido culturalmente influenciados pelo contato com as populações das devem ter absorvido a tecnologia cerâmica. 


\subsection{UM MODELO ESPECÍFICO PARA A COSTA DO ESTADO DE SÃO PAULO}

De modo similar ao modelo proposto para toda costa brasileira, a segunda parte do modelo de predição, que aborda especificamente a costa do estado de São Paulo, também procurou utilizar os paleovales e a batimetria do fundo marinho como uma indicação das lacunas e continuidades existentes entre a dispersão dos conjuntos de sambaquis.

No entanto, para a sua elaboração foram levados em consideração um maior e mais preciso número de dados. Além das referências utilizadas para a elaboração do modelo geral para a costa brasileira, foram também considerados o estudo geomorfológico da plataforma continental do estado de São Paulo (CONTI, 2004) e diversas outras informações a respeito das feições e características de fundo (como antigos níveis marinhos, linhas de praia, vales de rios e indicadores de áreas estuarinas).

Com base no cruzamento da espacialização e das profundidades dessas feições com as informações relativas às idades atribuídas à batimetria dos paleoníveis marinhos, identificados e datados por Kowsmann e Costa (1979), Furtado et. al. (1998) e Klein (2005), foram estabelecidos os locais mais prováveis para a ocorrência e a preservação do registro arqueológico dos sambaquis ao longo de 18.000, 12.000, 11.000 e 9.000 anos AP (figura 6.18). 


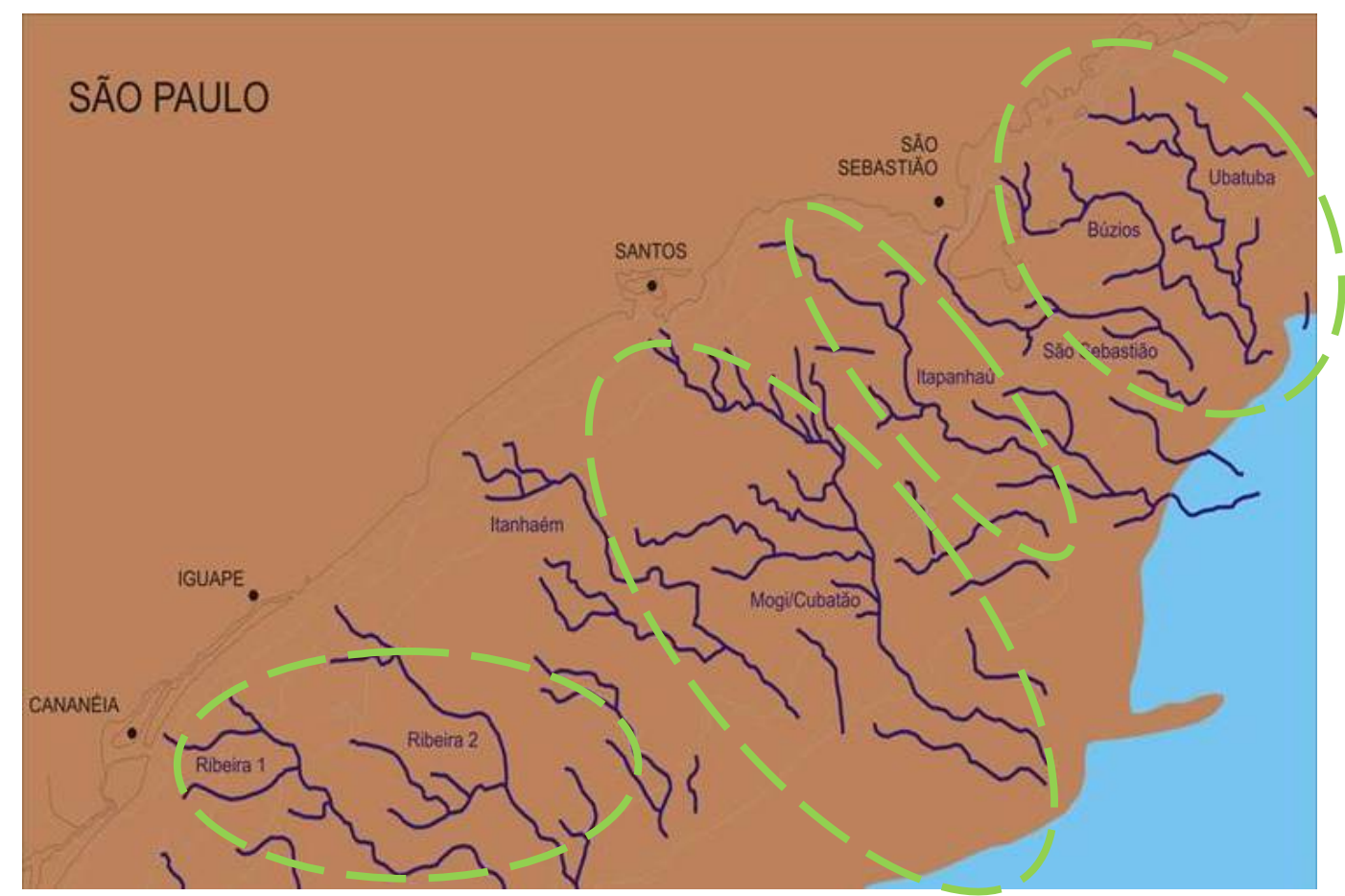

Paleodrenagem há 18.000 anos AP

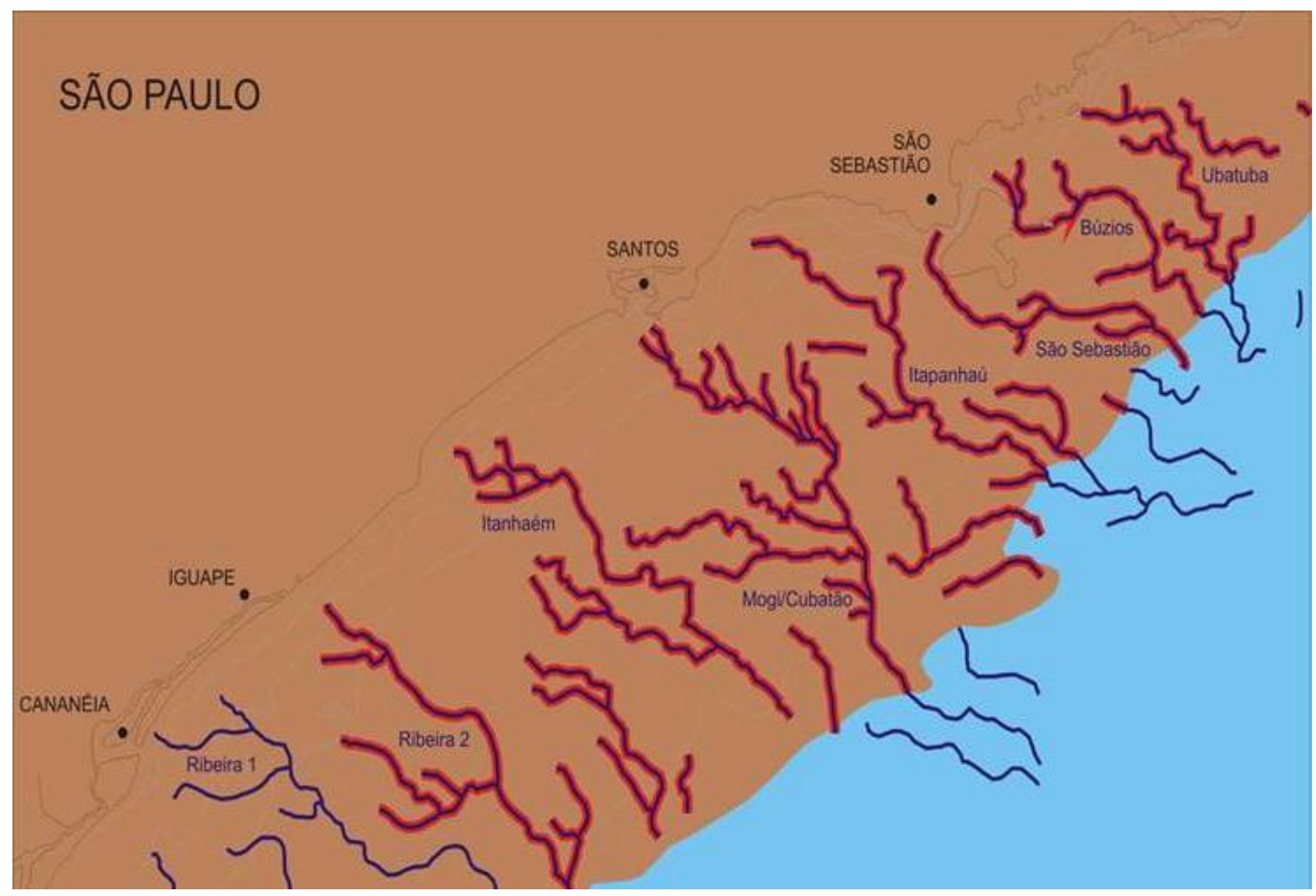

Paleodrenagem há 12.000 anos AP 


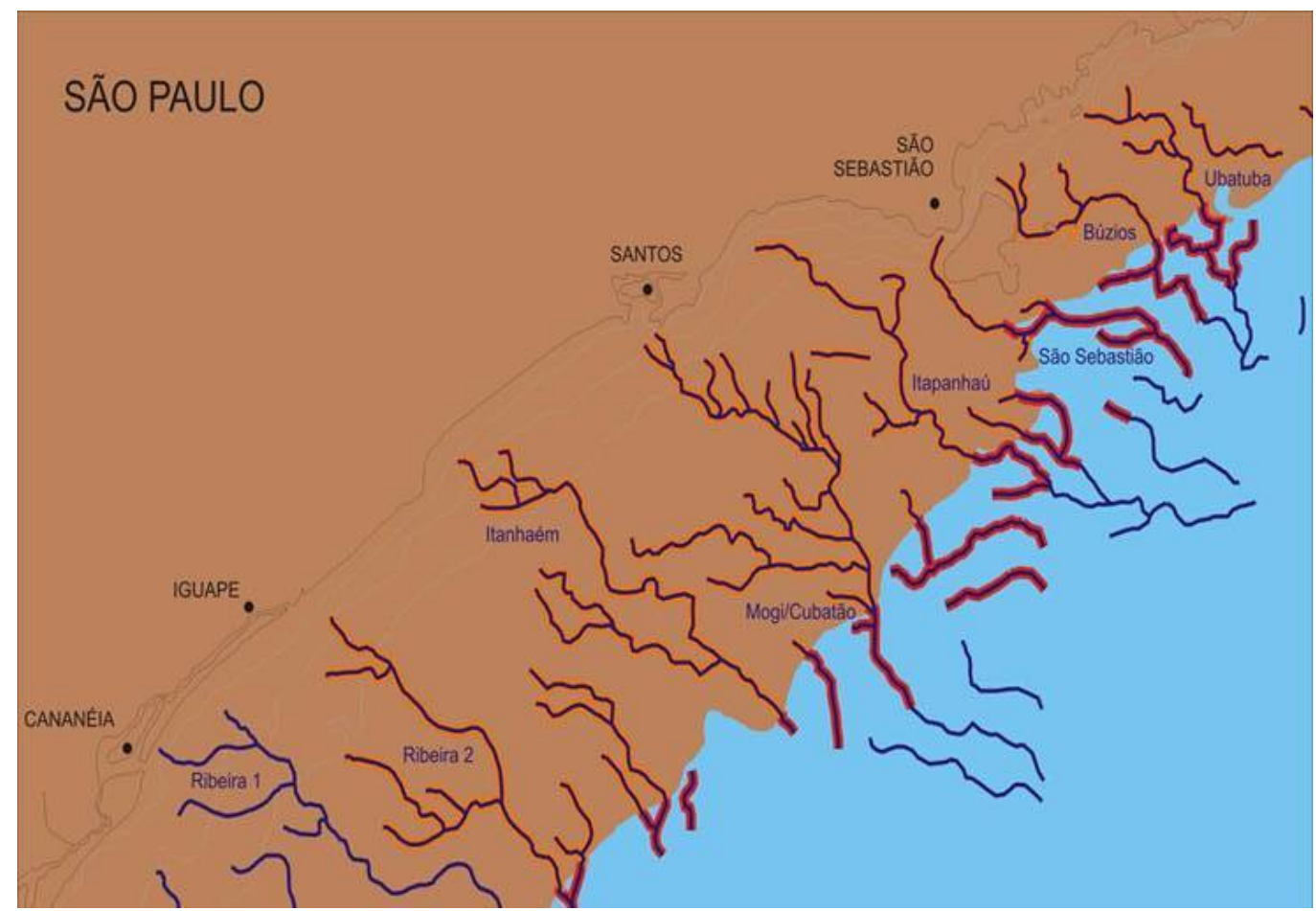

Paleodrenagem há 11.000 anos AP

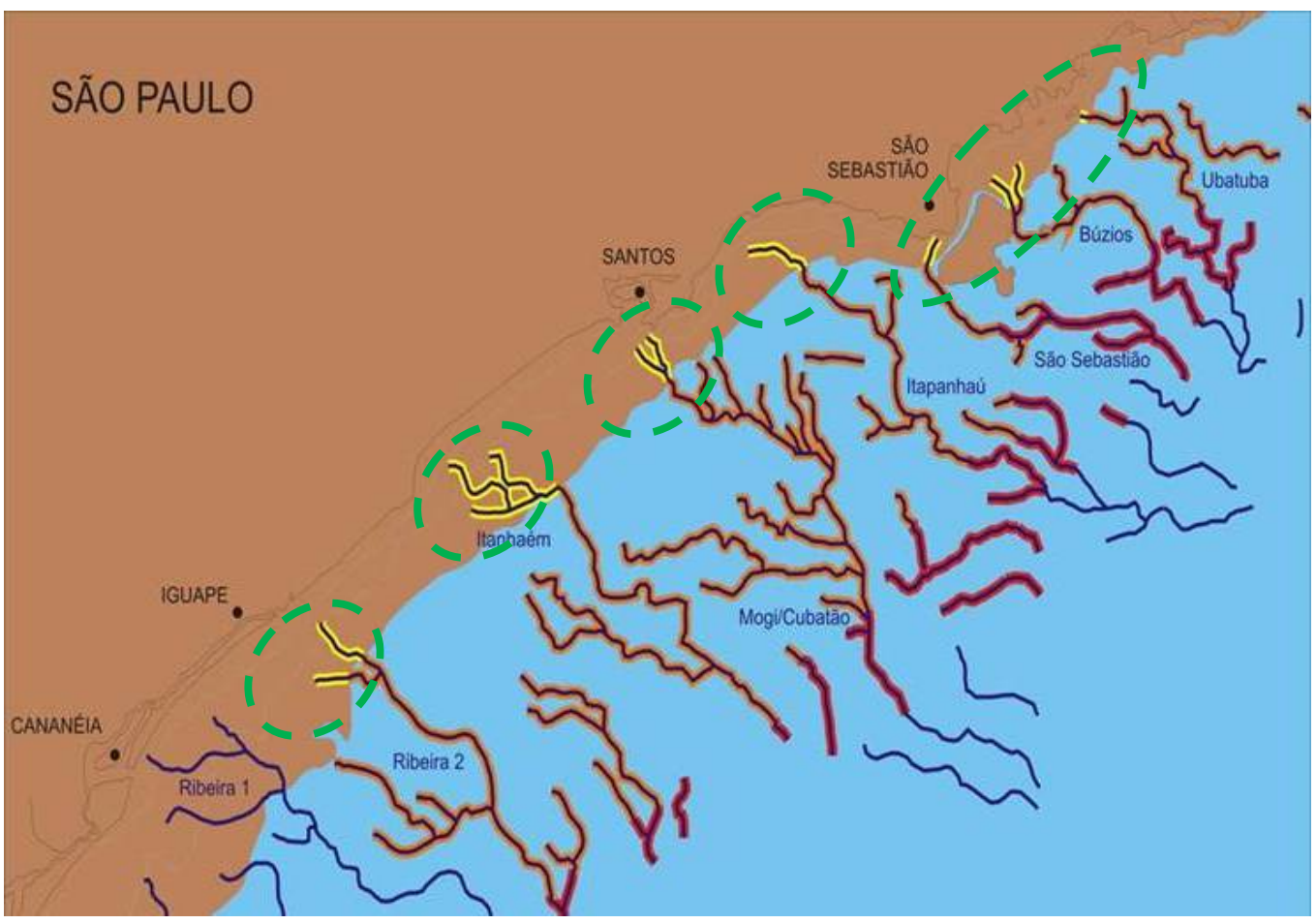

Paleodrenagem há 9.000 anos AP

Figura 6.18 - Distribuição dos paleovales submersos (ao longo da porção submersa da plataforma continental do estado de São Paulo) em relação à posição do atual litoral brasileiro e às antigas linhas de costa 
Como, para o caso dos sítios do litoral do estado de São Paulo, foram levados em consideração estudos mais detalhados e recentes a respeito do fundo marinho (do que os analisados para o entendimento da dispersão dos sambaquis ao longo costa brasileira), foi possível estabelecer, ainda, com base no estudo dos paleoníveis marinhos, quais as frações dos paleovales que um dia estiveram associadas às antigas faces praias.

De um modo geral, sambaquis submersos poderiam ser encontrados ao longo de todos os paleovales, pois, durante o evento transgressivo, diversas linhas de praias se formaram consecutivamente em direção ao interior do continente. No entanto, como grande parte de algumas dessas paleolinhas ainda encontram-se estruturadas (e, por isso, puderam ser identificadas e datadas), estimamos que é ao longo delas que poderemos encontrar os locais onde se estabeleceram as condições ideais para um maior potencial de preservação dos sítios. Nas figuras acima, esse local de maior potencial de ocorrências de sítios submersos estão exatamente sobre o contato do continente com o oceano (em todos os momentos apontados).

Ainda que não existam evidências concretas de sambaquis com idades tão recuadas quanto às apresentadas nesse modelo, devemos ressaltar que, em primeiro lugar, é bem provável que grande parte dessas áreas poderia estar sendo ocupada por povos caçadores mais antigos que os sambaquieiros, e, nesse sentido, sítios relativos a esses primeiros momentos também poderiam ser encontrados ao longo dos paleovales.

Em segundo lugar, existem no Brasil pelo menos dois sambaquis (do Algodão e Cambriu Grande) que apresentam idades suficientemente antigas para serem correlacionados aos antigos vales dos rios que estariam emersos entre 9.000 e 7.000 anos AP (quando o nível atual em ascensão passaria pelo nível que se encontra atualmente). Como esses sítios não devem ser os únicos, existem, sim, chances de que pelo menos alguns sambaquis contemporâneos a eles possam ser encontrados submersos ao longo dessa faixa da plataforma

Embora tal modelo tenha sido realizado (com tal aprofundamento) somente para o estado de São Paulo, ele pode ser ampliado para outras regiões. Para que se 
estabeleçam modelos de predição específicos para cada parcela da costa brasileira, basta somente que sejam consultados ou adquiridos dados locais semelhantes aos produzidos por Conti (op. cit.),

No que tange especificamente à localização dos sambaquis ao longo do litoral de São Paulo, o que é preciso agora, com base no modelo produzido, é começar a procurar por esses sítios. Ainda que essa possa ser uma tarefa demorada e trabalhosa, é totalmente praticável. Independente das profundidades em que se encontrem e dos métodos de localização, a tecnologia para tal fim existe e já é amplamente utilizada no Brasil. Para sítios de até 9.000 anos AP, localizados a uma profundidade máxima de 35 metros, pode ser empregado o mergulho autônomo. No caso dos sítios mais antigos, entre 9.000 e 18.000 anos AP, poderiam ser utilizadas tanto técnicas de mergulho técnico (descompressivo e/ou com a utilização de misturas) como métodos diretos (testemunhagem com amostrador tipo vibracorer) e indiretos (sonar de varredura lateral, perfilagem sísmica e diversos outros tipos de equipamentos geofísicos) de pesquisa submarina. Estes últimos, capazes, inclusive, de localizar vestígios arqueológicos enterrados sob o fundo marinho.

\subsubsection{A ocupação do litoral do estado de São Paulo}

Tendo como base o modelo específico para o litoral de São Paulo foi possível apontar, ainda, a existência de uma maior associação entre os sambaquis do baixo curso do Rio Ribeira (Cananéia e Iguape) com os sítios da região da Juréia e Baixada Santista, do que com os sítios do litoral norte (de Caraguatatuba a Ubatuba). Tal associação é indicada, principalmente, pela distribuição dos paleovales, os quais parecem agregar-se em duas antigas bacias: uma ao norte e outra ao sul (figura $6.19)$. 


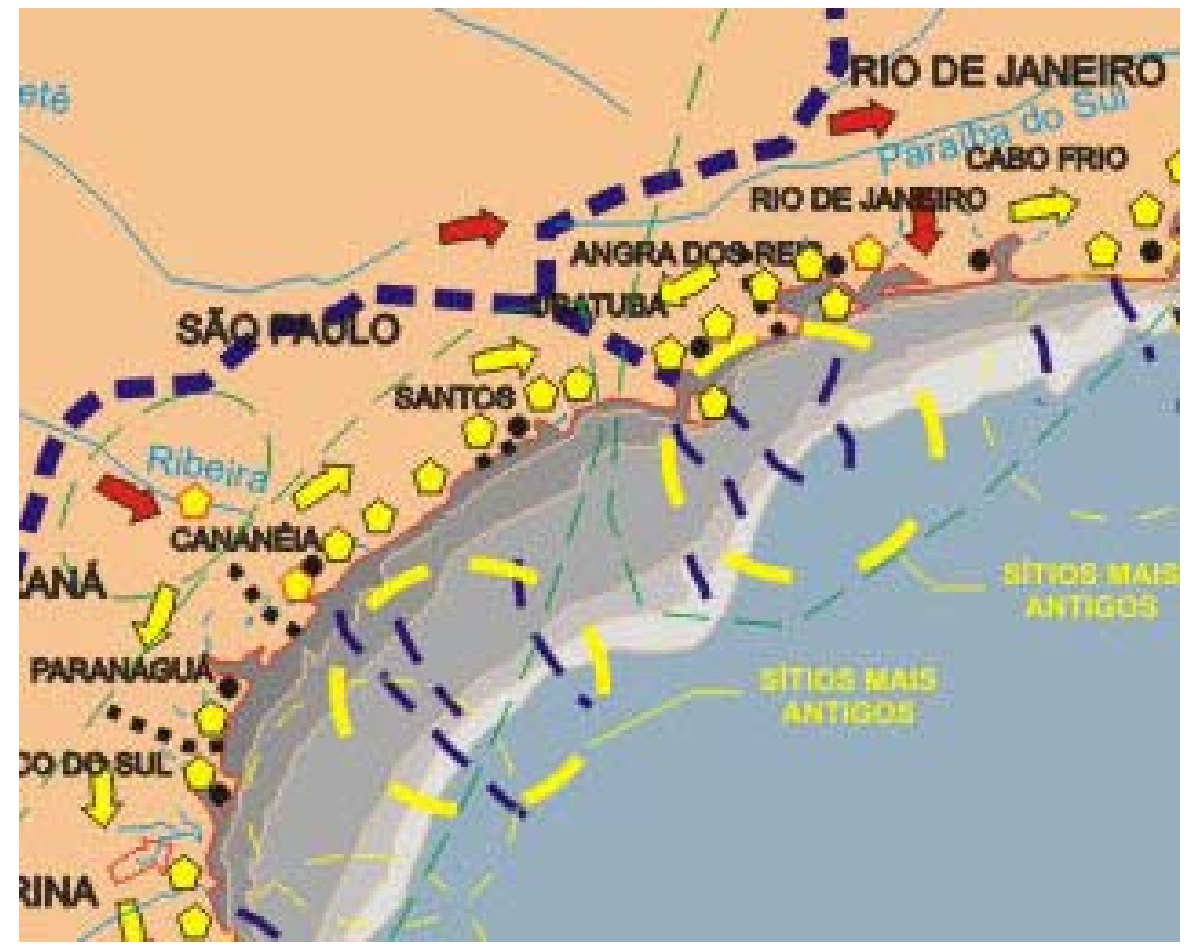

Figura 6.19 - Modelo de predição de sambaquis submersos ao longo da plataforma continental do estado de São Paulo.

Com base na evolução geomorfológica dessa região, podemos supor que a essas bacias favoreceram, em períodos anteriores há 8.000 anos AP, a formação de dois grandes sistemas fluvio-estuarinos ideais ao estabelecimento das populações sambaquieiras. A partir dos quais teriam se estabelecimento, mais tarde, pelo menos dois grandes agrupamentos de sítios ou duas grandes comunidades sambaquieiras distintas.

Embora essa diferenciação tenha sido elaborada apenas com base no registro de feições hídricas submersas, existem quatro outros conjuntos de evidências que dão suporte a sua elaboração. O primeiro desses quatro conjuntos aborda essa questão a partir do ponto de vista dos processos naturais de formação do registro arqueológico; e, os três seguintes, referem-se especificamente a questões de ordem cultural.

O primeiro deles, referente a processos naturais, diz respeito aos tipos de ambiente associados a cada um desses contextos. De modo contrário à região do litoral norte do estado de São Paulo, ao longo da região sul desenvolveu-se uma ampla planície costeira que se encontrada entremeada por diversos corpos d'água 
costeiros e morros. Os quais têm sua ocorrência diminuída na medida em que a Serra do Mar se aproxima da região costeira, até atingir, a norte, a sua menor distância do atual nível do mar.

Um padrão que também se repete ao longo das porções submersas adjacentes a ambas as regiões, indicando a possibilidade de que, ao longo do processo de ocupação sambaquieira relativo à costa paulista, tanto as comunidades sambaquieiras do norte como as do sul tiveram que se adaptar e desenvolver estratégias para explorar diferentes ambientes. Enquanto as comunidades sambaquieiras do sul se adaptaram a estuários e a corpos d'água maiores, as do norte tiveram que desenvolver uma prática de coleta e pesca associada, principalmente, a uma costa bem mais recortada e às águas marinhas que ligam o continente às ilhas.

O segundo está relacionado às principais características físicas que diferenciam os sambaquis encontrados no litoral sul e central (Baixada Santista, Guarujá e Bertioga) dos sítios do litoral norte de São Paulo e sul do estado do Rio de Janeiro. Os quais, de um modo geral, ao sul, são maiores (de quatro a dez metros) e apresentam uma matriz sedimentar composta majoritariamente por conchas estuarinas e marinhas (figura 6.20) (CALIPPO, 2004). Enquanto ao norte, os sítios constituem-se, principalmente, por uma menor espessura da camada sedimentar (por volta de dois metros) e possuem uma matriz arenosa rica em matéria orgânica (sedimento escuro), com a predominância de vestígios faunísticos provenientes de águas francamente marinhas (ouriços, otólitos de peixes marinhos e conchas marinhas) (figura 6.21) (AMENOMORI, 2005 p. 132). 

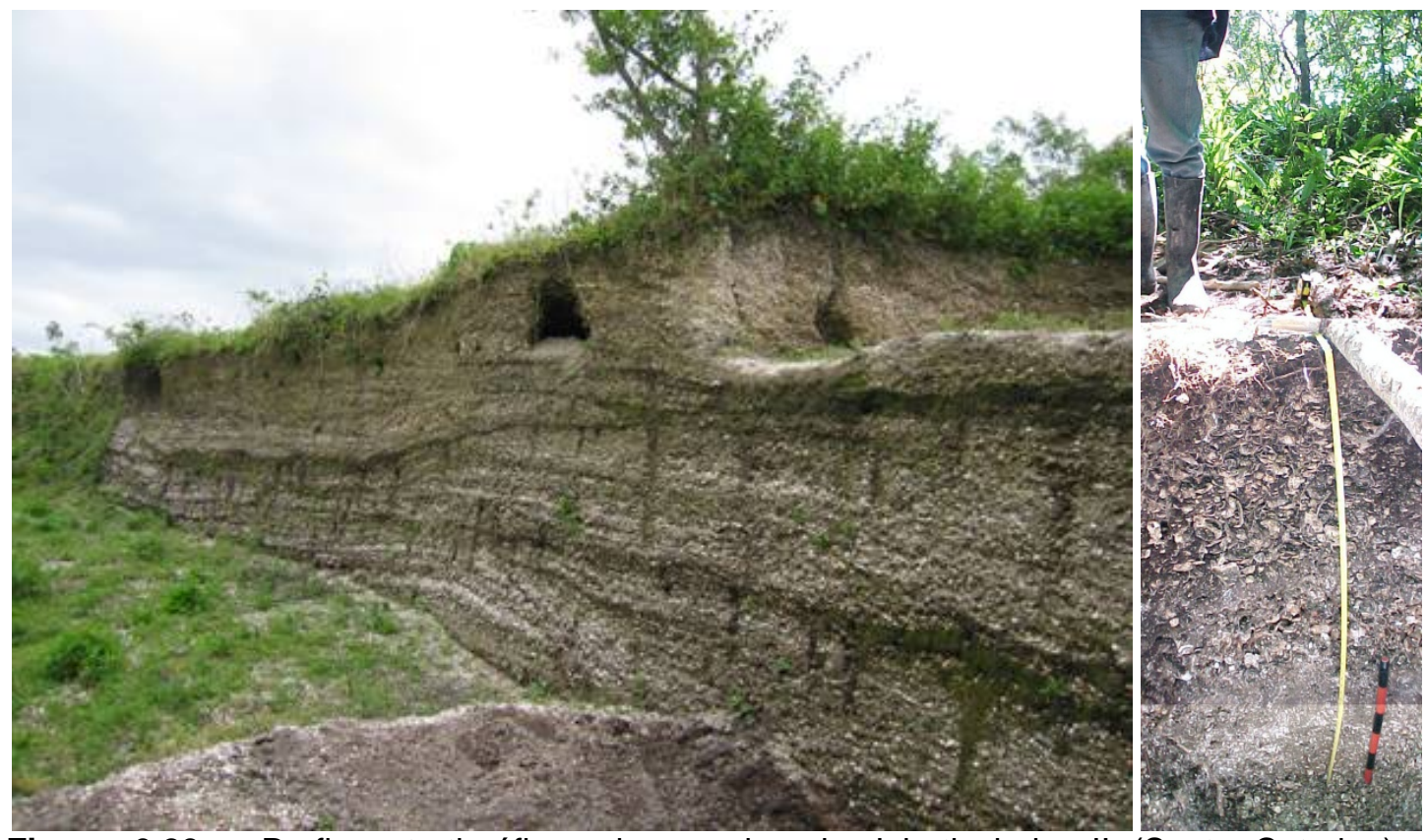

Figura 6.20 - Perfis estratigráficos dos sambaquis Jabuticabeira II (Santa Catarina) e Cachoeira Mirim (Cananéia, São Paulo) (fotos: Flávio Calippo)
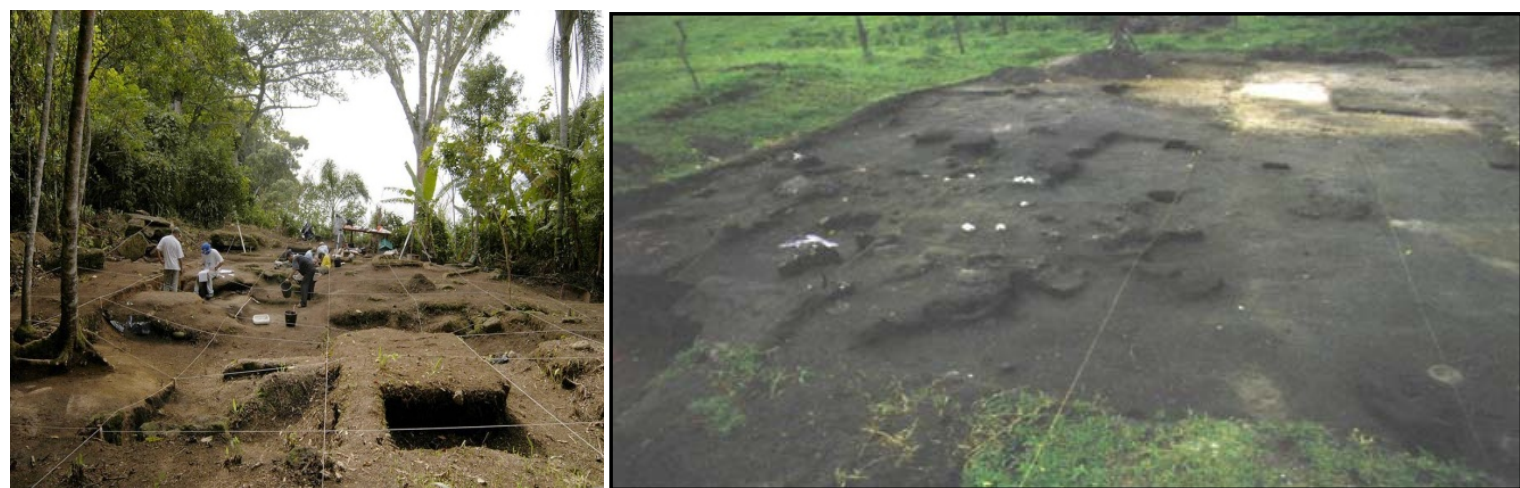

Figura 6.21 - Vista da superfície e das intervenções realizadas nos sambaquis Ilha do Mar Virado (Ubatuba, São Paulo) e Ilha da Boa Vista I (Tamoios, Rio de Janeiro). Fotos: : Amenonomi (2005) e Gaspar (1999)

Diferenças que, além de corroborarem com a hipótese do estabelecimento de duas comunidades sambaquieiras distintas ao longo do litoral, apontam também que em cada um desses conjuntos poderiam ser observados próprios padrões de assentamento e diferentes percepções e relações com o meio. No sul, predominaria uma pesca e coleta voltada às lagoas. Ao norte, por outro lado, o principal espaço de habitação e vivência seriam os ambientes marinhos. No caso da comunidade marítima do litoral norte, mais do que os estuários, seriam os costões rochosos e as 
ilhas costeiras os principais locais de obtenção de recursos aquáticos ${ }^{41}$ (AMENOMORI, 2005, p. 132).

É bem verdade que essa maior associação dos sambaquis às ilhas do litoral possa ser um reflexo do impacto antrópico decorrente da recente ocupação dessa região e da conseqüente destruição dos sambaquis que se encontravam associados aos pequenos estuários que ali se desenvolvem. No entanto, se comparado aos sítios do litoral sul, onde a quantidade de sambaquis costeiros assume uma das maiores densidades de toda a costa brasileira, a ocupação das ilhas não é, nem de longe, semelhante à presença de sambaquis nas ilhas costeiras ${ }^{42}$ do litoral norte. Talvez, a única exceção seja a Ilha do Cardoso, em Cananéia, onde foram localizados até o momento 28 sambaquis (CALIPPO, op. cit.).

Sugerindo, assim, o estabelecimento, ao norte, de uma comunidade marítima sambaquieira muito mais voltada ao mar e à navegação, onde, muito possivelmente, o uso de embarcações e o desenvolvimento de técnicas e tecnologias adaptadas aos recursos marinhos tenham atingido um ponto mais alto se comparado aos sítios do sul (que devem ter atingido essa mesma especificidade náutica para os ambientes estuarinos-lagunares).

Cabe ressaltar que, embora essa diferenciação entre os sítios do norte e sul do estado de São Paulo tenha sido inicialmente estabelecida a partir da análise de características ambientais, ela é aqui compreendida como resultado de um processo mais amplo, onde "a relação com o ambiente é inerente ao sistema sócio cultural" (GASPAR, 1998).

Se a ocupação sambaquieira do litoral tivesse sido condicionada exclusivamente pela dinâmica ambiental, o mais provável é que os povos dos

\footnotetext{
${ }^{41}$ Essa mudança nos ambientes de pesca e coleta pode ser verificada quando se analisam quaisquer sítios de ambas as regiões. Enquanto nos sambaquis de Cananéia podem ser identificadas duas ou três espécies principais (Uchôa e Garcia, 1983), Garcia (1972) indica um total de 68 espécies diferentes de moluscos e gastrópodes identificados no sambaqui Tenório.

${ }_{42}$ Ao longo do litoral sul existe uma série de ilhas ocupadas por sambaquis: Illha do Cardoso, Illha de Santo Amaro / Guarujá, etc). No entanto, essas ilhas, apesar de assim serem nomeadas, por estarem circundadas de águas, não podem ser associadas ao mesmo conjunto das ilhas do litoral norte. Pois, em sua maioria, encontram-se muito próximas à costa, ligadas a esta, em alguns pontos, por um estreito canal de águas calmas. Na única ilha da região de Cananéia (llha do Bom Abrigo) que se encontra distante da linha costa, como as ilhas do litoral norte (Ilha de São Sebastião / Ilha Bela, Ilha das Couves, Ilha do Mar Virado, etc), não foram encontrados quaisquer vestígios arqueológicos referentes aos sambaquis.
} 
sambaquis poderiam ter simplesmente se deslocado a um outro ponto do litoral e não escolhido se adaptar a esse ambiente, que apesar de recortado e pobre em amplas áreas lagunares, também apresenta condições ótimas ao estabelecimento de grupos pescadores e coletores.

Do ponto de vista dos processos culturais, essas características vêm ao encontro do terceiro conjunto de evidências aqui analisado, o qual diz respeito à diferenciação entre a cultura material (artefatos, ecofatos, vestígios faunísticos, enterramentos, etc) encontrada nos sambaquis de ambas as regiões.

Segundo Amenomori (2005 p. 132), nos sambaquis da costa e das ilhas do litoral norte, as conchas, em geral, estão restritas a pequenas lentes, que se distribuem em meio a uma matriz sedimentar negra - padrão que contrasta, totalmente, com a seqüência estratigráfica encontrada no litoral sul. Além dessa característica, existem dois outros elementos que parecem reforçar a diferença entre os sítios dessas regiões: o maior tamanho dos sítios do sul e a presença das bacias de polimento associadas aos sítios do norte.

O primeiro, indicando certa intencionalidade em monumentalizar e destacar os sítios na paisagem, atribuindo-lhes, dessa maneira, significados que extrapolariam as esferas prática e econômica. O segundo (bacias de polimento) apontaria, possivelmente, para o estabelecimento de uma atividade regional específica: a fabricação de canoas.

Para Tenório (1999), existe um vinculo entre a produção das lâminas de machado e a confecção de canoas:

Ao que tudo indica, a pesca era desenvolvida com a utilização de canoas. Chegamos a essa conclusão pela importância das laminas de machado para os habitantes do sítio, bem como pelas alterações nos ossos dos membros inferiores dos esqueletos encontrados, resultantes, provavelmente de um esforço constante de remar em pé. Acreditamos que a lamina de machado fosse utilizadas predominantemente utilizadas na elaboração das canoas (TENÓRIO, 1999, p. 239).

Embora concordemos com a autora a respeito da existência de um forte vínculo entre as bacias de polimento e a fabricação das canoas, acreditamos, por outro lado, que as bacias de polimento não estariam associadas ao surgimento da navegação e, sim, a um período e a um local onde a utilização dessa tecnologia 
intensifica-se e desenvolve-se. Gerando, provavelmente, não só um aumento na quantidade de canoas produzidas, mas, principalmente, o desenvolvimento de novas tecnologias específicas à construção naval.

Como evidência do desenvolvimento dessas novas tecnologias, apontamos aqui, por exemplo, o caso de alguns machados em que, segundo Semenov (1970), após uma cuidadosa análise, foram identificadas diversas marcas de uso que permitiram atribuir a essas ferramentas líticas a função de enxós ${ }^{43}$ (figura 6.22).

Ainda que esse tipo de ferramenta não tenha sido identificado nos sambaquis, não podemos deixar de destacar tal hipótese. Principalmente, porque essa questão ainda não havia sido levantada na Arqueológica brasileira. Devido ao grande número de bacias de polimento, o mais provável é que instrumentos desse tipo comecem a ser identificados à medida que as coleções forem revistas. Isso porque tal análise não demandaria grandes investimentos. Enxós e machados são diferenciados com base na simetria e na inclinação das estrias que se desenvolvem a partir do gume. As quais se formam em conseqüência das diferentes inclinações com que, em cada uma dessas ferramentas, o gume e o objeto atingem a madeira (SEMENOV, 1970, p. 127) (figura 6.23).

An axe is recognized by its simmetrical profile, an adze or hoe by its assimetry, and a chisel by its small size. Adzes can be straight or convex (SEMENOV, 1970, p. 126).

Enquanto nos machados predominam estrias inclinadas em ambos os lados e as bordas da lâmina tendem a estar desgastadas (figura 6.24), nos enxós, por outro lado, as estrias tendem a ocorrer de forma perpendicular ao gume e de maneira assimétrica em relação a seus lados (figura 6.25).

\footnotetext{
${ }^{43}$ Ferramentas normalmente utilizadas para a escavação do interior de canoas monóxilas.
} 

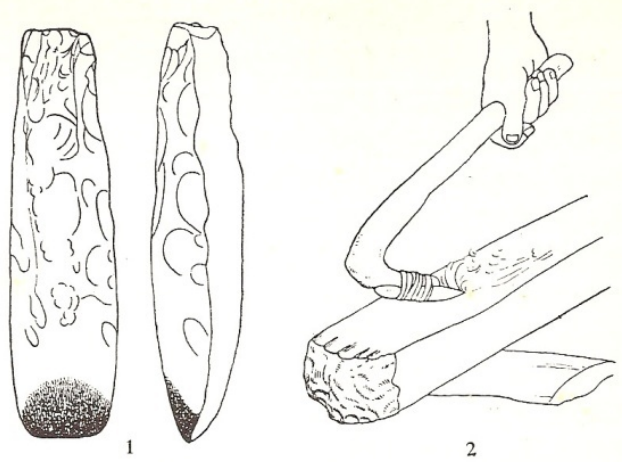

Figura 6.22 - Duas vistas de um enxó (com as áreas desgastadas pelo uso) (esquerda) e um esquema de sua utilização (SEMENOV, 1970, p. 135)
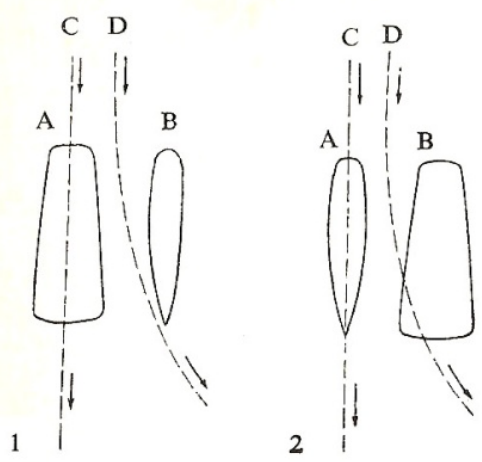

Figura 6.23 - Esquema dos ângulos de incidência de um enxó sobre a madeira (SEMENOV, 1970, p. 126)
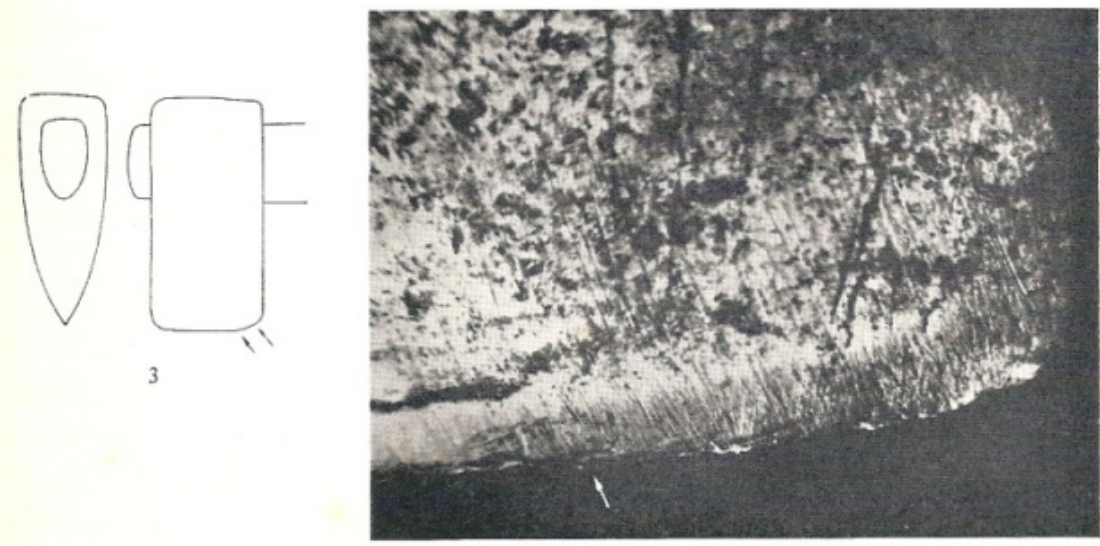

4

Figura 6.24 - Desenho esquemático e detalhe da borda de um machado, onde se pode verificar a predominância de formas simétricas (esquerda) e a inclinação das estrias em relação ao gume (direita) (SEMENOV, 1970, p. 124) 


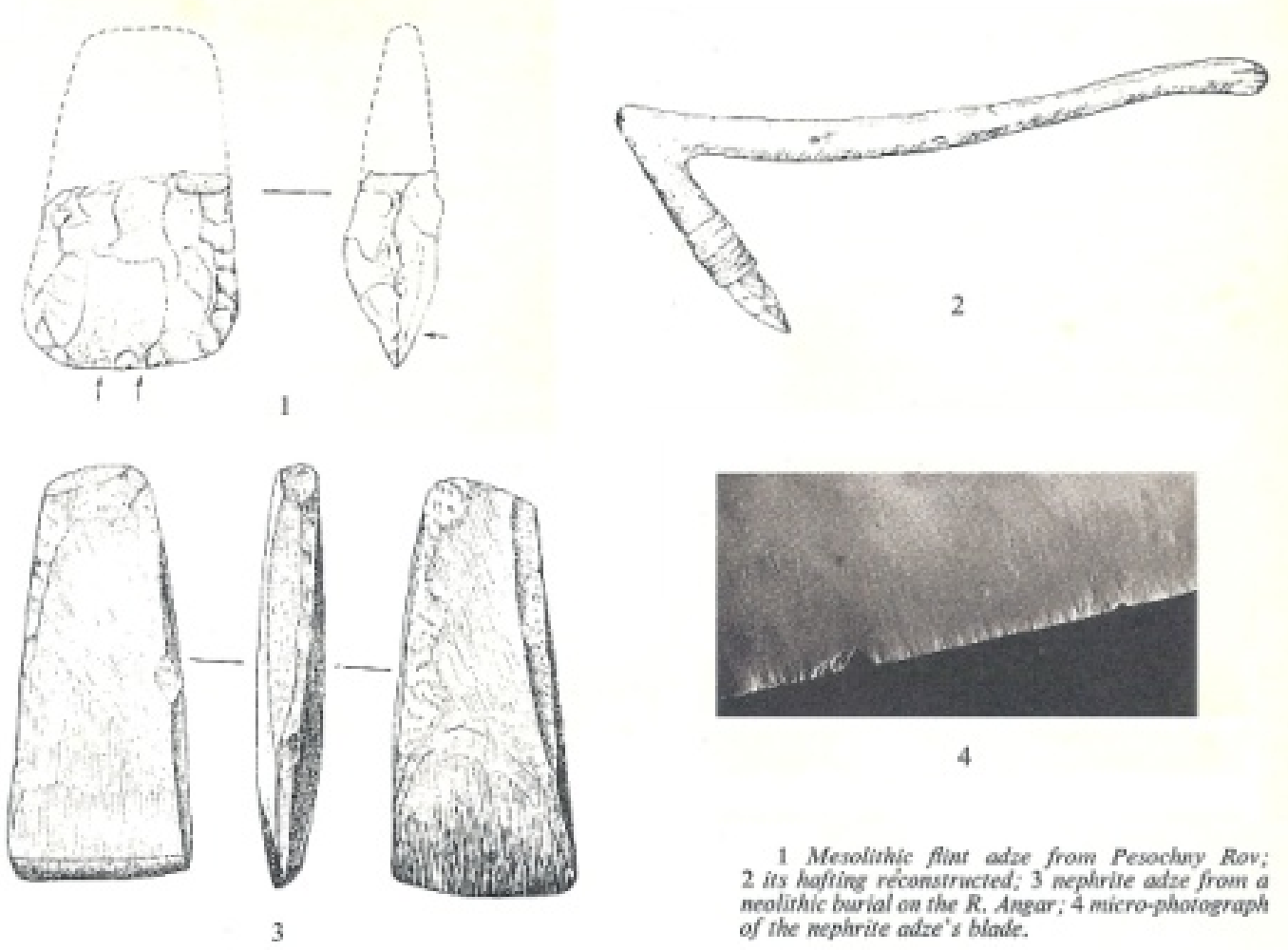

Figura 6.25 - Desenho esquemático e detalhe da borda de um enxó, onde pode-se verificar a predominância de estrias perpendiculares ao gume e a sua assimetria em relação a ambos os lados (SEMENOV, 1970, p. 127)

Ainda que a identificação de enxós seja um argumento interessante para começarmos a refletir sobre a possibilidade da especialização náutica, é possível que ele não tenha surgido no momento da origem das técnicas de fabricação dos equipamentos de navegação sambaquieiros. Nesse caso, o mais provável é que, no inicio, os próprios machados foram as principais ferramentas utilizadas e, a partir da experimentação e de sua utilização para a elaboração de equipamentos flutuadores mais simples (troncos, jangadas, canoas de casca de árvore, etc), a serem empregados nos ambientes mais protegidos (rios, estuários, lagos e lagoas), é que tenham surgido os enxós.

Somente com a conseqüente exploração de novos ambientes em direção ao exterior dessas regiões mais tranqüilas (áreas costeiras e marinhas), é que surgiria a necessidade do desenvolvimento de embarcações mais adequadas à navegação através de ondas e contra correntes marinhas Nesse processo, além do desenvolvimento de canoas mais complexas, surgiriam também as ferramentas para 
sua elaboração. Inovações úteis não só para a derrubada da árvore e sua escavação, mas também, para a preparação de superfícies e contornos mais simétricos e hidrodinâmicos.

Esse parece ser o contexto em que se inserem as bacias de polimento do norte do estado de São Paulo e sul do Rio de Janeiro. Uma vez extrapolados os limites das áreas lagunares que ocorrem, principalmente, ao longo do litoral sul de São Paulo e central do Rio de Janeiro (marcados, também, pela presença dos sítios mais antigos), as comunidades sambaquieiras passaram a especializar-se na exploração dos ambientes costeiros e marinhos abertos, para os quais seria fundamental a utilização de canoas mais rápidas e manobráveis, que fossem capazes não só de transportas pessoas, conchas e pescado, mas, principalmente, todo os conjuntos de materiais provenientes de terra. Onde, além da água (que muitas vezes não existe nas ilhas), deve-se considerar também a questão dos mortos. Os quais deveriam ser transportados através das canoas para serem enterrados nos sítios insulares.

Levando-nos, assim, a compreender que essa intensificação poderia não se dar somente em conseqüência de necessidades econômicas. Não seria estranho supor que a exploração e a apropriação desses novos ambiente fizessem com que eles passassem, cada vez mais, a compor, também, o universo cultural ou simbólico dos sambaquieiros. À medida que as canoas passaram a fazer parte desse contexto funerário, simbolizando, possivelmente, "uma viagem, uma travessia dos vivos ou dos mortos" (AMENOMORI, 2005, p. 132), se abre para a prática da navegação um universo que extrapola o seu uso como elemento de transporte.

A canoa era o seu meio de locomoção, de circulação, seu referencial de visualização da paisagem para a escolha do local de enterramento e seus rituais, isto é, o seu meio de vida, sem a qual esses grupos não conseguiriam ocupar áreas tão distantes do continente e áreas costeiras tão recortadas com a Serra do Mar penetrando até o mar (AMENOMORI, 2005, p. 141).

Nesse sentido, como apontado por Malinowski, em relação ao kula praticado pelas sociedades insulares tobriandesas, a navegação entre as ilhas e os conjuntos de sítios sambaquieiros atuariam como um elemento de conexão entre as 
comunidades, reforçando, talvez, uma identidade sambaquieira e compartilhando valores, conhecimentos, percepções e novas tecnologias.

No que tange ao quarto e último desses conjuntos de evidências, pode-se dizer que está diretamente relacionado com o resultado de análises das razões isotópicas do estrôncio (presentes nas conchas de sambaquis do litoral sul e norte) realizada no âmbito desta Tese. Embora a quantidade de amostras analisadas ainda seja restrita (vinte e duas ao total), tal análise permitiu a elaboração de uma hipótese inicial a respeito da mobilidade e da subdivisão das populações sambaquieiras ao longo do litoral do estado de São Paulo.

Subdivisão que, além de indicar uma provável fronteira entre os grupos do sul e do norte (pelo menos a ponto de não aparecer no registro arqueológico), coincide, exatamente, com o limite entre os conjuntos de sítios apontados pelos dados geomorfológicos e culturais. Reforçando, assim, a idéia de que ao longo do litoral do estado de São Paulo desenvolveram-se duas comunidades sambaquieiras marítimas que, mesmo compartilhamento elementos intrínsecos a uma sociedade sambaquieira maior, possuíam características culturais e percepções ambientais próprias e diferenciadas.

\subsubsection{As conexões com os sítios do médio curso do Ribeira}

Quando se trata da ocupação sambaquieira do estado de São Paulo, existe um conjunto de sítios que, apesar de não se encontrar associado a nenhum tipo de litoral (atual ou antigo), deve ser levado em consideração quando o que se objetiva é discutir o processo de formação do registro arqueológico dos sambaquis. Esse conjunto diz respeito aos sambaquis fluviais do médio Ribeira.

No entanto, embora ainda se discuta se os sambaquis fluviais integrariam a mesma unidade biológica e/ou cultural dos povos que construíram os sambaquis costeiros, não restam mais dúvidas de que eles mantiveram contato. Além de possuírem idades contemporâneas aos sambaquis litorâneos mais antigos e de haverem entre eles elementos comuns (conchas marinhas, formação de aterros de 
conchas, acompanhamentos funerários), se localizarem ao longo do mesmo vale em que, a jusante, se formou umas das maiores concentrações de sambaquis da costa brasileira (o baixo vale do Ribeira).

Desde, pelo menos, a década de 1970, o Vale do Ribeira foi compreendido como um eixo a partir do qual grupos caçadores vindos do interior chegaram ao litoral, entre 8.500 e 6.500 anos AP, se adaptando a uma região costeira hoje submersa (SCHMITZ, 1984) ${ }^{44}$. Embora essa hipótese tenha sido apontada pela maioria dos pesquisadores (Prous, 1977; NEVES, 1984), devido à ocorrência de evidências de origem marinha e zoólitos presentes em alguns sambaquis fluviais, Barreto (1988) defende que a origem desses sítios esteja associada a grupos sambaquieiros do litoral ${ }^{45}$.

Assim, apesar de os sítios concheiros do interior do vale se localizarem em um ambiente de alguma forma mais semelhante ao planalto, principalmente quanto aos recursos naturais disponíveis, eles apresentam características que só podem se relacionar a um padrão de assentamento litorâneo (BARRETO, 1988, p. 225).

Com base no modelo de predição elaborado para a costa brasileira, podemos propor que ambas as hipóteses tenham sido possíveis. Atuando, inclusive, de forma concomitante. Isso por que tal modelo nos indica que quando o nível do mar começou a subir, as condições ambientais da região onde hoje se encontra o atual litoral eram semelhantes às do local onde estavam sendo construídos os sambaquis fluviais. Nesse momento, o nível do mar em ascensão (que estaria entre 70 e 35 metros abaixo do atual) deslocava a cota da atual planície costeira (na época, uma planície aluvial) para uma posição semelhante a que, na atualidade, se encontra o médio Vale do Ribeira (figura 6.26).

\footnotetext{
${ }^{44}$ Alguns autores como Schmitz (1984) e Prous $(1978 ; 1979 ; 1980)$ alertam para a possibilidade de que haveria sítios ainda mais antigos, hoje submersos pelo mar (BARRETO, 1988, p.31).

45 Embora hipóteses de uma ocupação do vale do Ribeira, a partir do litoral, já tenham sido formuladas por Prous e Piazza (1977) e, também, Neves (1984), Barreto (1988) foi a primeira pesquisadora a efetivamente testar tal hipótese.
} 


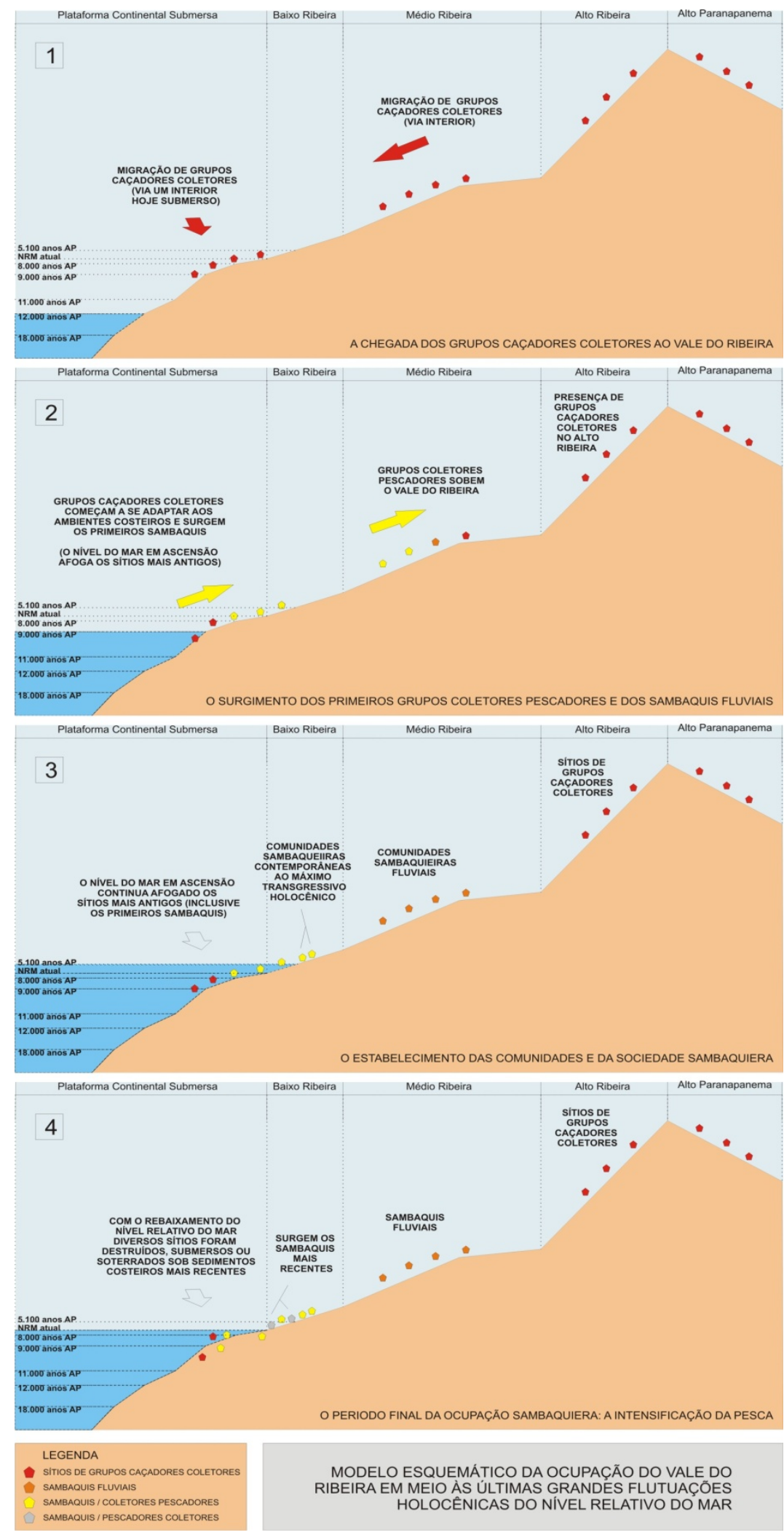

Figura 6.22 - Modelo esquemático da ocupação do Vale do Ribeira 
Assim, as populações que, naquela época, ocupavam o litoral, provavelmente, ainda não seriam os sambaquieiros; e, sim, os mesmo grupos caçadores que se encontravam rio acima, ou que, talvez, estivessem iniciando um processo de adaptação aos ambientes costeiros.

Sob esse ponto de vista, independente das rotas que utilizaram para chegar à região, via litoral ou interior, o mais provável é que os sambaquis fluviais teriam sido formados por populações que se originaram no litoral e subiram o vale do ribeira. As quais, apesar de estarem migrando em busca das condições que passavam a não mais encontrar no litoral, já não eram os mesmos caçadores coletores que ali chegaram antes da elevação do nível do mar e da intensificação das modificações climáticas que assolaram a região. Por outro lado, também ainda não eram os sambaquieiros propriamente ditos

De um modo geral, são essas populações mais antigas, que começavam a se adaptar às regiões costeiras, migrando de um modo de vida caçador coletor para coletor pescador, as possíveis responsáveis pela formação desses primeiros sítios. Os quais, nessa época, estariam sendo gerados tanto na Serra do Mar como ao longo da planície aluvial que hoje está submersa.

No que tange à questão paleoclimática, é importante ressaltar que, nesses momentos, a mata atlântica, principal responsável pela manutenção do modo de vida caçador coletor nessa região, encontrava-se em um franco processo de retração (figura 6.23). Segundo Ledru et al. (2005), que analisaram a diversidade de polens da mata atlântica para a região do topo da Serra do Mar (em São Paulo), ao longo dos últimos 100.000 anos, a mata atlântica só voltaria a se expandir ao longo da Serra do Mar por volta de 8.000 anos atrás ( 5000 anos AP), quando o nível marinho também atingiria seu máximo. Fomentando-se, assim, a idéia de que a elevação do nível relativo do mar não seria o único grande impulso para a migração a partir do litoral. 


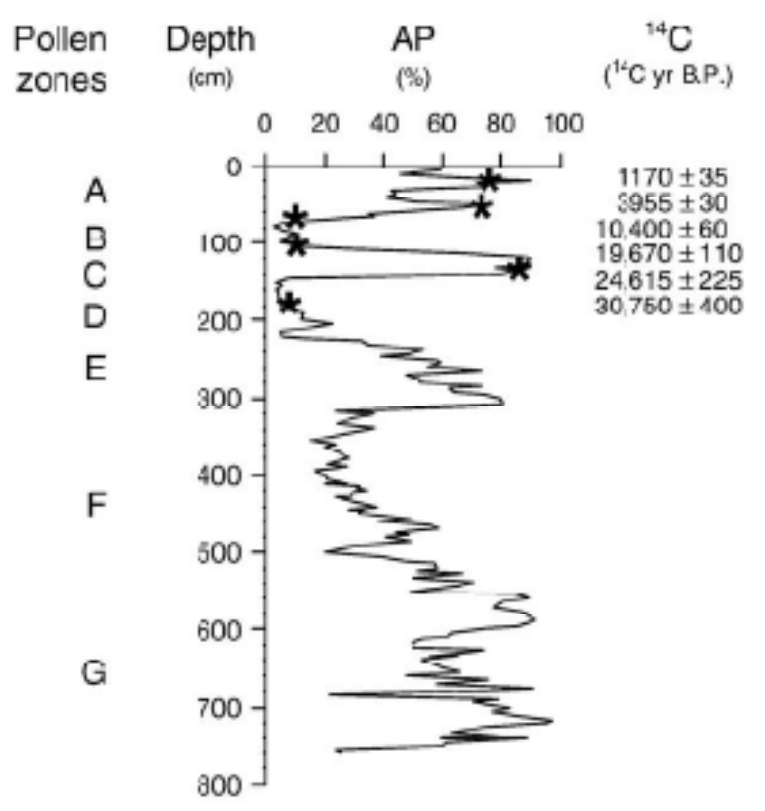

Figura 6.27 -. Diagrama de percentagens de polens arbóreos encontrados ao longo da cratera Colônia, localizada na periferia da cidade de São Paulo (há aproximadamente 100 $\mathrm{km}$ do mar) (LEDRU et al., 2005)

Nesses momentos anteriores ao intervalo de 8.000 a 3.000 anos AP, quando esses autores acreditam que se forma a atual distribuição da mata atlântica, o mais provável é que tanto as populações humanas que vivessem do interior como as que estivessem habitando a extensa planície fluvial (caçadores ou os primeiros coletores pescadores) e, posteriormente, costeira, encontrariam no limite entre a Serra do Mar e o litoral as melhores condições de sobrevivência. Ainda mais se já estivessem adaptadas à exploração dos ambientes costeiros.

Talvez, tais ocupações possam ainda ser encontradas associadas às camadas mais inferiores dos sambaquis que se localizam entre o litoral e o médio Ribeira. Ou ainda, sob espessas camadas de sedimentos, provenientes dos deslizamentos das encostas da Serra do Mar que formaram, ao longo do final do pleistoceno e do holoceno, os leques aluviais que caracterizam tal área de transição. Possíveis evidências desses sítios, constituídas por lascas descorticadas (produzidas por percussão direta) em diabásio-basalto, sílex, sílex (ou siltito silicificado), diabásio e quartzo hialino, foram encontradas na região de Caraguatatuba, soterradas (entre os 2,6 e 2,8 metros de profundidade) sobre camadas de sedimentos mais recentes (BROCHIER, 2009). 
Apesar de continuarem existindo vínculos que os contextualizam como integrantes de uma sociedade sambaquieira maior, os quais podem ser identificados através das semelhanças culturais materiais e da maneira como ambos se relacionam com o ambiente, os sambaquieiros da costa passam a cada vez mais adaptarem-se à pesca e a coleta e os sambaquieiros fluviais aos ambientes florestais, formando, ao longo do Vale do Ribeira, duas comunidades sambaquieiras diferenciadas.

No caso do médio Ribeira, uma comunidade que, mesmo situando-se longe da costa, apresenta diversos elementos de uma cultural material costeira (como, por exemplo, a formação de acúmulo de conchas, presença de conchas e artefatos de origem marinha, etc). Os quais, talvez, possam ser compreendidos tanto como reforço de uma identidade sambaquieira costeira ou de uma ligação cultural ou simbólica com o mar e com os sambaquis costeiros.

Se o contrário tivesse ocorrido e os grupos caçadores coletores tivessem dado origem aos sambaquis costeiros, possivelmente, só haveriam sítios com evidências costeiras associados ao médio Ribeira (sambaquis fluviais) em períodos mais recentes (entre 7.000 e 5.100 anos AP), quando, parte dos grupos sambaquieiros, subiriam esse vale em busca do habitat ou da manutenção de uma condição e de um espaço social que, no litoral, passariam a desaparecer em conseqüência da redução dos espaços que eram continuamente dominados pelas águas do mar. 


\section{CONSIDERAÇÕES FINAIS}

O principal objetivo desta Tese foi o desenvolvimento de uma hipótese capaz de identificar e compreender a heterogeneidade dos povos dos sambaquis a partir das relações que os sambaquieiros estabeleciam com o seu meio. Propósito que acreditamos ter alcançado, pois, além de apresentar uma interpretação da sociedade sambaquieira, propusemos um modo novo e complementar de compreender os sambaquis e as sociedades responsáveis por sua construção.

Com essa proposta contribuímos com abordagens teóricas e metodologias a respeito de algumas das principais problemáticas sobre os sambaquieiros, as abordando os sambaquieiros como comunidades marítimas ou costeiras e com a elaboração de hipóteses em relação aos modos através do quais os diversos povos dos sambaquis se relacionariam dialeticamente com os seus ambientes.

Embora essas propostas tenham sido elaboradas para o estudo das sociedades sambaquieiras, elas podem ser extrapoladas para além de suas fronteiras. Tanto a análise das percepções ambientais e marítimas, como as análises isotópicas e o modelo preditivo de sítios submersos, podem contribuir também para um melhor entendimento de outras sociedades pré-coloniais. No caso do modelo de predição, por exemplo, a distribuição do sistema de paleovales e a espacialização das antigas planícies litorâneas e fluviais poderão contribuir ainda para o estudo dos primeiros momentos da ocupação paleoíndia do território brasileiro. Em relação às análises da composição dos isótopos estáveis e instáveis, a situação é ainda mais promissora. Independente da cronologia ou da sociedade em questão, tais metodologias poderão continuar a ser utilizadas como indicadores de mobilidade e territorialidade dos grupos humanos (estrôncio) e das relações que estabeleceriam com o meio (carbono e oxigênio).

No que tange especificamente à compreensão dos sambaquieiros como uma sociedade heterogênea, formada por diversas comunidades locais (umas mais marítimas que outras), entendemos que nossa hipótese constitui uma contribuição significativa sobre o tema. Embora as amostras de ossos humanos (com idades conhecidas) disponíveis para as análises de estrôncio obrigaram a restringir 
abordagem a uma escala macro, o resultado obtido permitiu compreender que existem fronteiras entre a ampla distribuição dos sambaquis pela costa brasileira.

Além de apontar concretamente uma fronteira cultural entre as comunidades sambaquieiras do litoral do estado de São Paulo, localizada entre o litoral central e norte, a análise da composição isotópica do estrôncio indicou que entre esses dois subsistemas maiores existem também diferenças em seus padrões de mobilidade e na exploração de seus territórios. Enquanto no litoral sul e centro predominariam grupos mais adaptados aos grandes corpos lagunares internos, no litoral norte de São Paulo (e, provavelmente, em todo o litoral sul do Rio de Janeiro) eram os ambientes marinhos mais próximos à costa que formavam os territórios sambaquieiros. Um espaço social e culturalmente percebido, através do qual as ilhas, as pequenas praias e os costões rochosos que marcam a região eram interligados.

Uma das questões mais interessantes sobre o resultado da análise da composição do estrôncio e da proposição de uma fronteira cultural é que, embora tenha sido estabelecida com base em 22 amostras, ela não é um conjunto de dados isolados. Os sistemas de paleovales ao longo da porção submersa da plataforma continental, apontados pelo modelo de predição de sítios submersos, indicam também um limite entre essas duas regiões. Reforçando, assim, os dados apontados pela análise dos isótopos instáveis.

Especificamente em relação ao modelo de predição, além da distribuição dos paleovales e da espacialização das antigas zonas costeiras e planícies fluviais, podemos ressaltar ainda outra importante contribuição, ligada, principalmente, à interrupção (na costa nordeste) da porção submersa da plataforma continental brasileira. Coincidindo com esse ponto, onde a plataforma continental submersa é muito estreita, parece estar localizada uma das possíveis fronteiras da expansão sambaquieira. Acima da região nordeste somente ocorrem sítios semelhantes (aterros de concha) a partir do litoral da região norte. Esses, ainda que semelhantes, devem, provavelmente, compor o registro arqueológico de uma outra sociedade coletor-pescadora, cuja origem poderia também estar associada às populações précoloniais do vale do Amazonas. 
Com o intuito de compreender as relações com o ambiente também a partir do ponto de vista em meso e micro escalas, foi realizada ainda uma análise da composição dos isótopos estáveis de carbono e oxigênio nas conchas dos sambaquis de Cananéia. Estudo através do qual conseguimos compreender que o comportamento dos povos dos sambaquis, bem como a sua relação com os ambientes costeiros, não está, necessariamente, condicionada pela maior disponibilidade alimentar ou pelas razões mais práticas. A análise realizada em quatro sítios com processos formativos diferentes, que abrangem um período de pelo menos 4.000 anos (aproximadamente entre 8.000 e 3.500 anos AP), tornou evidente que a coleta ao longo de todo esse período não era realizada em todo o estuário. Independente das intensas modificações ambientais (que alteravam a espacialização dos micro-ambientes da região) e da ampla distribuição das espécies ao longo do estuário, os locais de coleta eram recorrentes e, provavelmente, localizados onde havia maior salinidade dentro do estuário e/ou nas praias próximas à desembocadura.

Os únicos momentos em que as paleosalinidades em que as conchas foram capturadas se alteram estão relacionados aos períodos em que os sítios sofrem um processo de rápida acumulação (construção de base, camadas de rápida acresção, etc). Além de, nesses momentos, haver uma alteração no propósito e no significado da construção dos sítios, os quais demandariam a obtenção de maiores quantidades de concha, as coletas são praticadas em ambientes em que esses moluscos não são tão abundantes. Ao contrário do esperado (sob o ponto de vista da máxima eficiência da exploração dos recursos), nesses momentos, a coleta passa a abranger também ambientes de salinidade mais altas, ligadas, possivelmente, às praias arenosas da face marinha da llha do Cardoso ou das praias das ilhas da região.

No caso dos isótopos de carbono e oxigênio, além da quantidade de amostras (64 de cada) ter sido aproximadamente três vezes maior do que a utilizada nas análises da composição isotópica do estrôncio (22 ao total), as alterações de paleosalinidade e paleotemperatura em consonância com a função e o significado dos sítios e das camadas, são verificadas em mais de um sítio e ao longo de todo 
período analisado. Apontando, assim, que, pelo menos na comunidade sambaquieira de Cananéia, tanto a coleta como a construção dos sítios estariam associados a aspectos culturais, sociais e/ou simbólicos e não às condições ambientais.

Ainda que essa e as demais interpretações a respeito das comunidades sambaquieiras se alinhem aos pressupostos teóricos assumidos no âmbito desta Tese e tenham atingido os objetivos propostos (contribuindo com o estudo dos sambaquis e, também, com a Arqueologia brasileira), é preciso reconhecer que a pesquisa arqueológica foi capaz de identificar (com base no estudo da cultura material) somente uma parte do que foi inicialmente proposto como o universo marítimo dos povos dos sambaquis, deixando a serem pesquisadas uma ampla gama de práticas sociais.

Embora buscássemos o estabelecimento de um entendimento a respeito dos sambaquieiros que incorporasse as críticas pós-processualistas, nos deparamos com a limitação do nosso objeto de estudo, que, na maioria das vezes, é composto por uma amostra limitada, que corresponde à natureza da pesquisa realizada até o momento. Algumas das questões poderão ser respondidas com a realização de escavações que estão programadas para alguns sítios selecionados.

Em relação ao estudo de mobilidade, por exemplo, embora os sambaquis sejam os sítios arqueológicos mais abundantes do litoral, uma das linhas de pesquisa mais antiga do Brasil e, durante muito tempo, os sítios mais pesquisados ao longo do litoral de São Paulo, possuímos poucos dados. Foram identificados ,na literatura arqueológica e na coleção do MAE/USP, apenas cinco esqueletos humanos datados ao longo do litoral do estado de São Paulo.

Mesmo tendo consciência da dificuldade em estabelecer uma conexão real entre as propostas teóricas e as evidências presentes nos sítios, a qual, neste caso, reside justamente em romper os limites entre as abordagens processualistas e pósprocessualistas, resolvemos encarar o problema de frente. Uma vez estabelecida a abordagem marítima e sócio ambiental a respeito das sociedades sambaquieiras, procuramos encontrar um caminho através do qual nosso referencial teórico 
pudesse ser concretamente correlacionado com as metodologias de análises e as evidências arqueológicas disponíveis.

Para isso adotamos o estudo dos processos formativos inicialmente apontados por Schiffer (1972), a partir de uma adequação de alguns de seus principais processos e evidências para a realidade estudada. Através deles foi possível reconhecer e interpretar as evidências arqueológicas através de um ponto de vista focado nos aspectos marítimos e nas relações dialéticas que os sambaquieiros estabeleciam com o meio.

É importante ressaltar, ainda, que para o estabelecimento dessas correlações marítimas e socioambientais utilizamos como apoio alguns referenciais etnográficos e abordagens desenvolvidas para sociedades modernas. Mesmo correndo o risco de parecer interpretar uma sociedade a partir de valores e significados que não foram necessariamente desenvolvidos por seus indivíduos, resolvemos utilizar a analogia como fonte de inspiração para a formulação de hipóteses sobre os grupos construtores dos sambaquis.

No entanto, a seleção e o estabelecimento desses referenciais não foram aleatórios. Além de escolher sociedades que vivem um tipo de contexto ambiental e antropológico semelhante, procuramos ao máximo evitar a construção de analogias feitas de maneira mecânica e linear. Na medida do possível, as informações provenientes dessas outras sociedades foram utilizadas somente como um referencial para a construção teórica do que teria sido uma sociedade marítima préhistórica ou como se configurariam as relações dialéticas que os sambaquieiros estabeleceram com o meio ambiente.

$\mathrm{Na}$ realidade, as compreensões das sociedades marítimas e das percepções ambientais aqui desenvolvidas serviram como um cenário que nos permitiu entender que o comportamento de uma sociedade, seja ela marítima ou não, não está necessariamente vinculado a processos normativos, onde o comportamento humano é geralmente vinculado à máxima eficiência da exploração dos recursos ou é definido a partir de padrões e regras gerais de comportamento.

Nesse sentido, mais do que substanciar interpretações a respeito dos comportamentos, dos significados e práticas sociais sambaquieiras, tal referencial 
antropológico e etnoarqueológico permitiu que pudéssemos romper com essa visão normativa, propondo interpretações sensíveis ao entendimento de que tais regras e símbolos constroem-se, principalmente, através dos modos com os quais cada sociedade, comunidade ou cultura se relaciona dialeticamente com o seu meio - o qual engloba tanto o ambiente natural como o contexto sócio-cultural em que os sambaquieiros se inseriam.

Ainda que, em um primeiro momento, a utilização de padrões gerais nos permita a compreensão da cultura material dos sambaquieiros a partir de uma ampla perspectiva, à medida que buscamos entender as particularidades regionais e a articulação entre os diversos sub-sistemas dessa sociedade, tais regras gerais começam a perder sua eficiência. Sob esse novo enfoque, mais específico a cada uma das comunidades regionais de sambaquis, é preciso compreender que a cultura material relativa a cada um desses conjuntos possa assumir, pelo menos em parte, diferentes significados e particularismos.

Embora tenhamos conseguido avançar na elucidação de questões que decorrem diretamente da dicotomia homem versus natureza, como resultado de todas as análises e correlações aqui realizadas, chegamos à conclusão que, exceto em alguns casos específicos, é ainda difícil para os arqueólogos (onde me incluo) estabelecer um entendimento onde natureza e cultura sejam analisadas sempre a partir de um único ponto de vista sócio-ambiental. Entretanto, para que continuemos avançado nessa direção, independente de nosso posicionamento teórico (enquanto cientistas humanos ou ligados às ciências biológicas, exatas ou da terra), de nossos propósitos e objetos de estudos, é preciso entender a relação das sociedades com a natureza a partir de um ponto de vista dialético, onde, ao transformar a natureza, os indivíduos modificam-se a si próprios. A natureza não deve continuar a ser vista como algo passivo, pois, mesmo para a sociedade moderna, ela continua carregada de mitos, símbolos e significados que variam de cultura para cultura e, em alguns casos, até de individuo para individuo.

Como exemplo da utilização desse contexto marítimo, podemos destacar, ainda, a contribuição da releitura que fizemos a respeito da cultura material sambaquieira, com base em um referencial marítimo e em estudos de tecnologia 
publicados no exterior, através dos quais identificamos a existência de alguns tipos de artefatos que até, então, vinham sendo interpretados como unicamente associados à caça e à ornamentação dos sambaquieiros. Artefatos que, sob esse novo ponto de vista, podem ser também interpretados como instrumentos de pesca ou utensílios empregados na construção de canoas. É o caso, por exemplo, de pontas duplas em osso que podem ser anzóis, pingentes que, na verdade, podem ter sido utilizados como pesos de rede ou de anzóis, ou machados que seriam enxós.

Nessa mesma linha, ressaltamos também a contribuição do modelo de predição de sítios submersos. Não só por sua capacidade de gerar hipóteses explicativas a respeito dos primeiros momentos da ocupação sambaquieira, mas, principalmente, por tornar evidente que, daqui em diante, não podemos mais pensar na ocupação do território brasileiro desconsiderando a porção do registro arqueológico submerso. Mesmo que apenas algumas poucas evidências arqueológicas associadas a contextos submersos tenham sido localizadas, no Brasil e no exterior, não podemos mais tratá-las como se fossem apenas uma mera hipótese. Agora é preciso que, realmente, procuremos por elas.

Concluindo, pensamos com este trabalho ter contribuído para uma mudança na abordagem das pesquisas sobre os sambaquis, tanto no que se refere às técnicas de análise inovadoras que foram utilizadas como das hipóteses interpretativas formuladas. O resultado do trabalho abriu um caminho para o direcionamento de futuras pesquisas visando o esclarecimento de questões ainda não respondidas na sua totalidade e esperamos que possa servir também de referência para outros projetos sobre o tema. 


\section{CONCLUSÕES}

Através de diferentes análises, correlações e hipóteses a presente Tese demonstrou que os sambaquieiros estariam organizados em uma sociedade mais heterogênea do que se acreditava. Além de subdivididos em diversas comunidades ou subsistemas de âmbito regional, os dados aqui produzidos indicam que tais diferenças seriam ainda uma conseqüência dos modos através dos quais cada uma dessas comunidades relacionar-se-ia historicamente e dialeticamente com o seu meio.

Ainda que houvesse uma unidade cultural capaz de aglutinar todos os sambaquieiros em uma única e ampla sociedade, esta unidade dar-se-ia principalmente através de relações e acordos políticos, religiosos ou ideológicos. Nas comunidades regionais, por outro lado, tal unidade seria provavelmente uma conseqüência de relações de afinidade e parentesco.

Dependendo do tipo de ambiente em que estavam inseridos e de como cada uma dessas comunidades percebia e relacionava-se com o meio, desenvolveram-se, a partir de uma relação dialética com o meio (onde a experiência de transformação do meio desencadeia um processo de transformação cultural), diferentes comunidades sambaquieiras fluviais, costeiras e marinhas.

Com base na análise da composição isotópica do estrôncio presente em ossos e dentes humanos de sambaquis do estado de São Paulo, foi possível estabelecer, pelo menos, três desses subsistemas ou comunidades regionais, os quais dizem respeito, especificamente, aos sambaquis fluviais do médio (conjunto 1), ao conjunto de sambaquis do litoral centro e sul (conjunto 2) e aos sítios do litoral norte (conjunto 3). Uma configuração que é confirmada pelas diferenças da cultura material sambaquieira relativa a essas três áreas.

Além de apontar concretamente uma fronteira cultural entre essas três áreas, a análise da composição isotópica do estrôncio indicou, ainda, que, entre as comunidades do litoral, estabeleceram-se diferentes padrões de mobilidade. No litoral sul e centro, predominariam grupos mais adaptados aos grandes corpos lagunares internos que, provavelmente, percorriam maiores distâncias ao longo de seu território. No litoral norte de São Paulo (e, provavelmente, em todo o litoral sul 
do Rio de Janeiro), por outro lado, eram os ambientes marinhos mais próximos à costa que formavam os territórios sambaquieiros. Um espaço social e culturalmente percebido, através do qual as ilhas, as pequenas praias e os costões rochosos (que marcam a região) eram interligados.

Tal interpretação é ainda reforçada pelo modelo de predição de sambaquis submersos, o qual aponta que os vales dos antigos rios que cortavam a plataforma continental submersa do estado de São Paulo, em períodos anteriores há 7.000 anos AP, configuram-se, nessa região, em dois grandes sistemas de paleovales. $O$ primeiro localiza-se mais ao sul, conectando-se com os atuais rios que deságuam no litoral centro e sul do estado de São Paulo. O segundo, ao norte, engloba os paleovales que se ligam aos rios do litoral norte de são Paulo e sul do Rio de Janeiro.

Embora o modelo de predição de sítios submersos tenha sido elaborado em maior detalhe para a costa do estado de São Paulo, seus resultados não se referem, exclusivamente, a essa região. Na realidade, uma de suas principais contribuições foi apontar as áreas submersas provavelmente ocupadas, entre 18.000 e 8.000 anos $A P$, pelos indivíduos que deram origem aos povos dos sambaquis e pelos primeiros sambaquieiros. Permitindo-nos, ainda, entender que a ausência de sambaquis ao longo da região nordeste está provavelmente relacionada à mínima extensão da plataforma continental (hoje submersa) adjacente a essa região.

Como última contribuição desse modelo ressalta-se também a sua capacidade em, a partir da correlação dos paleovales e da extensão da plataforma com o desenho da bacia hidrográfica brasileira, apontar ao menos duas possíveis rotas (não excludentes) para o estabelecimento dos povos construtores de sambaquis ao longo do litoral e também do médio Ribeira.

$\mathrm{Na}$ primeira dessas rotas, populações caçadoras, migrando através de uma extensa planície fluvial hoje submersa, estabelecer-se-iam ao longo dos vales dos rios que, com a elevação do nível do mar, começaram a ser afogados, dando origem aos extensos estuários e planícies costeiras ricas em recursos aquáticos. Em meio a esse processo, parte dos grupos que começavam a organizar-se como comunidades marítimas sobem o rio Ribeira de Iguape e fixam-se em seu médio curso, explorando os recursos fluviais. Embora possuindo, no inicio, semelhanças culturais e uma 
identidade comum, com o passar do tempo, estabelece-se entre esse grupo e os do litoral uma fronteira cultural.

$\mathrm{Na}$ segunda dessas hipóteses, em vez de migrarem através da porção da plataforma continental que hoje se encontra submersa, as populações caçadoras atingem a extensa planície fluvial (em que, mais tarde, darão origem aos povos dos sambaquis) pelos rios que nascem no planalto e tem sua foz no litoral. Nesse momento, formam-se ao longo do médio Ribeira uma série de sítios líticos e conchíferos de caçadores-coletores. Com a elevação do nível relativo do mar, parte dessas populações que chegaram ao litoral se mantém nos novos ambientes costeiros que se passam a se formar e parte sobe o Ribeira.

Especificamente em relação aos sambaquis de Cananéia, a análise da composição isotópica do carbono e oxigênio mostrou que a percepção ambiental dos sambaquieiros estaria mais relacionada à importância cultural dos locais de coleta do que, necessariamente, a uma maior disponibilidade do recurso ao longo dos ambientes aquáticos da região. Embora as conchas se distribuíssem ao longo de todo estuário, os sambaquieiros de Cananéia realizavam a coleta nos ambientes estuarinos mais próximos ao mar, onde não se encontram condições ótimas para o seu desenvolvimento. Em momentos de intenso crescimento do sítio, quando havia uma demanda por conchas muito maior do que a normal, ao contrário do esperado, as conchas eram capturadas em ambientes ainda mais marinhos. Indicado, possivelmente, uma importância cultural e simbólica das conchas provenientes do mar.

Quando tais evidências foram correlacionadas às curvas de variação do nível relativo do mar, mostraram que entre, aproximadamente, 8.000 e 3.500 anos AP, esse processo manteve-se constante. Independente da flutuação do nível das águas, da influência salina dentro do estuário ou da localização espacial dos pontos de coleta, as conchas continuaram a ser capturadas em ambientes de alta salinidade por um período de, pelo menos, 4.500 anos. Sugerindo, nesse caso, a existência de processos culturais de longa duração.

Com base no entendimento de que essas evidências, juntamente com outros elementos de cultura material presentes nos sambaquis da região (zoólitos, bacias 
polimento, etc), constituem um conjunto de dados que aponta para o estabelecimento de comunidades que desenvolveram práticas sócio-culturais intrinsecamente ligadas ao mar e aos significados a ele atribuídos, foram também reinterpretadas algumas evidências encontradas em sambaquis. A partir de artefatos identificados ao longo de sítios pré-históricos de grupos pescadores americanos e europeus, pontas duplas (em osso) foram, por exemplo, reinterpretadas como anzóis. Nesse mesmo sentido, alguns tipos de machados foram reconhecidos como enxós para a fabricação de canoas. Evidenciando, assim, entre o sambaquieiros, o estabelecimento de técnicas e instrumentos específicos à prática da pesca e à construção de canoas. 


\section{REFERENCIAS BIBLIOGRÁFICAS}

ADAMS, Jonathan. Maritime Archaeology. In: Charles E. Orser, Jr (Ed.). Encyclopedia of Historical Archaeology. London: Routledge, 2002, p.328-330.

AFONSO, Marisa C.; DE BLASIS, Paulo A. Aspectos da formação de um grande sambaqui: alguns indicadores em Espinheiros II, Joinville, SC. Revista do Museu de Arqueologia e Etnologia, Museu de Arqueologia e Etnologia da Universidade de São Paulo, 4, p. 21-30. 1994.

ALBUQUERQUE, Leila Marrach Basto de. Comunidade e sociedade: conceito e utopia. Raízes, 20, p. 50-53. 1999.

AMENOMORI, Sandra Nami. Paisagem das ilhas, as ilhas da paisagem: A ocupação dos grupos pescadores-coletores pré-históricos no litoral norte do estado de São Paulo. Tese de Doutorado em Arqueologia. Universidade de São Paulo. Museu de Arqueologia e Etnologia. Programa de Pós-Graduação em Arqueologia. São Paulo. 2005

ANGULO, R. J., LESSA, G. C. The brasilian sea level curves: a critical review with emphasis on the curves from Paranaguá and Cananéia regions. Marine Geology, 1997.

ARAÚJO, Astolfo Gomes de Mello. A variabilidade cultural no período paleoíndio no Brasil (11.000 e 8.000 anos AP): algumas hipóteses. Revista do CEPA, v.28, 39, p. 111-130, 2004.

ATEN, LAWRENCE E. Indians of the upper Texas Coast. New York: Academic Press, 1983.

BANDEIRA, D. R. Mudanças na estratégia de subsistência do sítio arqueológico Enseada 1 - Um estudo de caso. Dissertação de Mestrado. Universidade Federal de Santa Catarina. Florianópolis. 1992

BARRETO, C. A ocupação pré-colonial do vale do Ribeira do Iguape, SP: os sítios concheiros do médio curso. Dissertação de Mestrado. Faculdade de Filosofia, Letras e Ciências Humanas da universidade de São Paulo, 1988.

BATE, L. F. Notas sobre el materialismo histórico en el proceso de investigación arqueológica. Boletin de Antropologia Americana, 19, p. 5-30. 1898. 
BATE, L. F. Culturas y modos de vida de los cazadores recolectores en el poblamiento de America del Sur. Revista de Arqueologia Americana, 2, p. 89-153. 1990.

BATE, Luis Felipe. El Proceso de Investigación em Arqueologia. Barcelona: Crítica, 1998.

BAVA DE CAMARGO, Paulo Fernando. Arqueologia de uma cidade portuária: teoria e método. Trabalho final da disciplina Ambiente Cultura e Sociedade (AS014). Programa de Doutorado em Ambiente e Sociedade do Núcleo de Estudos e Pesquisas Ambientais (NEPAM/IFCH/UNICAMP), 2006.

BASTOS, Murilo Quintans Ribeiro. Mobilidade humana na pré-história do litoral brasileiro: Análise de isótopos instáveis de estrôncio no sambaqui do Forte Marechal Luz. Tese de Mestrado em Saúde Pública. Fundação Oswaldo Cruz. Escola Nacional de Saúde Pública Sérgio Arouca. Rio de Janeiro. 96 p. 2009.

BEATTIE, John. Introdução à Antropologia Social: objetivos, métodos e realizações da antropologia social. São Paulo: Companhia Editora Nacional, 344p, 1977.

BECK, A. Variação do conteúdo cultural dos sambaquis: litoral de Santa Catarina. Faculdade de Filosofia Letras e Ciências Humanas da Universidade de São Paulo. Tese de Doutorado. São Paulo. 1972.

BENTLEY, R. A, KRAUSE, R, PRICE, T. D, KAUFMANN, B. Human mobility at the early neolithic settlement of Vahingen, Germany: evidence from strontium isotope analysis. Archaeometry, 2003; 44: 471-486.

BIGG, G. R. 1998. The Oceans and the climate. Cambridge University Press, New York.

BIRD-DAVID, N. Beyond "The Original Afluent Society": a culturalist reformulation. Current Anthropology, 33, p. 25-47. 1992.

BLOT, Jean-Yves. O mar de Keith Muckelroy: o papel da teoria na arqueologia do mundo náutico. Al-Madan, Almada, Centro de Arqueologia, série 2, n. 8, p. 41-55, out. 1999.

BOAS, Franz. The mind of primitive man. Revised edition. New York. The Free Press. 1965. 
BOEHS, G. e MAGALHÃES, A.R.M. 2004. Simbiontes associados com Anomalocardia brasiliana (Gmelin) (Mollusca,, Bivalvia, Veneridae) na Ilha de Santa Ctarina e região continental adjacente, Santa Catarina, Brasil. Revista Brasilieria de Zoologia, 21(4): 865-869.

BONHOMME, Theresa. Shell middens on the central coast of New South Wales: A discussion of problems in distinguishing natural Shell deposits from cultural Shell accumulations. In: HALL, Jay; MCNIVEN, Ian J. (Org.). Australian Coastal Archaeology. Canberra, Australia: ANH Publications, Department of Archaeology and Natural History, RSPAS, the Australian National University, 1999, p. 229-233.

BORGES, Cláudia Cristina do Lago. Uma narrativa pré-histórica. O cotidiano de antigos grupos humanos no sertão do Seridó/RN. Tese de Doutorado em História. Universidade Estadual Paulista. Assis. 182 p. 2008.

BROCHIER, Laércio Loiola. Controles Geoarqueológicos e modelos morfoestratigráficos: Implicações para o estudo das ocupações pré-históricas na costa sul-sudeste do Brasil. Tese de Doutorado em Arqueologia. Universidade de São Paulo. Museu de Arqueologia e Etnologia. Programa de Pós-Graduação em Arqueologia. São Paulo. 130 p. 2009.

BRYAN, Alan L. The problem of finding early man in the northeast. In: NEWMAN, Walter S.; SALWEN, Bert (Org.). Amerinds and Their Paleoenvironments in Northeastern North America. New York: Annals of the New York Academy of Sciences, 1977. v. 288, p. 160-162.

BUENO. Lucas de Melo Reis. Variabilidade tecnológica nos sítios líticos da região do Lajeado, médio rio Tocantins. Tese de Doutorado em Arqueologia. Universidade de São Paulo. Faculdade de Filosofia, Letras e Ciências Humanas. Museu de Arqueologia e Etnologia. Programa de Pós-Graduação em Arqueologia. São Paulo. 552 p. 2005.

BUELA, Alberto. Aportes al Pensamiento Nacional. Cultura et Labor. Buenos Aires. 1987.

BUSE, H. História Marítima Del Peru: Época Prehistórica. Dos tomos. Ediciones Ausonia. Lima. 1973.

BUTTEL, F. H. Environmental and resource sociology: theoretical issues and opportunities for synthesis. Rural Sociology, v. 61 (1), pp. 56-76. 1996. 
BUTZER, K. W. Environment and Archaeology: an introduction to Pleistocene geography. Aldine, Chicago: 1964.

CALIPPO, Flávio Rizzi. Os sambaquis submersos de Cananéia: um estudo de caso de arqueologia subaquática. 2004, p.135, anexos. Dissertação (Mestrado em Arqueologia). Universidade de São Paulo, São Paulo, 2004.

CALIPPO, F. R. The submerged shell mounds of Cananéia, São Paulo, Brazil: a case study of underwater archaeology. Proceedings of the XVth Congress of the UISPP, Colloquia Coastal Geoarcheology. 2006

CALIPPO, Flávio Rizzi. Os sambaquis submersos de Cananéia: um estudo de caso de arqueologia subaquática. Revista de Arqueologia Americana, 26, p. 153-172.

CAPASSO, L., KENNEDY, K. A. R., WILCZAK, C. A., 1999. Atlas of Occupational Markers on Human Remains. Teramo: Edigrafital S.P.A.

CARABIAS, Diego. Navegación prehispánica em el Norte de Chile: uma contribución al estúdio de lãs práticas náuicas em lãs áreas Andes Centro-Sur y Meridional. Revista Werkén, $n^{\circ}$ 1, octobre. Santiago, 2000, p. 31-53.

CARVALHO, Claudia Rodrigues. Marcadores de estresse ocupacional em populações sambaquieiras no litoral fluminense. 2004. Tese (Doutorado em Saúde Pública) - Escola Nacional de Saúde Pública, Rio de Janeiro, 2004.

CHAPLIN J. M.; STEWART, I. A. The prevalence of exostoses in the external auditory meatus of surfers. Clin Otolaryngol, 23-24, p. 326-330. 1998.

CHILDE, Gordon. Arqueologia e História. In: CHILDE, Gordon. Que sucedio en la História. Buenos Aires: La Pléyade, p. 19-37, 1981.

CLAASSEN, Cherryl. Normative thinking and shell - bearing sites. In: SCHIFFER, Michael (Ed). Archaeological Method and Theory. Tucson: The University of Arizona Press, p. 249-287. 1991.

Cleyet-MERLE, Jean-Jacques. La Prehistoire de la Peche. Editions Errance. Paris. 195 p. 1990. 
COLLET, G. C.; LOEBL, E. Informações sobre os sambaquis fluviais de Itaoca (São Paulo). Anuário de Staden (Estudos Brasileiros), 36. São Paulo, Fundação Martius (Inst. Hans Staden), 1988.

CONTI, Luis Américo. Geomorfologia da plataforma continental do estado de São Paulo. 2004, p.179, anexos. Tese (Doutor em Ciências, área de Oceanografia Química e Geológica) - Instituto Oceanográfico, Universidade de São Paulo, São Paulo, 2004.

COSTA, K. B. 2000. Variações Paleoceanográficas na Porção Oeste do Atlântico Sul entre o Último Máximo Glacial e o Holoceno: Isótopos Estáveis do Oxigênio e Carbono e a razão $\mathrm{Cd} / \mathrm{Ca}$ em Foraminíferos Bentônicos. Tese do Doutorado. Instituto de Geociências, Universidade Federal do Rio Grande do Sul, RS.250p.

DE BLASIS, P. A. D. A ocupação pré-colonial do vale do Ribeira de Iguape, SP: os sítios líticos do médio curso. Dissertação de Mestrado. São Paulo, Universidade de São Paulo. 1988.

DE BLASIS, Paulo; EGGERS, Sabine; LAHRS, Martha; FIGUTI, Levy; AFONSO, Marisa \& GASPAR, Maria Dulce. Padrões de assentamento e formação de sambaquis em Santa Catarina. Revista do Museu de Arqueologia e Etnologia, São Paulo, n. 8, p. 319-321, 1998.

DE BLASIS, Paulo; KNEIP, Andréas; SCHEEL-YBERT, Rita; GIANNINI, Paulo César; GASPAR, Maria Dulce. Sambaquis e Paisagem. Dinâmica natural e arqueologia regional no litoral do sul do Brasil. Arqueologia Suramericana/Arqueologia SulAmericana, 3, p. 20-28. 2007.

DELGADO, J. P. Encyclopaedia of Underwater and Maritime Archaeolog. British Museum Press. London. 1997.

DEMARTINI, Célia Maria C. Caracterização cultural e gerenciamento do patrimônio arqueológico do Parque Estadual da Ilha do Cardoso. 2004. Tese (Doutorado em Arqueologia) - Faculdade de Filosofia, Letras e Ciências Humanas da Universidade de São Paulo, São Paulo, 2004.

DE MASI, Marco Aurélio Nadal. Pescadores Coletores da Costa Sul do Brasil. Revista Pesquisas, Antropologia, $\mathrm{n}^{\circ}$ 57. Instituto Anchietano de Pesquisas, Unisinos. São Leopoldo, 2001. 
DESCOLA, P. Societies of nature and nature of society, in: KUPER, $A$. Conceptualizing society. London: Routledge, 1992.

DESCOLA, P. Estrutura ou sentimento: a relação com os animais na Amazônia MANA. Estudos de Antropologia Social 4 (1), 23-45, 1998.

DESCOLA, P. Construyendo naturalezas. Ecologia simbólica y práctica social, In: Descola, P. \& Pálsson, G. (Coordenadores) Naturaleza e Sociedad. Perspectivas Antropológicas. México: Siglo Veintiuno Editores, [1996] 2001.

DESCOLA, P. Genealogia de Objetos e Antropologia da Objetivação, Horizontes Antropológicos. Porto Alegre, ano 8, n. 18, p. 93-112 Dezembro, 2002.

DIAS JR, O. F. A fase itaipú, RJ novas considerações. Arquivos do Museu de História Natural. UFMG, Belo Horizonte, v. 8/9, p. 95-105. 1983/84.

DIAS JR, O. F. Síntese da pré-história do Rio de Janeiro, uma tentativa de periodização. Revista de História, Rio de Janeiro, v.1, n. 2, p.75-83. 1972.

DIEGUES, Antônio Carlos Sant'Ana. Ilhas e mares: simbolismo e imaginário. São Paulo: Editora Hucitec, 1998.

DIEGUES, Antonio Carlos Sant'Ana. Os ex-votos marítimos da sala de milagres da Basílica do Senhor Bom Jesus de Iguape, São Paulo. In: Antonio Carlos Sant'Ana Diegues (Org.). A imagem das águas. São Paulo: Hucitec, p. 157-207. 2000.

DIEGUES, Antonio Carlos Sant'Ana. Povos e Mares: Uma Retrospectiva de Socioantropologia Marítima in "A pesca construindo sociedades.", outubro de 2003.

DILLEHAY, T. Settlement of the Americas - A New Prehistory. Basic Books, New York. 371 p. 2000.

DIXON, E. J. Bones, Boats and Bison - Archaeology and the First Colonization of Western North America. University of New Mexico Press. Albuquerque. 322 p. 1999.

DIXON, E. J. Human colonization of the Americas: timing technology and process. Quaternary Scinece Reviews, 20, p. 277-299. 2001. 
DURAN, Leandro D. Arqueologia Marítima de Um Bom Abrigo. Tese (Doutorado em Arqueologia) - Museu de Etnologia e Arqueologia, Universidade de São Paulo, São Paulo, 2008, p.338.

DURKHEIM, E. De la division du travail social. Paris: Presses Universitaires de France, 1960.

EMERY, K. O.; EDWARDS, R. L. Archaeological Potential of the Atlantic Continental Shelf. American Antiquity, v. 31, p. 733-737, 1966

EMILIANI, C. Depth habitats of some species of pelagic foraminifera as indicated by oxygen isotope ratios. Am. J. Science, 252, p. 149-158. 1954.

EMILIANI, C. Pleistocene temperatures. Journal of Geology, 63, p. 538-578. 1955.

EMPÉRAIRE, J.; LAMING, A. Les sambaquis de la côte méridionale du Brésil. Campagne de Fouilles (1954-1956). J. Soc. Am. Mus. de I'Homme, v. 45, p. 5-163, 1956.

FIGUTI, Levy. Economia/Alimentação na Pré-História do Litoral de São Paulo. In: TENÓRIO, Maria Cristina (Org.). Pré-História da Terra Brasilis. Rio de Janeiro: UFRJ, 1999. p. 197-203.

FIGUTI, L. Investigações Arqueológicas e Geofísicas dos sambaquis fluviais do Vale do Ribeira do Iguape, Estado de São Paulo. Fundação de Amparo à Pesquisa do Estado de São Paulo. Relatório Final de Atividades do projeto Temático (Processo Fapesp no.99/12684-2). 2004.

FONTENOY, Paul. A Discussion of Maritime Archaeology. In: BABITS, Lawrence; TILBURG, Hans Van (Eds.). Maritime Archaeology - A Reader of Substantive and Theoretical Contributions. New York: Plenum Press, 1998. (The Plenum Series in Underwater Archaeology).

FREITAS, J. C. B. 1983. Estudo da composição isotópicas de carbono e oxigênio em conchas do litoral de Salvador - BA. Dissertação de Mestrado em Geofísica. Universidade Federal da Bahia. 51p.

GAGLIANO, Sherwood M. Geoarchaeology of the northern gulf shore. In: DAVIS, Dave; BULLEN, Ripley P. Perspectives on Gulf Coast Prehistory. Monographs in Anthropology and History, n. 5. Gainesville: University of Florida Press and the Florida State Museum, 1984, p. 1-40. 
GARCIA, C. D. Estudo comparado das fontes de alimentação de duas populações pré- $\quad$ históricas do litoral paulista. Tese de Doutorado. Instituto de Biociências, USP. São Paulo. 128 p. 1972.

GASPAR, Maria Dulce. Aspectos da organização social de um grupo pescador coletor - caçador: região compreendida entre a Ilha Grande e o delta do Paraíba do Sul, Rio de Janeiro. Tese (Doutorado em Arqueologia) - Faculdade de Filosofia Letras e Ciências Humanas, Universidade de São Paulo, 364 p.1991.

GASPAR, Maria Dulce. Aspectos da organização social de um grupo de pescadores, coletores e caçadores que ocupou o litoral do Estado do Rio de Janeiro. A. J. G. Araújo; L. F. Ferreira (Eds.). Paleopatologia e Paleoepidemiologia - Estudos multidisciplinares. Editor Fiocruz. Rio de Janeiro, p. 95-110. 1992.

GASPAR, Maria Dulce. Considerations of the sambaquis of the Brazilian coast. IN: Antiquity. Special Section: Issues in Brazilian archaeology, v 72, $\mathrm{n}^{\circ} 277,1998, \mathrm{p}$. 592-615.

GASPAR, Maria Dulce. Análise das datações radiocarbônicas dos sítios de pescadores-coletores-caçadores. Boletim do Museu Paraense Emílio Goeldi. 2000.

GASPAR, M. D; DE BLASIS, P. A. D. Construção de sambaqui. In Reunião Científica da Sociedade de Arqueologia Brasileira, 6. Rio de Janeiro. Anais, 2: 811-820. 1992.

GEISTDOERFER, A. Anthropologie maritime: appropriation technique, sociale et symbolique des resources maritimes. CNRS. Paris. 1989.

GIBBINS, David. Analytical approaches in maritime archaeology: a mediterranean Perspective. American Antiquity, vol.64, 1990, p.376-89.

GIBSON, J. J. The ecological approach to visual perception. Boston Hougon Mifflin. 1979.

GLADWIN, T. Culture and logical process. In Explorations in cultural anthropology. Ed. W. H. Goodenough. New York: Mc Graw-Hill, p. 167-177. 1964. 
GOODYEAR, Albert C.; WARREN, Lyman O. Further observations on the submarine oyster shell deposits of Tampa Bay. Florida Anthropologist, 25 (2), v. 1. p. 52-66, 1972.

HASSLÖF, Olof. Ships and Shipyards, Sailors and Fishermen. Copenhagen: Copenhagen University Press, 1972.

HAYDEN, Brian. Fabulous feast a Prolegomenon to the importance of festing in Feast archaeological and etnographic perspectives on food, politics and power. Washington and London: Smithisonian Institution Press. 2001

HEREDIA, Oswaldo. Mariscadores e pescadores pré-históricos do litoral centro-sul brasileiro. Pesquisas, Série Antropologia. São Leopoldo, v 31, p. 101-19, 1980.

HEREDIA, Osvaldo; BELTRÃO, Maria da Conceição; OLIVEIRA, Maria Dulce \& GATTI, Marcelo. Pesquisas Arqueológicas no Sambaqui de Amourins, Magé, Rio de Janeiro. Arquivos do Museu de História Natural. UFMG. Belo Horizonte, v. 3, p. 175-187, 1981/82.

HEREDIA, Oswaldo; TENÓRIO, Maria Cristina; GASPAR, Maria Dulce \& BUARQUE, Angela. Environment exploration by prehistorical population of Rio de Janeiro. In: NEVES, C. (Ed.) Coastlines of Brazil. New York: American Society of Civil Engineers, p. 230-39, 1989.

HERRERA, G. C. Naturaleza, sociedad e historia en America Latina. Ecologia Política. Naturaleza, sociedad y utopía. Clacso. Buenos Aires. 2002.

HODELL, D. A.; QUINN, R. L.; BRENNER, M.; KAMENOV, G. Spatial variations of strontium isotopes $\left({ }^{87} \mathrm{Sr} /{ }^{86} \mathrm{Sr}\right)$ in the Maya region: a tool for tracking ancient human migration. Journal of Archaeological Science, 2004, p. 1-17.

HODDER, Ian; SHANKS, Michael; ALEXANDRI, A.; BUCHLI, V.; CARMAN, ? ;LAST, J. \& LUCAS, G.(Eds.). Interpreting Archaeology. Finding meaning in the past. London and New York: Routledge.1995.

HODDER, Ian et al. Interpreting Archaeology - Finding meaning in the past. Routledge: London, 1998.

HÖLZL, S. Heavy Elements Isotope Ratios in Archaeometry. Revista do Museu de Arqueologia e Etnologia, São Paulo, Suplemento 2, p. 181-189, 1997. 
HORNELL, James. Water Transportation: origins \& early evolution. David \& Charles: Newton Abbot, 1970.

INGOLD, Tim. The appropriation of nature: essays on human ecology and social relations. Manchester: Manchester Univesity Press. 1986.

INGOLD, Tim. Humanidade e Animalidade. Revista Brasileira de Ciências Sociais, n. 28, ano 10, p. 39-54. 1994.

INGOLD, Tim. The perception of the environment. Essays on livelihood, dwelling and skill. London: Routledge, 2000.

INGOLD, Tim. El forrajero óptimo y el hombre económico, in: Descola, P. \& Pálsson, G. (Coordenadores) Naturaleza e Sociedad. Perspectivas Antropológicas. México: Siglo Veintiuno Editores, [1996] 2001.

KEITH, M. L.; ANDERSON, G. M.; EICHLER, R. Carbon and oxygen composition of mollusk shells from marine and fresh-water environments. Geochimica et Cosmochimica Acta, 28, 1964, p. 1757-1786.

KENNDY, G. E. The relationship between exostoses and cold water: a latitudinal analysis. Am J. Phys Anthrop, 71-74, p. 401-415. 1986.

KERN, Arno Alvarez. Pescadores-coletores pré-históricos do litoral norte do Rio Grande do Sul. Documentos. São Leopoldo. Instituto Anchietano de Pesquisas, n.3, 1989.

KLÖKLER, D. M. Construindo ou deixando um sambaqui? Análises de sedimentos de um sambaqui do litoral meridional brasileiro - processos formativos. Região de Laguna - SC. Dissertação de Mestrado. Museu de Arqueologia e Etnologia da USP. 164p. 2001

LARAIA, Roque de Barros. Cultura: Um conceito antropológico. Rio de Janeiro: Jorge Zahar, 115 p. 1989.

LLAGOSTERA, A. La navegación prehispánica en el Norte de Chile: bioindicadores e inferencias teóricas. Chungará, 24-25, p. 37-51. 1990.

KNEIP, Lina Maria; FERREIRA, A . M. \& MUEHE, Dieter. Contribuição ao estudo da pré-história e do paleoambiente da região entre Cabo Frio e Guaratiba, RJ. In: TENÓRIO, Maria Cristina \& FRANCO, Teresa Cristina (Eds). Seminário para 
Implantação da pré-história brasileira. Universidade Federal Fluminense, Niterói, p. 127-133, 1994.

LEDRU, M. P. ISEM/Paléoenvironnements. CNRS UMR 5554 Université de Montpellier. France. 2005.

LESSA, Andrea. Reflexões preliminares sobre paleoepidemiologia da violência em grupos ceramistas litorâneos: (I) Sítio Praia da Tapera - SC. Rev. do Museu de Arqueologia e Etnologia. São Paulo, 15-16, p. 199-207. 2005.

LEVI-STRAUSS, Claude. Tristes Trópicos. Lisboa: Martins Fontes. 272 p. 1962 [1955].

LIMA, T. A. Em busca dos frutos do Mar: Os pescadores-coletores do litoral com o sul do Brasil. Revista da Universidade de São Paulo, 44, p. 270-327. 1999/2000.

LIMA, Tania Andrade \& MAZZ, Jose Maria Lopez. Complejidad Emergente entre los Cazadores/Recolectores de la Costa Atlantica Meridional Sudamericana. Revista de Arqueologia Americana, 17,18 e 19, p 129-176. Mexico. 1997.

LIMA, T. A; MACARIO, K. D; ANJOS, R. M; GOMES, P. R. S; COIMBRA, M. M; ELMORE, D. The earliest shellmounds of the central-south brazilian coast. Nuclear Instruments and Methods in Physics Research, 223-224, p. 691-694. 2004

LISIANSKY, U. A Voyage round the World. 1803-1806.

LUBY, Edward \& GRUBER, Mark F. The dead must be fed: The symbolic meaning of the shellmound of the San Francisco Bay area. Cambridge Archaeological Journal, Cambridge, v. 9, p.105-108, 1999.

MACHADO, M. C. Método SrlSr em foraminíferos pleitocênicos. Dissertação de Mestrado IG/UFRGS, 101 p. 2003.

MAGALHÃES, Nícia Wendel de. Descubra o Lagamar. São Paulo: Embratur, 1997.

MALINOWSKI, Bronislaw. Argonautas do Pacífico Ocidental. Um relato do empreendimento e da aventura dos nativos nos arquipélagos da Nova Guiné Melanésia. Ed. Abril Cultural. São Paulo. 428 p. 1984. 
MARTIN, L. Holocene sea-level hiistory along Eastern-Southeastern Brazil. Anuário do Instituto de Geociências. 16. UFRJ. 2003.

MARTIN, L.; SUGUIO, K. Excursion routhe along the coastline between the town of Cananéia (State of São Paulo) and Guaratiba outlet (State of Rio de Janeiro ). International symposium on coastal evolution in the Quaternary. São Paulo: Special Publication, $\mathrm{n}^{\circ}$ 2, 1978. $97 \mathrm{p}$.

MARTIN, L.; SUGUIO, K.; FLEXOR, J. M. Informações adicionais fornecidas pelos sambaquis na reconstrução de paleolinhas de praia quaternária: exemplos da costa do Brasil. Revista de Pré-História, Instituto de Pré-História da Universidade de São Paulo, v. 6, p. 128-147, 1984.

MARTIN, L.; FLEXOR, J.M.; BLITZKOW, D.; SUGUIO, K. Geoid change indications along the brazilian coast during the last 7,000 years. Tahiti, Proc. V Int. Congr. Coral Reef, 3, p. 85-90, 1985.

MARTIN, L., SUGUIO, K. \& FLEXOR, J. M. Informações adicionais fornecidas pelos sambaquis na reconstrução de paleolinhas de praia quaternária: exemplos da costa do Brasil. Revista de Pré-História, Instituto de Pré-História da Universidade de São Paulo, 6, p.128-147. 1986.

MARTIN, Gabriela. Pré-História do Nordeste do Brasil. 4ª . ed. Recife: Universitária da UFPE, 2005. v. 1. 395 p.

MASON, Otis T. The Origins Of Inventions. 1895.

MAYORGA, E. A. Teoría Crítica y crítica política en la cuestión ambiental: problemas e perspectives. Los tormentos de la matéria. Aportes para una ecologia política latinoamericana. Clacso. pp 41-56. 2006.

MEGHAN, Barbara. Shell bed to shell midden. Camberra: Australian National University. 1982.

MENDONÇA DE SOUZA, Alfredo. A Pré-História Fluminense. Rio de Janeiro: Instituto Estadual do Patrimônio Cultural e Secretaria Estadual de Educação e Cultura Brasileira, 1981.

MENDONÇA DE SOUZA, Alfredo. Povoamento pré-histórico do litoral do Rio de Janeiro: Repensando um modelo. In: BELTRÃO, Maria (ed.) Arqueologia do 
Estado do Rio de Janeiro. Rio de Janeiro, Arquivo Público do Estado do Rio de Janeiro, p. 43-50, 1995.

MENTZ RIBEIRO, Pedro Augusto. Os mais antigos caçadores do sul do Brasil. In: TENÓRIO, Maria Cristina (org.). Pré-História da Terra Brasilis. Rio de Janeiro: EDUFRJ, 1999.

MENTZ RIBEIRO, P. A. E CALIPPO, F. R. Arqueologia e História da porção central da planície costeira do Rio Grande do Sul, Brasil. Arqueologia, História e SócioEconomia da restinga da Lagoa dos Patos: uma contribuição para o conhecimento e manejo da Reserva da Biosfera. Editora da FURG, Rio Grande, RS, Brasil, 2000.

MENTZ RIBEIRO, Pedro Augusto; VANZ, Argeu. Sobre uma ponta de projétil no litoral sul do Rio grande do sul. Rio Grande do Sul: história, historiografia e memória. Rio Grande: Fundação Universidade Federal de Rio Grande, p. 9-17. 1999.

MIZUTA, D. D. Contribuição das análises isotópicas de carbono e oxigênio para o estudo dos sambaquis da região de Cananéia, SP. Trabalho de Conclusão de Curso (Graduação em Oceanografia. Instituto Oceanográfico, Universidade de São Paulo. São Paulo, 2007, 57 p.

MUCKELROY, Keith. Maritime Archaeology. Cambridge: Cambridge University Press, 1978. (New Studies in Archaeology).

MURDOCK, G. P. The current status of the wourld's hunting and gathering people. In: LEE, Richard \& DEVORE, Irven (Eds.). Man the hunter. Chicago: Aldine. p. 13-22, 1968.

NELSON, R. K. Make prayer to the raven: a Koyukon view of the northern Forest. University of Chicago Press. Chicago. 1983.

NEVES, Walter. Paleogenética dos grupos pré-históricos do litoral sul do Brasil. Tese de Doutorado, Instituto de Biociências, USP. 1984.

NEVES, Walter. Paleogenética dos grupos pré-históricos do litoral sul do Brasil (Paraná e Santa Catarina). Pesquisas, Série Antropologia, São Leopoldo, n.43, p.1-178, 1988. 
OKUMURA, M. M. M.; Análise de exostose do meato auditivo externo como um marcador de atividade aquática em restos esqueletais humanos da costa e do interior do Brasil. Revista do Museu de Arqueologia, $n^{\circ}$ 15/16. Universidade de São Paulo. São Paulo, 2005/2006, p. 181-189.

PEARSON, Charles E. Dating the course of the lower red river in Louisiana: the archaeological evidence. Geoarchaeology, 1, 39-43, 1986.

PEIXOTO, M. V. Avaliação radiológica do torus auditivus nos grupos formadores de Sambaquis do litoral meridional brasileiro: contribuição ao estudo dos traços não métricos em populações pré-históricas do Brasil. MSc thesis. Depto. de Anatomia Humana. Universidade Federal do Rio de Janeiro. 1989.

PIAZZA, Wilson. Estudos de sambaquis - o sambaqui de Pontas das Almas. Anais do Instituto de Antropologia. Série Arqueologia. Universidade Federal de Santa Catarina, Florianópolis, vol. 2, p.1-72, 1966.

PINHEIRO, Elisa Dalcin; PEIXOTO, Silvia Alves. Sambaqui: status diferenciado entre os pescadores-coletores. Resumos do XII Congresso da Sociedade de Arqueologia Brasileira - SAB, São Paulo, p. 177. 2003.

PLENS, Cláudia Regina. Sítio Moraes, uma biografia não autorizada: análise do processo de formação de um sambaqui fluvial. Tese (Doutorado em Arqueologia) - Museu de Etnologia e Arqueologia, Universidade de São Paulo, São Paulo, 2008, p. 254, anexos.

PLENS, Cláudia Regina; DE BLASIS, Paulo; EGGERS, Sabine; FIGUTI, Levy. Um sepultamento de 9000 Anos: cultura, saúde e atividade. In: Resumos do XI Congresso da Sociedade de Arqueologia Brasileira. Rio de Janeiro, 2001.

POLITIS, G. Revisão dos sítios pleistocênicos do território argentino. Anais da Conferência Internacional sobre o Povoamento das Américas. Fundhamentos, 1, p. 154-170. 1993.

PRICE, T. D; MANZANILLA, L; MIDDLETON, W. D. Immigration and the ancient city of Teotihuacan in Mexico: A study using strontium isotope ratios in human bone and teeth. Journal of Archaeological Science, 27 (10), p. 903-913. 2000.

PRICE, T. D; BURTON, J. H; BENTLEY, R. A. The characterization of biologically available strontium isotope ratios for the study of prehistoric migration. Archaeometry, 44:, p. 117-136. 2002 
PROUS, André. Les sculptures zoomorphes du sud brésilien et de l'Uruguay. Cahiers d'Archéologie d'Amérique du Sud, 5. Paris. 1977.

PROUS, André. Arqueologia Brasileira. Brasília: Editora Universidade de Brasília, 1992.

RAMBELLI, Gilson. Arqueologia subaquática do Baixo Vale do Ribeira, SP. 2003 259 p. Tese (Doutorado em arqueologia) - Museu de Arqueologia e Etnologia, Faculdade de Filosofia, Letras e Ciências Humanas - Universidade de São Paulo. São Paulo, 2003.

READ, J. The Indian Ocean in Antiquity, London: New York, 1996.

REMAC. Geomorfologia da Margem Continental Brasileira e das Áreas Oceânicas Adjacentes. Centro de Pesquisa e Desenvolvimento Leopoldo A. Miguel de Mello. Divisão de Informação Técnica e Propriedade Industrial. Rio de Janeiro. 51 p. 1979.

ROSS, J. L. S.; MOROZ, I. C. Mapa Geomorfológico do Estado de São Paulo. Faculdade de Filosofia Letras e Ciências Humanas, Univesidade de São Paulo, São Paulo, 1997, 63 p, mapas.

ROUSE, Irving. Prehistory typology and the study of society. In: CHANG, K.C. Settlement archaeology. Palo Alto: Yale University, National Press Books, 229 p. 1968.

SCHAEFFER-NOVELLI, Y. 1976. Alguns aspectos ecológicos e análise da população de Anomalocardia brasiliana (Gmelin, 1791) Mollusca - Bivalvia, na praia do Saco da Ribeira, Ubatuba, Estado de São Paulo. Tese de Doutorado. Instituto de Biociências da Universidade de São Paulo. 119p.

SCHELL-YBERT, R.; EGGERS, S.; WESOLOWSKI, V.; PETRONILHO, C. C.; BOYADJIAN, C. H.; DE BLASIS, P. A. D.; BARBOSA-GUIMARÃES, M.; GASPAR, M. D. Novas perspectives na reconstituição do modo de vida dos sambaquieiros: uma baordagem multidisciplinar. Revista de Arqueologia. Sociedade de Arqueologia Brasileira, São Paulo, v. 16, 2003, p. 109-137.

SCHIFFER, Michael B. Archaeological context and systemic context. American Antiquity, 37, p. 156-165, 1972. 
SCHIFFER, Michael. Behavior Archaeology. New York: Academic Press, 1976.

SCHMITZ, Pedro Inácio. Caçadores e coletores da pré-história do Brasil. Instituto Anchietano de Pesquisas/UNISINOS, São Leopoldo. 68 p. il. 1984.

SCHMITZ, Pedro Inácio. Escavações arqueológicas do Pe. João Alfredo Rohr, S. J. - Visão de conjunto dos sítios da Tapera, Armação do Sul, Laranjeiras I e II, Pântano do Sul e Cabeçudas. Pesquisas. Série Antropologia, 53, p. 183-190. 1996.

SCHMITZ, P. I; VERARDI, I; DE MASI, M. A; ROGGE, J. H; JACOBUS, A. L. Escavações arqueológicas do Pe. João Alfredo Rohr, S. J. - O sítio da Praia de Laranjeiras II. Uma aldeia da Tradição ceramista Itararé. Pesquisas. Série Antropologia, 49. 1993.

SEMENOV, S. A. Prehistoric Technology: an Experimental Study of the oldest Tools and Artifacts from traces of Manufacture and Wear. Adams \& Dart, Great Britain, 1970, 211 p, ilustr.

SERVICE, Elman. Os caçadores. Rio de Janeiro: Zahar. 1977.

SHACKLETON, N.J. 1967. Oxygen isotope analyses and Pleistocene temperatures re-assessed. Nature, 215: 15-17.

SHALLINS, Marshall. Cultura e Razão Prática. Rio de Janeiro: Zahar, 1979.

SHANKS, Michael, HODDER, Ian. Processual, postprocessual and interpretative archaeologies. Interpreting Archaelogy. 1995.

SILVA, J. R. M. Composição isotópica de carbono e oxigênio na determinação de paleoambientes. São Paulo. Dissertação de mestrado. Instituto de Geociências da Universidade de São Paulo. 1978.

SILVA, S. B; SCHMITZ, P. I; DE MAIS, M. A; JACOBUS, A. L. L. Escavações arqueológicas do Pe. João Alfredo Rohr, S. J. O sítio arqueológico da Praia da Tapera: um assentamento Itararé e Tupiguarani. Pesquisas. Série Antropologia, 45. 1990.

STADEN, V. G; ARRIAZA, B. T; SANTORO, C. M. External auditory exostosis in prehistoric chilean populaions: a test of the cold water hypothesis. Am J Phs Anthrop, 103, p. 119-120. 1997. 
STEIN, Julie K.. A review of site formation processes and their relevance to Geoarchaeology. In: GOLDBERG, Paul; HOLLIDAY, Vance T.; FERRING, C. Reid (Org). Earth Sciences and Archaeology. 2000. p. 37-51.

STEWARD, Julian. Theory of culture change. Urbana: University of Illinois, 1955.

STEWART, Hilary. Indian Fishing. Early Methods on the Northwest Coast. Douglas \& Mclntyre. Vancouver. Toronto. 181 p. 1977.

STOKES, J. L. Discoveries in Australia. 2 vols.1846.

SUGUIO, K. Geologia do quaternário e mudanças ambientais (passado + presente = futuro?). São Paulo: Paulo's Comunicações e Artes, 1999.

SUGUIO, K; FLEXOR, J. M; MARTIN, L. Mapa geológico do litoral paulista, folhas Cananéia e Iguape (1:100.000). São Paulo. 1978.

TENÓRIO, Maria Cristina. Os fabricantes de machado da llha Grande. In: TENÓRIO, Maria Cristina (org.). Pré-história da Terra Brasilis. Rio de Janeiro, EDUFRJ, 1999.

TENÓRIO. M. C. O Lugar dos Aventureiros: identidade, dinâmica de ocupação e sistema de trocas no litoral do Rio de Janeiro há 3500 anos antes do presente. Tese (Doutorado em Arqueologia). Faculdade de Filosofias e Ciências Humanas, Pontifícia Universidade Católica do Rio Grande do Sul . Porto Alegre, 536 p. 2003.

TIBURTIUS, G.; BIGARELLA, J. J; BIGARELLA, I. K. Nota prévia sobre a jazida paleoetnográfica de Itacoara, Joinville. Estado de Santa Catarina. Arquivos de Biologia e Tecnologia, 5-6, p. 315-346. 1950/1951.

TRIGGER, Bruce. História do Pensamento Arqueológico. Tradução Ordep Trindade Serra. São Paulo: Odysseus, 2004.

TYLOR, Edward Burnett. The origins of culture. New York: Harper \& Row, 416p. 1970.

LARAIA, Roque de Barros. Cultura: Um conceito antropológico. Rio de Janeiro: Jorge Zahar, 115 p. 1989.

UCHÕA, Dorath Pinto; GARCIA, Caio Del Rio. Cadastramento dos sítios arqueológicos da baixada Cananéia-Iguape, litoral sul do estado de São Paulo, 
Brasil. Revista de Arqueologia, Museu Paraense Emílio Goeldi, Belém, Pará, v. 1, n.1, 1983.

VIALOU, A. V. Pré-História do Mato Grosso, 1: Santa Elina. Edusp, USP, São Paulo. 2005

VIVEIROS DE CASTRO, Eduardo. A inconstância da alma selvagem e outros ensaios de antropologia. Cosac \& Naify, São Paulo, 2002, 552 p.

WAINER, Ilana Elazari Klein Coaracy; COLOMBO, Patrícia de Miranda. Boletim de monitoramento climatológico para as bases "Norte" e "Dr João de Paiva Carvalho" do Instituto Oceanográfico da Universidade de São Paulo São Paulo. Boletim Técnico do Instituto Oceanográfico, v. 38, p.1-13, 1996.

WAKAMATSU, T. A ostra de Cananéia e seu cultivo. SUDELPA/ Instituto Oceanográfico, Universidade de São Paulo. 141p. 1973.

WARREN, LYMAN O. Possibly submerged oyster shell middens of upper Tampa Bay. Florida Anthropologist, 17 (4), p. 227-230, 1964.

WATERS, M. R. Principles of Geoarchaeology: a north american perspective. Tucson: University of Arizona Press, 1992.

WHITE, Leslie. Energy and the evolution culture. American Anthropologist, 45. 1943.

WOODBURN, J. Hunters and gatherers today and reconstructions of the past. In Soviet and Western anthropology. Ed. E. Gellner. London: Duckworth. 1980.

WOODBURN. Egaliarian societies. Man (N.S.), 17, p. 431-451. 1982.

WOODBURN. African hunter-gatherer social organization: is it best understood as a product of encapsulation? In Hunters and gatherers, I: history evolution and social change. Eds T. Ingold, D. Riches and J. Woodburn. Oxford: Berg, p. 31-64. 1988.

YBERT, Jean-Pierre; BISSA, Walter Mareschi; CATHARINO, Eduardo Luís Martins; KUTNER, Miryam. Environmental and sea-level variations on the southeastern Brazilian coast during the Late Holocene with comments on prehistoric human occupation. Paleogeography, Palacoclimatology, Palaeocology, 189, p. 11-24, 2003 
ZEIDLER, J. El intercambio primitivo, el comercio prehistórico y el problema de una conexión mesoamericana-sudamericana. En Arqueologia de la costa ecuatoriana, Centro de Estudios Arqueológicos y Antropológicos, p.131-162. Quito. 1986. 
ANEXOS 
ANEXO 1

Perfil estratigráfico do sambaqui Cambriu Grande 


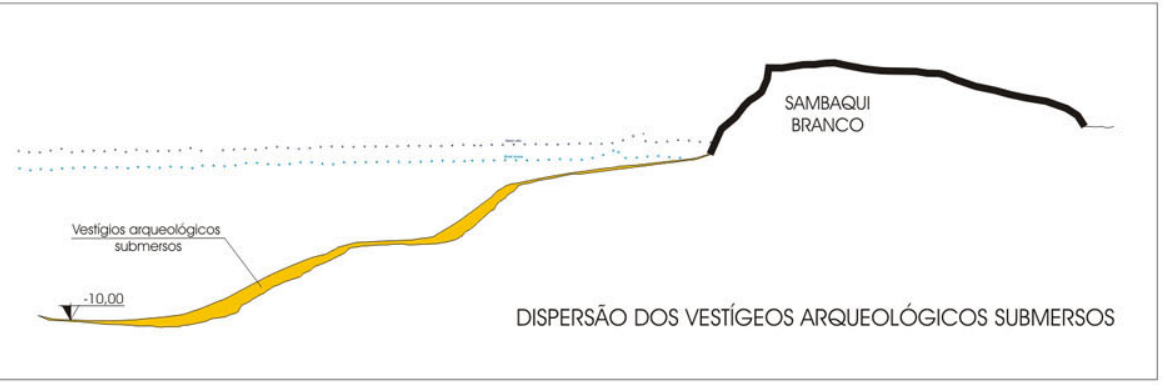

\section{Testemunho c01}

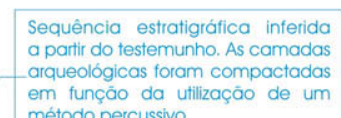

DISPERSĀO DOS VESTIGEOS ARQUEOLÓGICOS SUBMERSOS

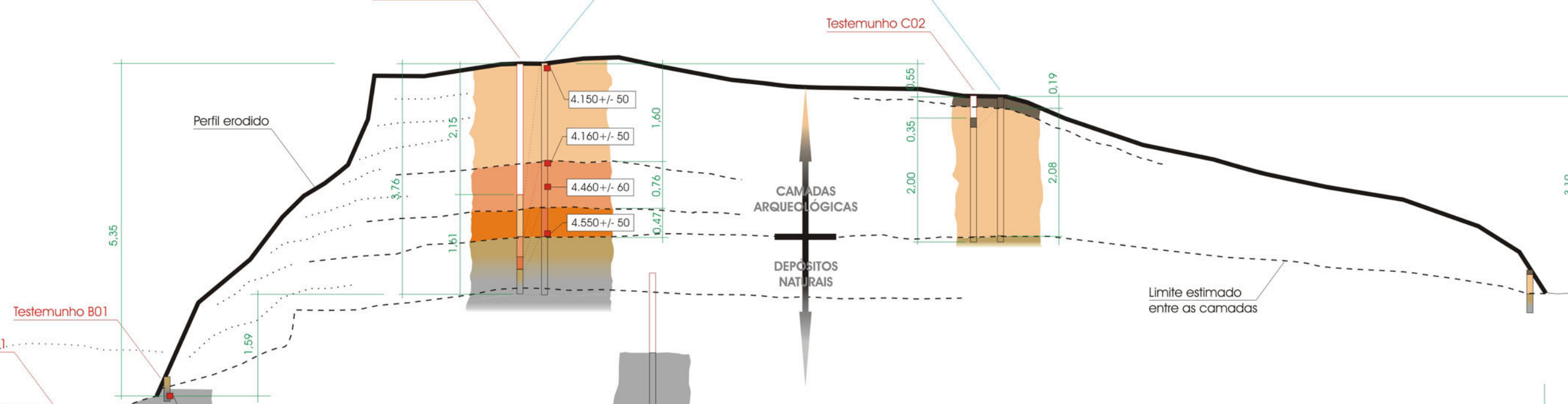

Mare alto submensas (resultados evaluas do sambaqui Branco pela
migraçáao do Canal do Atarapira

Maré baixa Testemunho A03

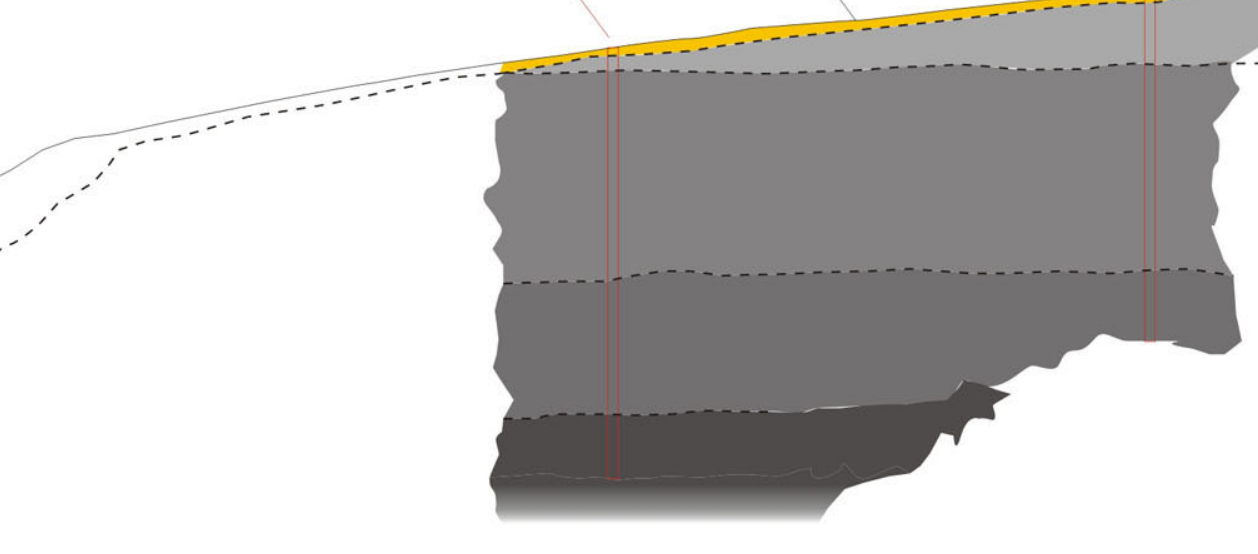

$4.590+1.0$

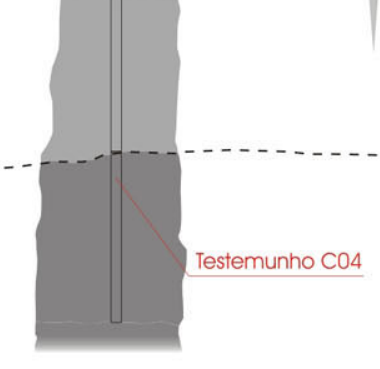

CORTE AA - PERFIL LONGITUDINAL DO SAMBAQUI BRANCO

10 metros

\section{ESCALA GRÁFICA}

(Flávio Calippo - 05/2004)

\section{LEGENDA}

Camadas arqueológicas

Camada I - valvas inteiras e muita vezes fechadas

Camada II - valvas fragmentadas e alto teor de matéria orgânica

Camada III - valvas inteiras, de coloraçã alaranjada

Valvas erodidas do sambaqui $e$ retrabalhadas pelas gua do canal

\section{Depósitos naturais}

- Camada húmica / serrapilheira

Sedimento associado ao mangue

Sedimento arenoso

Sedimento areno-lamoso

(às vezes com estratificação)

Sedimento lamo-arenoso

(borda de canal)

Sedimento lamoso (encosta de canal)

Sedimento lamoso (fundo de canal)

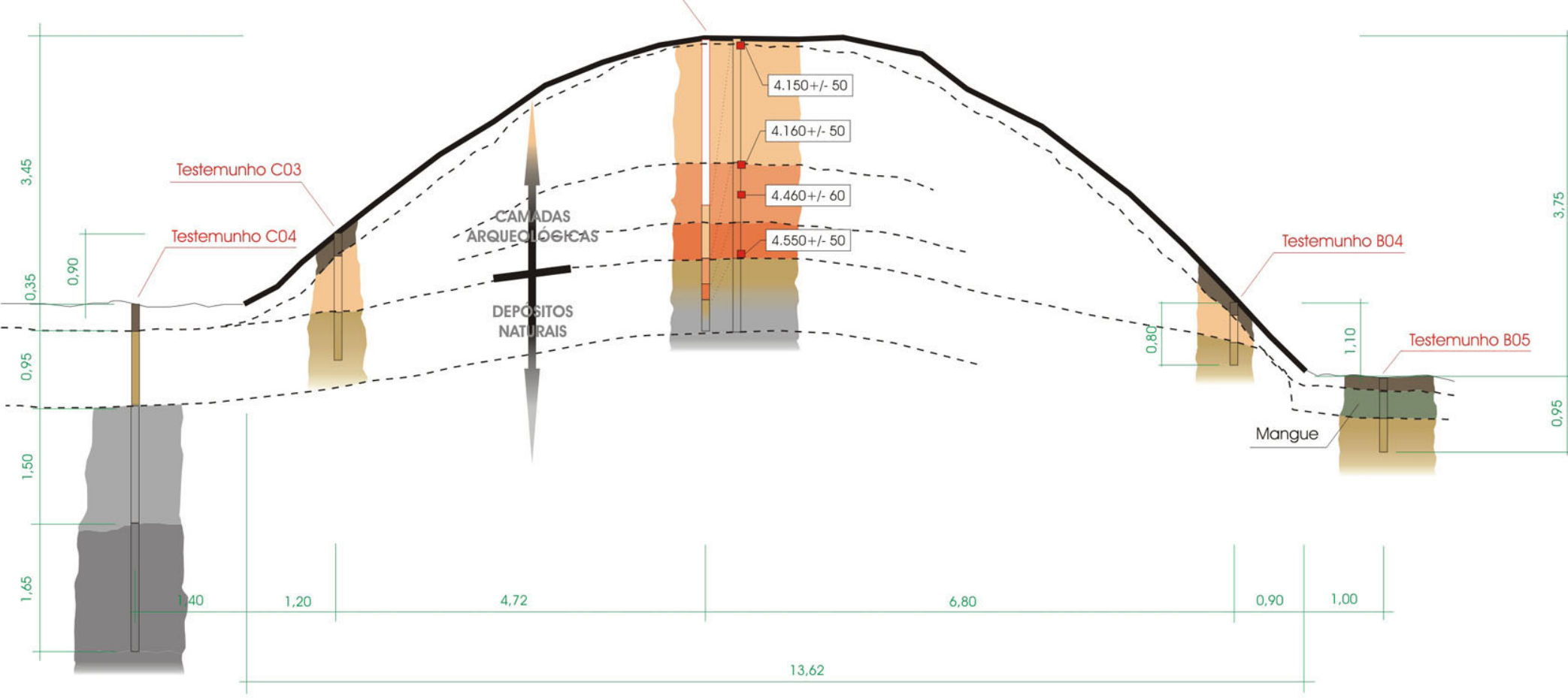

CORTE BB - PERFIL TRANSVERSAL DO SAMBAQUI BRANCO 


\section{ANEXO 2}

Modelo de predição de sambaquis submersos ao longo da plataforma continental brasileira 
 \\ \begin{tabular}{r|l}
$55^{\circ}$ \\
\hline
\end{tabular}}

SURINAME

$\because$ CRAN

SURINAME

quador

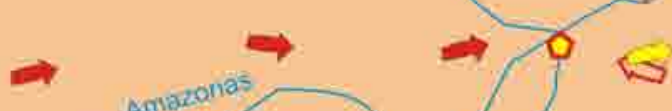

IUADE
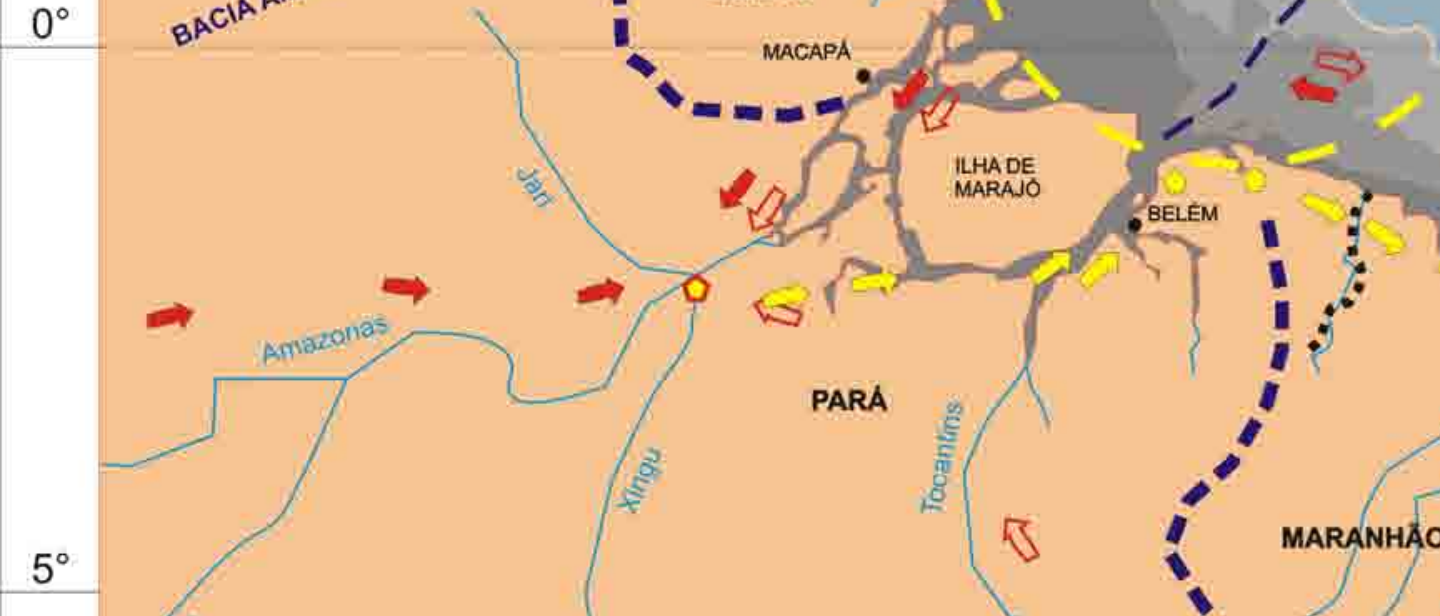

PARA
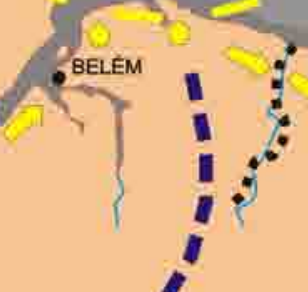

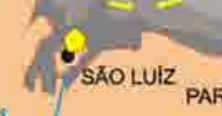
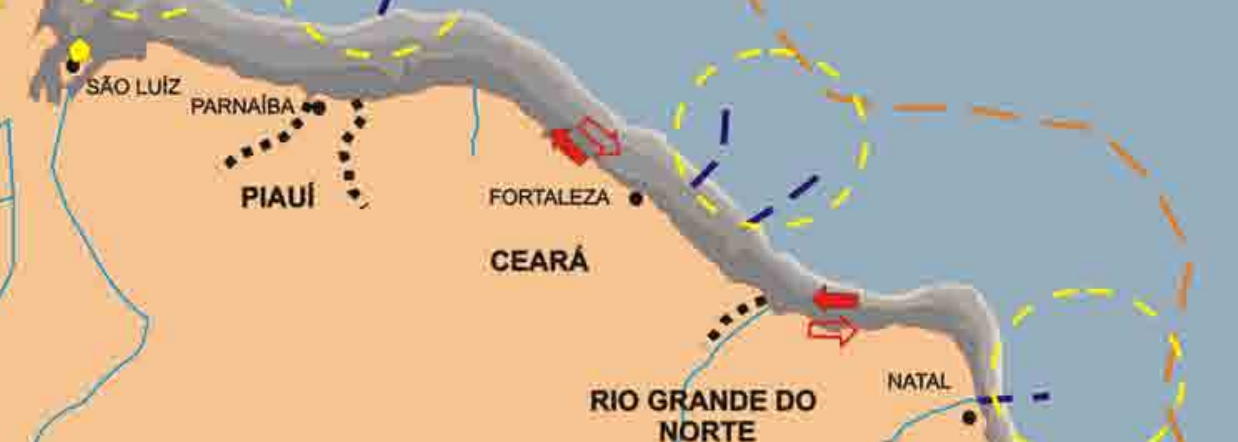

AR

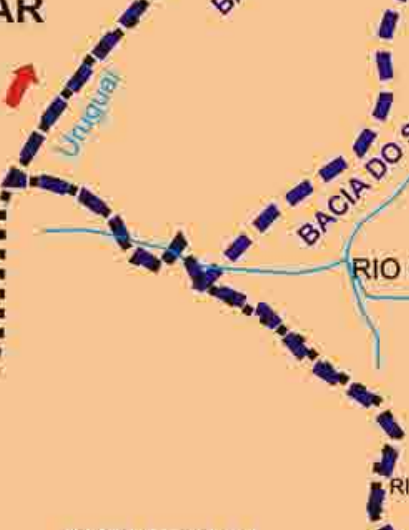

URUGUAI
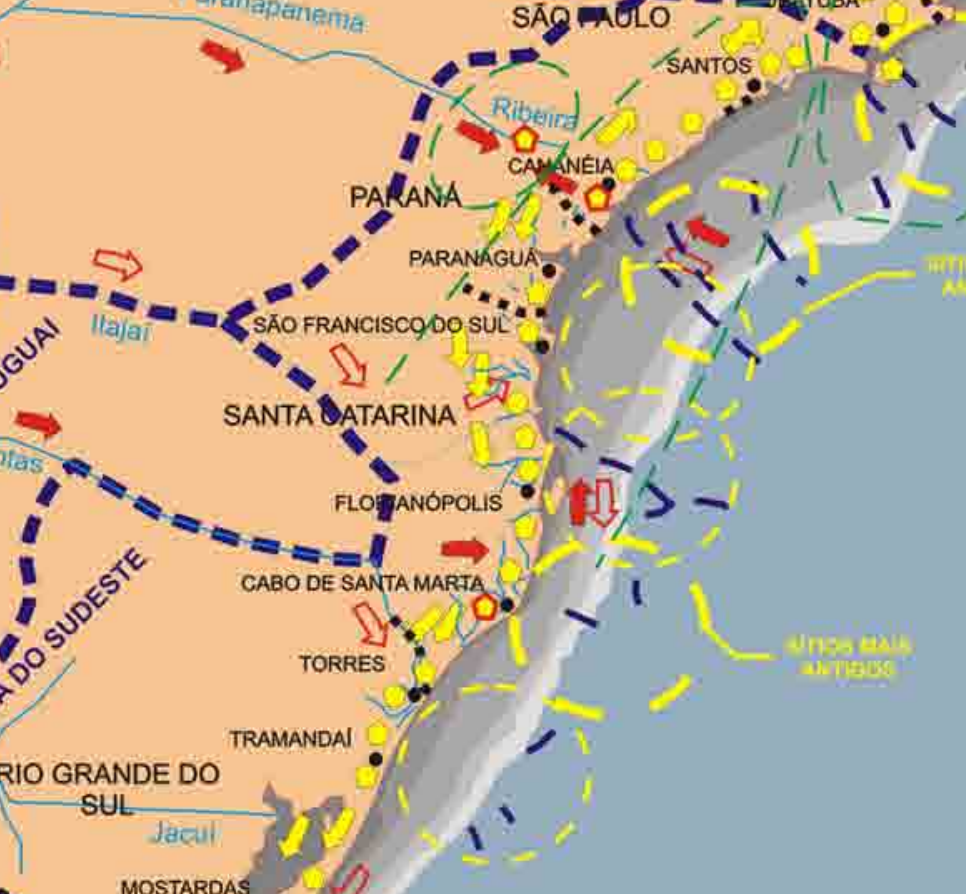

1 RIO de Janeiro $\cdots$...

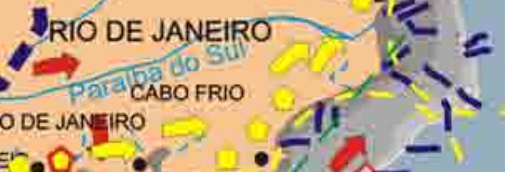

?...

(4)

PARAIBA

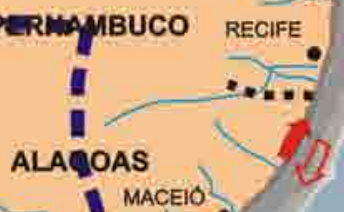

